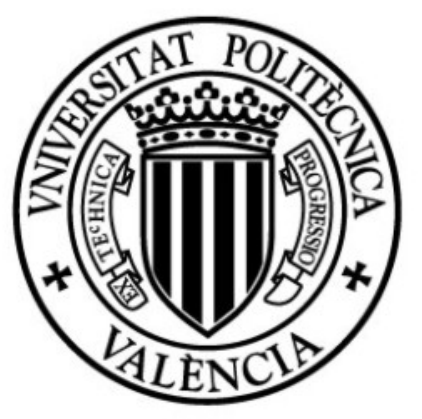

Universidad Politécnica de Valencia

Departamentos de Pintura y Escultura

\title{
ESTRUCTURAS NARRATIVAS LÚDICAS: \\ UN RESORTE CREATIVO \\ PARA ARTISTAS DIGITALES
}

Tesis Doctoral

Doctoranda: Xóchitl Tortolero Cervantes Directores: Ma. José Martínez de Pisón Ramón

Moisés Mañas Carbonell

México, 2013 

A mis dos Gonzalos, Sabrina, Cibeles, Mary y Oscar

A mi familia y amigos que tuve un poco abandonados este tiempo

A Mariajo y René

A todos los que me acompañaron y animaron con su apoyo y cariño. 

ESTRUCTURAS NARRATIVAS LÚDICAS:

UN RESORTE CREATIVO

PARA ARTISTAS DIGITALES 



\section{INDICE}

INTRODUCCIÓN ..... viii

Interés del Tema de Estudio ..... ix

Partes del Trabajo y Metodología ..... xi

I. HOMO NARRANS ..... 1

El hombre y las Historias ..... 3

Definiendo Narrativa, Historia y Relato ..... 4

1.1 El Lenguaje y las Historias ..... 7

1.2 El Papel del Lenguaje en la Formación del Pensamiento..... 9

1.3 Las Primeras Historias de la Humanidad ..... 13

Las Historias Gráficas ..... 16

1.4 Lenguaje y Juego Creativo ..... 20

II. HOMO LUDENS ..... 23

2.1 Origen, Etimología e Importancia del Juego .... 26

Etimologías de "Juego" ..... 26

Importancia del Juego ..... 28

Juego y creatividad ..... 30

2.2 Juego y Lenguaje; una Mancuerna Creativa ..... 33

De Juegos Poéticos, Palabras Ocultas a Lenguajes Artísticos ..... 34

Los Códigos Secretos ..... 36

Lenguajes Inventados .... 38

Lenguajes Artísticos en la Literatura ..... 40

2.3 Literatura Lúdica ..... 42

Los Caligramas ..... 46

Ideogramas, Logogramas y Caligrafías ..... 48

Las Vanguardias y el Juego Desbordado ..... 49

Partituras de Sucesos, Libros-caja de Artistas y Algo Más ..... 58

2.4 Scriptor Ludens vs. Lector Ludens .... 61

OuLiPo ..... 61 
III. NARRANS ET LUDENS ..... 67

3.1 Literatura Inspirada en Juegos ..... 68

Juego de Cartas de Max Aub ..... 72

Rayuela de Julio Cortázar ..... 73

La Vida; Instrucciones de Uso, de Georges Perec

73

El Castillo de los Destinos Cruzados, de Italo Calvino ..... 74

3.2 ¿Juegos o Literatura Encubierta? ..... 76

3.3 Teorías para Componer Historias ..... 80

3.4 La Migración a los Sistemas Digitales .....88

El Origen de las Máquinas Narrativas ..... 90

Textos Estocásticos o Aleatorios ..... 91

El Ordenador Comienza a Narrar Historias ..... 92

Máquinas, Historias y Arte Digitales ..... 103

Generadores de Historias ..... 103

IV. JUEGOS NARRATIVOS DIGITALES ..... 107

4.1 Generalidades sobre los Juegos Digitales .... 110

4.2 Los Juegos Digitales desde la Óptica Narrativa ..... 118

4.3 Ludólogos vs. Narratólogos; Historia de un Conflicto ..... 122

4.3.1 Opiniones Ludológicas ..... 123

4.3.2 Opiniones Narratológicas ..... 128

4.3.3 Opiniones Integradas ..... 131

4.4 Cualidades entre narrativas y juegos

en entornos digitales ..... 134

4.4.1 Elementos Narratológicos ..... 136

4.4.2 Elementos de Poética Digital ..... 138

Transtextualidad $\ldots . .138$
Interactividad $\ldots . .140$
Inmersión $\ldots . .141$

Sistemas Emergentes ..... 142

4.4.3 Elementos Hermenéuticos ..... 144

4.4.4 Elementos Formales ..... 146

4.4.5 A manera de desenlace ..... 150 


\section{PROCESO DE CREACIÓN PARA ESTIMULAR}

HABILIDADES NARRATIVAS LÚDICAS ..... 155

5.1 La Creación Narrativa en 5 Pasos: Idear, Componer Experimentar, Editar y Evaluar ..... 157

5.1.1 Primera Etapa: IDEAR ..... 158

5.1.2 Segunda Etapa: COMPONER ..... 159

5.1.3 Tercera Etapa: EXPERIMENTAR ..... 161

5.1.3.1 Recursos Narratológicos ..... 161

El Manejo del Tiempo, ¿Cuál Tiempo? ..... 161

Creación de Personajes ..... 162

Construcción del Mundo Narrativo ..... 165

Elementos no Narrativos, Textos Imbuidos:

Cut-scenes y Scripted Events ..... 167

5.1.3.2 Recursos de Poética Digital ..... 168

Interactividad ..... 170

5.1.3.3 Recursos Hermenéuticos ..... 173

5.1.3.4 Recursos Formales ..... 174

5.1.4 Cuarta Etapa: EDITAR 177

5.1.4.1 Recursos Analógicos ..... 177

5.1.4.2 Recursos Multimedia ..... 177

5.1.5 Quinta Etapa: EVALUAR _.... 179

5.2 El modelo de Narrativas Lúdicas en Grim Fandango ..... 180

5.2.1 Elementos Narratológicos ..... 183

5.2.2 Elementos Hermeneúticos ..... 188

5.2.3 Elementos Formales ..... 192 
VI. 150 RETOS PARA NARRAJUGADORES .... 195

6.1. Labores Previas ..... 197

6.2. Prácticas para Idear Relatos ..... 198

6.3. Prácticas para Imaginar Historias .... 199

6.4. Generar Historias a partir de Imágenes .... 201

6.5. Fuentes de Inspiración Literaria, Histórica o Lúdica ..... 205

6.5.1. Fuentes Literarias ..... 205

6.5.2. Fuentes Históricas ..... 208

6.5.3. Fuentes Lúdicas ..... 210

6.6. Componer Historias .... 214

6.6.1. Determinar un Género, ¿De Juego o Literario? ..... 214

6.6.2. Recursos de Composición ..... 216

6.6.3. Organizadores de Relatos ..... 221

6.7. Experimentar .... 224

6.7.1. Recursos Narratológicos ..... 224

6.7.1.1. Nivel del Texto ..... 224

6.7.1.2. Nivel de la Historia ..... 226

6.7.1.3. Nivel de la Fábula ..... 227

6.7.2. Recursos de Poética Digital .... 229

6.7.3. Recursos Hermenéuticos ..... 231

6.7.4. Recursos Formales o Estructurales ..... 233

6.8. Editar .... 239

6.8.1. Historias en Formatos Analógicos .... 239

6.8.2. Proyectos Digitales ..... 241

6.9. Producto Final: Evaluar ..... 244

CONCLUSIONES ..... 247

RESÚMENES

Resumen en Castellano ..... 259

Abstract in English ..... 260

Resum en Valencià ..... 261

BIBLIOGRAFÍA .... 263

WEBLOGRAFIA .... 275

SITIOS WEB RECOMENDADOS .... 278 
1. Esquema de la Novela Life a User's Manual

de Georges Perec, Verba Mundi Book, Boston, 2009.

2. Clasificación de los Tipos de juego según Bob Hughes y Sandra Melville que aparece en: Playworker's taxonomy of play types, PLAYLINK, London, 2002.

3. Algunas Tareas de los Escritores de Medios Digitales, Tomado de: New Writing Universe [Texto on line] en: http://www.australiacouncil.gov.au/writersguide Consultado: 18/01/2013.

2. The Future of Books by James Warner [Texto on line] en: http://www.mcsweeneys.net/articles/the-future-of-books 286 Consultado: 21/01/2013. 



\section{INTRODUCCIÓN}

Presentamos este trabajo de investigación con el cual aspiro a obtener el grado de Doctor ante la Universidad Politécnica de Valencia. En él se examinan aspectos que buscan establecer una conexión entre la literatura y el videojuego desde la óptica de la composición narrativa. Buscamos que el juego se convierta en un detonante creativo. Para ello analizamos los puntos donde convergen y distinguen las historias y los juegos. Identificando sus propias cualidades nos permitirá apreciar lo que la literatura puede hacer por el videojuego y viseversa, teniendo como principal interés, encontrar los mecanismos que faciliten las labores de los escritores de relatos y diseñadores de juegos. Deseamos promover la composicón de un tipo de historias que se generen a partir de "estructuras lúdicas", entendidas como aquellas que poseen atributos propios de los juegos, ya sea con formatos que deben armarse, explorarse o que demandan cierta interacción por parte del jugador con la historia o el sistema. El principal interés al elaborar este trabajo es dotar de recursos narrativos y lúdicos a cualquiera interesado en componer y relatar historias, ya sea diseñadores, escritores, guionistas o artistas digitales. Esperamos facilitar su camino de creación narrativa, al ofrecer algunos ejemplos de piezas que pueden servir de modelo para experimentar sus propias versiones.

El título del trabajo "Estructuras narrativas lúdicas: un resorte creativo para artistas digitales" refiere como primera idea, la de estructuras narrativas lúdicas, entrelazando los conceptos de literatura y juego, con la intención de aportar elementos teóricos y metodológicos que permitan conformar una "Narratología Digital". Porque nos parece necesario identificar aquellos elementos que resultan precisos de atender para la composición de textos en entornos digitales. De ahí que el mismo título refiera además, a la idea de resorte creativo, en el sentido de lograr establecer confluencias y conexiones entre el lenguaje como medio de composición y la narrativa lúdica como forma de creación. Sin duda podemos relatar historias de muy diversas maneras, sin embargo, nuestra intención es utilizar el juego como motor para generar historias, de ahí que la idea de juego sirva de resorte de estructuras narrativas, que presenten cualidades semejantes a un juego e incluso inspiradas en videojuegos. Porque estamos seguros que esta conexión entre literatura y videojuego nos permite generar textos que puedan aplicarse a entornos digitales y presenten una nueva posibilidad que debemos explorar al relatar historias.

Partimos de la premisa de que todas las personas poseen, en mayor o menor medida, la habilidad para narrar historias, cierta cosmoplasticidad que nos caracteriza al permitirnos, de manera secuencial, estructurar pensamientos y experiencias $\mathrm{y}$ 
convertirlas en historias o en algo muy semejante a éstas, en forma casi natural. Confirmar cómo las historias forman parte del desarrollo no sólo intelectual sino cultural de la humanidad, motiva nuestro interés de promover, entre las nuevas generaciones, la necesidad de estimular esta actividad y sobre todo, encontrar nuevas maneras de hacerlo al adaptar nuestras historias a los recursos tecnológicos que disponemos y que debemos aprovechar para estas labores.

\section{Interés del tema de estudio}

El interés de estudio proviene del vinculo profesional que he desarrollado con las letras, las prácticas de artes plásticas, el diseño de materiales de divulgación y exhibiciones que buscan revalorar el poder del lenguaje y de las historias, con el incentivo de aprovechar el potencial del videojuego como recurso de experimentación, al ser un modelo que ofrece un gran potencial.

A través de este trabajo deseamos explorar y conocer las bases de la narratología digital contemporánea y las posibilidades narrativas de los videojuegos que nos permitan responder a tres inquietudes iniciales: Primera, encontrar nuevos formatos, emplear diversas maneras de estructurar las acciones, introducir elementos que permitan una mayor interacción entre lectores e historias, la búsqueda de recursos que amplíen el potencial creativo de los escritores; porque los entornos digitales han provisto nuevos formatos para generar y distribuir las historias. Herramientas como el Internet, los dispositivos móviles, las redes sociales ofrecen herramientas que se pueden aprovechar. Partimos de una simple corazonada y de una inquietud que nos intriga: Si existen tantos medios que facilitan la comunicación, lectura, creación y circulación de nuevos textos, seguro también existen nuevas formas (tecno-artísticas) para crearlas. Segunda, potenciar la labor de artistas, diseñadores o guionistas, interesados en componer relatos, desarrollar historias o estructuras de significación que complementen las obras artísticas y favorezcan el surgimiento de historias cuyos contenidos enriquezcan cualquier proyecto u obra artística.

Nos referiremos a la posibilidad de generar andamiajes narrativos para entornos digitales, como una estructura que permita organizar elementos narratológicos, desarrollar tramas y emplear formatos de mayor complejidad que la fórmula iniciodesarrollo-desenlace de las historias tradicionales y pueda "relatar" historias con múltiples visiones, dotada de metáforas o símbolos y cuya estructura permita la interacción o la concurrencia de múltiples elementos como el hecho de que las historias puedan tener diferentes niveles de significación y complejidad narrativa y contribuir a desarrolar formas expresivas con mayor riqueza formal y de contenidos. Y la tercera inquietud busca revalorar las cualidades narrativas que pueden desarrollarse a partir del formato que algunos videojuegos presentan y que pueden servir como modelo para componer narrativas. Esto nos resulta importante dado el menosprecio de algunos estudiosos y teóricos de los videojuegos quienes defienden la autonomía del fenómeno y niegan cualquier vínculo con la narrativa o la literatura, por el detrimento que pudiera causar a su "jugabilidad". Al respecto, buscamos limar esta distinción apoyados en 
nociones dictadas por teóricos que revaloran el potencial narrativo del videojuego. Ludólogos y narratólogos, encontrarán en este estudio una manera de no sólo convivir, sino de integrar ambas posturas con el único fin de avanzar en el diseño de nuevas historias.

Porque apreciamos que las historias y los juegos pueden no sólo se complementan sino que incluso se enriquecen mutuamente y porque, en el fondo, deseamos que el mismo interés que generan los juegos en los jugadores, puedan despertar las historias en los lectores. Que los nuevos lectores busquen en nuevas formas narrativas lúdicas, jugar, interactuar y recomponerlas a partir de la solución de enigmas o el cumplimiento de tareas y misiones. Porque estamos seguros que el juego puede aportar mucho a la literatura, como la literatura al juego. Ya tendremos oportunidad de confirmarlo a lo largo del trabajo, buscando que ésto permita mejorar la composición de nuestras historias. Mediante recursos del lenguaje, la literatura y el juego, obtenemos nuevas maneras de articular historias. Porque estamos convencidos que la literatura contemporánea, en su afán de innovación y búsqueda de nuevas formas de creación, ha encontrado en el juego un recurso que deseamos explorar y experimentar.

\section{Objetivos}

El objetivo principal de esta investigación es estimular a los nuevos creadores de arte digital la utilización del lenguaje, la narración y las estrategias del juego como recurso de creación, esperando que las aportaciones de esta tesis propicien su revaloración por la nueva generación de artistas digitales, conscientes de que al incluirlo en sus recursos creativos incrementen la significación de sus piezas. Deseamos subrayar el acercamiento a la literatura como fuente de inspiración, sobre todo buscamos este acercamiento a través de ciertos textos que emplean el juego como recurso de composición. Apreciar las cualidades que han ganado las historias al emigrar a entornos digitales, nos obliga a apreciar las cualidades narrativas que los videojuegos poseen o pueden desarrollar.

Aprender a relatar historias y apoyar las labores de otros interesados en componerlas, implica otros objetivos específicos, como:

Explorar nuevos caminos que apoyen el potencial expresivo e informativo de los futuros contadores de historias.

- Que este trabajo sea un "resorte" que estimule, guíe y fortalezca sus habilidades narrativas.

- Que incentive la experimentación de nuevas formas narrativas fragmentarias, laberínticas o hipertextuales.

- Que tengan deseos de explorar la complejidad de las "imágenes que se leen", las lecturas que se observan o los textos que se van armando a partir de la interacción de los lectores-jugadores.

Nuestro enfoque de investigación atiende dos aspectos principales: por un lado integrar una visión panorámica que permita conocer los vinculos que se han establecido entre la 
literatura y los juegos; apreciando cómo ambos han sido fundamentales para el desarrollo de la humanidad y en cierta medida el juego ha favorecido la composición de algunos textos literarios, cuyas características deseamos destacar en este estudio y que se analizarán a detalle. Y en un segundo plano, aportar recursos narratológicos capaces de relacionar los elementos tradicionales tales como el manejo de personajes, tiempos, organización de las secuencias y acciones narrativas, la focalización, entre algunos otros, con los elementos de la poética digital como la transtextualidad, la inmersión o la interactividad y poder además incluir elementos visuales, sonoros y aquellos elementos formales propios de los videojuegos, como reglas, retos, enigmas o acertijos.

\section{Estructura y metodologìa}

Hemos organizado este documento en seis apartados; a grandes rasgos planteamos en los primeros cuatro, una base informativa y teórica que conforma el sustento conceptual de nuestra investigación, apoyada en la revisión bibliográfica de destacados trabajos de teóricos y especialistas en la materia. En el quinto apartado se propone un modelo para el análisis de narrativas digitales lúdicas y en el último ofrecemos, de manera práctica, ejercicios para comenzar a escribir, planteados como "Retos para narrajugadores".

En el Apartado 1. Homo narrans, apreciamos el origen, valor y trascendencia de la habilidad expresiva y narrativa como una herramienta cultural de la humanidad. La capacidad humana de contar historias confirma su importancia como producto creativo y revaloriza su herramienta fundamental: el lenguaje y su vínculo con el desarrollo del pensamiento. La herencia narrativa y su experimentación se han fusionado por siempre y hoy requiere que se evalúe y adecúe a nuevas condiciones tecnológicas. Buscamos en la mitología, en el arte rupestre, en los rituales o en piezas ornamentales, motivos y recursos narrativos que además nos confirmen la necesidad de componer las "mitologías" de nuestro tiempo. Reconocemos la capacidad creativa del hombre y la necesidad e importancia de revalorar y ampliar el manejo del lenguaje y sus aplicaciones adecuadas a nuevos dispositivos tecnológicos. En el Apartado II. Homo ludens, apreciamos la relación entre el hombre y el juego en el entendido de ser una habilidad expresiva e imaginativa de la humanidad. Establecemos un nexo entre juegos, lenguaje y creación literaria en el cual se convierten en herramientas muy poderosas para la generación de nuevas formas narrativas. Revisamos piezas que combinan sistemas de juego y lenguaje. Juegos en los que el lenguaje establece conexiones lúdicas y analizamos la posibilidad de promover la articulación de historias a través de juegos. Con estas reflexiones esperamos que se aprecie el juego como un recurso esencial en la creación, la experimentación y la invención. En el Apartado III. Narrans et Ludens exploramos cómo el juego ha sido una herramienta de creación narrativa ejemplificado a través del trabajo de escritores que han fusionado estas cualidades en piezas experimentales e innovadoras, que pueden tomarse como modelos y favorecer el desarrollo de narrativas cuya complejidad estructural pueda favorecerse al utilizar los entornos digitales para componerlos, distribuirlos o reproducirlos. Algunos juegos, tanto 
analógicos como digitales; también han enriquecido la composición de historias. Contemplaremos algunos elementos teóricos que sustentan la creación narrativa, sobre todo aquellas propuestas metodológicas que facilitan la generación y "migración" a distintos medios, como parte de la función que los escritores pueden desarrollar. Deseamos facilitar el acercamiento de los interesados a la literatura y a referencias que puedan convertirse en futuras líneas de investigación. Con el Apartado IV. Los Juegos Narrativos Digitales, se confirma la importancia de la fusión entre juego y narrativa, a partir de un estudio histórico que muestra el panorama entre ambos fenómenos desde los orígenes de los juegos digitales, las primeras aventuras gráficas o los juegos conversacionales. El objetivo de este apartado es completar el escenario que permita confirmar el balance que existe entre las posturas de narratólogos y ludólogos. Partimos de la identificación de las cualidades comunes entre narrativas y juegos en entornos digitales, tanto desde la óptica narratológica como desde la óptica del juego con la intención de conformar un listado de elementos que integren una especie de narratología lúdica digital. Entendida como la posibilidad de recurrir a las propiedades de los juegos para componer relatos y narrativas. Buscamos que puedan generar textos que reflejen elementos creativos, que promuevan la interacción entre los usuarios/jugadores/lectores que incentiven su poder de exploración y descubrimiento; introduzcan elementos relacionados con la competición, como el plantear retos y enigmas por resolver o tareas por emprender. Que transmita sensaciones de participación activa, como si tomaran el rol de los personajes en un grado de inmersión gracias a las simulaciones fantásticas a las que se enfrentan. Esperamos que dicha narratología, inspirada en juegos, sea una aportación de esta investigación que muestre a los diseñadores de textos una manera de componer historias con elementos que podemos asociar a los recursos propios de los sistemas interactivos, sin perder el interés de generar productos artísticos que transmitan placer y curiosidad.

Para clasificar los elementos que conforman la narratología digital hemos determinado cuatro líneas de análisis que son los elementos propiamente narratológicos, los de la poética digital, los hermenéuticos y los formales o estructurales. Los cuales serán ampliados y servirán para generar narrativa o textos a partir de los elementos que los escritores deben considerar para componerlos, considerando principalmente un modelo textual con cualidades que podemos asociar a las que son propias de los juegos. En el Apartado V. Proceso de Creación para Estimular Habilidades Narrativas Lúdicas, presentamos diversas propuestas que permiten experimentar formas narrativas innovadoras. Se trata de ciertos modelos de un proceso sistemático que oriente a los escritores a componer mejores textos con estructuras y contenidos más complejos, que puedan apoyarse en juegos con mejores historias, más activas y emocionantes. En un segundo momento, mostramos un modelo de narrativa lúdica ejemplificado por el análisis del videojuego Grim Fandango en el que mostramos sus cualidades narratológicas (dentro de la poética digital), hermenéuticas y formales o estructurales. Finalmente, en el Apartado VI. Retos para Narrajugadores, proponemos un método conducido que pone en práctica estas cualidades de la narratología digital que hemos integrado y permita ser un laboratorio de creación y experimentación lúdico-narrativo. 
Para ello hemos organizado las actividades de acuerdo a cinco etapas que facilitan las labores de los narrajugadores al dotar de ideas y procedimientos que le ayuden a entender las labores de composición narrativa como un proceso. Estas etapas son: Idear,

Componer, Experimentar, Evaluar y Editar. Esperamos que estos ejercicios conducidos, sirvan de estímulo para la invención ingeniosa de nuevas propuestas y sobre todo, despierte el interés de las nuevas generaciones para experimentar en el mundo de la narrativa, porque consideramos que el presente trabajo puede orientar, tanto a profesores como alumnos, incluso de grados de enseñanza media en el uso de los nuevos medios y las tecnologías informáticas y de comunicación para generar proyectos audiovisuales. Porque creemos que a la par de manejar estos dispositivos, los jóvenes estudiantes deben tener herramientas para llevar a cabo ejercicios que les faciliten el diseño de textos y guiones.

\section{Justificaciones}

Cada día es más común llevar a cabo conexiones entre distintos campos de estudio, con el fin de ampliar el nivel de entendimiento y análisis de los recursos disponibles que ofrecen un potencial de experimentación creativa. Por ello, como se ha señalado antes, uno de los objetivos de este trabajo es analizar el lenguaje y sus cualidades lúdicas, con el fin de que pueda considerarse como un elemento de creación. Crear historias a partir de juegos de palabras, imágenes que relaten sucesos, metáforas que representen historias o la incorporación de estructuras gráficas como resorte narrativo, son solo algunas de las propuestas que nos gustará promover con proyectos concretos aplicados a trabajos de divulgación, artísticos o de cualquier índole porque entendemos que la conjunción de el juego y el lenguaje pueden despertar un potencial creativo entre los creadores. Nuestra intención a lo largo del trabajo ha sido mostrar un panorama de piezas literarias y modelos de juego que faciliten y detonen nuevas propuestas para estructurar proyectos a partir de los contenidos y las historias que puedan acompañar cualquier trabajo artístico. Nuestro enfoque por ende busca llevar a cabo un análisis que considere el valor del lenguaje, de las historias y de la necesidad de adoptar modelos para generar nuevas propuestas de composición.

Deseamos que los jugadores revaloren la importancia de las historias al interior de sus aventuras lúdicas. Porque es innegable que las historias contribuyen a ampliar y enriquecer las experiencias de los jugadores para que se vuelvan más significativas. Basta echar un vistazo a algunos videojuegos y apreciar su origen literario como And then there were None [Diez Negritos] de Ágatha Christie, con sus aventuras y misterios por resolver. Novelas clásicas que se han convertido en videojuegos como: Inkheart [Corazón de tinta], Los Tres Mosqueteros de Alejandro Dumas, Sherlock Holmes de Sir Arthur Conan Doyle, Robinson Crusoe, de Daniel Defoe, entre otros. Encontramos por otro lado, videojuegos que se apoyan en mitos o leyendas tan arraigadas como la 
tradición prehispánica del culto a los muertos como: Grim Fandango ${ }^{1}$ (PC, 1998). The longest Journey ${ }^{2}$ (PC, 2000), Beyond Good and Evil ${ }^{3}$ (PS2, GC, PC, Xbox, 2003), Psychonauts ${ }^{4}$ (Xbox, PC, 2005) y algunos otros que confirman el valor de las historias en estrategias inspiradas en batallas épicas, intrigas o romances que confirman lo valioso que son las historias para las experiencias del juego.

En cierta medida algo que justifica la necesidad de emprender un proyecto de investigación en este campo atiende a enmendar en lo posible, la desproporción que existe en relación al avance tan significativo que la tecnología ha conseguido a través del diseño de los recursos gráficos, sonoros y de manipulación y capacidad de respuesta e interacción, únicos en los medios digitales y de manera particular, en los videojuegos; en relación a la experimentación y desarrollo de nuevas maneras de contar historias. Porque pareciera que no existe proporción entre este avance técnico-artístico y el desarrollo de mejores historias o maneras más creativas para contarlas. Esta motivación dio origen a este estudio, porque estamos convencidos que los entornos interactivos ofrecen recursos que requieren de más experimentación que favorezca la composición de mejores historias y demandan mayor atención por parte de académicos y artistas.

Además deseamos establecer un balance entre las posturas teóricas que han establecido un debate y han distanciado los juegos de las narrativas. Pretendemos confirmar que no existe razón para que permanezcan indiferentes; al contrario, deseamos mostrar cómo pueden favorecerse mutuamente al ser herramientas útiles para la composición de historias más lúdicas y de juegos más narrativos. Con ello buscamos ampliar las herramientas de creación de los artistas analógicos y digitales, al mostar recursos que complementen proyectos culturales y estéticos como: guiones para películas, videos, performances, o cualquier otra presentación que requiera una mayor complejidad narrativa y sobre todo, creativa.

Entendemos que presentar y defender una tesis de narrativa y videojuego en la Facultad de Bellas Artes de la Universidad Politécnica de Valencia, dentro del programa de Doctorado en Artes Visuales e Intermedia, puede darse por el creciente desarrollo de líneas de investigación interdisciplinares, dentro de este contexto nuestro trabajo pretende aportar recursos e ideas para facilitar el trabajo de artistas y diseñadores que buscan integrar en sus proyectos, textos y otros recursos narrativos. Compartimos una visión que confirma el valor agregado que "mejores historias" pueden otorgar a sus proyectos. Porque nuestra actividad académica y profesional ha estado vinculada a la composición de historias con el afán de promover nuevas maneras de llevarlas a cabo. Véase en el siguiente esquema las diversas disciplinas desarrolladas profesionalmente que han originado y justificado este estudio.

\footnotetext{
${ }^{1}$ Véase: http://www.grimfandango.net/ Consultado: 19/09/2012

${ }^{2}$ Véase: http://www.longestjourney.com/ Consultado: 19/09/2012

${ }^{3}$ Véase: http://beyond-good-and-evil.ubi.com Consultado: 19/09/2012

${ }^{4}$ Véase: http://www.psychonauts.com/ Consultado: 19/09/2012
} 
Esquema de prácticas e interés profesional de este estudio.

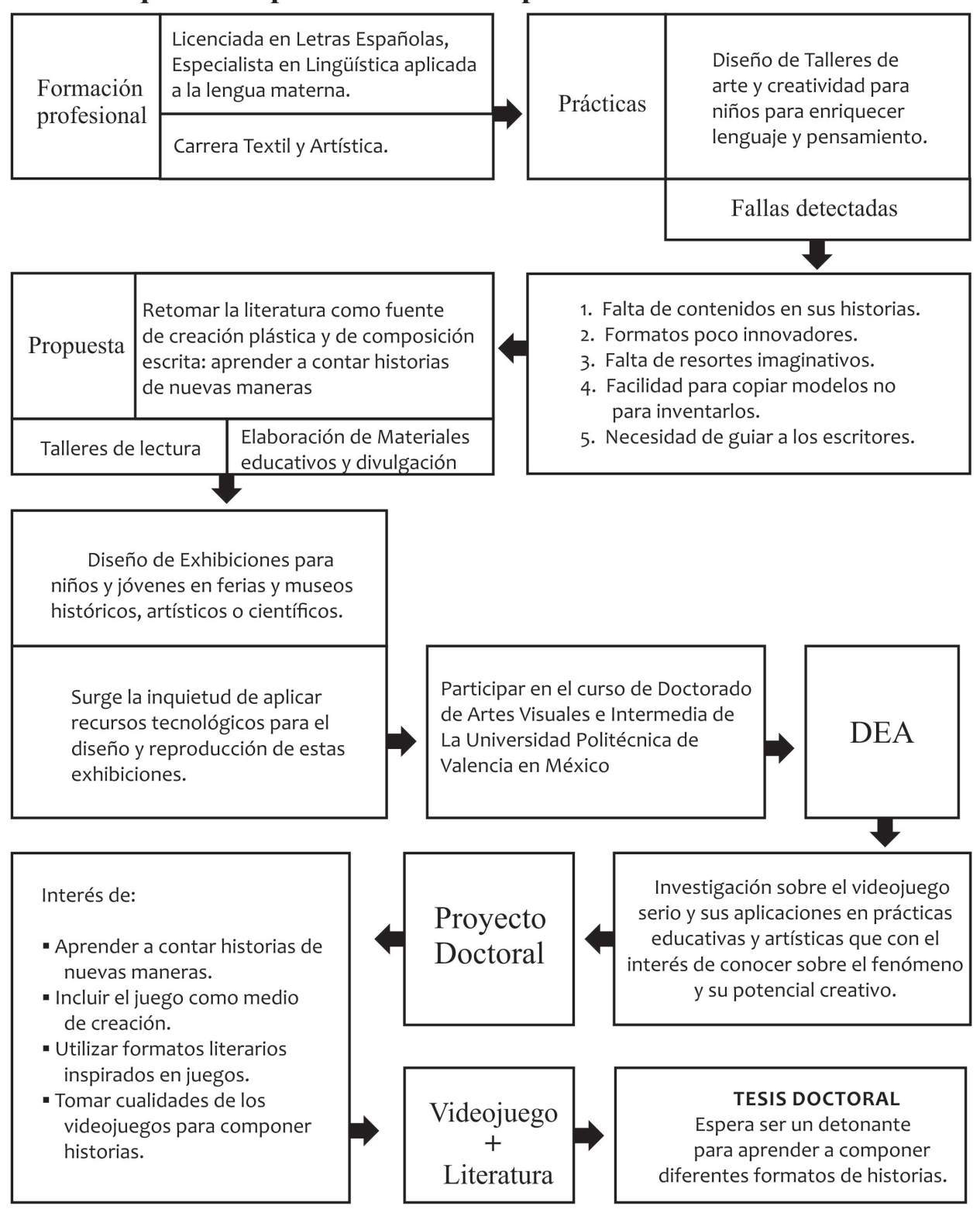

Si a través de este trabajo logramos despertar el interés de jugar y crear estructuras narrativas innovadoras; si además transmitimos la urgencia de revalorar el poder de la palabra y buscamos integrar el lenguaje y la conformación de ideas al campo de la creación artística, habremos conseguido el principal objetivo de nuestro trabajo: contribuir a formar narradores y diseñadores de textos que puedan componer sus relatos en cualquier entorno, incluso en medios digitales. 


\section{HOMO NARRANS}

Nuestra especie se ha distinguido por construir una rica herencia cultural a partir de la composición de historias. En este apartado deseamos reflexionar en torno a las historias; su origen, evolución e importancia para el mundo de la creación artística contemporánea. Nuestro objetivo es apreciar cómo las historias que hemos conocido a través de libros, películas o videojuegos son producto de varios milenios de experimentación creativa. Las historias han experimentado formatos y estructuras narrativas que han evolucionado y se han fusionado con otras actividades como la pintura, la danza o el juego. De ahí el interés de contribuir al diseño de historias que sean acordes a las nuevas condiciones culturales y tecnológicas de nuestro momento.

Si nos remontamos al origen antropológico de las primeras historias, seguramente apreciaríamos que estuvieron ligadas a sus costumbres, creencias y rituales; reflejando no solo su identidad, sino el grado de desarrollo alcanzado por su lenguaje y su pensamiento. Resulta por lo tanto interesante determinar en qué medida las historias de nuestro tiempo reflejan el grado de desarrollo tecnológico y son el reflejo de nuestra actualidad.

La literatura y el cine nos han provisto de mitos, leyendas e historias inspiradas en mundos míticos que han sido fuente de inspiración para generar las mitologías de nuestro tiempo; pero debemos seguir construyendo nuevas mitologías con formas y temáticas que sean el reflejo de la visión contemporánea. Si la tecnología ha permitido grandes avances $\mathrm{y}$ nos ha permitido disfrutar nuevos formatos, debemos adaptar nuevas posibilidades creativas. Advertimos la necesidad de implementar nuevas maneras de contar historias, evitando así el mantenernos anclados, repitiendo los viejos formatos, limitando la utilización de los recursos tecnológicos disponibles.

Si queremos descubrir nuevas maneras de escribir historias; proponemos echar un vistazo al pasado narrativo de la humanidad y obtener un panorama que nos permita apreciar cómo las historias se han ajustado a cada momento histórico y a cada formato; ya sea de manera oral o a través de tablillas de cera o barro, los pergaminos, textos manieristas

\footnotetext{
${ }^{5}$ SHANK, Roger C., Tell me a story; narrative and intelligence, Northwestern University Press, Evanston, 1990. (p. 241)
} 
ilustrados a mano o impresos por medios mecánicos hasta su evolución a pantallas y medios electrónicos. La migración de un medio al siguiente ha enriquecido el potencial expresivo de las historias. Las cuales han evolucionado de manera ininterrumpida desde siempre. Hoy deseamos conocer cómo producir nuevas historias y cómo enriquecerlas con programas informáticos que activan sonidos, desplantan gráficos $3 \mathrm{D}$ o videos y admiten cualidades de inmersión o interacción. Porque estas herramientas son propias de nuestro tiempo. Por ello es preciso experimentar ciertas propiedades que permiten generar hilos narrativos laberínticos, ligados a la solución de enigmas o al cumplimiento de ciertas pruebas o tareas. El lector ha aprendido a formar parte de las historias y a transformarlas a su antojo. Mediante el uso creativo de estas nuevas herramientas, podemos construir las historias del presente y del futuro.

Al respecto James Warner con mucho humor y exageración plantea que el futuro de las lecturas será así:

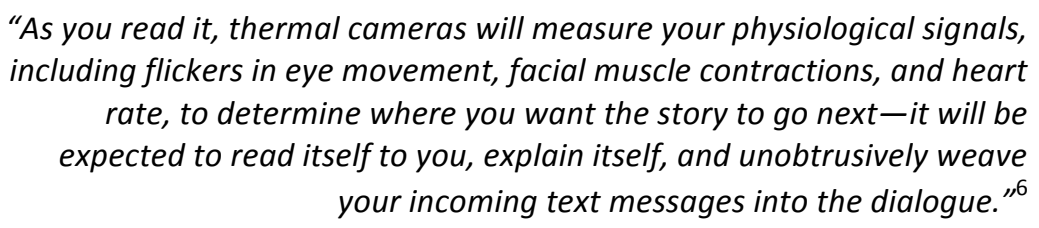

Estas predicciones quizá estén muy distantes de ocurrir, sin embargo es importante mostrar formas innovadoras pero que tengan cierto apego con la tradición, y que sobre todo cuenten algo significativo. ¡Qué placer nos da descubrir una buena historia! Ya sea a través de un libro, una película, la narración imaginativa de un amigo, leer el periódico, visitar una exposición de arte, ver la televisión o jugar videojuegos nos permite entrar en contacto con diferentes tipos de historias. Las historias se vuelven inolvidables, según Italo Calvino, cuando:

\footnotetext{
"Leo lo que me parece suficiente para descubrir los tres elementos que me sirven para establecer si un libro existe o no: si tiene un lenguaje, si tiene una estructura, si muestra algo; de ser posible, algo nuevo" $^{7}$
}

Estoy más que convencida que si deseamos aprender a construir mejores historias, debemos considerar estos tres puntos de partida: apreciar el valor del lenguaje, buscar una estructura narrativa novedosa y tener algo que contar.

Si contribuimos en estimular el incremento de las habilidades narrativas, también favorecemos que los estudiantes y los artistas aumenten sus ideas. Alex Grijelmo ${ }^{8}$ confirma que hemos perdido nuestra capacidad de generar ideas y por su parte, Nicholas

\footnotetext{
6WARNER, James "The future of books" [Texto on-line] en: http://www.mcsweeneys.net/articles/thefuture-of-books Consultado: 15/06/2011 [Anexo 1:1]

${ }^{7}$ LOPEZ PORTILLO, Esther, El Castillo de los destinos cruzados de Italo Calvino [Texto on-line] en: http://sepiensa.org.mx/contenidos/2005/I_castillo/castillo_1.htm Consultado: 23/03/2010

${ }^{8}$ GRIJELMO, Álex, Defensa apasionada del idioma español, Taurus, México D.F., 2002. (p.23)
} 
Carr $^{9}$ menciona que la pobreza del lenguaje refleja la pobre calidad de los pensamientos. De ahí la importancia de buscar propuestas que nos ayuden a estimular y fortalecer estas habilidades.

\section{EI hombre y las historias}

Desde tiempos remotos el hombre ha dado forma a sus pensamientos, recuerdos y vivencias a través de las historias. Poder relatar sucesos reales o imaginarios le ha dado oportunidad de revivir, protagonizar y habitar mundos oníricos; transportarse a lugares y tiempos distantes, pero sobretodo, confirma algo sustancial: que los hombres no sólo generan historias, sino que buscan hacerlo de manera creativa; transformando casi cualquier cosa en una historia. Esta idea está soportada por las siguientes nociones de antropólogos, filósofos y sociólogos comoErick Havelock ${ }^{10}$, quien sugiere que "las historias han sido la trama y urdimbre de nuestra existencia"; Roger Shank ${ }^{11}$ argumenta $^{2}$ que atesoramos experiencias que compartimos con los demás en forma de historias. Nacemos entre historias y anécdotas familiares; y a lo largo de la vida recopilamos muchas más. Poseemos una habilidad innata de estructurar el mundo en forma de historias; Jerome Bruner ${ }^{12}$, confirma que la narrativa y el contar historias es una parte intrínseca de la experiencia humana. Por su parte, Liam Durcan ${ }^{13}$ confirma que tenemos una predisposición para generar una especie de orden secuencial de las cosas y H. Porter Abbot sugiere que poseemos cierta capacidad genética para narrar historias:

"The gift of narrativeis so pervasive and universal that there are those who strongly suggest that narrative is a "deep structure" a human capacity genetically hard-wired into our minds" 14

John D. Niles, designa el término "cosmoplasticidad" a la habilidad de reconstruir el mundo en forma de historias y denomina al género humano como "Homo narrans" en relación a esta destreza que nos distingue del resto de los seres vivos. "Los hombre no

\footnotetext{
${ }^{9}$ Nicholas Carr plantea que el cerebro de los lectores es diferente del de los no-lectores, no sólo por la manera que entienden el lenguaje, sino cómo procesan signos visuales, razonan y forman su memoria, véase: CARR, Nicholas, The Shallows; What the Internet is doing to our brains, W.W. Norton \& Company, New York, 2010. (p. 51)

${ }^{10}$ HAVELOCK, Erik A. The muse learns to write, Yale University Press, New Haven, 1986.

${ }^{11}$ SHANK, Roger C., Tell me a story; narrative and intelligence, Northwestern University Press, Evanston, 1990. (p. 16)

${ }^{12}$ BRUNER, Jerome, Acts of Meaning. Harvard University Press, Cambridge MA, 1990 (p.77)

${ }^{13}$ DURCAN, Liam [Texto on-line] en: http://braindetectives.blogspot.com/Consultado: 28/05/2011

${ }^{14}$ ABBOT, H. Porter, The Cambridge introduction to narrative, Cambridge University Press, Cambridge, 2008.
}

(p.3) 
sólo han tenido éxito negociando con la naturaleza en la búsqueda de sustento y refugio, sino ha aprendido a poblar los mundos mentales que son la materia de los sueños". ${ }^{15}$

El hombre a través de las historias desarrolló su imaginación e intelecto. ¿Y si no hubiera desarrollado las historias? ¿Se hubiera detenido el desarrollo evolutivo intelectual? Seguramente nuestra vida sería muy diferente si no tuviéramos esta capacidad. John Polkinghorne $^{16}$ afirma que el cerebro humano está construido de tal manera que capta muchas relaciones complejas en forma de estructuras narrativas, metáforas o analogías. Por su parte, Katherine Nelson, Michael Mateas y Phoebe Sengers ${ }^{17}$ retoman la idea de que "los marcos narrativos que generamos son una importante manera de asimilar el mundo". Monika Fludernik amplía esta opinión al señalar que: "We may all conceive of each of our lives a journey constituted by narration... Life is described as a goal-directed chain of events" ${ }^{, 18}$.

Estamos tan acostumbrados a vivir rodeados de historias que resulta difícil imaginar cómo sería nuestro mundo si no las tuviéramos; crecer sin leyendas y mitos sería una pena: no conocer héroes inmortales como Odín, Marduk, Theseo o Hécules; apreciar las bondades divinas de Visnú, Tezcaltlipoca o Zeus. Sentirse atrapado en el laberinto de Minos; escapar ante la mirada de Medusa o del embrujo de las sirenas; navegar con Noé o visitar el paraíso de Adán y Eva; cruzar el rio de la muerte en ancas de un xolo izcluintli $^{19}$ marrón o sobre el bote de Carón; pesar nuestro corazón ante el tribunal de Osiris, esconderse dentro de una escultura gigante en la Plaza de Troya, sobrevivir a diluvios, o vivir hechizados por cuentos fantásticos y mitos que nos dan cuenta de nuestra historia ancestral; cosmogonías y fábulas que nos acompañan desde niños, son la más grande herencia que podemos atesorar en nuestra imaginación.

\section{Definiendo narrativa, historia y relato}

Narrar es referir oral, visual o lingüísticamente una sucesión de hechos que resultan interconectados con cierta causalidad y sucedan de forma más o menos lógica, no sólo de manera estructural sino semánticamente. Donde no hay sucesión de acontecimientos narrados, no hay relato, sólo descripción.

En este trabajo utilizamos "historia", "narrativa" o "relato" de manera indistinta. Apoyados en definiciones como la de Roland Barthes ${ }^{20}$ quien menciona que el relato

\footnotetext{
${ }^{15}$ NILES, John D., Homo Narrans, the poetics and anthropology of oral literature, University of Pennsylvania, 
puede ser soportado por el lenguaje articulado, oral o escrito, por la imagen fija o móvil, por el gesto y por la combinación ordenada de estos elementos. Desde esta visión semiológica, la narración puede ser muy diversa, contener cualquier tipo de signos y designar una gran variedad de elementos. Esto explica por qué una pintura o una fotografía posee ciertas cualidades narrativas; sin embargo, si deseamos contemplar la definición lingüística-analógica, solo consideraremos las secuencias basadas en las estructuras construidas a partir de signos lingüísticos.

Generalmente asociamos las historias a ciertas manifestaciones literarias de valor artístico como cuentos, novelas, obras teatrales o guiones para cine o televisión; sin embargo, cuando intentamos componerlas, nos damos cuenta que toman un sinnúmero de formas y posibilidades muy variadas; de ninguna manera las historias están exclusivamente escritas o impresas en libros; ya que podemos encontrarlas en imágenes gráficas, retratos, murales, grabados, vitrales, esculturas y en otras manifestaciones artísticas e incluso en piezas ornamentales y utilitarias como cerámicas, tapices o anuncios publicitarios y en otras manifestaciones culturales como las tiras de historietas, juegos de mesa y videojuegos. Así como cualquier mensaje o idea puede convertirse en un relato, éstos pueden adaptarse a cualquier formato.

Volviendo a las definiciones, Gerard Genette ${ }^{21}$ propone que las historias o relatos tienen diferentes grados de "narratividad" es decir, la facilidad para relatar una sucesión de acontecimientos en el que distingue tres niveles de significación de la palabra "relato" [recit]: el primero considera el acto que realiza el narrador; el segundo contempla el discurso o texto narrativo (el producto) y el tercero, considera la historia que el discurso narrativo relata, representa o significa. Por su parte, los Formalistas Rusos emplearon el término "fábula" [fable] para designar el nivel básico de la narrativa, el cual puede representarse por diferentes medios: un ballet, un cuento de hadas, una película una historieta, etc.

Complementando estas definiciones, Hayden White $^{22}$ sugiere partir de su origen etimológico: "narrativa", "narración" o "narrar" se derivan del adjetivo latino gnārus, que significa conocer, experiencia o destreza y provienen de la raíz del Sánscrito gna [conocer] y del término latino narrare, que designa la acción de narrar. Por lo que etimológicamente, "narrativa" reúne el doble aspecto: el adquirir conocimiento y el de expresarlo, ambas tareas resultan trascendentales para el desarrollo y progreso humano y de su habilidad creativa. Finalmente otros teóricos como H. Porter $\operatorname{Abbot}^{23}$ sugiere que narrativa es la representación verbal de una serie de eventos que se suceden y producen un todo coherente; Meir Stenberg y Marie-Laure Ryan ${ }^{24}$ señalan respectivamente, que las

\footnotetext{
${ }^{21}$ PRINCE, Gerald, "Observaciones sobre la narratividad", Criterios num. 29, 1991, [Texto on-line] en: http://es.scribd.com/doc/32944921/Gerald-Prince Consultado:18/08/11

${ }^{22}$ WHITE, Hayden, The content of the form: narrative discourse and historical representation, John Hopkins University Press, Baltimore, 1987, (p. 215)

${ }^{23} \mathrm{ABBOT}, \mathrm{H}$. Porter, The Cambridge introduction to narrative, Cambridge University Press, Cambridge, 2008. (p. 13)

${ }^{24}$ ABBOT, H. Porter., The Cambridge introduction to narrative, Cambridge University Press, Cambridge, 2008. (p. 25)
} 
narrativas son "juegos de suspenso, curiosidad y sorpresa" y "una habilidad para darle vida al mundo"; Seymour Chatman ${ }^{25}$ define la narrativa como una cadena de acontecimientos representados de forma diegética, es decir, que cuenta algo y que establecen una relación causal o temporal entre sus eventos, acontecimientos o acciones. Gerald Prince ${ }^{26}$ sugiere que dentro de las narrativas, la presencia de un evento presupone o conlleva al siguiente, por lo que dentro nada es gratuito, cada elemento forma parte de una unidad relacionada con el todo en una relación causal.

Al momento de generar cualquier proyecto ya sea de divulgación o artístico es posible generar una historia a partir de una diversidad de los elementos (textuales, gráficos, visuales, sonoros) que organice de manera articulada. Mientras tengan algo que contar de manera coherente y cada uno de los elementos que lo integran tengan una función significativa dentro del todo y contribuyen a conformar una idea completa, tenemos un relato. Todo aquello que no podemos relacionar de alguna manera, debe desecharse, buscando generar un todo coherente, en el cual la causalidad y temporalidad de los acontecimientos cumplan una función de cohesión interna.

\footnotetext{
${ }^{25}$ CHATMAN, Seymour, Story and discourse; narrative structure in fiction and film, Cornell University Press, Ithaca, 1978. [texto on-line] Ver link en apartado de Bibliografía. (p. 6)

${ }^{26}$ PRINCE, Gerald, A Dictionary of narratology, University of Nebraska Press, Lincoln, 2003. (p. 12)
} 
Las palabras no viven fuera de nosotros... Nosotros somos su mundo y ellas el nuestro.

Octavio $\mathrm{Paz}^{27}$

\subsection{EL LENGUAJE Y LAS HISTORIAS}

Hablar de historias nos obliga a retomar conceptos como: léxico, habla y lenguaje, los cuales resultan ser sus componentes esenciales. El lenguaje más allá de su relación con el mundo de la creación artística y literaria, es la herramienta tecnológica más importante creada por el hombre a lo largo de su evolución. Esto lo apreciaremos al revalorar la trascendencia e importancia del lenguaje. Según lo define la Real Academia de la Lengua Española ${ }^{28}$, "el lenguaje es un sistema de comunicación que utiliza de manera arbitraria signos auditivos, vocales, gestuales, gráficos o escritos." El léxico es el conjunto de palabras de una lengua y el habla es el acto individual del ejercicio del lenguaje, producido al elegir determinados signos entre los que ofrece la lengua, mediante su realización oral o escrita; es la manera como cada individuo hace uso del lenguaje.

El antropólogo lingüísta Edward Sapir (1884-1939) señala que el lenguaje es un sistema que el hombre ha ido desarrollando y ajustando a sus necesidades vitales. Se trata de un fenómeno anónimo, colectivo e inconsciente; el cual ha sido el producto creativo de miles de generaciones. $\mathrm{Y}$ ha sido la herramienta obligada para llegar al pensamiento. "Pensar sin palabras," es algo que a juicio de Sapir ${ }^{29}$, dista mucho de ser válido. Por su parte confirmando su importancia, Herbert Read ${ }^{30}$ (1893-1968) confirma que la supervivencia de nuestra especie, en gran medida, fue posible gracias a le existencia del lenguaje. Menciona además, que el lenguaje nombraba aquello que resultaba trascendente y significativo para la experiencia humana. Roger Shank ${ }^{31}$, aprecia el valor de contar una serie de "cosas" interesantes y refiere a la inteligencia humana la capacidad de tener historias que contar a los demás. Mauricio Swadesh ${ }^{32}$ (1909-1967), lingüista histórico considera que el lenguaje le permitió al hombre la ruta de la aventura intelectual: "[mediante el lenguaje] conoce su mundo interior, construye su espiritu, crea a partir de descubrir un gozo estético."

\footnotetext{
${ }^{27}$ PAZ, Octavio, El Arco y la lira, Fondo de Cultura Económica, México, 1956. (p.31)

${ }^{28}$ Definiciones basadas en el Diccionario de la Real Academia Española [Texto on-line] en: http://www.rae.es Consultado: 06/08/2011

${ }^{29}$ SAPIR, Edward, El Lenguaje, Fondo de Cultura Económica, México, 1954. (p. 23)

${ }^{30} \mathrm{READ}$, Herbert, Imagen e idea, Fondo de Cultura Económica, México, 1957.

${ }^{31}$ SHANK, Roger C., Tell me a story; narrative and intelligence, Northwestern University Press, Evanston, 1990. (p. 54)

${ }^{32}$ SWADESH, Mauricio, El lenguaje y la vida humana, Fondo de Cultura Económica, México, 1966. [Prólogo]
} 
Erick Havelock $^{33}$ (1903-1988) define al lenguaje como las palabras que intercambiamos; pensamos silenciosamente; vemos escritas en textos o aquellas que los nuevos medios electrónicos nos "hablan" y otorgan su ingenio a enriquecer su poder expresivo. Del ingenio se desprende su expresividad o su capacidad de exteriorizar sensaciones, impresiones y sentimientos entre los individuos. En el estudio sobre el origen del lenguaje y su importancia en la formación del pensamiento, desde una visión filosófica y psicológica, Alexandr G. Spirkin ${ }^{34}$ sostiene que el pensamiento surgió a la par del lenguaje: no existen uno sin el otro y permitieron al hombre adquirir conciencia de sí mismo. Algunas visiones sobre el lenguaje, realmente poéticas; son las de Taylor Coleridge ${ }^{35}$ quien lo define como la "armadura de la mente humana que contiene los trofeos del pasado y las armas para las conquistas futuras." Ludwig Wittgestein ${ }^{36}$ (1889-1951) lo define como "un laberinto de caminos". Octavio Paz ${ }^{37}$ afirma que la historia del hombre podría reducirse al de las relaciones entre las palabras y del pensamiento. Resulta imposible pensar sin palabras; como también resulta imposible contar historias sin estas.

Estudios sobre el lenguaje y la comunicación contemporánea como: Gutemberg Galaxy (1962) de Marshall McLuhan ${ }^{38}$; Orality and literacy: the technologizing of the Word (1982) de Walter J. Ong ${ }^{39}$; The printing revolution in early modern Europe (1983) de Elizabeth Eisenstein ${ }^{40}$ y Acts of meaning (1990) de Jerome Bruner ${ }^{41}$, no sólo amplían la visión, sino que confirman la importancia del lenguaje como herramienta de pensamiento, aprendizaje y creación. Además complementan los trabajos previos como: The work of art in the age of its technological reproducibility and other writings on media (1936) de Walter Benjamin ${ }^{42}$, El pensamiento salvaje (1964) de Claude Levi-Strauss ${ }^{43}$; The Consequences of literacy (1968) de Jack Goody e I. Watt ${ }^{44}$. El lenguaje como medio expresivo de comunicación, debe adecuarse al mundo tecnológico contemporáneo; buscar las maneras de experimentar e innovar, apreciando sobre todo su poder de creación artística.

\footnotetext{
${ }^{33}$ HAVELOCK, Erik A, The muse learns to write, Yale University Press, New Haven, 1986.

${ }^{34}$ SPIRKIN, Alexander G., Op. Cit. (p. 65)

${ }^{35}$ NORDQUIST, Richard, "What is language?" [Texto on-line] en: http://grammar.about.com/od/grammarfaq/f/whatislang.htm Consultado: 08/09/2011

${ }^{36}$ WITTGESTEIN, Ludwig, Philosophical Investigations, Blackwell publishing, Malden, Ma, 1953, (p. 203)

${ }^{37}$ Paz, Octavio, El arco y la lira, Fondo de Cultura Económica, México, 1956. (p. 29)

${ }^{38}$ MCLUHAN, Marshall, The Gutenberg galaxy: the making of typographic man, University of Toronto Press, Toronto, 1962.

${ }^{39}$ ONG, Walter J., Orality and literacy: the technologizing of the Word, Routledge, New York, 1982.

${ }^{40}$ EISENSTEIN, Elizabeth L., The printing revolution in early modern Europe, Cambridge University Press, 1983, 2005.

${ }^{41}$ BRUNER, Jerome, Acts of Meaning, Harvard University Press, Cambridge MA, 1990.

${ }^{42}$ BENJAMIN, Walter, The work of art in the age of its technological reproducibility and other writings on media, Harvard University Press, Cambridge, Ma, 2008.

${ }^{43}$ LEVI-STRAUSS, Claude, El pensamiento salvaje, Fondo de Cultura Económica, México, D.F. (1964)

${ }^{44}$ GOODY, J. \& WATT, I., The Consequences of literacy de Jack Goody (Eds.), Cambridge University Press, Cambridge, 1968.
} 


\subsection{EL PAPEL DEL LENGUAJE EN LA FORMACIÓN DEL PENSAMIENTO}

Deseamos destacar la importancia del lenguaje y su relación con el pensamiento en la construcción de historias: a partir de etiquetar experiencias que guardamos de manera organizada en nuestra memoria que cuando las necesitamos, las manipulamos y readaptamos a nuevos propósitos y usos, buscamos su coherencia y encontramos una forma de cristalizarla o comunicarla. Gracias al desarrollo tecnológico, las posibilidades expresivas se han ampliado; demandando se desarrollen y apliquen nuevas prácticas que amplíen las operaciones mentales y creativas de los generadores de historias. Entender cómo ha sido el desarrollo evolutivo de estas habilidades de pensamiento y expresión nos permite apreciar la extraordinaria ruta intelectual de la humanidad, pero sobre todo nos debe incentivar a buscar nuevos caminos de creación que permitan generar nuevas aplicaciones.

Relatar historias fue posible, a partir de que el hombre pudo desarrollar acciones de habla y pensamiento cada vez más complejas. Alexander Spirkin ${ }^{46}$ enuncia que en cierto momento de la vida de los primeros hombres, los sonidos que emitían reiteradamente en una determinada situación impresionaban la corteza cerebral y provocaban la formación de conexiones temporales entre los sonidos dados y las emociones que asociaban. Después de miles de repeticiones, las conexiones se generalizaron y se hicieron más complejas; estos elementos fónicos inarticulados dejaron de estar vinculados a emociones y entraron en relación con objetos reales, es decir con las imágenes de dichos objetos. Herbert Read, ${ }^{47}$ menciona que el hombre primitivo era capaz de construir imágenes mentales a partir de lo que veía y escuchaba. Sucesos y acontecimientos fueron conservados en su memoria y gracias a la imaginación eidética ${ }^{48}$ podía "estampar" en su mente imágenes visuales y auditivas; renombrar lo que recordaba y transformarlo con diversos fines: convencer, instruir, divertir, o comunicar.

Motivados por construir mejores historias, los primeros narradores comenzaron a buscar nuevos recursos para enriquecer sus historias, surgió entonces el símbolo que permitía

\footnotetext{
${ }^{45}$ Citado por: VAN CAMPEN, Jessica, "Hyprocrisy or merely condradiction? A brief look at the life and work of Karl Krauss" [Texto on-line] en: http://www.theabsolute.net/minefield/kraus.html Consultado: $12 / 15 / 2012$.

${ }^{46}$ SPIRKIN, A.G., “Origen del lenguaje y su papel en la formación del pensamiento”, (pp. 8-67) En: GORSKI, D.P., KIPNIN, P.V. et Al (eds.), Pensamiento y Lenguaje, Editorial Grijalbo, México, D.F., 1961. (pp. 30-31)

${ }^{47}$ READ, Herbert, Imagen e idea, Fondo de Cultura Económica, México, 1957.

${ }^{48}$ Del griego eidés, esencia: la memoria de lo esencial.
} 
"Hacer que un hecho correspondiera a otro" "49; aparecieron las metáforas y alegorías y con ellas surgieron los mitos; iniciándose así la aventura narrativa literaria de la humanidad, la cual como ya mencionamos, no se ha detenido jamás. Esto no ha sido fácil, Mauricio Swadesh ${ }^{50}$ sugiere que debieron de pasar miles de años para que un grito instintivo (miedo, dolor, sorpresa, rabia, asombro, etc.) se transformara en una intención informativa, comunicativa o expresiva más compleja.

Debemos entonces considerar que transformar una idea en una historia, requirió de un verdadero esfuerzo intelectual. No sólo fue necesario que se desarrollara el cerebro humano $^{51}$, tuvo que desarrollarse un sistema de señales llamativas cada vez con mayor inteligencia y efectividad con "la inventiva suficiente para hacerse entender" 52 . E1 lenguaje se formó poco a poco sobre una base intuitiva, mediante un paulatino crecimiento de conceptos y convencionalizaciones; de ninguna manera fue un acontecimiento repentino o individual. Sino un largo proceso cuya evolución jamás se detiene, sigue aumentando el léxico e inflexiones en todo momento. Esta magnífica herramienta que tenemos a nuestra disposición, nos confirma el potencial latente, que debemos atender, fortalecer y estimular día con día.

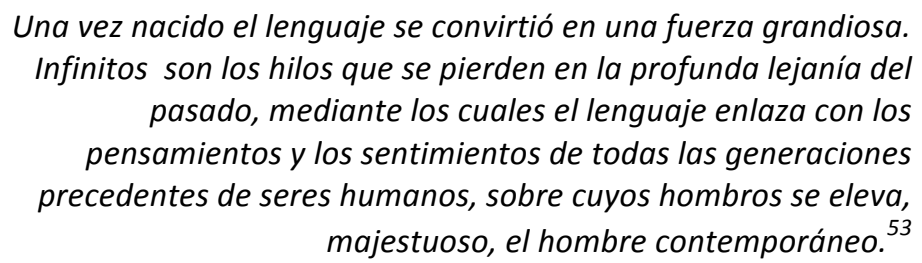

Reflexionar en torno al surgimiento de las primeras historias y conocer cómo evolucionaron y dieron lugar a otras formas expresivas, lejos de resolver los enigmas o agotar el tema, pretende mostrar la importancia de las habilidades narrativascomunicativas del hombre y conocer las herramientas que utilizó para ello. Resulta imposible saber con certeza, cuándo comenzó el hombre a narrar historias; sin embargo, ciertos trabajos antropológicos y lingüísticos nos dan algunas claves; Edward Sapir ${ }^{54}$, Mauricio Swadesh ${ }^{55}$ y Joseph Campbell ${ }^{56}$ coinciden con la idea de que los primeros

\footnotetext{
${ }^{49}$ READ, Herbert, Imagen e idea, Fondo de Cultura Económica, México, 1957. (p. 17)

${ }^{50}$ SWADESH, Mauricio, El lenguaje y la vida humana, Fondo de Cultura Económica, México, 1966 (pp. 14-

18), Menciona que el hombre atravesó por tres épocas, en la evolución del lenguaje: 1) Paleoglótico

Inferior, hace más de un millón de años; 2) Paleoglótico Superior: hace unos cien mil años y 3) Neoglótico, hace unos diez mil años.

${ }^{51}$ El volumen del cráneo tuvo un aumento considerable: el Australopitecus (anterior al Homo habilis poseía un cráneo de 300 a 500 cm3; el Homo habilis de 630 cm3; el Homo erectus de 900 a 1200 cm3; el Hombre de Neanderthal de 1300 a $1500 \mathrm{~cm} 3$ y finalmente el Hombre de Cro-Magnon alcanzó los $1450 \mathrm{~cm} 3$ de volumen craneal. Esto lo confirma Gilles Muhlach en: http://www.pole-prehistoire.com

${ }^{52}$ SWADESH, Mauricio, El lenguaje y la vida humana, Fondo de Cultura Económica, México, 1966. (p. 54)

${ }^{53}$ SPIRKIN, A.G., "Origen del lenguaje y su papel en la formación del pensamiento", (pp. 8-67) En: GORSKI, D.P., KIPNIN, P.V. et Al (eds.), Pensamiento y Lenguaje, Editorial Grijalbo, México, D.F., 1961. (p. 67)

${ }^{54}$ SAPIR, Edward, El Lenguaje, Fondo de Cultura Económica, México, 1954.

${ }^{55}$ SWADESH, Mauricio., El lenguaje y la vida humana, Fondo de Cultura Económica, México, 1966.
} 
hombres cobraron conciencia de su entorno, distinguieron el transcurrir del tiempo motivados por el deseo de trascender y demandando su pertenencia dentro de un orden social, comenzaron a dejar rastros de su memoria. Tuvieron necesidad de aprender, enseñar a los suyos, recordar y comunicarse, y encontraron en la narrativa oral un vehículo de comunicación efectivo. En un principio habrán buscado la manera de expresar y transmitir ideas e información relacionadas con la protección ante el peligro inminente, mediante sonidos, mímica y otros gestos con el fin de advertir a otros y asegurar su supervivencia; interesados en transmitir información y enseñanzas relacionadas con las prácticas cinegéticas y la recolección de alimentos; debieron haber podido trazar caminos, dejar señales mnemotécnicas en rocas o palos y quizá trazar croquis o mapas que facilitaran su movilidad a sitios más prósperos; darían instrucciones a otros para fabricar y utilizar armas y utensilios básicos. Necesitaron educar y preparar a los hijos para la vida y transmitirles su memoria. Herbert $\operatorname{Read}^{57}$ señala que conforme los primeros humanos fueron solucionando sus asuntos vitales (alimento y sustento) comenzaron a desarrollar nuevas tareas gracias a las herramientas cognitivas que poseían; la inteligencia y el lenguaje les permitió, en un primer momento, llevar a cabo la comunicación cotidiana básica; posteriormente, originaron su poder reflexivo en torno a cuestiones abstractas más complejas como: "conciencia", "pensar", "conocimientos" y otras similares que implican mayor complejidad. A propósito, Edward Sapir menciona:

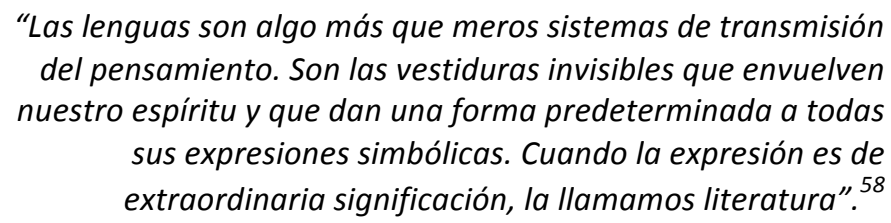

Las primeras palabras que aprendemos las unimos para contar algo, en cuanto unimos un sustantivo a un predicado ya hemos iniciado una posibilidad narrativa. El surgimiento de las habilidades narrativas con cierta utilidad práctica como informar, educar o recordar, se fortalecieron con la riqueza y potencial creativo del lenguaje.

Howard Gardner ${ }^{59}$ plantea que la "Inteligencia Artística" no existe como tal, sin embargo, si utilizamos metafórica o expresivamente el lenguaje, de manera que llame nuestra atención, ya sea por las propiedades formales o sonoras o por el juego de los significados o sentidos que refiere, desarrollamos cierta destreza importante. En cambio, David Blair y Tom Meyer" 60 llaman "Inteligencia Narrativa" a la habilidad humana de organizar experiencias en formas de narrativas que ofrecen cierta dramaturgia, lógica o patrón estético al resolver sus problemas. Para Gerd Waloszek, ${ }^{61}$ con los mitos surgió la

\footnotetext{
${ }^{56}$ CAMPBELL, Joseph., “Los mitos, su importancia en el mundo actual”, Editorial Kairós, Barcelona, 1993. [Texto On-line] en: http://en.wikipedia.org/wiki/The_Power_of_MythConsultado: 02/09/2011.

${ }^{57}$ READ, Herbert, Imagen e idea, Fondo de Cultura Económica, México, 1957.

${ }^{58}$ SAPIR, Edward, El Lenguaje, Fondo de Cultura Económica, México, 1954.(p. 250)

${ }^{59}$ GARDNER, Howard, Multiple intelligences, Basic Books, New York, 2006.

${ }^{60}$ Véase: http://www.cs.cmu.edu/ michaelm/cfp.html Consultado: 07/03/2012

${ }^{61}$ WALOSZEK, Gerd, Narrative User Interfaces [texto on-line] en: Qué son las historias en:

http://www.sapdesignguild.org/community/design/narrative_interfaces.asp Consultado: 01/07/2010
} 
genialidad poética de las personas. El desarrollo de habilidades creativas y estéticas. Para Herbert Read, el progreso estético se ha dado en dos direcciones: el de la vitalidad y el de la belleza, "el arte como la actividad por medio de la cual se conserva alerta nuestra sensación, viva nuestra imaginación y penetrante nuestra facultad de razonamiento"62.

Buscamos producir objetos que despierten nuestros sentidos, aviven nuestra imaginación y preserven nuestra memoria. Al componer narrativas, debemos atender esos mismos fines y ligarlos al mundo cibernético, el cual ha facilitado el acceso, obtención y almacenamiento de información; ampliando nuestra capacidad de memoria al ofrecernos medios para guardar, organizar, clasificar e indexar información.

En la actualidad contamos con dispositivos electrónicos que ayudan, pero requerimos aprender a desarrollar nuestro potencial creativo: avivar la imaginación, los sentidos y aprender a estructurar nuevos formatos que nos permitan componer historias. El lenguaje es una herramienta de creación primordial que nos permitirá llevar a cabo la experimentación de nuevos tipos de historias. Si comenzamos a jugar con algunas posibilidades, seguro surgirán ideas que pueden convertirse en proyectos narrativos.

${ }^{62}$ READ, Herbert, Imagen e idea, Fondo de Cultura Económica, México, 1957.(p.38) 


\subsection{LAS PRIMERAS HISTORIAS DE LA HUMANIDAD}

El hombre desarrolló su oralidad para comunicar ideas, pensamientos y sentimientos. A lo largo de miles de años, las historias orales se fueron hilvanando y conformando un entramado de mitos y leyendas que reflejaban el saber de los pueblos y representaban su memoria. Joseph Campbell, ${ }^{64}$ conocedor de mitos y religiones comparadas, los considera como: "los cuentos de la sabiduría de la vida" "65 y confirma que han sido fieles acompañantes de los hombres, incluso se ha definido como: "[the] DNA of cultural identity or the window into the workings of human mind. "66

A través de las primeras narrativas orales, el hombre representaba su saber y daba explicación a su mundo, llevando a cabo cuatro funciones culturales básicas: mística, cosmológica, sociológica y la pedagógica. Seguramente sus primeras historias debían abordar estas cuestiones, sólo que al no haber testimonios que confirmen con exactitud cómo fueron sus primeras historias, ya que desconocemos el formato que tuvieron, gracias a estudios antropológicos sabemos que los seres humanos de la antigüedad se comunican de incontables maneras: Walter J. Ong ${ }^{67}$ señala que empleaban sus capacidades sensoriales, su riqueza gestual y se apoyaban seguramente en señales como el humo de la hoguera, el ruido del choque de dos piedras o las huellas en el lodo. Estos objetos, según otro antropólogo lingüista, A.G. Spirkin; "prepararona la humanidad para inventar la escritura." 68

Mucho antes de contar con un sistema de escritura, las primeras muestras de narrativa oral de la humanidad fueron los mitos. Cierto tipo de historias, explicaciones o descripciones alegóricas, simbólicas, más complejas buscaban dar respuesta a sus interrogantes. Quizá estaban relacionados con alguna práctica ritual, encontrar alimento $u$ honrar a sus muertos. Estas primeras muestras artísticas de narrativa oral de la humanidad fueron muy similares a los mitos que hasta nuestros días se conservan. Con el fin de

\footnotetext{
${ }^{63}$ WITTGENSTEIN, Ludwig, Tractatus Logico-Philosphicus, Cosimo Inc., New York, 2009. (p. 88)

${ }^{64}$ CAMPBELL, Joseph., Los mitos, su importancia en el mundo actual, Editorial Kairós, Barcelona, 1993.

[Texto on-line] en: http://en.wikipedia.org/wiki/The_Power_of_Myth Consultado: 02/09/2011.

${ }^{65}$ CAMPBELL, Joseph., Los mitos, su importancia en el mundo actual, Editorial Kairós, Barcelona, 1993.

[Texto on-line] en: http://en.wikipedia.org/wiki/The_Power_of_Myth Consultado: 02/09/2011 (p. 3)

${ }^{66}$ Mythology; the study and analysis of those stories.[Texto on- line] en: http://www.as.ysu.edu Consultado: 13/09/2011

${ }^{67}$ ONG, Walter J., Orality and literacy: the technologizing of the word, Routledge, New York, 1982, 2002.

${ }^{68}$ SPIRKIN, A.G., “Origen del lenguaje y su papel en la formación del pensamiento", (pp. 8-67) En: GORSKI,

D.P., KIPNIN, P.V. et Al (eds.), Pensamiento y Lenguaje, Editorial Grijalbo, México, D.F., 1961. (p. 57)
} 
ubicarnos temporalmente, Joseph Campbel1 ${ }^{69}$, afirma que las primeras pruebas tangibles del pensamiento mitológico datan del periodo del Hombre de Neanderthal, que vivió entre los años 250,000 y el 50,000 AC.

Según Gilles Muhlach, ${ }^{70}$ los mitos coinciden con el periodo en el cual los hombres comenzaron a sepultar a sus muertos, practicaron rituales y trataron de asimilar y entender los interrogantes relacionados con la naturaleza y la vida que les rodeaba; crearon mitos sobre la creación del mundo, la humanidad, la función de los astros y los fenómenos naturales. Estos relatos, producto del imaginario colectivo, y que presentan semejanzas en diferentes culturas, testimonian su cosmogonía basada en cuestiones mágico-místicas, abordan los misterios del universo, personifican objetos inanimados y fuerzas naturales y resuelven de cierta manera didáctica, transmitir enseñanzas a las nuevas generaciones.

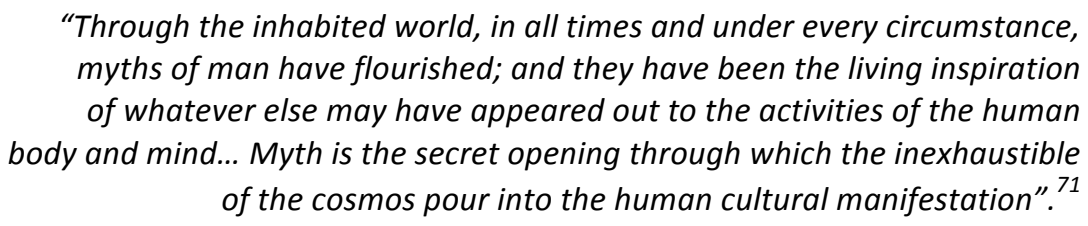

Las historias daban sentido a la existencia de los hombres y les recordaban algo fundamental: "an experience of being alive." Por su parte James Frazer plantea que el "hombre primitivo fundamentó sus creencias basado en leyes mágicas, más tarde comenzó a perder su fe en la magia e inventó los mitos religiosos con el objeto de apaciguar a los dioses. "72 El interés particular que tenemos en los mitos, más allá de replantearlos como el origen de las narrativas y el surgimiento del poder narrativo de las personas, debe confirmar el mundo tan colorido que las historias nos han legado.

"Modern society is going through a transition from the old mythologies and traditions to a new way of thinking where a global mythology will emerge" ${ }^{\text {,73 }}$

Para ampliar el tema se recomienda revisar los estudios antropólogos de: Georges Dumézil $^{74}$, Mircea Eliade ${ }^{75}$, Claude Levi-Strauss ${ }^{76}$, Friedrich Max Müller ${ }^{77}$, Eliphas Levi

\footnotetext{
${ }^{69}$ Joseph Campbell, apreciar su trabajo en: http://www.jcf.org

${ }^{70}$ Gilles Muhlach,Director de EPCC Pôle International de la Prehistorie, enlista sintética y cronológicamente el devenir de la humanidad de la siguiente manera: El Homo habilis hace (2.5 a 1.6 Millones de años [ $\mathrm{M}$ de a.]) fue capaz de producir los primeros utensilios de roca con cualidades simétricas; el Homo erectus (1.9 a 0.3 M. de a.) domina el fuego; el Hombre de Neandertal(0.12 a $0.03 \mathrm{M}$. de a.) entierra a sus muertos, lo cual resulta significativo para este estudio ya que podría ser el origen de los rituales y ceremonias en las que irían acompañados de danzas, música y posiblemente el surgimiento de las primeras narraciones y leyendas; finalmente, el Hombre de Cro-magnon o Homo sapiens (0.2 M. de a. hasta nuestros días) dibujó en cuevas, grabó y esculpió en hueso y roca y fabricó objetos decorativos e instrumentos musicales. [Sitio en Internet] en: http://www.pole-prehistorie.com Consultado: 05/09/2011.

${ }^{71}$ CAMPBELL, Joseph, The hero with a thousand faces, Joseph Campbell Foundation \& New World Library Press, Novato, 2008. (p. 1)

72 FRASER, James, The golden bough, McMillan, New York, 1922. (p. 711)

73 "The power of Myths" [Texto on-line] en: http://en.wikipedia.org/wiki/The_Power_of_Myth Consultado: 02/09/2011.
} 
${ }^{78}$ o Helena Petrovna Blavatsky ${ }^{79}$, sólo por mencionar algunos que sin duda ampliarán el tema y motivarán futuros trabajos de investigación relacionado con los mitos y el lenguaje.

Los mitos han contribuido como detonantes del desarrollo intelectual y cultural de la humanidad. Por siempre han despertado en artistas de todas las disciplinas desde la antigüedad hasta nuestros días. Pinturas, esculturas, sinfonías, novelas, películas; todas las épocas y culturas de la humanidad se han interesado por los mitos y el manejo de símbolos e imágenes metafóricas. Deseamos reconocer el vínculo entre mito y creatividad al plantear que de cierta manera, los artistas dan respuesta a su mundo circundante e interno mediante historias que formulan y por ello se convierten en fabricantes de mitos, "An autor is inevitably involved in the process of myth formation." 80

\footnotetext{
"Hasta qué punto esto nos libera de la seriedad de la vida y nos permite emitir respuestas explicables a lo inexplicable, el destino de la imaginación, los misterios de la vida, las maravillas de la creación, la intersección entre lo conocido y lo desconocido" ${ }^{\prime 81}$.
}

El mismo Paul Avis, en un afán de promover la narrativa inspirados en mitos, enlista doce posibilidades que los escritores pueden considerar como temáticas de creación: los transcribimos porque los consideramos un potencial creativo para cualquier artista: 1) El Asombro: ¿De dónde surgió el mundo? Planteando sus posibles respuestas. 2) Buscando significados a través de historias. 3) Vinculando épocas diferentes y/o elementos de la naturaleza distantes. 4) Relación con uno mismo y con los demás. 5) Establecer un sentido de conexión. 6) Novedad. 7) Disfrutar y sufrir. 8) Celebrar la creatividad y el misterio de la vida. 9) Imaginación para crear el mundo. 10) Algo con qué compararnos. 11) Jugar entre los concreto y lo abstracto. 12) Entender el caos.

Estas propuestas resultarán una fuente de inspiración para generar temas, construir metáforas y alegorías que puedan a su vez integrar guiones, textos, juegos o cualquier otro proyecto, anteriormente en este mismo trabajo habíamos planteado la necesidad de componer las mitologías de nuestro tiempo, sin duda esto servirá.

\footnotetext{
${ }^{74}$ DUMEZIL, George, Del mito a la novela, Fondo de Cultura Económica, México, D.F., 1993.

${ }^{75}$ ELIADE, Mircea, Mito y realidad, Kairos, Madrid, 2002.

${ }^{76}$ LEVI-STRAUSS, Claude, Mito y significado, Alianza Editorial, Madrid, 2002.

${ }^{77}$ MÜLLER, Friedrich Max, Three lectures on the science of language and its place in general education, Bibliolife, 2008.

${ }^{78}$ LEVI, Eliphas, Fábulas y símbolos, [Texto on-line] en:http://upasika.com/docs/levi/Levi\%20Eliphas\%20\%20Fabulas\%20y\%20simbolos.pdf Consultado: 02/11/11

${ }^{79}$ BLAVATSKY, Helena Petrovna, Isis sin velo, Colofón, México, D.F., 2006.

${ }^{80} \mathrm{FIFE}$, Austin E., "Myth formation in the creative process" [Texto on-line] en: http://www.j.stor.org/pss/1520664Consultado: 13/09/2011

${ }^{81}$ AVIS, Paul, God and the creative imagination: metaphor, symbol and Myth, Routledge, New York, 1999.
} 


\section{Las historias gráficas}

Junto al desarrollo de la oralidad mítica surgió una rica herencia cultural gráfica que también ha venido evolucionando hasta nuestros días y se ha nutrido de propuestas digitales. Testimonios de cuevas decoradas del Paleolítico ${ }^{82}$ con sus grabados y dibujos además de confirmar un gran avance tecnológico y mental del hombre de la antigüedad, según apunta A.G. Spirkin ${ }^{83}$; confirman ser las primeras "historias gráficas" de la humanidad. Estas imágenes de toros, caballos y venados, cuyos detalles, proporciones, profundidades y colorido confirman su destreza técnica y en cierta forma demuestran cómo sus historias orales, también presentaban cierta complejidad y fueron evolucionando a formas más elaboradas de composición.

El surgimiento de la escritura es algo relativamente nuevo en relación a la existencia del hombre; Walter $\mathrm{Ong}^{84}$ sugiere que de los 30 mil a 50 mil años del surgimiento del Homo sapiens, sólo en los últimos 6 mil años ha existido la escritura. Por lo que la oralidad fue la base original para la construcción de historias. Hacemos tal hincapié en la oralidad, porque es una destreza que debe retomarse y replantearse de nuevas maneras.

En el planeta se hablan alrededor de tres mil idiomas, de los cuales sólo 78 poseen una muestra literaria escrita ${ }^{85}$. Con este dato deseamos llegar a un punto que merece nuestra atención: las historias se pueden componer con palabras, pero también con imágenes tanto visuales como auditivas, que de acuerdo a la evolución tecnológica pueden contar con herramientas muy diversas para componerlas. Esto es algo que debe saber y experimentar todo aquel interesado en contar historias. Las representaciones gráficas se transforman, convencionalizan y se vuelven más complejas; un buen ejemplo puede apreciarse en formas naturalistas muy detalladas que evolucionaron en otras más simbólicas y estilizadas, como se aprecia en las imagen de Lascaux (15,000 años a.C.) la Cueva de la Vieja Alpera ${ }^{86}$ (10,000 años a.C) y representaciones de los $\operatorname{San}^{87}$, pobladores del desierto Kalahari en África (aprox. Hace 300 años). Independientemente de su estilización o abstracción; basta observar éstas tres imágenes, para apreciar las fabulosas historias gráficas que contienen; historias que están en espera de ser "leídas" o interpretadas: arqueros, danzantes, toros y ciervos en una fusión de imágenes no sólo figurativas, sino además, esquemáticas y abstractas.

\footnotetext{
${ }^{82}$ Ver LAXCAUX en: http://www.lascaux.culture.fr; PID Pole International de la Prehistoire: http://www.pole-prehistoire.com, Arte Paleolítico, Pintura rupestre Levantina en: http://www.arteespana.com, El arte rupestre levantino: http://www.liceus.com Consultados: 26/11/2011 ${ }^{83}$ SPIRKIN, A.G, "Origen del lenguaje y su papel en la formación del pensamiento", (pp. 8-67) En: GORSKI, D.P., KIPNIN, P.V. et Al (editores), Pensamiento y Lenguaje, Editorial Grijalbo, México, D.F., 1961. (p. 54) ${ }^{84}$ ONG, Walter J., Orality and literacy: the technologizing of the word, Routledge, New York, 1982, 2002. (pp.2-7)

${ }^{85}$ De ahí que se considere el grado superior de desarrollo de las culturas que manifiestan la capacidad de generar una literatura escrita.

${ }^{86}$ Ver imagen en Anexos (La Cueva de la Vieja, Alpera ) [imagen On-line] en: http://mitotaurico.blogspot.com Consultado: 22/05/2011

${ }^{87}$ Nativos Africanos conocidos como San ó Bushman, ver: Rock Art Research Institute en: http://www.bradshawfoundation.comConsultado: 27/05/2011
} 


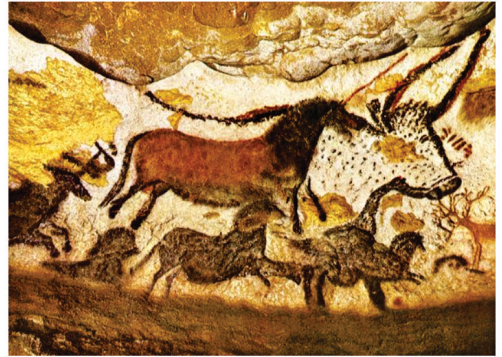

Lascaux, 15.000 a.C.

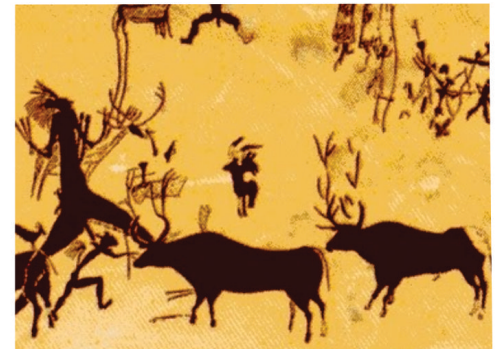

La Cueva de la Vieja, 10,000 a.C.

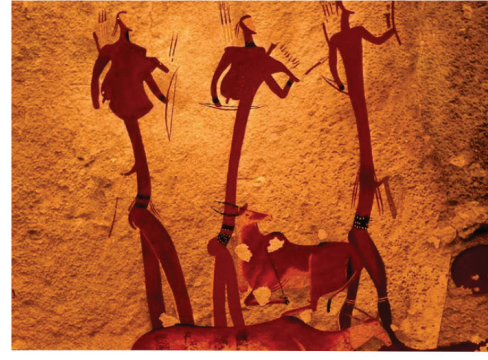

San, Kalahari, Siglo XVIII n.E.

En un mero afán de búsqueda de resortes narrativos, apreciamos las historias "ocultas" que estas imágenes ofrecen. Otras manifestaciones como piezas ornamentales, vasijas, muebles, artefactos de labranza, muros pintados de templos egipcios, o códices Prehispánicas Aztecas, Mayas o Incas, que confirma el interés de la humanidad por encontrar los medios para preservar sus fabulosas historias. Cuando buscamos ideas para componer proyectos textuales, tenemos un acervo de historias gráficas en espera de ser descubiertas y estructuradas junto a una tradición narrativa de muchos siglos. Solo hace falta voltear al pasado, echar a andar un poco la imaginación y comenzar a escribir.

Más allá de conseguir un recuento histórico evolutivo en este apartado, pretendemos enfatizar cómo la escritura amplió el potencial narrativo de la humanidad. Cada nuevo medio o formato lo ha hecho; enriqueciendo el discurso a través de imágenes sonoras o gráficas. Pero además, los sistemas de escritura poseen importantes cualidades:

\footnotetext{
"Are components of knowledge systems... they are philosophical because they assist in synthesizing ideas, thoughts, and deeds through the use of signs, symbols or other pictorial renderings. Specifically, writing is a means by which people record, objectify, and organize their activities and thoughts through images and graphs. Writing is a means to inscribe meanings that are expressed through sounds. Further, writing provides an aspect of historicallity. This means that writing facilitates the proper recording and transmissions of events and deeds from one generation to another. ${ }^{\prime 88}$
}

Revalorar la escritura más allá de ser una herramienta tecnológica del lenguaje, nos invita a reflexionar cómo ha evolucionado para conocer, entender y experimentar nuevas propuestas que amplíen nuestras experiencias sensoriales y estructurales al elaborar historias. Herbert Read relata cómo el hombre evolucionó de un instinto "distractivo" (brincar de una sensación a otra, alerta siempre ante el peligro inminente) a un estado mental de atención que exigía mayor concentración como observar imágenes plasmadas. Esto fue un gran avance que permitió que las percepciones se ampliaran y sintetizaran a través de una sucesión de gráficos que ya mostraban cierta organización lineal; como en el caso de los primeros sistemas de escritura, conocidos como: cuneiforme ${ }^{89}$, pictográfico $^{90}$, ideográfico ${ }^{91}$, jeroglífico ${ }^{92}$ y silabario $^{93}$. Así debemos "brincar" de modelos tradicionales a otros más complejos.

\footnotetext{
${ }^{88}$ Puede consultarse en: http://www.library.cornell.edu/africana/Writing_Systems/Amharic.html Consultado: 26/05/2011

${ }^{89}$ Término que proviene de dos voces latinas: cuneus, cuña, y forma, figura; designa la escritura de los asirios y persas. Se utilizaba una cuña con la cual el escriba hacía incisiones sobre tablillas de arcilla
} 
A partir de los petroglifos, incisiones y pinturas de símbolos en rocas de hace unos 9 a 8 mil años ${ }^{94}$, el hombre se enfrentó al primer procesamiento de señales, al tener que establecer conexiones visuales y conceptuales, en torno a dibujos y muescas o hendiduras en pequeños pedruscos que aún hoy se conservan y muestran las primeras formas de guardar y transmitir información. Posteriores son las tablillas y cuentas mnemotécnicas que diversas culturas utilizaban para registrar cantidades, años, cabezas de ganado, etc. La Piedra del Sol, o calendario solar azteca ${ }^{95}$, propia de la cultura Mexica en México, no sólo ejemplifica una manera de dividir el tiempo y llevar su registro; sino de cómo organizar gráficamente información compuesta de días relacionados con imágenes rectoras que ofrecen cierta connotación y pueden ser un recurso para generar historias.

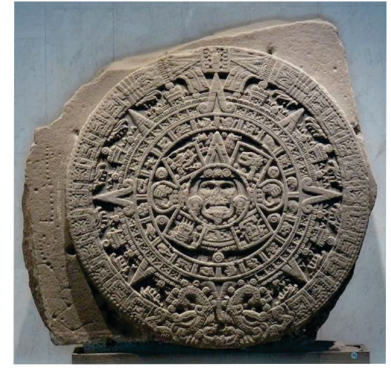

Piedra del Sol Azteca

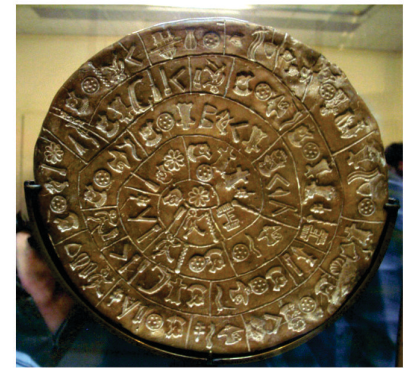

Disco de Festos

Los Antiguos Mexicanos diseñaron un sistema calendario que incluía signos aritméticos (1: Dedo; 20: Bandera; 400 Árbol) y signos pictográficos para designar los días y los años, conformaron un calendario solar de 18 meses con 20 días con nombres distintos; su combinación no se repetía en 52 años, lo que conformaba un ciclo. Al nacer las personas recibían no sólo el nombre del día correspondiente en el calendario, además heredaban ciertas cualidades, propias de cada fecha de las que no podían librarse jamás. Existen otros sistemas como el calendario "Azteca" que ofrecen múltiples posibilidades combinatorias, que consideramos pueden emplearse para generar historias; al permitir establecer un patrón para organizar las imágenes gráficas que, ligadas a ideas puedan conectar en forma de historias. Esto lo tendremos oportunidad de poner en práctica en el apartado de ejercicios más adelante.

que se cocían. La cuña se podía manejar en diversas posiciones, obteniéndose impresiones horizontales, perpendiculares y oblicuas; otro símbolo de forma triangular se hacía con la punta. Estos signos primarios permitieron elaborar una gran combinación de caracteres. Este sistema se usó durante más de tres milenios.

${ }^{90}$ Término que proviene del latín pictus, pintado, y del griego graphein, escribir; designa los signos especiales que corresponden a cada objeto representado. El significado de una serie de pictogramas se deducía por sentido común y por deducción lógica, según su yuxtaposición.

${ }^{91}$ Derivada de dos voces griegas: idea, idea, y gramma, carácter. En este sistema de escritura los signos representan ideas.

92 Término que viene del griego hieros, sagrado, y glyphein, grabar.

${ }^{93}$ Esta palabra proviene del latín syllabay significa "lo que se mantiene junto". Un silabario es un sistema en el cual cada sílaba se representa por un signo fonético individual. Sirvió de enlace entre las primeras formas de escritura y los sistemas alfabéticos.

94 JEAN, Georges, Language de signes: L'ecriture et son doublé, Gallimard, Paris, 1989. (p. 15)

${ }^{95}$ Véase: http://www.azteccalendar.com/ Consultado:07/03/2012 
El Disco de Féstos (véase imagen anterior), del cual se desconoce su significado, es otro sistema gráfico que puede servir como detonante estructural para crear narrativas. Siguiendo esta idea, podemos migrar las historias a objetos y cualquier medio físico conocido; historias labradas o plasmadas en piezas ceremoniales como bastones de mando, armas, y otros artefactos; seguramente provistos de cierto "poder mágico" como una especie de amuletos de cacería, otras quedaron estampadas gráficamente en rocas, tablillas de barro, figuras ornamentales y otros objetos como vasijas o espejos. Estas serán modelos que querrán utilizar para generar nuevas historias.

Nuestro interés es encontrar nuevas formas que propicien la creación de narrativas y textos artísticos. ¿Cómo trasladar esos formatos a nuevos medios multimedia? Habrá que buscar en el pasado, historias que se enrollan por metros en materiales orgánicos, textos impresos y horneados como panes, historias escritas en capas de cera, saberes fundidos o entretejido en tapetes orientales o en pieles de animales. Manuscritos iluminados en tiempos oscuros, escribas, manieristas o tipógrafos buscando la manera de darle forma a las historias. Buscamos aprender a reformular la escritura del futuro, semejante a como utilizaron fotografías, recortes, estampillas, etiquetas y algunas letras y palabras combinadas en los trabajos de Kurt Schwitter ${ }^{96}$, Max Ernst (sus originales collages), Pablo Picasso y Georges Braque y sus "papeles pegados" [papier colle].

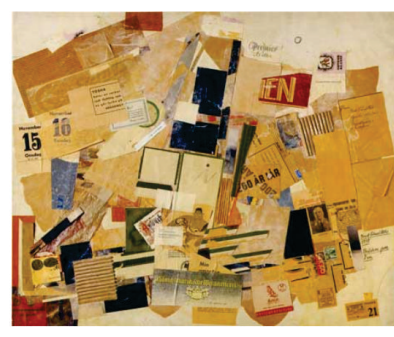

Kurt Schwitters

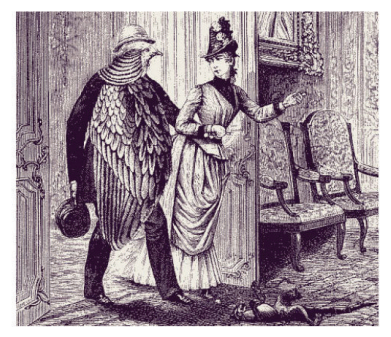

Max Ernst

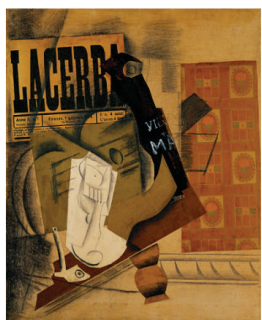

Pablo Picasso

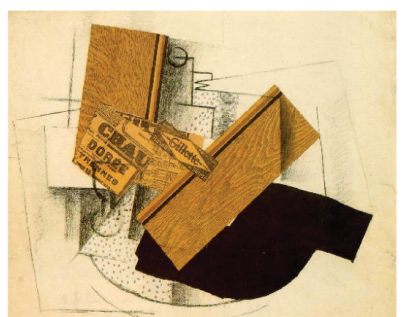

Georges Braque

Las rupturas visuales y narrativas de nuestro momento; menciona Nicholas Carr ${ }^{97}$ han sido una búsqueda incansable de experimentación gráfica y narrativa. Entender a escritores como James Joyce, Jorge Luis Borges, William Burroughs o Carlos Fuentes, entre muchos otros, es posible por cierta destreza lectora que hemos asimilado. La escritura ha desarrollado una extensa línea de experimentación ligada a la visualidad de sus formas que se puede desarrollar al margen del poder narrativo del lenguaje.

Conocer y apreciar los sistemas de escritura primitivos permitirá ampliar las posibilidades creativas y facilitar la generación de formas narrativas más complejas y de mayor expresividad. Imágenes que cambian, se transforman y no están estáticas; ofrecen un mayor potencial creativo que los generadores de historias querrán explorar.

\footnotetext{
${ }^{96}$ Ver: http://www.youtube.com/watch?v=Exd8VrWRGto\&feature=player_embedded\#!

${ }^{97}$ CARR, Nicholas, The Shallows; What the Internet is doing to our brains, W.W. Norton \& Company, New York, 2010. (p.75)
} 


\subsection{LENGUAJE Y JUEGO CREATIVO}

Comentamos anteriormente cómo el hombre, además de nutrirse de experiencias visuales y sensoriales, estableció conexiones entre los saberes y las herramientas que disponía, entre otros, del lenguaje. Las palabras le permitieron nombrar su entorno, desarrollar su potencial imaginativo y adquirir cierto nivel de abstracción y complejidad. Herbert Read ${ }^{99}$ confirma que los humanos fueron capaces de retener las imágenes que percibían, reproducirlas, manipularlas y otorgarles nuevas cualidades; entre las que surgió el poder jugar con el lenguaje. Cuando conjugó el juego con la imaginación, surgieron las metáforas y los acertijos, los cuales seguramente son tan antiguos, como las primeras historias y mitos.

Una permanente aventura creativa comenzó cuando el hombre adaptó sus conocimientos de manera práctica y encontró nuevos tratamientos para preservar su memoria y sus historias. Edward Sapir ${ }^{100}$ sugiere que una piedra se volvió arma, utensilio para producir fuego, instrumento sonoro (tanto para hacer música como para emitir información a distancia) y esta misma piedra, dispuesta de cierto modo en el suelo, podía ser una señalización que ofrecía información a sus semejantes. De manera similar, otros objetos comenzaron a ampliar sus posibilidades significativas al efectuar comparaciones tácitas. El hombre jugó con las similitudes de las formas y aprendió a divertirse con las palabras, amplio y buscó nuevos significados y nuevas maneras de utilizarlo, desarrollo una destreza fabulosa, aprendió a jugar con el lenguaje, con las palabras y a crear historias.

Johan Huizinga agrega lo siguiente:

"Language allows him to distinguish, to establish, to state things;
in short, to name them and by naming them to raise them into
the domain of the spirit. In the making of speech and language
the spirit is continually "sparking" between matter and mind,
as it were, playing with this wondrous nominative faculty.
Behind every abstract expression there lie the boldest of
metaphors, and every metaphor is a play upon words."101

\footnotetext{
${ }^{98}$ ELKIND, David, "The power of play: learning what comes naturally", en: V.V.A.A., American Journal of Play, Vol. 1, Num. 1, University Illinois Press, Champaign, 2008. (p. 1)

${ }^{99}$ READ, Herbert. Op. Cit. ,

${ }^{100}$ SAPIR, Edward, El Lenguaje, Fondo de Cultura Económica, México, 1954. (pp. 23-31)

${ }^{101}$ HUIZINGA, Johan, Homo ludens, a study of the play element in culture, The Beacon Press, Boston, 1950. (p.4)
} 
Según Huizinga, en un principio, los acertijos eran juegos sagrados relacionados con un grado de formalidad y preparación que reflejaban la educación de aquellos que lograban descifrarlos. Aparecieron juegos que reflejaban el grado de desarrollo y progreso de la humanidad, restándole seriedad a la vida y ofreciendo un medio para promover la creatividad.

Este estudio desea enfatizar la importancia del juego como motor creativo. Porque estamos convencidos que desde las primeras prácticas narrativas de la humanidad, hasta gran parte de la producción artística y narrativa de nuestros días, en gran medida han sido motivadas por acciones creativas inspiradas en prácticas lúdicas. Los mitos y rituales que practicaban los ancestros, propiciaban un carácter parecido a un juego. Incluso en un afán educativo o aleccionador, promovieron el aprendizaje mediante el uso de metáforas y acertijos. La lucha por la sobrevivencia demandaba desarrollar un espíritu competitivo que exigía la solución de enigmas que confirman el valor del juego y su vínculo con el lenguaje y con la creatividad textual. Eso será motivo para retomar en los siguientes apartados en el que apreciaremos el valor del juego y su vinculación con la producción de historias. 


\section{HOMO LUDENS}

En este apartado presentamos un panorama que muestra cómo el juego ha propiciado el desarrollo creativo de la humanidad. Esto a partir de las opiniones de distintos estudiosos que han buscado respuestas ante la relación que ha surgido entre el hombre y el juego. Hemos querido orientar esa relación hombre-juego hacia el potencial creativo que el juego ha detonado en la humanidad, sobre todo, veremos a lo largo del apartado, cómo el juego ha sido una constante en diversas prácticas relacionadas con el manejo de la palabra.

Buscamos confirmar la importancia del juego como factor del desarrollo cultural el cual ha sido de gran trascendencia para desarrollo del hombre porque entre otras cosas ha despertado y propiciado su capacidad creativa.

Desde el origen de los tiempos ha existido cierta fascinación por ligar el lenguaje y el juego; como detonantes creativos. Esperamos que este trabajo sirva de referencia y estimule un análisis de mayor profundización teórica y en la práctica permita generar modelos para desarrollar proyectos textuales. Este panorama que presentamos, por un lado tiene el objetivo de reflexionar sobre la importancia del juego como una herramienta expresiva e imaginativa de la humanidad, y por el otro, mostrar cual ha sido la experiencia lúdica de algunos escritores. Porque existe una arraigada tradición literaria inspirada en juegos de palabras, palabras ocultas y experimentos literarios vanguardistas, que rescatamos, porque estamos convencidos que pueden inspirar nuevas propuestas creativas.

Desde siempre la literatura se ha nutrido de juegos, de la misma manera como los juegos se pueden complementar con formas narrativas. Ya sea a través de movimientos literarios experimentales en los que el juego ha sido motor y sustento de creación, o a partir del trabajo literario de ciertos escritores que son un referente para la consulta y la inspiración creativa. Deseamos conocer las cualidades que los juegos aportan a la narrativa y detectar las herramientas que los escritores pueden descubrir a partir de prácticas lúdicas.

${ }^{102}$ Citado por AMORÓS, Andres (Ed.) en Prólogo (p. 79) en: CORTAZAR, Julio, Rayuela, Cátedra 
Tener un acercamiento a diversos tipos de juegos puede aportarnos elementos que detonen, igual que los mitos y las imágenes grabadas del pasado, nuevas propuestas artísticas. Juegos ancestrales que además de ser antecedentes de nuestros actuales juegos de damas, tableros o cartas; sirvan como modelo para organizar elementos narrativos y conducir ejercicios textuales lúdicos. Esperamos despertar el interés de continuar la búsqueda de otras piezas narrativas similares y llevar a cabo tareas experimentales de escritura.

Parte de la importancia del juego para la vida del hombre se aprecia en su existencia. Desde que se tiene noticias, el hombre y el juego han sido inseparables; vestigios del juego $\mathrm{Ur}^{103}$ con más de 6 mil años, confirman su antigüedad, importancia y universalidad.
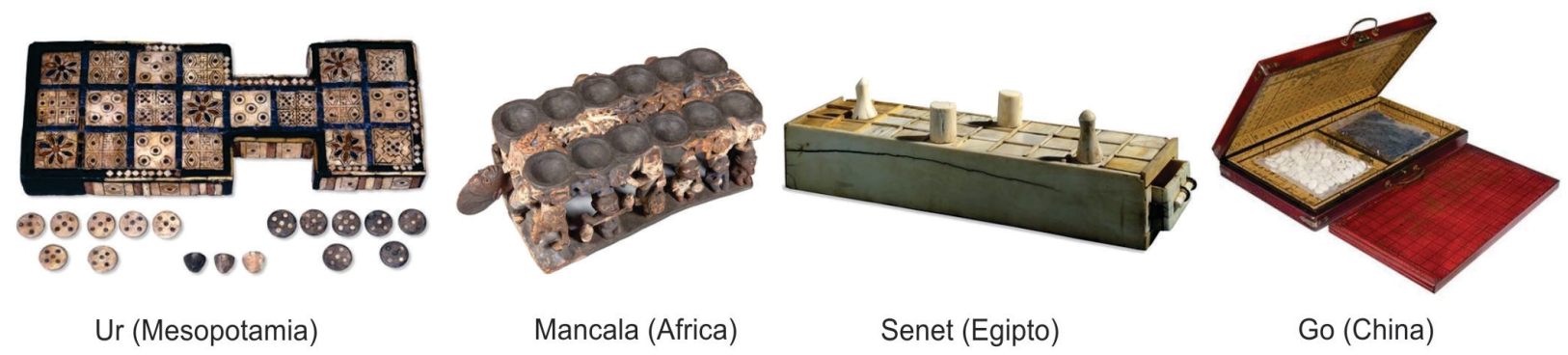

Irving Finkel menciona que "los juegos trascienden fronteras porque compartimos una pasión por el entretenimiento y por la competición."104 Ya sea como pasatiempo, competencia o como forma de expresión cultural, el juego ha despertado el interés de estudio desde diferentes ópticas y disciplinas. Nuestro interés se enfoca al campo de la composición narrativa, porque estamos convencidos que con el juego, o con prácticas muy similares a éstos la humanidad ha encontrado una manera de imaginar y armar historias.

Jugamos con palabras: hacemos rimas, resolvemos enigmas, trabalenguas, acertijos, crucigramas; inventamos metáforas y alegorías. Los escritores, cineastas y guionistas juegan con las historias y continuamente buscan nuevos recursos para armar juegos verbales que despiertan en los lectores un afán lúdico de lectura. Estamos convencidos que la composición creativa y el juego resultan herramientas fundamentales para armar historias en cualquier medio y por ello al buscar como componer las historias de nuestro tiempo, empleando nuevos medios, el juego es un recurso que deseamos revalorar.

Porque deseamos que la capacidad lúdica que poseemos se traslade a otras actividades que realizamos. Hablar del juego es algo que demanda cierta atención por la amplitud de

\footnotetext{
${ }^{103}$ Juego de tablero encontrado en las Tumbas Reales de Ur, Mesopotamia. Véase además el juego africano Mancala; el Senet egipcio o los juegos chinos, Go (Wei-qi) o Mah Jong; han dado lugar a juegos de tablero, fichas o cartas que en la actualidad jugamos.

${ }^{104}$ Entrevista a Irving Finkel, curador del British Museum, especialista en juegos de tablero por: GREEN, William, "Big Game Hunter", Time Specials, June 19, 2008. [Artículo on-line] en: http://www.time.com/time/specials/2007/article/0,28804,1815747_1815707_1815665,00.html Consultado: 07/12/2011.
} 
conceptos que denota. Y por la cantidad de definiciones, significaciones y aplicaciones que a lo largo de la historia ha adoptado. Basta considerar que el concepto "juego" se emplea tanto para designar el retozo de los animales, el juego infantil, el recreo, la competición, la representación teatral, los pasatiempos, las bromas, el ingenio, la alegría y mucho más. Apreciamos su riqueza metafórica y semántica en alusiones como: "se juega en la bolsa", "le seguimos el juego a alguien". Nuestro atuendo en ocasiones "hace juego"; asistimos a "juegos florales" y creamos "juegos poéticos". Nos "jugamos la vida", o "ponemos en juego nuestros intereses". Los prestidigitadores hacen "juegos de manos" y nos encanta "hacer juegos".

Asociamos el juego a una buena parte de nuestras acciones sociales, culturales, colectivas y cotidianas, como competencias deportivas, entretenimientos o la creación artística. Teorías inspiradas en juegos conducen prácticas financieras o desentrañan las leyes biológicas de la evolución. El juego define gran parte de las acciones que hacemos por lo que lo asociamos con un impulso vital. Este impulso no sólo es físico, sino también mental, por ello en un segundo momento de este trabajo mostraremos un panorama sobre la influencia lúdica que ha desarrollado el lenguaje. Ya sea a partir de sistemas de comunicación criptográficos o secretos, llenos de ingenio y otras aplicaciones más estéticas o sistemáticas como los lenguajes artificiales y los lenguajes artísticos, las cuales tienen su origen en prácticas lúdicas de la infancia como inventar palabras para hablar con seres de otros mundos.

Esto se lo ha permitido la literatura con gran ingenio: plantear juegos del lenguaje, formas laberínticas, criptográficas, caligráficas que exploran la visualidad que fusiona la sonoridad y visualidad de los textos. Sin duda que el juego ha dotado a los escritores de ciertas herramientas que le han permitido experimentar y ampliar sus estructuras narrativas, incrementar elementos gráficos y visuales y jugar con las posibilidades significativas de los textos. Troy E. Camplin ${ }^{105}$ afirma que la literatura ha hecho buen uso del elemento "juego" al "jugar" con las palabras, las estructuras, las imágenes y formas de ficción; especialmente ha jugado a armar argumentos, personajes, narradores o con el manejo de los tiempos narrativos, entre muchos otros recursos.

En diferentes momentos históricos, como el de las vanguardias artísticas; se amplían las posibilidades estéticas y el poder de la palabra se renueva: los artistas juegan con la sonoridad y visualidad de las letras y las palabras. Los textos cobran vida y movimiento aún en formatos analógicos, impresos en papel. El poder de la textualidad se enriquece gracias al juego, dotándolo de mayor expresividad y creatividad.

La explosividad creativa del lenguaje nos confirma su potencial y nos obliga a considerarlo como un recurso que diseñadores de textos y artistas de cualquier índole deben apreciar y revalorar.

\footnotetext{
${ }^{105}$ CAMPLIN, Troy E., "literature as a game: game-play in reading, creating and understanding literature", Consciousness, Literature and the Arts, Vol. 7, Num. 2, 2006, (P. 33) [Texto on-line] en: http://blackboard.lincoln.ac.uk/bbcswebdav/users/dmeyerdinkgrafe/archive/camplin.html (Consultado: $13 / 09 / 2011$
} 
Los juegos disciplinan los instintos, son un espacio para el placer y la invención.

Roger Callois $^{106}$

\subsection{ORIGEN, ETIMOLOGIA E IMPORTANCIA DEL JUEGO}

El desarrollo de la humanidad ha estado ligado al juego, Johan Huizinga ${ }^{107}$ lo considera un pilar de la civilización, al ser una de las funciones humanas más significativas que permite comunicar necesidades, pensamientos o sentimientos y adquirir enseñanzas y diversión. Su importancia cobra tal fuerza que incluso se sugiere, antecedió al lenguaje:

"The play attitude must have been present before human culture of human speech existed, hence the ground on which personification and imagination work was a datum from the remotest past onward."108

Mauricio Swadesh ${ }^{109}$, Herbert Read ${ }^{110}$ y Edward Sapir ${ }^{111}$ coinciden en otorgarle gran importancia al juego y considerarlo como un elemento inherente de todo ser vivo. Especies animales que retozan, conviven y compiten por alimento o gustan de mostrar o poner a prueba su fuerza o destreza al realizar ciertas tareas comunes, llevan a cabo acciones de supervivencia que se ha considerado semejante a un tipo de juego primitivo.

\section{Etimologías de "juego"}

Delimitar el concepto "juego" resulta esencial, como un primer paso para definir su importancia. Reflejo de su importancia es evidente a partir de las múltiples definiciones y orígenes etimológicos; que confirma como ha sido un concepto muy apreciado para las diverentes culturas.

\footnotetext{
${ }^{106}$ CALLOIS, Roger, Los juegos y los hombres; la máscara y el vértigo, Fondo de Cultura Económica, México, 1994. (Portada, Presentación editorial)

${ }^{107}$ Historiador y filósofo Holandés quien considera que el juego permitió el desarrollo del pensamiento científico-cultural de la humanidad y lo vincula al mito y al ritual como una gran fuerza instintiva de la vida civilizada en la cual se apoyan las leyes, el comercio, el arte y las ciencias; "All are rooted in the primeval soil of play."HUIZINGA, Johan, Homo Ludens, a study of the play element in culture, The Beacon Press, Boston,1950.(p. 5)

${ }^{108}$ HUIZINGA, Johan, Homo Ludens, a study of the play element in culture, The Beacon Press, Boston,1950.(p.141)

${ }^{109}$ SWADESH, Mauricio, El lenguaje y la vida humana, Fondo de Cultura Económica, México, 1966.

${ }^{110} \mathrm{READ}$, Herbert, Imagen e idea, Fondo de Cultura Económica, México, 1957.

${ }^{111}$ SAPIR, Edward, El lenguaje, Fondo de Cultura Económica, México, D.F., 1984.
} 
Johan Huizinga ${ }^{112}$ realiza un minucioso análisis sobre el significado del término "juego"; en primer lugar nos remonta al origen semítico: el término la'ab (jugar), está emparentado con la'at (reir y burlar). En árabe la'iba designa jugar y burlarse y Laib significa tocar algún instrumento musical (similar connotación de ciertos idiomas europeos actuales: play or spielen). Con relación al sánscrito, Huizinga enlista términos como: kridati que designa el juego de los animales, de los niños y de los adultos, cercano a la raíz $n r t$, que refiere a la danza y la representación dramática; divyati, que designa al juego de dados, de azar, bromear, retozar y burlar y el término līla y lilayati que denota apariencia, imitación (como el inglés like o likeness)

En griego se utilizan los conceptos: $\pi \alpha 1 \delta i ́ \alpha$ [paidia] "perteneciente a los niños" y del cual se desprenden: $\pi \alpha i \zeta \varepsilon ı v$ (jugar) y $\pi \alpha \imath \gamma \mu \alpha, \pi \alpha \imath v ı v$ (juguete); y el concepto es $\alpha \gamma \omega v$ [agon] para designar la competencia.

Dentro de las lenguas sajonas existe la forma gótica laikan, que designaba el jugar y saltar, del cual se desprende el sustantivo Leich (alemán) y lacan (anglosajón) que se refieren al juego, la danza y los ejercicios corporales. Actualmente, encontramos en noruego spill; en sueco, spel; en alemán spielen, en holandés, spelen. Con relación al término en ingles, "play", que se traduce como juego, diversión, jugar y tocar un instrumento, esto porque procede del inglés antiguo plega, plegan que significa juego y jugar y se emplea además para designar un movimiento rápido y tocar un instrumento.

En relación con el término castellano “juego", Según Jesús Paredes ${ }^{113}$, citando a Corominas; menciona que proviene del latín iocus/ ioci (broma, chanza, gracia, frivolidad, ligereza, pasatiempo, diversión).

Por su parte, Huizinga, señala además que iocāri, es hacer algo con alegría, entretenerse y divertirse. De aquí se desprenden: juego y jugar; joc y jugar en catalán, valenciano y mallorquín; en francés jeu y jouer, en italiano gioco y giocare, en portugués jogo y jogar. También surge asociado al término latino Ludus/Ludere que es el acto de jugar y ludicrus/ludicrum que significa divertido o entretenimiento; y ludicrí, juego público o espectáculo; los juegos de azar se designaban como alea. El término "lúdico" es un galicismo que se ha adoptado en castellano.

El Diccionario de la Real Academia Española define "juego" como: "Un ejerció recreativo sometido a reglas en el cual se gana o se pierde",114.

Un concepto que resulta por demás complejo, por la cantidad de acepciones y conceptos que denota: acciones, estados de ánimo, labores o diversiones. Todo apunta a que es preciso revalorar su importancia.

\footnotetext{
${ }^{112}$ HUIZINGA, Johan, Homo Ludens, a study of the play element in culture, The Beacon Press, Boston,1950. (pp. 28-45)

${ }^{113}$ ORTÍZ PAREDES, Jesús, El deporte como juego; un análisis cultural, Tesis Doctoral, Universidad Alicante, 2002. (pp.13-18) [Texto On-line] en: http://www.cervantesvirtual.com/autor/paredes-ortiz-jesus--0/ Consultado: 09/12/2011.

${ }^{114} \mathrm{RAE}$, véase: http://buscon.rae.es/drael/SrvltConsulta?TIPO_BUS=3\&LEMA=juego Consultado:12/12/2011
} 


\section{Importancia del Juego}

El interés por estudiar el juego ha sido una constante histórica; Johan Huizinga (Homo Ludens, 1938), Friedrich Georg Jünger (Die Spiele, 1953) y de Roger Callois (Les jeux et les hommes, 1958) han realizado los estudios más sistemáticos; sin embargo Platón, Aristóteles y pensadores en distintas épocas han abordado el tema del juego, el cual puede ampliarse con algunos otros estudios ${ }^{115}$.

Con el fin de acotar y puntualizar la relación entre el juego y la capacidad creativa, transcribimos algunas ideas de algunos teóricos que nos permite remitirnos a sus cualidades y confirmar su importancia.

Arthur A. Krentz ${ }^{116}$, citando a Platón menciona que: "The final stage in the education of philosophical rulers - are described as play (paidia)"; Una etapa en la formación de las personas que busca la perfección, el balance y la belleza. Esto lo expresa Jim Flowers, citando al mismo Platón de la siguiente manera:

"Plato writes in the Republic about not just the pleasure of games,
but of their necessity. For him they represent artfully, and
incarnationally the human struggle, the human aspiration
towards perfection, balance, and the beautiful...games involving
the human body require discipline and courage, persistence and
resilience... and then the joy that comes with victory...joy the state
to which all humans aspire"

Para Johan Huizinga el juego es un elemento formal, biológico, cultural y universal inherente al hombre, el cual define como: [una]

\section{"Voluntary activity or occupation executed within certain fixed limits of time and place, according to rules freely accepted but absolutely binding, having its aim in itself and accompanied by a feeling of tension, joy, and the consciousness that it is different from ordinary life" ${ }^{118}$}

A partir de esta definición de Huizinga destaca siete características fundamentales de los juegos: 1) Demandan cierta libertad para jugarlos; 2) No persiguen fin alguno; 3) Se llevan a cabo bajo límites de espacio y tiempo; 4) Jugar implica llevar a cabo un orden; 5) Generan cierta tensión-emoción; 6) Facilita la asociación con otros y 7) Es evidente que es algo que no es igual a la vida real.

\footnotetext{
${ }^{115}$ Para ampliar contenido, sugerimos revisar los trabajos de: ELKONIN, D. (Psicología del juego, 1980); ELSCHENBROICH, D. (El juego de los niños, 1979); BATESSON,G. ("Theory of play and fantasy" en Steps to an Ecology of mind, 1972); BLANCHARD, K. (The many faces of play, 1986) y CHATEAU, J. (Lénfant et le jeu, 1954)

${ }^{116}$ KRENTZ, Arthur, "Play and Education in Plato's Republic" [Texto on-line] en: http://www.bu.edu/wcp/Papers/Educ/EducKren.htm Consultado el :15/09/2011.

${ }^{117}$ FLOWERS, Jim, "Of all Dem Saints" [Texto on-line] en: http://allsaintsmobile.net/blog/2010/02/of-alldem-saints/ Consultado el: 17/09/2011.

${ }^{118}$ HUIZINGA, Johan, Homo Ludens, a study of the play element in culture, The Beacon Press, Boston, 1950. (p. 19)
} 
Estas cualidades deben ser un punto focal que podamos trasladar a la composición de textos narrativos. ¿De qué manera estas mismas cualidades se pueden desarrollar en ciertos textos?

Mientras tanto, Roger Callois ${ }^{119}$ amplía las nociones en torno a los juegos, delimitando ciertos tipos de juegos y sugiriendo cuatro categorías para clasificarlos:

1) Agôn (juegos competitivos)

2) Aleas (j. de azar)

3) Mimicry [Simulacrum+Mímesis] (de imitación o roles) e

4) Ilinx (de vértigo, i.e. las montañas rusas o juegos mecánicos)

F. Georg Jünger ${ }^{120}$ señala que los juegos son actividades que se ejecutan sólo por placer sin tener un propósito consciente, que se conforman a partir de una serie de comportamientos espontáneos elegidos libremente, cuya motivación es intrínseca y autónoma. Wolfgang Kramer, ${ }^{121}$ citando a Manfred Eigen y Ruthild Winkler sostiene que: [game] "is a natural phenomenon; half necessity and half coincidence." Eugene Fink $^{122}$ añade que "[el juego] es un quehacer activo y un impulso que busca la felicidad" y asegura que, "mientras más se manifiesta la seriedad de la vida, más desaparece el juego.",123

Evidentemente los juegos implican experimentación, lucha, enfrentamiento y nos remiten a una búsqueda por resolver problemas. Brian Sutton-Smith define el juego como: " $a$ facsimilization of the struggle for survival." ${ }^{24}$ Sobrevivir a una aventura, luchar para resolver un problema, es algo que también los artistas deben sobre llevar al emprender cada nuevo proyecto.

Por su parte Gordon Sturrock ${ }^{125}$, ante la complejidad del término, admite la dificultad de definirlo argumentando que: "es como tratar de definir el amor".

Si nos referimos a juegos complejos, evidentemente tenemos que hablar del videojuego, como un sistema que reúne la mayor complejidad posible en un formato lúdico. Hasta cierto punto, la tecnología ha permitido el surgimiento de estos sistemas que a pesar de su nivel de desarrollo técnico, siguen teniendo los mismos principios rectores básicos de cualquier otro juego analógico; sólo que gracias a los sistemas digitales interactivos, la visión y las cualidades de los juegos se ampliaron. No sólo cebemos resolver desafíos en

\footnotetext{
${ }^{119}$ CALLOIS, Roger, Los juegos y los hombres; la máscara y el vértigo, Fondo de Cultura Económica, México, 1994.

${ }^{120}$ Citado por KRAMER, Wolfgang, "What is a game?" (2000) [Texto on-line] en:

http://www.thegamesjournal.com/articles/WhatlsaGame.shtml Consultado: 27/08/2011

${ }^{121}$ KRAMER, Wolfgang, "What is a game?" (2000) [Texto on-line] en: http://www.thegamesjournal.com/articles/WhatlsaGame.shtml Consultado: 27/08/2011

${ }^{122}$ FINK, Eugene., Oasis de la felicidad, Centro de Estudios Filosóficos, UNAM, México, D.F., 1966.

${ }^{123}$ FINK, Eugene.,Op. Cit.

${ }^{124}$ SUTTON-SMITH, Brian, Toys as culture, Gardner Press Inc., Mattituck, NY, 1986, (p.231)

${ }^{125}$ DYSON, John-Paul (Ed.) "The cultural origins and play philosophy of play workers: an Interview with Penny Wilson" (pp. 269-282) en: American Journal of Play, University of Illinois Press, Vol. 1 Number 3, Champaign, III, 2009.
} 
tiempo real; tenemos múltiples funciones por llevar a cabo y recursos para aprovechar como el poder guardar en la memoria del sistema, nuestras acciones.

El fenómenos del juego digital despertó desde hace un par de décadas el interés de teóricos contemporáneos que han buscado definirlos. Entre otros se encuentran Katie Salen y Eric Zimmerman ${ }^{126}$ quienes señalan que los juegos pueden definirse a partir de los siguientes tres elementos: un sistema de reglas, como juegos en sí y como productos culturales.

Marshall McLuhan, confirma que es una actividad primordial del hombre y lo define como una de sus extensiones cuya función es ser un "translator or transformer of human experience $^{\text {"127 }}$. Will Wright ${ }^{128}$ sugiere que los juegos desarrollan en las personas la habilidad de la "agencia" que permite alterar nuestro mundo o nuestra situación dentro de él, nos permite dejar de ser quienes somos para convertirnos en alguien más. La simulación y los juegos de roles son ejercicios que facilitan el estimulo creativo.

Los diseñadores de juegos deben contemplar las cualidades de los juegos analógicos los cuales entre otros, según sugiere Wolfgang Kramer:

Games are objects which have certain criteria: rules, a goal; always changing
course; chance; competition; common experience; equality; freedom;
activity; diving into the world of the game; and no impact on reality ${ }^{\prime 129}$.

La importancia de los juegos se aprecia también al ser un reflejo del desarrollo cultural de la humanidad. Las formas, temas y tratamientos ponen de manifiesto la complejidad del progreso cognitivo y creativo de la humanidad.

\section{Juego y creatividad}

Gracias al juego y a la comunicación simbólica, el hombre ha desarrollado su proceso creativo. Konrad Lorenz ${ }^{130}$ lo confirma al mencionar que el juego es prerrequisito para cualquier proceso creativo. En un principio, las representaciones rituales asociadas al juego fueron las que inspiran a la humanidad y la condujeron a niveles superiores de desarrollo, en donde afloraba lo emocional y lo creativo. Mediante el juego se estimula la imaginación y desarrollamos habilidades intelectuales al promover la organización de ideas y la planeación de estrategias para resolver tareas o problemas.

\footnotetext{
${ }^{126}$ SALEN, K. \& ZIMMERMAN, E., Rules of play; game design fundamentals, The MIT Press, Cambridge, 2004.

${ }^{127}$ McLUHAN, Marshall, Understanding Media, Gingko Press, Corte Madera, Ca., 2003. (p. 314)

${ }^{128}$ WRIGHT, Will, (Forward) En: FREEMAN, David (Ed.), Creating Emotion in Games: the craft and art of emotioneering, New Riders Games, Indianapolis, 2003, (pp. xxxii).

${ }^{129}$ KRAMER, Wolfgang, "What is a game?" (2000) [Texto on-line] en:

http://www.thegamesjournal.com/articles/WhatlsaGame.shtml Consultado: 27/08/2011

${ }^{130}$ LORENZ, Konrad, The foundations of ethology, Springer-Verlag, New York, 1981. (p. 336)
} 
Carl Jung sugiere que la vena creativa de los artistas parte de su instinto de juego y lo plantea así: "The creation of something new is not accomplished by the intellect, but by the play instinct". 131

Jugar implica resolver problemas; la creatividad también lo demanda. Platón entendía la creatividad como un juego y por ello apreciaba la actitud mental del artista como la de un imitador que juega ${ }^{132}$. Para Georges Colin ${ }^{133}$ el juego se alimenta de ficciones e imágenes similares de las que los artistas se nutren.

Por ello resulta tan necesario generar modelos textuales inspirados en juegos, que permitan la experimentación e innovación narrativa. Deseamos poder desarrollar textos a partir de reglas, retos, fantasías y otros recursos propios de los juegos. Cualidades que despierten la curiosidad, faciliten el descubrimiento de herramientas sistemáticas y expresivas; que favorezcan la construcción de historias bien elaboradas.

¿Hasta qué punto la vena creativa de los artistas parte de su instinto lúdico? ¿Dónde termina el juego y comienza el arte? Deseamos promover este vínculo al servicio de la creación. Crear y jugar permiten echar a andar la imaginación porque son resultado de una expresión libre, espontánea, desinteresada y autónoma. Arte y juego reconfiguran nuestras acciones y sentimientos en situaciones que no son la vida real, sino semejantes a..., por ende, todo puede ser convertido en juego o todo puede convertirse en una historia; gracias al "círculo mágico" que los juegos ofrecen, término que fue acuñado por Huizinga $^{134}$ y que refiere al mundo alterno que se crea al jugar.

"All play moves and has its being within a play-ground marked off beforehand either materially or ideally, deliberately or as a matter of course. Just as there is no formal difference between play and ritual, so the 'consecrated spot' cannot be formally distinguished from the play-ground. The arena, the card-table, the magic circle, the temple, the stage, the screen, the tennis court, the court of justice, etc, are all in form and function play-grounds, i.e. forbidden spots, isolated, hedged round, hallowed, within which special rules obtain. All are temporary worlds within the ordinary world, dedicated to the performance of an act apart."

El concepto de "círculo mágico" fue retomado nuevamente por Katie Salen y Erik Zimmerman $^{135}$ para designar la idea de un espacio temporal o lugar imaginario que estimula la invención y donde el juego se desarrolla: "to play a game means entering into a magic circle o perhaps creating one as a game begins" "136

\footnotetext{
${ }^{131}$ Retomado del Museo del Juego: http://www.museumofplay.org consultado el 27/05/2008

${ }^{132}$ HUIZINGA, Johan, Homo Ludens, a study of the play element in culture, The Beacon Press, Boston, 1950 (p.162).

${ }^{133}$ COLIN, Georges, Compendio de psicología infantil, Kapelusz, Buenos aires, 1974.

${ }^{134}$ HUIZINGA, Johan, Homo Ludens, a study of the play element in culture, The Beacon Press, Boston, 1950. (p.10)

${ }^{135}$ SALEN, K. \& ZIMMERMAN, E., Rules of play; game design fundamentals, The MIT Press, Cambridge, 2004. (p.95)

${ }^{136}$ SALEN, K. \& ZIMMERMAN, E., Rules of play; game design fundamentals, The MIT Press, Cambridge, 2004. (p.95)
} 
Esta idea involucra la participación creativa del propio jugador, quien aporta algo genuino casi mágico al juego; no sólo se trasporta a este mundo mágico, también le da sentido a la historias que puede articular a partir del juego. Con esto confirmamos que a través del "juego creativo", tanto el artista como del jugador, adquieren libertad para experimentar con aquellas opciones que resultaría impermisibles en un mundo real. El círculo mágico, despierta el poder de la imaginación y de la creación. Nos otorga el poder transformar experiencias y liberarnos de ataduras y estereotipos.
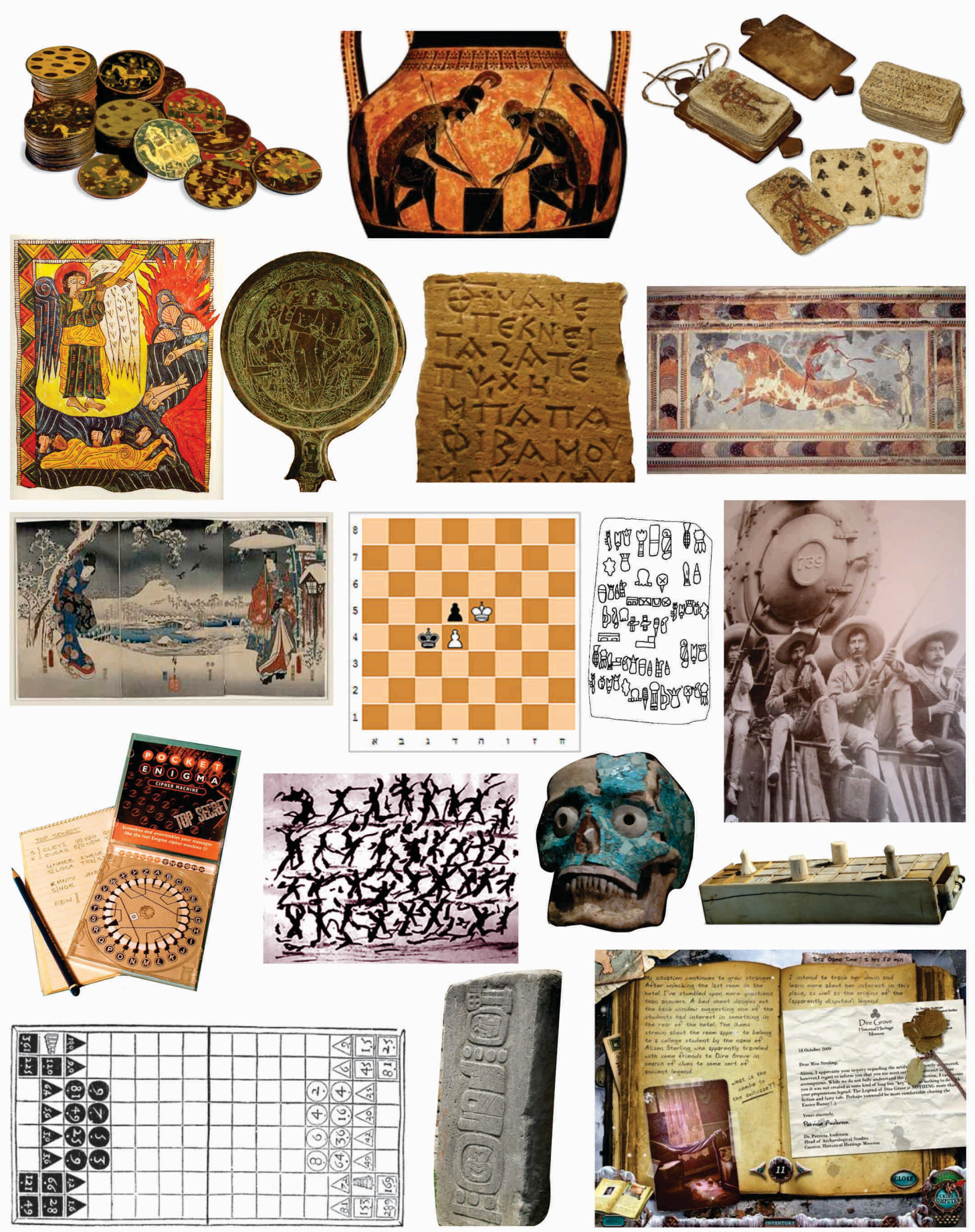

Descubre las historias en estas piezas 


\subsection{JUEGO Y LENGUAJE; UNA MANCUERNA CREATIVA}

El lenguaje puede utilizarse tanto con fines comunicativos como estéticos. Ha sido objeto de manipulación y experimentación realmente curiosa e incluso en ciertos casos ha sido sorprendente. El lenguaje se ha transformado en juegos infantiles, códigos criptográficos o lenguajes artificiales o artísticos, mostrando su versatilidad y potencial creativo. En este apartado deseamos conocer diversas muestras que lo ejemplifican. Nuestro interés atiende a la necesidad de re-plantear el amplio potencial creativo que el lenguaje puede desarrollar en función a su invención artística. Mostramos un abanico de posibilidades que además de ser un referente para seguir investigando, sirvan de modelo para generar nuevas propuestas en las que las cualidades lúdicas y artísticas se confundan.

Resulta indudable la fascinación que ha generado en escritores, la manipulación del lenguaje con fines utilitarios, de entretenimiento o artísticos. Anticipamos que abordaremos formas textuales poco ortodoxas con el único interés de que sirvan para complementar cualquier proyecto, que requiera de articular historias, guiones o diseñar textos.

Ojalá consideren que el lenguaje puede enriquecer y dotar de sentido a cualquier texto, ya sea mediante recursos poéticos, simbólicos o lúdicos. La palabra es materia prima para la invención al igual que una pella de barro, un bote de pintura color verde, las notas de la escala musical o cualquier otro material que elijan los artistas para la creación. Sin embargo y a diferencia de estos objetos que sólo adquieren significado al transformarse en piezas artísticas, las palabras, en cambio, como lo señala Benjamín Valdivia ${ }^{138}$, tienen un significado propio independientemente de las aplicaciones que le demos. Las lenguas poseen por sí mismas, elementos estéticos expresivos (fonéticos, rítmicos, simbólicos, morfológicos) que se transforman en literatura, poesía y en otras formas artísticas y noartísticas; gracias a la creatividad ludo-lingüística del hombre. Si nos referimos a la poesía, Warren Motte ${ }^{139}$ sugiere que ésta es un sistema lúdico interactivo, provocativo y fructífero y Johan Huizinga confirma que "Poiesis, is a play function. It proceeds within the play ground of the mind. ${ }^{140 "}$

\footnotetext{
${ }^{137}$ Véase: The Marcel Duchamp Studies Online Journal [Sitio web] en: http://www.toutfait.com/ y Dada Companion [Sitio web] en: http://www.dada-companion.com/ Consultados: 15/15/2012.

${ }^{138}$ VALDIVIA, Benjamín, La literatura como arte, en Los Objetos Meta-Artísticos, Azafrán y Cinabrio ediciones, Guanajuato, 2007.

${ }^{139}$ MOTTE, Warren F., Playtexts: lúdics in contemporary literature, University of Nebrasca Press, Lincoln, 1995. (p. 6)

${ }^{140}$ HUIZINGA, Johan, Homo Ludens, a study of the play element in culture, The Beacon Press, Boston, 1950. (p. 119)
} 
Las historias, la literatura y el arte son portadores de su propia significación a dos niveles diferentes: el de la codificación que lleva a cabo el escritor o compositor y el nivel del receptor o decodificador que reinterpreta los textos. Y dependiendo de su experiencia, logra otorgarle más de un significado(s) a las lecturas. De ahí que un buen escritor y un buen lector sean inventores de universos imaginarios, porque han aprendido a poner en práctica un gran número de descubrimientos y conexiones de significación a partir de las palabras que codifican-decodifican. Porque son capaces interpretar y obtener información que les resulta significativa. Esto es lo que busca todo creador de textos, que sus escritos transmitan cierta significación.

Con respecto a la significación, Robert Scholes y Robert Kellogg ${ }^{141}$ sostienen que, "el significado en una narrativa artísticas es el entendimiento de dos mundos: el mundo de la ficción, creado por el autor y el mundo "real" es decir, el mundo aprehensible. Por lo que decimos que es significativo cuando logramos establecer esa conexión con lo conocido. El arte permite extender la conciencia humana y ampliar nuestros sentidos. Al respecto el lingüista Pierre Guiraud ${ }^{142}$ señala que "comprender y sentir" son una doble función poética o estética del lenguaje. Buscamos el "sentido" en las cosas, creamos representaciones imaginarias. "Buscar sentido", como dice Michel Foucault, es sacar a la luz lo que asemeja, ${ }^{143}$ es jugar con las experiencias sensoriales y crear diferentes tipos de mensajes $^{144}$. De ahí nuestro interés, en este apartado, de mostrar diferentes prácticas comunicativas y literarias en las que se aprecia el desarrollo creativo del lenguaje. Deseamos conocer y retomar el acervo lúdico-creativo que el mismo lenguaje ha legado; este acercamiento seguramente ampliará nuestra visión acerca del lenguaje y sobre su potencial poético.

\section{De juegos poéticos, palabras ocultas a lenguajes artísticos}

El juego poético inició como tal en un mero afán de entretenimiento. Por ello para algunos puede resultar no sólo intrascendente, sino incluso peyorativo; en cambio para otros, los juegos de palabras son una expresión muy apreciada, producto del ingenio lúdico-literario. Porque a pesar de ser cosas de niños, han atraído la atención de algunos escritores como Julio Cortázar, encantado por la perfecta simetría de los palíndromos ${ }^{145} \mathrm{y}$

\footnotetext{
${ }^{141}$ SCHOLES, Robert, et al, The nature of narrative, Oxford University Press, New York, 1966. (p. 82)

${ }^{142}$ GIRAUD, Pierre, La Semiología, Siglo XXI Editores, México, 1972.

143 FOUCAULT, Michael, Les mots et les choses, Siglo XXI Editores, México, 1968. (p. 38)

${ }^{144}$ La relación entre el lenguaje y el significado es compleja (imposible agotar en este estudio). El lenguaje posee una función creativa en el sentido que las personas eligen e interpretan las palabras de manera diferente basados tanto en el significado denotativo (del diccionario) como en el connotativo, entendido como la interpretación emocional que se da en una situación particular. Ya tendremos oportunidad de retomarlo más adelante como una herramienta para enriquecer las lecturas con contenidos que podamos conectar a múltiples referencias dentro de un mismo texto, similar a la idea de un palimpsesto.

${ }^{145}$ Composiciones capicúas, que pueden leerse de manera idéntica en ambas direcciones como: (Ola moro moro malo; No tardes y sed ratón y No deseo ese don)
} 
su ingenio de leerse en ambas direcciones como este que compuso: Átale, demoniaco Cain, o me delata.

Quizá el palíndromo más famoso es el Cuadrado de Sator, el cual decoraba casas en Pompeya y muestra las palabras SATOR AREPO TENET OPERA ROTAS, cuya posible traducción sería algo como "el sembrador (arepo) toma con destreza el arado". Pero que resulta más significativo por el juego y orden que presentan las cinco palabras que pueden leerse en todas direcciones, siempre resultando las mismas, un texto cuadrático en capicúa. Lo curioso es que estas inscripciones aparecen con frecuencia en libros esotéricos o de magia ${ }^{146}$.

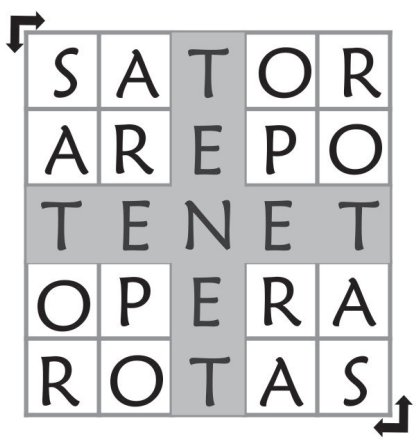

\section{Cuadrado de Sator}

Matriz que recuerda los cuadrados mágicos numéricos. Las cinco palabras se repiten si se leen de derecha a izquierda (y viceversa) o bien, de arriba a abajo o al revés. En el centro se forma una cruz con la palabra TENET.

Los escritores han adoptado el juego poético más allá de un mero afán de entretenimiento. Verdadero malabares textuales como el Cuadrado de Sator evidencian el potencial lúdico del lenguaje y confirman la destreza de los escritores por componer textos muy originales.

Las fronteras entre el juego y la seriedad de la vida se desdibujan con interpretaciones de sueños, sistemas adivinatorios, leyendas, mitos y otras manifestaciones en las que la fantasía, el ingenio y la imaginación son un motor creativo. Francisco de $\operatorname{Cozar}^{147}$ nos remite a formas mágico-lúdicas, palabras que en cierto contexto adoptan sentidos adivinatorios, esotéricos o relacionados con la superstición. Palabras que adquieren sentido mágico en la voz de taumaturgos y adivinadores, vocablos que se convierten en "talismanes", hechizos o han adoptado ciertas cualidades adivinatorias o cabalísticas como Shabiri, Abracadabra o Sésamo ${ }^{148}$. Vocablos para pedir deseos o invocar algún favor divino o evitar la mala suerte, ¡Por arte de birlibirloque! Pero si son cosas de niños, aunque no dejamos de admitir que tienen gran ingenio al igual que otras figuras del lenguaje (empleadas principalmente en la poesía) como Acrósticos (poemas con frases o palabras escondidas); anagramas (palabras formadas de la reagrupación de las letras de

\footnotetext{
${ }^{146}$ Referido en: http://objetosmagicos.blogspot.com/2009/05/palabras-magicas.html Consultado: 23/03/2012.

${ }^{147}$ DE COZAR, Rafael, Poesía e Imagen; formas difíciles de ingenio literario, [Texto on-line] en: http://josecrespo.es/pdf Consultado: 24/11/2011.

${ }^{148}$ Rafael de Cózar menciona que Shabiri y Abracadabra se usaban para curar a las personas; Sésamo aparece referenciada en Las Mil y una Noches y Athoray era escrito en una tablilla de cobre para dotar de poderes a los marinos, soldados y alquimistas. En: DE COZAR, Rafael, Op. Cit. (p.47)
} 
otra palabra o frase); lipogramas (aquellos que omiten alguna letra) y algunas otras que aunque parecen formas suspendidas en el pasado, pueden retomarse con nuevas intenciones, aplicarse a nuevos medios y abordar diferentes contenidos. Seguro pueden ser de utilidad para los diseñadores de textos. El libro de Pere Ruíz Lozano ${ }^{149}$, aborda un listado considerable de figuras y formas retóricas que siguen siendo válidas como recursos para el diseño de estructuras narrativas que pueden adaptarse a proyectos digitales.

Nuevos lenguajes, tropos o figuras retóricas, juegos de palabras infantiles, han sido y pueden seguir siendo herramientas recurrentes de los constructores de historias. Música, sonoridad y juego de palabras como en el caso del poema "Leyenda" del cubano Mariano Brüll $^{150}$, del cual Alfonso Reyes acuñó el término de jitanjáforas, poema hecho en su totalidad de palabras inventadas; resulta ser un ejercicio de creación con muchas posibilidades pero no por ello carente de sonoridad y belleza:

\section{Leyenda}

Filiflama alabe cundre ala olalúnea alífera alveola jitanjáfora liris salumba salifera...

Alejandro Murgía señala que lo interesante de una palabra inventada es que puede establecer asociaciones con palabras existentes; al crearla existe un código lógico que le permite cierta coherencia y en este caso, mucha sonoridad; "la palabra jitanjáfora, por ejemplo, se nos presenta como una incógnita absoluta, pero su misterio es más intenso porque en ella hay algo de gitano, de jirafa, de metáfora, de desaforado, de ánfora, de tinaja..."151 Otras jitanjáforas ${ }^{152}$ como "Abracadabra", o "Super califragilístico espiralidoso", canciones de cuna, "Ala-rro-rro-niño..." y las coplas y juegos infantiles confirman el potencial creativo del lenguaje: "Piso- pisuela, color de ciruela, me dijo mi abuela, que saques, es-te-pie", "Mantantirulirulá"; "Se me ha perdido una niña, cataplín, cataplín cataplero"; "Mambrú se fue a la guerra, chiribin, chiribin, chin chin".

\section{Los códigos secretos}

Admitimos que orientaremos un momento nuestra atención a asuntos poco serios, pero no por ello, ausentes de ingenio. Al abordarlos buscamos que narradores y guionistas contemplen el potencial creativo que resultan estas formas lúdicas de recomponer y jugar

\footnotetext{
${ }^{149}$ RUIZ LOZANO, PERE, "Palíndromos literarios y literatura palindrómica”, [Texto on-line] en: http://www.albaiges.com/cpi/icpi/palindromosliterariosliteraturapalindromica.htm Consultado: 03/10/2011.

${ }^{150}$ Véase: http://www.poesi.as/Mariano_Brull.htm Consultado: 09/03/2012

${ }^{151}$ Publicado por Alejandro Murguía en Blog Hurgapalabras (Octubre 16, 2007) en: http://hurgapalabras.blogspot.com/2007/10/jitanjforas.html Consultado: 28/09/2011

${ }^{152}$ La Real Academia de la Lengua Española reconoce su invención, definiéndolas como: "Enunciado carente de sentido que pretende conseguir resultados eufónicos". [Def. Eufonía: sonoridad agradable resultado de la acertada combinación de los elementos acústicos de las palabras, fuente: RAE]
} 
con el lenguaje como: Sopas de Letras, Juegos del Ahorcado, crucigramas y otros juegos que no sólo se han difundido y popularizado en medios digitales, sino que han inspirado la narrativa contemporánea.

Las jerigonzas, estructuras surgidas con el afán de codificar o encriptar mensajes (decir en jerigonza "amigo" seria: apa-mipi-gopo) o podríamos "decirlo en efe" (afa-mifi-gofo). Algunas jerigonzas invierten el orden silábico, repiten alguna vocal o interponer alguna partícula como cuti (cutifa-cutimi-cutigo). Estos juegos de niños, se han utilizado en muestras literarias, películas ${ }^{153}$ adaptaciones radiofónicas o programas de televisión.

Los lenguajes ocultos, curiosamente existen mucho antes de La Enigma ${ }^{154}$, aparato mecánica similar a una máquina de escribir para encriptar mensajes y que fue utilizada por las inteligencias militares durante la Segunda Guerra Mundial. Otros sistemas de comunicación ocultos fueron practicados por algunas organizaciones monásticas del siglo décimo de nuestra era. ${ }^{155}$ Quienes con el afán de respetar sus votos de silencio, desarrollaron mensajes manuales basados en un código alfabético, representado por la elección de diferentes partes de los dedos y palma de la mano [véase imagen], estos sistemas facilitaban la comunicación secreta o discreta en un mundo de silencio.

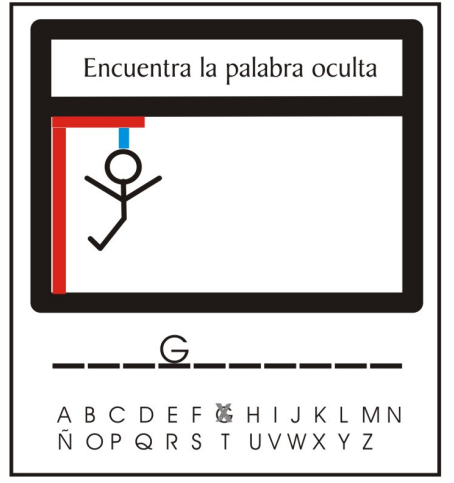

Juego del Ahorcado

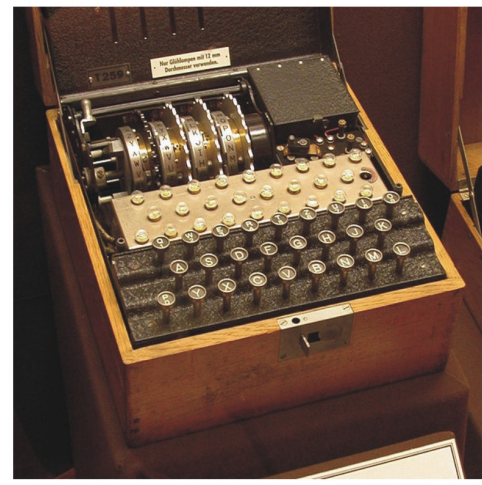

Máquina Enigma

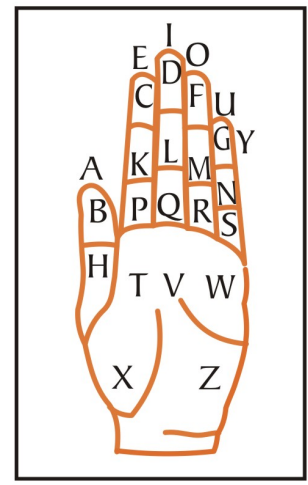

Código en Manos

La tradición artrológica, de utilizar ciertas partes de las manos para comunicar o efectuar cálculos matemáticos fue una práctica utilizada por las culturas egipcia, asiria o romana; inspiraron el desarrollo de sistemas de dígitos romanos y fueron el antecedente para el surgimiento de alfabetos gráficos para sordomudos ${ }^{156}$.

\footnotetext{
${ }^{153}$ Nos referimos a la película Rosarigasinos Dirigida por Rodrigo Grande (2001), que retrata el dialecto de Rosario Argentina.

${ }^{154}$ Para ampliar información sobre Enigma Machine, consultar:

http://www.dmoz.org/Science/Math/Applications/Communication_Theory/Cryptography/Historical/ Y pueden utilizar un simulador de Enigma en: http://russells.freeshell.org/enigma/ Consultado: 09/03/12

${ }^{155}$ SKOMOROCHO, Dimitri et al., Monastic sign language, Benedictine communication in the II th Century England,[Texto-On line] en: http://www.thebluefool.com/society/artsci/MSL_Report.pdf Consultado: 03/04/2011

${ }^{156}$ En 1620 Juan de Pablo Bonet publica el primer Diccionario Dactilológico para enseñar a hablar a los sordos y mudos titulado Reduction de las letras y Arte para enseñar á ablar los Mudos. Véase: GASCON R. Antonio, A. "Señas o signos? Evolución Histórica, (2003) [Texto on-line] en:

http://www.ucm.es/info/civil/bardecom/docs/signos.pdf consultado: 16/05/2012.
} 
Existen referencias de la existencia de señales, signos o sistemas lingüísticos alternativos en el siglo XII; un ejemplo es el lenguajes privado Lingua Ignota de de la monja Hildegard de Bingen, según menciona la historiadora lingüista, Arika Okrent, ${ }^{157}$ quien señala que durante la Edad Media surgió el interés de recrear la lengua original de la humanidad, el lenguaje de Adán y Eva. Esta idealización promovida por los místicos se contrastó al surgimiento de lenguajes esotéricos que incorporaban símbolos cabalísticos y sistemas adivinatorios a partir de generar una terminología propia de magos y alquimistas.

El lenguaje ha sido un sistema en constante evolución, nuevas palabras surgen y otras se desechan; el Renacimiento incrementó conceptos relacionados con el conocimiento mientras que el siglo XVIII amplio los conceptos relacionados con el pensamiento filosófico. Posteriormente aparecerían nuevos términos que reflejaban la modernidad e industrialización de la vida en una creación desbordante del lenguaje en la que participan también las vanguardias artísticas de principios del XX. La Era tecnológica digital, ha provisto de nuevos términos y vemos como éste seguirá adaptándose a las necesidades comunicativas de la humanidad; también el lenguaje ha sido objeto de múltiples experimentos, invenciones y propuestas originales.

\section{Lenguajes inventados}

Apreciamos cómo la fascinación por la invención de lenguajes ha sido una constante cultural que se ve reflejada por una muestra ${ }^{158}$ muy nutrida y original. Algunos como Solresol $^{159}$, inspirado en la notación musical; el Ro creado por Edward Powell Foster ${ }^{160}$ en 1904 a partir de clasificaciones conceptuales; o el P@x'áãokxāã creado en 2004 por E. Ohlms, quien se enfoca en las emociones, los sentidos y destaca opiniones filosóficas. La lista resulta por demás extensa y sería motivo de otro estudio, sin embargo deseamos apreciar el potencial de la creación de lenguajes con diversos fines como el caso de "lenguajes sensoriales" que complementen proyectos para ciegos o sordos y otros que pueden aportar ciertas pautas de experimentación creativa.

La invención de lenguajes surge con la finalidad de facilitar la comunicación y suprimir las barreras lingüísticas entre hablantes de diferentes lenguas; también conocidos como Lenguajes Auxiliares Artificiales como el Bahái Faith, la Lingua Franca y el Esperanto $^{161}$, éste último creado en 1880 para unir Rusos, Polacos, Alemanes y Judíos en la ciudad de Bialystok, Rusia; cuenta con publicaciones periódicas, libros, obras de teatro

\footnotetext{
${ }^{157}$ OKRENT, Arika, In the land of invented languages, ofrece un Listado sólo de 500 lenguajes organizados cronológicamente que resulta informativo. Véase: In the land of Invented Languages de Arika Okrent [sitio Web] http://inthelandofinventedlanguages.com Consultado 16/05/2012.

${ }^{158}$ Puede también revisarse el sitio FrathWiki, el cual ofrece una extensa colección de Conlangs o lenguajes compuestos en: http://www.frathwiki.com Consultado: 07/03/2012.

${ }^{159}$ SOLRESOL, Lenguaje articulado a partir de las notas de la escala musical, el cual podía tararearse, cantarse o interpretarse en un violín fue inventado por J.F. Sudre en 1866.

160 POWELL F. Edward, Ru Ro: Outline of universal language, publicado originalmente en 1913, y reeditado por la Biblioteca de la Universidad de Michigan en 2009.

${ }^{161}$ Asociación universal de Esperanto en: http://www.uea.org/info/hispana.html Consultado: 09/03/2012
} 
e incluso filmografía: Angorg $^{162}$ (Agonía en Esperanto) del director Jacques-Louis Mahé en 1963 fue la primera película en Esperanto, le seguiría Incubus ${ }^{163}$ de Leslie Stevens.

Motivados con la posible existencia de civilizaciones extraterrestres, se crearon lenguajes matemáticos y científicos que buscaban la comunicación con habitantes de otros planetas como Interglossa (1943) de Lancelot Hogben ${ }^{164}$; Lincos (Lingua cósmica, 1960), de Hans Freundenthal $^{165}$ o la novela Contacto (1985) de Carl Sagan ${ }^{166}$ o The Hercules Text (1986) de Jack McDevitt ${ }^{167}$. Con un fin estético se han inventado lenguajes que la literatura, la televisión o el cine han utilizado con fines estéticos y que se conocen como Langart. Existe una gran diversidad de ejemplos con mayor o menor complejidad lingüística y basados en muy diversas propuestas: algunos inspirados en la comunicación gestual, onomatopéyica, fusionan varios lenguajes; otros son creados a partir de complejos sistemas léxicos, gramaticales y fonéticos. Tim Conley y Stephen Cain ${ }^{168}$ hacen una selección y clasificación de langarts que puede interesar a los narradores de nuevos medios $^{169}$ atraídos por la invención de mundos ficcionales, utópicos y distópicos. Lenguajes que simulan conversaciones con animales, seres inanimados, extraterrestres o seres míticos. Avatar (2009) de James Cameron emplea el $\mathrm{Na}^{\prime} v i^{170}$, diseñado con tal esmero que se espera pueda ser un medio de comunicación efectivo entre algunas comunidades de seguidores fuera de Pandora. Otros ejemplos son el lenguaje $K U$ utilizado en The Interpreter (2005) de Sydney Pollack quien recrea la lengua de la ficticia República de Matobo, o el Krakozhian en The Terminal (2004) de Steven Spielberg. Ben Burtt, es otro lingüista que ofreció soluciones innovadoras para los lenguajes ficticios de las películas Star Wars de George Lucas (Huttese, Ewok, Shyriiwook, Mando'a, Rodese y otros $^{171}$; Klingon es el lenguaje de Star Trek (2009) de J.J. Abrahams; Atlantean aparece en Atlantis: the lost empire (2001).

Cuando se trata de desarrollar el potencial narrativo, y dotar de herramientas a diseñadores de textos, vale la pena contemplar la generación sistemas lingüísticos con

\footnotetext{
${ }^{162}$ ANGORJ: http://www.imdb.com/title/tt0229990/ Consultado: 09/03/2012

163 INCUBUS: filme http://es.wikipedia.org/wiki/Incubus_(1966_film) Consultado: 16/05/2012.

${ }^{164}$ HOGBEN, Lancelot, Interglossa: a draft of an auxiliary for democratic world order, being an attempt to apply semantic principles to language design, Penguin Books, New York, 1943.

${ }^{165}$ FREUDENTHAL, Hans, Lincos: Design of a language for cosmic intercourse, North Holland Publishing Company, Amsterdam, 1960.

${ }^{166}$ SAGAN, Carl, Contact, Editorial Simon \& Shuster, New York, 1885. En 1997 Robert Zemeckis, filma Contact inspirado en la novela Sagan.

${ }^{167}$ McDEVITT, Jack, The Hercules text, Ace Books, New York, 1986.

${ }^{168}$ CONLEY, Tim \& CAIN, Stephen, Encyclopedia of fictional and fantastic languages, Greenwood Press, Westport, 2006.

${ }^{169}$ ROSENFELDER, Mark, The language construction kit, Yonagu Books, Chicago, 2010.

${ }^{170}$ Conoce y aprende Na'vi en: http://www.learnnavi.org/o en sitio de su inventor, Paul Frommer en: http://naviteri.org/ Consultados: 25/09/2011.

${ }^{171}$ Los lenguajes creados para la película Star Wars no son sistemáticos, están basados en otros lenguajes humanos: El Galactic Basic con su alfabeto Aurabesh y el lenguaje de los Ewoks basado en el tibetano, el Xyro basado en gruñidos; y otros lenguajes de los Droides, el Shyriiwook, Rodese, Huttese, Mando'a, Jawa y Gungan. El androide C-3PO "tenía capacidad de decodificar 6 millones de formas de comunicación".
} 
afanes estéticos, ya sea como sistemas alternativos, de ficción o lenguajes experimentales o artísticos. ${ }^{172}$

Basta revisar algunos artlangs ${ }^{173}$ [acrónimo de Artistic Language] como: Albic, Baljek, Dmezk, Eastern Kelanian, Hesperic, Iljena, Kelen y apreciar las aplicaciones que pudieran tener. Uno de los casos más notables en el manejo de lenguajes artísticos es el de J.R.R. Tolkien, quien desde niño jugaba a inventar lenguajes como el Nevbosh ${ }^{174}$ del cual, generaría los lenguajes que utiliza en sus obras como el Sindarin, Elvish Tongues y el Ardalambion, entre otros sistemas bien estructurados. ${ }^{175}$ Tolkien aprecia el valor del lenguaje diciendo: "To me a name comes first and the story follows" ${ }^{, 176}$ Comenzar una historia a partir de "palabras" puede ser un buen resorte narrativo.

La lista seguramente se ampliará y se complementará con grafías y sistemas de escritura que enriquecen aún más las posibilidades del lenguaje artístico artificial; muchos han sido aplicados en la literatura y en otras muestras artísticas que a continuación mencionamos.

\section{Lenguajes artísticos en la literatura}

En la literatura existen obras como: Gargantúa y Pantagruel de Francis Rabelais (siglo $\mathrm{XVI}$ ); uno de los primeros casos en la literatura que maneja un lenguaje de manera original y creativa al introducir palabras griegas, latinas e inventar otras:

"There the countries Cidentine and Tradentine, that is, behither and beyond the teeth"177.

Apreciamos el lenguaje Houyhnhnms, propio de una raza de caballos "perfectos" creado por Jonathan Swift en Los Viajes de Gulliver (1762). Tenemos conocimiento de la existencia del Nautilus, lenguaje inventado por Julio Verne en 20000 leguas de viaje Submarino. La creación de mundos fantásticos, ambientados en Marte o el centro de la tierra de Edgar Rice Burroughs (1875-1950), invita a generar formas de comunicación particular. Del mismo autor es el célebre Tarzán quien podía comunicarse en el lenguaje de los animales. Otros textos presentan grafías, palabras e incluso sistemas comunicativos inventados para enriquecer la ficción de novelas como: El nombre de la rosa (1980) de Umberto Eco; Tlon Uqbar, Orbis, Tertius de Jorge Luis Borges; Silvie y Bruno de Lewis

\footnotetext{
${ }^{172}$ Véase la clasificación de Constructed languages (conlangs) Artistic Languages (artlangs); Engineered Languages (engelangs), Universal Language, Fictional language en:

http://en.wikipedia.org/wiki/List_of_constructed_languages\#Literature Consultado: 09/03/2012.

${ }^{173}$ Véase: http://en.wikipedia.org/wiki/Artistic_language Consultado 09/03/2012.

${ }^{174}$ Puede ampliar la información sobre los lenguajes inventados de J.R.R. Tolkien en: http://www.uib.no/People/hnohf/nevbosh.htm o en: http://www.freewebs.com/lordfingulfin/index.htm ${ }^{175}$ The Hobbit (1936), The lord of the rings (1954-1955), The Silmarillion (1977; póstuma).

${ }^{176}$ Véase Sitio Web: J.R.R.Tolkien \& Language en : http://www.tolkien-online.com/tolkien-language.html Consultado: 26/09/2011.

${ }^{177}$ RABELAIS, Francis, Gargantua \& Pantagruel, Capítulo 2, XXXII, [Texto on-line] en:

http://www.gutenberg.org/files/1200/1200-h/p2.htm\#2HCH0030 Consultado: 25/09/2011
} 
Carroll $^{178}$ o Symzonia (1829) de Arthur Gordon Pyn. Parseltongue y Gobbedegook son los lenguajes creados por J.K. Rowling para Harry Potter, que engrosan la extensa lista de lenguajes construidos ${ }^{179}$ sobre experimentos fonéticos, aliteraciones, acoplamientos de onomatopeyas y asociaciones vanguardistas o experimentales sonoras. Algunas canciones también inventan sus lenguajes estéticos, como el caso del álbum Amarantine (2005) de Enya o el humorístico Gulevache de Les Luthiers ${ }^{180}$.

Estos recursos creativos del lenguaje realzan las historias. De ahí nuestra idea de considerar el lenguaje más allá de un instrumento de comunicación y expresión artística; debemos contemplarlo como la materia prima de la invención que deseamos experimentar y ahondar sus posibilidades creativas en medios digitales.

\footnotetext{
${ }^{178}$ Clive Staples Lewis, Las crónicas de Narnia (1949-1954) publicado por Planeta Mexicana, México, D.F., 2005.

${ }^{179}$ Véase: Constructed Languages en:

http://en.wikipedia.org/wiki/List_of_constructed_languages\#Literature Consultado: 09/03/2012

${ }^{180}$ Les Luthiers, Cardoso en Gulevandia (en idioma Gulevache) puede escucharse en:

http://www.youtube.com/watch?v=hJ8WxhctsPI Consultado:04/10/2011
} 
La poesía es pintura que habla y

la pintura, poesía muda

Simónides de Ceos ${ }^{181}$

\subsection{LITERATURA LÚDICA}

La contribución que hace el juego a la literatura es innegable; juegos de palabras, nuevos lenguajes, metáforas y tropos, rimas, alusiones, textos gráficos y tipográficos entre muchos otros recursos expanden y flexibilizan el uso del lenguaje, otorgándole una dimensión visual y acústica; y un poder creativo insospechado e ilimitado. El lenguaje, en una búsqueda lúdica se aleja de su sentido comunicativo y adquiere uno nuevo, que revela una notable fuerza imaginativa de la cual se develan formas visuales, sonoras, estructurales y conceptuales ingeniosas. Deseamos conocer el provecho que los escritores contemporáneos pueden obtener de la relación entre la creación y el juego.

Desde siempre un proceso lúdico ha favorecido la observación, imitación y renovación de las estructuras conocidas por otras nuevas y originales, al mismo estilo de los centones $^{182}$ griegos. Compartimos la idea de que "El juego debe interpretarse como un componente esencial de cualquier actividad creativa" $" 183$ ya que permite la invención, la trasformación y se convierte en un detonante para la innovación y la experimentación expresiva en la composición de historias. Troy E. Camplin lo confirma: "Cualquier texto literario que contenga elementos de ritmo, armonía, contraste, tensión, variación y solución; posee elementos asociados con el juego" "184. Requerimos un verdadero motor de cambios, por ello Edwards Brian, sostiene que el juego es: "[como] the principle of energy and difference which unsettles arrangements, promotes change and resists closure." ${ }^{185} \mathrm{El}$ juego permite un proceso narrativo muy diverso. Y de acuerdo a Blanca Montalvo" ${ }^{186}$, "la narración anida en tejidos espaciales: estructuras geométricas, combinatorias,

\footnotetext{
${ }^{181}$ Simónides de Ceos, poeta griego del siglo V a.C. citado en Wikiquote: http://es.wikiquote.org Consultado: 16/05/2012.

182 Tipo de poemas que se elaboraban a partir del ingenio creativo del poeta, basado en otro poema.

${ }^{183}$ GUINESS G. \& HURLEY, A. (Eds.) Auctor Ludens, essays on play in literature, John Benjamins Publishing Co., 1986. (p. Viii)

${ }^{184}$ CAMPLIN, Troy E., "literature as a game: game-play in reading, creating and understanding literature", Consciousness, Literature and the Arts, Vol. 7, Num. 2, 2006, (P.26) [Texto on-line] en: http://blackboard.lincoln.ac.uk/bbcswebdav/users/dmeyerdinkgrafe/archive/camplin.html Consultado: 8/10/2011

${ }^{185}$ BRIAN, Edwards, Theory of play and postmodern fiction, Garland Publishing, New York, 1998. (Introduction)

${ }^{186}$ MONTALVO, Blanca, La narración espacial: propuesta para el estudio de los lenguajes narrativos en el arte multimedia, Tesis doctoral, Universidad Politécnica de Valencia, Departamento de Escultura, Valencia, 2003.
} 
laberínticas, fragmentos- recortes- discontinuos, módulos para armar; juegos diseñados para el extravio y el mareo, que revelan sus intenciones de desacomodar y deshabituar al jugador".

En este apartado deseamos conocer cuál ha sido la relación del juego con la palabra y su innegable repercusión y potencial para generar textos. ¿Qué elementos son útiles para los escritores y diseñadores de Textos? Esperamos que este apartado ofrezca un mosaico de referencias literarias. Por lo pronto, la recomendación de Vladimir Nabokob a sus alumnos escritores resulta muy apropiada: "When dealing with a work of art, we must always bear in mind that the art is a divine game". ${ }^{187}$ El juego dota a los escritores de ciertas herramientas que amplían sus estructuras narrativas, los contenidos temáticos, los recursos gráficos y visuales; aumentando la significación.

"Great literature makes good use of this play element, playing as much with words and sentence structures as with images, form, ideas, and, in fiction especially, plot and character." ${ }^{188}$

Hemos tratado de plasmar en este trabajo la rica y diversa herencia literaria ${ }^{189}$, producto de una permanente transformación lúdica entre juegos poéticos, visuales, caligráficos, tipográficos, sintácticos, semánticos y algunos otros que nos falta por analizar. No podemos restarle valor al instinto del juego al crear narrativas contemporáneas. Menos aún cuando la percepción visual y sonora ha sido objeto de nuevas y variadas formas literarias. Si nos remontamos a épocas anteriores a la invención de la imprenta, apreciamos que la escritura adquirió un esplendor visual por medio de la caligrafía, la ilustración de libros (principalmente religiosos) por miniaturistas y dibujantes, herederos de una tradición iconográfica, que fusiona arte y escritura, desarrollando el arte de dibujar con palabras.

Los ejemplos (más antiguos de los que se tiene registro) en los que se aprecia el origen plástico de la palabra son ciertas composiciones de poesía y prosa que creaban imágenes al ajustar las extensiones de sus líneas de acuerdo a las formas por representar o a los acertijos por resolver. Estas formas poético-visuales se conocen como Technopaegnia, surgieron en Grecia en el siglo III a. de C. ${ }^{190} \mathrm{Y}$ de los cuales prevalecen sólo unas cuantas

\footnotetext{
${ }^{187}$ Citado por: GUINESS G. \& HURLEY, A. (Eds.) Auctor Ludens, essays on play in literature, John Benjamins Publishing Co., 1986.(p. 11)

${ }^{188}$ CAMPLIN, Troy E., "literature as a game: game-play in reading, creating and understanding literature", Consciousness, Literature and the Arts, Vol. 7, Num. 2, 2006, (P. 33) [Texto on-line] en: http://blackboard.lincoln.ac.uk/bbcswebdav/users/dmeyerdinkgrafe/archive/camplin.html consultado: 8/10/2011

${ }^{189}$ Piezas literarias que ofrecen innovaciones formales y estructurales que recomendamos considerar: Vida y opiniones de Tristán Shandy (1759-1767) de Laurence Sterne, En el laberinto de Robe-Grillet, Ulises de James Joyce, La mujer del teniente francés de John Fowles, El viento de Claude Simon, La subasta del lote 49 de Thomas Pynchon, La señora Dalloway de Virginia Wolf.

190 PAPPAS, Alexandra, "Language Arts: The Hellenistic Tecnhopaegnia as art historial theory and practice", en: TANNER, Invention of art history in ancient Greece, 2006. [Artículo on-line] en: http://apaclassics.org/images/uploads/documents/abstracts/Pappas_1.pdf Consultado: 2/12/2011.
} 
obras: Las Alas, El Hacha y El Huevo ${ }^{191}$ de Simias de Rodas, Syrinx (flauta de pastor) de Teócrito y Los Altares de Dosidas y Vestinus ${ }^{192}$. Las cuales se presentan como productos tanto literarios como visuales ${ }^{193}$.

\section{Technopaegnia}

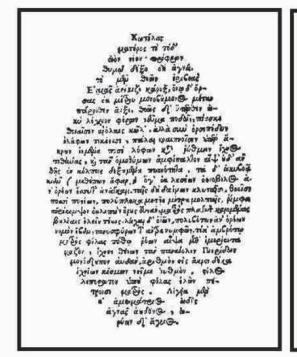

El Huevo

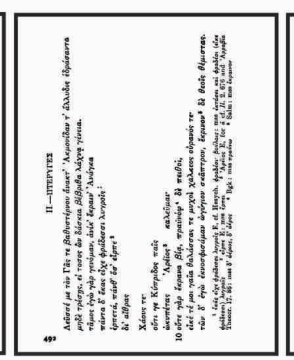

Las Alas

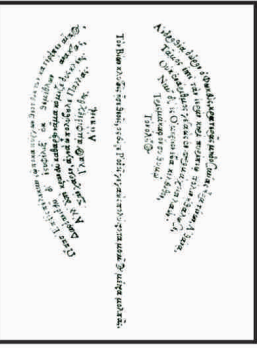

El Hacha

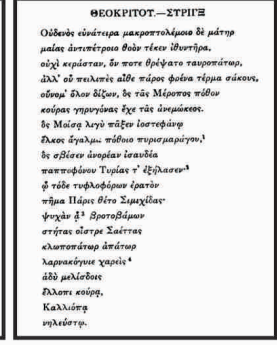

La Flauta

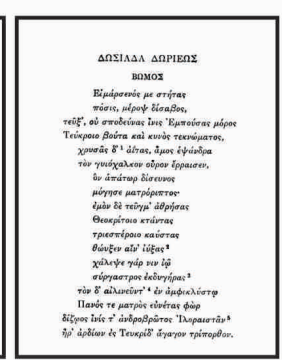

El Altar

Estos son los antecedentes de los caligramas, los Carmina figurata, tautogramas, laberinthus cubicus ${ }^{194}$, acrósticos, palíndromos y otras $^{195}$ formas experimentadas que fueron muy utilizadas durante la Edad Media, el Renacimiento y el Barroco; y que serían retomadas por los simbolistas y vanguardistas de los siglos XIX y XX.

Felipe Muriel $^{196}$ realiza un recorrido histórico y presenta complejas formas laberínticas criptográficas, resultado del ingenio humano. Imágenes de poemas pentacrósticos (en forma de cruz) como los 28 poemas publicados por Rabano Mauro (s. IX a. C) "De Laudibus Santae Crucis" y otras formas "complejas" y recursos poéticos propios, basados en formas geométricas o de objetos reconocibles que guardan mensajes ocultos en vertical, diagonal o incluso en lecturas laberínticas como en los Discos de Abulafia, las palabras y giran y mediante técnicas de la combinación y permutación, se desprenden las formaciones lingüísticas.

\footnotetext{
${ }^{191}$ La lectura del poema obliga la forma visual de una metáfora que se refiere al huevo perdido de un ruiseñor.

${ }^{192}$ Véase: The Pattern poems [Sitio Web] en: http://www.theoi.com/Text/PatternPoems.html Consultado: $16 / 05 / 2012$.

${ }^{193}$ HIGGINS, Dick, Pattern Poetry, Guide to an unknown literature, State University of New York Press, Albany, 1987.

194 Poema cúbico, con un verso palindrómico: SATOR AREPO TENET OPERA ROTAS

195 Listado que puede ampliarse con los trabajos de: HIGGINS, Dick, Pattern Poetry: guide to an unknown literature, SUNY Press, Albany, 1987. WITEWAKA-WAZABINSKA, Barbara y TABOUROT, Etienne ${ }^{196}$ MURIEL, Felipe, "Pintar con la palabra", Revista Séneca Digital, Núm. 3, 2010 [Texto on-line] en: http://www.juntadeandalucia.es/averroes/iesseneca/revista/spip.php?article24 Consultado: 30/11/2011.
} 


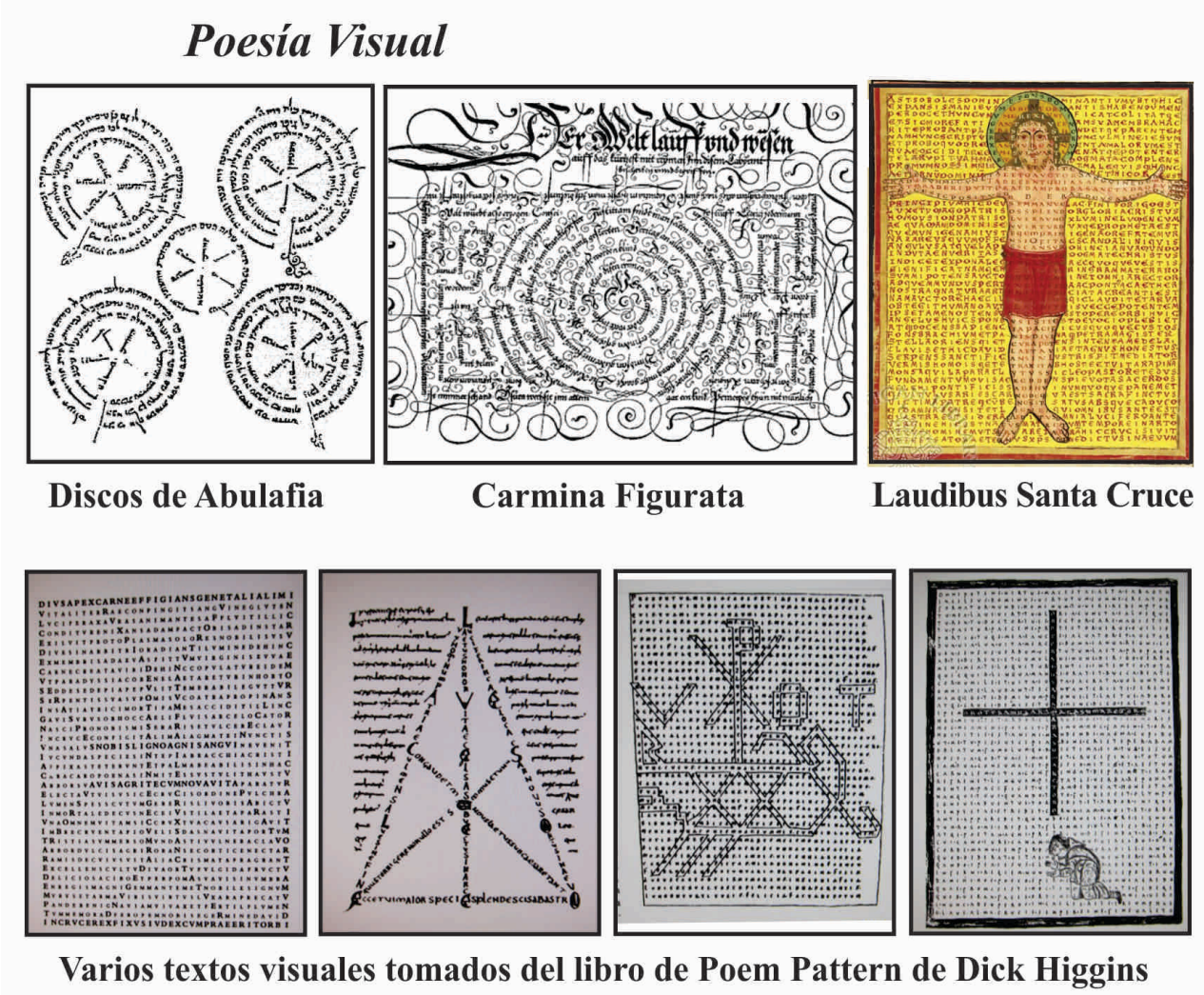

Discursos retóricos y visuales propios de la criptografía que tuvieron una profunda tradición en la Edad Media y que serán motivo de otro estudio orientado hacia la preceptiva literaria ${ }^{197}$. Letras que devienen en imagen e imágenes que se convierten en textos, dando como resultado la ruptura de la linealidad del discurso; con lo que apreciamos que la distribución de las letras sobre las páginas no es algo nuevo, como tampoco es la manera como el lenguaje se relaciona con el mundo; y como lo hacen las palabras con las cosas. La complejidad caligráfica, los textos laberínticos y las formas visuales estuvieron presentes mucho antes del simbolismo del siglo XIX, o del desarrollo experimental de las vanguardias artísticas de principios del XX. La estética de la palabra y el juego creativo muestran una indisoluble conexión en diversos periodos de la historia. Belén Gache ${ }^{198}$ los considera como "un género hibrido en las fronteras entre el leer y el ver, es decir entre las palabras y la imágenes, poesía que presenta tanto elementos lingüisticos como icónicos".

\footnotetext{
${ }^{197}$ MURIEL, Felipe, Pintar con la palabra desde la Edad Media al Siglo de las Luces [Texto on-line] en: http://www.juntadeandalucia.es/averroes/iesseneca/revista/spip.php?article248\&art Consultado: 30/11/2011.

${ }^{198} \mathrm{GACHE}$, Belén, “Poesía visual como género híbrido en las fronteras entre el leer y el ver", Revista De Guarda, No. 2 (pp. 137-150), 2006. [Texto on-line] en:

http://www.paginasdeguarda.com.ar/_pdf/articulos/2_gache.pdf. Consultado: 18/12/2011
} 
Los primeros escritos caligráficos visuales de la antigüedad, generaron "fusión y confusión" entre poesía y pintura, como sostiene Rafael de Cozar ${ }^{199}$. Cada nuevo medio confunde pero amplía las posibilidades creativas del anterior y ofrece un potencial por descubrir y acrecentar. Creemos que estas formas poético-visuales de la antigüedad, pueden dotar de un potencial estético a los generadores de narrativas: que encuentren en sus formas, una manera no sólo resolver nuevas propuestas estructurales, sino que los modelos sirvan de inspiración para recurrir a nuevos contenidos.

Requerimos de recursos formales y tecnológicos para acrecentar el ingenio plásticopoético y proponer piezas digitales compuestas con la idea de evocar diferentes propuestas como el diseño de textos tridimensionales ${ }^{200}$. Apoyarnos en libros decorados bíblicos, también puede ser un pretexto de creación artística en entornos digitales. Los recursos ornamentales y estilísticos ${ }^{201}$ de estos libros, ofrecen patrones de gran riqueza visual. Imágenes fantásticas o lenguajes simbólicos ligados a nociones astrológicas, míticas, ceremoniales que confirman el encanto que ha existido entre la palabra y su representación visual y sonora. $\mathrm{Y}$ que ha dejado huella en manifestaciones incluso cotidianas como en piezas numismáticas, inscripciones en muros, bóvedas decoradas, mosaicos, rosetones o incluso en mobiliario y adornos ornamentales. La magia de la palabra, ligada a textos legendarios como el Poema de Gilgamesh, la literatura hindú de los Vedas, la mitología propia de diversas culturas antiguas o los textos plasmados en códices indígenas precolombinos, los cuales la belleza de su escritura, presenta una manera particular de interpretación de sus contenidos ${ }^{202}$.

\section{Los caligramas}

Imágenes que componen textos o textos que desplantan imágenes, conocidos como caligramas, popularizados por Guillaume Apollinaire tienen un origen y tradición muy arraigada y antigua. Al respecto Rafael de Cózar plantea como posibles antecedentes de los caligramas a las Mandalas hindúes, las cuales pudieron estar relacionados con escritos en espiral. Otro antecedente pudo haber sido El Disco de Festos (Phaistos, encontrado en Creta, cuyas inscripciones en barro agrupan pictogramas en espiral aún no descifrados, mostrando un tipo de escritura no convencional que mantiene ciertas semejanzas con los caligramas o representaciones Prehispánicas como sus sistemas

\footnotetext{
${ }^{199}$ DE COZAR, Rafael, Poesía e Imagen; formas difíciles de ingenio literario, [Texto on-line] en: http://josecrespo.es/pdf/POESIA_E_IMAGEN_Rafael_de_Cozar.pdf Consultado: 24/11/2011

${ }^{200}$ Recomendamos revisar: "Figure Poems, Greek Technopaegnia", tomado de MOLNAR, Albert, Lusus poetici, 1614, en el Web site, The library of symbolism en:

http://www.camrax.com/symbol/figurepoemsintro.php4 Consultado: 2/12/2011.

${ }^{201}$ Galerías on-line sobre el arte caligráfico pueden consultarse en:

http://www.sakkal.com/articles/art_arabic_calligraphy/arabic_calligraphy_styles.html, http://www.worldofcalligraphy.com/calligraphyartists.html Consultados: 09/03/2012

${ }^{202}$ Véase Documental Tlacuilo de Enrique Escalona (1987) para conocer como se lee un códice.
} 
calendáricos. El disco también ha sido asociado, según algunos historiadores sobre el juego, al origen del Juego de la $\mathrm{Oca}^{203}$.

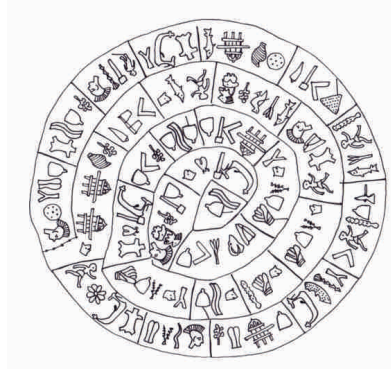

Disco de Festos

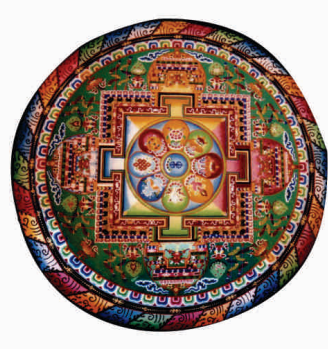

Mandala

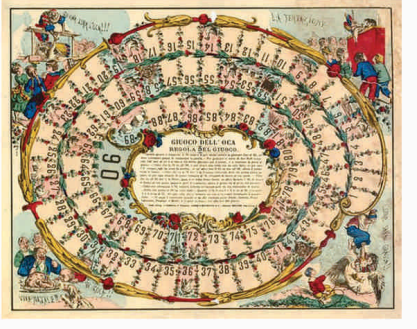

Oca

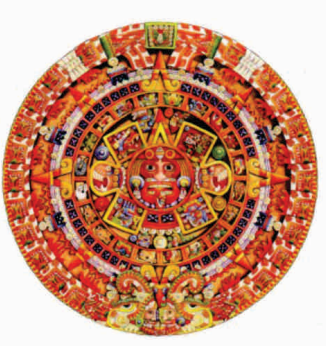

Calendario Maya

Los primeros caligramas se remontan al siglo III a.C. Se trata de textos que mediante una sintaxis elíptica generan imágenes, involucrando al lector en un mayor esfuerzo de descubrimiento y ensamblaje de fragmentos gráficos inspirados en el dibujo, lo que permite una lectura no convencional y dando origen a cierta poesía narrativa visual que busca efectos plásticos en las palabras. Reconocemos que Guillaume Apollinaire 204 contribuyó a difundir y popularizar la noción de los caligramas a partir de 1918, porque tuvo conocimiento de los Technopaegnia griegos, y a su vez fueron inspiración para otros escritores como: Eugen Gomringer ${ }^{205}$ en Constelaciones; Vicente Huidobro ${ }^{206}$ en Molino y Triángulo Armónico; El Sapo de José Juan Tablada, Les formigues de Joan Salvat Papasseit o Old Maza Lamp de John Hollander, y de muchos otros caligramistas que han experimentado el uso de la tipografía dibujada o deformada, su aspecto visual y la disposición gráfica de las letras, atentando contra la escritura lineal; incrementando la proximidad entre el texto y la imagen ${ }^{207}$.

\footnotetext{
${ }^{203}$ Ver: http://www.juegodelaoca.com/Origenes/origenes.htm Consultado: 25/11/2011.

${ }^{204}$ Los Caligramas son composiciones tipográficas, poemas cuyos versos se disponen dibujando imágenes. Guillaume Apollinaire en el siglo XX, impulsó la creación de este tipo de poemas visuales herederos de una tradición que se remonta al periodo helenístico griego con los Technopaegnia griegos y los Carmina figurata latinos. Formas que han dado lugar a poesías visuales o escritura ideogramática; reflejando el valor de la imagen y el poder de la palabra.

${ }^{205}$ GOMRINGER, Eugen, The book of hours and Constellations [Texto on-line] en:

http://www.ubu.com/historical/gomringer/Gomringer-Eugen_Book-of-Hours-and-Constellations.pdf Consultado: 10/11/2012

${ }^{206}$ Vicente Huidobro (1893-1948) Su primer caligrama "Triangulo armónico" (1912) y otros puede consultarse en http://www.memoriachilena.cl/temas/dest.asp?id=huidobrocaligramas Consultado: 09/03/2012 http://bib.cervantesvirtual.com/portal/bnc/huidobro/huidobro.shtml En 1921 Huidobro preparó una exposición de Poemas pintados, la cual fue clausurada por ser demasiado "rupturista". ${ }^{207}$ Un sitio web que resulta muy representativo es el del proyecto For all Seasons en: http://www.hahakid.net/forallseasons/storyboard.html Consultado: 09/03/2012
} 


\section{Caligramas}

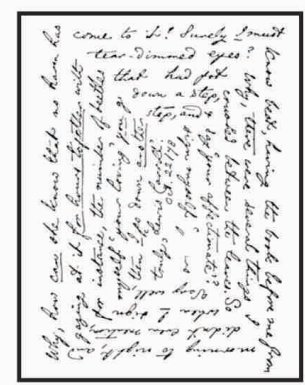

Anónimo Circular
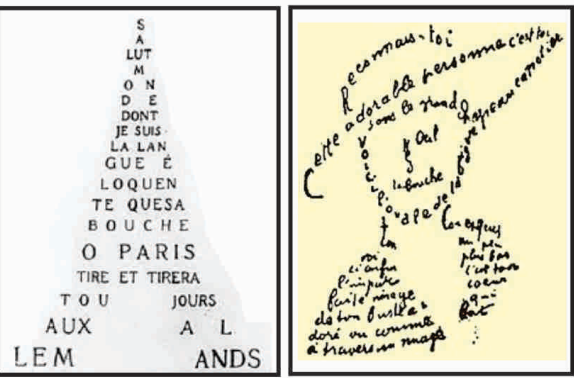

Apollinaire Caligramas
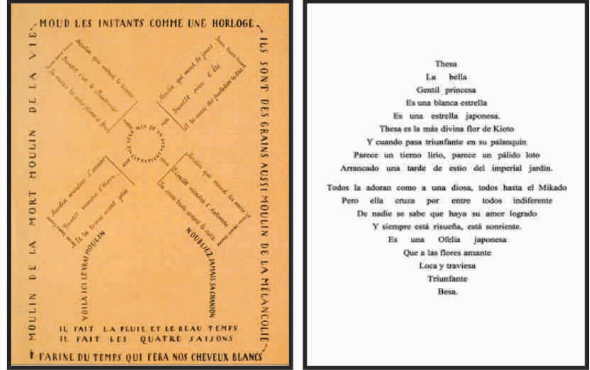

Huidobro

Molino

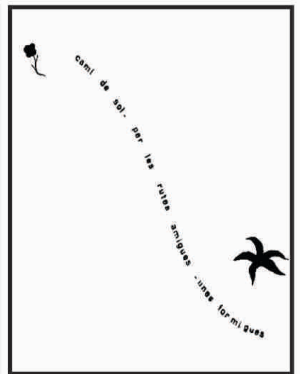

Papaseit

Les Formigues

Triángulo armónico

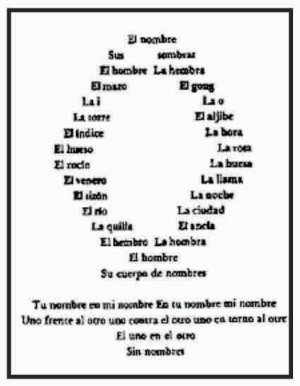

Paz

Piedra de sol

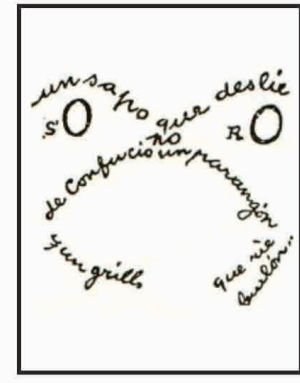

Tablada El Sapo

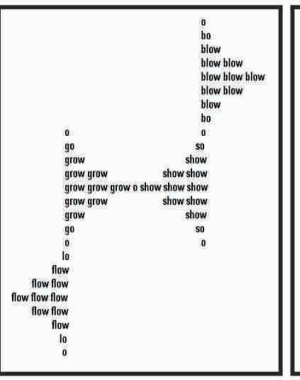

Gomringer Constelaciones

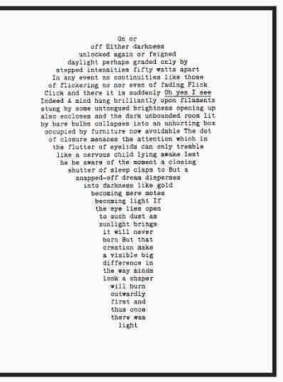

Hollander Old Maza lamp

\section{Ideogramas, logogramas y caligrafías}

Por su parte Ezra Pound en The Cantos (1925), se interesó en los ideogramas como medio poético y Ernest Fenollosa en su ensayo sobre los ideogramas chinos, The chinese written characters as a médium for poetry ${ }^{208}$ (1920) los considera con mayor posibilidad expresiva que los alfabetos occidentales. Christian Dotremont ${ }^{209}$ en los años 70, crea obras a partir de escrituras arabescas a las que designa como logogramas los cuales serán un distintivo de la caligrafía (quasi oriental) del Grupo CoBrA. ${ }^{210}$

\footnotetext{
${ }^{208}$ FENOLLOSA, Ernest, "The chinese written character as a medium for poetry" (1920) [Texto on-line] en: http://www.pileface.com/sollers/IMG/pdf/The_Chinese_Written_Character_As_A_Medium_For_Poetry_ Ernest_Fenollosa-Ezra_Pound_.pdf Consultado: 25/11/2011

${ }^{209}$ GUIHARD; Karine, Le Surréalisme Révolutionnaire, suivi de projet de these sur l'oeuvre de Christian Dotremont [Texto on-Line] en: http://karine.guihard.pagesperso-orange.fr/docs/dea.pdf Consultado: $10 / 11 / 2011$

${ }^{210}$ Acrónimo de Copenhague, Bruselas y Ámsterdam, fundado por el danés Asger Jorn. Puede verse su obra en: http://www.museumjorn.dk/en/museum_jorn.asp consultado:10/11/2011
} 


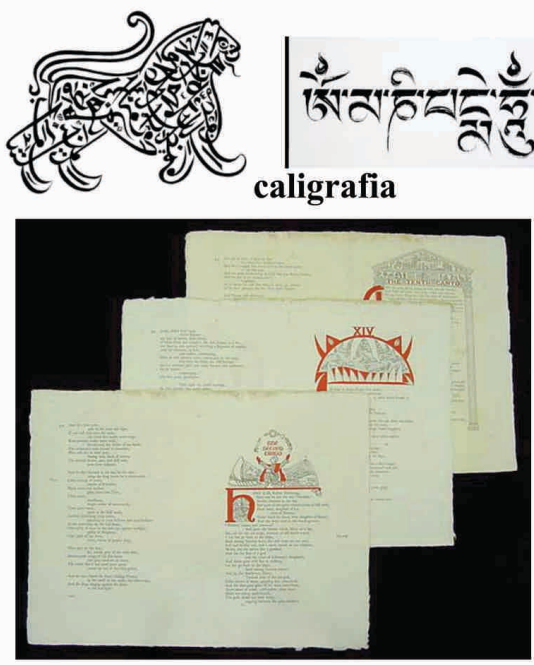

Ezra Pound The Cantos

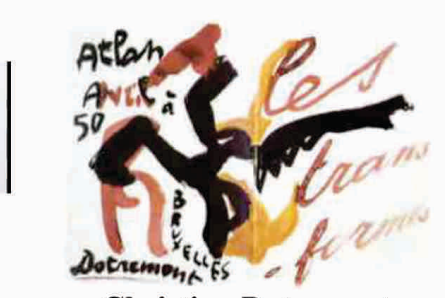

Christian Dotremont

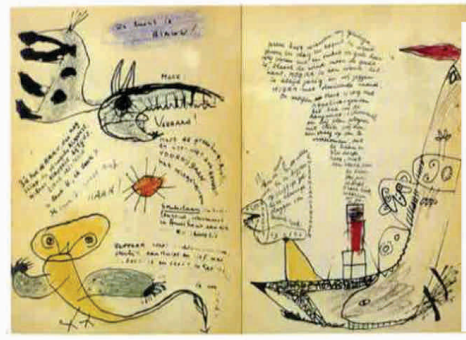

Constant \& Kouwenaar Buenos días gallo

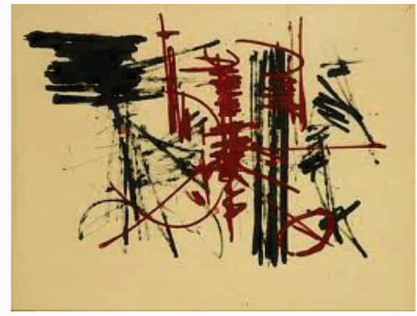

George Mathieu

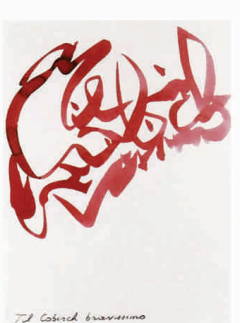

Dotremont

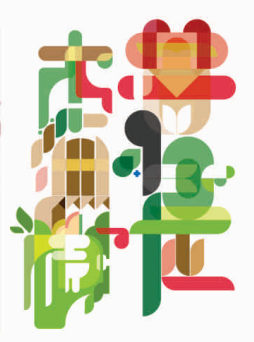

Tipografia artistica

\section{Las vanguardias y el juego desbordado}

El siglo XX fue testigo de juegos y experimentaciones de nuevas técnicas, formas y temas artísticos; innovación, desarrollo tecnológico y cambios sociales que promovieron el surgimiento de manifestaciones culturales que celebran la expresión legítima en contra de la ortodoxia. La pluma de los escritores comenzó a propagar nuevos aires de creación a través de las propuestas de impresionistas, futuristas, cubistas, surrealistas, dadaístas y otros vanguardistas, que buscaban la manera de ampliar los lenguajes del arte y sus posibilidades expresivas: pintores, músicos o escritores incursionan en medios como el cartel, la fotografía, el radio o el cine; experimentan haciendo música con el lenguaje o textos sonoros o visuales: "el momento más rico para la fusión y confusión de las artes va de 1905 a 1940 y coincide con la aparición de los ismos "211

En un afán de innovación, las vanguardias amplían las posibilidades estéticas y de renovación del lenguaje y de la palabra. Los futuristas emprenden la ruptura tipográfica y el diseño constructivo de las páginas impresas, Un coup de dès jamais n'abolira le hazard [Una tirada de dados jamás abolirá el azar] (1897), poema que antecede al movimiento, de Stèphane Mallarme recupera el valor formal y la diagramación de las estructuras poéticas y literarias tradicionales y convierte el espacio impreso en una "partitura visual", en donde las líneas de los versos cobran cierto sentido similar a las notas musicales y los espacios en blanco, son silencios.

\footnotetext{
${ }^{211}$ BONET, J.M., El aporte de la poesía al arte moderno, El poeta como artista. Las Palmas de Gran Canaria, Centro Atlántica de Arte Moderno, 1995, p.18.
} 


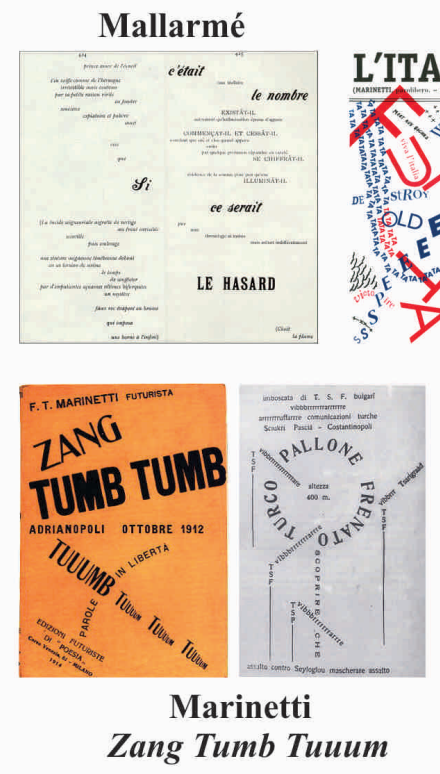

Zang Tumb Tuuum
Marinetti, Parole in Liberta
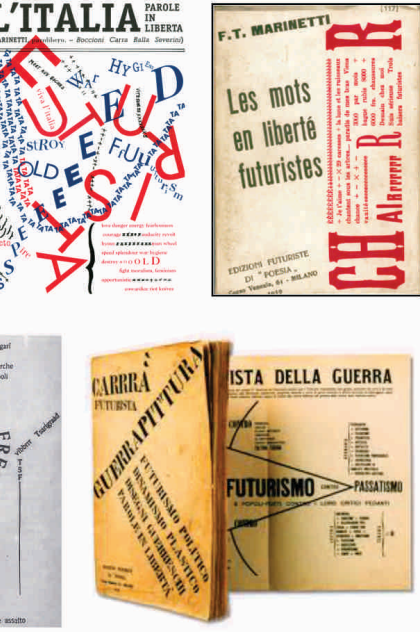

Carra

Guerrapittura
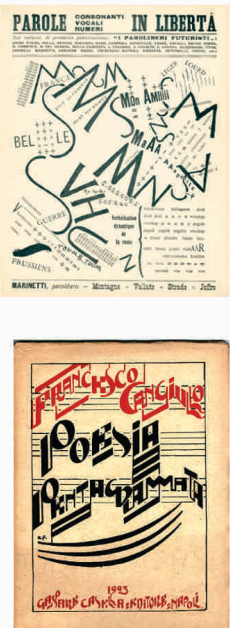

Cangiullo
Futuristas

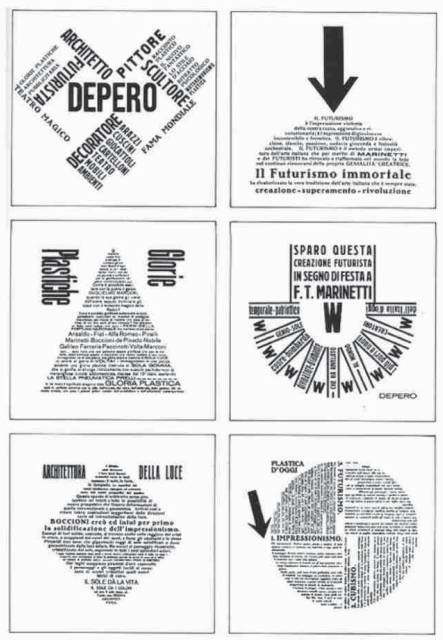

Depero

La creación literaria vanguardista de las primeras décadas del siglo $\mathrm{XX}$, se enriqueció con la influencia de la escritura de poesía ornamental tanto lírica como religiosa, plasmada en muebles, tapices y edificios. Solemnes inscripciones coránicas dieron origen a la estilización de la caligrafía árabe y el sentido visual. La tradición manierista de la micrografía que acompañaba los libros con diseños florales, geométricos, fueron inspiración para el rediseño de tipografías innovadoras de nuestros días. Cuando Raymond Roussell (1877-1933) publica Impresiones de África ${ }^{212}$ (1910), presenta una obra literaria que tendrá gran influencia en la plástica ${ }^{213}$ y será un detonante para la producción precedente: juegos verbales, imaginación desbordada y procesos absurdos descritos con seriedad como en Locus Solus ${ }^{214}$ (1914). Textos homófonos, mediante sonidos semejantes pero de sentido diferente y forzando a generar puentes de significado. La experimentación de las estructuras textuales cobra gran auge que se refleja en el surgimiento de una abundancia de manifiestos. Filippo Tomasso Marinetti publica en 1905 la revista Poesía ${ }^{215}$, planteando la ruptura de la sintaxis, la revolución tipográfica para "redoblar la fuerza expresiva de las palabras"216. En 1909 él mismo publicaría en el periódico Le Figaro el primer "Manifeste du Futurisme":

\footnotetext{
${ }^{212}$ ROUSSEL, Raymond, Impressions of Africa, Dalkey Archive Press, Champaign, III., 2011.

${ }^{213}$ Su obra inspiró artistas como: Salvador Dalí, Marcel Duchamp, Max Ernst, Rodney Graham, Roberto Matta, Man Ray, Joseph Cornell, Julio Cortazar, y otros; Tomado del reportaje Viaje al planeta de "El Ilustre desconocido" publicado por El País, La explosión Raymond Roussel, 8 de Noviembre de 2011. [Texto on-line] en:

http://www.elpais.com/articulo/cultura/explosion/Raymond/Roussel/elpepicul/20111024elpepicul_1/Tes Consultado: $18 / 11 / 2011$

${ }^{214}$ ROUSSEL, Raymond, Locus Solus, Gallimard, Paris, 1963.

${ }^{215}$ Ver: Words in Freedom: Futurismo at 100 [Exhibición en Museo de Arte Moderno de Nueva York] en: http://www.moma.org/interactives/exhibitions/2009/futurism/ Consultado:28/11/2011

${ }^{216}$ Citado por: SCUDIERO, Maurizio, "Italian Futurist Book", [Artículo on-line] en:

http://colophon.com/gallery/futurism/ Consultado: 25/11/2011
} 
La littérature ayant jusqu'ici magnifié l'immobilité pensive, l'extase et le sommeil, nous voulons exalter le mouvement agressif, l'insomnie fiévreuse, le pas de course, le saut mortel, la gifle et le coup de poing. ${ }^{217}$

Fue uno de los muchos manifiestos ${ }^{218}$ que emitieron hasta 1944 y en los que expresaron sus ideas acerca del arte visual, el cine, literatura, música, danza y las artes en general. Las nuevas tendencias artísticas buscaban la ruptura desafiando la tradición. Los escritores reconstruyeron el libro; no sólo desde la linealidad del discurso, sino a partir de la negación de las convenciones sintácticas y formales, y la reorganización visual de los elementos con el fin de generar la hoja en movimiento, a través de imágenes textualizadas que, según los mismos autores, ampliaban los patrones de percepción de los lectores y el significado de los textos. Del empleo del verso libero se pasó a la utilización de la parole in libertà; enunciado en su manifiesto de 1913 aparece:

"Futurism is grounded in the complete renewal of human sensibility that has
generated our pictorial dynamism, our antigraceful music in its free,
irregular rhythms, our noise-art and our words-in-freedom ...
By the imagination without strings I mean the absolute freedom of images or
analogies, expressed with unhampered words and with no connecting strings
of syntax and with no punctuation."

La utilización de diferentes tipografías, modificadas, estilizadas y coloreadas promulgaban la libertad para transformar no sólo la palabra, sino el propio alfabeto y jugar con la sonoridad y visualidad de los textos, lo que impulsó a los poetas a considerar el espacio físico y sonoro como otro recurso de creación poética; resultando un género hibrido entre la escritura, la pintura y en ocasiones, la música, como las "Construcciones Fonovisivas" 220 de Giacomo Balla, ${ }^{221}$ fusiones onomatopéyicas de Fortunato Depero, ${ }^{222}$ Poesía plástica que se re-apropiaba de algunas estrategias publicitarias y refleja el espíritu innovador y transgresor de la época.

"Estos aspectos de la reconstrucción eran los siguientes: pasar de la publicidad al grafismo, al libro como objeto artístico, de la prosa narrativa al texto teatral, a la poesía (en las "palabras en libertad" a la visualización de las tavole parolibera); de la fotografía y del fotomontaje a la película, a la comunicación de masas (sobre toda a través de la radio) al arte postal; del ejercicio de la crítica a la práctica de la ciencia, de la política a los hábitos, al comportamiento"223

\footnotetext{
${ }^{217}$ Le Figaro, Paris, 20 de febrero de 1909. Véase: http://gallica.bnf.fr/ark:/12148/bpt6k2883730.langFR

${ }^{218}$ Veanse Manifiesto Tecnico della Letteratura futurista, 1912; L'immaginazione senza fili e le parole in libertá, 1913; Lo splendore geométrico e maccanica e la semsibilitá numérica, 1914; I plastici paroliberiManifesto sintético futurista, 1922; L'arte diguerra e dopoguerra, 1940; Manifesto delle parole musicali futuriste - alfabeto in libertá, 1944)

${ }_{219}$ Manifiesto de Marinetti, en: http://arteest.org/futurism.htm Consultado:26/11/2011

${ }^{220}$ MANCEBO, Juan, "Palabras en libertad a la poética de acero" [Texto on-line] en: http://www.uclm.es/profesorado/juanmancebo/descarga/textos/palabraslibertad.pdf Consultado: 02/12/2011

${ }^{221}$ Elementos de pintura empleados en la decoración y la ambientación.

${ }^{222}$ MANCEBO, ROCA, Juan Agustín, “El mago futurista en tres momentos, pintura, teatro diseño, publicidad y arquitectura en Fortunato Depero" [Texto on-line] en: http://www.uclm.es/profesorado/juanmancebo/descarga/textos/Mago\%20Futuistas.pdf Consultado: 14/12/2011.

${ }^{223}$ CARAMEL, L., LOERS, V., Y CRISPOLTI, E., (eds.) Vanguardia italiana de entreguerras; Futurismo y Racionalismo. IVAM, Valencia, 1990, (p.24)
} 
Textos como explosiones de visualidad y sonoridad; páginas en movimiento cercanas a la pintura y el cartel gráfico, experimentos tipográficos que desafían los cánones lingüísticos. Textos que suenan a máquinas, que parecen tener movimiento; que incursionan en nuevos formatos y nuevos materiales; resultan un referente básico y una fuente de inspiración creativa contemporánea para los escritores de nuevos medios. Por el interés que tienen para nuestro proyecto, pasamos a referir algunas piezas y sus autores en este trabajo, esperando despertar la atención de su estudio y profundización.

Textos como: Zang Toumb Toumb (1914), Les mots en liberté futuristes (1919) de Marinetti ${ }^{224}$; Guerrapittura (1915) de Carlo Carrá ${ }^{25}$, L'Art dei rumori [El arte del ruido] (1916) de Luigi Russolo. ${ }^{226}$ Piedigrotta (1916), Caffe concerto, Alfabeto sorpresa, Poesia Pentagrammatta (1923) de Francesco Cangiullo ${ }^{227}$ muestran una exploración gráfica y una deformación tipográfica, alfabetos transformados en imágenes, poesías sonoras y musicales marcaron un parteaguas en la fabricación de los primeros textos poéticos vanguardistas.

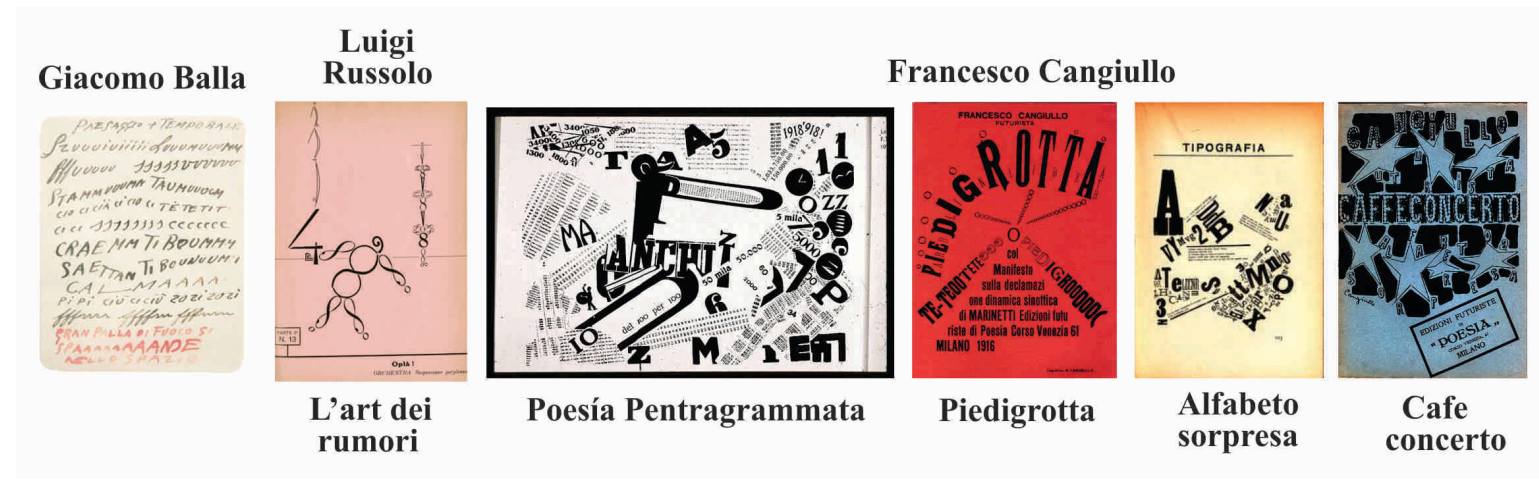

Resulta obligado conocer los libros-objeto como el Dinamo-Azari: Depero Futurista (1927) de Fortunato Depero, impreso en diferentes papeles con distintas tipografías, sujetado con tuercas; que podía leerse de muy diversas formas, de hecho podía girarse: "In order to read the text, the book has to be turned round and round again",228.

\footnotetext{
${ }^{224}$ Para una referencia de estas obras consultar Colophon, Sitio web de ilustradores contemporáneos y diseñadores de libros en: http://colophon.com Consultado: 18/05/2012.

${ }^{225}$ CARRÁ, Carlo, Guerrapittura, S.P.E.S - Salimbeni, Florencia, 1978.

${ }^{226}$ Es un manifiesto en el que propone cómo la tecnología permitirá a los músicos futuristas "sustituir la limitada variedad de timbres que una orquesta procesa hoy por una infinita variedad de timbres que se encuentran en los ruidos, reproducidos con los mecanismos apropiados", es considerado como un influyente texto en estética musical del siglo XX. Puede extenderse la información en: http://www.uclm.es/artesonoro/elarteruido.html Consultado: 18/05/2012.

${ }^{227}$ Véase Centro de Documentación e Investigación sobre la Vanguardia Histórica Primo Conti [Sitio online] http://www.fondazioneprimoconti.org/archivio/fondi/cangiullo_francesco.html Consultado: $14 / 12 / 2011$.

${ }^{228}$ SCUDIERO, Maurizio, Italian futurist book, [Texto on-line] en: http://colophon.com/gallery/futurism/ Consultado: $24 / 11 / 2011$
} 
Libros que mezclaban la tradición con la modernidad e invitaban a realizar lecturas sensoriales como: Equatore notturno (1916) de Francesco Meriano, ${ }^{229}$ quien afirmaba: "cuando se añade el endecasílabo y el verso libre a la intuición sintética y simultánea del mundo, no existen más separaciones entre los sentidos de vista, tacto, oído, olor y gusto, la línea gramatical se interrumpe y la única vía de exploración son las palabras en libertad" escribió el autor a Marinetti en $1916^{230}$.

Textos en movimiento como los de Paolo Buzzi con L'Ellisse a la spirale (1915) en un intento de construir páginas móviles ${ }^{231}$. Ese mismo año de 1915, Giacomo Balla y Fortunato Depero presentan Reconstruzione futurista dell' universo en la cual exponen una nueva propuesta de diseño e impresión del libro; el libro conceptualizado, hecho de nuevos materiales, libros-objeto, libros anillados, impresos en lámina, unidos con tuercas $^{232}$, son el reflejo de una segunda etapa del Futurismo que busca la reconstrucción del arte. En la primera etapa (hasta antes de 1915) el síntoma de ruptura y destrucción es la constante; ahora se busca proponer nuevos medios de creación, acentuando el carácter industrial, temáticas ligadas a la guerra, la máquina y las palabras en libertad "onomalingües" que fusionaban onomatopeyas y ruidos "es un lenguaje poético de comprensión universal por el cual no son necesarios los traductores". ${ }^{233}$ Por su parte, Tullio D'Albisola representó visualmente los poemas de Marinetti en su "Litolatte" titulado Parole in Liberta Futuriste, olfattive, tattili, termiche (1932) 27 hojas de láminas policromas impresas. Y junto con Bruno Munari produjeron L'anguria Lirica ${ }^{234}{ }_{\text {[Sandía }}$ Lírica] (1934) otro "libro di latta" "Litolatta», con estos, la expresión futurista llegó a su máxima expresión. Posteriormente, Vittorio Osvaldo Tommasini publica Farfa il miliardario delle fantasia ${ }^{235}(1933)$, otro litolatta ilustrado por Munari y presentado por Marinetti.

\footnotetext{
${ }^{229}$ Véase Centro de Documentación e Investigación Sobre la Vanguardia Histórica Primo Conti [Sitio online] en:http://www.fondazioneprimoconti.org/archivio/fondi/meriano_francesco.html Consultado: $14 / 12 / 2011$.

${ }^{230}$ Citado por: MANCEBO R. Juan, “De las palabras en libertad, a la poética de acero” (p.10) [Texto on-line] en: http://www.uclm.es/profesorado/juanmancebo/descarga/textos/palabraslibertad.pdf

${ }^{231}$ Véase CARUSO, Di Luciano, “Ebrezza trionfale nel Futurismo, anche”, en Ameritalia 1, Núm.1 (2002) [Texto on-line] en: http://www.ameritalia.id.usb.ve/Amerialia.001.caruso.htm Consultado: 15/12/2011.

232 "Este libro es MECANICO anillado como un MOTOR PELIGROSO puede constituir un arma proyectil INCLASIFICABLE no se puede colocar en un librería entre otros volúmenes" Citado por: MANCEBO R. Juan, "De las palabras en libertad, a la poética de acero" (p.6)[Texto on-line] en: http://www.uclm.es/profesorado/juanmancebo/descarga/textos/palabraslibertad.pdf Consultado: $15 / 12 / 2011$

${ }^{233}$ Es el lenguaje de la naturaleza (viento, lluvia, mar, arroyo, etc.; de las máquinas, los transportes (bicicletas, tranvías, automóviles) y de todas las máquinas junto a sensaciones y emociones expresadas que permite hablar y entenderse eficazmente con los elementos del universo, los animales y la máquinas. Citado por MANCEBO R. Juan, "De las palabras en libertad, a la poética de acero" (p.10) [Texto on-line] en: http://www.uclm.es/profesorado/juanmancebo/descarga/textos/palabraslibertad.pdf Consultado: 18/05/2012. (P.6) tomado de DEPERO; F., Depero Futurista - Libromacchina imbullonato, SPES, Florencia, 1987.

${ }^{234}$ MUNARI, Bruno \& D'ALBISOLA, Tullio, I'anguria lirica, Edizione futuriste di Poesía. Litolatta, Savona, Roma, 1934.

${ }^{235}$ TOMMASINI, Vittorio Osvaldo, Farfa Il miliardario delle fantasia, Marco sabatelli Editore, Savona, 1986.
} 


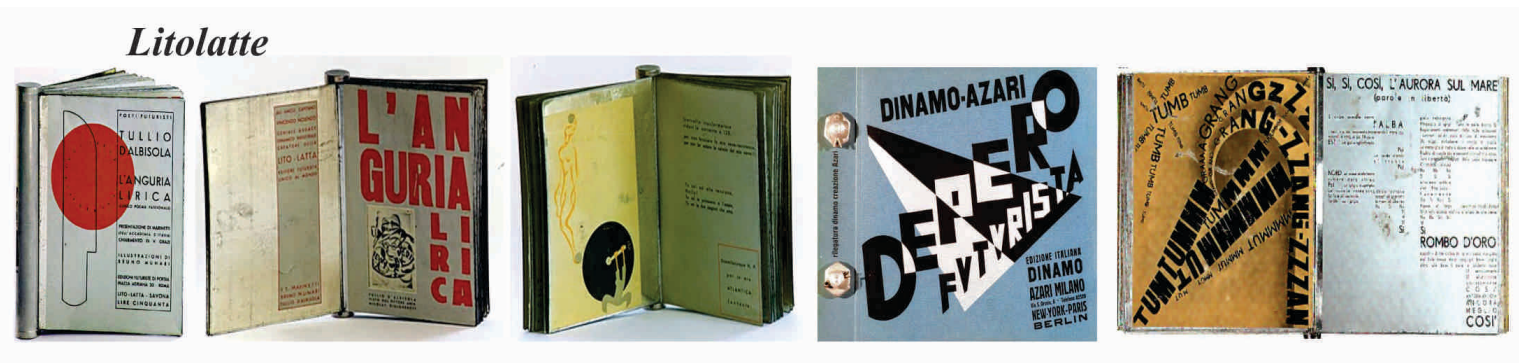

Los futuristas asociaron literatura las máquinas y las artes plásticas, mediante collages textuales. Renovaron el potencial narrativo generando "textos-artefacto", "poemas tipográficos", "estructuras visuales", "juegos textuales" y "narrativas gráficas". Piezas que resultaron una aportación importante a la poética y a la narrativa visual, la $\operatorname{radio}^{236} \mathrm{y}$ cine experimental; y por ello lo consideramos un referente creativo primordial para los escritores de nuevos medios.

"Futurismo no es exceso de modernidad, quiere decir acontecimiento artístico único. Libre. Fascinación por el presente, por el rumbo irreversible del "progreso". Es artes visuales, literatura, cine, arquitectura, teatro, danza, cocina y moda.",237

Otras propuestas vanguardistas surgieron: Isidore Isou [Samuel Goldstein], al fundar el Letrismo $^{238}$, buscaba producir efectos análogos al arte plástico; expandió su propuesta a las "hipergrafías", que contemplaban el uso de letras, signos alfabéticos, sistemas de escritura, como las notaciones musicales y matemáticas; generando una técnica que sintetiza escritura y arte visual y dando lugar a la creación de las "Novelas hipergráficas" generadas a partir de imágenes y palabras entrelazadas, como Les Journaux des dieux (1950) y Les Nombres (1952) del mismo Isou. Canailles, de Maurice Lemaître o Saint Ghetto des Préts ${ }^{239}$, de Gabriel Pomerand.

\footnotetext{
${ }^{236}$ Véase poema visual radiofónico: DEPERO, Liriche Radiofoniche, (1934). “lirismo poético, fónico, sonoro, ruidista, onomatopeyas imitativas, lenguajes inventados, maquinismo inagotable".

${ }^{237}$ Presentación de la exhibición El Universo Futurista [Sitio Web] en: http://www.proa.org/esp/exhibition-el-universo-futurista.php Consultado: 15/12/2011.

${ }^{238}$ Ver: manifiesto Letrista en: http://www.391.org/manifestos/1942isidoreisou_letterist.htm Sitio Oficial: http://www.thing.net/ grist/Ind/lettrist/isou.htm. Se recomienda leer. Letristas franceses, 1940-1970: ¿Por qué el letrismo? Potlatch", no 22, 9 septiembre 1955. Traducción del Archivo Situacionista (1997) [artículo on line] en: http://horadelsur.wordpress.com/2010/01/29/letristas-franceses-1940-1970\%c2\%bfpor-que-el-letrismo-guy-debord-y-gil-j-wolman-seguido-de-algunas-obras-de-albert-dupontisidore-isou-gabriel-pomerand-francois-poyet-y-alain-satie/Consultado:25/11/2011.

${ }^{239}$ Traducido al inglés: KASPER, M., Saint Ghetto of the loans, Uggly Duckling Presse, New York, 2006.
} 


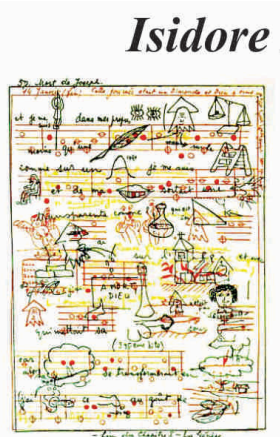

Les Journaux des dieux

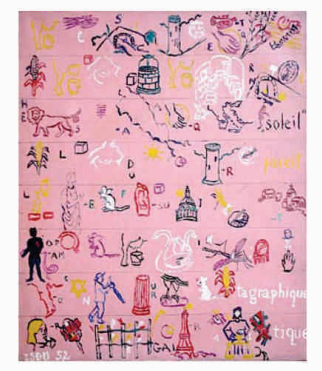

Les Nombres

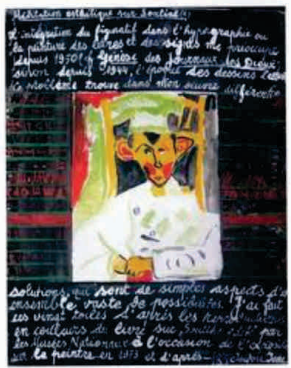

Pour finir la conspiration du silence

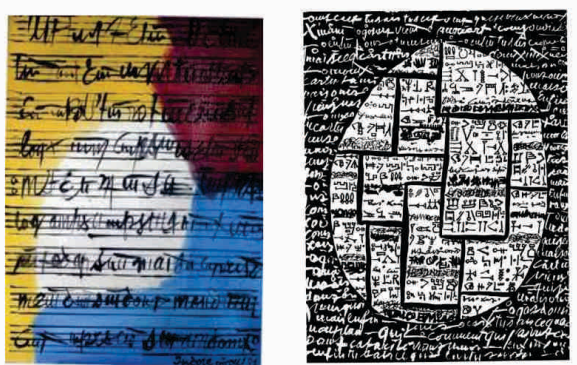

$s / t$
Maurice Lemaître

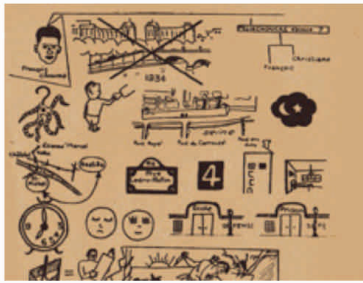

Canailles

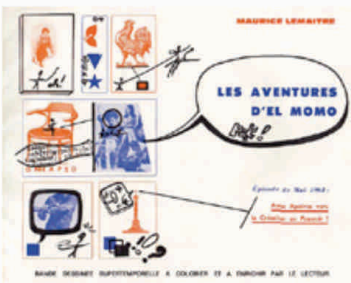

Les aventures d'el momo

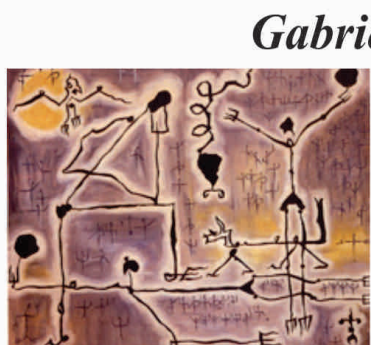

$s / t$

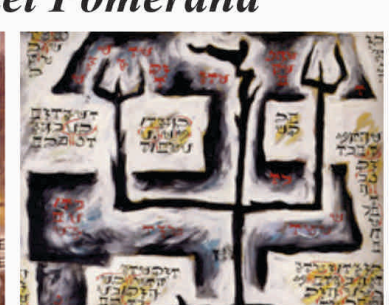

Spirituel

Maurice Lemaître ${ }^{240}$ y los letristas incursionan en la plástica, el teatro, la fotografía y el cine; sus piezas fueron pioneras del cine experimental "Cineprosa" y del denominado "Sincinema", que promovía partículas desprovistas de sentido en filmes pintados, cincelados, rayados como su film: Le film est déjà commencé? ${ }^{241}$ (1951). Fundaron la Escuela de Letristas de Pantalla ${ }^{242}$, proponiendo ciertas aportaciones estilísticas como la disociación de las bandas sonora y visual; el desbordamiento de la pantalla, la búsqueda de la pantalla activa y los recorridos posibles. Proponían la eliminación del guión apriorístico y en cambio, el nacimiento de una pieza supertemporal; el montaje discrepante, la fijeza de los planos de fondo y el impulso de los elementos lúdicos. Pietro Ferrúa $^{243}$, ofrece un panorama sobre el cine letrista y la influencia en directores como Guy Debord, Pierre Jouvet o Jean Luc-Godard. Esto sería el antecedente del videoarte, el cual debe ser motivo de otro estudio.

\footnotetext{
${ }^{240}$ Puede consultarse su obra en [Sitio web]: http://mauricelemaitre.wordpress.com Consultado:18/11/2011

${ }^{241}$ Véase en: http://ubu.com/film/lemaitre_film.html Consultado: 15/12/2011.

${ }^{242}$ Véase: FERRUA, Pietro, "Suerte y desdicha del letrismo cinematográfico", en revista Miradas, Escuela Internacional de cine y televisión [Texto On-line] en:

http://www.eictv.co.cu/miradas/index.php?option=com_content\&task=view\&id=383\&Itemid=53

Consultado: 16/12/2011.

${ }^{243}$ FERRUA, Véase: FERRUA, Pietro, "Suerte y desdicha del Letrismo cinematográfico", en revista Miradas, Escuela Internacional de cine y televisión [Texto On-line] en:

http://www.eictv.co.cu/miradas/index.php?option=com_content\&task=view\&id=383\&/temid=53

Consultado: 16/12/2011.
} 
Otro referente estilístico es la Poesía concreta ${ }^{244}$ y el Concretismo, los cuales surgieron a mediados de los cincuenta y buscaban en las piezas un impulso visual y espacial que tuvieran el mismo nivel de importancia de la rima y el ritmo ${ }^{245}$. Esta noción nos permite apreciar la importancia de todos los elementos que componen los textos. Eugen Gomringer a través del manifiesto Vom Vers zur Konstellation (1954) [Del verso a la constelación] promueve la idea de crear una poesía universal, común a todos los hombres; aboliendo la sintaxis y la gramática, jugando con las posibilidades combinatorias propias del lenguaje y promoviendo un cambio en los hábitos de lectura. Constelaciones marca el inicio de la poesía concreta y sugiere que:

"La constelación es la posibilidad más simple de diseño en la poesía, basada en la palabra. Esta comprende un grupo de palabras al igual como si ella comprendiese un grupo de estrellas e hiciese de éstas una configuración estelar"246

El movimiento Concretista ${ }^{247}$ fue secundado por el Grupo Noigandres (1952) en Brasil ${ }^{248}$ con sus "ideogramas textuales" los cuales conciben tanto el significado gráfico como el significado profundo del texto y revaloran la palabra en sus tres dimensiones: lingüística, visual y fónica confirmando que la conformación de textos va más allá de la estética de la página y apreciando como éstos recursos "del pasado" tienen vigencia y son una herramienta creativa para los escritores contemporáneos. Algunos de estos recursos literarios son el denominado "verbivocovisual" 249 que evoca el carácter sinestésico del lenguaje, es decir la fusión de varios sentidos, producto de una experimentación formal pluridimensional. Tal como lo plantea James Joyce en Finnegan's wake ${ }^{250}$ (1939):

"un enrevesado juego de palabras, un rompecabezas... el juego cobra
una importancia inusitada, obligando al lector a participar en la
solución de los acertijos. El libro se asemeja a ciertos libros infantiles
conocidos como <inventa tu propia historia y el lector podía
escoger entre varias opciones, saltando de una página a otra,
generando diferentes desenlaces"

\footnotetext{
${ }^{244} \mathrm{El}$ concepto de lo concreto existía en las artes plásticas, dentro de la pintura abstracta, desde 1930; con la aparición del Manifiesto del arte concreto formulado por Theo van Doesburg y la obra de los futuristas De Stijl, Kandinsky, Max Bill, Naum Gabo y Auguste Herbin.

${ }^{245}$ Véase Vision Leap para ampliar listado de poesía concreta y publicaciones raras de este periodo artístico. [Sitio web] en: http://www.divisionleap.com Consultado: 27/12/2011.

${ }^{246}$ Blog Culpina K, 9/06/2006 "Galaxia Eugene Gomringer" en: http://culpinak.blogspot.com/2006/06/galaxia-eugen-gomringer.html Consultado: 19/05/2012.

${ }^{247}$ Revisar el listado de artistas pertenecientes al movimiento en: http://concretismo.zip.net Consultado: 30/11/2011.

${ }^{248}$ El Grupo Noigandres estuvo integrado por los poetas Decio Pignatari y los hermanos Augusto y Haroldo de Campos, entre los años de 1953-1957.

${ }^{249}$ SABATINI, Federico, "It can't be all in one language: Poetry and verbivocovisual, language in Joyce and Pound", en: Revue des litteratures de l'Union Europeene, [Texto on-line] en: http://www.rilune.org Consultado: 16/12/2011. Término empleado por James Joyce en Finnegan's Wake, libro 2 cap. 10 p. 341.

${ }^{250}$ Citado por Belem GACHE, “De Ekfrasis, Caligramas y Rebus"[Texto on line] en: http://findelmundo.com.ar/belengache/rebus.htm Consultado: 25/11/2011

${ }^{251}$ Citado por Jefferey Simons, Silver powdered olive trees: Reading Joyce in Spain [Texto on-line] en Google Books. Consultado 28/11/11 (p.273)
} 
La novela, similar a un hipertexto compuestos de fragmentos, pasajes de textos, dibujos, reportes de revistas, canciones, juegos de palabras y otros recursos entremezclados.

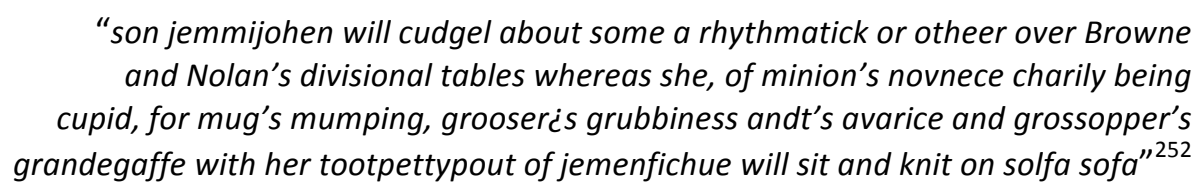

Ya sea mediante la incorporación de juegos de palabras o la distribución de letras sobre las páginas impresas o la incorporación de elementos visuales y caligráficos chinos ${ }^{253}$ como los textos de Paul Claudel, ${ }^{254}$ Idéogrammes Occidentaux ${ }^{255}$ y Henri Michaux o el juego creativo entre el juego de palabra (crucigramas, juegos de repetición, omisión, recurrencia, caligramas y estructuras combinatorias) de los textos de Georges Perec $^{256}$ (1936-1982) como La disparition ${ }^{257}$ (1969) novela de intriga que omite la letra E. O Les Revenentes (1972) que sólo utiliza la letra E y Alphabets (1976) en la que Perec no repite una consonante antes de haber usado el resto de las consonantes del alfabeto. Finalmente en $W$ o el recuerdo de la infancia, realiza un ejercicio narrativo que se aproxima a una estructura hipertextual; "un texto con ejes narrativos que se multiplican exponencialmente ${ }^{258}$; las posibilidades discursivas lúdica que se ampliarán con otros textos que enlistamos a continuación; se trata de piezas de literatura combinatoria y experimental. "Libros para armar, desentrañar, recorrer y construir" como dice el poeta chileno Juan Luis Martínez ${ }^{259}(1942-1993)$. Esbozar un panorama completo resulta difícil por la diversidad y proliferación de ejemplos que abordan juegos del pensamiento, de la palabra, o de la tipografía; sin embargo, esperamos despertar el interés por la búsqueda, ampliación y revaloración creativa del lenguaje en piezas literarias semejantes. ${ }^{260}$ Este apartado busca afirmar el poder experimental de la literatura: apreciar cómo perviven los recursos vanguardistas en nuestros días. Cómo la liberación de la sintaxis, las nuevas formas de visualidad textual, experimentaciones estilísticas y el manejo de signos y

\footnotetext{
${ }^{252}$ JOYCE, James, Finnegan's Wake, Parte 2, Episodio 3 (p.193) [Texto on-line] http://www.4shared.com Consultado: 18/12/2011.

${ }^{253}$ Véase: MONTI, Enrico, The reception of ideograms in Early 20th Century European Poetry, Review of literatures of the European Union, 8, (2008) [Texto on-line] en: http://www.rilune.org/ENGLISH/mono8/ideograms.htm Consultado 17/12/2011

${ }^{254}$ Véase Sociedad Paul Claudel [sitio Web] en: http://www.paul-claudel.net/ Consultado: 19/15/2012.

${ }^{255}$ Véase: HAUNG, Bei, “Le mouvement et la fixation: la pratique claudélienne de la calligraphie dans Cent phrases pour éventails"Boletín de la Sociedad Paul Cludel, Núm. 196, [Texto on-line] en: http://www.paulclaudel.net/print/book/export/html/176 18/12/2011

${ }^{256}$ VAZQUEZ ROCCA, Adolfo, "Georges Perec; pensar y clasificar", en Revista Digital de Creación ADAMARen: http://www.adamar.org/ivepoca/node/232 Consultado: 16/12/11.

${ }^{257}$ Fue traducida como El Secuestro (1972) por Anagrama y omite la letra A, por ser la más usada en español.

${ }^{258}$ En: Revue des Litteratures de L'Union Europeene [Texto on-line] en: http://www.rilune.org Consultado: 15/12/11.

${ }^{259}$ VAZQUEZ ROCCA, Adolfo, "El Hipertexto y las nuevas retóricas de la postmodernidad, textualidad, redes y discurso excéntrico" en PHILOSOPHICA, Revista del Instituto de filosofía de la Pontificia Universidad Católica del Valparaíso, Chile, Vol.27, 2004.

${ }^{260}$ Véase: SERRA, Marius, Verbalia; juegos de palabras y esfuerzos del ingenio literario, Península, 2000.
} 
significados contribuyen no sólo a engrosar el potencial comunicativo del lenguaje, sino adquieren una importancia visual, sonora y semántica en piezas digitales, que adquieren el poder de generar múltiples niveles de significación, a partir de los recursos empleados; Federico Sabatini ${ }^{261}$ menciona la polifonía como el sonido de varias voces o melopoeia [mots et son] o el potencial acústico, phanopoeia como la creación y revelación de las imágenes y su potencial visual y la logopoeia o la progresión del intelecto. Son los tres elementos vitales para la recreación del sentido, la expresión sensorial y la escritura experimental.

\section{Partituras de sucesos, Libros-caja de Artista y algo más}

Otros ejemplos que estimulan la experimentación textual, al replantear una nueva manera de presentar el arte, son libros en forma de una "caja". Un medio que fue utilizado por diversos artistas. El precursor fue Marcel Duchamp ${ }^{262}$ con su Caja verde (1934) en la que almacenaba recortes, anotaciones, reflexiones, fotografías, facsímiles, dibujos, croquis a pluma y diferentes esquemas de obras realizadas. Posteriormente, con Boîte-etvalise, realizado a partir de 1935, el artista reproducía sus obras en miniatura y las integraba en una valija como si fuera un museo portátil ${ }^{263}$. El colectivo Fluxus retomaría esta propuesta, a lo cual George Brecht publica en 1963 Water Yam, un libro-caja diseñada por George Maciunas y cuya tipografía diseñó Tomas Schmit, el cual contiene alrededor de 70 tarjetas impresas con ciertos recortes o "Event Scores" [partituras de sucesos] o Fluxscores las cuales se componen de juegos interactivos, recortes de periódicos e ideas sencillas de acciones y objetos cotidianos que pueden recontextualizarse como un performance ${ }^{264}$; se trata de textos que pueden verse como instrucciones para llevar a cabo acciones interpretativas y de cierta variación.

Consider an object. Call what is not the object "other". Add to the object, from the "other", another object, to form a new object and a new "other". Repeat until there is no more "other". Take a part from the object and add it to the "other", to form a new object and a new "other". Repeat until there is no more object ${ }^{265}$.

\footnotetext{
${ }^{261}$ SABATINI, Federico, "It can be all in one language: Poetry and "Verbivocovisual" language in Joyce and Pound, riLUnE, núm. 8, 2008, pp. 97-114. [Texto on-line] en: http://www.rilune.org/ENGLISH/mono8/IdeogramsArticles.htm Consultado: 22/12/2011.

${ }^{262}$ Véase: Sociedad Lunar [Blog] en: http://www.sociedadlunar.org/blog/librosylibros/?tag=marcelduchamp Consultado: 19/05/2012

${ }^{263}$ Véase: Duchamp's Boîte-en-valise, or Box in a Suitcase en sitio Internte de MOMA: http://www.moma.org/interactives/exhibitions/1999/muse/a rtist_pages/duchamp_boite.html Consultado: 22/12/2011.

${ }^{264}$ Tomado del Sitio web de Alison Knowles; http://www.aknowles.com/eventscore.html consultado: $22 / 12 / 2011$

${ }^{265}$ BRECHT George, Two exercises, 1961. [Texto on-line] en: http://www.artnotart.com/fluxus/gbrechttwoexercises.html Consultado: 30/11/2011
} 
El valor de estos "scores" reside en el potencial imaginativo que permite la interpretación a partir de objetos, imágenes, recortes, pequeños textos y cualquier elemento que obligue la composición de un texto. Una especie de palimpsesto que puede armarse a diferentes niveles de significación.

En 1966 Dan Graham publica Schema, el cual presenta un tipo de instrucción para escribir poemas a razón de un listado de ingredientes que se deben seguir:

"35 adjetivos, 7 adverbios, 35.52\% del área libre de escritura, $64.52 \%$ del área ocupada por texto, 1 columna, 1 conjunción, 0 gerundios, 0 infinitivos, 247 letras de un alfabeto, 28 líneas, 6 símbolos matemáticos, 51 sustantivos, 6 participios, tipografía de 10 puntos, 3 palabras en mayúscula..."

Yoko Ono, con Grape Fruit (1970) buscó en los Event Scores, un acercamiento creativo mediante una serie de instrucciones lingüísticas que proponían acciones físicas con un afán de performance. Otro tipo de proyectos artísticos inspirados en libros u objetos se presentan como rollos, acordeones, plegados o piezas sueltas en una caja, al estilo de los Fluxboxes; conocidos como Artist's Books ${ }^{267}$. Como es el caso de Francis Van Maele y su Franticham's Fluxus Island ${ }^{268}$. Entre 1965 y 1967 Dick Higgins publicó los manifiestos y piezas experimentales en la serie The Great Bear Pamphlet ${ }^{269}$ entre los colaboradores estan Alison Knowles ${ }^{270}$, George Brecht, Claes Oldenburg, Allan Kaprow, Nam June Paik, John Cage, Robert Filliou, David Antin y otros. Por su parte, Marcel Duchamp, con el antes mencionado libro de recortes, Boîte Verte, lo publica anexo a Gran vidrio, al cual incluye anotaciones, reflexiones, fotografías, dibujos, croquis y esquemas que el lector va armando a partir de lo que encuentra en la caja.

Ya sea a partir de estos libros en caja, o mediante textos inspirados en grafías y simbología que asemeja cierta escritura como las obras de: Michael Jackobson, The Giant's fence (2006); Connected de Suzan Sary; Aussie Runes \& Hybrid meta-art essays de Tim Gaze; Seeking the truth (2007) de Morgan Taubert, o Mnemopolis de Fracois Rojares; las posibilidades de la narrativa visual artística se han ampliado. Más aún si contemplamos las tendencias experimentales en la fabricación de nuevos formatos de libros como Daily mirror Book (1961) de Dieter Roth, quien publica un ejemplar de 2 x 2 $\mathrm{cm}$, en donde reduce y amplia la tipografía a sus límites.

\footnotetext{
${ }^{266}$ GRAHAN, Dan, Poem Schema (1966) [Texto on-line] en: [http://www.vvork.com/?p=13296 Consultado: $19 / 05 / 2012$.

${ }^{267}$ KLIMA, Stefan, Artist Book: a critical survey of the literature, Granary Books, New York 1998. Véase: The center for book arts in New York, en: http://centerforbookarts.org/ Consultado: 21/05/2012.

${ }^{268}$ Véase: http://www.redfoxpress.com/FH-fluxusbox.html

${ }^{269}$ HIGGINS, Dick et al, The Great Pamplhlet Series, Something Else Press, New York, 1965-1967.

${ }^{270}$ Véase: http://www.mdfschool.ru/files/knowles_by.pdf Consultado: 27/12/2011.
} 
Memoires y Fin de Copenhague ambas obras de Guy Debord y Asger Jorn impreso en papel de lija utilizando técnicas de impresión sobrepuesta. O la tradición pictórica-letrista como el de de Mike Rose ${ }^{271}$ y muchos otros pintores inspirados en letras o tipografía que pueden ser motivo de futuros trabajos de investigación. Por lo pronto deseamos destacar los recursos que aporta el ordenador a la generación de nuevos formatos de libros y a la experimentación; confirmada por la idea de Jacques Derrida: "si escribimos diferente, leemos diferente y pronto entenderemos el mundo de diferente manera"272. También nuestros libros serán diferentes, no sólo en cuestiones formales sino lingüísticas, gráficas, visuales, sonoras; todo aquello que permita que las historias se enriquezcan con el mayor número de elementos creativos. Belén Gache ${ }^{273}$ cita a Ludwig Wittgenstein y menciona que el lenguaje diferente implica una forma diferente de ver el mundo. Vivimos un mundo interactivo resultado de una tradición milenaria que no podemos negar, mucho menos omitir; debemos apostar a crear piezas que otorguen al lenguaje una mayor expresividad y creatividad.

\footnotetext{
${ }^{271}$ Véase: http://www.mikerose.de Consultado: 27/12/2011

${ }^{272}$ Citado por Belem GACHE, "De Ekfrasis, Caligramas y Rebus"[Texto on line] en: http://findelmundo.com.ar/belengache/rebus.htm Consultado:25/11/2011

${ }^{273}$ GACHE, Belén, “La poesía visual como máquina de guerra del lenguaje”, en: Poesía visual Argentina, Ediciones Vórtice, Buenos Aires, 2006. [Texto on-line] en:

http://www.findelmundo.com.ar/belengache/libropvisual.htm Consultado: 16/11/2011
} 


\subsection{SCRIPTOR LUDENS vs. LECTOR LUDENS ${ }^{275}$}

Encontrar un tema para desarrollar un proyecto artístico puede ser relativamente fácil; pero desarrollarlo para que tome forma de una historia requiere mucho trabajo. Experiencias en talleres de narrativa nos han enseñado que no es posible seguir recetas, pero resulta más fácil si partimos de modelos previos. En este apartado deseamos acercarnos a la literatura y a ciertas prácticas narrativas que han estado ligadas a "formulas" para construir textos, esperando sirva para ampliar la perspectiva de las labores de un diseñador de textos que pueda obtener modelos que amplíen sus recursos experimentales que le permitan componer de manera innovadora.

\section{OuLiPo}

Escribir poemas usando términos que "entienden" perros, zorros o cuervos, no es el borde de la locura de esta doctorando; es una propuesta de François Le Lionnais ${ }^{276}$ quien, junto a un grupo de matemáticos- literatos franceses integró el grupo OuLiPo, acrónimo de Ouvroir de Litterature Potentielle [Taller de literatura potencial]. El colectivo propuso nuevas formas de creación basados en la exploración de las potencialidades de la literatura: los lenguajes inventados, figuras poéticas reconfiguradas, aplicación de ecuaciones en la creación textual; juegos con letras y números, son algunos de los recursos, propuestos. En este trabajo deseamos revalorar su carácter lúdicoexperimental al servicio de la creación literaria contemporánea, un referente indiscutible para cualquier escritor contemporáneo.

Plantear interrogantes es el comienzo de cualquier ejercicio creativo, ¿Qué productos se obtienen si se vinculan las estructuras narrativas a las matemáticas, integrando algoritmos, sustituciones y otras operaciones? ${ }^{277}$ ¿Cómo integrar elementos retóricos de

\footnotetext{
${ }^{274}$ PERKINS, D.N., The mind's best work, Harvard University press, Cambridge, 1981.

${ }^{275}$ Título utilizado en la Introducción de: MOTTE, Warren F., OULIPO: a Primer of potential literature, Nebraska University Press, Lincoln, 1986. (P.20)

${ }^{276}$ Citado por: MATHEWS, Harry \& BROTCHIE, Alastair (eds.), Oulipo Compendium, Atlas Press, London and Make Now Press, Hollywood, 2005, (p.49)

${ }^{277}$ Revisar a Nicolas Bourbaki, cuyo trabajo con matemáticas debió inspirar a los miembros fundadores de Oulipo. También puede revisarse el ALAMO o Atelier de Littérature Assistée para la mathematique et les ordinateurs, fundado por Paul Braffort y Jacques Roubaud.
} 
la tradición clásica de manera innovadora como acrósticos, anagramas, lipogramas, palíndromas? ¿Cómo dotar de recursos lúdicos a los textos, jugando con los significados, "armando" las palabras o incluso las letras de acuerdo a reglas similares a las de un juego? Responder a estas cuestiones fue uno de los objetivos de OuLiPo. El resultado ha conformado un arsenal de formas literarias susceptibles de promover creaciones novedosas y creativas. OuLiPo es un pasaporte a la experimentación y al descubrimiento de las potencialidades de la creación. Con el mismo afán surge $O u-x$-Po como una tendencia en otras disciplinas como la pintura, la arquitectura, incluso las artes culinarias y las historietas de animación ${ }^{278}$.

En estos casos, la literatura se explora desde la visión matemática, simulando la solución de problemas, algunos de los cuales son imaginarios, como los que ocupan al Collège de Pataphysique $^{279}$. Esta conexión entre literatura, matemáticas e imaginación ha existido a lo largo de la historia ${ }^{280}$. OuLiPo ${ }^{281}$ se encargó de revalorar esta posibilidad. Fundado en 1960 por François Le Lionnais (1901-1984) y Raymond Queneau ${ }^{282}$, éste último, era reconocido por Exercises de style ${ }^{283}$ (1947), el cual presenta la misma historia de 99 maneras distintas y Zazie dans le metro ${ }^{284}$ (1959). Le Lionnais, ingeniero experto en ajedrez y en matemáticas, escritor de: Les Nombres remarquables, quien se mantuvo como teórico del grupo ${ }^{285}$. Hoy, después de 50 años el grupo sigue vigente ${ }^{286}$ con 37 miembros de distintas nacionalidades, contribuyendo con la literatura, ofreciendo procedimientos que estimulan la inspiración y creatividad. ${ }^{287}$

Entre los primeros OuLiPianos encontramos a: Albert-Maria Schmidt, Juan Lescure, Jaques Duchateau, Claude Berge, Latis y Jean Queval; se sumaron posteriormente nuevos miembros como Noël Arnaud, Georges Peréc, Jacques Roubaud, Luc Etienne, Italo

\footnotetext{
${ }^{278}$ OuPeinPo [peinture], OuArchPo [architecture], OuCuiPo [Cuisine, OuBaPo [Bande desinée Potentielle]; respectivamente. La lista de potencialidades [Ou-X-Po] puede consultarse en: http://ouxpo.voila.net/page1/index.html Consultado: 05/01/2012. Sobre el OubaPo, véase: http://gciment.free.fr/bdoubapo.htm Consultado: 05/01/2012.

${ }^{279}$ Se trata de una corriente filosófica vinculada a un movimiento cultural francés dedicada "al estudio de las soluciones imaginarias" Puede ampliarse en: http://www.college-depataphysique.org/college/accueil.html Consultado: 18/12/2011.

${ }^{280}$ Véase MOTTE, Warren, OULIPO, A primer of potential literature, Dalkey Archived ed., UrbanaChampaign, 2007 (p.14 en adelante) es buen inicio para otro proyecto de investigación.

${ }^{281}$ Véase sitio oficial: http://www.oulipo.net y http://www.nous.org.uk/oulipo Consultado: 20/12/2011

${ }^{282}$ Véase: http://www.queneau.net Consultado: 09/01/2012

${ }^{283}$ QUENEAU, Raymond, Ejercicios de estilo, Cátedra, Madrid, 1999.

${ }^{284}$ Novela que explora por primera vez en francés, el lenguaje coloquial, fue adaptada al cine en 1960 por Louis Malle. puede revisarse el texto en: http://www.complete-review.com/reviews/queneaur/zazie.htm Consultado: 06/01/2011.

${ }^{285}$ Los dos manifiestos del Oulipo se deben a Le Lionnais, fueron publicados originalmente en Oulipo, La littérature potentielle creations, re-creations, récreations, Gallimard, Paris, 1973. Véase: MOTTE, Warren, OULIPO, A primer of potential literature, Dalkey Archived ed., Urbana-Champaign, 2007. (pp. 26-31) ó su traducción al castellano en la Revista virtual de literatura El Hablador núm. 9, 2005, en: http://www.elhablador.com/patafisica3.htm Consultado: 06/01/2011.

${ }^{286}$ Oulipo, [Sitio web] en : http://www.oulipo.net Consultado:06/01/2011.

${ }^{287}$ Citado por Warren Motte en: MOTTE, Warren, OULIPO, A primer of potential literature, Dalkey Archived ed., Urbana-Champaign, 2007. (p. 51).
} 
Calvino, Marcel Duchamp y otros ${ }^{288}$. El colectivo se caracteriza por generar textos a partir de técnicas de Littérature á contraintes [Literatura controlada o limitada] basada, en una búsqueda y experimentación de formas y estructuras, o sistemas preestablecidos (categorías lógico-formales) denominadas "restricciones" "289: "Puesto que la escritura es una combinación de signos, sobre ella se pueden aplicar criterios de composición, variación, intersección, etc. ${ }^{290}$ Considerando en cierta medida, determinados procedimientos semejantes a recetas de creación lúdicas:

"To explore the potential of literariness by imposing gamelike conditions, in constructing specific rules prior to writing upon its production ${ }^{\prime 291}$.

Es algo similar a "Ceñir la lengua con un corsé para hacer brotar la imaginación"292, bajo la idea de constreñir, forzar e imponer; "OuLiPo no busca imponer tesis alguna, sino formular problemas y eventualmente, ofrecer soluciones que permitan a cualquiera, construir letra por letra, palabra por palabra un texto. El objetivo de OuLiPo es descubrir nuevas estructuras y arroparlas con un pequeño número de ejemplos. "293 $\mathrm{Su}$ inspiración está basado por el juego del lenguaje y la experimentación de todo tipo de formas: alfabéticas, fonéticas, sintácticas, numéricas e incluso sintácticas que se complementan con las posibilidades de transposición de conceptos geométricos, algebraicos, matriciales que favorecían la multiplicación y la conexión de elementos en un texto.

"En el fondo, me doy reglas para ser totalmente libre", decía Perec... "un autor OuLiPiano es una rata que construye ella misma el laberinto del cual se propone salir" respondían Marcel Benabou y Jacques Roubaud ${ }^{294}$. Queneau por su parte sostenía la idea que cualquier poeta o cualquier interesado en escribir, pudiera elegir ciertas estructuras para crear; promoviendo el descubrimiento y la búsqueda de soluciones que exigen cierta maestría en el manejo del lenguaje y replanteando una nueva relación entre la obra, el escritor y el lector, en donde las posibilidades de interpretación, configuración y construcción de textos se multiplican.

"Every literary work begins with an inspiration (at least that's what its author suggests) which must accommodate itself as well as possible to a series of constraints and procedures

\footnotetext{
${ }^{288}$ Véase lista completa de oulipianos [Sitio web]: http://www.oulipo.net/oulipiens Consultada:06/11/2011

${ }^{289}$ LESCURE, Jean, "Brief history of the Oulipo" (pp. 172-176) en: WARDRIP-FRUIN, Noah \& MONTFORT, Nick, The new media reader, The MIT Press, Cambridge, 2003.

${ }^{290}$ CAMARERO, Jesús, Metaliteratura: estructuras y formas literarias, Anthropos, Barcelona, 2004. (p.177)

${ }^{291}$ MOTTE, Warren F., OULIPO: a Primer of potential literature, Nebraska University Press, Lincoln, 1986.

${ }^{292}$ [Mettre la langue sous corset pour faire jaillir l'imaginaire?] citado por : PROUST, Jean-Marc, “Avec

l'Oulipo, les mots son un jeu depuis 50 ans", Slate, 24/10/2010, [Artículo on-line] en:

http://www.slate.fr/story/30693/oulipo consultado: 04/01/2012.

${ }^{293}$ LESCURE, Jean, “Brief history of the Oulipo" (pp.32-39) en: MOTTE, Warren F., OULIPO: a Primer of potential literature, Nebraska University Press, Lincoln, 1986.

${ }^{294}$ Tomado de la Breve historia de los estudios de Oulipo [Texto on-line] en El hablador, Núm. 9,

Septiembre 2005 en: http://www.elhablador.com/patafisica1.htm Consultado: 26/11/2011.
} 
Muchas de las estructuras que utilizan ya habían sido inventadas en el pasado, como acrósticos, lipogramas o palíndromos. El nuevo interés de reutilizarlos atiende al deseo de crear piezas artísticas. Algunos ejemplos de estructuras que fueron utilizadas son los Poemas Fibonacci ${ }^{296}$, basados en la secuencia de los mismos números $(0,1,2,3,5,8,13$, 21...) construidos con el mismo número de sílabas de la secuencia. En el Homosintaxismo, la escritura se da a partir de una secuencia preestablecida de componentes discursivos del tipo SVAVSSAVV... (Donde $\mathrm{S}=$ sustantivo; V= Verbo y $\mathrm{A}=$ adjetivo). La Cadena de citas, propone que cada palabra de un texto sea sustituida por su definición recogida en un diccionario (formando parte de la llamada "literatura semodefinicional" ${ }^{297} . \boldsymbol{S}+7$ es otra forma que genera un texto a partir de otro cuyos sustantivos localizados en el diccionario, pueden ser sustituidos por el séptimo sustantivo siguiente de ese mismo diccionario. La constricción del prisionero no permite introducir las letras que sobresalen por encima o por debajo del límite (impreso) de las letras "redondas", de tal suerte que las líneas pueden aproximarse hasta tocarse y ahorrar considerablemente papel. El Anagrama busca la transposición de letras de una palabra o una frase, formando una nueva frase que tenga sentido; o como el Heterograma, variante del anterior que consiste en permutar también una secuencia de elementos combinada con otros elementos para ordenar después el resultado de una iteración significante; o la estructura de los Bellos presentes, textos construidos con las letras de los nombres de las personas presentes.

A lo largo de estos 50 años de experimentación; el listado de restricciones ha llegado a ser considerable, podemos apreciar otras como Baobab, Boule de neige, Caradec, Eclipse, Haï-kä̈sation, Inventaire, Lipposible, Mongine, Terrine, Villanelle y otros tantos, hasta completar 119 restricciones que pueden conocerse en el sitio oficial del grupo $^{298}$; así como ejemplos y bibliografía ${ }^{299}$; dado que nos resulta imposible abordarlos en este trabajo; referimos ciertas obras que consideramos son un referente obligado por conocer: Le petit meccano poétique n. 00, Modeste exercise for begginers o Le Vol d'Icare de Raymond Queneau, junto a Cent Mille milliards de poémes (1961) éste último de mayor complejidad, al utilizar el formato clásico de los sonetos y recomponer un texto que permite al lector armar a voluntad cien billones de sonetos estructuralmente correctos; ya que Queneau presenta 10 sonetos de 14 versos cada uno que pueden intercambiarse y recombinarse entre sí, permitiendo escribir $10^{\wedge} 14$ poemas diferentes;

\footnotetext{
${ }^{295}$ LE LIONNAIS, LIPO, First Manifesto, (p.26), en: MOTTE, Warren F., OULIPO: a Primer of potential literature, Nebraska University Press, Lincoln, 1986.

${ }^{296}$ Un número fibonacci se obtiene de la suma de los dos números anteriores, de manera sucesiva.

${ }^{297}$ Término referido por: CAMARERO, Jesús, Metaliteratura, estructuras formales literarias, Arthropos, Barcelona, 2004. (p.179)

${ }^{298}$ Véase Contraintes en: http://www.oulipo.net/contraintes Consultado:21/05/2012.

299 Para conocer el listado de las Constricciones oulipianas véase: ROUBAUD, Jacques \& BENABOU, Marcel, "Une liste de contraintes oulipiennes" [Texto on line] en:

http://www.oulipo.net/oulipiens/document13302.html. Consultado: 27/12/2011
} 
para hacerlo, los versos se imprimen y recortan de manera independiente y se siguen ciertas reglas estructurales.

Aunque no hay noticias de que un editor haya realizado otro texto de manera semejante, esto constituye una máquina para fabricar poemas y debe verse como un resorte creativo estupendo. No sólo escribieron poesía; empleaban las mismas estructuras para generar textos de mayor amplitud y complejidad. Tal como hemos mencionado antes, Georges Perec $^{300}$ utiliza la forma del Lipograma y escribe La Disparition(1969), una novela sin la letra "E", y después Les revenentes (1972) un contrapunto a la anterior, ya que sólo usa la vocal "E". Walter Abish (sin ser del grupo) realiza Alphabetical Africa (1974) cuyo método empleado parece haber sido inspirado por éstos: su novela contiene 52 capítulos. En el primero todas las palabras comienzan con la letra "a". En el segundo, comienzan indistintamente con la a ó la b; en el tercero, con a,b,c, así hasta el 26 que utiliza todas las letras, del 27 en adelante comienza el proceso inverso hasta llegar al último capítulo, a la letra a, aquí esta una muestra:

"Ages ago, Alex, Allen and Alva arrived at Antibes, and Alvo allowing all, allowing anyone, against Alex's admonition against allen's angry assertion: another African amusement... anyhow as all argued, an awesome African Army assembled and arduously advanced against African anthill..."1301

Zinga huit de Jacques Duchateau ${ }^{302}$ es una novela de ficción que utiliza varias restricciones que le permite crear intersecciones, disparidades simétricas, conjunciones y regular el orden de los eventos. Veremos en el siguiente apartado otras piezas de cierta complejidad estructural en el que ejemplifiquemos estos procedimientos. El interés al abordar a OuLiPo atiende a apreciar la innovación lúdica de su proceso creativo; la escritura como una práctica que parte de un modelo. Un modelo que requiere el juego bipartito, entre el escritor y los lectores. Warren Motte ${ }^{303}$ lo define como un sistema lúdico de intercambio entre autor y lector: Scriptor ludens, lector ludens. Confirmamos una vez más como el juego es fundamental a la literatura y en sentido amplio, a la experiencia estética. Los OuLiPianos adoptan la noción de Johan Huizinga ${ }^{304}$ y sostienen que la poesía es producto del juego. Mientras algunos críticos atacan su falta de seriedad e incluso les designan como "humoristas poco serios" y no como escritores; sus defensores reconocen a la literatura potencial como algo de gran seriedad. Nuestra tarea es apreciar su carácter experimental y la utilización de estructuras como un principio creador y no como un fin en sí mismo; que requiere la destreza, imaginación y solución de problemas. Cuestión valiosa al llevar a cabo talleres de escritores. Otra valía en el acercamiento al colectivo es el interés que despertaron, al tener los primeros

\footnotetext{
${ }^{300}$ Véase: http://associationgeorgesperec.fr/ Consultado: 9/01/2012

${ }^{301} \mathrm{ABISH}$, Walter, Alphabetical Africa, (fragmento Primer párrafo, primer capítulo), en: MATHEWS, Harry \& BROTCHIE, Alastair (eds.), Oulipo Compendium, Atlas Press, Hollywood, 2005. (p.47)

302 DUCHATEAU, Jacques, Zinga huit, Gallimard, 1967.

${ }^{303}$ MOTTE, Warren F., OULIPO: a Primer of potential literature, Nebraska University Press, Lincoln, 1986. (p.20)

${ }^{304}$ Véase apartado anterior dedicado al juego en este mismo trabajo.
} 
acercamientos con las máquinas como herramientas de creación, varios de sus integrantes eran expertos programadores. Raymond Queneau lamentaba en 1964, la falta de acceso a máquinas sofisticadas y anticipaba como el futuro sería llevado hacia una exploración sistemática de las posibilidades literarias que ofrece el ordenador.

"We believe, that the aid of a computer, far from replacing the creative act of the artist, permits the latter rather to liberate himself from the slavery of a combinatory search, allowing him also the best chance of concentrating on this clinamen [inclinación] which, alone, can make of the text a true work of art. ${ }^{1305}$

También reconocemos las dos ideas básicas de creación planteadas por Le Lionnais ${ }^{306}$, el Anoulipismo entendido como la devoción de descubrimiento y el Synthoulipismo, el deseo de la invención; dos prácticas que todo escritor debe buscar. Esto es justamente una de las principales ideas que deseamos destacar en este trabajo de tesis; todo texto requiere de búsqueda, experimentación e innovación. No creamos una pieza de la nada, por lo general partimos de un modelo que sirve como resorte para desarrollar el proyecto original y creativo.

Esperamos que estos recursos logren integrar un arsenal creativo, al mismo estilo Queneunean; en donde el juego estimule la creación del lenguaje; recordándonos el potencial que éste adopta si lo ligamos a sus cualidades sensoriales de visualidad y sonoridad. Esperamos que los artistas plásticos puedan pensar en el lenguaje como una herramienta que enriquece cualquier proyecto artístico, y en el juego como un motor creativo para darle forma al lenguaje y a la imaginación.

Tal como Marcel Duchamp dice:

"You pick up something from an earlier period and adapt it to your own work an approach can be creative. The result is not new; but it is new insomuch as it is a different approach"307

El arte, como el juego establecen relaciones y posturas para los creadores, permitiéndoles resolver problemas, encontrar nuevos métodos, plantear acciones y situaciones para la invención.

\footnotetext{
${ }^{305}$ MOTTE,Warren F., OULIPO: a Primer of potential literature, Nebraska University Press, Lincoln, 1986. (p.17)

${ }^{306}$ LE LIONNAIS, “LIPO: First Manifesto”, en: MOTTE, Warren F., OULIPO: a Primer of potential literature, Nebraska University Press, Lincoln, 1986. (p.26-31)

${ }^{307}$ Citado por: FLANAGAN, Mary, Critical play: radical game design, The MIT Press, Cambridge, 2009. (p.3)
} 
The idea that games have something to do with stories deserves at least to be challenged.

Richard Rouse III $^{308}$

\section{NARRANS ET LUDENS}

La narrativa ha sido un elemento clave en los estudios humanos. Jan Simons ${ }^{309}$ la considera como una herramienta fundamental para construir identidades, conformar nuestra historia y adquirir conocimientos. Este apartado está destinado a apreciar los puntos de encuentro entre las narrativas y los juegos. Revisaremos algunas propuestas que tienen un acertado manejo de elementos lúdicos en su estructura narrativa y apreciaremos el potencial que tienen los juegos para relatar historias. Esperamos que éste análisis sirva a los escritores como manantial creativo y como base teórica para la composición de historias. Este apartado es una invitación a detectar nuevos recursos lúdicos y experimentar las potencialidades del juego narrativo. Buscamos revalorar las cualidades lúdicas en la literatura y los atributos narrativos en los videojuegos, para ello consideramos necesario contemplar las nociones teóricas y críticas de ambas disciplinas, que permiten el entendimiento de sus cualidades y componentes filosóficos, semióticos, narratológicos, estructurales, lingüísticos, entre otros.

Dos cuestiones trataremos de resolver a lo largo de este apartado: ¿Existen textos jugables?, y ¿De qué manera el juego puede fomentar la creatividad?

En el apartado anterior pudimos confirmar el potencial creativo del lenguaje a través de prácticas lúdicas que favorecen la experimentación, el reacomodo de las formas e incluso la invención. Por ello consideramos que el juego es un recurso importantísimo para la creación, porque "se concibe como espontáneo, exploratorio, constructivo y creativo."”10 No solo se ha utilizado el juego para describir y explicar diversas actividades humanas como el aprendizaje, la interacción social e incluso ciertas manifestaciones del arte y la literatura. Esperamos que con este análisis contribuyamos a estructurar ideas, plantear mejores estrategias, mejorar el grado de interacción, simulación y expresividad en diversas formas de creación.

\footnotetext{
${ }^{308}$ ROUSE, Richard III, Game Desisng theory \& Practice, Wordware Publishing, Plano, Tx., 2004. (p.47)

${ }^{309}$ SIMONS, Jan, "Narrative, games \& theory" en Game Studies, Vol. 7, Issue 1, 2007. [Artículo on-line] en: http://gamestudies.org/0701/articles/simons Consultado: 31/02/2012

${ }^{310}$ WILSON, R. RAWDON, Palamede's shadow; explorations in play, game \& narrative theory,

Northeastern University Press, Boston, 1990. (p. 10)
} 
Para mí escribir, hasta lo que usted llama literatura seria, es un juego. Los juegos de palabra son palabras cuyo significado depende del juego; es el jugador quien dispone los movimientos"

Guillermo Cabrera Infante

\subsection{LITERATURA INSPIRADA EN JUEGOS}

Un lector, al enfrentarse a una lectura se convierte en un jugador. Debe explorar el texto de manera activa: introduciéndose en un mundo de ficción, recombinando elementos narrativos para descubrir uno o varios sentidos (según sea su grado de interacción e inmersión). Los lectores deben seguir las reglas del juego narrativo para avanzar a lo largo de la trama y durante este viaje, se enfrentan a un sinnúmero de elementos que le generan emociones y le permiten hacer inferencias y conexiones con otras aventuras. Tanto leer una novela como jugar algún juego, nos permite introducirnos a un mundo de ficción.

A continuación enlistamos algunos de textos que presentan cualidades narratológicas, estéticas, hermenéuticas y formales que podemos asociar a juegos, por la exigencia que demandan al usuario, como la solución de enigmas y acertijos; y por su grado de experimentación, ingenio y frescura. La intención es mostrar el amplio y variado potencial de creación textual.

La primera es Memorias póstumas de Brás Cubás (1881) del brasileño Joaquim María Machado de Asiss. ${ }^{312}$ Integrada por 160 fragmentos textuales irregulares, algunos son breves escenas o largas disquisiciones filosóficas en desorden; secuencias que el lector debe restructurar. En Nadja (1928) André Bretón ${ }^{313}$ incluye 44 fotografías esperando que el corpus visual facilite que el texto cobre una estructura de novela, al ir interconectando las imágenes con las descripciones y textos interpuestos. Las imágenes relatan historias que al articularlas con otras, permiten que se consigan textos realmente complejos. En Pale Fire (1962) Vladimir Novokov ${ }^{314}$ integra de 999 versos que además de leerse en cualquier orden, invitan al lector de detective para resolver una intriga. El juego de Novokov reside en conjugar tres partes; un poemario, un comentario de un supuesto rey que comenta el poema y una tercera parte que escribe el supuesto editor del texto. Se trata de textos dentro de otros textos.

\footnotetext{
${ }^{311}$ Citado por: MOYANO, Marisa, "Tres tristes tigres" [Artículo on line] en: http://www.ucm.es/info/especulo/numero28/trestigr.html Consultado: 22/01/2012

312 Publicada originalmente en 1880 en forma de folletín por entregas.

${ }^{313}$ BRETON, André, Nadja, Grove Press, New York, 1960.

${ }^{314}$ NOVOKOV, Vladimir, Pale Fire, Vintage International, New York, 1989.
} 
En ciertos casos, la lectura se arma a partir de las elecciones del lector, como en The Money spider (1988) de Robin Waterfield y Wilfred Davies ${ }^{315}$ y Falcon 5: The dying sun (1986) de Mark Smith y Jamie Thompson ${ }^{316}$. Al respecto existe una industria de librosjuego muy abundante que presentan obras literarias que involucran al lector permitiéndole decidir sobre el curso de las historias. Por lo general son historias ramificadas. Algunas fueron publicadas dentro de colecciones como Elige tu propia aventura que fueron muy populares en los 80 's entre el público juvenil. Con la llegada del ordenador, estos formatos se popularizaron en aventuras conversacionales por menús de opciones o hiperficciones explorativas.

En Composition no. 1(1960) Marc Saporta ${ }^{317}$ invita al lector a barajar las cartas de la novela y cambiar el orden de los hechos. La obra está impresa en hojas sueltas que el lector acomoda y lee de manera aleatoria. Por otra parte hay textos que juegan con los formatos y los materiales en donde se imprimen como es el caso de la obra de Randi Strand $^{318}$, Ordakt, el cual fue impreso en páginas blancas, negras y transparentes; el libro presenta juegos y transformaciones de palabras conocidas. En cierto modo esta posibilidad amplía el carácter artístico y utilitario al permitirse desarrollar una línea de libros con texturas que se pueden desarrollar para invidentes.

En Invención a dos voces (1963) Enrique Lafourcade ${ }^{319}$ ofrece, mediante el Tablero de D indicaciones de cómo puede leerse la novela, de forma tradicional o de manera independiente los capítulos pares de los nones, "puede leerse de atrás para delante, saltarse es muy recomendable, ${ }^{, 20}$. Milorad Pavic (1929-2009) con el Diccionario $J_{\text {Jázaro }}^{321}$ presenta una novela en forma de diccionario con una versión femenina y otra masculina, con pistas que el lector debe descubrir y en el que se intercalan tres versiones sobre el pueblo Jázaro: la cristiana, islámica y la judía. Su lectura obliga cierta destreza por parte del lector y un poco de esfuerzo para interconectar las versiones.

Algunas obras literarias latinoamericanas que consideramos un referente en relación a las nuevas formas de representación narrativa, entre las cuales se presenta la ruptura y la fragmentación de los puntos de vista que demandan un nuevo lector que sepa reconstruir los textos, son La casa verde (1966) de Mario Vargas Llosa ${ }^{322}$ en la cual múltiples historias se entrelazan en dos escenarios distantes con una técnica narrativa con tiempos y lugares cambiantes, mezclando situaciones reales e imaginarias como un enorme rompecabezas que al final se completa. Tres tristes tigres (1967) de Guillermo Cabrera Infante $^{323}$, es una novela que plantea un juego permanente del lenguaje y su oralidad a

\footnotetext{
${ }^{315}$ WATERFIELD, R. \& DAVIES, W., Money spider, Penguin Books, New York, 1988.

${ }^{316}$ SMITH, Mark \& THOMSON, Jamie, Falcon: the dying sun v.5, Sphere, 1986.

${ }^{317}$ SAPORTA, Marc, Composition no. 1, Simon \& Shuster, New York, 1963.

${ }^{318}$ Citado por: AARRE, Mari, "The Aesthetics of language" [Artículo on-line] en:

http://www.randistrand.no/tekst/textenglish.html consultado:10/03/2012

319 LAFOURCADE, Enrique, Editorial Zig Zag, Santiago de Chile, 1965.

${ }^{320}$ CORTAZAR, JULIO, Rayuela, Cátedra, Madrid, 2011. (En Introducción de Andrés Amorós)

${ }^{321}$ PAVIC, Milorad, Diccionario Jázaro, Anagrama, México, D.F. 1998.

322 VARGAS LLOSA, Mario, La casa verde, Alfaguara, México, D.F. 2005.

${ }^{323}$ CABRERA INFANTE, Guillermo, Tres tristes tigres, Seix Barral, Barcelona, 1967.
} 
través de trabalenguas narrativos inspirados en el juego del lenguaje, un perpetuo juego que se convierte en la misma materia significante. En Cien años de soledad (1967) Gabriel García Márquez ${ }^{324}$ muestra su creatividad a través de la complejidad formal que se aprecia en el manejo de múltiples tiempos, espacios y personajes. De dónde son los cantantes de Severo Sarduy ${ }^{325}$ muestra su originalidad con su trama basada en un poema escrito como epitafio y el resto escrito como obra teatral.

En Siberia Blues (1967) Néstor Sánchez ${ }^{326}$ pone en práctica su fino oído musical convirtiendo en lenguaje los ritmos del tango y del jazz Según cita Liliana Guaragno ${ }^{327}$ : el jazz se integra en su onda de improvisación con reiteraciones y variaciones de motivos en avance o retroceso en una escritura en marcha, fraseo que atrae por resonancias y da lugar a pliegues que discolocan tiempos y espacios con efectos de simultaneidad". En un estilo similar, Aire de Tango (1973) Manuel Mejía Vallejo ${ }^{328}$ integra el hilo argumental de la novela con estrofas y versos de tangos de Carlos Gardel $^{329}$.

Obras con estructuras narrativas fraccionadas como 62 Modelo para armar (1968) de Julio Cortázar ${ }^{330}$, surgida del capítulo 62 de Rayuela, demanda la participación del lector para construir la trama ${ }^{331}$. Job Boj de Jorge Guzmán ${ }^{332}$ presenta dos líneas narrativas paralelas; En Garabato (1967) Vicente Leñero ${ }^{333}$ introduce una novela dentro de otra. En Háblenme de Funes (1970) Humberto Constantini ${ }^{334}$ presenta una serie infinita de autores creando personajes. En Piedra de mar (1968) el venezolano Francisco Massiani ${ }^{335}$ crea un narrador que se comunica con los personajes quienes nunca hacen nada y éste debe inventar algo para continuar su novela. Obsesivos días circulares (1969) de Gustavo Saínz ${ }^{336}$ exhibe su complicada estructura y un lenguaje que se desintegra. En Último Round (1969) Julio Cortázar ${ }^{337}$ muestra un collage en el que entremezcla textos e imágenes.

Resultaría imposible agotar el listado de escritores latinoamericanos que han utilizado el juego experimental sin referirnos a Jorge Luis Borges ${ }^{338}$, cuya obra ha influenciado a las

\footnotetext{
${ }^{324}$ GARCÍA MARQUEZ, Gabriel, Cien años de soledad, Editorial Sudamericana, Buenos Aires, 1967.

${ }^{325}$ SARDUY, Severo, De dónde son los cantantes, Seix Barral, Barcelona, 1980.

${ }^{326}$ SANCHEZ, Nestor, Siberia blues, Paradiso Ediciones, Buenos Aires, 2006.

${ }^{327}$ GUARAGNO, Liliana, "Un narrador inquietante", Artículo on-line en:

http://www.lanacion.com.ar/859769-un-narrador-inquietante Consultado: 20/09/2012

${ }_{328}$ MEJIA VALLEJO, Manuel, Aire de Tango, Plaza \& Janés Editores, Bogota, 1979.

${ }^{329}$ Véase el trabajo de Perla Ábrego, "Tango y mito en el Aire de Tango de Manuel Mejía Vallejo" [Artículo on-line] en: http://www.ucm.es/info/especulo/numero28/tangomit.html Consultado: 22/01/2012

${ }^{330}$ CORTAZAR, Julio, 62 Modelo para armar, Alfaguara, Buenos Aires, 1995.

${ }^{331}$ KULIN, Katlin, "Discurso 62. Modelo para armar de Julio Cortázar" [Artículo on-line] en:

http://revistas.ucm.es/index.php/ALHI/article/view/ALHI8383110099A/24314 Consultado: 22/01/2012

${ }^{332}$ GUZMÁN, Jorge, Job Boj, Seix Barral, Barcelona, 1967.

333 LEÑERO, Vicente, Garabato, Editorial Planeta, México, D.F., 2008.

334 CONSTANTINI, Humberto, Háblenme de Funes, Editorial Nueva Imagen, Buenos Aires, 1980.

335 MASSIANI, Francisco, Piedra de Mar, Monte Ávila Editores, Caracas, 1981.

${ }^{336}$ SAÍNZ, Gustavo, Obsesivos días circulares, Joaquín Mortíz, México, D.F., 1969.

${ }^{337}$ CORTAZAR, Julio, Último round, Siglo XXI Editores, México, D.F., 1985.

${ }^{338}$ Véase aparato crítico sobre la obra del autor en el Centro Borges de la Universidad de Pittsburgh [Sitio Web] en: http://www.borges.pitt.edu/es/criticism/articles-books-dissertations Consultado: 28/05/2012.
} 
generaciones posteriores de escritores. Defensor de la ruptura y de la imaginación en libertad, relacionado con el movimiento Ultraísta y la literatura fantástica; desafía al lector a una competencia intelectual que transite a través de laberintos narrativos y estructuras en palimpsesto con múltiples interconexiones intertextuales. Los mundos posibles de sus relatos además de universales, son eternos. El juego mental que demanda a sus lectores está sustentado en la complejidad de sus estructuras narrativas sincrónicas, estructuras enciclopédicas en donde es necesario entrelazar elementos entre sí; así como opina Carolina Depetris, "Borges continuamente entrelazaba en su literatura, el acto de escribir con el de leer y el de razonar, con el de imaginar: realidad y ficción, historia e invención, pierden especificidad en sus textos, 339

Sin duda estos nuevos criterios de creación inspirados en el juego literario ha favorecido la producción de libros que no tienen forma de libro: sin ataduras secuenciales de escritura (párrafos, páginas y capítulos), que se ofrece como "textos diseminados", fijados en soportes diferentes y organizados en múltiples subtextos, carentes de orden material o cronológico. Semejante a las hipernovelas electrónicas ${ }^{340}$, basadas en técnicas de escritura aleatoria o sistemas abiertos o inacabables, entendidos como aquellos que se organizan de manera independiente con cada acto de lectura y gracias a cada lector. Sistemas interactivos que demandan ciertas prácticas detectivescas por parte del lector, o como dice José Valles, "proponen múltiples itinerarios de lectura para que se actualice sólo uno de ellos en cada acto lector concreto" ${ }^{341}$. El mérito de estas piezas con sus múltiples recorridos de lectura, es haber trazado un nuevo rumbo de la narrativa que se ha favorecido con los medios digitales, pero que no olvidan su origen en medios tradicionales impresos en papel.

Si deseamos incursionar en la escritura de nuevos medios, bien vale conocer las cualidades de estos modelos, sobre todo de aquellos que supieron integrar magistralmente la narrativa y el juego, ya sea, surgidas de la inspiración formal de algún juego ya sea cartas o de tablero. Porque resulta que la literatura ha sido el producto de una herencia experimental que ha utilizado un sinfín de recursos, lúdicos y formales. Podemos afirmar que los escritores y los lectores de nuestro tiempo se han transformado: han aprendido a leer jugando y a jugar historias; participan con la "jugabilidad" de los sistemas interactivos $\mathrm{y}$ han adquirido mayor presencia, control y poder de navegación $\mathrm{o}$ exploración. Son jugadores de múltiples opciones; lectores que juegan a descifrar códigos, cambian o modifican tramas o personajes y recrean las historias activamente, aguzando sus capacidades imaginativas y creativas. La participación del lector ha cobrado más vida que nunca, exigiéndole mayor nivel de respuesta. En cierta medida las historias usan el juego para involucrar al lector e interesarlo, y también utilizan las

\footnotetext{
339 DEPETRIS, Carolina, "Revelan procedimientos literarios de Borges", Nota Periodística El Universal, México, 26 de diciembre de 2006, [Texto-on line] en: http://www.eluniversal.com.mx/notas/396615.html Consultado: 28/05/2012.

${ }^{340}$ Dedicaremos un breve espacio a los sistemas artificiales de generación de textos en el siguiente apartado.

${ }^{341}$ VALLES C., José R., “Max Aub: juegos narrativos en juegos de cartas” [artículo on-line] en:

http://www.jornada.unam.mx/2007/11/04/sem-jose.html Consultado: 25/04/2010.
} 
historias para encontrarle sentido a los juegos que les encantan, haciendo una mancuerna fabulosa.

Siguiente nuestro interés, destacamos la importancia del ejercicio lúdico como cualidad para generar propuestas estructurales para diseñar narrativas. El juego ha sido muy apreciado con fines estéticos y creativos: "Max Ernst observó, que el juego funciona como un "barómetro" de los contagios intelectuales dentro de un círculo de creadores",342 por ello experimentó con el collage gráfico. Produjo ilustraciones que similares a las técnicas digitales ${ }^{343}$ desarrollaba un tipo de instalación interactiva colectiva, en la que participaban varios, con sus colaboraciones narrativo-visuales.

El juego poético lúdico también puede ligarse a la escritura automática de los Surrealistas, mediante el ensamblaje de objetos incongruentes, como el caso de las prácticas literarias del Cadavre Exquis ${ }^{344}$, los Alimónes $^{345}$ de Pablo Neruda y Federico García Lorca; y los Quebrantahuesos de Nicanor Parra y Vicente Huidobro ${ }^{346}$; los cuales pueden generar ejercicios creativos por experimentar.

Algunas otras obras literarias ejemplares con respecto a su proceso de creación y búsqueda experimental que basan su planteamiento en un formato estructural original y resultan ser un referente por conocer y analizar son:

Juego de Cartas (1962) de Max Aub ${ }^{347}$. El cual se conforma a partir de un juego de estrategias narrativas, más allá de la dilogía del término "carta" (naipe/epístola) presenta 106 naipes de 17 x $11 \mathrm{~cm}$, dibujadas por su anverso y en su reverso figura una epístola dirigida a un personaje y firmada por otro. Los naipes pueden agruparse en los cuatro subconjuntos de los palos de la baraja (Picas-oros, diamantes-bastos, tréboles-espadas, corazones-copas); sin importar el orden de lectura, muestran una imagen fragmentaria y poliédrica del personaje Máximo Ballesteros. Cada lectura-jugada recrea una nueva historia que se arma de manera aleatoria, según se tiren las cartas.

\footnotetext{
${ }^{342}$ Citado por José Gordon, Cadáver exquisito: Azar y poesía colectiva [Artículo on-line] en: http://redescolar.ilce.edu.mx/redescolar2008/proyectos/imaginantes_secundaria/pdf/cadaverexquisito.p df Consultado 13/11/2011.

${ }^{343}$ Le Cadavre Exquis, Espacio de creación colaborativo que puede consultarse en: http://www.lecadavreexquis.net/terms/ Busca la producción un filme en constante creación, generado completamente por colaboradores. Consultado: 28/02/2012.

${ }^{344}$ Técnica de escritura alternada en la cual los jugadores escribían por turnos en la misma hoja que doblaban y pasaban a que otro jugador contribuyera con su aportación. Los poetas asiduos al juego, Robert Desnos, Paul Éluard, André Bretón y Tristan Tzara sostenían que la creación debe ser anónima, grupal intuitiva, espontánea, lúdica y en lo posible automática.

${ }^{345}$ Alimón (al), término que indica que dos o más personas hacen una cosa a la vez, en colaboración, conjuntamente.

${ }^{346}$ Véase: http://www.letras.ufmg.br/espanhol/Anais/anais_paginas_\%200-502/Nicanor\%20Parra.pdf Consultado: 29/12/2011.

${ }^{347}$ AUB, MAX, Juego de cartas, Cuadernos del Vigía, Granada, 2010. Véase: http://www.maxaub.org Consultado: $28 / 02 / 2012$
} 
Rayuela (1963) de Julio Cortázar ${ }^{348}$, con la alusión al juego infantil el cual se presenta como una compilación de fragmentos diversos: versos, letras de canciones, cartas, recortes de periódico, documentos que se articulan entre sí, mediante un formato de secciones por dónde se debe avanzar; similar a las mandalas hindúes cuya fijación gráfica cumple un proceso de recorrido por ciertas casillas consideradas como etapas espirituales. De manera semejante, el lector de Rayuela avanza por los sectores ayudando a crear el libro, el cual puede armarse según el Tablero de dirección que sugiere un orden de lectura posible de los 151 capítulos en los que "los lectores jugamos a la Rayuela"349 como un libro abierto, inacabable, "Como una caja de Pandora" 350 según dice Carlos Fuentes. Se trata de un muestrario de técnicas narrativas; tanto desde el punto de vista de su estructura como desde su discurso narrativo. La estética de lo fragmentario, la ruptura de los planos, el juego del lenguaje: "jugando con las palabras, se hacen malabarismos con las ideas, se suscitan asociaciones insólitas, se corroe la seriedad ceremoniosa" ${ }^{\text {,51. }}$. Entre el humor y el juego se esconde un collage literario que resulta un modelo de creación muy complejo y diverso, "lo que interesa es crear zonas de sombra y perspectivas de profundidad, abrir el cuadro a muy diversos horizontes: reales, imaginarios simbólicos"352. Se trata de una obra que merece mayor atención y tratamiento en futuros trabajos, pero que sin duda es un referente que servirá de modelo en la conducción de técnicas narrativas novedosas para entornos digitales.

La Vie mode d'emploi (1969) [La vida: instrucciones de uso] de Georges Perec ${ }^{353}$, plantea una novela basada en reglas matemáticas sobre un bi cuadro latino ortogonal ${ }^{354}$ que simula un inmueble parisino habitado por sus habitantes y en el cual, el narrador describe los sucesos en un instante particular: el 23 de junio de 1975. Cada capítulo se refiere a una habitación diferente. Jesús Camarero ${ }^{355}$ menciona que Perec combina 100 pares de cifras e integra una narrativa a partir de 42 componentes que se desplazan de la misma manera como las piezas sobre el tablero de ajedrez ${ }^{356}$; con casi doscientos personajes y centenares de historias que se entrecruzan, Perec ofrece cuatro elementos al lector para facilitar la comprensión del texto y la unión de las diferentes historias: un plano del inmueble; un listado de los nombres; ciertas referencias cronológicas y un índice de algunas historias contadas. Vease en anexos (pág. 273) el Esquema de la novela Life a User's manual, a partir de los habitantes y sus relaciones en el inmueble.

\footnotetext{
${ }^{348}$ CORTAZAR, Julio, Rayuela, Catedra, Madrid, 2011.

${ }^{349}$ AMORÓS, Andrés, Introducción crítica, en CORTÁZAR, Julio, Rayuela, Cátedra, Madrid, 2011.

${ }^{350}$ Citado por AMORÓS, Andrés, Introducción crítica, en CORTÁZAR, Julio, Rayuela, Cátedra, Madrid, 2011.

${ }^{351}$ AMORÓS, Andrés, Introducción crítica, en CORTÁZAR, Julio, Rayuela, Cátedra, Madrid, 2011.

${ }^{352}$ AMORÓS, Andrés, Introducción crítica, en CORTÁZAR, Julio, Rayuela, Cátedra, Madrid, 2011. (p. 45)

353 PEREC, Georges, La vida: instrucciones de uso, Editorial Anagrama, Barcelona, 1988.

${ }^{354}$ Ver término relacionado con la geometría del Cuadrado latino, Cuadrados mágicos, Sudoku, en: http://es.wikipedia.org/wiki/Cuadrado_latino Consultado: 26/11/2011

${ }^{355}$ CAMARERO, JESUS, Metaliteratura, estructuras formales literarias, Editorial Anthropos, Barcelona, 2004. [Texto-on line] en Google Books.

${ }^{356}$ Se recomienda revisar el estudio sobre La vie mode d'emploi de Georges Perec de: Emmanuel Bec, Deug Masse-se, Université de Marseille II en:

http://mathenjeans.free.fr/amej/edition/actes/actespdf/95121128.pdf Consultado:26/11/2011
} 
El Castillo de los destinos cruzados (1973) de Italo Calvino ${ }^{357}$, fue ideado a partir de las cartas del tarot como un artificio o juego narrativo combinatorio. Inspirada en el trabajo de Paolo Fabbri sobre las estructuras del relato a partir de la cartomancia y la construcción de narraciones secuenciales. "Posar las figuras de las cartas unas al lado de otras constituía una forma de sintaxis; a pesar de no existir conexión semántica entre ellas, las palabras crean dependencias y oposiciones, construyendo un gramática narrativa implícita" ${ }^{358}$. El relato se construye a partir de la interpretación de las asociaciones según una iconografía imaginaria. "escenas sucesivas de un relato pictográfico, reunidas al azar, me deban una historia en la que podía reconocer un sentido" ${ }^{359}$ Bastaba dejar que otras historias que se entrecruzaban cobraran forma, y así obtuve una especie de crucigrama hecho de figuras y no de letras. Y como en todo crucigrama, había que pedirle al lector-jugador que llenara los espacios en cada secuencia. Además Calvino buscaba establecer reglas de juego; "trazaba cientos de esquemas en forma de cuadrados, de rombo, de estrella pero siempre quedaban fuera cartas esenciales y terminaban en el centro cartas superfluas y los esquemas se complicaban tanto (adquiriendo una tercera dimensión, volviéndose cúbicos, poliédricos) que yo mismo me perdía"360

El interés por construir narraciones secuenciales a partir de la cartomancia dio lugar a una sintaxis similar a la poesía surrealista donde una palabra detrás de otra cobra cierta conexión semántica implícita y obligada a pesar de que no exista conexión de otra forma.

Otras obras que plantean formas laberínticas, imágenes narrativas como reflejadas en espejos y juegos de ingenio son: El manuscrito encontrado en Zaragoza de Jan Potocky, Los cuentos de Canterbury, de Geoffrey Chaucer. Historias organizadas en función de reglas de juegos como las historias de Lewis Carroll, quien invita a jugar con cartas vivientes en Alicia en el país de las maravillas y nos muestra una loca partida de ajedrez en $A$ través del espejo y lo que Alicia encontró allí. Construcciones combinatorias, al estilo del hipertexto digital, como Las mil y una noches o Si una noche de invierno un viajero (1979) de Italo Calvino, resultan ser construcciones combinatorias que junto a $L a$ jornada de un escrutador, se nos presentan como "los borradores del futuro narrativo, al asemejarse a la literatura pre-hipertextual... El hipertexto es mantener en el interior de un solo texto todos los textos virtuales posibles" ${ }^{\text {"61 }}$. Los medios informáticos han promovido la aparición de piezas narrativas y lúdicas, nos referimos a Telecraft creator de Ria Lu, un juego de cartas en línea para contar historias, promueve la creación al

\footnotetext{
${ }^{357}$ CALVINO, Italo, El castillo de los destinos cruzados, Ediciones Siruela, Madrid, 2010.

${ }^{358}$ Entrevista a Paolo Fabbri por Covadonga G. Fouces González, el 16 de noviembre de 2000, [Texto online] en: http://www.antroposmoderno.com/antro-articulo.php?id_articulo=510 Consultada: 05/11/2011

359 CALVINO, Italo, El castillo de los destinos cruzados, Ediciones Siruela, Madrid, 2010. (P.11)

${ }^{360}$ CALVINO, Italo, op. Cit. (p.12)

${ }^{361}$ Entrevista a Paolo Fabbri por Covadonga G. Fouces González, el 16 de noviembre de 2000, [Texto online] en: http://www.antroposmoderno.com/antro-articulo.php?id_articulo=510 Consultada: 05/11/2011
} 
elegir de manera aleatoria cartas que plantean los elementos clave de la narrativa con tres tipos de cartas: género (de las historias), arquetipos (personajes) claves (para la trama o palabras claves para utilizar): los jugadores toman una de cada una de las cartas y tienen cinco minutos para crear historias y compartirlas ${ }^{362}$.

Con este listado de obras y autores deseamos haber aumentado el panorama literario de los diseñadores de textos; mostrando el universo creativo que surge a partir del juego narrativo, esperando que estas referencias sean herramientas que les resulten recursos para conocer, implementar y sobretodo, experimentar.

${ }^{362}$ Puede consultarse en: http://telecraft.komikasi.com Consultado: 05/11/2011 


\section{2 ¿JUEGOS, O LITERATURA ENCUBIERTA?}

Reconocemos que el principal propósito de jugar no es contar historias; como tampoco el juego es la finalidad de la literatura; sin embargo, el hecho de que puedan hacerlo, no debe restarles crédito, al contrario en este apartado veremos cómo unos se sirven de los otros. Al respecto, Nick Montfort ${ }^{364}$ sugiere que ambos parecen haberse "alineado": por un lado tenemos literatura inspirada en juegos y por el otro, juegos textuales. El interés por enriquecer los juegos con temáticas y estructuras más complejas y estéticas, favorecidos por prácticas narrativas ha permitido el desarrollo de una buena parte de la literatura digital interactiva, ${ }^{365}$ así como de algunos juegos digitales que invitan a la lectura. Nuestro objetivo, más allá de enlistar un sinnúmero de materiales que pueden dotar de ideas a los creadores, busca contribuir a la reflexión en torno a las fronteras que dividen los juegos de las narrativas; si es que acaso quedara duda de lo íntimamente ligados que siempre han estado.

En este apartado haremos un recuento de algunos juegos de tablero, de cartas y otros similares, en formatos analógicos que surgieron a partir de novelas y obras literarias. Y también revisaremos algunas publicaciones que tienen gran influencia en juegos. Esperando que despierten el interés de su lectura o consulta. Seguramente existirán muchos otros títulos no incluidos en esta selección, que esperamos se irán integrando en posteriores estudios. Comenzamos con Rebecca Gable $\mathrm{e}^{366}$ y su novela, Die Siedler von Catan (2003), inspirada en el juego de tablero ${ }^{367}$ de Kaus Teuber ${ }^{368}$ Settlers of Catan (2007). Otro ejemplo es el juego Inkheart ${ }^{369}$, inspirado en la novela Tintenherz de Cornelia Funke. Algunos diseñadores de juegos se inspiraron en títulos de novelas para recrear sus historias: como el caso de Reiner Knizia ${ }^{370}$ con su juego, Quo Vadis? [¿A dónde Vas?] (1992); se trata de un juego de tablero, de estrategia y negociación para

\footnotetext{
${ }^{363}$ FAIDUTTI, Bruno, "Themes \& Mechanics 1.0" [Artículo on-line] en http://www.thegamesjournal.com/articles/themes/ThemesMechanics1.shtml Consultado: 28/05/2012.

${ }^{364}$ MONTFORT, Nick, "Literary Games", en Poems That Go, núm.14, 2003 [Revista on-line] en: http://www.poemsthatgo.com/gallery/fall2003/print_article_games.htm Consultado: 11/01/2012.

$\overline{365}$ Véanse muestras narrativas lúdicas digitales en: http://eliterature.org Consultado: 18/12/2011.

${ }^{366}$ GABLE, Rebecca, The Settlers of Catan, Amazon Crossing, Las Vegas, 2003.

${ }^{367}$ http://www.catan.com Consultado: 23/01/2012

${ }^{368}$ TEUBER, Klaus, Catan das Kartenspiel, [sitio web] en: http://www.catan.com/electronic-games.html

${ }^{369}$ Ambos juegos pueden consultarse en KOSMOS, [Sitio Web] en: http://www.kosmos.de/ Consultado: 23/01/2012

${ }^{370}$ Reiner Knizia también diseñó una versión de juego The Lord of the Rings (2001) y Beowulf (2005).
} 
elegir al Senado Romano; aunque conserva ciertas afinidades y semejanzas, no reproduce el argumento y las acciones de la novela de Henryk Sienkiweics, Quo Vadis? (1896). Por su parte, Britta Stockmann y Jens Jahnke ${ }^{371}$ enlistan algunos juegos de tablero basados en literatura, entre los que mencionan los juegos de Kai Haferkam: Das Kline Gespenst (The Little ghost) y Die kleine Hexe (The Little witch), ambos inspirados en textos de Otfried Preußler $^{372}$. Blue Moon ${ }^{373}$ (2006) y Anno 1701 ${ }^{374}$ (2007), ambos juegos multiformes, diseñados por Reiner Knizia, un prolífico diseñador de juegos, son muestra de cómo un juego puede convertirse en juego de tablero, juego de cartas y una novela ${ }^{375}$.

Los juegos de tablero, al igual que las películas, no reproducen las historias igual que en las novelas, pero ofrecen ciertos elementos, atmósferas y acciones que se desprenden de situaciones similares; son adaptaciones, algunas muy creativas y bien logradas, en las que el tema, como dice Bruno Faidutti ${ }^{376}$, “ayuda a los jugadores a introducirse al juego". De ahí el interés de ligar temas tratados en novelas con mecanismos propios de juegos; cualquier tipo de juego, de roles, tipo trivia, o de estrategia. Además de conocer los elementos y recursos para la composición de una novela, se pueden considerar los puntos de conflicto que puedan convertirse en acciones de juego. Ningún medio se adapta de manera idéntica a otro medio, sino cada uno presenta sus elementos a partir de su propia creatividad, originalidad y de acuerdo a lo permisible por cada formato. En ocasiones sólo comparte un tema; lo cual, para los desarrolladores de cuentos o de juegos, es un verdadero reto creativo.

\footnotetext{
"While the game author has to look for hard facts and leave aside the incalculable emotional level of the story, the novelist on the other hand will weave the narrative around the main elements of the game, filling it with the emotional life an elaborate characters, for such the game board offers no room ${ }^{\prime 377}$.
}

Historias y juegos se complementan porque es posible transportar ciertos recursos de uno a otro y favorecer una experimentación creadora. Pero no resultaría lógico que un juego se apegara completamente a un libro; si así fuera, sólo podría jugarse una vez, y al conocerse la historia, no tendría sentido alguno volverlo a jugar. De ahí que los

\footnotetext{
${ }^{371}$ STOCKMANN, Britta \& JAHNKE, Jens, "Playing by the book, literature and board games at the beginning of $21^{\text {st }}$ century", [Artículo on-line] en: http://www.hc.amu.edu.pl/numery/5/stockjahnke.pdf Consultado: $23 / 01 / 2012$

${ }^{372}$ Véase sitio web del autor en: http://www.preussler.de/index1.htm Consultado: 23/01/2012

${ }^{373}$ Diseñado por Reiner Knizia, puede verse en: http://new.fantasyflightgames.com/edge_minisite.asp?eidm=62 Consultado: 23/01/2012.

${ }^{374}$ Juego de tablero diseñado por Klaus Teuber, convertido en un videojuego de estrategia, véase web site: http://anno.de.ubi.com/ Consultado: Consultado: 23/01/2012

${ }^{375}$ Citado por STOCKMANN, Britta \& JAHNKE, Jens, Playing by the book, literature and board games at the beginning of $21^{\text {st }}$ century. [artículo on-line] en: http://www.hc.amu.edu.pl/numery/5/stockjahnke.pdf Consultado: $23 / 01 / 2012$

${ }^{376}$ FAIDUTTI, Bruno, "Themes \& Mechanics 1.0", 2005. [Artículo on-line] en: http://www.thegamesjournal.com/articles/ThemesMechanics1.shtml Consultado: 23/01/2012

${ }^{377}$ STOCKMANN, Britta \& JAHNKE, Jens, "Playing by the book, literature and board games at the beginning of $21^{\text {st }}$ century". [artículo on-line] en: http://www.hc.amu.edu.pl/numery/5/stockjahnke.pdf Consultado: 23/01/2012.
} 
diseñadores de textos deben considerar los sistemas abiertos que ofrecen múltiples posibilidades de historias que se traduzcan en acciones de juego.

Seguramente en cierto momento hemos tenido contacto con juegos que se pueden leer; crucigramas y laberintos de palabras ocultas, como el juego del ahorcado, jugar a hacer listados de palabras usando el alfabeto o agregando prefijos. O hemos "jugado" a componer historias, rellenando espacios en blanco como los Mad libs ${ }^{378}$. Quizá hayan leído libros tipo Choose your own adventure ${ }^{379}$, en el cual el lector elige entre varias opciones por donde continuar la historia. Seguramente habrán jugado con tarjetas ${ }^{380}$, dados o tableros que ayudan a componer secuencias narrativas: esto se ha popularizado como recurso didáctico en muchas escuelas, para facilitar la generación de argumentos narrativos.

Con el interés de ampliar los recursos formales de los escritores, enlistamos juegos digitales para ordenador que han marcado un importante acercamiento entre la literatura y el juego. Se trata de: Fields of dream (2003) de Nick Montfort y Rachel Stevens; en el cual se deben completar las palabras del texto oculto que alguien ha escrito previamente y dejado espacios en blanco o "dream fields". Basho's Frogger \& Jabber ${ }^{381}$, de Neil Hennessy, quien inspirado en el juego Frogger, presenta una pantalla con letras en movimiento que cuando chocan entre sí, un cálculo determina si pueden fusionarse hasta formar palabras, algunas resultan reales y otras sin sentido, del tipo "jabberwocky"que Lewis Carroll popularizó en A través del Espejo. Este es el mejor ejemplo del empleo de una metáfora similar en una pieza artística, inspirado en Matsuo Basho, inventor del Haiku (1644) quien escribió algo que traducido sería:

El viejo estanque / Una rana salta en él / El ruido del agua. Este sería la inspiración para el juego y la pieza de e-literatura ${ }^{382}$.

The Intruder ${ }^{\mathbf{3 8 3}}$ (1999) de Natalie Bookchin, es otra narrativa digital que se puede jugar en línea. A través de 10 juegos diferentes se va relatando una historia basada en el cuento La Intrusa de Jorge luis Borges ${ }^{384}$ (1970). La cual trata sobre un par de hermanos que comparten una misma mujer a la que tienen que matar para evitar dificultades. Bookchin

\footnotetext{
${ }^{378}$ Mad libs; formatos de juegos que retan al jugador a completar una historia siguiendo las indicaciones de los espacios en blanco. Se popularizaron en aplicaciones digitales on-line: http://www.wordlibs.com , http://www.madlibs.org, http://www.rinkworks.com/crazytales. Véase: Mad Lib de Mario Heidenbrink en http://www.angelfire.com/magic/masterdam Consultados: 12/01/2012.

379 Véase sitio oficial: http://www.cyoa.com/ Consultado: 21/01/2012

${ }^{380}$ Rory's Story Cubes, http://www.storycubes.com; Storymatic, http://www.thestorymatic.com/; Dixit, version iDixit en applicaciones Itunes; http://itunes.apple.com/us/app/idixit/id438442408?mt=8 Once Upon a time, http://www.atlas-games.com/onceuponatime/ Son sólo una pequeña muestra de algunos juegos comerciales.

${ }^{381}$ Véase: http://collection.eliterature.org/2/works/hennessy_frogger_jabber.html Consultado:

$12 / 01 / 2012$

${ }^{382}$ las obras de Literatura electrónica están compuestas por un ordenador y sólo pueden exhibirse en pantallas digitales.

${ }^{383}$ Véase: http://bookchin.net/intruder/index.html Consultado: 12/01/2012

384 BORGES, Jorge Luis, La intrusa, Ciudad SEVA [Texto on-line] en:

http://www.ciudadseva.com/textos/cuentos/esp/borges/intrusa.htm Consultado:12/01/2012
} 
Emplea formatos de juegos tradicionales como el Pong, Kaboom, Laser Blast y otros que mantienen conexión entre el lenguaje visual, sonoro y una coherencia temática. Mediante el juego se va armando partes de la historia. El lector-jugador debe completar estos juegos para escuchar, leer y ver la historia. Por su parte, Dominoa ${ }^{385}$, es un juego literario que ofrece el placer de jugar y el encanto de la lectura. Se juega con pasajes de textos que se deben ensamblar; como en un juego de dominó. Arteroids $2.5^{386}$ es otro juego literario en la web, una batalla poética de Jim Andrews. Nine, de Jason E. Lewis, un poema dinámico que presenta imágenes de la vida del artista, en donde el formato empleado se compone de un rompecabezas de 9 piezas con un espacio vacío que desplanta un fragmento de un texto que se va armando en una historia y se sustituye por otra, en una liga interminable. Bad Machine $\boldsymbol{e}^{387}$ de Dan Shiovitz, es un trabajo de ficción interactiva; permite teclear, entender y simular acciones, un texto que mezcla literatura y código de programación y funciona como una ficción interactiva. Roulette ${ }^{388}$ (2008), de Daniel C. Howe y Bebe Molina, es un trabajo de combinación narrativa que se arma a partir de las líneas de un texto que se compone a partir de la manipulación del usuario a tres dados. Con cada tirada, aparece una colección fracturada de historias que cobran sentido con cada lectura. En esta obra se emplean tres cubos que resultan ser una figura significativa dentro de la literatura electrónica. A ser un elemento 3D, representa la conversión de los textos impresos que podemos considerar como 2D. Roulette se compone de tres dados traslúcidos que contienen una palabra en cada cara, La lectura y el juego no son predictivas per se, está basado en reglas sintácticas y en algoritmos programados.

Seguramente este listado se ampliará con otros videojuegos narrativos que comentaremos en posteriores apartados. La idea de transmedialidad de Henry Jenkins ${ }^{389}$ confirma que hemos entrado a una era de convergencia en donde el flujo de contenidos se presenta a través de múltiples canales, de tal suerte que sin importar que esté impresa en una vasija; tejida en un gobelino o cantada por intérpretes, detrás exista una buena historia. Un diseñador de textos debe aprender a trasladar historias de cualquier otro medio; para ello requiere conocer las cualidades y potencial de cada medio y debe tener presente algunas nociones teóricas o narratológicas. Así sumando al potencial de los juegos, podremos conformar una poética de juegos que tengan, el complemento de transmitir historias estupendas. Estos requerimientos se analizarán en los siguientes apartados.

To create an imaginative and imaginary world it is

\footnotetext{
${ }^{385}$ Véase: http://www.servus.at/dominoa/englexpl.html Consultado: 12/01/2012

${ }^{386}$ Véase: http://www.vispo.com/arteroids/ Consultado: 12/01/2012

${ }^{387}$ Véase: http://www.poemsthatgo.com/gallery/fall2003/bmch/index.htm Consultado:20/09/2012

${ }^{388}$ Véase: http://collection.eliterature.org/2/works/howe_roulette.html Consultado:20/09/2012

389 JENKINS, Henry, "Transmedia storytelling" (2003) [Artículo on-line] en:

http://www.technologyreview.com/biomedicine/13052/?a=f Consultado: 24/01/2012
} 


\subsection{TEORÍAS PARA COMPONER HISTORIAS}

Para describir y clasificar la infinidad de relatos, se requiere una teoría; para componerlos, también. Consideramos necesario apreciar los componentes básicos de los relatos: de qué manera se estructuran sus elementos; apreciar no sólo el qué sino el cómo en todo relato; cómo son sus secuencias narrativas (ya sea lineales, complejas, ramificadas) Cómo manejan la inserción de acertijos o pruebas de ingenio; cómo es el flujo de varias historias, o cómo interconectar las complejas combinaciones de elementos entre sí. El propósito de este apartado es explorar algunas ideas producto del análisis crítico del estudio de la literatura que pueden ser útiles para ampliar el concepto de juego.

Desde tiempos remotos, surgió la preocupación por delimitar las formas narrativas y encontrar modelos universales. Platón en el Diálogo con Fedro refiere que todo discurso está compuesto a manera de un animal, con cierto cuerpo y extremidades y en el cual todas las partes resultan convenientes entre sí y con el todo; "Yo, mi querido Fedro, gusto mucho de descomponer y componer de nuevo por su orden las ideas, es el medio de aprender a hablar y a pensar" 391

El interés de conocer y distinguir las partes del discurso y su manera de articularlo ha estado vigente desde entonces. Su discípulo, Aristóteles (siglo IV a. C) inspirado en la tragedia, fue el primero en establecer los fundamentos y principios bajo los cuales se constituyen las historias. Proponiendo la división de la estructura en 6 partes: 1 - Mythos o argumento. (Resulta ser la combinación de las acciones) 2 -Ethos o carácter. (Son los rasgos de los personajes) 3 - Dianoia o pensamiento. (Es todo lo que se dice, relacionado a la historia) 4 - Lexis o elocución, discurso, dictado. (Es el texto en sí) 5 Melos o música, cantos y melodías que se integran. 6-Opsis o espectáculo. (Estos tres últimos definen el medio, es decir el lugar en el cual se da la Mímesis [imitación]). Aristóteles fue el primero en descomponer el argumento en sub-partes: una introducción, una parte media y un final. A través de La Poética buscaba explicar el ser de las obras dramáticas, cuyo "entramado, esqueleto, intriga o argumento y los elementos que lo

\footnotetext{
${ }^{390}$ Citado por Katelyn Swope [Tesis Doctoral] In defense of Fantasy, April 2012. [Texto on-line] en: http://katelyn_swope_thesispaper_2012.doc_wix.com Consultado: 28/05/2012.

${ }^{391}$ Dialogo platónico El Fedro (370 a.C.) sobre el valor de la retórica de la escritura y su relación con la memoria [Texto on-line] en: http://www.filosofia.org/cla/pla/azc02261.htm Consultado: 17/01/2012
} 
integran", según palabras de Aristóteles, resultan clave para conseguir los sentimientos más profundos"392

Roland Barthes (1915-1980), semiólogo estructuralista, interesado en el estudio textual (como un sistema cuyos elementos se interrelacionan como una estructura) sugiere que para entender la composición narrativa, ésta debe verse como, "un mosaico formado de pequeñas piezas deslindadas, intercambiables que conforman un cuadro." 393 De ahí que nadie pueda producir un relato sin referirse a un sistema implícito de unidades y reglas. A principios del siglo XX, un grupo de estudiosos buscaron definir la literatura científicamente, dejando de lado los estudios subjetivistas (psicológicos, psicoanalíticos o sociológicos) y propusieron en su lugar métodos formales para su estudio. Surgió un grupo de intelectuales rusos conocidos como los Formalistas ${ }^{394}$, quienes tuvieron gran influencia con los lingüistas ${ }^{395}$ estructuralistas franceses de los años 60. Las aportaciones de los formalistas y estructuralistas al servicio de la composición de textos debe verse como una serie de propuestas formales para analizar y generar textos. Por lo que es un referente muy valioso por la influencia, aportación y dirección de escritores contemporáneos.

Los formalistas contribuyeron al análisis de las obras como sistemas formados por unidades narrativas a tres niveles: El Nivel de las Funciones, ideas desarrolladas por Vladimir Propp y Claude Bremond; El Nivel de las Acciones, ejemplificado con la noción de actantes de Algirdas J. Greimas ${ }^{396}$ y El Nivel del Discurso planteado por Tzvetan Todorov $^{397}$. Los tres niveles están ligados entre sí; una función solo tiene sentido si se relaciona con la acción del actante o personaje y ésta adquiere sentido por el hecho de estar estructurada en un discurso. Estas nociones teóricas deben verse como recursos que permitan una percepción de nuevas dimensiones estéticas, que se deben contemplar al generar narrativas; volver la atención hacia la teoría es como recorrer una espiral que regresa a un punto cercano al anterior para avanzar a un nivel superior de entendimiento y de experimentación estética. "We must acknowledge that an artist must move beyond imitation to something original" 398 .

Un escritor debe conocer y tener ciertos modelos que le permitan comprender la necesidad de componer relatos y que no solo presentan las historias como estadios o

\footnotetext{
${ }^{392}$ Citado por KLEMENS, Franz \& NISCHELWITZER, Alexander, "Adaptive digital storytelling: a concept for narrative structures in digital storytelling build on Basic storytelling principles, adaptive story schemas and structure mapping techniques" [Artículo on-line] en: http://www.mediaeducation.gr/adst_paper.pdf Consultado: 15/01/2012.

${ }^{393}$ BARTHES, Roland Barthes Análisis estructural del Relato, Premia Editores, México, D.F., 1986.

${ }^{394}$ Véase: Boris Tomashevski, luri Tiniánov o Vladimir Propp.

${ }^{395}$ Véase: Ferdinand De Saussure, Louis Hjelmslev, Antoine Meillet, Émile Benveniste, Roman Jakobson o Nikolai Trubezkoy o Leonard Bloomfield, entre otros.

${ }^{396}$ GREIMAS, Algiras, j. “Elementos para una teoría de la interpretación del relato mítico" (pp. 39-76) en: BARTHES, Roland et al, Análisis estructural del Relato, Premia Editores, México, D.F., 1986.

${ }^{397}$ TODOROV, Tzvetan, “Las categorías del relato literario" (pp. 159-195) en: BARTHES, Roland et al, Análisis estructural del Relato, Premia Editores, México, D.F., 1986.

${ }^{398}$ DAVIS, Todd F. \& WOMACK, Kenneth, Formalist criticism and reader-response theory, Palgrave, New York, 2002. (p. 47)
} 
encadenamientos horizontales, sino además que éstas acciones narrativas pueden pasar de un nivel a otro sobre un eje vertical; "leer (escuchar) un relato no solo es pasar de una palabra a otra, es también pasar de un nivel a otro" 399 Esto es justamente lo que nos referimos al plantear los textos tipo "palimpsesto"; por ello los futuros escritores de textos digitales no deben desligarse de las teorías que entienden el texto como un sistema o estructura de signos, que les permita entender el proceso narrativo como una labor compleja integrada de muchas acciones y elementos por entender y atender. Sin afán de agotar el tema, proponemos algunas propuestas teóricas para estructurar las historias, que a nuestra consideración son recursos vigentes y útiles para los escritores.

En 1895 Georges Polti publica Les Trente-six situations Dramatiques ${ }^{400}$ e identifica éste número de situaciones dramáticas posibles en cualquier historia; siguiendo la idea original del dramaturgo Carlo Gozzi ${ }^{401}$ quien las había identificado previamente. Seguramente estas 36 situaciones fueron conocidas por el ruso Vladimir Propp, quien en La Morfologia del cuento o Las transformaciones del cuento maravilloso (1928), ${ }^{402}$ presentó un estudio realizado a un corpus de 100 cuentos tradicionales y determinó que compartían semejanzas con relación a su composición y estructura. Propp fue el primero en identificar las regularidades narratológicas a partir de estructuras comunes; aportando un ejercicio sistemático de análisis literario de gran utilidad. Apoyado en el juego, relacionó las reglas a la representación, y al igual que Claude Levi-Strauss, sostenían que el significado de las narrativas estaba basado en estructuras formales. Identificó además ciertos personajes que llevaban a cabo dichas acciones ${ }^{403}$. Los cuentos tradicionales fueron estudiados como modelos funcionales cuyas acciones, además de ser semejantes, presentaban un mismo orden de sucesión y determinó la existencia de 7 tipos de personajes dramáticos conocidos como Dramatis personae o actantes ${ }^{404}$; los cuales podían intervenir en una o varias funciones. El resto de los elementos de un relato, aquellos que no encajan en las funciones, se clasificaban como enlaces y motivaciones; lo que permite que a pesar de las funciones y personajes constantes, los rasgos de cada cuento sean muy diversos.

Aquí podemos apreciar cómo puede completarse el inicio de un cuento al estilo de Propp, y se observa como su listado de funciones es una herramienta no sólo para estudiar y entender la estructura de los cuentos, sino para crearlos.

\footnotetext{
${ }^{399}$ BARTHES, Roland et al, Análisis estructural del Relato, Premia Editores, México, D.F., 1986. (p.11)

${ }^{400}$ Véase Anexos, "36 situaciones dramáticas de Georges Polti”, citado por: GUERRA, Fabio W., Engenharia de Estorias, 2008 [Tesis de Maestría] [Texto on-line] en:

http://biblioteca.universia.net/html_bura/ficha/params/title/engenharia-estorias-um-estudogera\%C3\%A7\%C3\%A3o-narra\%C3\%A7\%C3\%A3o-automatica-estorias/id/35229700.html Consultado: 22/02/2012

${ }^{401}$ Véase: http://carlogozzi.com/ Consultado: 02/02/2012

402 PROPP, Vladimir, Morphology of the folk tale, Texas University Press, Austin, 1968.

${ }^{403}$ Véase las 31 funciones de Vladimir Propp en anexos de este mismo trabajo.

${ }^{404}$ Los 8 actantes posibles son: 1) Villano, 2) Dador, 3) Ayudante, 4) Princesa/Persona-que-sufre, 5)

Despachador o enviado, 6) héroe y 7) Falso héroe.
} 

le obliga a [cometer un crimen, ir a un lugar

lejano, no hacer alguna tarea] El personaje viola la prohibición [se come algo, rompe un amuleto, visita a un ser prohibido] y es castigado [obligado a....]

En casos como este, seguir una receta, resulta ser un estupendo resorte narrativo; el ejercicio de componer textos a partir de funciones que pueden revestirse con un sinnúmero de posibilidades, permitiendo el fluir de ideas y la organización de la estructura narrativa. Considérese como una herramienta que proporcione cierta conducción y se adquiera la destreza creativa, que facilite componer historias coherentes y atractivas para el lector.

Otra cuestión que nos interesa del trabajo de Propp, son las similitudes que presenta con la escritura de códigos informáticos similares a la modularidad de las acciones. Parecen ser parte de un algoritmo (como si Propp hubiera anticipado la llegada del ordenador); ya que su trabajo ha servido de modelo para el desarrollo de los SGS (Story Generation systems) sistemas informáticos para la escritura automática de historias [en Anexos presentamos un listado de algunos que resultan referencias por considerar]. La Universidad de Brown ofrece The fairy tale generator ${ }^{405}$ (2001), sitio on-line para generar historias al azar a partir del seguimiento de 29 de las 31 acciones de Propp; se trata de un generador que recibe el input del usuario quien elige las acciones, las cuales tienen hasta 10 diferentes posibilidades de escritura; el sistema, de manera aleatoria, elige una para cada acción y las coloca en un orden secuencial, las cuales a pesar de no siempre ser del todo coherentes, sí resultan muy bien revestidas. Las funciones que el generador de Seifert utiliza son:

1- Absention, 2- Interdiction, 3- Violation, 4- Reconnaissance, 5- Delivery, 6Trickery, 7- Complicity, 8- Villainy, 9- Lack, 10- Mediation, 11- Beggining counteraction, 12- Departure, 13- First function of the Donor, 14- Hero's reaction, 15- Receipt of magical agent, 16- Guidance, 17- Strugle, 18- Branding, 19Return, 20- Pursuit, 21- Rescue, 22- Unrrecognized arrival, 23- Difficult Task, 24- Solution, 25- Recognition, 26- Exposure, 27-Transfiguration, 28- punishment, 29- Wedding.

Retomaremos este y otros proyectos de Narrativa digital generados por sistemas informáticos automáticos aquí mismo más adelante.

Lévi-Straus, complementando el trabajo de Propp, propone sustituir el orden cronológico de las funciones por una matriz atemporal; sin embargo esto es posible siempre y cuando

\footnotetext{
${ }^{405}$ Desarrollado por Lewis Seifert en la Universidad Brown, Véase: http://research.brown.edu/myresearch/Lewis_C._Seifert el vínculo al sitio del Generador de Cuentos de Hadas, por el momento se encuentra deshabilitado esperando se restablezca en un futuro en: http://www.brown.edu/Courses/FR0133/Fairytale_Generator/gen.html \& http://beta.picks.yahoo.com/picks/2530/proppian-fairy-tale-generator Consultado: 05/02/2012
} 
la estructura tenga sentido. Claude Bremond en La lógica de los posibles narrativos ${ }^{406}$, de manera semejante a Propp, se basa en la función como la unidad narrativa, pero identifica una agrupación de tres funciones que integran la secuencia elemental de toda narración: 1- una función que abre la posibilidad del proceso, ya sea una conducta a observar o un acontecimiento a prever; 2- Una función que realiza esta conducta o acontecimiento en un acto concreto y 3- Una función que cierra el proceso en forma de resultado alcanzado. Las funciones de Bremond no siguen la secuencia de Propp, se trata de secuencias-tipo menos numerosas y que forman parte de los roles asumidos por los personajes de los relatos. $^{407}$ Son formas narrativas simples, secuencias, roles, encadenamiento de situaciones cada vez más complejos que ofrecen un juego inagotable de combinaciones.

Incorporamos también las ideas de Joseph Campbell (1904-1987) expuestas en The hero with a thousand faces ${ }^{408}$ (1968); ligadas al estudio de las mitologías, los sueños y la teoría del Monomito ${ }^{409}$ la cual considera que todas las historias están basadas en la idea de un héroe que realiza un viaje el cual se representa por una partida, separación o iniciación y un retorno. Véase el apartado de anexos para conocer su propuesta estructural, la cual al propio estilo de Propp, puede revestirse de varias opciones.

Por su parte Gustav Frytag ${ }^{410}$ desarrolló otra estructura que podemos visualizar como una pirámide dividida en 5 partes: introducción, elevación de la acción, clímax, caída o desenlace y resolución o conclusión.

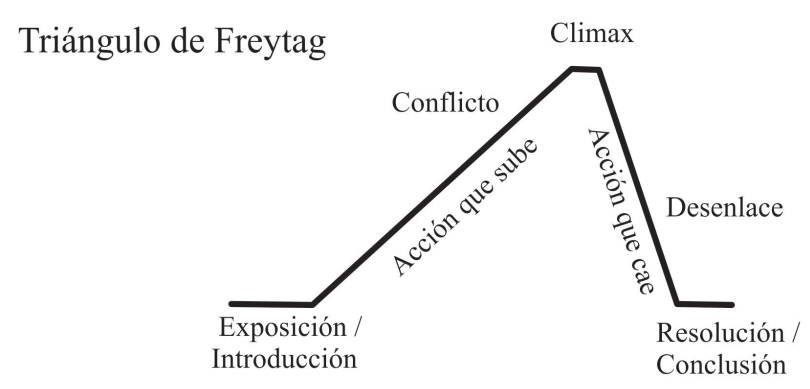

Bengt Holbek ${ }^{411}$ detalla un método para analizar cuentos fantásticos y sugiere que pueden dividirse en cinco etapas las cuales están ligadas a las tres principales líneas de tensión de los cuentos: los jóvenes frente a los adultos, los pobres y los ricos, los hombres frente a las mujeres, y algunos otros que pueden consultarse en el apartado de los anexos.

\footnotetext{
${ }^{406}$ BREMOND, Claude, "La lógica de los posibles narrativos" (pp. 99-121), en: BARTHES, Roland et al, Análisis estructural del Relato, Premia Editores, México, D.F., 1986.

${ }^{407}$ Véase en anexos, aquí mismo las modalidades de las funciones que propone Claude Bremond.

${ }^{408}$ CAMPBELL, Joseph, The hero with a thousand faces, Joseph Campbell Foundationd \& New World Library Press, Novato, 2008.

${ }^{409}$ CAMPBELL, Joseph, The hero with a thousand faces, Joseph Campbell Foundationd \& New World Library Press, Novato, 2008. (Prólogo, pp.1-18)

${ }^{410}$ FREYTAG, Gustav, Technique of the Drama, (1863) Propuso un método conocido como el triángulo o pirámide.

${ }^{411}$ VAZ DA SILVA, Francisco, "Bengt Holbek and the study of meanings in fairy tales" [Artículo on-line] en: http://socrates.berkeley.edu/ caforum/volume1/pdf/silva.pdf 12/03/2012
} 
Antti Aarne y Stith Thompson ${ }^{412}$ crearon un índice de cuentos tradicionales que clasificaron por categorías a partir de sus motivos, buscaron establecer patrones en sus estructuras narrativas; a pesar de que algunos otros folcloristas han clasificado los cuentos de otras maneras, muchos se han apoyado en el trabajo de Aarne y Thompson que junto al estudio morfológico de Vladimir Propp, son trabajos notables para identificar las estructuras comunes de los cuentos.

Por otra parte, Roland Barthes ${ }^{413}$, en su propuesta de análisis estructural del relato, plantea una triple división: el "nivel de las funciones", el "nivel de las acciones", y el "nivel de la narración". Considera que hay dos clases de unidades: las funciones (functions) y los indicios (indices), de éste último se desprenden las informaciones que permiten situar el relato en el espacio y en el tiempo, son "creadores de atmósfera, caracterizadores" $" 14$. Y por su parte, divide las funciones en cardinales o núcleos (noyaux) y catalizadores ${ }^{415}$ (catalyses); los primeros forman el esqueleto básico de la acción, el andamiaje narrativo que será completada por los catalizadores.

También Claude Bremond parte del modelo funcional de Propp y lo reformula, transformándolo de un modelo cerrado, a uno abierto: flexible a partir de la sucesión de las funciones, posibilitando que los relatos tengan varias líneas de acción.

García Landa ${ }^{416}$ cita algunos otros teóricos (que comparten esta idea similar de Bremond) por ejemplo: Petsch distingue entre Motivos nucleares, Motivos marco y Motivos de relleno; Sperber habla de motivos primarios, secundarios y accesorios; Chatman propone entre kernels y satellites una idea similar. Cesara Segre $^{417}$ divide los textos entre fábula, intriga y discurso; en donde la fábula son sus elementos esenciales colocados en un orden lógico-cronológico: la intriga es el contenido del texto en el mismo orden que se presentan los acontecimientos; y el discurso es el texto narrativo significante. Van Dijk ordena los elementos de una narración bajo la siguiente teoría: la narrativa es un sistema $<\mathbf{E}, \mathbf{R}>$ en donde $\mathbf{E}$, son una serie de eventos $(\mathrm{e} 1, \mathrm{e} 2, \ldots)$ y $\mathbf{R}$ son una serie de relaciones

\footnotetext{
${ }^{412}$ AARNE, Anti, The types of folktale: a classification and bibliography. Translated and enlarged by Stith Thompson, Communications, FF Communications, Helsinki, 1961). Puede consultarse on-line en: http://scandinavian.wisc.edu/mellor/taleballad/pdf_files/motif_types.pdf Consultado: 17/01/2012.

${ }^{413}$ BARTHES, Roland et al, Análisis estructural del Relato, Premia Editores, México, D.F., 1986.

${ }^{414}$ Citado por GARCÍA LANDA, José A., Acción, relato, Discurso: Estructura de la ficción narrativa [Texto online] en:

http://www.unizar.es/departamentos/filologia_inglesa/garciala/publicaciones/ard/1.2.Accion.html Consultado: 20/01/2012.

${ }^{415}$ BARTHES, Roland, Image, Music \& Text, Hill and Wang, New York, 1978.

${ }^{416}$ GARCÍA LANDA, José A., Acción, relato, Discurso: Estructura de la ficción narrativa [Texto on-line] en: http://www.unizar.es/departamentos/filologia_inglesa/garciala/publicaciones/ard/1.2.Accion.html Consultado: 20/01/2012.

${ }^{417}$ Citado por GARCÍA LANDA, José A., Acción, relato, Discurso: Estructura de la ficción narrativa [Texto online] en:

http://www.unizar.es/departamentos/filologia_inglesa/garciala/publicaciones/ard/1.2.Accion.html Consultado: 20/01/12.

${ }^{417}$ Citado por GARCÍA LANDA, José A., Acción, relato, Discurso: Estructura de la ficción narrativa [Texto online] en:

http://www.unizar.es/departamentos/filologia_inglesa/garciala/publicaciones/ard/1.2.Accion.html Consultado: 20/01/12.
} 
sobre los miembros de $\mathbf{E}$. Podemos decir que $\mathbf{E}$ es una especie de vocabulario de la teoría de la narrativa y $\mathbf{R}$ es una serie de reglas gramaticales, que definen una secuencia narrativa de un número dado de $\mathbf{E}$ eventos ordenados por una o más relaciones, una de estas relaciones es la relación Prec (de preceder) la cual será introducida como un término indefinido ${ }^{418}$.

Rawdon Wilson ${ }^{419}$, en Palamede's Shadow; realiza un análisis que resulta obligado conocer dado su interés por establecer parámetros socioculturales que relacionan el juego al análisis literario. Retomando las teorías de Jacques Derrida, Mikhail Bakhtin y Hans Goerg Gadamer, se plantean algunas ideas que deseamos retomar, como la adquisición de sentido, la noción de transgresión o ruptura y el concepto de carnaval. Jacques Derrida enfoca su teoría del texto en la transgresión del lenguaje y en la búsqueda de significados. La transgresión refiere una condición lingüística generalizada: "es lo que adopta formas tan diversas como los anagramas en Nabokob, las narrativas deformadas en Robbe-

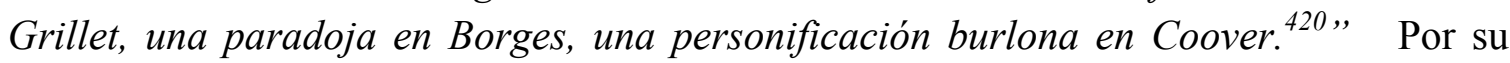
parte Bakhtin retoma la idea de transgresión y la liga a la noción de carnaval y de juego libre; ambas, resultan conceptos que permiten asociar la literatura y el juego y de las cuales se desprende la idea de estructuras caóticas "que promueven la anarquía creativa, las parodias, el absurdo, la heteroglosia, la invención de léxico, la incorporación de significados no convencionales, irrupción de la sintáxis, entre otros recursos ${ }^{421}$.

"Carnival is free, voluntary, creative, a manifestation of the human double voice, and whole-making... Play is voluntary, creative and exploratory" ${ }^{\prime 422}$

Rawdow Wilson ${ }^{423}$ señala que transgresión y carnaval son conceptos que se derivan del juego; y señala que con estas prácticas se favorece la experimentación, la exploración y la ruptura de reglas. Por ello son elementos fundamentales en la composición no solo textual, sino artística. Además, resulta lógico asimilar los conceptos de transgresión y carnaval a una versión extrema de ludismo, entendido como el juego abierto de la significación. Con esto nuevamente confirmamos la relación entre juego y narrativa, confirmando nuestra teoría de vincularlo desde distintas perspectivas de análisis. El

\footnotetext{
${ }^{418}$ Citado por GARCÍA LANDA, José A., Acción, relato, Discurso: Estructura de la ficción narrativa [Texto online] en:

http://www.unizar.es/departamentos/filologia_inglesa/garciala/publicaciones/ard/1.2.Accion.html

Consultado: 20/01/2012

${ }^{419}$ WILSON, R. RAWDON, Palamede's shadow; explorations in play, game \& narrative theory, Northeastern University Press, Boston, 1990.

${ }^{420}$ WILSON, R. RAWDON, Palamede's shadow; explorations in play, game \& narrative theory, Northeastern University Press, Boston, 1990. (p.39)

${ }^{421}$ RYAN, Marie-Laure., Narrative as virtual reality: Immersion and interactivity in literature and electronic media, The Johns Hopkins University Press, Baltimore, 2001 (p. 186)

${ }^{422}$ WILSON, R. RAWDON, Palamede's shadow; explorations in play, game \& narrative theory, Northeastern University Press, Boston, 1990. (p.70)

${ }^{423}$ Para ampliar el concepto de transgresión, juego y carnaval, se recomienda "The play of carnival and the carnival of play" (pp. 25-74) en: WILSON, R. RAWDON, Palamede's shadow; explorations in play, game \& narrative theory, Northeastern University Press, Boston, 1990.
} 
anterior ha sido un intento de esbozar un panorama de las teorías lingüísticas y literarias en sí mismas y en relación a los juegos. El tema resulta de tal complejidad y amplitud que es imposible ahondarlo en este trabajo; sin embargo recomendamos considerar que los aspectos estructurales del relato son una herramienta fundamental para la composición de estructuras narrativas de cierta complejidad y eficiencia. En los siguientes apartados retomaremos otros elementos propios de la narratología que complementarán este estudio. Para ampliar el tema y tener acceso a los textos teóricos se recomienda revisar $A$ Bibliography of Literaty Theory, criticism and philology, de José Angel García Landa ${ }^{424}$ y el texto de R. Rawdon Wilson, Palamede's Shadow: explorations in play, game and narrative theory. ${ }^{425}$ Otros recursos que conducen la composición de historias y pueden ser de gran ayuda son las guías metodológicas de: David Howard \& Edward Mabley, The tools of screenwriting, a Writer's guide to the craft and elements of a screenplay ${ }^{426}$ (1972); Syd Field, Screen play: the foundations of screenwriting ${ }^{427}$ (1982); Ronald B. Tobias, 20 Master plots and how to build them, ${ }^{428}$ (1993); Robert MCKEE, Story; substance, structure, style and the principles of screenwriting, ${ }^{429}$ (1997); Christopher Vogler, The writer's journey; mythic structure for writers ${ }^{430}$ (1998, 2007); Hans-Jörg Uther, The types of international folktales: a classification and bibliography based on the system of Antti Aarne and Stith Thompson, ${ }^{431}$ (2004).

Esperamos haber mostrado un panorama de los aspectos teóricos desde la óptica literaria, sin embargo para complementar esta visión, revisaremos cómo fue la migración de los juegos a los entornos digitales y conoceremos sus teorías y análisis desde su propia perspectiva; la del juego y principalmente a partir del surgimiento de los sistemas interactivos; sin perder, su relación con las historias.

\footnotetext{
${ }^{424}$ Citado por GARCÍA LANDA, José A., Acción, relato, Discurso: Estructura de la ficción narrativa [Texto online] en:

http://www.unizar.es/departamentos/filologia_inglesa/garciala/publicaciones/ard/1.2.Accion.html Consultado: 20/01/2012.

${ }^{425}$ WILSON, R. RAWDON, Palamede's shadow; explorations in play, game \& narrative theory, Northeastern University Press, Boston, 1990.

${ }^{426}$ HOWARD, David \& MABLEY, Edward., The tools of screenwriting; a writer's guide to the craft and elements of a screenplay, St. Martin's Press, New York, 1993.

${ }^{427}$ FIELD, Syd., Screen play; the foundations of screenwriting, Bantam Dell - Random House, Inc., New York, 2005.

${ }^{428}$ TOBIAS, Ronald B., 20 Master plots and how to build them, Writer's Digest Books, Cincinnati, 1993.

${ }^{429}$ MCKEE, Robert., Story; substance, structure, style and the principles of screenwriting, Harper-Collins Publishers, Inc., New York, 1997.

${ }^{430}$ VOGLER, Christopher, The writer's journey; mythic structure for writers, Sheridan Books, Inc., Chelsea, 2007.

${ }^{431}$ Véase The Types of International Folktales, FF Communications, Núm. 284-86, Academia Scientiarum Fennica, Helsinki [Sitio web] en: http://oaks.nvg.org/uther.html Consultado: 22/01/2012
} 
Because electronic writing technology is so malleable, however, it can in fact support a variety of forms of representation and can be understood according to a variety of critical theories.

Jay David Bolter ${ }^{432}$

\subsection{LA MIGRACIÓN A LOS SISTEMAS DIGITALES}

Las comunicaciones tanto como las historias y los juegos han emigrado desde los petroglifos en cuevas prehistóricas, las tablillas de barro, vasijas, códices, pergaminos y los primeros libros impresos; hasta los actuales sistemas digitales. De la oralidad, pasamos a los medios impresos y de ahí a las pantallas. ¿Qué ganamos y qué perdimos? Esperamos descubrir algunos indicios que nos ayuden a responderlo. Deseamos concluir este tercer apartado apreciando cómo los medios digitales han ampliado el potencial narrativo y reformulado nuevas prácticas de escritura que nos invitan a experimentar nuevas posibilidades. Hoy podemos contar cuentos utilizando diversos formatos como: Blogs y miniblogs, chats, tarjetas digitales, Páginas Web, teléfonos móviles; empleando fotos e imágenes en movimiento o archivos sonoros. Podemos hacer transmisiones Podcasts de archivos multimedia, a través de redes sociales, Mensajes de texto, Sistemas de navegación GPS, correos electrónicos, videojuegos y mucho más.

Es nuestra intención detectar y contrastar las cualidades narrativas analógicas con las digitales y apreciar las características que nos ayuden a conformar una narratología digital: autores colaborativos, múltiples visiones, símbolos y lecturas a diferentes niveles, textos fragmentados, ramificados, multi-lineales, historias enciclopédicas y panópticas, cualidad de inmersión e hipermedialidad entre otras; aunadas a las facilidades que brinda el Internet, los dispositivos digitales y las herramientas que ofrecen interactividad, inmersión, realidad virtual, realidad aumentada y otros serán aquí mismo abordados.

La era digital ha sido una revolución de revoluciones, en el ámbito literario debemos ver a los ordenadores como máquinas literarias, no sólo como medio de distribución y almacenamiento de textos analógicos que se distribuyen en el Internet, sino como aparatos que potencien la generación de textos ${ }^{433}$.

Estas cualidades amplían las posibilidades creativas en los medios digitales, dotando historias más complejas y mejor elaboradas, "no hay razón por la que creadores más

\footnotetext{
${ }^{432}$ BOLTER, Jay David, Writing space: computers, hypertext, and the remediation of print, Georgia Institute of Technology, Routledge, New York, 2001. (p.232)

${ }^{433}$ ELISABET, "Hermeneia, la literatura en la era digital, Entrevista a Laura Borras", Revista Literaria

Prosofagia núm. 9, Agosto 2010. [Texto on-line] en:

http://issuu.com/prosofagia/docs/prosofagiagosto2010online Consultado: 13/03/2012
} 
sofisticados no puedan hacer historias con más calidad dramática e interés humano",434 señala Janet Murray. Henry Jenkins lo denomina "environmental story-telling" a los entornos creados por los diseñadores de juegos en los cuales los jugadores pueden construir sus historias. Murray ${ }^{435}$ agrega el término de "historias participativas" y plantea cuatro cualidades esenciales de los medios digitales: sucesivos, participativos, espaciales y enciclopédicos. Sucesivos, porque se ejecutan en cierto orden gracias a que son están interconectados de manera compleja; Participativos, porque permiten la interacción con el sistema; Espaciales se entiende como espacios navegables para circular y finalmente, Enciclopédicos porque los medios digitales tienen la capacidad de almacenar grandes cantidades de información. Murray atestigua como la informática está entrando en terrenos que antes eran del dominio de artistas creativos. Investigadores en el campo de la inteligencia artificial y la realidad virtual han preparado nuevos entornos de entretenimiento, prometiendo la expansión de las capacidades del ordenador.

Para Marie-Laure Ryan, uno de los elementos distintivos de los sistemas digitales es su capacidad de respuesta ante un entorno de cambios operados por la entrada de datos del usuario, lo que se conoce como interactividad.

El desarrollo tecnológico ha fomentado que los estudios teóricos reorienten su rumbo. Con el advenimiento de la era digital, la expansión de los ordenadores y del Internet, se promovieron nuevas posibilidades estéticas que dieron paso a diversas formas artísticas. Surgieron nuevas disciplinas de estudio interesadas en los aspectos técnicos, sociales, humanos, estéticos y culturales del nuevo medio. Los videojuegos son justamente uno de estos nuevos formatos culturales que por un lado presentan un potencial narrativo, lo que Kevin Shut refiere como "rango de posibilidades narrativas", y por ello han cobrado gran interés de estudio. Al ofrecer cualidades particulares que presentan mayores complejidades estructurales y formales como: la múltiple autoría, es decir, la participación colectiva de jugadores-creadores; la multimedialización de las historias, que amplían las experiencias visuales y auditivas; la interactividad y el poder de auto elaboración de historias y el juego narrativo, el potencial lúdico que tienen las historias.

En un mundo inundado de historias, los videojuegos se contemplan como un medio idóneo para generar la literatura del futuro.

"We are entering an age of narrative chaos", where traditional frameworks are being derrocaded by emergent experimental and radicl attempts to remaster the art of storytelling in developing technologies". ${ }^{436}$

\footnotetext{
${ }^{434}$ MURRAY, Janet H., Hamlet en la Holocubierta, el futuro de la narrativa en el ciberespacio, Paidós, Barcelona, 1999. (p.65)

435 MURRAY, Janet H., Hamlet en la Holocubierta, el futuro de la narrativa en el ciberespacio, Paidós, Barcelona, 1999. (p.83)

${ }^{436}$ RIESER, Martin \& ZAPP, Andrea., New screen media: Cinema / Art/ Narrative, British Film Institute, London, 2004. (Foreword)
} 
Apreciar elementos narratológicos estructuralmente más originales, métodos previos a la informática que dieron origen a un potencial expresivo original y creativo permitirá ampliar los procedimientos que nos ayuden a armar narrativas digitales. Convencidos de que la aplicación de sistemas gráficos interactivos requieren de una solidez estructural, técnica y narrativa, esto confirma nuestra inquietud de revestir los trabajos digitales con una narratología que aproveche de las cualidades que posee.

Antonio Rodríguez de las Heras ${ }^{437}$, plantea diez cualidades que admiten los medios digitales: alta densidad, gran accesibilidad, actualización permanente, la conjunción de múltiples medios (texto, imagen audio) que se mezclan bajo un mismo código (multimedia); la interacción, la ubicuidad de tener la información en un lugar preciso y al mismo tiempo la deslocalización, la amorfía le otorga la cualidad de no tener forma concreta, la asincronía le otorga la capacidad de revisarse en cualquier momento y lugar y finalmente la hipertextualidad que le otorga la posibilidad de irse desplegando proporciones del texto completo en el espacio físico de la pantalla. Considerar las anteriores cualidades es esencial para innovar propuestas narrativas en diversos formatos y géneros: desde instalaciones, videoarte, Internet, videojuegos, televisión y cine interactivo, sólo por mencionar algunos.

Este potencial se refleja en la creación artística de las últimas décadas, principalmente a partir del desarrollo de la ingeniería informática en el campo de las nuevas tecnologías al servicio de la narrativa. Desde los primeros softwares orientados a la composición poética, los hipertextos y los sistemas automáticos de generación de historias, hasta la narrativa digital existe un mundo de experimentación que vale la pena revisarse y conocerse. A continuación expondremos algunos proyectos, sin afán de agotarlos, pero buscando puedan ser retomados y consultados, en esta búsqueda de promoción del desempeño de habilidades expresivas lingüísticas, mediáticas y del estímulo creativo para futuros guionista y diseñadores de textos.

\section{El origen de las máquinas narrativas}

Ramón Lull (1232-1316) a través de Ars Magna, en su intento religioso de conversión a Judíos y musulmanes, fabricó un objeto para cifrar mensajes, que sería retomado por otros "inventores" comenzando el desarrollo, de las ciencias computacionales. Se trata de las primeras máquinas lógicas, según confirma Martin Gardner. ${ }^{438}$ A través de un objeto compuesto por tres discos giratorios, se producían un considerable número de combinaciones posibles de letras y luego éstas las relacionó a ciertos conceptos que simbolizaban posibles respuestas ante cuestionamientos divinos. ${ }^{439}$. Llull fue un precursor en el desarrollo de un lenguaje formal articulado por reglas lógicas, un sistema de

\footnotetext{
${ }^{437}$ RODRIGUEZ H. Antonio, "El libro digital “ [Artículo on-line] en: http://www.uoc.edu/humfil/digithum/digithum2/catala/Art_Heras/heras_6.htm Consultado: 24/05/2012.

${ }^{438}$ Citado por CROSSLEY, John N., "Ramon's Llull's contributions to computer science”, [Artículo on-line] en: http://www.raimunduslullus.eu/textos/crossley-llull-revised.pdf Consultado: 29/05/2012

439 Véase: http://lullianarts.net/Ars-Magna/ars-magna Consultado: 27/05/2012.
} 
relaciones binarias y ternarias, lo que permitía el manejo de símbolos y la noción matemática de la sustitución de variables ${ }^{440}$. Posteriormente, Giordano Bruno en el siglo XVI con sus círculos concéntricos buscaba favorecer la memoria. Aparato conocido como La Rueda Mnemotécnica ${ }^{441}$ permitía la codificación de mensajes. Por su parte, Gottfried Leiebniz en el siglo XVII con su Stepped Reckoner o máquina de operaciones aritméticas básicas, aplicaría el principio de Las Ruedas de Bruno a un cilindro dentado portátil que haría funciones de una calculadora personal.

Textos y máquinas tuvieron un primer intento de fusión y articulación, ya sea para recordar la memoria, la obtención de mensajes o la ejecución de operaciones matemáticas. Su potencial influenció el desarrollo de los sistemas digitales orientados a la producción de historias con fines literarios que a continuación de manera breve enlistamos.

\section{Textos Estocásticos o aleatorios}

Max Bense ${ }^{442}$ afirma que uno de los primeros vínculos entre poesía e informática se originó durante la experimentación vanguardista de la literatura que buscaba componer cierto tipo de poesía tecnológica. Esta incipiente literatura hecha de máquinas comenzó a cobrar gran interés. Y mediante sistemas y dispositivos de procesamientos automáticos de datos informáticos, se comenzaron a producir textos poéticos; satisfaciendo el rigor de las estructuras gramaticales, semánticas y algunos incluso mostraban cierta cualidad estética mínima. Estos textos conocidos como estocásticos <entendidos como variables aleatorias $>$ ofrecen un potencial de creación a partir de teoremas de la estética estadística de la información, un sistema que permite ordenar palabras mediante un generador aritmético de azar, que proporciona, formas casuales, aflorando estilos convencionales y no convencionales de creación textual. Se puede considerar como una poesía simulada o con más exactitud, textos estocásticos con poesía simulada. El primer programa escrito para generar poesía proviene de Theo Lutz, considerado como una de las primeras fértiles uniones entre poesía e informática que se iría desarrollando en los años subsiguientes.

Este es el texto que se consiguió:

"no toda mirada está cerca. Ninguna aldea está tarde. Un castillo está libre y todo campesino está lejos. Todo forastero está lejos. Un días [sic] es tarde. Toda casa está oscura. Un ojo es profundo. No todo castillo es viejo. Todo día es viejo. ${ }^{\text {"443 }}$

\footnotetext{
${ }^{440}$ Véase: http://lullianarts.net/Ars-Magna/ars-magna Consultado: 29/05/2012

${ }^{441}$ El Instituto Warburg reproduce y describe http://warburg.sas.ac.uk/index.php?id=446 Consultado: 29/05/2012

442 BENSE, Max, Estética de la información, Simón Marchan Fiz, Madrid, 1973. (pp.183-186)

${ }^{443}$ BENSE, Max, Textos estocásticos con poesía simulada, [sitio web de Antonio Miranda] [Texto on-line] en: http://www.antoniomiranda.com.br/poesia_visual/textos_estocasticos_con_poesia_simulada.html Consultado: 28/05/2012.
} 
Lutz, tomó las primeras 100 palabras del vocabulario del Castillo de Kafka y programó frases cortas a partir de esto con ciertas estructuras sencillas, sujeto, verbo, y predicado. Estas frases se construirían a partir de conectores lógicos como el de la negación, la coordinación, etc.

\section{El ordenador comienza a narrar historias}

En la década de 1970, con el desarrollo de la informática y el nacimiento de la Inteligencia Artificial como disciplina de estudio en diversas áreas, comenzaron a surgir aplicaciones capaces de realizar un sinnúmero de tareas; algunas tan complejas como narrar historias, incluso algunas parecidas a las de los humanos. Con el auge de los videojuegos, se ampliaron las necesidades de mejorar los niveles de interacción entre los jugadores y las historias. Esto originó la proliferación de programas cuyo principal reto fue componer textos coherentes, interesantes que enriquecieran el potencial artístico de estas aplicaciones, desde el diseño de narrativas para interfaces de usuario y sistemas complejos para generar historias mediante la interacción hombre-máquina en la generación, ya sea de diálogos automáticos, robótica cognitiva, o la implementación de historias en tiempo real.

Se trata de prototipos capaces de contar y generar historias. Especialistas como Janet Murray, Andrew Glassner y Chris Crawford, interesados en la los sistemas interactivos, proponen narrar historias utilizando medios que aumenten la inmersión del usuario en el mundo virtual. Revalorando la narración como parte esencial en el proceso y destacando la importancia de los conceptos que afectan no sólo la transmisión de historias sino su propia generación; lo cual se popularizó con los medios interactivos mediante modelos y métodos para la producción de historias. ¿Cómo crear historias? ¿Cómo narrarlas? Labores de diseñadores narrativos informáticos comenzaron a aplicar aspectos científicos y tecnológicos al arte con el fin de concebir, generar y narrar historias. Ingeniería de textos como señala Fabio Wanderley, quien además propone que la generación de historias debe verse como un proceso de destrezas diestras. La generación automática de historias es algo realmente complejo, desde el punto de vista informático y también de acuerdo a la organización de los contenidos; por un lado tenemos las acciones de la historia y por el otro las emociones que la historia despierta en el usuario. Contamos con operadores que modifican los vínculos, entre los usuarios y los parámetros que servirán para generar una nueva historia.

Entre los primeros sistemas generadores de historias a partir de programas informáticos $<$ Story Generation Systems, SGS $>$ encontramos los siguientes. Es preciso señalar que éste fenómeno ha cobrado tal interés para desarrolladores de inteligencia artificial, que podemos apreciar un panorama muy amplio; el cual sólo abordaremos superficialmente sin agotarle de ninguna manera. Entre los primeros sistemas de narradores automáticos 
encontramos TALE-SPIN ${ }^{444}$, [Meehan, 1977] el cual genera historias textuales coherentes y sencillas a partir de una plantilla de sustituciones capaz de generar historias a través de la simulación del comportamiento de los personajes. Durante la ejecución el usuario puede definir la historia inicial y configurar el principal objetivo del protagonista. La historia cobra forma a partir de la toma de decisiones y la interacción entre los personajes y la solución de sus problemas; luego un algoritmo es responsable de traducir esas opciones en lenguaje natural y mostrarlo al usuario en forma de un texto. Véase una historia generada por Tale-Spin: ${ }^{445}$

Once upon a time George Ant lived near a patch of ground. There was a nest in an ash tree.

Wilma Bird lived in the nest. There was some water in a river. Wilma knew that the water was in the river. George knew that the water was in the river. One day Wilma was very thirsty.

Wilma wanted to get near some water. Wilma flew from her nest across

the meadow through a valley to the river. Wilma drank the water. Wilma wasn't thirsty anymore.

George was very thirsty. George wanted to get near some water. George walked from his patch

of ground across the meadow through the valley to a river. George fell into the water.

George wanted to get near the valley. George couldn't get near the meadow.

Wilma wanted to get near George. Wilma grabbed George with her claw.

Wilma took George from the river through the valley to the meadow.

George was devoted to Wilma. George owed everything to Wilma.

Wilma let go of George. George fell to the meadow. ${ }^{446}$

Otro sistema es "UNIVERSE"447 [Michael Lebowitz, 1984] genera argumentos interminables a partir de algoritmos planeados con un buen elenco de personajes y con un resultado bastante complejo ya que contiene un buen elenco y además se deben cumplir los objetivos del autor. Para comenzar una nueva historia en UNIVERSE, el sistema simula una historia de fondo, existe una bibliteca de fragmentos de la trama relacionadas con los objetivos de las historias y continene restricciones que dictan cierta orientación entre los personajes y estas variables. Véase una muestra textual:

Liz was married to Tony. Neither loved the other, and indeed, Liz was in love with Neil. However, unknown to either Tony or Neil, Stephano, Tony's father, who wanted Liz to produce a grandson for him, threatened Liz that if she left Tony, he would kill Neil. Convinced that he was serious by a bomb that exploded near Neil, Liz Told Neil that she did not love him, that she was still in love with Tony, and that he should forget about her. Neil was eventually convinced and married Marie. Later when Liz was finally free from Tony (because Stephano had died), Neil was not free to marry, her and their troubles went on.

\footnotetext{
${ }^{444}$ MEEHAN, James R., "TALE-SPIN, an Interactive Program that writes stories", en Proceedings of the Fifth International Joint Conference on Artificial Intelligence, Springer, 1977, (pp.91-98)

${ }^{445}$ Tomada de: WANDERLEY Guerra, Fabio, Engenharia de Estórias, um estudo sobre a gereção automática de estórias. Tesis de Maestría, Departamento de Informática da PUC-Rio, Brasil, 2008. [Texto on-line] en: http://www2.dbd.puc-rio.br/pergamum/tesesabertas/0521489_10_cap_02.pdf Consultado: $1 / 06 / 2012$

${ }^{446}$ Los tres fragmentos presentados en este apartado fueron tomados de PEINADO, Federico, “Un armazón para el desarrollo de aplicaciones de narración automática basado en componentes ontológicos reutilizables" [Tesis doctoral] Facultad de Informática, Universidad Complutense de Madrid, Madrid, 2008. [Texto on-line] en: http://www.fdi.ucm.es/profesor/fpeinado/publications/2008-peinado-armazonPhD.pdf consultado: 18/11/2011. Al no estar disponible los códigos ni sus aplicaciones en línea.

$\overline{447}$ LEBOWITZ, Michael, Creating Characters in a Storytelling Universe, 1984
} 
TAILOR $^{448}$ [Smith \& Witten, 1991] difiere de Tale-spin al no tener el input del usuario, el sistema funciona como un proceso que resuelve problemas que los personajes enfrentan. En cambio MINSTREL ${ }^{449}$ [Scott R. Turner, 1992] es una aplicación para generar historias breves sobre basado en historias del rey Arturo y los caballeros de la mesa redonda. Federico Peinado y Pablo Verás implementaron una nueva versión de mismo Minstrel (Turner, 1992) que utiliza un esquema de memoria episódica para almacenar casos de resolución de problemas; con este esquema similar, el sistema que aplica es una técnica de Case-Based Reasoning, que re-usa piezas de una historia conocida en la composición de otras nuevas.

\section{The vengeful Princess}

Once upon a time there was a lady of the court named Jennifer. Jennifer loved a knight named Grunfeld. Grunfeld loved Jennifer. Jennifer wanted revenge on a lady of the court named Darlene because she had the berries which she picked in the Woods and Jennifer wanted to have the berries. Jennifer wanted to scare Darlene. Jennifer wanted a dragon to move towards Darlene so that Darlene believed it would eat her. Jenniever wanted to appear to be a dragon so that a dragon would move towards Darlene. Jennifer drank a magic potion. Jennifer Transformed into a dragon. A dragon moved towards Darlene. A dragon was near Darlene. Grunfeld wanted to impress the King. Grunfeld wanted to move towards the woods so that he could fight a dragon. Grunfeld moved towars the Woods. Grunfeld was near the Woods. Grunfeld fought a dragon. The dragon died. The dragon was Jennifer. Jennifer wanted to live. Jennifer tried to drink a magic potion but failed. Grunfeld was filled with grief. Jennifer was buried in the Woods. Grunfield became a hermit. MORAL: Deception is a weapon difficult to aim.

En estas tres historias apreciamos tres niveles de complejidad estructural y de contenidos. Oraciones encadenadas yuxtapuestas, lo cual es un buen modelo para, recomponer de manera más compleja, nuevas historias mediante la subordinación de eventos interrelacionados, justificando la conexión entre una idea y otra.

En un segundo momento, los proyectos de narración automática se volvieron más complejos al admitir mayores grados de interacción del usuario e integraron gráficos y audio de mejor calidad cada vez.

MIMESIS [Michael Young, 2001, Riedl, 2004] fue construido para ser utilizado en juegos digitales. El sistema combina la planeación de historias con el uso de un sistema comercial de juego. Riedl señala que el éxito de las historias reside en su argumento coherente y la credibilidad de los personajes. OZ PROJECT ${ }^{450}$, fue uno de los sistemas narrativos más influyentes, por el grado de inmersión que buscaba, al expandirse el uso de la interactividad, se volvió un mundo animado en donde el usuario interactúa con personajes autónomos llamados Woggles, sería el antecedente del drama interactivo que

\footnotetext{
${ }^{448}$ SMITH, Tony C., y WITTEN, lan H. "A planning mechanism for generating story text" (technical report 1991) University of Calgary, 1991. [Sitio en Internet] en: Story Understanding Resources, en: http://xenia.media.mit.edu/ mueller/storyund/storyres.html Consultado: 29/05/2012.

${ }^{449}$ TURNER, Scott R., MINSTREL, “A computer model of creativity and storytelling”, 1992.

[Texto on-line] en: ftp://ftp.cs.ucla.edu/tech-report/1992-reports/920057.pdf Consultado: 01/06/2012

${ }^{450}$ Véase: http://www.cs.cmu.edu/afs/cs/project/oz/web/oz.html Consultado: 04/06/2012.
} 
se desarrollaría Virtual Theatre Project ${ }^{451}$ y basado en la idea de administrador dramático del sistema PLAYWRIGHT propuesto por Brenda Laurel en el cual utiliza un sistema experto para conectar acciones con una estructura dramática o teatral dentro de un ambiente interactivo. "enable a person to participat in a dramatic action in a relatively unsconstrained way, influencing events and outcomes through his or her choices and actions as a carácter in the action " 452 Controlando los eventos así como sus diálogos dentro del entorno dramático.

Michael Mateas y Andrew Stern analizaron Oz Project y propusieron una nueva disciplina llamada Expressive AI "where AI research and art mutually inform each other and use this discipline in developing yet another interactive drama system." 453 Entre 2002 y 2003 desarrollaron FAÇADE ${ }^{454}$, juego en primera persona y drama interactivo cuyo objetivo es enfrentar al jugador con una situación dramática con la cual debe interactuar y resolver. El sistema cuenta tanto con narrativas estructuradas, en un sentido tradicional y simulaciones de procedimiento dentro de un mundo virtual con diversos agentes interactuando con el jugador quien ayuda a construir secuencias de eventos que se pueden considerar como un tipo de narrativa visual emergente. El resultado es una mezcla de drama y videojuego en un entorno 3D. El usuario-jugador puede tomar parte en la conversación. Fue reconocido por el grado de simulación e interacción humana que presenta. Sin embargo recibe críticas tanto favorables como adversas, ya que el dialogo resulta pobre de acuerdo a su complejidad lingüística y poco interesante.

BRUTUS $^{455}$ es otro sistema desarrollado por Selmer Bringsjord y David Ferrucci en 1999, en el que la lógica se liga a la creatividad buscando crear un programa informático capaz de generar ficción literaria. ¿Cómo hacerlo si la lógica y la creatividad no van ligadas? Estos sistemas pueden apreciarse por la imaginación que generan en la mente del lector. "Creativity is generally regarded to involve breaking hte kind of rigid rules standing at the heart of logic" "456

LOGTELL $^{457}$ [Pozzer, 2005, Ciarlini et al 2005, Karlsson et al. 2006] es un sistema que que se enfoca a la generación de presentación de historias en tres dimensiones. El usuario no participa directamente en la dramatización; el sistema utiliza un plan de acercamiento

\footnotetext{
${ }^{451}$ Véase: http://www.ksl.stanford.edu/projects/cait/index.html Consultado: 04/06/2012.

${ }^{452}$ Véase: http://www.cs.cmu.edu/afs/cs/project/oz/web/oz.html Consultado: 04/06/2012.

${ }^{452}$ Véase: http://www.ksl.stanford.edu/projects/cait/index.html Consultado: 04/06/2012.

452 LAUREL, Brenda., Computers as theatre, Adidson-Wesley Publishing Company, 1993. (p.135).

${ }^{453}$ MATEAS, Michael, Interactive Drama, Art and Artificial Intelligence, Tesis Doctoral, Computer Science Department, Carnegie Mellon University, Pittsburgh, 2002 [Texto on-line] en: http://www.cs.cmu.edu/ dod/papers/CMU-CS-02-206.pdf Consultado 1/06/2012.

${ }^{454}$ Véase Sitio en Internet: http://www.interactivestory.net/ Consultado:1/06/2012

${ }^{455}$ BRINJSJORD S. y FERRUCCI, D., Artificial intelligence and literary creativity, Inside the Mind of BRUTUS, a storytelling machine, [Artículo on-line] en: http://kryten.mm.rpi.edu/brutus.preface.pdf Consultado: 04/06/2012.

${ }^{456}$ BRINGSJORD Selmer y FERRUCCI David, Artificial intelligence and literary creativity, Inside the Mind of BRUTUS, a storytelling machine, Lawrence Erlabaum, Mahwah, NJ, 1999. (Preface, XV)

${ }^{457}$ Véase muestra de LOGTELL en [Video on-line] en: http://www.youtube.com/watch?v=S87hPB4WuK0 Consultado: 01/06/2012.
} 
a los personajes cuyas acciones están restringidas a un repertorio pre-definido similar al trabajo de al de las acciones predefinidas que revisamos aquí mismo sobre Vladimir Propp $^{458}$.

IDA $^{459}$ [Magerko, 2005,2006] acrónimo de Interactive Drama Architecture, parte del problema de crear un espacio a una historia y cómo manejar la experiencia del jugadorusuario dentro de los límites de ese espacio narrativo. IDA emplea un agente conductor omnisciente en tiempo real quien guía la experiencia del jugador, el sistema anticipa la situación y plantea un posible desenlace: "My goal for interactive drama: to create a system that presents story experiences that are directly influenced in consistent, meaningful ways by both the autor of the system and the playes as he intentionally acts out a role in a dramatic setting" $" 460$. Utiliza un acercamiento enfocado en la predicción que guía el comportamiento de jugador y establece lazos con la historia.

Algunos otros sistemas son: MIRAGE ${ }^{461}$ [Maggy El-Nasr, 2007] dicho por su autora, utiliza una representación que se adapta a la teoría teatral, conflictos dramáticos y un arco teatral que conduce la historia. LOGTELL ${ }^{462}$, es otro proyecto interactivo de generación de historias para el Internet, la televisión o el cine. El cual busca el desarrollo de herramientas integradas para almacenar tanto la generación como la representación de historias interactivas. GESTER [GEnerating STories from Epic Rules, 1989] es otro programa que genera líneas de historias basado en una gramática modular de conocimientos independientes ${ }^{463}$. Se deriva de la épica medieval francesa. Produciendo historias coherentes y bien estructuradas. GADIN ${ }^{464}$ [Barber \& Kudenko, 2007] es el Generator of Adaptive Dilemma-Bassed interactive Narratives, basado en clichés de telenovelas y enfocado en dilemas que ayudan a provocar una tensión dramática. Los cinco dilemas que el sistema utiliza son: traición, sacrificio, gran bondad, derrumbar y favor. El sistema utiliza un modelo de usuario que asegura su entretenimiento.

MEXICA $^{465}$ [Perez, 2001] es un generador de argumentos a partir de la interacción del usuario en torno a un modelo de emociones de los personajes y sus relaciones. Como dice Rafael Pérez, "Emotions are integral par of the creative process. Emotions among

\footnotetext{
${ }^{458}$ Véase algunos proyectos desarrollados a partir de LOGTELL [Sitio de Internet] en: http://www.icad.pucrio.br/ logtell/publications.php Consultado: 01/06/2012

${ }^{459}$ MAGERKO, Brian S., Player Modeling in the interactive Drama archicture, Tesis Doctoral, Universidad de Michigan, 2006. [Texto on-lin] en:

http://lcc.gatech.edu/ bmagerko6/papers/magerko.dissertation.final.pdf Consultado: 04/06/2012.

460 MAGERKO, Op. Cit. (p. 14)

${ }^{461}$ EL-NASR SEIF, Maggy, Sitio en Internet: http://nuweb.neu.edu/magy/cv.html Consultado: 04/06/2012

${ }^{462}$ Véase Sitio en Internet: http://www.icad.puc-rio.br/ logtell/index.html Consultado: 01/06/2012

463 PEMBERTON, Lyn, A modular approach to story generation, [texto on-line] en: http://acl.Idc.upenn.edu/E/E89/E89-1030.pdf Consultado: 05/06/2012

${ }^{464}$ BARBER, Heather \& KUDENKO, Daniel, Games, Interactive Entertainment and drama, [Sitio en Internet] en: http://www.cs.york.ac.uk/gidy/people.php?person=heather Consultado: 05/06/2012

465 PEREZ, Rafael, "Employing emotions to drive plot generation in a computer-based storyteller" ELSEVIER \& Science Direct, 2006.
} 
characters to progress a story" ${ }^{\prime 466}$ Mexica es un modelo narrativo con un fuerte carga no sólo emotiva sino de contenido; inspirado en tradiciones del pueblo Mexica (los antiguos habitantes de lo que hoy conocemos como México, nombrados equívocamente como Aztecas) que refleja elementos socio-culturales que determinan la personalidad de los personajes. Generando estructuras que están almacenadas en la memoria del sistema y otras que son completamente nuevas. Las emociones para generar historias o para evaluar su grado de interactividad es un valor que complementa las historias generadas y refleja un trabajo creativo. "Una historia es un racimo de vínculos emociones y tensionales", dice Pérez... organizado de manera creativa, al mostrar como revestir las simples acciones argumentales y adaptarse a otros temas y otros con mayor grado de complejidad y detalle.

La proliferación de estos sistemas, según lo confirma Federico Peinado ${ }^{467}$ es producto del interés que ha despertado la industria del videojuego, la optimización de los servicios de Internet y el avance técnico, al ampliar las posibilidades de implementación de la narración automática de ser únicamente textos a convertirse en sistemas automáticos que hoy han incorporado gráficos, audio y permiten una mayor interacción del usuario.

Fabio Wanderley Guerra ${ }^{468}$ sugiere una clasificación de estos sistemas en tres grupos distintos: a) Simulaciones de personajes autónomos; b) Sistemas basados en argumentos planeados y c) Una categoría enfocada en el usuario, no en los personajes o los argumentos que designa como manipulación y experiencia.

Algunos otros proyectos que fusionaron la narrativa a la Inteligencia artificial son $\mathrm{OZ}$ PROJECT $^{469}$ [Bates et al, Universidad de Carnegie Mellon, 92] el cual estuvo activo hasta 2002 y se auto denomina "Drama Interactivo" al permitir al usuario un nivel superior de interacción e inmersión. Por otra parte THE VISTA PROJECT ${ }^{470}$ [Proyecto de Narrativa digital de la Universidad del Norte de Texas] integra un campus de historias grabadas por los usuarios con las cuales se pueden reconstruir nuevas propuestas. ${ }^{471}$

HEFTI Storytelling Engine (Hybrid Evolutionary-Fuzzy Time-based Interactive) utiliza algoritmos para recombinar, mutar, seleccionar y evaluar componentes de una historia generados a partir de un grupo de plantillas de historias predefinidas. El sistema permite a

\footnotetext{
${ }^{466}$ PEREZ Y PEREZ, Rafael, "Employing emotions to drive plot generation in a computer-based stroyteller", [Artículo on-line] en: http://digis.ewha.ac.kr/data/test/employing.pdf Consultado: 09/7/2012

467 PEINADO, Federico, “Un armazón para el desarrollo de aplicaciones de narración automática basado en componentes ontológicos reutilizables" [Tesis doctoral] Facultad de Informática, Universidad Complutense de Madrid, Madrid, 2008. [Texto on-line] en:

http://www.fdi.ucm.es/profesor/fpeinado/publications/2008-peinado-armazon-PhD.pdf consultado: 18/11/2011.

${ }^{468}$ WANDERLEY Guerra, Fabio, Engenharia de Estórias, um estudo sobre a gereção automática de estórias. Tesis de Maestría, Departamento de Informática da PUC-Rio, Brasil, 2008. [Texto on-line] en: http://www2.dbd.puc-rio.br/pergamum/tesesabertas/0521489_10_cap_02.pdf Consultado: 1/06/2012

${ }^{469}$ Véase sitio de Internet: http://www.cs.cmu.edu/afs/cs/project/oz/web/overview2.html 1/06/2012. Consultado: 1/06/2012.

${ }^{470}$ http://www.courses.unt.edu/efiga/DigitalStorytellingProject/ Consultado:1/06/2012

${ }^{471}$ Véase:FIGA, Elizabeth, The VISTA Project: an agent architecture for virtual interactive Storytelling, University of North Texas, [Texto on-line] en: www.http://courses.unt.edu/e_ga Consultado: 1/06/2012
} 
los usuarios generar variantes congruentes y lógicas a partir de la historia original, ${ }^{472}$ la cual se fracciona en múltiples porciones manipulables que generan diversas secuencias de historias. Los autores crean "hilos narrativos" potenciales, eligiendo la extensión de la historia así como los elementos de las plantillas, el orden y duración de los mismos y las reglas que permiten el fluir de la historia.

La lista parcial de proyectos similares se amplía con trabajos relacionados en esta área como: CHOROS (N.M. Sgouros, 2001) que ha sido usado para la creación de una producción teatrales, Choros controla la actuación de una pareja de robots-actores ${ }^{473}$.

CARD SHARK AND STORYSPACE ${ }^{474}$ [M. Bernstein, 1999] compuesto a partir de patrones de hipertexto que toman forma de "hipercartas" considerados como nodos que se vinculan entre sí al agregarle una conexión. "Why not start with everything interlinked, and remove links until everything is just right? We might call this sculptural hypertext. As opposed to calligraphic hypertext."

El sistema se compone de textos, restricciones y afirmaciones; el usuario recibe siete cartas que debe ir anexando a la historia. Un ejemplo de carta es:

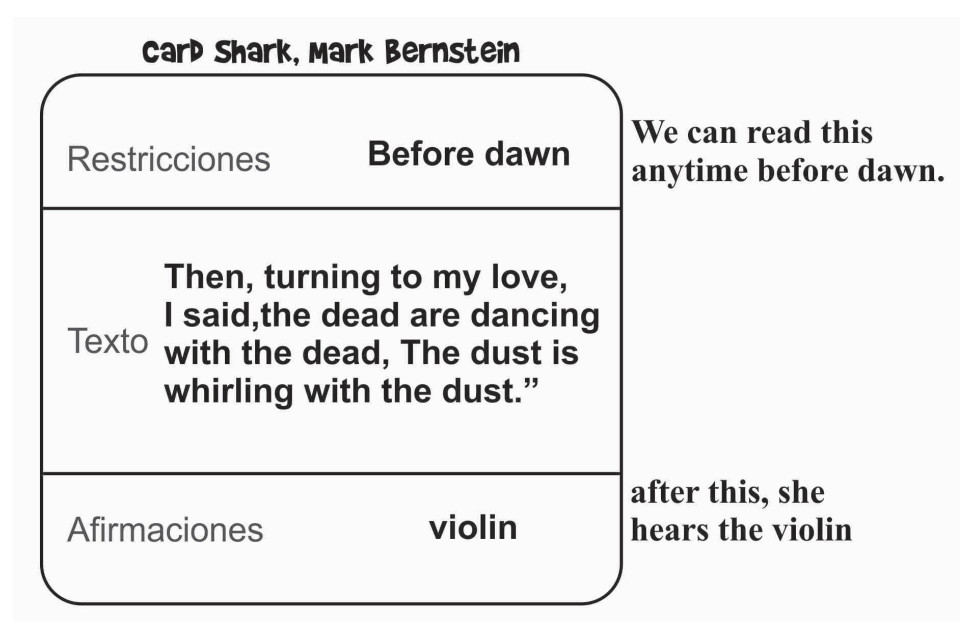

\footnotetext{
${ }^{472}$ Véase: ONG, TeongJoo y LEGGETT, John, “A genetic algorithm approach to interactive narrative generation" [Artículo on-line] en:

http://dl.acm.org/citation.cfm?id=1012856\&dl=ACM\&coll=DL\&CFID=85695214\&CFTOKEN=57718443

Consultado 1/06/2012.

${ }^{473}$ SGOUROS, Nikitas M., "Generation and Implementation of Mixed-reality, narrative, performances involving robotic actors", en BALET, Olivier et al, Virtual Storytelling, Using virtual reality technologies for storytelling, ICVS, Springer, Avignon, 2001. (pp. 69- 79)

${ }^{474}$ Véase: MARK BERNSTEIN, [sitio en Internet]: http://www.markbernstein.org/talks/HT01.swf en:

Consultado:1/06/2012
} 
METALINEAR CINEMATIC NARRATIVE ${ }^{475}$ (K.M. Brooks, 1999) es según afirma su autor, Kevin Michael Brooks, una colección de pequeñas piezas de una historia que pueden componerse de diversas maneras para relatar diferentes historias lineales desde diferentes puntos de vista mediante una herramienta informática. STORYBEADS ${ }^{476}$ (B. Barry, 1998) propone una serie de cuentas digitales que admiten imágenes y textos preseleccionados y se organizan como una red informática que permita crear historias al plantear diversas secuencias narrativas. Por su parte Federico Peinado ${ }^{477}$ amplia la lista con otros sistemas generadores automáticos de historias como: STORYBOOK de Charles B. Callaway y J.C. Lester ${ }^{478}$, JOSEPH de R.R. Lang $^{479}$, TERMINAL TIME, de Steffi Domike, Michael Mateas y Paul Vanouse ${ }^{480}$; y WIDE RULED de James Slorupski, Lakshmi Jayapalapan, Sheena Márquez and Michael Mateas ${ }^{481}$, quizá una de las interfaces más amigable para generar historias ${ }^{482}$. SWAN de Ruquian Lu y Songmao Zhang $^{483}$, ISRST ${ }^{484}$, un modelo de narrativa interesada en el uso de las relaciones retóricas, de Arturo Nakasone an Misturu Ishizuka. Y la lista de los Sistemas generadores de historias continúa; PaSSAGE (Player-Specific Stories via Automatically Generated Events $)^{485}$ desarrollado por el Grupo de investigación IRCL compuesto por Vadim Bulitko, Charles Crittenden, Trevon Romanuik y otros; el cual emplea una selección específica de eventos, ligados a la asignatura de roles otorgados a un jugador en un mundo 3D. Finalmente el sistema ERASMATRON desarrollado por Chris Crawford ${ }^{486} \mathrm{el}$ cual trata de balancear la base de la trama con la de los personajes, usando nociones de verbos y oraciones. Las acciones se representan por verbos asignados a los roles que cada personaje tiene para crear una oración.

Estos sistemas tendrán aplicaciones muy diversas orientados a distintos campos artísticos o educativos; ya sea la composición de dramas interactivos, materiales de divulgación o en el desarrollo de juegos serios de tipo de entrenamiento, museos virtuales y simuladores.

La noción de vincular significación + simulación + narración de historias ha estimulado el desarrollo de estructuras dinámicas, de mayor complejidad emergente, con mejores

\footnotetext{
${ }^{475}$ BROOKS, Kevin, M., Metalinear Cinematic Narrative: Theory, Process, and tool. Tesis Doctoral, Massachussetts Institute of Technology, 1999. [Texto on-line] en:

http://ic.media.mit.edu/icSite/icpublications/Thesis/brooksPHD.html Consultado: 04/06/2012.

${ }^{476}$ BARRY, Barbara, Story Beads: a wearable for distributed and Mobile Storytelling, Tesis de Master, MIT (2000)

477 PEINADO, Federico, Op. Cit.

${ }^{478}$ CALLAWAY, Charles \& LESTER, J.C. Narrative Prose generation, http://homepages.inf.ed.ac.uk/ccallawa/papers/callaway-diss.pdf

${ }^{479}$ LANG, R.R., A formal Model for simple narratives, Tesis doctoral Universidad de Tulane, 1997.

${ }^{480}$ Véase: http://www.terminaltime.com/contact.htm Consultado: 04/06/2012.

${ }^{481}$ Véase: $\mathrm{http://users.soe.ucsc.edu/} \mathrm{jskorups/wiki/academia/wide \_ ruled} \mathrm{Consultado:} \mathrm{04/06/2012}$

${ }^{482}$ Véase: http://eis.ucsc.edu/Wide_Ruled Consultado: 04/06/2012

${ }^{483}$ RUQUIAN, Lu \& SONGMAO Zhang, Automatic generation of computer animation: using Al for movie animation, Lecture Notes in Artificial Intelligence. Springer-Verlag, Berlin, 2002.

${ }^{484}$ Véase: http://arturo.prendingerlab.net/isrst/isrst.html Consultado:05/06/2012

${ }^{485}$ Véase: https://sites.google.com/a/ualberta.ca/ircl/projects/passage Consultado: 05/06/2012

${ }^{486}$ Véase: http://www.erasmatazz.com/ y http://www.robotwisdom.com/ai/crawford.html Consultados: 04/06/2012
} 
mecanismos de participación. Sistemas informáticos que pueden utilizarse en diferentes plataformas que permiten generar narrativas interactivas, ya sea del tipo de juegos de aventuras gráficas o ficciones interactivas. Puede revisarse HUGO de Kent Tessman, TADS acrónimo de Text Adventure Development System de Michael Roberts o INFORM de Ibraham Nelson.

Seguramente existirán muchos otros sistemas para generar historias de manera automática; que integren textos, gráficos, audio, etc., a un contenido, una estructura, en una versión final, que podemos considerar como narrativa emergente las cuales han florecido en los últimos tiempos a través de colectivos y proyectos multimedia como el caso de E-CIRCUS ${ }^{487}$ desarrolló FearNot! (2004) Y ORIENT ${ }^{488}$ [Aylett, Vannini, André, Paive, Enz, y Hall, 2009] creados para generar empatías en jóvenes de distintas culturas y el primero generaba dramas narrativos que simulaban problemas de "bullying" entre niños de 8 a 12 años en Alemania, Inglaterra y Portugal, el objetivo era crear vínculos de empatía con los usuarios. PROYECTO OZ ${ }^{\mathbf{4 8 9}}$, del Carnegie Mellon University (Joe Bates, Bryan Loyall, Scott Neal Reilly, Phoebe Sengers and Peter Weyhrauch. Construye mundos a partir de personajes e historias. Y el Projecto IRIS, Integrating Research in Interactive Storytelling, con su red de excelencia $<$ Network of Escellence (NoE) a partir de 2009 reúne desarrolladores en un laboratorio de diferentes perspectivas téoricas y metodológicas $^{490}$.

Nicoletta Di Blas y Franca Garzotto ${ }^{491}$, entre otros, enlistan una serie de proyectos educativos que vinculan la narrativa interactiva digital que recomendamos revisar ${ }^{492}$ : $\operatorname{KidPad}^{493}$ una herramienta para la composición de historias gráficas colaborativas. $\mathrm{POGO}^{494}$, desarollado por Antonio Rizzo es un entorno informático narrativo para niños de 6-8 años, " $a$ world where children create, explore and develop narrative language and social skills." ${ }^{495}$ El proyecto FaTe2 ${ }^{496}$, acrónimo de Fairy Tales and Technology es otro

\footnotetext{
${ }^{487}$ Véase: http://www.e-circus.org/ Consultado: 29/05/2012 Ambos proyectos pueden descargarse en este sitio de Internet.

488 KURDYUKOVA et al. IRIS Project, Integrating Research in Interactive Storytelling, Teeside University, 2010 (pp. 12-16) [texto on-line] en. http://iris.scm.tees.ac.uk/ Consultado: 27/05/2012.

${ }_{489}$ OZ Project. Véase Sitio en Internet: http://www.cs.cmu.edu/afs/cs/project/oz/web/papers.html Consultado: $28 / 05 / 2012$.

${ }^{490}$ Véase:

http://tees.openrepository.com/tees/browse?type=author\&value=Cavazza\%2C+M.+0.+\%28Marc\%29\&va lue_lang=en consultado: 06/06/2012

${ }^{491}$ DI BLAS, Nicoletta, GARZOTTO, Franca et al, "Digital storytelling as a whole-class learning activity Lessons from a three-years project" en: IURGEL, Ido, ZAGALO; Nelson en PETTA, Paolo (eds) Interactive Storytelling, Second joint international conference, Springer, Verlag (pp.14-25)

492 Decortis, François y RIZZO, Antonio, New active tools for supporting narrative structures, ACM, [Artículo on line] en: http://dl.acm.org/citation.cfm?id=592614\&CFID=107352251\&CFTOKEN=31223235 Consultado: 06/06/2012.

${ }^{493}$ Véase: KidPad [sitio en Internet] en: http://www.cs.umd.edu/hcil/kiddesign/kidpad.shtml Consultado: 06/06/2012.

${ }^{494}$ The POGO Consortium: Philips Design (coordinator)

495 RIZZO, Antonio et al, The design of POGO Story World [Artículo on-line[ en:

http://www.nbu.bg/cogs/events/2002/materials/Antonio/Pogo_design_rizzo.pdf

Consultado:06/063/2012.
} 
sistema colaborativo de aprendizaje de narrativas con niños de 5 a 7 años a través de juegos. MOOSE Crossing ${ }^{497}$ : “a text-based virtual world designed to be a construcionist learning environment for children ages 8 to 13 " que puede reconocerse en la tesis de Amy Bruckman. Puppet ${ }^{498}$ es un proyecto que vincula la narrativa de historias con los títeres virtuales. Y el último que señalamos es Teatrix ${ }^{499}$, un entorno virtual para la composición de historias. Existirán muchos otros que seguramente ampliarán estas referencias que esperamos sirvan como punto de arranque para futuros estudios.

En torno a estos sistemas existen algunas inquietudes que deseamos considerar como la falta de contenidos disponibles para generar historias, Federico Peinado lo dice así: "[es] escasa y su variedad queda reducida a un solo dominio temático muy limitado" 500 Por lo general las historias son todas similares sin mucho espacio para la invención. La utilización de estos sistemas debe ofrecer una posibilidad de inmersión en una historia en la que tanto los personajes como la trama son complejos e interesantes. Y en cierta medida, asumen la participación del usuario quien altera, con sus decisiones, el desarrollo de las posibles historias generadas.

Cualquier elemento del sistema debe ser significativo a la historia, los eventos y acciones deben atender a una organización causal, lógica. Otro aspecto es el flujo de la historia, el cual debe coincidir con la interacción del usuario. Por lo general se trata de sistemas basados a partir de restricciones y limitaciones por lo que las historias no acaban de satisfacer a los usuarios, que por lo general limitan su capacidad creativa. Por ello debemos entender que los productos no son historias finitas, sino argumentos que deben ampliarse y mejorarse. Por lo general son historias que presentan lagunas o huecos e incluso algunos fragmentos sin sentido o historias que no concluyen en algo concreto o lógico. Y en relación a la participación de los usuarios, por lo regular se enfrentan a cierta limitación que pone en duda su carácter de "interactividad" al ofrecer pocas opciones que están previamente establecidas en el sistema. Será importante seguir analizando cómo van mejorando estos sistemas; los escritores deben replantearse su misión: utilizar las herramientas disponibles para crear historias con mayor grado de complejidad, interacción e inmersión y escribir para una amplia y variada gama de posibilidades de aplicación. Finalmente detrás de una buena historia, está un narrador, los sistemas deben ser su herramienta pero el trabajo creativo debe surgir desde el ingenio del autor.

Antes de esperar que los sistemas hagan todo por sí mismos y produzcan historias de calidad literaria; porqué no pensar en utilizar esos sistemas generadores narrativas que

\footnotetext{
${ }^{496}$ GARZOTTO, Franca y RIZZO, Francesca, Interactive story-telling, cooperative e-Learning, and kids: a field study, [Artículo on-line] en: http://www.daimi.au.dk/ evae/Blandat/Intet/posters/garzotto.pdf consultado: 06/06/2012.

497 BRUCKMAN, Amy, MOOSE Crossing: Construction, community and learning in a networked virtual world for kids, Tesis doctoral, MIT, [Texto on-lin] en: http://www.cc.gatech.edu/ asb/thesis/ Consultado:04/06/2012

${ }^{498}$ Véase: http://www.dfki.de/imedia/workshops/i3-spring99/w11/w11-summary.html \& http://gaips.inesc-id.pt/teatrix/papers/teatrix-its2000.pdf consultados: 06/06/2012

${ }^{499}$ Véase: http://gaips.inesc-id.pt/teatrix/papers/teatrix-its2000.pdf Consultado: 29/05/2012

${ }^{500}$ Op.cit. (p.5)
} 
puedan dar la pauta para armar historias que los escritores pueden ampliar y completar a partir de un toque personal y creativo. Sin duda estos sistemas son otros "resortes" para la composición de textos que los diseñadores de textos consideren para generar historias coherentes, estructuralmente creativas y con un tratamiento de los contenidos de manera innovadora.

Para ampliar el tema de los sistemas narrativos automáticos recomendamos revisar La Tesis doctoral de Federico Peinado ${ }^{501}$, La Tesis doctoral de Fabio Wanderley Guerra ${ }^{502}$; la compilación de recursos sobre narrativa automática de Erik T. Mueller ${ }^{503}$ (2010); la revisión documental de artículos especializados de congresos internacionales como: ICIDS, International Conference on Interactive Digital Storytelling ${ }^{504}$; ICIVS, International Conference on Virtual Storytelling ${ }^{505}$; TIDSE, Tecnologies for Interactive Digital Storytelling and Entertaining ${ }^{506}$; ICCC, Computational Creativity ${ }^{507}$. Así como conocer algunos proyectos colectivos como: $\operatorname{Red~} \mathrm{Cap}^{508}$, plataforma de diseñadores de textos que presentan sus métodos de creación así como descripciones, vínculos y referencias a otros medios de composición de historias. Storytron ${ }^{509}$ es otro proyecto que debe apreciarse, a pesar de estar extinto, muestra un excelente trabajo. Interactive Storytelling@teeside ofrece vínculos y artículos relacionados que pueden consultarse en su sitio web ${ }^{510}$. Interactive Cinema ${ }^{511}$ (activo hasta 2004) que fue sustituído por Media Fabrics $^{512}$ (Activo hasta2006), ambos coordinados por Gloriana Davenport ${ }^{513}$, presenta proyectos de cine y narrativa interactiva.

Este panorama sin duda se ampliará y servirá para tener un acercamiento a algunos proyectos que han desencadenado una complejidad formal, tecnológica y artística; esperando este trabajo contribuya con la aportación de modelos para la composición de historias que contengan una riqueza conceptual y significativa para facilitar nuevos modos de creación. Sin duda estos sistemas de narrativas inteligentes son una herramienta muy valiosa.

\footnotetext{
501 PEINADO, Federico, “Un armazón para el desarrollo de aplicaciones de narración automática basado en componentes ontológicos reutilizables" [Tesis doctoral] Facultad de Informática, Universidad Complutense de Madrid, Madrid, 2008. [Texto on-line] en:

http://www.fdi.ucm.es/profesor/fpeinado/publications/2008-peinado-armazon-PhD.pdf consultado: 18/11/2011.

${ }^{502}$ WANDERLEY Guerra, Fabio, Engenharia de Estórias, um estudo sobre a gereção automática de estórias. Tesis de Maestría, Departamento de Informática da PUC-Rio, Brasil, 2008. [Texto on-line] en: http://www2.dbd.puc-rio.br/pergamum/tesesabertas/0521489_10_cap_02.pdf Consultado: 1/06/2012.

${ }^{503}$ MUELLER, Erik T., Story Understanding resources, [Texto on line] en: http://xenia.media.mit.edu/ mueller/storyund/storyres.html Consultado:2/06/2012

${ }^{504}$ Véase: www.icids.org Consultado: 3/06/2012

${ }^{505}$ Véase: www.virtualstorytelling.com Consultado: 3/06/2012

${ }^{506}$ Véase: www.interactive-storytelling.com Consultado: 3/06/2012

${ }^{507}$ Véase: http://computationalcreativity.net/ Consultado: 3/06/2012

${ }^{508}$ Véase: http://redcap.interactive-storytelling.de/Consultado: 3/06/2012

${ }^{509}$ Véase: http://www.storytron.com/ Consultado: 3/06/2012

510 Véase: http://www.scm.tees.ac.uk/f.charles/index.php Consultado: 04/06/2012

${ }^{511}$ Véase: http://ic.media.mit.edu/ Consultado: 04/06/2012

${ }^{512}$ Véase: http://mf.media.mit.edu/ Consultado: 04/06/2012

${ }^{513}$ Véase: http://ic.media.mit.edu/people/gid/ Consultado: 04/06/2012
} 


\section{Máquinas, historias y arte digital}

Otra vertiente de la producción literaria ligada a software es la que brevemente exponemos en este apartado, comenzando con El proyecto IP Poetry, desarrollado por Gustavo Romano a partir de 2004, éste se basa en la generación de poesía a partir de la búsqueda en tiempo real de material textual en la web. Robots que conectados a Internet convierten los textos encontrados en sonidos de imágenes pregrabados de una boca humana recitando fonemas. Una especia de poemas aleatorios recitables, semejantes los poemas monocordes sinsentido del dadaísmo.

Del Ultimate Poem al IBM poem (pasando por la sinfonía alfabética) propuesta del poeta Emmett Williams ${ }^{514}$, ligado a Fluxus, quien elaboró en la década de los 50, combinatorias que surgían a partir de las siguientes instrucciones:

1. Elegir 26 palabras al azar.

2. Sustituirlas por las 26 letras del alfabeto.

3. Elegir otra palabra o frase para que se constituya como título del poema.

4. Sustituir las letras de esta palabra o frase por las correspondientes palabras del alfabeto.

5. Repetir el paso 4 con la primera línea del poema.

6. Repetir con la segunda línea, etcétera.

El resultado de su primer Poema IBM fue: Red up going (primera frase)

$\mathrm{A}=$ money, $\mathrm{B}=$ up, $\mathrm{C}=$ Idiots, $\mathrm{D}=$ Sex, $\mathrm{E}=$ like, $\mathrm{F}=$ quivering, $\mathrm{G}=$ evil, $\mathrm{H}=$ old, $\mathrm{I}=$ red, $\mathrm{J}=$ Zulus, $\mathrm{k}=$ ticklish, $\mathrm{L}$ $=$ Kool, $\mathrm{M}=$ going, $\mathrm{N}=$ black, $\mathrm{O}=$ Jesus, $\mathrm{P}=$ hotdogs, $\mathrm{Q}=$ coming, $\mathrm{R}=$ perilous, $\mathrm{S}=$ action, $\mathrm{T}=$ virgins, $\mathrm{U}=$ yes, $V=$ easy, $W=$ fear,$X=$ death, $Y=$ naked, $Z=$ White.

Tape Mark 1, del italiano Nanni Balestrini, (1961) con la ayuda de un ordenador IBM 7070; se basa en unidades de sentido tomadas de tres textos (El Diario de Hiroshima, de Nichihito Hachiya, el Tao te King, de Lao Tsé y El Misterio del ascensor de Paul Goodwin) que se recombinaban entre sí según determinadas reglas métricas.

\section{Generadores de historias}

Quizá el más antiguo sistema generador de textos es el libro del I Ching, el libro de adivinación basado en un sistema binario, las dos caras de las monedas que se arrojan de manera aleatoria y se pueden crear combinaciones que permiten encontrar leyendas que se aplican a la solución de una inquietud.

\footnotetext{
${ }^{514}$ Véase: http://www.sociedadlunar.org/blog/literaturaymaquinas/2011/01/22/emmett-williams-delultimate-poem-al-ibm-poem-pasando-por-la-sinfonia-alfabetica/ Consultado: 06/06/20152
} 
Retomamos Cien mil millones de poemas, de Raymond Queneau, quien se dio a la tarea de construir una máquina literaria analógica que permitía a los lectores componer a voluntad cien mil millones de sonetos, siendo todos perfectamente correctos estructuralmente. El texto de Queneau se compone de diez sonetos de catorce versos cada uno, los cuales se pueden intercambiar entre sí ya que están presentados en tiras individuales de papel, y al efectuares las 1014 veces, lo convierte en una autentica máquina de fabricar poemas. Ya lo volveremos a abordar más adelante.

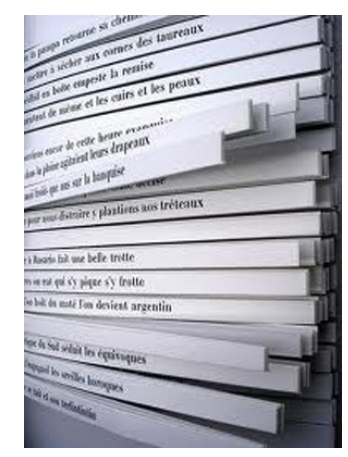

Pomelo < Grapefruit> de Yoko Ono ${ }^{515}$, produjo en 1962 una exhibición que mostraba instrucciones registradas en hojas de papel. Se trata de una obra visual llevada al terreno lingüístico. Un ejemplo:

\section{PINTURA PARA LOS CIELOS}

Hacer un agujero en el cielo. Recortar un papel del mismo tamaño que el agujero.

Quemar el papel.

El cielo debe ponerse azul puro.

Belén Gache, y los juguetes lingüísticos, “WordToys" presenta obras que parten de estrategias como la interactividad, las combinatorias de textos, el azar y el uso de instrucciones. Eugenio Tisseli, MidiPoet, pieza textual digital, una pantalla en la que los textos y las imágenes se recomponen y desfiguran en líneas, colores y formas visuales y auditivas. Otros referentes importantes dentro de las narrativas digitales son: Colectivo Dorkbot $^{516}$ y Eugenio Tisselli, Ambas caras de la moneda hacen el mismo ruido al caer, ofrece una pieza textual digital, una pantalla en la que los textos y las imágenes se recomponen y desfiguran en líneas, colores $y$ formas visuales $y$ auditivas. Synonymovie $^{517}$, es otra de sus obra que mediante variaciones algorítmicas, crea una película en la que combina palabras e imágenes, refleja la asociación conceptual que

\footnotetext{
${ }^{515}$ Véase: http://pomelo-yokoono.tumblr.com/ Consultado: 28/05/2012

${ }^{516}$ Véase sitio en Internet: http://dorkbot.org/ Consultado: 28/05/2012

517 Tisseli, Eugenio, Synonymovie, [sitio web] en:

http://collection.eliterature.org/2/works/tisselli_synonymovie.html Consultado: 28/05/2012
} 
emerge de la traducción de una palabra a una imagen que significa o evoca lo mismo. ${ }^{518}$; El proyecto Fantastic prayers de Tony Oursler, Stephen Vitiello y Constance DeJong ${ }^{519}$; Mark America presenta Grammatron ${ }^{520}$ (2000), un proyecto narrativo de dominio público que consiste en más de 1100 textos, 2000 enlaces y más de 40 minutos de audio original para generar estructuras narrativas hipervinculadas que señalan la manera cómo se componen, publican y distribuyen las historias en el era de la diseminación digital. Otra pieza textual digital es Filmtext $2.0^{521}$ una producción de vídeo, audio y textos que se trasladan por la pantalla, con diferentes entradas y textos que se desplantan al igual que mapas y diversos gráficos.

Algunos artistas de narrativas digitales que han utilizado los sistemas informáticos de combinatorios al mismo estilo del recorte de palabras oulipiano, el sistema aunque reproduce historias repetitivas, debe ser un sugestivo esquema para la propia composición de nuevos proyectos. Nannette Wylde ${ }^{522}$ Storyland, es una narrativa creada de manera aleatoria que genera historias a partir del tradicional "Érase una vez", con historias diferentes cada entrada. David Clark en 88 constellations for Wittgenstein (para ser interpretada por la mano izquierda ${ }^{523}$ ) es una pieza interactiva que explora la vida y filosofía de Ludwig Wittgenstein a través de un destello de imágenes, textos y viñetas que permiten la interacción con las preguntas que el filósofo formulaba en torno a la lógica, el lenguaje y el pensamiento y los límites del conocimiento. La mareadora, es un blog que genera de manera automática ciertos fragmentos que aunque nos son textos propiamente, pueden componerse en una pieza narrativa; cada día el sistema encuentra en Internet "es un pequeño script en PHP que busca frases que le gustan, marea las frases con mi receta mágica y cuando esta todo a punto, hago mi post ${ }^{\text {"524 }}$, el cual puede apreciarse en inglés y francés. Charles Cumming, escritor de novelas de espionaje y suspenso presenta en The 21 steps,${ }^{525}$ una historia que se construye a partir de mapas navegables: "Erase un hombre en un lugar incorrecto a la hora incorrecta", inicia una historia que se puede ir localizando visualmente en un mapa de google. El libro flotante de Caytran Dolphin ${ }^{526}$, sitio web que parte de un supuesto ejemplar de Estuario, un texto que resulta inaccesible en su versión original, por lo que su protagonista ha elegido algunos fragmentos que se combinan con otros [apócrifos] que los lectores pueden cambiar, todo puede modificarse de manera colectiva por los lectonautas, "al final un estuario es una entrada en tierra firme de un mar que se ramifica en distintos canales... que al final, aunque separados,

\footnotetext{
${ }^{518}$ Su obra puede apreciarse en sitio web: http://www.motorhueso.net/ Consultado:28/05/2012

${ }^{519}$ Véase sitio en Internet: http://awp.diaart.org/fp/ Consultado: 28/05/2012.

${ }^{520}$ Véase sitio en Internet: http://www.grammatron.com/bandwidth.html Consultado: 29/05/2012

${ }^{521}$ Véase sitio en Internet: http://www.markamerika.com/filmtext/ Consultado 28/05/2012.

${ }^{522}$ Sitio de Internet de la autora: http://preneo.org/nwylde/ Consultado: 28/05/2012.

${ }^{523}$ Sitio en Internet: http://88constellations.net/ Consultado: 28/05/2012.

${ }^{524}$ Véase sitio en Internet: http://mareadora.motorhueso.net/quien.htm Consultado: 28/05/2012.

${ }^{525}$ We tell stories, pueden consultarse otras 5 piezas narrativas: Slice, de Toby Litt; Fairy tales, de Kevin Brooks, Your place and mine, de Nicci French; Hard times, de Matt Mason \& Nicholas Felton y The (former) general, de Mohsin Hamid. Ficciones digitales de Penguin [sitio Web] en: http://wetellstories.co.uk/stories Consultado: 28/05/2012

${ }^{526}$ Valencia, Leonardo El libro flotante de Caytran Dölphin, Sitio en Internet: http://www.libroflotante.net/intro.htm Consultado: 28/05/2012.
} 
están conectados entre sí y forman parte del mismo mar narrativo. ${ }^{„ 527}$ Muchos y muy diversos proyectos engrosarán esta lista, qué sólo buscaba mostrar una muestra del amplio espectro creativo en torno a las historias y la tecnología.

La tecnología fue el detonante que permitió transitar del rollo al códice y luego al libro. En su migración, se cambiaron las estrategias lectoras y se ampliaron las posibilidades tipográficas y estructurales; en cierta manera el tipo de soporte condiciona el texto, en algunos casos gana y en otros pierde algunas cualidades. Con respecto a los medios digitales, han democratizado la lectura al ampliar el acceso el acceso a lecturas en varios formatos antes inimaginables. Las historias interactivas tienen el potencial para convertirse en formas artísticas del siglo XXI, están en camino de conseguirlo, aunque hay mucho por hacer en relación a los retos tecnológicos que involucren aspectos de diseño, estructuras narrativas que permitan encontrar los mecanismos de contar historias llenas de contenido y significado. Tenemos herramientas que deben complementarse con la lectura de textos literarios; historias conocidas pueden recomponerse con estos sistemas y generar otros nuevos. Apreciamos el interés que se refleja en la cantidad de proyectos y experimentos que tratan de abordar la posibilidad de narrar historias desde muy diversas ópticas. Dejarle el trabajo completo a un ordenador todavía dista de ser una realidad, si buscamos es que produzca textos de calidad; sin embargo nada evita que algún día sea posible. Seguramente ese día habremos perdido una de las habilidades más maravillosas que poseemos: inventarnos una historia.

\footnotetext{
${ }^{527}$ Valencia, Leonardo El libro flotante de Caytran Dölphin, Sitio en Internet: http://www.libroflotante.net/intro.htm Consultado: 28/05/2012
} 


\section{LOS JUEGOS NARRATIVOS DIGITALES}

Los juegos encontraron en las nuevas tecnologías un medio idóneo para evolucionar. Nuestro interés se centra en conformar un análisis histórico que dibuje el panorama en el cual los juegos digitales, de ordenador o de consolas, se vinculan con las historias al poseer cualidades narrativas significativas.

Los primeros juegos de ordenador demandaban la solución de enigmas a través de la interacción del jugador y el sistema informático, mediante el tecleo de palabras y textos que hoy día resultan rudimentarias en comparación con los avances que han conseguido los videojuegos actualmente. Pero sin duda, ésta fue la primera manera de cómo los ordenadores comenzaron a contar historias. A partir de los 90 's, gracias al Internet y al desarrollo de los sistemas, la evolución y mejora de los gráficos y demás aspectos técnicos han recorrido una incansable carrera experimental. En cierta forma, estas Aventuras conversacionales, estaban condicionadas a la escritura de textos que dan seguimiento a una estructura argumental que relata una historia. Aunque existen todavía actualmente, otros géneros se han vuelto más apreciados al incluir imágenes y otros recursos multimedia. Los cuales presentan gran complejidad en los videojuegos actuales.

Este asunto de la "narratividad" en los videojuegos ha despertado un amplio espectro de opinión; por un lado tenemos los que están convencidos de su dependencia al género narrativo y en el extremo opuesto están quienes lo niegan categóricamente, demandando la autonomía del juego. En este apartado presentamos un abanico de criterios, producto de esta nutrida discusión. Buscamos que la diversidad de perspectivas enriquezca nuestro entendimiento y nos permita encontrar los límites de colaboración de ambas posturas; la de los narratólogos que se muestran a favor de las historias dentro de los videojuegos y la visión de los ludólogos, que no lo admiten y sólo conciben el valor del juego en sí mismo.

A lo largo de esta investigación hemos retomado diferentes elementos y recursos que han sido producto de la fusión entre el juego y las historias. Eso nos permite confirmar la fructífera amalgama que se ha generado entre ambos, dando paso a nuevas formas de creación, representación e interacción entre escritores y lectores.

\footnotetext{
${ }^{528}$ WILSON, R. RAWDON, Palamede's shadow; explorations in play, game \& narrative theory, Northeastern University Press, Boston, 1990. (p.82)
} 
La relación entre el ordenador, los juegos y los textos tiene profundos orígenes, Dough Church $^{529}$ los define como la fusión tecnológica que involucra diseño, arte, audio, código y por supuesto; una historia por descubrir. Con los nuevos sistemas digitales se han ampliando las formas de creación hipermedial ${ }^{530}$. Además estamos convencidos que si experimentamos y exportamos ciertas cualidades de los juegos a las narrativas y viceversa; tenemos mayores y mejores oportunidades de creación. Al permitirnos productos más complejos y sofisticados como podemos apreciar tanto en algunos videojuegos o en muestras de ciberliteratura ${ }^{531}$. Cada día nos familiarizamos con sistemas más poderosos, pantallas con mejores resoluciones y más herramientas artísticas que mejoran la calidad de sonido, imagen y amplían las posibilidades de la interfaz. También debemos preparamos para generar mejores historias.

El videojuego cobró tal impacto artístico, económico y cultural que desde su aparición ha sido objeto de todo tipo de estudios y análisis. En un principio, este fenómeno, atrajo la atención de teóricos y estudiosos que buscaban su entendimiento a partir de la óptica de diferentes disciplinas como el cine, el teatro o la literatura. Se le aplicaron distintos tipos de teorías sociológicas, psicológicas, antropológicas o filosóficas con el fin de estudiarlo. Lo cual aunque resultaba interesante, no mostraba el verdadero ser del videojuego; por ello algunos ludólogos demandaron se emplearan sus propios métodos de estudio con el fin de desarrollar una teoría funcional que permitiera no sólo definir sus cualidades, sino mostrar sus potencialidades e influencias en la cultura digital contemporánea. Mark Wolf y Bernard Perron confirman cómo los videojuegos admiten la convergencia de múltiples perspectivas teóricas, esto debe verse como una riqueza y no como una limitante.

"The emerging field of videogame theory is itself convergence of a wide variety of approaches including film and television theory, semiotics, performance theory game studies, literary theory, computer science, theories of hypertext, cybertext, interactivity, identity, post-modernism, ludology, media theory, narratology, aesthetics and art theory, pshychology, theories of simulacra and others ${ }^{\prime \prime 332}$.

Deseamos revisar las diferentes posturas y la diversidad de perspectivas de análisis que el medio ha generado. Nuestra atención se enfocará en cuestiones relacionadas con las narrativas, reconociendo la aportación que ambas posturas de los narratólogos y ludólogos hacen y revalorando los méritos propios que los juegos poseen, así como las

\footnotetext{
${ }^{529} \mathrm{CHURCH}$, Doug, "Formal abstract design tools"; Gamasutra, Julio 16, 1999. [Texto on-line] en: http://www.gamasutra.com/view/feature/3357/formal_abstract_design_tools.php Consultado: 01/03/2012

${ }^{530}$ Entendido como aquellos soportes digitales que integran textos, imágenes, videos y audios.

531 "The writer's guide to making a digital living: choose your own adventure" (2008) [Texto on-line] en http://www.australiacouncil.gov.au/writersguide Consultado: 18/02/2012

${ }^{532}$ WOLF, Mark J.P. \& PERRON, Bernard, The Videogame theory reader, Routledge, New York, 2003. (p.2)
} 
cualidades de creación que ofrecen. El principal objetivo de esta tesis ha sido establecer un balance entre ludología y narratología, reconociendo la importancia de cada visión y considerando los beneficios que se pueden obtener, si consideramos el valor de las historias dentro de los videojuegos y el potencial lúdico que podemos añadir a las historias.

Buscamos determinar cuáles son las cualidades que se asemejan entre las narrativas y los juegos digitales; esto además de confirmar cuánto tienen en común; permitirá establecer ciertos parámetros de comparación a partir de una clasificación de cuatro elementos fundamentales que ambos poseen: elementos narratológicos, poéticos digitales, hermenéuticos y formales que revisaremos a detalle en lo que resta del estudio. 


\subsection{GENERALIDADES SOBRE LOS JUEGOS DIGITALES}

En este estudio utilizamos de manera indistinta los términos "juego digital" y "videojuego" siendo su sentido aquel que designa a ciertos sistemas de software creados para el entretenimiento; diseñados por medios digitales para ser reproducido por este mismo formato por la interacción entre una o varias personas a través de dispositivos electrónicos como ordenadores, consolas de Arcade, videoconsolas o dispositivos móviles personales. ${ }^{534}$

En apartados anteriores apreciamos el extenso y variado corpus de narrativas experimentales vinculadas al juego; en este, emigramos a la era digital y apreciamos cómo se ampliaron los recursos y las cualidades de los juegos y de las narrativas. Al respecto traemos de nuevo a colación que Janet Murray ${ }^{535}$ enlista cuatro cualidades que nos ofrecen los medios digitales: son sucesivos, porque nos permiten ejecutar una sucesión de órdenes o una secuencia de acontecimientos que vuelven los sistemas complejos y dependientes unos de otros. Son participativos, al permitirse codificar comportamientos de respuesta en los que los usuarios toman parte, es lo que conocemos como interactividad. Los entornos digitales son espaciales porque representan espacios navegables a través de los cuales es posible "moverse" y finalmente son enciclopédicos al considerar su gran capacidad de almacenamiento de información y de organización de la misma. Esto le confiere según Murray, un medio atractivo para la narrativa y una herramienta para los artistas que les ofrece la posibilidad de representar el mundo con amplitud y minuciosidad, contar historias desde distintos puntos de vista o construir historias entrecruzadas que formen una extensa red de posibilidades.

El videojuego ha transitado por un largo y fértil camino de experimentación en su medio siglo de existencia. Apreciamos notorios avances: basta contrastar los puntos en pantalla

\footnotetext{
533 JUUL, Jesper, A clash between game and narrative, a thesis on computer games and interactive fiction, Tesis de Maester, Institute of Nordic language and literatura, Universtiy of Copenhagen, 1999. [Texto online] en: http://www.jesperjuul.net/thesis/ Consultado: 06/06/2012.

${ }^{534}$ Los tipos de dispositivos móviles, teléfonos inteligentes, videoconsolas portátiles, tabletas digitales y agendas, cámaras, GPS y otros que cuentan con pantalla, conexión a la red, memoria y pueden llevar a cabo varias funciones.

${ }^{535}$ MURRAY, Janet H., Hamlet en la Holocubierta, el futuro de la narrativa en el ciberespacio, Paidós, Barcelona, 1999. (pp. 83-96)
} 
de Tennis for two ${ }^{536}$ (Higinbotham, 1958); al colorido visual y sonoro del Pac-man ${ }^{537}$ (Iwatani, 1980); hasta la complejidad visual, sonora y técnica de Prince of Persia (Broderbund, 1991-2010) o de Assassin's creed brotherhood ${ }^{538}$ (Dèsilets, Puel \& Jade Raymnond, 2010) Sólo por mencionar algunos. Será motivo de otro estudio profundizar en temas relacionados con la historia y evolución de los videojuegos o con las distinciones entre sus géneros o sus cualidades tecnológicas.

Enfoquemos la atención en las Aventuras textuales o Conversacionales, los cuales son juegos-relatos basados en retos que demandan la solución de enigmas a través de la interacción del jugador mediante el tecleo de palabras y frases textuales. Estas "Aventuras Textuales" también son designadas como "Ficciones Interactivas ${ }^{539 "}$ resultaron muy populares a fines de los $70 \mathrm{~s} \mathrm{y} 80 \mathrm{~s}^{540}$, gracias a los primeros ordenadores personales ${ }^{541}$.

El juego se consigue a partir de la interacción del usuario con el sistema; mediante dos modos de escritura: el "output" del sistema y el "input" 542 del jugador, quien dirige la acción del juego al introducir breves líneas de texto. Estos comandos son indicaciones que permiten la progresión del juego a partir de una estructura episódica similar a una historia. Las historias se van superponiendo y requiriendo la solución de enigmas, la toma de decisiones y la realización de acciones plasmadas mediante indicaciones textuales.

Estas historias presentan un guión narrativo seguido de un ">_l" que indica la necesidad de la participación del jugador, quien se ve obligado a escribir las acciones que desea llevar a cabo. Mediante una conversación un tanto rudimentaria con el ordenador; el jugador controla los personajes, abre puertas, explora espacios descritos textualmente, interactúa con objetos y resuelve algunos acertijos. Estos juegos aunque estaban limitados técnicamente y cabían en floppys de $51 / 2$, fueron las primeras historias interactivas. Posteriormente, durante los 90s se ampliaron los recursos multimedia y los sistemas siguieron su evolución y transformación, en una incansable carrera experimental que no tiene para cuando detenerse.

Estas Aventuras Conversacionales fueron apreciadas no sólo por ofrecer nuevas formas de narrar historias, sino además por permitirle al jugador participar activamente y asumir el papel de protagonista, mucho antes de poder llevar a cabo acciones cinéticas con los joysticks y otros dispositivos que pudiera manipular. En un principio, estas aventuras textuales eran géneros en sí mismos; hoy los videojuegos más sofisticados utilizan textos

\footnotetext{
${ }^{536}$ Véase: http://www.abadiadigital.com/articulo/tennis-for-two-el-primer-videojuego-de-la-historia/ Consultado: 16/02/2012

${ }^{537}$ Véase: http://pacman.com/en/ Consultado:16/02/2012

${ }^{538}$ Véase: http://assassinscreed.es.ubi.com/brotherhood/ Consultado: 16/02/2012

539 Ficción Interactiva es una historia en la cual eres el personaje principal y puedes explorar como si fueras un detective, un espía o un héroe.

${ }^{540}$ Véase: http://www.adventuregamers.com Consultado: 08/02/2012

${ }^{541}$ Las Aventuras textuales fueron diseñadas para los siguientes equipos: Amiga, Amstrad CPC, Apple II, Apricot, Atari 8-bit, Commodore (Plus 4, 64 y 128) Epson QX-10, Macintosh, Osbourne, PC, Tandy, TI99/4Am, TRS-80.

${ }^{542}$ Véase: Interactive Fiction [Texto on-line] en: http://en.wikipedia.org/wiki/Text_adventure Consultado: $17 / 02 / 2012$
} 
en forma de cut-scenes $^{543}$ y otros recursos que demandan la lectura. La importancia y valor de estos elementos textuales puede determinar que la historia se enriquezca o se vuelva un atorón agonizante para los jugadores.

Los diseñadores de textos deben llevar a cabo guiones textuales efectivos; con el fin de que la conversación no esté limitada a una historia lineal en la cual no hay mucho control sobre las situaciones; sino que presente la posibilidad de navegación en torno a varias posibilidades, o historias alternas bien conectadas y con varias posibilidades de desarrollo y desenlace. De ahí la necesidad de desarrollar tanto las estructuras arquitectónicas como los sistemas semióticos al diseñar narrativas para entornos digitales interactivos. Contemplamos las pantallas de algunas aventuras conversacionales con el fin de apreciar su mecánica, evolución y el eventual potencial que pueden desarrollar actualmente, gracias a recursos gráficos y sonoros.

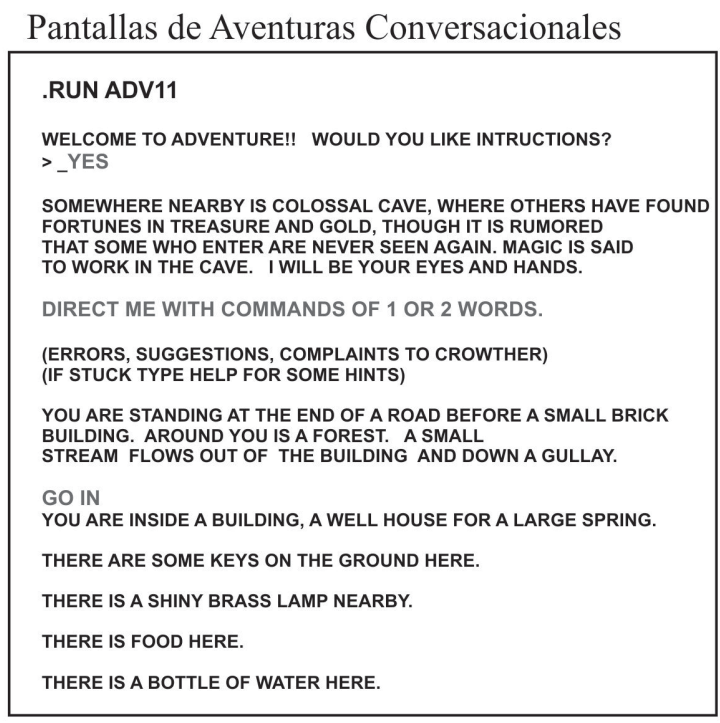

Collosal Cave adventure (1972)

West of House Score: 0 Moves: 3
ZORK I: The Great Underground Empire
Infocom interactive fiction - a fantasy story
copyright $\odot 1981$
West of House
You are standing in a onpen field west
of a white house, with a boarded front
door.
There is a small mailbox here.
> examine mailbox
The small mailbox is closed
> open mailbox
Opening the small mailbox reveals a leaflet.
> get leaflet
Taken.
>_l

Zork (1977)

Estos primeros juegos demandan a los jugadores aplicar su imaginación para irle dando forma a un tipo de historias. Como señala Marie Laure Ryan ${ }^{544}$, "comenzaron a soñar que había que desarrollar juegos que las personas quisieran jugar por la misma razón que leen una novela o van al cine." En cambio otros desarrolladores de juegos prefirieron hacer a un lado las historias y defendieron los juegos a partir del "gameplay" [jugabilidad] o el gusto de jugar, descalificando el poder de sus historias y del contenido.

Con el fin de apreciar la diversidad y calidad de algunos juegos, presentamos un listado referencial de juegos que a nuestra consideración, resultan piezas estimables de las cuales

\footnotetext{
${ }^{543}$ Textos que se desplantan para dar explicación u ofrecer información que puede leerse en letreros, libros, o cualquier objeto que aparece en el juego.

${ }^{544}$ RYAN, Marie-Laure., Avatars of story, University of Minnesota Press, Minneapolis, 2006. (Introduction, xvii)
} 
se pueden tomar ideas para armar otros tipos de textos, dado el grado de complejidad de sus argumentos. Las versiones originales de estos juegos posiblemente se puedan jugar si se conserva alguno de los primeros ordenadores; sin embargo, algunos juegos se pueden jugar en línea y otros se han adaptado versiones para sistemas actuales. El género como tal sigue vigente, existen desarrolladores como el grupo $\mathrm{CAAD}^{545}$ que siguen produciendo aventuras textuales contemporáneas on-line. Algunos títulos son: 15 meses y un dia ${ }^{546}$ (Jenesis, 2011); Transilvania Corruption, el amanecer de los vivos ${ }^{547}$ (KambreKat, 2010); 222 contra el cangrejo ${ }^{548}$ (Jarel, 2008); Venenarius verborum $^{549}$ (Jarel, 2008) y otros.

La primera aventura conversacional, Collosal Cave adventure (1972) [en la imagen anterior], fue desarrollada por William Crowther un espeleólogo que deseaba jugar con sus hijas y convirtió la experiencia de visitar una cueva en un mundo virtual creado por localizaciones en las que textualmente se explicaban las ubicaciones y los objetos circundantes y los jugadores interactuaban a través de teclear textos hasta conducirse por los diferentes caminos de la cueva y resolver enigmas. Don Woods amplió y mejoró el juego al introducir ciertos elementos fantásticos al agregar nuevas acciones; y el juego cambió de nombre a Adventure (1976) o ADVNT. A partir de ésta versión, se han desarrollado al menos una veintena de nuevas versiones ${ }^{550}$; en las cuales se han insertado recursos sonoros y visuales.

El otro gran pionero es Zork ${ }^{551}$ (MIT, 1977), fue uno de los primeros descendientes de Collosal Cave adventure; la calidad de la historia ${ }^{552}$ y la complejidad sintáctica del sistema hizo que fuera muy atractivo y apreciado. Es además el precursor de los juegos de mazmorras conocidos además como MUDs (originalmente, Multi User Dungeon); en el que el jugador es un aventurero cuya meta es encontrar los tesoros ocultos y regresar con vida, a su paso se encuentra con criaturas y objetos móviles que dificultan su misión.

La lista de las aventuras conversacionales ${ }^{553}$ pronto se nutrió de muchos juegos como: Adventureland (Scott Adams, 1979); The hitchhicker's guide to the galaxy (Adams \& Meretzky, Infocom: 1984); Leather Goddesses of Phobos (Steve, Meretzky, Infocom, 1986). El crecimiento exponencial del fenómeno permitió el surgimiento de compañías especializadas en el desarrollo de juegos como Sierra on Line ${ }^{554}$, Lucas films ${ }^{555}$ o

\footnotetext{
${ }^{545}$ Véase "Listado de aventuras conversacionales favoritas" en: CAAD, Club de Aventuras AD, sitio web: http://www.caad.es Consultado: 23/02/2012

${ }^{546}$ Para jugar on-line: http://www.caad.es/jenesis/online/15_meses_online.html Consultado: 23/02/2012

${ }^{547}$ Véase: http://www.aliensuavito.com/juegos.php Consultado: 23/02/2012

548 Descargue juego en: http://www.caad.es/?q=node/1495 Consultado:23/02/2012

${ }^{549}$ Descargue el juego en: http://iplayif.com/?story=http://caad.es/jarel/games2/venenariusverborum.z5 o a través de CAAD. Consultado: 23/02/2012

${ }^{550}$ DALENBERG, Russel, “Adventure family tree" (2004) en: http://www.mipmip.org/adv/advfamily.shtml Consultado: 22/02/2012

${ }^{551}$ Creado por Tim Anderson, Marc Blan, Bruce Daniels y Dave Lebling del MIT.

552 Para ampliar la información y conocer el script original del juego véase: http://www.thezorklibrary.com/history/00-resources.html Consultado: 24/02/2012

${ }_{553}$ Lista tomada de INFOCOM: http://adventure.if-legends.org/Infocom.html Consultado: 17/02/2012

${ }^{554}$ Véase: http://www.sierragamers.com/ Consultado:24/02/2012
} 
Infocom $^{556}$. No sólo los títulos se multiplicaron, además muchos ofrecían diversas versiones que se iban mejorando. El siguiente listado, más allá de agotar el tema, busca revalorar un género olvidado y que cuenta con guiones, muchos de los cuales son realmente muy originales y de calidad, otros serán una fuente creativa para desarrollar nuevas propuestas.

Recomendamos revisar estos títulos: Deadline (1982), Starcross (1982); Suspended, a Cryogenic nightmare (Michel Berlyn, 1983); The Witness (Stu Galley, 1983); Planetfall (Steve Meretzky, 1983); Infidel (Michael Berlyn \& Patricia Fogleman, 1983); Enchanter (1983), Sorcerer (1984), Seastalker (Stu Galley \& Jim Lawrence, 1984) Spellbreaker (1985); A mind forever voyaging (Steve Meretzky, 1985). El primer juego de ciencia ficción; Moonmist (Stu Galley \& Jim Lawrence, 1986); Hollywood Hijinx (Dave Anderson \& Cyr-Jones, 1986); Bureaucracy (Douglas Adams et al., 1987); Stationfall (Steve Meretzky, 1987); Amnesia (Thomas M. Disch, 1987); Border Zone (Marc Blanc, 1987); Sherlock: The riddle of the crown jewels (Bob Bates, 1987) el cual contaba con la novedad de contar con audio integrado; Journey (Marc Blanc, 1989) fue de los primeros gráficos de mapas de bits; Curses (Graham Nelson, 1993) considerado como el primer juego moderno. En la década de los noventa, a la par del naciente género de los videojuegos gráficos, surgieron algunos otros títulos de aventuras de texto: Gabriel Knight (Sierra on-Line, 1993: 1-3); So Far (Andrew Plotkin, 1996) Anchorhead (Michael s. Gentry, 1998), Photopia (Adam Cadre, 1998); y Galatea (Emily Short, 2000).y Slouching towards Bedlam (Star C. Foster \& Daniel Ravipinto, 2003) presentaba mejoras formales y funcionales.

A partir de los años 90s, con el progreso tecnológico nuevos géneros comenzaron a surgir y las aventuras conversacionales se enriquecieron con otros recursos multimedia: la introducción de imágenes, la memoria aumentada, los gráficos de mapas de bits de alta calidad y la evolución a los gráficos 3D. Surgieron otro género de juegos digitales: las Aventuras Gráficas, que tenían menos dependencia de un guión textual y que aprovecharon el desarrollo técnico del software ${ }^{557}$.

Las aventuras conversacionales se transformaron en aventuras gráficas. Predominaron los juegos de aventura de "apuntar y disparar", los videojuegos de roles enfocados a resolver problemas y las aventuras de intriga que exigían la exploración y la decodificación de acertijos para avanzar; otro género sería las novelas de aventura interactivas que emplean menús en pantalla como son el caso de Snatcher (1988) y Policenauts (1994); ambas de la empresa digital, Konami ${ }^{558}$; Where in the world is Carmen Sandiego?(1991), Dofus (2004), Darfur is Dying (2006) o Touch Detective (2006), los cuales utilizan diálogos que

\footnotetext{
${ }^{555}$ Véase: http://www.lucasarts.com/ Consultado:24/02/2012

${ }^{556}$ Véase: http://adventure.if-legends.org/Infocom.html Consultado: 17/02/2012.

${ }^{557}$ MONTFORT, Nick, The new media reader, The MIT Press, Cambridge, 2003. [se introducen las imágenes los gráficos de mapas de bits se transformaron en gráficos de alta calidad y la memoria de los sistemas aumenta]

${ }^{558}$ Véase: http://www.konami.com/ Consultado: 21/02/2012
} 
se desplantan, cut-scenes, mapas y la aparición de cualquier tipo de elemento que requiera ser leído: cartas, notas, letreros y cualquier otro recurso que integra un universo de ficción narrativa inmerso entre las acciones del juego.
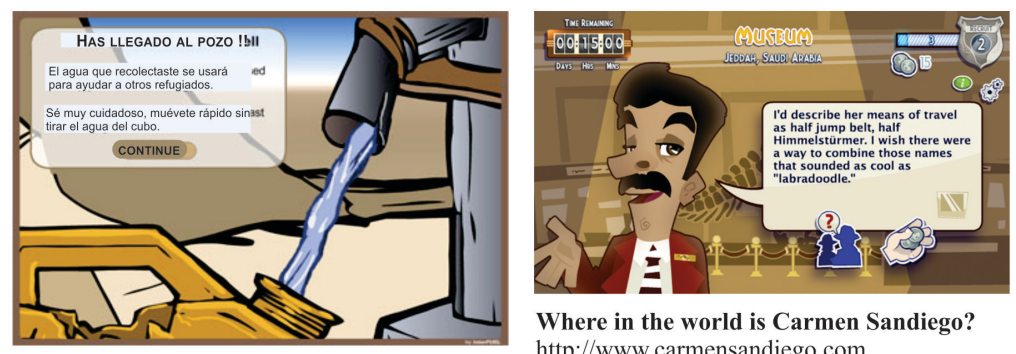

Where in the world is Carmen Sandiego?

Darfur esta muriendo

http://www.darfurisdying.com

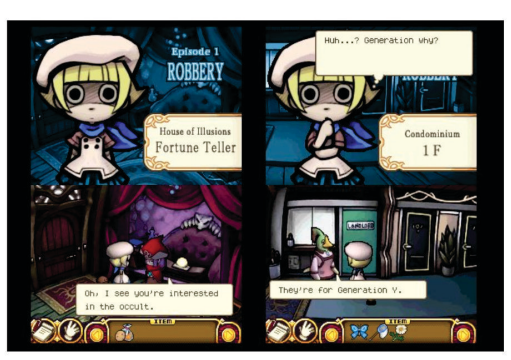

Touch Detective

http://www.atlus.com/touchdetective/

http://www.carmensandiego.com

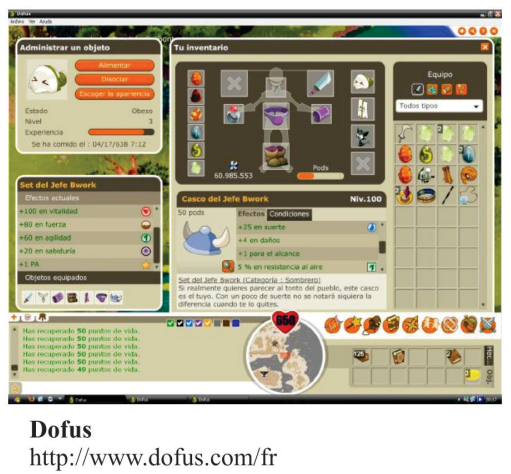

Mystery House $e^{559}$ (para Apple II) fue uno de los primeros en insertar gráficos dentro de una historia detectivesca inspirada en la novela And then there were none [ $Y$ no quedó ninguno o Diez Negritos] (1939) de Agatha Christie ${ }^{560}$; una trama que se adapta muy bien a la especificidad del medio, al igual que otras novelas de la misma escritora. El medio fue evolucionando y realizó adaptaciones de "apuntar-y-tirar" lo que volvió aún más atractivo a los juegos. ${ }^{561}$ Basta con revisar títulos de juegos como: The secret monkey island (Lucas Films, 1990: 1-3); Maniac Mansion: Day of the Tentacle (Dave Grossman \& Tim Schafer, 1993); King's Quest (Roberta Williams,1984: 1-6) The legend of Zelda (Miyamoto \& Tezuka,1986) o The longest Journey (Funcom, 2000) para apreciar su grado de desarrollo.

Existen juegos que pueden estimular a recomponer las historias con ciertos formatos lúdicos o "jugables". Algunos buenos ejemplos son la Abadía del crimen (1987), una de las primeras video aventuras diseñada por los españoles Paco Méndez y Juan Delcán.

\footnotetext{
${ }^{559}$ Mystery House, desarrollado por Ken y Roberta Williams a fines de los 70s

${ }^{560}$ AWE Games \& The Adventure Compay, publicaron un serie de videojuegos inspirados en las novelas de Agatha Christie: And then there were none (2005); Murder on the Oriente Express (2006); Evil under the sun (2007) y The Abc murders (2009).

${ }^{561}$ Pueden ejecutarse estos juegos en la actualidad con programas como ScummVm en: http:///www.scummvm.org Consultado: 17/02/2012. Existen programas que permiten escribir Aventuras de texto, véase: Ficción Interactiva en Wikipedia.
} 
Inspirado en El Nombre de la Rosa de Umberto Eco. El juego está diseñado mediante gráficos isométricos (primeros en presentar imágenes 3D) fue programado en 8 bits y cuenta con audio. La aventura se compone de siete días de intrigas y asesinatos por resolver inspirados en la trama de la novela de Eco.

Grim Fandango ${ }^{562}$ (Lucas Arts, 1998) es otra de las aventuras gráficas que demanda nuestra atención más que por su desarrollo gráfico o técnico, por su temática, diseño y argumento basados en la tradición prehispánica del culto a la muerte y en el trabajo plástico del grabador José Guadalupe Posada ${ }^{563}$. La cuestión histórica-antropológica que gira en torno a la festividad de los Muertos entre los pueblos Mesoamericanos así como el trabajo artístico del prolífico ilustrador, resultan ser elementos de mucha riqueza semiótica y gráfica para componer materiales, que pueden enriquecerse con el formato del juego. Grim Fandango fue de los primeros en utilizar gráficos en 3D. El jugador debe escuchar las historias, conversar con los personajes, examinar, seleccionar los objetos y usarlos correctamente para resolverlos a acertijos que se presentan a lo largo del juego. El interés particular reside en el humor y simpatía de los personajes, es notable.

Otro estupendo ejemplo es Myst III: Exile (2001), una aventura de juego de rol en la que el jugador asume el papel de un extranjero amigo de Atrus, quien posee el poder de crear vínculos a otros mundo a través de libros que escribe. La metáfora del libro como un portal de acceso a otros mundos resalta la importancia de las historias dentro de los juegos y sin duda resulta un motor interesante por desarrollar.

Con un estilo completamente diferente, Portal 2 (2011) presenta un juego del tipo de "apuntar y disparar" muy particular, con elenco de personajes que jamás imaginarías que existen. El juego rompen con las leyes de la física de manera que no pensarías fuera posible que sucediera, pero lo interesante es la historia expansiva que se crea a partir de este juego de tipo colaborativo. Ha sido uno de los juegos mejor evaluados, de todos los tiempos. Habrá que revisar las historias que pueden desprenderse.

¿Qué le pasó a las historias? Algunos teóricos (Murray, 1999; Salen, 2006) sugieren que fue la demanda comercial lo que obligó a producir más juegos de apuntar-y-disparar o de plataformas por lo que los diseñadores y las empresas no se esforzaron por ofrecer juegos con contenidos interesantes. Algunos desarrolladores comenzaron a defender la idea que la acción es lo más importante en los videojuegos, no su historia. ${ }^{564}$ Esta doble visión permanece hasta nuestros días, marcando dos posturas en torno al estudio del videojuego que analizaremos a detalle más adelante. Sin embargo sólo deseamos destacar el grado de desarrollo tecnológico que han llevado a tal nivel de perfección mediática a los juegos; que resulta interesante replantear la importancia de las historias y los contenidos a la par

\footnotetext{
${ }^{562}$ Véase: http://www.youtube.com/watch?v=AszsfF87E9c\&feature=player_embedded Consultado: $06 / 02 / 2012$

563 José Guadalupe Posadas, grabador e ilustrador mexicano del siglo XIX, mejor conocido por su Catrina, véase: http://www.artcyclopedia.com/artists/posada_jose_guadalupe.html Consultado: 21/02/2012

${ }^{564}$ Para ampliar listados de videojuegos se recomienda revisar los sitios de: Sierra on-line (http://www.sierragamers.com); Lucas Arts ( http://www.lucasarts.com); y los catálogos de juegos de: Meristation (http://www.meristation.com) y Moby Games http://www.mobygames.com Consultados: $21 / 02 / 12$
} 
del gameplay de los juegos. El auge en el desarrollo de los "Juegos Serios" 565 es solo una muestra de lo que han logrado desarrollar. El panorama de recursos para componer historias en los juegos resulta muy extenso: anécdotas, historias conocidas o desconocidas, argumentos de novelas, mitologías antropológicas de distintas culturas, sueños y cualquier otro producto creativo puede ser una inspiradora fuente de creación para diseñadores de textos en videojuegos. Nos sorprende apreciar que cuentan con una amplia y variada muestra textual integrada por diálogos conversacionales, mensajes codificados, aventuras en forma de rompecabezas, acertijos, menús en pantalla, e historias fabulosas.

Ciertos ejemplos muy originales como: The prisioner (1980) de David Mullich; Hampstead (1984) y Torremolinos (1985) de Trevor Lever y Peter Jones; The Colonel's bequest (1989) de Roberta Williams; Loom (1990) de Brian Moriarti; y King's Quest VIII: The mask of eternity (1998) de Roberta Williams.

El nuevo medio demanda autonomía; tanto por su avance técnico, sus complejos sistemas interactivos, mejores recursos audiovisuales y la disponibilidad de una nueva generación de consolas inalámbricas y portátiles, ${ }^{566}$ así como por su experimentación e innovación; los videojuegos se convirtieron en un fenómeno cultural que comenzó a cobrar su propia identidad, demandando legitimidad, oponiéndose a ser visto como una extensión de la narrativa. A partir del año 2000, proliferaron los estudios teóricos, que examinaban los aspectos formales de los videojuegos como: la inmersión, interfaces, jugabilidad ${ }^{567}$, estructuras, reglas, formas estéticas, interactividad y otros elementos esenciales que ampliaremos aquí mismo. En un principio, a falta de una teoría sobre el juego que delimitara sus cualidades, se retoma la narratología y otras disciplinas con el afán de definir el fenómeno del juego. "Echar mano de teorías propias de otras disciplinas ejerce un papel colonizador" según Markku Eskelinen ${ }^{568}$, quien rechaza entender los videojuegos como extensiones de medios anteriores: ya sea como formas evolucionadas del teatro, cine o televisión. Recomienda estudiar los videojuegos con teorías propias, sólo así se fortalece cada sistema y se traza el camino de las innovaciones. Además sugiere que estas descripciones teóricas sean heurísticas ${ }^{569}$ y propongan nuevas prácticas de composición.

\footnotetext{
${ }^{565}$ Véase TORTOLERO, Xochitl, El videojuego en la formación de sensibilidades creativas (2008) [proyecto de DEA] del cual surgió el interés de llevar a cabo una investigación que abordara el videojuego desde la óptica narratológica.

${ }^{566}$ El Nintendo DS apareció en 2004, la Xbox 360 en 2005; la Sony PlayStation 3 (PS3); el Wii de Nintendo, en 2006 y El Kinect, en 2010. Hoy en día, los videojuegos se encuentran en todo tipo de dispositivos personales.

567 Jugabilidad o GamePlay; entendida como la propia de la experiencia y calidad del jugador ante el juego.

568 ESKELINEN, Markku \& KOSKIMAA, Raine, "Towards a functional theory of media", Cybertext Year book, [Texto on-line] en: http://cybertext.hum.jyu.fi/index.php?browsebook=5 Consultado: 18/02/2012.

${ }^{569}$ Entendida como la capacidad de un sistema para realizar innovaciones positivas para sus fines o el arte-ciencia del descubrimiento, de la invención y de la solución de problemas mediante la creatividad y los caminos alternativos.
} 


\subsection{LOS JUEGOS DIGITALES DESDE LA ÓPTICA NARRATIVA}

La expansión de los ordenadores propició el auge de los juegos y también de los estudios teóricos. Nuestro objetivo en este apartado es ligar distintas teorías a las estructuras de los juegos y de las narrativas para detectar puntos de encuentro y desencuentro, con el fin de determinar las aportaciones que puede hacer uno a otro en los entornos digitales. En un primer momento, la teoría literaria fue otra de las disciplinas, que como la sociología, la psicología o la pedagogía, estuvieron interesadas en aportar una visión teórica y crítica a los nuevos productos digitales, como fue el caso de los videojuegos, con el fin de ampliar su entendimiento.

Nuestro interés atiende a la posibilidad de conocer cómo los estudios literarios pueden contribuir a desarrollar formas expresivas con mayor riqueza formal, de contenidos y con mayor interactividad e inmersión, valiéndose de las estructuras de los videojuegos; en una especie de colaboración interdisciplinaria y contemplando las propiedades que los sistemas digitales ofrecen. ¿Cómo podemos ayudarnos de la teoría para componer mejores historias dentro de sistemas digitales interactivos con cualidades propias de los videojuegos? Deseamos averiguarlo. Partimos de un hecho innegable, los juegos y las historias han cambiado en los últimos tiempos; influenciados por los entornos digitales, la cultura mediática o la interacción entre personas y ordenadores. Se han conformado nuevas tipologías que han enriquecido las posibilidades para crear, jugar y contar relatos, "Ambos han sabido ajustar y desarrollar formatos narrativos particulares" $" 571$. No sólo se han ampliado los canales de creación, difusión y adquisición de modelos narrativos; sobre todo se han perfeccionado nuevas herramientas de comunicación y expresión: "all facets of culture and cognition are shaped or determined by the tools we use to talk, ${ }^{, 572}$. Véase en anexos (pág. 274) una clasificación de juegos con el interés de apreciar su diversidad.

\footnotetext{
${ }^{570}$ MOULTHROP, Stuart, Pax, writing and change, [Artículo on-line] en http://www.electronicbookreview.com/thread/firstperson/terminal Consultado: 06/06/2012.

${ }^{571}$ MURRAY, Janet H., Hamlet en la Holocubierta, el futuro de la narrativa en el ciberespacio, Paidós, Barcelona, 1999. (p.62)

572 SHUT, Kevin, "Technology tells a tale: digital games and narrative", [Texto on-line] en:

http://www.digra.org/dl/db/05150.17157 Consultado:10/02/2012
} 
Las nuevas tecnologías, según lo han expresado Marshall McLuhan, Erik Havelock, Jack Goody y Walter J. Ong han generado un profundo impacto en la sociedad ofreciendo nuevos modelos culturales. Tres décadas antes de la aparición de los primeros juegos digitales $^{573}$ (1961), Walter Benjamin (1936) ${ }^{574}$ afirmó que el avance tecnológico propició la producción, reproducción y replicación de los medios de comunicación y que éstos medios ofrecían nuevas maneras de articular historias.

En esos mismos años surgieron los primeros entornos interactivos, las ficciones hipertextuales y los primeros sistemas artificiales para componer historias como: Eliza (1966) un charlarrobot [chatbot] conversacional o Afternoon $(1996)^{575}$. Estos sistemas de escritura automática se han multiplicado y por cuestión de espacio y atención nos resulta imposible abordarlos.

Por su parte, Michael Young reconoce que la narrativa: "holds a position of privilege in our minds, being a fundamental mode of understanding the worlds around us. ${ }^{576,}$ Confirmando las nociones de cosmoplasticidad a la que nos referimos en el apartado I. Homo Narrans, de este mismo estudio. Al aquilatar esa cualidad innata de convertir en historia todo lo que nos rodea, encasillamos a los videojuegos en el orden de las historias. Estudios sobre las posibilidades textuales en los videojuegos, es decir, desde una perspectiva narratológica comenzaron a germinar con los primeros trabajos de Brenda Laurel, en Computers as theatre (1993), quien fue la primera en proponer una "arquitectura" para la composición narrativa interactiva, resaltando sus cualidades de representación y participación de los usuarios y estableciendo una analogía entre el teatro y los ordenadores. Por un lado, Laurel sugiere que el usuario sea un intérprete activo y el ordenador sea un medio de comunicación que ofrece una visión "inmersiva" del mundo; semejante al teatro, argumentando que puede desarrollarse similar a la poética aristotélica (con un inicio, un desarrollo o clímax y un desenlace). Al igual que en el teatro, señala Laurel; algunas partes de la historia se vuelven "transparentes, dejamos de ser conscientes del medio y no vemos que es un libro impreso o una película, sólo sentimos el poder de la historia que cuenta"577. En cierta forma, entendemos que el lector debe "armar" esas partes transparentes de la misma manera como las acciones de un jugador van organizando un sistema de tramas que generan un argumento que va resultando un todo coherente. Esta es una manera de integrar historias en los juegos.

\footnotetext{
${ }^{573}$ Se consideran los primeros videojuegos, Tennis for Two (1958) de W. Higinbotham y Spacewar! (1961) de Steve Russell.

${ }^{574}$ BENJAMIN, Walter, The work of art in the age of its technological reproducibility and other writings on media, Harvard University Press, Cambridge, Ma, 2008. (p.226)

575 JOYCE, Michael, Afternoon, (1996) [Sitio web] en: http://www.eastgate.com/catalog/Afternoon.html Consultado:14/02/2012

${ }^{576}$ YOUNG, Michael "Crack in the fourth wall, digging into a humanistic phenomenon using computational models", AAIIDE 2010, [Sitio web] en: http://www.aaide.org Consultado: 14/02/2012

${ }^{577}$ LAUREL, Brenda., Computers as theatre, Adidson-Wesley Publishing Company, 1993.
} 
Otro importante teórico, Espen Aarseth ${ }^{578}$, en Cybertext, Perspectives on Ergodic Literature (1997), reconoce que existe cierta afinidad entre los videojuegos, hipertextos y la literatura generada por medios digitales. Confirma la idea de que son un medio que cuenta historias. Su enfoque parte de analizar aquellos sistemas que demandan cierto grado de participación del usuario-lector; determinando que una de las cualidades más apreciadas de los nuevos medios es su "ergodicidad" entendida como "la participación activa del lector" 579 . Aarseth plantea tres semejanzas entre juegos y ficciones: primero, permiten diferentes lecturas y distintos modos de juego; segundo, tanto el lector como el jugador deben tomar decisiones con el fin de que el juego y el texto cobren sentido y por último, sólo pueden hacerse en una secuencia lineal-temporal: "todo acto de lectura o de juego siempre es straight forward ...[Los textos] dan la idea de ser juegos laberínticos o mundos imaginarios en donde el lector explora a voluntad: se pierde, descubre veredas secretas, juega, sigue las reglas y más. " la idea de establecer un balance entre la producción de signos y la materialidad encargada de esa producción, el cual puede tomar forma de un juego narrativo que busca la espontaneidad, creatividad y ante todo, dotar de una estructura formal a las composiciones. Por último sugiere: "que aunque algo pueda ser presentado bajo forma narrativa, no implica que lo sea. ${ }^{, 581} \mathrm{Y}$ si un medio no es capaz de contar historias, resulta un medio inservible.

"Literature is a combinatorial game that pursues the possibilities implicit in its own material, independent of the personality of the poet, but it is a game that at a certain point is invested with an unexpected meaning, a meaning that is not patent on the linguistic plane... but has slipped in from another level ${ }^{\prime 582}$.

Otra investigadora pionera en el campo de las narrativas digitales es Janet H. Murray. En Su libro, Hamlet en la Holocubierta, el futuro de la narrativa en el ciberespacio $(1997)^{583}$, considera al ordenador como una herramienta tecnológica muy expresiva, que permite contar un nuevo tipo de narrativas ligadas a los videojuegos. Murray introduce el término cyberdrama y se interesa por describir el nuevo medio, contrastándolo a los formatos tradicionales de la literatura, cine o teatro.

\footnotetext{
${ }^{578}$ AARSETH, Espen J., Cybertext: Perspectivess on ergodic literature, The Johns Hopkins University Press, Baltimore, 1997.

${ }^{579}$ AARSETH, Espen J., Cybertext: Perspectives on Ergodic literature, The Johns Hopkins University Press, Baltimore, 1997. (p.4-5)

${ }^{580}$ AARSETH, Espen J., Cybertext: Perspectives on Ergodic literature, The Johns Hopkins University Press, Baltimore, 1997. (p.3)

${ }^{581}$ AARSETH, Espen J., Cybertext: Perspectivess on ergodic literature, The Johns Hopkins University Press, Baltimore, 1997. (p.3)

${ }^{582}$ CALVINO, Italo, citado por: AARSETH, Espen J., Cybertext: Perspectivess on ergodic literature, The Johns Hopkins University Press, Baltimore, 1997. (Prólogo)

${ }^{583}$ MURRAY, Janet H., Hamlet en la Holocubierta, el futuro de la narrativa en el ciberespacio, Paidós, Barcelona, 1999.
} 
Se da la tarea de determinar las cualidades de estos nuevos medios y de conocer cómo impactan en los usuarios. Parte de tres cualidades que resultan esenciales para entenderlos y componerlos; éstas son: Inmersión, entendida como el pretender ser o "creer ser"; Agencia [por la mediación de] es la capacidad de llevar a cabo acciones que tengan consecuencias o respuesta de interacción; y Transformación, la habilidad de moverse entre perspectivas múltiples y complejas; de manera que sea fácil la búsqueda, participación y modificación de sus estructuras.

Por su parte, Marie Laure Ryan ${ }^{584}$, ha enfocado principalmente su atención en la narratividad de los nuevos sistemas digitales y ha mostrado interés en establecer patrones para componer Narrativas Incrustadas [Embeded] en el sentido de que puedan establecer conexiones a varios niveles de complejidad. Consideremos que los creadores de textos digitales deben componer textos de una riqueza no sólo conceptual, al permitir establecer conexiones temáticas, sino además tener una especie de lecturas en "palimpsesto": a diferentes niveles de profundidad. Ryan asegura que el universo textual digital ofrece un material perfecto para el juego" 585. En Avatars of stories ${ }^{586}$ (2006) destaca la participación imaginativa del lector, otorgándole el poder de crear, armar y estructurar historias; algo que los nuevos medios, sin duda, favorecen.

A partir del segundo milenio, surgieron nuevos enfoques en torno a los juegos. Un parteaguas se plantea en los estudios que buscaban la autonomía del medio. La formalidad de los estudios buscaban concebir el fenómeno más allá de un mero entretenimiento: "Videogames are able to present worlds and ideas to us in new ways",587

En cierta forma, los estudiosos de los juegos digitales, demandaban legitimidad Per se y no por las cualidades propias de otras disciplinas (teatro, literatura, sociología, etc.) Los primeros en reconocer su autonomía fueron: Markku Eskelinen, The gaming situation (2001); Mark J.P. Wolf, The medium of the video game (2002); Barry Atkins, More than a Game (2003) y Jesper Juul, Half Real (2005) entre algunos otros que revisaremos a detalle en el siguiente apartado.

\footnotetext{
${ }^{584}$ RYAN, Marie-Laure., Narrative as virtual reality: Immersion and interactivity in literature and electronic media, The Johns Hopkins University Press, Baltimore, 2001. - Narrative across media; the languages of storytelling, University of Nebraska Press, Lincoln, 2004. - Avatars of story, University of Minnesota Press, Minneapolis, 2006.

${ }^{585}$ RYAN, Marie-Laure., Narrative as virtual reality: Immersion and interactivity in literature and electronic media, The Johns Hopkins University Press, Baltimore, 2001. (p. 176).

${ }^{586}$ RYAN, Marie-Laure., Avatars of story, University of Minnesota Press, Minneapolis, 2006.

${ }^{587}$ KONZAK, Lars, “Philosophical game design” (pp. 33-44) en: WOLF, Mark J.P. \& PERRON, Bernard, The Videogame theory reader 2, Routledge, New York, 2006.
} 
I've always had a hard time accepting the idea that games should aspire to tell better stories

Will Wright ${ }^{588}$

La literatura no es un solo tipo de acto de lenguaje, sino una galaxia de fenómenos discursivos o de modos de usar los textos José Angel García Landa ${ }^{589}$

\subsection{LUDÓLOGOS VS. NARRATÓLOGOS: HISTORIA DE UN CONFLICTO}

Dos epígrafes abren este apartado porque dos visiones se conjuntan; por un lado los juegos pueden contar mejores historias y por el otro, las historias demandan nuevos modelos textuales. A lo largo de este estudio hemos procurado establecer los vínculos posibles entre juegos y textos. Sin embargo conoceremos la postura de aquellos que no consideran que las historias sean parte fundamental de los juegos y rechazan esta potencialidad narrativa; nuestro objetivo es reconocer las cualidades particulares de los juegos y atender las opiniones que se han generado al respecto. Buscamos ampliar las nociones teóricas que se han desprendido de los teóricos y especialistas en el área, con el fin de completar y contrastar las nociones de juego tradicional y su carácter antropológico y cultural que revisamos en el apartado II. Homo Ludens que dedicamos a reflexionar en torno al juego.

A partir del 2001, comenzaron a plantearse marcadas diferencias entre ludólogos y narratólogos, fue a partir de esta fecha que los teóricos empezaron a conformar una especie de movimiento crítico anti-narrativo en defensa del videojuego; apoyados en métodos de estudio inherentes, y no como habíamos visto en el punto anterior, como extensiones del teatro, cine, televisión o literatura.

\footnotetext{
${ }^{588}$ Citado por: MURRAY, Janet, "From game-story to Cyberdrama", (pp. 2- 15) en: WARDRIP-FRUIN, Noah \& MONTFORT, Nick, (Eds.) First Person: New Media as story, performance and game, The MIT Press, Cambridge, 2004.

${ }^{589}$ GARCIA LANDA, José Ángel, Acción, relato, Discurso: estructura de la ficción narrativa, [Texto on-line] en: http://www.unizar.es/departamentos/filologia_inglesa/garciala/publicaciones/ard/4.Conclusion.html Consultado: 06/06/2012.
} 
Su interés era destacar la función del juego y defender sus posturas ante ciertos conceptos que en ocasiones no resultan del todo definidos o claros; porque, como podremos apreciarlo, en ocasiones resulta difícil diferenciar donde termina la historia y comienza el juego. Más allá de ampliar esta discusión y negar las opiniones de alguno de los grupos, hemos considerado, como principal motor de nuestra investigación, encontrar las consecuencias positivas de este conflicto. Más allá de la demanda de atención; despertó el interés de analizar las cualidades y potencialidades del videojuego. Esto provocó que los teóricos ampliaran y profundizaran su material de estudio, arrojando nuevos enfoques.

Estos enfoques se contemplan a partir de tres niveles que nos permiten establecer tres relaciones distintas: la del juego en sí; la relación entre el juego y el jugador; y finalmente, la correspondencia entre el juego y la realidad circundante. Considerando estos tres niveles de análisis; podemos determinar cómo se dan las condiciones narrativas en cada uno: entendiendo que es en el segundo nivel; el del juego y el jugador en el que la generación de historias es más representativo. Con esto tomamos nota para considerar mejorar o al menos explorar las relaciones entre las historias y los usuarios o jugadores, que en cierto punto son los "creadores" de historias. Independientemente de si el diseñador pretendía o no contar historias; siempre existirá una tendencia a volver las acciones entendibles a partir de algo similar a una historia. Nos falta revisar los otros dos niveles, en los que el jugar es la esencia del juego y por lo tanto, es el imperativo para los ludólogos, de quienes retomamos las siguientes opiniones.

\subsubsection{Opiniones Ludológicos}

Los ludólogos niegan a toda costa la presencia de historias en los juegos. El crítico más agudo, defensor de la independencia entre los juegos y las historias fue el finés Markku Eskelinen ${ }^{590}$ (2001). Reconocemos que su visión fue un detonante que impulsó e incrementó el corpus teórico del videojuego. Sus observaciones fundamentan la idea de desarrollar una Teoría funcional de los medios que permitiera no solo definir sus cualidades, sino engendrar o inventar nuevas prácticas estéticas y deshacernos de cierta parálisis limitante, referido a que se apoyen en otras disciplinas para el entendimiento y la validez del medio. Para ello sugiere conocer cómo funciona el videojuego, en tanto máquina que produce signos; signos que adoptarán nuevas formas que permitan conectar diversas expresiones culturales como historias y representaciones. Propone para ello generar una textonomía, entendida como una teoría que se ocupe del medio textual. Evitando así que se vean como extensiones de medios anteriores y sean estudiados por teorías ajenas.

Eskelinen admite que los textos existen dentro de los juegos, sólo que deben estudiarse por teorías ajustadas a las propiedades de los juegos y no a los de la literatura. Parte de la

\footnotetext{
${ }^{590}$ ESKELINEN, Markku, "Cybertext theory and literary studies", a user's manual" The electronic Book Review, 12 (2001) [Artículo on-line] en: http://www.altx.com/ebr/ebr12/eskel.htm Consultado: 20/05/2010.
} 
premisa de que es imposible considerar los mismos principios de la narratología impresa o aplicar las teorías dramáticas del hipertexto para definir los videojuegos. Por definición propia, "you won't argue that games are (interactive or procedural) narratives or anything even remotely similar. ${ }^{591 " ~ L o s ~ n u e v o s ~ m e d i o s, ~ a l ~ n o ~ c o n t a r ~ c o n ~ t e o r i ́ a s ~}$ particulares, han padecido una "colonización imperialista", como lo sugiere Eskelinen, a tal grado, que los narratólogos han sido incapaces de distinguir la finalidad del juego. Su famosa frase: "si te arrojo una pelota, no espero que comiences a contar una historia," no es más que el resumen de su descontento y la demanda por deslindar y darle a cada uno su propio espacio.

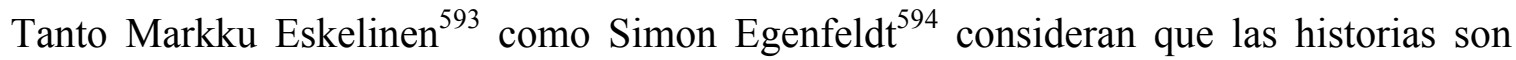
meros ornamentos que envuelven a los juegos y por ello resultan una pérdida de tiempo y energía estudiarlos desde esta perspectiva: esta cuestión la consideramos realmente despectiva; ya que nos ha tomado un par de docenas de hojas de este estudio, apreciar que las historias y los juegos no están tan desligados.

Los ludólogos defienden las cualidades estructurales y formales de los juegos, por ser, según ellos, más importantes que las historias que pueden contener. Jesper Juul enfatiza que resulta imposible traducir los videojuegos en un formato narrativo en el sentido tradicional o a la inversa. Gonzalo Frasca ${ }^{595}$ incluso planteó que "el modelo de contar historias además de ser inadecuado, limita el entendimiento del medio y la habilidad de crear juegos más irresistibles". Esto debido a que los juegos están basados en la simulación y poseen cualidades retóricas diferentes de las narrativas. En cambio, Michael Mateas $^{596}$ con cierta más tolerancia plantea la necesidad de generar una nueva narratología para las historias digitales interactivas.

El término "ludología", según Jesper Juul ${ }^{597}$, fue utilizado por primera vez por Mihaly Csikszentimihalyi ${ }^{598}$ (1982) en un artículo que examinaba las dinámicas particulares de los juegos. Posteriormente, fue popularizado por Gonzalo Frasca en “Ludology meets

\footnotetext{
591 ESKELINEN, Markku, "Towards computer game studies, Introduction: Ludology and Narratology" (pp.36-44) en: WARDRIP-FRUIN, Noah \& HARRIGAN, Pat Harrigan (eds.) First Person. Cambridge: MIT Press, 2004.

592 ESKELINE, Markku, "Towards computer game studies, Introduction: Ludology and narratology, [Artículo on line] en Electronic Book Review, 2004:

http://www.electronicbookreview.com/thread/firstperson/anticolonial?mode=print Consultado:

26/01/12.

593 ESKELINEN, Markku, “Cybertext theory and literary studies", a user's manual” The electronic Book Review, 12 (2001) [Artículo on-line] en: http://www.altx.com/ebr/ebr12/eskel.htm Consultado: 20/05/2010 (P.65)

${ }^{594}$ EGENFELDT N. Simon, HEIDE S. Jonas \& PAJARES T. Susana., Understanding Videogames: The essential introduction, Routledge, New York, 2008. (P.197)

595 FRASCA, Gonzalo, “Ludologists love stories, too: notes from a debate that never took place" [Artículo on-line] en: http://www.ludology.org/articles/Frasca_LevelUp2003.pdf Consultado: 12/02/2012.

${ }^{596}$ MATEAS, Michael, A preliminary poetics for interactive drama and games, (2001), Digital Creativity, Vol.12, No., 3 (pp.140-152)

597 JUUL, Jesper., Half-Real: Video games between real rules and fictional worlds, The MIT Press, Cambridge, 2005. (P.16).

${ }^{598}$ CSIKSZENTIMIHALYI, Mihaly, "Does being human matter-on some interpretative problems of comparative ludology" en Behavioral \& Brain Sciences 5, Núm.1, 1982.
} 
narratology" $" 599$ (1999) dentro del contexto del estudio de los videojuegos, buscando la autonomía teórica y conceptual; confirmando la importancia del juego en el propio juego. En la actualidad, el término ludología se utiliza para referirse a los estudios específicos de los juegos, desde su propio campo de análisis y no necesariamente referido a marcar una distinción frente a los estudios narrativos. Porque en cierto sentido esta discusión ha quedado un poco en el pasado. Motivados por la búsqueda de nuevas propuestas de generar mejores juegos, con todo tipo de recursos. Y porque el corpus teórico en torno a los juegos, ha enriquecido su reflexión y análisis.

Una de las más importantes justificaciones de los ludólogos era remontarse al origen antropológico de los juegos; enfatizando que éstos habían surgido antes que las historias $^{600}$ y por lo tanto al ser una manifestación humana más antigua, no debían asociarse a ningún otro fenómeno cultural. Visto así, los videojuegos son el producto de miles de años de evolución de un fenómeno cultural que tiene dependencia propia y no necesita que otro medio le de validez alguna.

"the adventure game is an artistic genre of its own, a unique aesthetic field of possibilities, which must be judged on its own terms" ${ }^{601}$.

Esta defensa fue respaldada por fundamentos que sostienen que los juegos no son laberintos estáticos como los hipertextos o la ficción literaria; en su lugar, son simultáneamente objetos y procesos; no pueden leerse: deben jugarse. Hay acciones que seguir y descripciones gráficas, tanto visuales como sonoras; pero no hay narración en el sentido estricto del término: con un narrador que organice de manera lineal los acontecimientos. En todo caso, es preciso retomar el concepto de narrativa ergódica ${ }^{602}$, ya que requiere la participación activa del lector en tres niveles: de acuerdo a su función interpretativa, configurativa y explorativa; mediante las cuales: manipula, participa e interactúa, respectivamente.

Espen Aarseth designa a los juegos digitales como "Ficciones Interactivas" y los considera sistemas formales de reglas, y no medios narrativos ${ }^{603}$. Por su parte en "Genre Trouble" ${ }^{\text {604 }}$ sugiere que la clave está en la estructura oculta de los juegos; la cual no es una estructura narrativa ni interactiva, sino por la simulación, otra cualidad muy importante que ofrecen los videojuegos y que tendremos muy pendiente en apartados

\footnotetext{
${ }^{599}$ FRASCA, Gonzalo, "Ludology meets narratology: similitude and differences between (video) games and narrative" (1999) [Texto on line] en: http://www.ludology.org/articles/ludology.htm Consultado: 24/01/2012

${ }^{600}$ Véase Parte II. Homo Ludens en este mismo trabajo para apreciar la relación de la humanidad con los juegos.

${ }^{601}$ AARSETH, Espen, Cybertext: Perspectives on Ergodic Literature, Johns Hopkins University Press,Baltimore, 1997.

${ }^{602}$ AARSETH, Espen, Cybertext: Perspectivess on ergodic literature, Johns Hopkins University Press, Baltimore, 1997. (p. 1)

${ }^{603}$ Citado por Gonzalo Frasca, citando a Markku Esdelinen y Espen Aarseth.

${ }^{604}$ AARSETH, Espen, “Genre trouble: narrativism and the art of simulation” (pp. 45-55) en: WARDRIPFRUIN, Noah \& MONTFORT, Nick, (Eds.) First Person: New Media as story, performance and game, The MIT Press, Cambridge, 2004.
} 
siguientes porque servirá como parámetro para la composición de guiones textuales, ya sea para diseñar juegos o cualquier otro tipo de texto.

Entre las cualidades que plantea Jesper Juul ${ }^{605}$ para apreciar en los juegos, están sus reglas y su gameplay; las primeras organizan las acciones y generan el sentido competitivo; mientras que el otro factor es el que involucra la interactividad del jugador, el cual dependen más de sus reglas que de la ficcionalidad o narratividad que pudiera tener el juego. Juul nos recuerda que los videojuegos toman elementos de los juegos tradicionales y que jugar es una experiencia de aprendizaje y desarrollo de habilidades y destrezas óculo-manuales, de memoria (para recordar los recursos y formas y modos de transitar), aumentan la imaginación, plantean retos. ¿Acaso no podríamos también sugerir que pueden desarrollar una destreza narrativa?

Otra distinción planteada por los ludólogos considera que las historias son las secuencias predeterminadas, en el sentido que su autor así las dispuso, y el lector las irá desentrañando con la lectura; en cambio si los juegos estuvieran predeterminados, no serían juegos en el sentido que los juegos se van "armando" a partir de la interacción del jugador. Sin embargo en un sentido formal, de su creación, ambos sistemas requirieron del diseño de un "guión" que el diseñador prepara y en el cual se plantean las acciones que el jugador puede jugar.

Ciertos elementos propios de la narratología, como el manejo del tiempo es otro elemento que según los ludólogos como Jesper Juul ${ }^{606}$ son diferentes. Este tema requiere de mayor atención y sobretodo, será diferente en cada juego en particular. Además, debemos señalar que partimos de que tanto los juegos como las narrativas pueden llevar a cabo diversos tratamientos temporales: el tiempo de la narración o del juego, el tiempo de la historia o del argumento o el tiempo que te da el sistema para terminar el juego.

Las múltiples "lecturas"; después de todo, ambos pueden leerse o jugarse en repetidas ocasiones, las repeticiones permiten circular por nuevos caminos, como en la lectura, encontrar nuevos sentidos.

También se consideran las diferencias entre el lector-espectador dentro del mundo de la historia y la relación del jugador y el mundo del juego. En el último caso, existe un cierto poder de interacción y control mientras que en el primero por más inmersión que exista, el lector no puede conducir a su antojo la historia. Aunque esto es relativo porque hemos visto ejemplos de literatura experimental en el apartado anterior en donde podemos jugar con las lecturas a pleno antojo.

El placer que se desprende de uno y otro son diferentes, Greg Costikian" ${ }^{607}$, dice que "el placer que deriva del juego no depende de su habilidad de contar historias". Por su

\footnotetext{
605 JUUL, Jesper, Half-Real: Video games between real rules and fictional worlds, The MIT Press, Cambridge, 2005. (p.19)

606 JUUL, Jesper, “Games telling stories?”, (pp. 219-226) en RAESSENS, Joost \& GOLDSTEIN, Jeffrey

(eds.), HandBook of Computer Game Studies, The MIT Press, Cambridge, 2005.

${ }^{607}$ COSTIKIAN, Greg, "Where Stories End and Games Begin" [Artículo on-line] en:

http://www.costik.com/gamnstry.html Consultado: 02/11/2011
} 
parte Kevin Shut ${ }^{608}$ afirma que: "la experiencia de jugar cualquier juego no debe ser una experiencia narrativa" sin embargo, ambos teóricos admiten que muchos juegos pueden contar historias, conciliando y limando las posturas radicales de los ludólogos.

Otro aspecto que se debe contemplar es el relativo a la interactividad del sistema. Existe un serio conflicto en torno a contar historias interactivas en tiempo real ${ }^{609}$. ¿Cómo poder contar algo sensato cuando se puede "brincar" de un lugar a otro? Realmente es un verdadero reto, estructurar de tal manera las historias que permitan establecer múltiples posibilidades de interconexión, guardando ante todo una coherencia y una historia interesante. Walter Freitag, diseñador de juegos confirma, como muchos otros, la dificultad de conciliar interactividad e historias. Jesper Juul, en sus primeros artículos ${ }^{610}$, establece que esto genera enormes problemas, afirmando que es posible que exista narración e interacción al mismo tiempo; siempre y cuando las historias cumplan ciertas normas que le permitan tener un valor estético, coherente y estructuralmente eficiente.

"To get a good story out of a game, you Have to constrain gameplay in a way that Ensures that a story is told through play" ${ }^{\prime 611}$

El resultado de estos desacuerdos y discusiones no ha producido elementos teóricos concretos y claros; en el sentido de que se establezcan parámetros bien definidos para su composición. Michael Mateas lo confirma: "The debate has been sterile, primarily abandoned with no satisfactory progress ${ }^{612,}$

Incluso ante las visiones más críticas; lo interesante sería que a partir de estas diferencias, se obtuvieran mejores maneras de articular juegos e historias.

Una de las finalidades de este trabajo es poder contribuir a crear mejores historias; historias que puedan contarse de mejores maneras o que permitan participar en armarlas mediante acciones similares a un juego. Will Hindmarch confirma, "Players enjoy the total narrative and creative freedom of writing their own novel" ${ }^{\prime 613}$. En cierta medida debemos aprender a construir historias pensando en un colaborador activo porque el entorno digital lo ha convertido también en un creador en potencia.

\footnotetext{
${ }^{608}$ SHUT, Kevin, "Technology tells a tale: digital games and narrative", [Artículo on-line] en: http://www.digra.org/dl/db/05150.17157 Consultado: 26/08/2011

${ }^{609}$ Este ha sido un interés prioritario en varios centros de investigación, que buscan conciliar el conflicto entre las narrativas interactivas, véase: ICIDS, International Conference on Interactive Storytelling, (20072011) [Sitio Web] http://icids.org Consultada: 28/01/2012

610 JUUL, Jesper, "A clash between game and narrative" (1998) [Artículo on-line] en: http://www.jesperjuul.net/text/clash_between_game_and_narrative.html Consultado: 26/01/2012 ${ }^{611}$ COSTIKIAN, Greg, "Games, storytelling and breaking the string" (pp. 5-14) en: HARRIGAN, Pat \& WARDRIP-FRUIN, Noah., Second Person, Role-Playing and story in games and playable media, The MIT Press, Cambridge, 2007. (p.6)

${ }^{612}$ MATEAS, Michael \& STERN Andrew, "Build it to Understand it: Ludology meets narratology in game design space", [Artículo on-line] en: http://users.soe.ucsc.edu/ michaelm/publications/mateasdigra2005.pdf Consultado: 24/01/2012

${ }^{613}$ HINDMARCH, Will, "Storytelling games as a creative medium" (pp.47-56) en: HARRIGAN, Pat \& WARDRIP-FRUIN, Noah., Second Person, Role-Playing and story in games and playable media, The MIT Press, Cambridge, 2007.
} 


\subsubsection{Opiniones Narratológicas}

El interés por las historias en nuestro entorno cultural se refleja en el cúmulo de reflexiones y estudios teóricos surgidos en torno a cuestiones relacionadas con la narrativa, los relatos y los discursos. Pudimos apreciar en el apartado I. Homo Narrans cómo los relatos han jugado un papel trascendente en la historia de la humanidad y son parte inherente de la experiencia humana, "nuestra vida está tejida de relatos: a diario narramos y nos narramos el mundo. ${ }^{614,}$

Bajo una perspectiva narratológica, también conocida como teoría narrativa, contemplaremos al conjunto de estudios y teorías que se han realizado a los relatos, particularmente a partir de los trabajos de los formalistas rusos, en especial, a partir de las funciones de los cuentos tradicionales de Vladimir Propp. Sin embargo, el análisis de las narrativas puede darse a diversos niveles: a partir de la relación en sí mismas; en relación con un lector y con respecto a su vínculo a un entorno. A partir de las tramas argumentales, las anécdotas o historias que desplantan, los textos, en menor o mayor medida poseen elementos narrativos que los jugadores van "armando", una especie de historias que descubren a lo largo del juego, es decir que van formulándose una explicación un tanto lógica, a partir de la secuencia de acciones de juego que irán dando sentido implícito y una forma parecida a una narrativa. Mientras juegan: intuyen, arman, organizan y van completando historias.

A lo largo de este estudio hemos utilizado de manera indistinta los términos historia, relato y narrativa. Apoyados en la definición de "historicidad" de Paul Ricouer ${ }^{615}$ apreciamos que la experiencia humana se expresa verbalmente mediante la narratividad; de ahí que encontremos equivalencias entre estos términos y podamos afirmar que sin historia no hay relato. Para definir qué son las historias, dada su complejidad, recurrimos a diferentes delimitaciones que permitan conformar una descripción más completa del fenómeno. Una idea inicial plantea que los relatos o narrativas son más que una secuencia de acontecimientos organizados en forma cronológica (uno tras otro), sino lógica: "uno a causa del otro"; elementos que se interconectan de manera causal entre sí. A través del manejo temporal, se ensamblan las partes del mismo; Gerard Genette ${ }^{616}$ sostiene que podemos identificar un relato porque existe una afinidad cronológica; le da tal importancia que define al relato como: "la representación de por lo menos dos acontecimientos o situaciones reales o ficcionales en una secuencia temporal". En su definición se suman las nociones de "ficción" y "realidad" que permiten calificar los

\footnotetext{
${ }^{614}$ PIMENTEL, Luz Aurora, El relato en Perspectiva, Siglo XXI editores, México, D.F., 1998 (Introducción) [fragmentos del texto on-line] en: http://www.Ipimentel.filos.unam.mx/sites/default/files/textos/introduccion-relato-prespectiva.pdf ${ }^{615}$ RICOUER, Paul, The narrative function, Hermeneutics and the human sciences, Cambridge University Press, Cambridge, 1981 (p. 294)

${ }^{616}$ Citado por PIMENTEL, Luz Aurora, El relato en Perspectiva, Siglo XXI editores, México, D.F., 1998 [fragmentos del texto on-line] en: http://www.Ipimentel.filos.unam.mx/sites/default/files/textos/introduccion-relato-prespectiva.pdf Consultado: 23/02/2012.
} 
acontecimientos a partir de su grado de verdad o verosimilitud en relación con el mundo conocido.

Otro elemento básico de los relatos, en su sentido ortodoxo, es la noción de narrador; una voz que relata la historia, según plantea Gerald Prince, ${ }^{617}$ es el elemento que permite mediar la historia. Dentro de la narrativa contemporánea existe una gran diversidad de posibles narradores que pueden relatar las historias desde diferentes perspectivas. Paul Ricouer, citado por Pimentel ${ }^{618}$, confirma la importancia del narrador, definiendo "narrativa", como "la construcción progresiva, por la mediación de un narrador, de un mundo de acción e interacción humanas, cuyo referente puede ser real o funcional". 619

Las historias no se definen por su extensión, ni por su temática; algunas abarcan desde las anécdotas más simples hasta cualquier texto. De hecho, contar historias es una posibilidad que comparten muchos medios de comunicación y expresiones culturales; como el cine, teatro, tiras cómicas, incluso la pintura, el ballet o un videojuego; en tanto poseen una estructura semio-narrativa. Richard A. Bartle ${ }^{620}$, sugiere que pueden ser "eventos reales o imaginarios que aparecen de manera parcial o totalmente desarrollados" y pueden tomar cualquier formato o medio para expresarlo.

Existen dos elementos básicos, indivisibles e interrelacionados, dentro de las historias: la información que transmiten o su contenido (qué se dice) y el discurso que utiliza (cómo se dice) que incluye no solo texto, diálogos, sino cualquier otro elemento gráfico, visual o auditivo que amplíe, complemente, refiera o proyecte dicho universo relatado. En relación al contenido y al discurso también existe una doble postura en torno a la influencia del lector, quien participa mediante un acto narrativo y a partir de su experiencia lectora, las historias son "re-creadas". Según apuntan Robert Scholles y Robert Kellogg ${ }^{621}$ esta función permite la correlación entre el mundo de la ficción que plasma el autor y el mundo que aprehende el lector. Son las imágenes que emanan a partir de la lectura, interpretación y experiencia-destreza lectora que permite enriquecer a diferente medida cada historia; permitiendo no solo su entendimiento, sino su conexión a otros modelos.

Sin embargo apreciamos cómo las narrativas se han venido componiendo bajo una gran diversidad formal y temática. La búsqueda por la experimentación de sus componentes ha

\footnotetext{
${ }^{617}$ PRINCE, Gerald, "Observaciones sobre la narratividad", Criterios, 29 (pp. 25-34) La Habana, 1991. [Artículo on-line] en: http://www.criterios.es/pdf/princeobservaciones.pdf Consultado: 20/12/2012. ${ }^{618}$ PIMENTEL, Luz Aurora, El relato en Perspectiva, Siglo XXI editores, México, D.F., 1998 (Introducción, p.4) [fragmentos del texto on-line] en: http://www.lpimentel.filos.unam.mx/sites/default/files/textos/introduccion-relato-prespectiva.pdf Consultado: 23/02/2012.

${ }^{619}$ PIMENTEL, Luz Aurora, El relato en Perspectiva, Siglo XXI editores, México, D.F., 1998 (Introducción, p.4) [fragmentos del texto on-line] en: http://www.Ipimentel.filos.unam.mx/sites/default/files/textos/introduccion-relato-prespectiva.pdf Consultado: 23/02/2012.

${ }^{620}$ BARTLE, Richard A., "Alice \& Dorothy play together," (pp.105-117) en: HARRIGAN, Pat \& WARDRIPFRUIN, Noah., Third Person, Authoring and exploring vast narratives, The MIT Press, Cambridge, 2009. ${ }^{621}$ SCHOLES, Robert \& KELLOG Robert, The nature of narrative, Oxford University Press, New York, 1966. (p.82)
} 
sido constante sobre todo si deseamos retomar el interés de ligarlo a los videojuegos, identificamos que ambos comparten ciertos elementos recurrentes como: tema, argumento, atmósfera, incidentes, conflicto, diálogo, complicación, desenlace y sin duda, personajes y acciones. La presencia de ciertos elementos como el ingenio, la penetración psicológica, la fuerza intelectual, imágenes que evocan la memoria y otros elementos y recursos más subjetivos; también pueden existir en relatos y en videojuegos.

¿Entonces, los videojuegos narran historias?

Responder que sí, nos colocaría en la necesidad de encontrar historias en juegos como Pac-man o Tetris. Lo cual con un poco de ingenio, podríamos hacerlo porque cualquier medio puede contar un cierto tipo de historia, ya sea por asociación a un evento imaginario o recontando como se jugó el juego; sin importar que sea convincente, aún así pueden considerarse como cierto tipo de relatos. Decir que no, estaríamos negando el potencial que el juego genera en torno a ser una máquina productora de historias. Al respecto nos enfrentamos a varios grados o niveles de apreciación; en un extremo tenemos la perspectiva pan-narrativista, que todo lo asimila y entiende a partir del valor y sentido que le confieren las historias; en un nivel "Intermedio", que contempla la posibilidad de que los videojuegos pueden derivarse de historias; reconociendo la influencia de la literatura y la tradición histórica-mitológica que ha nutrido la construcción de juegos fabulosos de aventuras, misterio, espionaje y más; y finalmente tenemos la visión "ludológica” que no admite que los juegos cuenten historias.

Es indiscutible, la literatura y los juegos comparten elementos y cualidades filosóficas, semióticas, narratológicas, estructuralistas, lúdicas, entre otras. Curiosamente, no existe experiencia humana que no sea contemplada bajo el crisol del juego o del potencial narrativo. De hecho en ocasiones son las historias las que le dan el calificativo de buen o mal juego. Aunque apreciamos que la calidad reside en muchos factores; existen buenos videojuegos con una historia interesante; otros muy malos con historias muy buenas y juegos estupendos con historias terribles. La calidad de las historias dentro de un videojuego depende de muchos factores creativos y de contenidos relacionados con la jugabilidad y participación del jugador.

En torno a estas ideas de juegos e historias han surgido un sinnúmero de opiniones; con el afán de apreciar y conciliar las diferencias y sobretodo, detectar el potencial que cada análisis ofrece; revisaremos lo que los críticos han dicho. Susana Pajares Tosca ${ }^{622}$ reconoce que al limitar nuestra visión y distanciar narrativas y juegos; ha impedido el desarrollo de otras posturas más productivas a la hora de entender cómo los videojuegos cuentan historias: entender lo que cada uno es; debemos tener una propuesta que nos permita obtener un beneficio; el beneficio de aprender a desarrollar juegos con

\footnotetext{
${ }^{622}$ PAJARES TOSCA, Susana, ¿Jugamos una de vampiros? De cómo cuentan historias los videojuegos., Comunicación no. 7, 1, 2009 (pp.80-91) [Artículo on-line] en:

http://www.revistacomunicacion.org/pdf/n7/articulos/a6_Jugamos_una_de_vampiros_De_como_cuenta n_historias_los_videojuegos.pdf Consultado: 28/02/2012
} 
contenidos más interesantes y complejos e historias con mejores cualidades formales y con recursos que tengan sentido e lúdicos e inviten al juego.

\subsubsection{Opiniones Integradas}

Ante todo, en este apartado del estudio buscamos establecer un balance entre ludólogos y narratólogos. Algunos teóricos como Jesper Juul ${ }^{623}$ plantearon ciertas visiones integradoras ante la postura de los ludólogos; argumentando que parte del conflicto era causado por la amplitud conceptual del término "narrativa". A todo le damos el calificativo de narrativa; incluso si no es similar a una forma tradicional, basta con que relate una historia para serlo. En 1999 Doug Church ${ }^{624}$ admitía que el problema se originaba al no existir un vocabulario propio de diseño de juegos y narrativas y la falta de herramientas para componer juegos. Actualmente existen muchos estudios teóricos y propuestas metodológicas para componer historias en medios interactivos o en videojuegos (Glassner, 2004; Salen \& Zimmerman, 2004; Dille \& Zuur Platten, 2007; Bateman, 2007; Handler Miller, 2008; Fullerton, 2008; Brathwaite \& Schreiber, 2009) Estos trabajos resultan una guía muy útil para determinar las cualidades que poseen los sistemas de juegos digitales que pueden enriquecerse con narrativas. La dificultad que hemos detectado es que diferentes conceptos, elementos y cualidades de los juegos se designan con los mismos términos, por lo que habremos de considerar más allá de un listado de términos, un listado de cualidades que poseen los videojuegos en relación a sus posibilidades narrativas.

Jonas Carlquist ${ }^{625}$ sugiere que los videojuegos conforman un género particular que puede ser "leído" como narrativa pero debe entenderse y discutirse por sus propios méritos. Drew Davidson ${ }^{626}$ afirma que el juego forma parte de la historia, de la misma manera como la historia se convierte en parte del juego. Cada medio ofrece una nueva experiencia narrativa y la posibilidad de entrelazar viejas y nuevas formas de contar historias. Los juegos deben analizarse desde las acciones del mismo, indudablemente éstas pueden ligarse a una historia; es lo que le da sentido al juego. De hecho los obstáculos en los juegos y las tareas por resolver, son una manera ingeniosa de construir

\footnotetext{
${ }^{623}$ JUUL, Jesper, “Games telling stories?” (pp. 219-226) en: RAESSENS, Joost \& GOLDSTEIN, Jeffrey (eds), HandBook of Computer Game Studies, The MIT Press, Cambridge, 2005.

${ }^{624} \mathrm{CHURCH}$, Dough, "Formal abstract design tools", Gamasutra, July 16, 1999 [Texto on line] en: http://www.gamasutra.com/view/feature/3357/formal_abstract_design_tools.php Consultado: $1 / 03 / 2012$

${ }^{625}$ CARLQUIST, JONAS, "Playing the story; computer games as a narrative" genre, HUMAN IT 6.3 (2002): (pp. 7-53) [Artículo on Line] en: http://etjanst.hb.se/bhs/ith/3-02/jc.pdf Consultado:20/10/2011 ${ }^{626}$ DAVIDSON, Drew, Stories in between, narratives and mediums @ play, CMBook, [texto on-line] en: https://portal.acm.org/purchase.cfm id=1503495\&CFID $=25468422 \&$ CFTOKEN $=44521682$ Consultado:13/01/2012
} 
una historia. Otros teóricos como Marie-Laure Ryan ${ }^{627}$ y Julian Kücklich ${ }^{628}$, apuntan cómo mejorar el videojuego a partir de la narrativa, considerando que la ludología puede ser una amenaza al desarrollo de mejores videojuegos. Después de todo, un ludólogo como Gonzalo Frasca, ${ }^{629}$ admitió que a los ludólogos les encantan las historias, y con esta afirmación, el debate se marchitó aún más.

¿Acaso no podrían mejorarse los juegos con mejores narrativas? ¿Qué motiva a los investigadores a buscar en los videojuegos una vena narrativa?, ¿Atribuirle cualidades narrativas a los videojuegos demerita en algo su valor lúdico? ¿Hasta qué punto las cualidades lúdicas pueden enriquecerse con estructuras narrativas?

Nuestro estudio ha transitado por un amplio panorama cultural e histórico en donde el juego y las historias han estado indisolubles; nuestro objetivo ha sido destacar la importancia del juego para la narrativa y el valor que la narrativa ofrece al juego; ambos se enriquecen mutuamente y pueden favorecer el diseño de otros medios que requieran encontrar nuevas maneras de contar historias; finalmente detrás de todo puede existir una historia que debe enriquecer cualquier proyecto artístico o cultural.

De ninguna manera resaltar las cualidades narrativas debe verse como un demérito de las cualidades lúdicas de los juegos. Al contrario, muchos juegos de manera admirable, siguen patrones similares a los que hemos conocido en películas o novelas, no sólo su temática y contenidos. Además el medio ofrece cierto potencial, inexistente en otro medio: el poder que le confiere la interactividad de los jugadores con las historias. E1 jugador cobra mayor interés para entender los conflictos y la toma de decisiones. Will Hindmarch ${ }^{630}$ además sugiere que durante el juego, se llevan a cabo tres tareas narrativas interconectadas; primero se contextualizan las acciones; segundo, se mantiene una tensión dramática a lo largo del juego y tercera, la historia cobra su rumbo a partir de las decisiones que el jugador toma. La interconexión entre todos los elementos pretende fortalecer el potencial de los diseñadores de narrativas, que reconocen el valor no sólo de contar historias, sino de jugar con ellas; Jonas Carlquist ${ }^{631}$ recuerda que jugar con un videojuego no se trata de leer una historia sino de jugarla.

\footnotetext{
${ }^{627}$ RYAN, Marie-Laure., Narrative across media; the languages of storytelling, University of Nebraska Press, Lincoln, 2004.

${ }^{628}$ KUCKLICH, Julian, "Literary theory and digital games" (pp.95-111) en: RUTTER, Jason \& BRYCE, JO (eds.), Understanding digital games, Sage Publications, Thousand Oaks, 2006.

${ }^{629}$ FRASCA, Gonzalo, "Ludologists love stories, too: notes from a debate that never took place" [Artículo on-line] en: http://www.ludology.org/articles/Frasca_LevelUp2003.pdf Consultado: 12/02/2012

${ }^{630}$ HINDMARCH, Will, "Storytelling games as a creative medium" (pp.47-56) en: HARRIGAN, Pat \& WARDRIP-FRUIN, Noah., Second Person, Role-Playing and story in games and playable media, The MIT Press, Cambridge, 2007. (p. 54)

${ }^{631}$ CARLQUIST, JONAS, "Playing the story; computer games as a narrative" genre, HUMAN IT 6.3 (2002): (pp. 7-53) [Artículo on Line] en: http://etjanst.hb.se/bhs/ith/3-02/jc.pdf Consultado:20/10/2011
} 
Doug Church, interesado en conocer y aplicar las herramientas adecuadas para componer juegos, aprecia el valor de las historias para los diseñadores y dice:

"Story is another abstract tool used in various ways across

all game styles... story refers to any narrative thread that is continued throughout the game $e^{\prime \prime 632}$

Debemos ver que más allá de "enredarnos" en la discusión de narratólogos y ludólogos debemos encontrar la manera de avanzar y utilizar las diversas visiones para mejorar el armado de nuestras historias. Will Hindmarch lo sugiere así:

"Storytellers running pre-scripted stories are giving up the best aspects of both hobbies, the freedom of storytelling and the puzzle-like layered narrative of interactive fiction ${ }^{\prime 633}$

Por ello en el siguiente apartado revisaremos las herramientas que podemos echar mano para llevarlo a cabo.

${ }^{632} \mathrm{CHURCH}$, Doug, "Formal abstract design tools", Gamasutra, July 16, 1999 [Artículo on-line] en: http://www.gamasutra.com/view/feature/3357/formal_abstract_design_tools.php Consultado:12/03/2012

${ }^{633}$ HINDMARCH, Will, "Storytelling games as a creative medium" (pp.47-56) en: HARRIGAN, Pat \& WARDRIP-FRUIN, Noah., Second Person, Role-Playing and story in games and playable media, The MIT Press, Cambridge, 2007. (p. 54) 


\subsection{CUALIDADES ENTRE NARRATIVAS Y JUEGOS EN ENTORNOS DIGITALES}

En este apartado deseamos confirmar que las narrativas y los juegos no sólo pueden ser complementarios sino que comparten ciertos elementos que enriquecen sus posibilidades de diseño y creación. Para ello enlistamos ciertas cualidades que consideramos comparten tanto los videojuego y las ficciones y que permiten encontrar sus semejanzas, definirlos, entenderlos y componerlos. Esperamos que este listado de cualidades comunes a ambos, se traduzca en una especie de "herramientas" útiles para componer cualquier tipo de texto en medios digitales; que sirva como punto de partida, facilitando el diseño de guiones, relatos, historias o cualquier otro tipo de texto que pueda ser autónomo o acompañar cualquier proyecto artístico o videojuego.

Buscamos componer juegos narrativos significativos e innovadores. Sabemos que tenemos a la mano medios digitales muy complejos y poderosos que deseamos aprovechar; por ello deseamos conocer su potencial. Apreciaremos que los nuevos medios no son tan diferentes a los medios anteriores (cine, televisión, novelas) sino que representan con nuevos recursos muchos de los elementos que los medios tradicionales utilizaban: nos invitan a evadir la vida común y adentrarnos en mundos creados dentro de límites específicos de tiempo y espacio; nos ofrecen reglas de participación e interpretación que admitimos libremente y nos ofrecen recompensas gratificantes al transmitirnos ciertos grados de satisfacción o de emoción.

Las historias desde sus orígenes han migrado a todo tipo de medios y sistemas; su evolución y adaptación no se ha detenido, ni lo hará jamás. Cada nuevo medio le ha otorgado nuevas posibilidades de adaptarse a nuevos formatos y favorecerse de sus recursos.

"We must look at each system as a potentially different technical medium, with aesthetically distinct consequences" ${ }^{\prime \prime 35}$

\footnotetext{
${ }^{634}$ ESKELINEN, Markku, “Cybertext Theory: what an english profesor shoud know before trying” [Texto onlin] en: http://www.electronicbookreview.com/thread/electropoetics/notmetaphor?mode=print consutlado: 31/01/2012
} 
En su migración a la digitalización, las historias han ganado cualidades que deseamos explorar y recursos por experimentar para componer textos significativos e innovadores. Deseamos además adoptar algunos recursos propios de los videojuegos porque consideramos que ciertos procedimientos experimentales lúdicos, pueden transformar y expandir las opciones de los videojuegos e historias; fortaleciendo las estructuras narrativas; insertando temas, ampliando las intrigas y aportando nuevos tratamientos que los enriquezcan.

Tanto las narrativas como los juegos son sistemas complejos que integran una diversidad de elementos. Con el fin de facilitar nuestro análisis, partimos de una visión global que aprecie ambos sistemas a diferentes niveles de composición. Hemos detectado algunos elementos comunes y los hemos clasificado en base a cuatro aspectos fundamentales: Elementos Narratológicos, Poéticos, Hermenéuticos y Formales. Esta clasificación se basa en la de Julian Kucklich ${ }^{636}$ quien contempla "elementos estéticos, hermenéuticos y poéticos"; en nuestro trabajo sustituimos "estético" por "narratológico" e incluimos un cuarto aspecto, el elemento "formal" o estructural; por considerarlo otra herramienta que debe atenderse. Estos cuatro aspectos se subdividen a su vez en otros elementos que a continuación expondremos. Una vez identificados y definidas sus cualidades, esperamos extender sus nociones a aplicaciones experimentales en proyectos concretos; sin duda nuestro interés atiende a la necesidad de guiar las labores de diseño de textos, al ofrecer lineamientos que se pueden considerar y atender, aprovechando los recursos de los nuevos medios, de las herramientas de juegos y aplicarlos de maneras novedosas. Como dice Henry Jenkins ${ }^{637}$, debemos adecuar las posibilidades de distintos medios y aplicarlos de maneras innovadoras para promover la composición.

Debemos echar mano del potencial de cada medio; en relación a los medios digitales, su potencial de creación se ha ampliado al invitar al usuario a participar activamente: la interacción ha replanteado nuevas reglas de composición, no sólo para los juegos y las narrativas; contamos con sistemas en los que los usuarios se vuelven co-creadores, aportando su propia visión de interpretación y recomposición, transitando por múltiples posibilidades entre estructuras ramificadas o imbuidas que les permiten tomar elecciones de avance. Es importante considerar cómo los diferentes elementos propios de juegos y narrativas se han enriquecido gracias a los sistemas digitales. Volviendo a nuestras cuatro líneas de análisis en narrativas y juegos, explicamos que entendemos por cada una. En el caso de los Elementos Narratológicos consideramos aquellos elementos contenidos dentro de los sistemas textuales. Aquellos que integran y favorecen la composición de narrativas en su sentido estricto (personajes, escenarios, narradores, etc.) Conocerlos permitirá entender de qué manera intervienen en la construcción de textos narrativos. Apreciaremos cómo los mitos, los acontecimientos históricos, la literatura y otros medios

\footnotetext{
${ }^{635}$ AARSETH, Espen J., Cybertext: Perspectivess on ergodic literature, The Johns Hopkins University Press, Baltimore, 1997. (p.79)

${ }^{636}$ KUCKLICH, Julian, "Literary theory and digital games", (pp.96-111) en: RUTTER, Jason \& BRYCE, JO (eds.), Understanding digital games, Sage Publications, Thousand Oaks, 2006.

637 JENKINS, Henry, "Game design as narrative architecture" [Artículo on-line] en: http://web.mit.edu/cms/People/henry3/games\&narrative.html Consultado: 02/11/2011.
} 
como el cine, el teatro y otros similares, pueden ser fuente de inspiración para generar textos.

Dentro de los Elementos de Poética Digital, apreciaremos los recursos propios de los nuevos sistemas digitales como la interactividad la inmersión y otros que se desprenden. Deseamos entender la "Poética" de los nuevos medios y determinar qué cualidades son aptas para contar mejores historias y qué recursos tenemos para hacerlo.

En el apartado de los Elementos Hermenéuticos revisaremos la función semiótica de los signos que integran los textos; la participación del usuario-lector es de gran importancia. Gracias a los sistemas interactivos, la participación activa de los "juganarradores" quienes han desarrollado destrezas para armar las historias de diversas maneras, a partir de su participación activa el poder de su imaginación y de los retos que el sistema le presente que debe traducir en estrategias mentales.

Finalmente en el apartado de los Elementos Formales, revisaremos qué mecanismos existen para organizar los elementos dentro de un texto; por un lado contemplamos las estructuras "arquitectónicas" que nos permiten armar las secuencias de acontecimientos de maneras que puedan facilitar la interactividad de los hipertextos para armar las diferentes veredas de lectura y juego de los elementos textuales y conocer qué reglas gobiernan y organizan estos elementos.

\subsubsection{Elementos Narratológicos}

Los elementos narratológicos son considerados como la materia prima que nos ayuda a crear textos. Se apoya en teorías lingüísticas y literarias para determinar sus componentes y las relaciones entre éstos. Partimos de la noción de "texto" que ofrece Mieke Bal y de su listado de elementos:

"A text is a finite structured whole composed of signs. These can be linguistic units, such as words, sentences but they can also be different signs such as cinematic shots and sequences, or painted dots, line and blots"1638

Con el fin de facilitar el estudio de los elementos narrativos que integran los textos, Mieke Bal distingue tres niveles de análisis: el nivel de los textos, de la fábula y de la historia. 1. EI Texto Narrativo es el medio que se usa para relatar la historia, se trata del sistema de signos lingüísticos, visuales como las imágenes y cualquier otro elemento que sirva para ese propósito. 2. La Historia es el contenido o lo que trata el texto. Y 3. La Fábula es la manera como se estructura la historia, es como se organizan los eventos de acuerdo a un orden lógico o cronológico. Estos elementos a su vez se componen cada uno de diversos objetos. A continuación prácticamente los enlistamos; esperando desarrollar sus características en el apartado siguiente.

\footnotetext{
${ }^{638}$ BAL, Mieke, Narratology; Introduction to the theory of narrative, University of Toronto Press, Toronto, 2009. (p.5)
} 
A nivel del Texto Narrativo; consideramos un Agente Narrativo o narrador, quien relata la historia y Los Elementos No Narrativos que se presentan a manera de diálogos, descripciones y otros formatos del discurso como textos imbuidos y todos los recursos empleados para relatar la historia.

A nivel de la Historia contamos con varios elementos que nos permiten estructurar tanto el texto narrativo y la fábula, es decir, lo que se dice y la forma cómo se dice; para ello contamos con el manejo del Tiempo; los textos, al igual que teatro, el cine, la música y los videojuegos son artes basadas en tiempo; las historias implican un manejo particular del Orden Secuencial de los acontecimientos, los cuales presentan cierta dirección y el manejo de recursos como la alteración del orden cronológico de los acontecimientos (anacronía); las anticipaciones y el manejo temporal o atemporal (acronía) de los periodos de las historias. Otros elementos de la historia son el Ritmo y la Frecuencia; el primero refleja la velocidad y fluidez para relatar los acontecimientos y emplea recursos como las elipsis, pausas y las desaceleraciones. Y la segunda, presenta una relación entre los eventos de la historia y cómo se organizan en la fábula. La historia se compone además de Personajes que llevan a cabo las acciones y de Espacios, en donde suceden las acciones. También se presenta una visión de la historia que se conoce como Focalización, que presenta el punto de vista y una manera particular del autor de ver y presentar los hechos y eventos a pesar del género que elija para hacerlo como: el suspenso, la aventura, el romanticismo y más.

Finalmente a nivel de la Fábula, se contemplan los Eventos que intervienen y las relaciones que existen entre ellos: selecciones, cambios, elecciones o confrontaciones. Los Actores, o personajes ${ }^{639}$, determinar los tipos de eventos que se suceden y las funciones que se desarrollan. Esto estará muy relacionado con los tipos de Tiempos, en relación a su duración, interrupciones, paralelismos y una organización secuencial lógica de los acontecimientos en relación a sus actores.

Todos estos elementos integran la composición de cualquier historia; la cual parte de una serie de acontecimientos interrelacionados y/o consecuentes a partir de las acciones que los agentes o personajes llevan a cabo. Éstas se presentan a partir de un estado inicial que en cierto momento producen un cambio, del cual se desencadenan otra serie de eventos que conducen una o más de una historia a un determinado lugar. Chris Bateman ${ }^{640}$ sugiere que las historias en los videojuegos son un tipo de flujo que puede separarse de la mecánica del juego y contarse como una narración. Puede asociarse al modelo "del Viaje del Héroe" lo cual facilita armar los acontecimientos, explorar el espacio y entender las funciones de los personajes, es a través de las ideas del viaje del héroe de Joseph Campbell $^{641}$, abordado también por Christopher Vogler ${ }^{642}$ quienes plantean que el viaje

\footnotetext{
${ }^{639}$ BATEMAN, CHRIS (ed.), Game writing narrative skills for videogames, Game Development Series, IGTA, Charles River Media Publishing \& Course Technology, Boston, 2007. (pp.27-41)

${ }^{640}$ BATEMAN, CHRIS (ed.), Game writing narrative skills for videogames, Game Development Series, IGTA, Charles River Media Publishing \& Course Technology, Boston, 2007.(p.2)

${ }^{641}$ CAMPBELL, Joseph, The hero with a thousand faces, Joseph Campbell Foundationd \& New World Library Press, Novato, 2008.
} 
del héroe puede verse como una serie de principios que gobiernan el mundo de las historias: existencia en el mundo común; el llamado a la aventura; la negación de la llamada; el encuentro con el mentor; cruce del primer umbral; pruebas, aliados y enemigos; acercamiento a la cueva más recóndita; terrible experiencia; recompensa.

Si analizamos los videojuegos bajo los parámetros anteriores, apreciamos que comparten muchos elementos con las narrativas, que están en mayor o menor grado desarrollados; pero sin duda son elementos que se pueden considerar para componer mejores mundos de ficción. Porque estamos convencidos que los videojuegos pueden generar mejores mundos de ficción, invitando al jugador a organizar y reconstruir las historias. Estas herramientas resultan valiosas; reto es generar historias lo suficientemente estructuradas y flexibles para que puedan convertirse en historias para ser jugadas. Basta considerar su relación con los entornos interactivos, tal como Simon Egenfeldt dice:

"Their concerns thus mirror some of the most important theoretical discussions that we have examined: about how to make a story compatible with the interactive needs of a game and the clear relationship between the quality of a videogame's story and the player experience". ${ }^{643}$

\subsubsection{Elementos de Poética Digital}

Otro grupo de elementos que aportan recursos útiles a la composición de textos y videojuegos, provienen de sus cualidades intrínsecas, es decir, de aquellas inherentes a los medios digitales. Se trata de la Transtextualidad o la capacidad de adaptarse y experimentar nuevas formas de edición, expresión y transmisión; es decir de cómo se adaptan a partir de ciertos géneros, como novelas, mitos, acontecimientos históricos o cualquier anécdota o asunto. Además apreciamos: La Interactividad e Inmersión que ofrecen nuevas maneras participativas de armar las historias; y los Sistemas Emergentes que contemplan la Agencia, los Sistemas Abiertos, las Narrativas Imbuidas, y una Retórica Tecnológica.

\section{Transtextualidad}

Las historias pasan de un medio a otro a través de una cualidad que designamos como Transtextualidad. La cual ha sido un recurso para dotar de temas, muy utilizado en la

\footnotetext{
${ }^{642}$ VOGLER, Christopher, The writer's journey; mythic structure for writers, Michael Wiese Productions, Studio City, 2007.

${ }^{643}$ EGENFELDT N. Simon, HEIDE S. Jonas \& PAJARES T. Susana., Understanding Videogames: The essential introduction, Routledge, New York, 2008. (p. 194)
} 
industria del videojuego, ya sea apoyándose en novelas, historias, mitologías y en una gran diversidad de géneros literarios: ciencia ficción, combate, intriga, fantasía o terror ${ }^{644}$. Algunos casos sólo toman como excusa los títulos o parte de sus temas para convertirlos en plataformas de acción. En otros casos, la literatura ha inspirado juegos como: Age of Mythology, Tomb Raider, Harry Potter, Zork, Doom, Wolf3D ó el Príncipe de Persia. Nos enfrentamos a "ficciones jugables" que estimulan a re-componer partes de las historias que las incubaron. Basta apreciar And then there were none de Agatha Christie para apreciar las adecuaciones de un texto literario y convertirlo en un buen juego. Existen ciertos títulos en donde no por compartir el título dé una pieza narrativa de calidad, el juego presente las acciones y estrategias de juego de manera óptima, así como el manejo de los símbolos y otros elementos narratológicos de las novelas que les inspiraron; la posición de algunos teóricos y diseñadores señalando que su intención no es contar historias puede producir que se descuiden los contenidos. En cambio, si los diseñadores pusieran más empeño en armar historias coherentes, divertidas e interesantes; además de presentar acciones de juego y estrategias ligadas a historias, los juegos cobrarían nuevos sentidos y mejores cualidades que amplíen su valía. Como el caso de juegos basados en acontecimientos históricos o mitologías como: Caesar Games ${ }^{645}$, Age of Empires ${ }^{646}$, Sudden Strike ${ }^{647}$, o Rise of Nations ${ }^{648}$.

Este tipo de juegos nos dan la posibilidad de armar la historia, explorar los acontecimientos y situar una aventura no sólo cronológica sino geográficamente; ofreciendo un potencial de creación. Por ejemplo, en Assasin's creed Brotherhood ${ }^{649}$ se aborda el rescate de Leonardo da Vinci por los templarios; el tema en sí, ofrece una carga de información semántica que permite reconstruir parte de la historia a partir de los eventos observados en el juego, asociarlo a datos históricos, información cultural o ligarlo a cuestiones filosóficas es parte de revestir las acciones de los juegos y volverlos historias.

Otros juegos inspirados en guiones históricos o mitologías épicas son: Civilization $^{650}$ (Sid Meier, Micro Prose, 1991); Caesar III Heaven ${ }^{651}$ (David Lester, 1992) y juegos de estrategia como Heroes of Might and Magic ${ }^{652}$ (Olivier Ledroit, New World Computing, 1990); Command and Conquer ${ }^{653}$ (Westwood Studios, 1995); Warcraft ${ }^{654}$ (Blizzard Entertainment, 2004). Existen además muchos otros juegos que poseen ciertas referencias a historias de manera superficial o anecdótica.

\footnotetext{
${ }^{644}$ Ver listado Moby games; http://www.mobygames.com

${ }^{645}$ Véase: http://caesar4.heavengames.com/ Consutlado:14/03/2012

${ }^{646}$ Véase: http://ageofempiresonline.com Consutlado:14/03/2012

${ }^{647}$ Véase: $\mathrm{http://www.suddenstrike.com} \mathrm{Consutlado:14/03/2012}$

${ }^{648}$ Véase: http://www.riseofnations.com Consutlado:14/03/2012

${ }^{649}$ Véase: http://assassinscreed.es.ubi.com/brotherhood/ Consutlado:14/03/2012

${ }^{650}$ Véase: http://www.civilization.com/ Consultado: 16/02/2012

${ }^{651}$ Véase: http://caesar3.heavengames.com/info/lester-q.shtml Consultado: 04/03/2012

${ }^{652}$ Véase: $\mathrm{http}: / /$ mightandmagic.es.ubi.com/HeroesV_toe.php Consultado: 16/02/2012

${ }^{653}$ Véase: http://www.commandandconquer.com/ Consultado: 16/02/2012

${ }^{654}$ Véase: http://us.battle.net/wow/es/ Consultado: 16/02/2012
} 
A pesar de que los jugadores aprecien las historias, entendemos que juegan no por sus argumentos, sino por el gusto de la emoción del juego; sin embargo, como afirma MarieLaure Ryan ${ }^{655}$ son los elementos narrativos los que atraen y motivan a los jugadores. Esta idea, conectada a la creación artística, nos conduce a considerar y replantear la vasta fuente de inspiración y motivación que los escritores y diseñadores pueden encontrar en obras literarias, históricas e incluso en experiencias vivenciales. Lo más fascinante de armar historias dentro de sistemas interactivos con reglas, como los juegos, es poder contarlas y jugarlas de manera simultánea. Un buen ejemplo inspirador es el juego online de Los trabajos de Hércules en el cual "deben llevar a cabo las mismas 12 tareas del héroe, si tienen éxito sobrevivirán en la red y posiblemente se vuelvan inmortales" ${ }^{656}$ Las buenas historias se vuelven inmortales así como los buenos juegos inspirados en buenas historias.

\section{Interactividad}

El término "interactividad" se usa en muchos campos y generalmente designa cierta influencia por parte de un usuario. Deseamos enfatizar que en todo texto o historia existe cierto nivel de interactividad; ya que cualquier medio pretende que exista cierta interconexión con la audiencia. Antes de los ordenadores existía una diversidad de medios que favorecían estas prácticas de interacción entre los lectores y las historias; por ejemplo Charles Dickens publicó sus novelas por entregas en diarios londinenses; atendiendo las inquietudes de sus lectores. Hoy la interactividad es un recurso de los medios digitales. Nuestro interés es determinar el potencial que los sistemas interactivos otorgan al servicio de la creación de juegos y narrativas. Para ampliar esta idea, Espen Aarseth $^{657}$ añade que lo más innovador de los videojuegos, es el manejo espacial (cómo es posible la movilidad dentro del juego) y la manera cómo los objetos se interrelacionan entre sí y con el jugador. La movilidad por los diferentes espacios del juego y la manipulación de sus elementos, son dos elementos de gran innovación y también unos de los mayores retos a los que se enfrentan los diseñadores de textos. Por su parte, Simon Egenfeldt, plantea la relación entre narrativa e interacción; debate que está abierto y en busca de mejores maneras de articularlos.

\section{"If designers are able to truly integrate stories into the game, how can narratives ever be fully engaging if they always have to offer the player the possibility of sinning? And how can artificial intelligences ever become interesting fictional characters? All these questions are derived front the ongoing debate of interaction versus narrative ${ }^{\prime \prime 65}$.}

\footnotetext{
${ }^{655}$ RYAN, Marie-Laure., Narrative across media; the languages of storytelling, University of Nebraska Press, Lincoln, 2004. (p.333)

${ }^{656}$ Véase: http://www.the12labors.com Consultado: 16/02/2012

${ }^{657}$ Espen Aarseth se refiere a la tipología de los cibetextos y contrasta la función del usuario en la literatura, teatro y cine frente a la de los videojuegos, mientras los primeros tienen una función interpretativa, en cambio los segundos la tienen configurativa. En ciertos casos configuramos para interpretar; mientras que en otros, como en los videojuegos, configuramos para interpretar, denotando una posición dinámica del usuario frente una posición estática del arte y los medios antes mencionados. El juego se ve como una práctica configurativa y la situación del juego como una combinación de fines, significados, reglas y acciones que se manipulan.

${ }^{658}$ EGENFELDT N. Simon, HEIDE S. Jonas \& PAJARES T. Susana., Understanding Videogames: The essential introduction, Routledge, New York, 2008. (p. 197)
} 


\section{Inmersión}

La inmersión se refiere a un estado mental en donde una persona está completamente absorta por lo que está haciendo. Para los jugadores, el mundo real deja de existir y el mundo del juego se convierte en su realidad. Kendall Walton sugiere que los videojuegos funcionan como una proposición de Inmersión-Simulación [Make-believe]. Esta cualidad estimula la imaginación y propicia que el usuario se sienta parte del sistema. Simon Egenfeldt ${ }^{65}$ incide en que una de las razones principales para jugar es la posibilidad de convertirse en alguien más y poder controlar las acciones de un personaje, vivir y sentir sus aventuras. Hay mucho por experimentar para vincular de manera óptima las narrativas y la interactividad; encontrar la forma de articular las historias para que se consigan historias interactivas de calidad; es un asunto que se ha atendido por mucho tiempo, y esto lo confirma:

\footnotetext{
"The real issue is not the shortcoming of narrative techniques with respect to their utility in game design, but the lack of techniques genuinely suited for interactive media ${ }^{660}$ "
}

La inmersión puede establecerse a cuatro diferentes niveles: imaginativo, sensorial, cognitivo y emocional. Al respecto James Wallis ${ }^{661}$ afirma que de la misma manera como la mente busca patrones abstractos y reconoce un rostro conocido; la imaginación encuentra patrones de eventos y los convierte en una historia. Buscamos en historias y en juegos una fuente de talento que nos ayude a imaginar mundos diferentes del que conocemos. La simulación permite la libre exploración y la inserción a dimensiones internas de juegos e historias. Las historias transmiten más que meros hechos causales, también emanan ideas, pensamientos, sentimientos e información muy diversa.

De manera similar pintores, artistas, escritores, o jugadores echan a andar su imaginación frente a un texto o un juego. Johan Huizinga le llama a esto "Círculo Mágico"662 y se refiere a la existencia, fuera de la realidad, en una dimensión de tiempo y espacio a la cual los sistemas invitan a sus usuarios o lectores a introducirse. La inmersión propicia la intensificación y extensificación de las emociones, esto último lo planteó Janet Murray y Brenda Laurel $^{663}$, como una de las propiedades de las narrativas interactivas. Las emociones también pueden ser un motor para generar historias; traemos a colación el

\footnotetext{
${ }^{659}$ EGENFELDT N. Simon, HEIDE S. Jonas \& PAJARES T. Susana., Understanding Videogames: The essential introduction, Routledge, New York, 2008. (p. 193)

${ }^{660}$ KREIMEIER, Bernd, "The case for game design patterns" Gamasutra, March 12, 2002. [Texto on-line] en: http://www.gamasutra.com/view/feature/4261/the_case_for_game_design_patterns.php Consultado: 28/02/12

${ }^{661}$ WALLIS James “Making games that make stories” (pp. 69-80) en: HARRIGAN, Pat \& WARDRIP-FRUIN, Noah., Second Person, Role-Playing and story in games and playable media, The MIT Press, Cambridge, 2007. (p. 69)

${ }^{662}$ Citado por BECKER, Katrin, "The invention of good games: Understanding learning design in commercial video games" (Tesis doctoral) University of Calgary, 2008. (p. 61) [Texto on-line] en: http://www.minkhollow.ca/becker/papers/becker_thesis.pdf Consultado: 26/08/2011

${ }^{663}$ Citado por MATEAS, Michael \& STERN Andrew, Build it to Understand it: "Ludology meets narratology in game design space", [Artículo on-line] en: http://users.soe.ucsc.edu/ michaelm/publications/mateasdigra2005.pdf Consultado: 24/01/2012 (p. 141)
} 
Sistema de IA, Mexica, mencionado anteriormente, para generar textos digitales de forma automática generado por Rafael Pérez ${ }^{664}$; basado en las emociones que generan los textos y de ahí se va desencadenando una secuencia narrativa gracias a la interacción del usuario y donde el sistema toma decisiones a partir de las emociones. Es un buen ejemplo que servirá para apoyar en el diseño de historias con mejores contenidos y en donde las decisiones estén relacionadas con ciertos sentimientos que muevan a los personajes y sus acciones hacia diferentes posibilidades de historias, considerando además el manejo eficiente de las destrezas sensoriales y la integración de retos mentales que intensifican el grado de inmersión de los usuarios. También es una buena propuesta para conciliar historias coherentes con sistemas interactivos; lo cual merece más atención en futuros trabajos de literatura digital.

\section{Sistemas Emergentes}

Otros elementos que nos permiten entender la poética de los sistemas digitales tiene que ver con los Sistemas Emergentes. Lo entendemos como la capacidad que tienen los usuarios, jugadores o lectores de armar de manera personal las historias que de manera fragmentada o parcial adquieren de una lectura o un juego. La noción de "Emergencia" se refiere, según Chris Crawford ${ }^{665}$ a la aparición o surgimiento de sistemas complejos que pueden producir comportamientos aún más complejos. La complejidad del sistema por sí solo no garantiza que se generen historias de calidad, es necesario trabajar, armar los elementos y entender los principios básicos de ambos sistemas, de los juegos y de las narrativas para estructurarlos. Para Katie Salen y Erik Zimmerman ${ }^{666}$, la emergencia es una faceta crucial para entender cómo el sistema de un juego se vuelve significativo para los jugadores; para ampliar el concepto, Jesper Juul ${ }^{667}$ considera que la emergencia incluye situaciones que no fueron contempladas por el diseñador; otorgándole al jugador la libertad de jugar utilizando varias estrategias; es la aplicación de diversas entidades de diferentes niveles, todos interconectados; es una propiedad relacionada con la interacción del sistema. Sin duda una de las cualidades más destacadas de los juegos es la posibilidad de permitirle al jugador crear sus historias. Juegos como Sims $^{668}$ o Half life ${ }^{669}$ son oportunidades para contar "Narrativas emergentes", experiencias que consigue el jugador con las que puede contar historias sobre el juego. Los sistemas emergentes contemplan cuatro aspectos fundamentales: primero, la variabilidad que posibilita varios estados, sesiones y niveles, que las reglas del juego permiten. Segundo, los patrones de juego que se generan a partir de las estrategias que se deducen a partir de las reglas del juego.

\footnotetext{
${ }^{664}$ PEREZ, Rafael \& SHARPLES, Mike, "Three computer-based models of storytelling: BRUTUS,MINSTREL and MEXICA", [texto on-line] en:

http://www.Isri.nottingham.ac.uk/msh/Papers/MEXICA\%20KBS.pdf Consultado: 06/07/2010

${ }^{665}$ CRAWFORD, Chris., Cris Crawford on interactive storytelling., New Riders Press, Berkeley, 2005. (P.137)

${ }^{666}$ SALEN, Katie \& ZIMMERMAN, Eric, The game design reader: a rules of play anthology, The MIT Press, Cambridge, 2006. (p. 159)

667 JUUL, Jesper., Half-Real: Video games between real rules and fictional worlds, The MIT Press,

Cambridge, 2005. (p. 82)

${ }^{668}$ Véase: http://www.thesims.com Consultado: 12/03/2012

${ }^{669}$ Véase: http://orange.half-life2.com/ Consultado: 12/03/2012
} 
Tercero, las posibilidades de combinación están determinadas y finalmente, la novedad o sorpresa que combina sus elementos de maneras nuevas.

La riqueza de los elementos digitales incluye la interconexión de elementos visuales, auditivos, narrativos e historias interconectadas. Además, todo texto debe interconectarse con su lector; en Tools for Tales ${ }^{670}$, Gloriana Davenport recomienda que las "Transiciones Fluidas" —entendidas como las habilidades que desarrollan los jugadores y lectores en relación a poder resolver los conflictos que la historia les presenta como parte del juego - es la manera cómo podemos resolver la tensión entre interactividad y narrativa. Conocer los elementos emergentes y sus cualidades permitirá la participación activa del jugador a partir de historias estructuradas con las siguientes características:

Agencia es otra cualidad de los sistemas emergentes; que permite al jugador experimentar una sensación de libertad de acción; es lo que permite al diseñador hacer creer al jugador que tiene el control sobre el sistema.

Sistemas Abiertos rompen con la idea aristotélica de "inicio - desarrollo - final"; existen sistemas con muchos principios y muchos finales; elementos interconectados, que les permiten establecer incontables vínculos semiológicos, e invitan al lector a descubrir estas conexiones de significado.

Narrativas Imbuidas, para Katie Salen y Erik Zimmerman ${ }^{671}$, son el contenido narrativo generado previamente que existe a pesar de la interacción del jugador y del juego. Están diseñadas para motivar las acciones y eventos del juego a través de las experiencias de los jugadores; como un contexto. Las narrativas imbuidas también ofrecen el mayor arco de la historia para el juego, estructurando la interacción del jugador y sus movimientos a través del mundo del juego en una manera significativa.

Retórica de la ficción, las historias emplean ciertos recursos retóricos, se trata de pistas que dan dirección e instrucción de cómo seguir la historia, cuando están bien estructuradas resulta difícil distinguirlas ya que se fusionan dentro del contenido y el sistema. La retórica en la ficción permite conocer cómo cuenta una historia cualquier medio; está muy relacionado con el sistema de símbolos discursivos y no discursivos que generan los textos, incluidas las imágenes y demás elementos hipermediales. Dentro de los sistemas digitales, las imágenes, audio y video se convierten en elementos retóricos de las historias. Los juegos ofrecen modelos dinámicos de los argumentos que los jugadores exploran, estos modelos, debido a las cualidades específicas de los ordenadores, vinculan los procesos de computación y las reglas del juego con la manipulación simbólica de los juegos, a esto es a lo que Ian Bogost llama Procedural Rhetoric. Todos los juegos son

\footnotetext{
${ }^{670}$ DAVENPORT, Gloriana, "Tools for tales", Interactive Cinema [Sitio de Internet] en: http://ic.media.mit.edu Consultado: 28/02/12

${ }^{671}$ SALEN, Katie \& ZIMMERMAN, Eric, The game design reader: a rules of play anthology, The MIT Press, Cambridge, 2006. (p. 383)
} 
retóricos, llenos de simbolismos visuales pero para Bogost esta simbiosis constituye una nueva figura retórica propia de los videojuegos ${ }^{672}$.

\subsubsection{Elementos Hermenéuticos}

La búsqueda de sentido es otra cualidad que narrativas y juegos comparten. Cuando leemos o jugamos nos involucramos de manera hermenéutica, buscando a toda costa significados. Según James Wallis ${ }^{673}$, el jugador tiene la ilusión de tener el control del juego y se enfrenta a una narrativa abierta, que demanda su participación. De ahí que debamos plantear las historias de tal forma que den libertad al jugador de elegir las opciones y determinar los posibles caminos del juego.

Los juegos y los textos, son después de todo, medios de comunicación que nos estimulan tanto emotiva como intelectualmente: admiten múltiples lecturas e interpretaciones; las interpretaciones de los usuarios dependen de muchos factores; como el estado de ánimo, su herencia lectora, su capacidad de asimilación y conexión a más información que dote de mayor sentido y complejidad a las lecturas. De manera semejante, entre más experiencias lúdicas se tengan, mayores facilidades de avance y entendimiento tendrán los jugadores.

Los juegos y la literatura son actividades semióticas que se apoyan en símbolos y significados, ambos considerados como secuencias de decisiones racionales (o al menos se espera que tengan cierto sentido lógico ${ }^{674}$ ), que toma tanto el escritor como el jugador. Las lecturas resultan un resorte para conectarnos a otra o a otras historias, leer entre líneas, aumentar el grado de emoción al imaginar nuevas posibilidades, otros finales, nuevos personajes, el sentir que podemos participar en las historias y "hacerlas a nuestro modo", ese juego creativo también está permitido. Por ello consideramos "buenas lecturas" aquellas que además que nos gustan, retan nuestro intelecto, imaginación y nuestra capacidad lúdica. También deseamos "jugar mejores historias", esto lo sugiere Espen Aarseth, quien reconoce que el objetivo de los videojuegos no es contar historias sino el permitirle a los jugadores jugarlas; historias que se agencien de opciones de recorrido más dramáticos, interesantes, de mayor complejidad conceptual, nueva temática que enriquezca sus aventuras; "We need to consider games as fairly formal structures that in complex ways spawn and seed player experiences" 675

\footnotetext{
${ }^{672}$ BOGOST, Ian, Persuasive Games. The Expressive Power of Videogames, The MIT Press, 2007. Respecto a las metáforas visuales, Véase: BOLTER, Jay David, Writing space: computers, hypertext, and the remediation of print, Georgia Institute of Technology, Routledge, New York, 2001. (p.52) ${ }^{673}$ WALLIS, James, "Making games that make stories" (pp.69-80) en: HINDMARCH, Will, "Storytelling games as a creative medium" (pp.47-56) en: HARRIGAN, Pat \& WARDRIP-FRUIN, Noah., Second Person, Role-Playing and story in games and playable media, The MIT Press, Cambridge, 2007. (p. 69)

${ }^{674}$ Esta cuestión será abordada nuevamente, dado que resulta ser uno de los principales problemas al que se enfrenta la narrativa interactiva; la necesidad de establecer conexiones lógicas en sistemas abiertos generados por los jugadores o lectores.

675 JUUL, Jesper., Half-Real: Video games between real rules and fictional worlds, The MIT Press, Cambridge, 2005. (P. 225)
} 
Es precisamente la capacidad semiótica lo que Julian Kücklich ${ }^{676}$ considera como la "similaridad" básica entre juegos y literatura. Entendida como el proceso mediante el cual se consigue un significado a partir de signos. O como lo define Charles Morris, es "El proceso de asociación de signos en la producción de significación interpretativa" Esto confirma al papel de los usuarios en la conformación del sentido.

¿Quién genera el sentido? ¿Quién cuenta la historia? En gran medida lo hacen los "Narrajugadores" quienes a diferencia de medios anteriores, como el cine, radio o televisión; con los medios interactivos han permitido a sus usuarios construir, ampliar, mejorar y conecta otras historias. Un mismo juego puede jugarse muchas veces y recontar múltiples historias; crear sus estructuras narrativas personales le da un valor extra al juego. Los juegos de video cuentan historias echando mano de la participación del narrajugador que va infiriendo o dando forma a una historia mientras recorre su aventura. A pesar de estar limitados por el código del sistema y por las acciones que el juego permite; existen "enlaces y motivaciones", como planteaba el mismo Vladimir Propp $^{678}$, que permiten establecer los vínculos entre las acciones, es lo que reviste al argumento de conexiones que ayudan a integrar el juego como una historia.

Los narrajugadores se apoyan en estrategias interpretativas que en cierto modo ayudan a darle sentido a los juegos que juegan; ya que carecen de textos y narraciones en el estricto sentido de la palabra, sin embargo la posibilidad de "llenar huecos" o desarrollar "claves ficcionales" permiten que el jugador eche a andar su imaginación y asocie los juegos a experiencias narrativas. Según Tracy Fullerton ${ }^{679}$, las historias atrapan emotivamente a los jugadores, al involucrarlos en un conflicto que está estructurado por elementos formales y dramáticos; que deben resolver. Tanto los retos como las acciones del juego, la premisa, los personajes, la historia; permiten construir el mundo del juego que puede tener menor o mayor poder emocional para el jugador.

La cualidad de darle forma de "historia" a todo lo que realizamos, nos confirma, lo que Liv Hausken ${ }^{680}$ dice: los jugadores son "constructores" de historias, a partir de una especie de competencia narrativa, desarrollan cierta predisposición a detectar y reorganizar, semánticamente y en orden, las estructuras producidas por la participación en

\footnotetext{
${ }^{676}$ KÜCKLICH, Julian, "Perspectives of Computer Game Philology", GAME studies, the international journal of computer game research $(3,1)$ 2003. [Artículo on-line] en: http://www.gamestudies.org/0301/kucklich/ Consultado: 19/11/2011

${ }^{677}$ Citado por: KÜCKLICH, Julian, "Perspectives of Computer Game Philology", GAME studies, the international journal of computer game research $(3,1)$ 2003. [Artículo on-line] en:

http://www.gamestudies.org/0301/kucklich/ Consultado: 19/11/2011

${ }^{678}$ Lo que no encaja en las funciones puede clasificarse en enlaces y motivaciones; Enlaces, sirven para explicar cómo un personaje A se entera de lo que el personaje B acaba de hacer y establece una relación inmediata entre dos personajes u objetos. Las motivaciones son las razones y los fines por los cuales actúan los personajes: Tomado de: http://www.slideshare.net/guest16006be/9-propp Consultado:05/03/12

${ }^{679}$ FULLERTON, Tracy, Game design workshop: a playcentric approach to creating innovative games, Morgan Kaufmann, Burlington, MA, 2008. (p. 41)

${ }^{680}$ HAUSKEN, Liv, "Textual theory and blind spots in media studies", (pp.391-403) en: RYAN, Marie-Laure., Narrative across media; the languages of storytelling, University of Nebraska Press, Lincoln, 2004.
} 
las acciones del juego. Al respecto, Jesper Juul afirma: "Any game can potentially be read as an allegory of something else... but some readings will be more convincing than others $^{681 "}$ " Algunos juegos son más narrativos que otros, como los casos de Myst o Riven and Exiles, en donde cada jugador armará sus historias de acuerdo a su imaginación y su experiencia lectora y lúdica.

Los juegos parten de una premisa: un elemento importante que guía y sienta el contexto para el desarrollo de los elementos formales en un juego; como una explicación básica del objetivo y sus elementos. Los juegos permiten desarrollar ese potencial creativo para generar historias, nuestro objetivo será considerar este elemento como otra de las cualidades por atender al diseñar textos; proveer de materiales adecuados para que estos marcos o líneas narrativos tengan mayor complejidad y se puedan desprender contenidos e interpretaciones mejores.

\subsubsection{Elementos Formales}

Es posible dividir casi cualquier sistema en dos elementos principales; su contenido y su forma o estructura, entendida como la parte que permite organizar esos contenidos. Dentro de los sistemas interactivos, las posibilidades estructurales se han vuelto muy complejas. El formato requiere un modo de articular sus elementos, que permite no sólo su interrelación, sino una manera de organizarse y gobernarse dentro de un sistema de reglas. Para Tracy Fullerton ${ }^{682}$, la estructura de los juegos se compone de reglas, conflictos, límites, recursos y resultados.

\section{Reglas}

Las reglas establecen cierta relación con la ficción, las historias y la premisa de los juegos. Son los comportamientos que especifican y restringen las acciones de los jugadores; constituyen la parte interna y formal del sistema de los juegos. Por un lado son operacionales porque guían al jugador durante el juego; y son lógicas porque se basan en principios matemáticos o lógicos. Para Salen y Zimmerman ${ }^{683}$, las cualidades de las reglas limitan las acciones de los jugadores; deben ser claras, explícitas y concisas; las comparten todos los jugadores; no se intercambian o alteran durante el juego, a menos que sea el juego Nomic ${ }^{684}$ (1982), cuyo objetivo es precisamente cambiar las reglas

\footnotetext{
${ }^{681}$ JUUL, Jesper, Half-Real: Video games between real rules and fictional worlds, The MIT Press, Cambridge, 2005. (p. 133)

${ }^{682}$ FULLERTON, Tracy, Game design workshop: a playcentric approach to creating innovative games, Morgan Kaufmann, Burlington, MA, 2008. (p.30)

${ }^{683}$ SALEN, K. \& ZIMMERMAN, E., Rules of play; game design fundamentals, The MIT Press, Cambridge, 2004. (pp. 116- )

684 Juego, Nomic, de Peter Suber, véase: http://www.earlham.edu/ peters/nomic.htm

Consultado:06/03/12
} 
mientras juegan; las reglas deben respetarse. Para Simon Egenfeldt ${ }^{685}$, las reglas son las características más determinantes de los juegos, de hecho son los elementos que permiten diferenciarlos de otros medios como las novelas o las películas. Es lo que da forma al juego, los retos que generan la satisfacción al ganar. Según Gonzalo Frasca, existen reglas tipo "Ludus", relacionadas a las condiciones mediante las cuales el jugador gana y las "Paideia" que se refieren a las reglas internas del juego. "Rules are abstract tools for thinking about the formal structure of a game and are not necessarily literally manifest in code, 686

Las reglas son la fuente de diversión más consistente para los jugadores; sin reglas tendrían poco sentido los juegos; y prácticamente no habría retos. En cierta medida las reglas favorecen que los juegos sean interesantes; si las reglas restringen o limitan de más, se pierde el interés por el juego; imaginen si las piezas del ajedrez pudieran moverse en todas direcciones, el sentido cambiaría. Según Juul ${ }^{687}$ lo interesante de los juegos es lo que deben hacer que les dictan las reglas, no tanto la historia, nosotros nos preguntamos ¿Qué pasaría si mejoramos las historias con reglas que tengan mayor relación con las historias? Sin duda podremos hacer mejores juegos y mejores historias.

Conflicto los juegos presentan enfrentamientos y problemas que los jugadores deben resolver.

Límites y fronteras entre el mundo del juego y el mundo real; las reglas permiten resolver los problemas de maneras poco ortodoxas, las cuales no necesariamente serían las apropiadas para resolver problemas similares en la vida real. Es lo que separa a un juego de lo que no es un juego.

\section{Resultados o consecuencias; castigos y gratificaciones}

El aspecto de incertidumbre ante el juego y el resultado es un elemento motivante para el jugador. Los juegos dependen de la tensión dramática que el sistema genere; las acciones, historia y la dificultad para resolver problemas. Dotar de recursos a los jugadores es parte de la motivación del juego; ofrecer vidas, unidades, salud, dinero, objetos que aumenten el poder [power-ups]. Son objetos útiles y valiosos que cobran aprecio por parte de los jugadores porque les facilitan conseguir sus objetivos. Los eventos narrativos pueden irse revelando gradualmente a lo largo del juego y entregarse como recompensas por conseguir logros y objetivos.

\footnotetext{
${ }^{685}$ EGENFELDT N. Simon, HEIDE S. Jonas \& PAJARES T. Susana., Understanding Videogames: The essential introduction, Routledge, New York, 2008. (p.99)

${ }^{686}$ SALEN, K. \& ZIMMERMAN, E., Rules of play; game design fundamentals, The MIT Press, Cambridge, 2004. (p. 149)

687 JUUL, Jesper., Half-Real: Video games between real rules and fictional worlds, The MIT Press,

Cambridge, 2005. (p.156)
} 


\section{Retos, Enigmas, Acertijos}

Las historias se desarrollan gracias a la solución de acertijos, el pasar obstáculos y desarrollar acciones; retos que otorgan un sentido al objetivo del juego, afloran las emociones y son una clave para mantener al jugador interesado y motivado en el juego. Los acertijos son una forma de juego que mantiene un cierto nivel de reto por parte del jugador, debe ser en cierto punto placentero para que quiera seguir jugando. Espen Aarseth confirma su valor en el cumplimiento de los retos del juego; por un lado mantienen el suspense de no saber qué pasa, el deseo de convertirse en experto. "High quality games are the ones whose choices provide high-quality mental challenges for players, 688

Chris Bateman asegura que una de las principales funciones de las narrativas en los juegos es ofrecer un contexto a las acciones del jugador, los retos están inmersos y se justifican en relación a las historias de los juegos; por ello, la creación de la historia es la tarea más creativa e importante a la que los escritores de juegos se enfrentan, "it makes up bulk of narrative \& arranges all the game elements"

Con la idea de establecer un puente entre narrativas y juegos, Ragnhild Tronstad (2001), Aarseth (2004) y Tosca (2003) proponen la idea de Acertijo [Quest] o intriga: que ofrece una conexión entre las reglas del juego y la ficción; visto como una secuencia de eventos que el jugador debe ir actualizando mientras juega; solucionando enigmas y encadenando ciertas secuencias de eventos parecidos a llevar a cabo una historia. Por ello se sugiere que los retos cumplidos son elementos que además de favorecer el juego, generan posibles historias. Simon Egenfeldt lo confirma: "Quests are small missions that players must perform; they structure a game's actions and create opportunities for storytelling.", 690

\section{Reglas y ficción}

El mundo ficcional en un juego se proyecta en una diversidad de maneras, utilizando diversos elementos: gráficos, sonidos, textos, manuales, reglas. Por ello Jesper Juul confirma que las reglas y la ficción interactúan, compiten y se complementan a sí mismos. La narrativa enlista los eventos del juego y ofrece un marco que puede apreciarse como una justificación, una razón o una escusa para llevar a cabo el juego. Simon Egenfeldt ${ }^{691}$ sostiene que a pesar de que la ficción de los videojuegos dependa de las reglas y a pesar de que las reglas no hagan mención de la ficción, la narrativa es parte importante de la experiencia del jugador. Principalmente a través de tres propiedades o

\footnotetext{
${ }^{688}$ Sid Meir, citado por: JUUL, Jesper., Half-Real: Video games between real rules and fictional worlds, The MIT Press, Cambridge, 2005. (p. 19)

${ }^{689}$ BATEMAN, CHRIS (ed.), Game writing narrative skills for videogames, Game Development Series, IGTA, Charles River Media Publishing \& Course Technology, Boston, 2007. (p.13)

${ }^{690}$ EGENFELDT N. Simon, HEIDE S. Jonas \& PAJARES T. Susana., Understanding Videogames: The essential introduction, Routledge, New York, 2008. (p. 183)

${ }^{691}$ BATEMAN, CHRIS (ed.), Game writing narrative skills for videogames, Game Development Series, IGTA, Charles River Media Publishing \& Course Technology, Boston, 2007.
} 
técnicas: la inmersión, la recompensa y la identificación; ésta última se refiere al contexto que se genera en torno a las acciones del jugador.

La teoría de los juegos y la teoría narrativa se basan justamente en la racionalidad de las opciones que ofrecen y ante las cuales los jugadores-escritores basan sus decisiones de argumento o acciones. El estudio de la teoría de los juegos se apoya en las reglas de los mismos. Para Rawdon Wilson ${ }^{692}$, las propiedades más importantes de los juegos (y por ende de la literatura que consideramos similar a los juegos) son la arbitrariedad, la complejidad de la estructura y la dependencia en sus reglas y afirma:

"Games \& literary texts are both... they have both an exterior and an interior dimension, both are objective building on physical objects, operations subjective, incorporating feelings, moods, thinking \& imagination. ${ }^{\prime 693}$

Ciertos formatos creativos, comunicativos o textuales se integran en los juegos como: mods $^{694}$, chats $^{695}$, walkthroughs ${ }^{696}$, que resultan básicos para el diseño y ejecución del juego. Además a lo largo de las sesiones aparecen editores de textos, mapas, listados y cualquier tipo de elemento que requiera ser leído como, cartas, notas, letreros, diálogos. Todos ellos integran un universo que puede formar parte de una estructura narrativa. Los diseñadores de juegos utilizan secuencias cinemáticas en las que se detiene la acción y se introduce una tensión narrativa que explique o dé indicaciones de lo que se debe hacer y que oriente las acciones del jugador en torno a varias opciones; compensando la falta de elementos narrativos y la posibilidad de ofrecer información. La cual se suministra en dosis breves, fragmentos cortos que resultan ser un resorte narrativo que permite que el jugador descubra cierta información para continuar el juego. Las escenas que rompen la acción, se entienden como cierta voz del discurso, que habla y dice lo esencial para facilitar el desarrollo del juego.

Los ludólogos se escudan en la diferencia de los escenarios con relación a las narrativas; estos espacios admiten la inserción del jugador por lo que también los jugadores son muy diferentes, pueden transitar; en cambio los lectores, lo hacen de otra manera, pero lo hacen. Según Simon Egenfeldt, los narrajugadores adquieren un "Repertorio literario" ${ }^{, 697}$, que les permite interpretar un juego o una historia y poder "introducirse" en ellos, es lo que ayuda a entender su contexto; nutrirse de experiencias de lecturas previas, normas sociales, eventos históricos y adquirir información; es una cuestión de competencia que puede afectar tanto a la forma como al contenido de un texto. Es otra cualidad que compartimos con los juegos; la de completar los espacios, "Filling Gaps"

\footnotetext{
${ }^{692}$ WILSON, R. RAWDON, Palamede's shadow; explorations in play, game \& narrative theory,

Northeastern University Press, Boston, 1990. (p.80)

${ }^{693}$ WILSON, R. RAWDON, Palamede's shadow; explorations in play, game \& narrative theory,

Northeastern University Press, Boston, 1990. (p.82)

${ }^{694}$ Mods en videojuegos, son extensiones que permiten la modificación de una versión original de un juego, realiazada generalmente por los mismos aficionados.

${ }^{695}$ Chat, entendidas como conversaciones en línea.

${ }^{696}$ Walkthrough se considera un tipo de guías de estrategia del recorrido del juego, pueden llegar a ser simples instrucciones o verdaderos libros de soluciones.

${ }^{697}$ EGENFELDT N. Simon, HEIDE S. Jonas \& PAJARES T. Susana., Understanding Videogames: The essential introduction, Routledge, New York, 2008. (p.184)
} 
[llenar huecos], es lo que necesitan hacer los lectores y jugadores para completar las historias, interpretar y entender lo que no se dice. Por eso son medios participativos, que requieren la agencia del jugador y del lector. El acto del juego con frecuencia se lleva a cabo llenando huecos de manera inconsciente; coordinando el movimiento y las acciones que deben realizar los jugadores con pruebas-error que permiten desarrollar un marco narrativo. Y confirmando que sin importar las acciones, es casi imposible no detectar que una historia está conformándose detrás de nuestras opciones de juego.

"A close Reading of a video game is not only possible, but that it also yields interesting insights about how a game that makes use of stories is experienced by a player. ${ }^{\prime 698}$

Con esto confirmamos como el proceso de interpretación va de la mano con las habilidades y destrezas del control del juego gracias a las reglas del sistema: apreciando cómo la perspectiva narrativa de los videojuegos no resulta opuesta sino que se fusionan uno en otro en una combinación única ${ }^{699}$. Vemos como Rawdon Wilson también confirma la jugabilidad de las narrativas diciendo:

"Literary texts may be games in several ways: that they may incorporate empirical games, that they may mark off the play-ground of the author's personal gamefulness, that they may engage the leader in textual games as well as in word play, that they may be constituted as games, the reader's own game playing and even that they may be transformed into games by the rule like procedures of interpretative criticism"700

\subsubsection{A manera de desenlace}

Enfatizamos que a pesar de los desacuerdos entre ludólogos y narratólogos; es innegable considerar que juegos y narrativas tienen muchos puntos en común: ambos requieren la mediación del lector o jugador; es mediante una historia que los autores comprenden, gustan y se involucran con las acciones de los juegos; ambos nos permiten hacer y enfrentarnos a cosas que no podríamos hacer en la vida real. Nos exigen cierto reto mental; hacer conexiones con un sin número de eventos, recuerdos y otras aventuras; tomar decisiones, descubrir elementos, que despiertan cierta liga emocional. Ambos pueden pasar de un medio o soporte a otro: de cartas a tablero a PC o de la oralidad, a una novela a una película a un videojuego. Son sistemas basados en reglas; cada juego plantea sus estructuras, así como cada lectura ofrece su forma de articulación y organización. Los juegos generan un resultado variable y medible que es cuantificable. Las lecturas,

\footnotetext{
${ }^{698}$ EGENFELDT N. Simon, HEIDE S. Jonas \& PAJARES T. Susana, Understanding Videogames: The essential introduction, Routledge, New York, 2008. (p. 189)

${ }^{699}$ EGENFELDT N. Simon, HEIDE S. Jonas \& PAJARES T. Susana, Understanding Videogames: The essential introduction, Routledge, New York, 2008. (p. 189)

${ }^{700}$ WILSON, R. RAWDON, Palamede's shadow; explorations in play, game \& narrative theory,

Northeastern University Press, Boston, 1990. (p.104)
} 
dependiendo de las experiencias lectoras, también ofrecen mayor o menor grado de interpretación y por ende los niveles de entendimiento y cognición están en función de la preparación de los lectores y su grado de concentración y asimilación. Tanto las historias como los juegos ofrecen retos a los lectores-jugadores; permitiéndoles múltiples interpretaciones.

El suspense provocado por la búsqueda de soluciones o la resolución de enigmas es algo que se resuelve leyendo o jugando, cierto aprendizaje se obtiene de ambas acciones; leer y jugar. Muchos juegos proyectan un mundo de ficción, en el que aparecen personajes con características que son coherentes a las historias que desarrollan. Tanto los juegos como las historias contienen espacios por "rellenar"; se trata de mundos incompletos que dan la oportunidad de la participación activa, mediante explicaciones que deben imaginar los lectores y jugadores para completar el sentido de las ficciones y los juegos. Ambos crean y complementan sus mundos de ficción. Esto es algo que Marie-Laure Ryan ${ }^{701}$ define como el principio de la "partida mínima", una cualidad que no está especificada y que demanda de nuestra participación y entendimiento.

Saltar de un lugar a otro en historias fragmentadas, múltiples perspectivas, multiplicidad de hilos narrativos entrecruzados, causalidades inciertas, formas laberínticas, ergodicismo, remediación, múltiples representaciones; son sólo algunas cualidades que adoptan los juegos y las narrativas.

A quienes atacan esta cualidad narrativa debemos preguntarles ¿Qué tiene de malo tratar de encontrar múltiples sentidos, encontrar estructuras de juego que pueden convertirse en ideas estupendas para armar historias o historias que se enriquezcan con acertijos y acciones por llevar a cabo; incluir cualidades que amplían los horizontes de los creadores y de los usuarios, debe ser una de las aportaciones de la tecnología y del trabajo creativo de cualquier diseñador de textos. Debemos entender que cada medio posee sus propias cualidades, que cada uno debe regirse y evaluarse bajo sus propios métodos de análisis, pero debemos destacar lo mucho que pueden contribuir uno por el otro. Por ello es preciso contemplar, que la doble visión (ludológica y narratológica) no ha establecido limites; sino que nos ha mostrado dos caminos para revalorar las propiedades de los videojuegos y de la literatura; contrastando sus puntos comunes.

"Literary texts do seem to be like games in many important respects, and games are powerfully textlike. Yet... are not the same, however many cognitive affects, on the side of the author or the reader, the game right or the player, they seem to share, and they should not be confused. As networks of signs, semiotic constructs built upon specific organizing assumptions, they are distinct. ${ }^{702,}$

No pretendemos que sean lo mismo, sino que puedan interrelacionarse y puedan incorporar sus cualidades y ampliar sus posibilidades y experiencias de creación; "sufrir

\footnotetext{
${ }^{701}$ RYAN, Marie-Laure, Narrative as virtual reality: Immersion and interactivity in literature and electronic media, The Johns Hopkins University Press, Baltimore, 2001. (pp. 48-60)

702 WILSON, R. RAWDON, Palamede's shadow; explorations in play, game \& narrative theory, Northeastern University Press, Boston, 1990. (p.239)
} 
una cierta metamorfosis", plantea Rawdon Wilson; que permitan intercambiar temas, formas argumentales o patrones episódicos que posibiliten la caracterización de agentes y la introducción de interludios simbólicos. Cualquier lector puede introducirse al mundo textual siguiendo ciertas reglas y enfrentándose a ciertas pruebas que le permitan avanzar por un tipo de laberinto; en cierto modo es un sentimiento similar a un juego lo que le incita a seguir avanzando.

Sabemos que el juego es un importante modo de exploración e invención; por ello hemos ligado los textos y los juegos, buscando apoyar la experiencia creativa de los artistas que trabajan con nuevos medios digitales y desean experimentar en el mundo de la composición de historias y guiones narrativos. Con el objetivo de encontrar nuevas herramientas para la creación, esperamos facilitar el contacto con la teoría y dar recomendaciones prácticas que puedan convertirse en materiales para componer historias o guiones narrativos que complementen proyectos artísticos de cualquier índole, historias, argumentos, estructuras innovadoras, nuevos medios para crearlas y difundirlas.

Por último formulamos la siguiente pregunta: ¿Serían mejores juegos si contaran historias?, ¿Haríamos mejores historias si pudiéramos añadirles cualidades de los juegos? ¿Esto restaría valor a alguno de los medios?

Visto desde una perspectiva creativa, la sinergia entre juegos y narrativas, a pesar de sus notables diferencias, pueden ser una importante fuente de inspiración mutua. Hay que dotar de buenos recursos para mejorarlos. Las narrativas pueden ofrecer experiencias de juegos más interesantes. Sin duda esta visión la comparten quienes gustan de buenas historias, coherentes a sus reglas, que generen su propia jugabilidad y nos introduzcan en círculos mágicos o mundos de ficción. La complejidad narrativa que los videojuegos pueden desarrollar, ha despertado en los diseñadores de juegos el interés de averiguar cómo pueden mejorarse las cualidades del mundo de ficción de sus juegos, o al menos, como dice Simon Egenfeldt en la siguiente cita, están haciendo sentir a los jugadores que están contribuyendo en crear un argumento, "the most successful narrative experiences

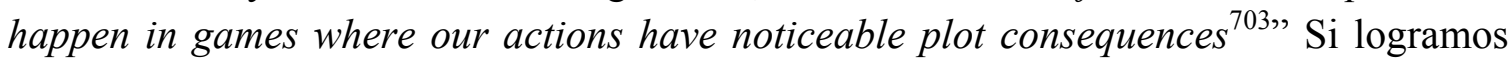
cierta destreza narrativa, seguro obtendremos importantes beneficios; ya la sugiere Chris Bateman:

\footnotetext{
"Creating a game story is about creating opportunities \& effects. The opportunities are emotional moments, it's a framework for Game play, a roadmap to reward and catharsis" ${ }^{\prime 704}$
}

Estamos a favor de establecer estructuras e implementar acciones diversas que favorezcan la imaginación e incentiven la creación; de ahí nuestro interés de llevar a cabo este trabajo como una guía que conduzca y estimule a los escritores; sin circunscribirnos a un acto conducido similar a seguir un instructivo porque reconocemos que esto produciría piezas totalmente predecibles y aburridas. Sino que deseamos ofrecer un caleidoscopio de

\footnotetext{
${ }^{703}$ EGENFELDT N. Simon, HEIDE S. Jonas \& PAJARES T. Susana., Understanding Videogames: The essential introduction, Routledge, New York, 2008. (p.183)

${ }^{704}$ BATEMAN, Chris (ed.), Game writing narrative skills for videogames, Game Development Series, IGTA, Charles River Media Publishing \& Course Technology, Boston, 2007. (p.13)
} 
rutas por donde circular; conocer modelos; tomar ideas tanto estructurales como de contenido que acompañen sus trabajos de creación. Sabemos que la escritura creativa puede favorecerse con nuevas prácticas; que para hacer innovaciones debemos conocer el potencial y echar mano de estrategias narrativas inspiradas en juegos y videojuegos puede ser una herramienta de gran valía; incluso el mismo Markku Eskelinen ${ }^{705}$, tan renuente en apreciar el valor narratológico en los videojuegos, discute la falta de creatividad para conducir talleres de escritura. Teon Joo Ong ${ }^{706}$ lo reduce de una manera muy sencilla; "Writing a good story requires inmense patience"; también requiere de mucho trabajo que esperamos se facilite con esta guía.

Decir que toda la literatura es un juego, más allá de facilitarnos el camino, nos lo complica; pudimos apreciar muestras en la literatura inspiradas en juegos, juegos mismos convertidos en historias y ante esto, no dudaríamos en confirmarlo sin embargo, debemos considerar algunas cuestiones que esta sentencia inicial nos sugiere: ¿Quién juega en la literatura? El escritor, el lector, la historia. ¿Con qué se juega? ¿Cuáles son los objetivos y cuales las reglas? ¿Son parte del juego o de la historia? Pongamos en práctica algunas ideas en el siguiente apartado.

\footnotetext{
${ }^{705}$ Y Refiere el trabajo de Fleister \& Amato, Reforming

706 JOO ONG, Teong, Interactive storytelling engines, Tesis doctoral, Texas A \& M, 2006. [Texto on-line] en: http://repository.tamu.edu/bitstream/handle/1969.1/4401/etd-tamu-2006B-CPSC- 
"Every designer needs strong core skills, you can only gain them by doing projects" David Sherwin $^{707}$

\section{PROCESO DE CREACIÓN PARA ESTIMULAR HABILIDADES NARRATIVAS LÚDICAS}

Con este apartado esperamos aterrizar de manera propositiva y concreta recursos y recomendaciones para emprender labores ligadas a la creación narrativa. Reconocemos que la escritura demanda trabajo, dedicación conocimientos y mucha práctica. Deseamos contribuir con éstas prácticas porque estamos seguros que bajo cierta dirección, la creatividad fluye. Esto lo sabemos quienes conducimos programas de arte o de escritura. Apreciamos que la creación narrativa implica el desarrollo de un proceso muy complejo integrado por una diversidad de elementos y recursos que intervienen en la construcción de historias. Deseamos conducir para componer. Como dice Andrew Glassner, "find nurture and develop such broadly-based, creative individuals, and give them the freedom to experiment so that we can discover the principles that will guide our success. "708

Experimentar formas narrativas innovadoras puede ser una labor sencilla si tomamos como base ciertos modelos y llevamos a cabo un proceso sistemático que oriente a los escritores a componer mejores textos con estructuras y contenidos más complejos, que puedan apoyarse en juegos con mejores historias, más activas y emocionantes. A lo largo de este trabajo nos hemos dado a la tarea de establecer el mayor número de conexiones entre las historias y los juegos porque estamos convencidos que favorecen el proceso de generación, manipulación y organización de ideas. Seguimos rindiéndole tributo al potencial creativo que el lenguaje ofrece y presentamos un cúmulo de recursos que los diseñadores de textos pueden utilizar para estimular sus prácticas narrativas estéticas. Esperamos formen y engrosen su arsenal de recursos que podrán transformar en grandes textos de todo tipo, artísticos, de divulgación o educativos que acompañen cualquier proyecto artístico, desarrollen cierto nivel de complejidad e innovación y lo enriquezcan.

\footnotetext{
${ }^{707}$ SHERWIN David, Creative Workshop, 80 challenges to sharpen your design skills, HOW Books, Cincinnati, 2010.

${ }^{708}$ GLASSNER, Andrew, Interactive Storytelling, techniques for $21^{\text {st }}$ century fiction, A. K. Peters, Ltd. Natick, 2004. (p. 33)
} 
Proponemos una especie de "Taller" orientado a prácticas de escritura cuyo principal motor son los elementos del videojuego. Para ello planteamos cinco momentos o acciones que los diseñadores de textos se enfrentan en sus labores narrativas. Estos son: Idear, componer, experimentar, evaluar y editar. Estas acciones sistemáticas servirán como eje para conducir prácticas de escritura concretas para Narrajugadores. A quienes deseamos preparar una especie de retos que estimulen su imaginación y que de ninguna manera sean limitantes, sino detonantes de ingenio.

Hemos procurado organizar las tareas que llevan a cabo los escritores con el fin de facilitar el proceso de escritura. Teóricos de diversas corrientes y épocas han buscado establecer modelos en la literatura para facilitar su estudio. Los Formalistas Rusos consideraron la obra literaria como un conjunto de "recursos" relacionados entre sí, como "funciones" dentro de un sistema textual total. Claude Levi-Staruss retoma la idea de las estructuras universales en los mitos tradicionales y con Vladimir Propp se identifican 31 acciones que integran los cuentos fantásticos. A.J. Greimás retoma esta idea de las acciones y las reduce a la función de los seis actantes que reducen los relatos a Sujeto, Objeto, Remitente, Receptor, Ayudante y Oponente. ${ }^{709}$ Conocer los recursos de poética tradicional y llevar a cabo prácticas experimentales con el fin de realizar ejercicios lúdicos y creativos, nos confirma lo que Nietzche ${ }^{710}$ sostenía, que el juego es una manera de acercarse a una gran tarea: la tarea de la creación.

En un segundo punto del apartado presentamos El Modelo de Narrativas lúdicas, un análisis del videojuego Grim Fandango, a partir de los elementos propuestos anteriormente. Con dicho análisis deseamos mostrar la complejidad narrativa de esta pieza y apreciar los elementos que la integran, porque consideramos que se trata de un buen ejemplo que servirá de modelo para componer guiones.

Nuestra propuesta muestra como se estructuran los elementos del juego a partir de los elementos que intervienen y que contribuyen a la creación de historias que estimulen la curiosidad del jugador, complementen las acciones lúdicas, así como su capacidad imaginativa y crítica, porque las historias bien estructuradas les permiten disfrutan más de sus juegos.

Con este análisis concluimos nuestro trabajo, esperando que a partir del modelo de narrativa lúdica permita construir o recomponer guiones que puedan tener mejores cualidades jugables y narrativas, que sean textos exploratorios, creativos y sobre todo, tengan un contenido interesante y divertido.

\footnotetext{
${ }^{709}$ Estas estructuras pueden apreciarse en los apartados 3.3 Teorías para Componer Historias y 4.2.2 Opiniones Narratológicas en este mismo trabajo.

${ }^{710}$ Citado por: MOTTE, WARREN F., Playtexts: lúdics in contemporary literature, University of Nebraska Press, Lincoln, 1995. [Texto on line] en: http://books.google.com.mx Consultado: 11/01/12
} 


\subsection{LA CREACIÓN NARRATIVA EN 5 PASOS: Idear, Componer, Experimentar, Editar y Evaluar}

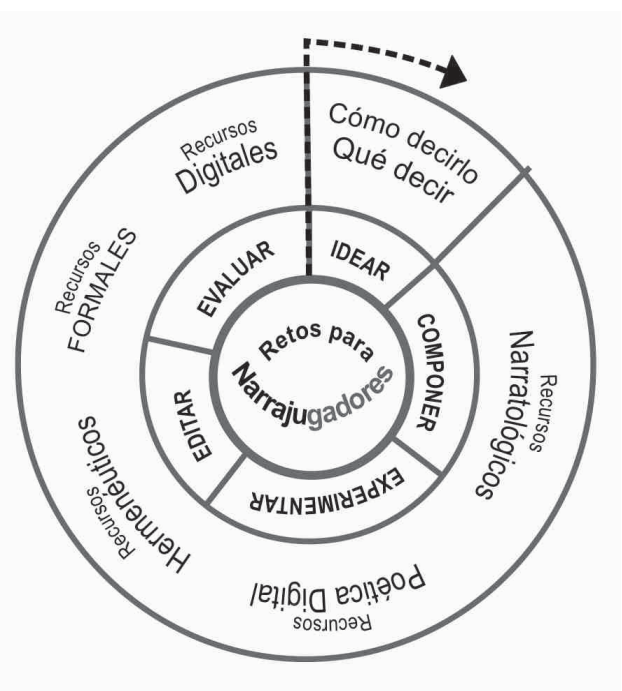

Cinco son los pasos o acciones que se sugiere emprender para la composición de textos narrativos: Idear, Componer, Experimentar, Evaluar y Editar. La primer tarea es idear, encontrar algo qué decir y la manera de decirlo. Elegir un tema, un motivo o una idea para emprender una historia. Una vez que las ideas aparecen, debemos orientar nuestras siguientes labores a Componer el texto. Apoyados en las Cualidades entre narrativas y juegos en entornos digitales que presentamos en el apartado anterior, retomamos 4 niveles de análisis: los Narratológicos, que corresponden a la poética tradicional, los de Poética digital, que integran los elementos propios de los entornos digitales y multimedia incluidos los videojuegos; los recursos Hermenéuticos que contemplan los aspectos relacionados con la significación y el contenido de los textos y los recursos Formales que señalan una manera de organizar y estructurar las historias. Retomaremos y ampliaremos de manera más ilustrativa estos elementos con la intención de aplicarlos en la construcción de relatos. Finalmente, dentro del Proceso de creación narrativa apreciaremos algunos recursos relacionados con la Edición de formatos digitales sobre todo conoceremos algunos recursos que facilitan estas labores y por último evaluaremos la calidad de los textos que diseñamos. Esperamos que este proceso propuesto sea una vereda por donde los diseñadores de textos puedan transitar y conseguir cierta dirección y apoyo. 


\subsubsection{Primera Etapa: IDEAR}

Cualquier idea puede convertirse en una historia. Esta puede ser cualquiera y provenir de cualquier fuente: un recuerdo, una palabra, un texto, el encabezado del periódico, algún título de libro, una anécdota, o cualquier pensamiento. Los juegos ofrecen un potencial muy valioso que facilita el surgimiento y flujo de ideas, porque nos ayudan a imaginar. Pero además tenemos otros modelos de donde obtenerlos, como son los recursos literarios y los acontecimientos históricos.

Una idea es todo lo que necesitamos para comenzar el proceso de creación narrativa, el cual requerirá de su incubación, trabajo, evaluación y reajuste. Esto lo apreciaremos de manera más concreta en el siguiente apartado en el que sugerimos algunas técnicas para obtener y darle forma a las ideas y determinar el rumbo que éstas pueden tomar.

The real problema isn't getting ideas, we are all bombarded with masses of Ideas in the news, magazines, friends, dreams, books, music and other interactions. The real problem is developing ideas, taking them and re-creating them into Ideas ${ }^{711}$.

\section{¿Para quién escribir?}

Es necesario determinar la audiencia de nuestro texto. Considerar edad, origen y en algunos casos incluso género y condición sociocultural de los posibles lectores o usuarios. Traemos a colación un ejercicio interesante de la British Broadcasting Corporation (BBC) en 2005, referido por Rhihanna Pratchett ${ }^{712}$ quien refiere a una revisión realizada a los usuarios de videojuegos en Reino Unido para determinar qué grupos tenían mayor relación con los videojuegos y por lo tanto, determinar que grupos no frecuentaban la experiencia del juego. De esta manera surge el interés de generar proyectos para determinados públicos no familiarizados con cierto fenómeno. Realmente resulta interesante promover el diseño de juegos basados en públicos de no jugadores. Lo cual resulta un reto interesante para diseñar un producto que pueda interesar a una población determinada. Este es sólo un caso entre algunos otros que puedan utilizarse para generar textos con una orientación bien definida. Quizá una propuesta que interese a este grupo de no jugadores puede ser el insertar un cierto tipo de juegos narrativos con mejores historias que amplíen el atractivo de los videojuegos. ¿Qué tal diseñar historias más creíbles y coherentes o considerar historias para audiencias multifacéticas en las que tanto el género literario como los géneros propios de los juegos se fusionen y complementen?

\footnotetext{
${ }^{711}$ BARKER, Mike, Brainstorms all day! (1), Writers Log, [texto on-line] en: http://web.mit.edu/mbarker/www/brain/b025093.txt Consultado: 12/06/2012.

712 PRATCHETT, Rhianna, "The needs of the audience" (pp. 185-200) en: BATEMAN, CHRIS (ed.), Game writing narrative skills for videogames, Game Development Series, IGTA, Charles River Media Publishing \& Course Technology, Boston, 2007.
} 


\subsubsection{Segunda Etapa: COMPONER}

Una vez que tenemos una idea es necesaria componerla en una historia. Debemos encontrar los elementos esenciales para relatarla. Los narrajugadores habrán de combinar los formatos narrativos con los propios de los videojuegos como acciones y estrategias del gameworld. Dicho en voz de Jay Posey, "The Narrative Designer, however, must consider the mothod by which written words become in-game assets" "713. Deseamos crear textos en los que el juego sea un modo atractivo para comunicar ideas de manera innovadora. Así que la tarea será determinar cómo articular las ideas bajo cierto nivel de complejidad. Para ello será necesario apreciar los elementos constitutivos de los textos. Mieke Bal distingue la composición de los textos a tres niveles: el texto narrativo, la historia y la fábula. El Texto Narrativo es la manera como se presenta la historia, considera los signos lingüísticos, visuales, imágenes y cualquier otro elemento que sirva para ese propósito. Se compone de Agentes Narrativos o narradores y de Elementos No Narrativos que se presentan a manera de diálogos, descripciones y otros formatos del discurso, como textos imbuidos historias conectadas y otros recursos similares. La Historia es el contenido de la historia, es la temática que trata el texto, las ideas que desarrolla y el tratamiento de las mismas. Y finalmente, la Fábula es la manera como se estructura la historia, es decir, cómo se organizan los eventos de acuerdo a un orden lógico o cronológico. Para ello contamos con el tiempo, el orden secuencial (orden cronológico de los acontecimientos) tanto anticipaciones (anacronías) como el manejo atemporal (acronías) de las historias. Apreciamos además el ritmo y la frecuencia; el primero refleja la velocidad y fluidez para relatar los acontecimientos y emplea recursos como las elipsis, pausas y las desaceleraciones. Y la segunda, presenta una relación entre los eventos de la historia y como se organizan en la fábula. Finalmente en las fábulas encontramos Personajes que llevan a cabo las acciones; Espacios, en donde suceden estas acciones y una visión de la historia o Focalización que presenta el punto de vista y una manera particular del autor de ver y presentar los hechos y eventos a pesar del género que elija para hacerlo como: el suspenso, la aventura, el romanticismo y más.

Otros elementos son los Eventos que intervienen y las relaciones que existen entre ellos: selecciones, cambios, elecciones o confrontaciones. Los Actores, o personajes ${ }^{714}$ determinan los tipos de eventos que suceden y las funciones que se desarrollan. Esto estará muy relacionado con los tipos de Tiempos, en relación a su duración, interrupciones, paralelismos y una organización secuencial lógica de los acontecimientos en relación a sus actores. Todos los elementos que integran la composición están interrelacionados y son consecuentes a partir de las acciones que los agentes o personajes llevan a cabo. Las historias parten de un estado inicial que en cierto momento, presenta

\footnotetext{
${ }^{713}$ POSEY, JAY, But what does a narrative designer do? (and can I be one?), (pp.55- 60) en: DESPAIN, Wendy (editor), Professional techniques for video game writing, A. K. Peters, Ltd. Wellesley, MA, 2008. (p.57)

${ }^{714}$ BATEMAN, CHRIS (ed.), Game writing narrative skills for videogames, Game Development Series, IGTA, Charles River Media Publishing \& Course Technology, Boston, 2007. (pp.27-41)
} 
un cambio del cual se desencadenan otra serie de eventos que conducen a una o más de una historia.

Chris Bateman ${ }^{715}$ sugiere que las historias en los videojuegos son un tipo de flujo textual que puede separarse de la mecánica del juego y contarse como una narración. Puede asociarse al modelo "Del Viaje del Héroe" lo cual facilita armar los acontecimientos, explorar el espacio y entender las funciones de los personajes. Fue precisamente la idea del viaje del héroe de Joseph Campbell ${ }^{716}$, abordado también por Christopher Vogler, ${ }^{717}$ lo que puede verse como uno de los principios que gobiernan el mundo de las historias: la existencia en el mundo común; el llamado a la aventura, la negación de la llamada, el encuentro con el mentor, cruce del primer umbral, pruebas, aliados y enemigos; acercamiento a la cueva más recóndita, terrible experiencia, y recompensa.

Si analizamos los videojuegos bajo los parámetros anteriores, apreciamos que comparten elementos con las narrativas, los cuales están en mayor o menor grado desarrollados y deben considerarse para componer mejores mundos de ficción. Los videojuegos invitan al jugador a organizar y reconstruir las historias en su imaginación, el reto es generar historias lo suficientemente estructuradas y flexibles que además de leerse, puedan jugarse. Basta considerar sus cualidades interactivas, como Simon Egenfeldt dice:

"Their concerns thus mirror some of the most important theoretical discussions that we have examined: about how to make a story compatible with the interactive

needs of a game and the clear relationship between the quality of a videogame's story and the player experience.". ${ }^{718}$

\section{¿Qué hace que los juegos sean efectivos?}

Sin duda uno de los principales atributos de los juegos es el desarrollo y transmisión de emociones, las cuales logran conectar a los jugadores con las acciones del juego. Los juegos permiten el contagio emocional, el deseo de competir y obtener alguna recompensa, despertar su imaginación y mantener alerta su curiosidad. Una historia bien creada y adaptada al formato de un juego será valorada por la riqueza que puede otorgarle a los juegos en el plano emocional y conceptual. Porque dice algo coherente, algo que le da mayor valor a las aventuras que lleva a cabo.

\footnotetext{
${ }^{715}$ BATEMAN, CHRIS (ed.), Game writing narrative skills for videogames, Game Development Series, IGTA, Charles River Media Publishing \& Course Technology, Boston, 2007.(p.2)

${ }^{716}$ CAMPBELL, Joseph., The hero with a thousand faces, Joseph Campbell Foundationd \& New World Library Press, Novato, 2008.

${ }^{717}$ VOGLER, Christopher, The writer's journey; mythic structure for writers, Michael Wiese Productions, Studio City, 2007.

${ }^{718}$ EGENFELDT N. Simon, HEIDE S. Jonas \& PAJARES T. Susana., Understanding Videogames: The essential introduction, Routledge, New York, 2008. (p. 194)
} 


\subsubsection{Tercera Etapa: EXPERIMENTAR}

La experimentación que proponemos debe llevar a un narrajugador a cuatro niveles: Narratológico, Digital, Hermenéutico y Formal. Admitimos que cada elemento requiere de mayor profundidad y análisis, de la expuesta en este trabajo, pero para los fines que proponemos, pueden considerarse como parámetros de partida que sin duda necesitarán extenderse y profundizarse con el ejercicio práctico. Lo importante será detectar la diversidad de recursos que se deben considerar al componer textos.

\subsubsection{Recursos Narratológicos}

Las historias son relatadas por un agente narrativo que ofrece una visión en torno a los acontecimientos del relato. No podemos identificarlo con el autor, ya que se trata, según Mieke Bal de un portavoz ficticio, es decir, narrador. Gérard Genette ${ }^{719}$ clasifica varios tipos de narrador según su ubicación (su distancia) respecto a la historia narrada: Narrador extradiegético si no participa en los hechos relatados; narrador intradiegético si a la vez que narra participa en los hechos como personaje o como testigo u observador. Narrador autodiegético si es el héroe y narra su propia historia y metadiegético si narra, en su calidad de personaje en primer grado, es decir dentro de una línea de los acontecimientos. Apreciamos además el narrador que lo sabe todo, el omnisciente y omnipresente que está en todas partes y todo lo sabe.

\section{El manejo del tiempo, ¿cuál tiempo?}

En las historias tenemos varios tiempos, el del relato, el del lector-jugador y el tiempo de la historia-juego. Leer al ritmo que uno guste, saltarse capítulos, regresar o leer en el orden que uno prefiera es permitido en ciertos textos y en los medios digitales; al poder detener, repetir, guardar lo jugado o avanzar si completamos las tareas y retos del juego. El tiempo es realmente importante, al permitirnos apreciar acciones que suceden en tiempo real y otras fuera del reloj y otras en tiempos ficticios que no corresponden a nuestro tiempo, una hora de juego puede equivaler a un día o a un año en el sistema. El tiempo es un recurso que los diseñadores de textos deben atender.

H. Porter Abbot ${ }^{720}$ encuentra su importancia argumentando que la narrativa es la manera principal cómo nuestra especie organiza el entendimiento sobre el tiempo. No sólo somos los únicos en apreciar el sentido del trascurrir del tiempo, además tenemos posibilidad de expresarlo y de manera creativa, alterarlo en una ficción.

\footnotetext{
${ }^{719}$ GENETTE, Gerard, "Fronteras del discurso" (pp.196-210) en VVAA, Análisis Estructural del relato literario, Premia editores, México, D.F., 1986.

${ }^{720}$ ABBOT, H. Porter, The Cambridge introduction to narrative, Cambridge University Press, Cambridge, 2008.
} 
Para Mieke Bal, cualquier acontecimiento, demanda tiempo. Un tiempo hipotético importante para que la fábula avance. Incluso una imagen estática como una fotografía, pintura o escultura, demandan cierto tiempo para apreciarla aunque éste no se desdoble. Una gran diferencia entre los entornos analógicos y digitales es justamente el manejo y entendimiento de un tiempo que avanza frente a nosotros y que podemos detener y revivir. Los sistemas tradicionales adolecen de la fluidez que caracteriza a las imágenes en movimiento utilizadas en el cine, videos o videojuegos. Aunque el tiempo y el espacio en entornos interactivos son más dinámicos que en otros medios, según afirma Carolyn Handler Miller ${ }^{721}$, en algunos juegos el tiempo puede detenerse, ampliarse o regresarse o se puede acceder de un espacio a otro y contener diferentes momentos y una multiplicidad de mundos paralelos en donde los acontecimientos suceden o no de manera simultánea y donde además, hemos aprendido a completar misiones en muchas horas de tiempo real.

El tiempo bajo presión es uno de los atractivos que despiertan la emoción por el juego, tener el tiempo limitado para resolver un enigma, realizar una tarea aunque sea buscar y encontrar a tu oponente, para dispararle, como señalan Brenda Brathwaite e Ian Schreiber $^{722}$; son emociones que la narrativa impresa no experimenta con tal intensidad; sin embargo al diseñar textos digitales sin duda será una consideración importante, el imponer retos y enigmas y restringir el tiempo para que éste pueda cobrar mayor impacto en los lectores. Narrativas armadas bajo reloj será una forma de experimentar y articular textos ya sea bajo un tiempo restringido que resulten además lógicos y coherentes.

\section{Creación De Personajes}

Según la Real Academia Española "Personaje" es cada uno de los seres humanos, sobrenaturales, simbólicos, etc., que intervienen en una obra literaria, teatral o cinematográfica. El personaje requiere que se conforme su historial y antecedentes relevantes, para que su persona resulte del todo creíble y coherente (rounded). Si se trata de un agente entrenado de una organización policiaca, una niña con cierta discapacidad, un entomólogo, o un experto relojero, deberán definir su carácter a partir del mayor número de cualidades y detalles que consideren.

"On day Roland Barthes strolled up the Champs Elysées and encountered a large man,
evidently a foreigner, wearing a dirty turtleneck and desert boots. He had glasses and
an unkempt beard with considerable gray in it. Over one shoulder he carried (a pure
gesture of style) an elegant leather purse. Barthes stopped to stare, and the man
returned the stare. Quite rapidly, the man's costume disappeared and his flesh
began to melt"

\footnotetext{
${ }^{721}$ HANDLER MILLER, Carolyn., Digital storytelling; a creator's guide to interactive entertainment, Focal Press, Burlington, MA, 2008. (p.83)

722 BRATHWAITE, Brenda \& SCHREIBER, lan, Challenges for game designers, Course Technology, Boston, 2009. (p.102)

${ }^{723}$ WILSON, R. RAWDON, Palamede's shadow; explorations in play, game \& narrative theory, Northeastern University Press, Boston, 1990. (p. 48)
} 
La creación del personaje debe verse como un sistema de signos y un cúmulo de significados, cada detalle, significa algo. Los personajes de las historias interactivas en relación con las personas reales no son iguales, los primeros requieren que se destaque con mayor definición su personalidad. Diseñar los personajes de las historias interactivas exige el reto de construir su modelo de personalidad. De acuerdo a Chris Crawford ${ }^{724}$ se deben considerar cuatro aspectos para obtener un modelo de personalidad integral, que reúna aquellos comportamientos que a lo largo de la historia, el personaje evoque y convenza, sea conciso, busque la simplicidad, más no la simpleza y evite a toda costa la complejidad excesiva; que sea ortogonal, es decir que mantenga una línea recta de coherencia sin que presente variables repentinas y cambios bruscos de comportamiento y que pueda ligar su personalidad y comportamiento al propósito de las acciones.

Para que los personajes adquieran un mayor grado de credibilidad deben considerar la siguientes variables: integridad, entendido como la cualidad de la honestidad, el no revelar secretos, romper promesas y ganarse la confianza de los usuarios; y la virtud que les permita tomar decisiones inteligentes y no egoístas, que no abusen o lastimen injustificadamente a otros personajes y que lleven a cabo acciones eficaces y correctas.

Crawford sostiene que deben tener cierto atractivo físico, esto lo consideramos cuestionable, ya que hay personajes que justamente su aspecto debe ser acorde a su modelo de personalidad y en ocasiones resulta fundamental para el personaje envolverse en un aspecto enigmáticos, que destaquen algún aspecto físico que lo aleje de estereotipos y modelos físicamente perfectos. Lo realmente importante será que la personalidad de los personajes refleje el comportamiento relacionado con las acciones y las decisiones que el personaje elija durante el devenir de la historia. De antemano un diseñador debe otorgar cualidades a los personajes para desarrollar su personalidad: sabiduría, sensualidad, codicia, orgullo, simpatía, confianza, honestidad, y por lo general, se deben considerar las variables antagónicas por ejemplo: cariño, estima frente a indiferencia y rencor. Se pueden crear personajes a partir de "mapas" de estados de ánimo que reflejen su personalidad en torno a cada una de las acciones que tendrán que tomar partido a lo largo de la historia con el fin de conseguir cierta coherencia y credibilidad en el personaje.

Lee sheldon ${ }^{725}$ sugiere que al diseñar a los personajes de los videojuegos debemos considerar que sean responsables de que la historia prospere y presenten su vida al

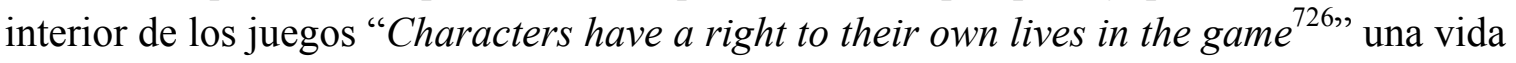
que debe determinarse en tres dimensiones: el carácter físico, sociológico y psicológico. Particularmente el medio visual permite reconocer las cualidades físicas de los personajes en función del juego; el aspecto sociológico debe reflejar su origen y cultura, añadiendo interés al personaje; y el carácter psicológico reúne sus actitudes, opiniones y su visión

\footnotetext{
${ }^{724}$ CRAWFORD, Chris., Cris Crawford on interactive storytelling., New Riders Press, Berkeley, 2005. (pp.179-199)

${ }^{725}$ SHELDON, Lee, Character development and storytelling for games, Course Technology PTR, Cengage Learning, Boston, 2004.

${ }^{726}$ SHELDON, Lee, Character development and storytelling for games, Course Technology PTR, Cengage Learning, Boston, 2004 (p.37)
} 
del mundo. No es necesario generar una radiografía detallada, eso además de aburrir, no resulta efectivo para la credibilidad del personaje. En ocasiones los asuntos más desconocidos del personaje resultan ser los más interesantes. Porque el personaje debe ir surgiendo en la historia de manera progresiva, creciendo y desarrollándose, es lo que les da la fuerza y cobran el interés de los jugadores-lectores, al verlos madurar a lo largo del juego.

Toda historia se compone de un personaje fundamental que genera el conflicto y consigue que el juego avance; resulta tan importante que sin él no hay historia. El personajejugador como lo designa Lee Sheldon, también se conoce como Player-Controlled Character o Avatar; es el personaje principal del juego y el protagonista de la historia; resulta incluso el vínculo entre juego e historia. Su manera de proceder e interactuar revela su naturaleza y la del juego. Ofrecen un cierto nivel de inmersión a los jugadores al permitirles jugar las aventuras, y crear empatías con los personajes en historias que cada vez son más complejas. Por ello los diseñadores deben considerar traducir las acciones acordes a los retos del juego y a las características tanto de personalidad como las habilidades que deben desarrollar los personajes-jugadores a lo largo del juego.

Mieke $\mathrm{Bal}^{727}$ confirma que un personaje es una unidad semántica compleja que nos encanta porque se parecen a las personas pero en esencia son criaturas prefabricados hechas de imitaciones de la fantasía y memoria, personas de papel y no de carne y hueso. En sí, los personajes no existen; es la narrativa la que produce "el efecto-personaje" las buenas historias los vuelven no solo posibles, sino inmortales.

Podemos basar la creación de los personajes en diferentes propuestas, como el Eneagrama de la personalidad, ${ }^{728}$ teoría que propone la existencia de patrones de pensamiento, emoción y comportamiento en las personas que pueden identificarse y clasificarse en nueve tipos y pertenecen a tres clasificaciones básicas: cordiales, cerebrales y viscerales. El tipo 1. El Reformador, se define por ser un idealista crítico y perfeccionista, organizado, perfeccionista y en ocasiones fastidioso que teme cometer errores. El tipo 2. El Ayudador, peocupado, empático, sincere, cálido, le gusta hacer cosas por otros y tienen problemas por hacerse cargo de ellos mismos, sin embargo son modelos para otros. El tipo 3. El Triunfador, adaptable y orientado al éxito, competente, energético, atractivo y encantador, ambicioso y preocupado por la imagen que tienen los demás sobre él. Son auténticos. Tipo 4. El Individualista, romántico, introspectivo, emocionalmente honesto, aunque egocéntricos, altamente creativos. Tipo 5 . El Investigador, intenso, cerebral, profundo, gran curiosidad y capacidad de concentración, desarrolla destrezas complejas. Se vuelven desconectados, pero intensos, son visionarios adelantados a su tiempo y son capaces de ver el mundo de forma distinta. Tipo 6. El

\footnotetext{
727 BAL, Mieke, Narratology; Introduction to the theory of narrative, University of Toronto Press, Toronto, 2009. (p. 113)

${ }^{728}$ George Gudijieff, fue el iniciador de esta teoría en los años 30s. Fundó el Instituto para el desarrollo armónico del hombre. En un inicio, el eneagrama de la personalidad fue un diagrama para describir las posibilidades de desarrollo humano. Para ampliar el tema véase: [artículo on-line] "El eneagrama de la personalidad" en: http://es.wikipedia.org/wiki/Eneagrama_de_la_Personalidad Consultado:4/07/2012
} 
Leal, comprometido, confiable, responsable, evasivo y altamente ansioso y quejumbroso. Pueden ser reactivos, desafiantes y rebeldes. Tipo 7. El Entusiasta, ocupado, productivo, versátil, práctico, y espontáneo, pueden ser un poco disperso, juguetón de gran espíritu, que busca experiencias nuevas, disfrutan todo y están llenos de gratitud. Tipo 8. El Desafiador, poderoso, dominante, confiado en sí mismo, fuerte protector, decidido, orgulloso y dominante, usan la fuerza para mejorar la vida de otros, son heroicos, magnánimos y a veces históricamente grandes. Tipo 9. El Pacificador, confiado y estable, de buena naturaleza, de temperamento fácil y apoyador, complacientes, intensamente vivos y conectados con ellos mismos y otros.

Entre los nueve tipos se establecen relaciones de afinidad y oposición, que se deben ampliar y servirán para crear personajes.

\section{Construcción del universo narrativo}

El espacio y la invención de los mundos posibles es un complemento que exige la literatura y los juegos. Debemos considerar el mayor número de detalles posibles; desde aquellos que definan su organización política y económica. Su lenguaje, creencias y todo lo que implica la descripción de un mundo físico con sus construcciones, espacios y ambientes. Richard Dansky ${ }^{729}$ contempla además el mundo físico, metafísico y cualquier otro elemento que permita definir el espacio en el cual se desarrollará la historia.

Mieke $\mathrm{Ba}^{730}$ nos recuerda que la historia está ligada al espacio en donde se desarrolla y plantea que la percepción de los personajes está relacionada con este espacio. Mediante los sentidos el espacio se muestra en una perspectiva particular, ampliando las posibilidades de invención de los mundos narrativos, cuyos atributos deben ayudar a crear mejores historias. Deseamos promover la creación de historias con mundos más complejos y verosímiles.

Traemos a colación la tradición de los artlangs comentados anteriormente ${ }^{731}$ para apreciar no solo el trabajo lingüístico de J.R.R. Tolkien sino la conformación de mundos narrativos de gran riqueza creativa y complejidad que incluso abarcan formas de comunicación alterna diseñadas ex profeso. Con la siguiente parábola podemos imaginar cómo se crean los mundos narrativos.

\footnotetext{
${ }^{729}$ DANSKY, Richard, "Introduction to narrative” en: BATEMAN, CHRIS (ed.), Game writing narrative skills for videogames, Game Development Series, IGTA, Charles River Media Publishing \& Course Technology, Boston, 2007. (p.3)

${ }^{730}$ BAL, Mieke, Narratology; Introduction to the theory of narrative, University of Toronto Press, Toronto, 2009. (p. 136)

${ }^{731}$ Véase pág. 41 aquí mismo.
} 
Erase una vez, no hace mucho tiempo en un lugar no tan lejano un par de hermanos que tenían una vida ordinaria. Un día se cansaron de la existencia de este mundo común y comenzaron a inventar una nueva existencia. El primer hermano se cuestionó si sería necesario caminar de manera derecha de un punto a otro, - Tal vez, razonó, tendría mayor sentido caminar en líneas curveadas, así podríamos ser más rápidos o sería más interesante. Reflexionó en las formas del universo que son particularmente curveadas. Y comenzó a enlistar las cosas que podían cambiar, como la noción de conectar dos puntos solamente mediante una línea recta o el paso lineal del tiempo.

Curiosamente estas nociones se invirtieron y un nuevo mundo comenzó a surgir.

Mientras tanto el segundo hermano comenzó a cansarse de la pesadez de las fuerzas de gravedad, de la materialidad de los objetos y del tedio ocasionado por la relación obligada entre la causa y el efecto. Así que imaginó un mundo en el cual los objetos flotaran a voluntad, las substancias se disolvieran y se recompusieran de maneras distintas y en el que los eventos fueran significativos unos a otros pero no se determinaran y comenzó a suponer que el viento estuviera hecho de luz, y el cielo, formado por flores. De esta manera los dos hermanos comenzaron a reinventar el mundo; es importante remarcar que lo hicieron sin prestar atención a nociones anti racionales y no-intuitivas; el resultado sin embargo fue fascinante, mundos imposibles se volvieron una realidad: el hombre fue capaz de olvidar los detalles y sin embargo, podía hacer abstracciones: Dios podía suspender el tiempo de algunos hombres y de otros no, una moneda podía tener sólo un lado, un libro podía tener un número infinito de páginas que además, no podían ser redescubiertas o podía existir un mundo cuya existencia dependiera de la percepción.

Así continuaron, imaginando espacios en los que objetos comunes y no comunes convivieran, las personas se "metamorfosearan" en animales o plantas exóticas, fantasmas y quimeras. Lo que daba cierta estructura a sus mundos eran dos códigos, uno organizaba las cosas con cierta naturalidad y sentido y el otro organizaba los eventos de tal manera que cualquier número de acontecimientos extraños podían ocurrir: hombres que nadaban al fondo de los mares descubriendo ciudades perdidas en donde la vida transcurría con normalidad o se construían faros con bloques de hielo. Ambos códigos estaban entretejidos fuertemente entre sí. Ambos hermanos aprendieron a contar historias de sus mundos inventados con gran ingenio. Lo hacían en forma clara y directa sin hacer omisión alguna, encogerse de hombros o pasando por alto algunas cosas, al fin de cuentas era sólo un cuento en el cual el mundo no se había reinventado, sólo se había disfrazado temporalmente y no requería de explicaciones porque sus mundos fácilmente generaban sus propias

creencias.

Sin duda siempre existen personas a los que les gustaría reinventar el mundo, y como no pueden hacerlo por sí solos, piden a otros que lo hagan para ellos; así que los dos hermanos pronto reunieron discípulos y seguidores que reinventaron a su vez sus propios mundos de acuerdo a estos códigos pre-formulados. El número de seguidores creció tanto que pronto los hermanos fueron confundidos con magos, hechiceros $e$ impostores, al final nadie sabía quiénes eran y se volvieron una colección de pequeños mitos. $^{733}$

${ }^{732}$ WILSON, R. RAWDON, Palamede's shadow; explorations in play, game \& narrative theory, Northeastern University Press, Boston, 1990.

${ }^{733}$ WILSON, R. RAWDON, Palamede's shadow; explorations in play, game \& narrative theory, Northeastern University Press, Boston, 1990. (pp. 169-171) [traducción y adaptación de autor] 
En esta historia, los dos hermanos reinventaron el mundo extra textual y al hacerlo, pudieron crear un nuevo mundo textual. Dicho desde la visión literaria, como afirma Rawdon Wilson, ${ }^{734}$ crear un mundo es una noción extraña, es un término empleado por críticos y académicos para expresar la percepción del contenido y coherencia del propio texto. Las metáforas de exploración, inmersión e interrelación como "perderse" en el texto describen las estrategias comunes de la práctica lectora. Los textos y los videojuegos son mundos producto del ingenio humano que integran elementos diversos de manera tan bien articulados que resulten un todo creíble aunque sean humanamente imposibles, lo que nos ofrece otro buen reto para considerar.

La narrativa formal contempla relatos que se presentan mediante métodos tradicionales; en cambio en los entornos digitales, las historias son producto de la interpretación del jugador, su interrelación y manipulación del sistema. La historia se desarrolla mediante diversas técnicas, diálogos que escuchamos o textos que se desplantan en pantalla en relación a escenas animadas que ayudan a relatar la historia detrás del juego. De hecho, señala, Richard Boon ${ }^{735}$, es una labor importante de los diseñadores de texto, reconocer las oportunidades narrativas de los diversos momentos del juego y proponer la manera de presentarlos. Mediante una visión particular, cada historia se desdobla ante sus lectores o usuarios. La Focalización es la posición a través de la cual se aprecian los eventos en la narrativa, similar al punto de vista o la voz narrativa en la cual el narrador, como elemento focalizador, da muestras de emoción, de su sentir y pensar en torno a los acontecimiento que relata.

Elementos no narrativos, Textos imbuidos, Cut Scenes y Scripted Events [Eventos pre-programados] Los videojuegos cuentan con la aparición de ciertos elementos como cartas, anuncios y cualquier tipo de texto incrustado o imbuidos dentro de otros textos en distintos momentos del juego. Estos pueden ser micro relatos que los personajes imaginan, recuerdan o dialogan a lo largo del curso de la historia principal. En los videojuegos esto se conoce como cut scenes. Chris Bateman los define como "in-game movies", secciones de escenas en movimiento, también consideradas como "footage" que el jugador observa pero no puede interactuar de manera alguna. Se utilizan para dar alguna explicación adicional o introductoria. Varios cut scenes forman una secuencia cinemática.

Los "Scripted Events"o Eventos pre-programados, son una parte del juego en donde el jugador no tiene control alguno, difieren de los cut-scenes en su construcción y presentación al ser más sencillas, una especie de escenas semejantes al de una cámara de vigilancia, enfocando ciertos objetos o acontecimientos que demandan atención.

\footnotetext{
${ }^{734}$ WILSON, R. RAWDON, Palamede's shadow; explorations in play, game \& narrative theory, Northeastern University Press, Boston, 1990. (p. 171)

${ }^{735}$ BOON, Richard, "Writing for games" en: BATEMAN, CHRIS (ed.), Game writing narrative skills for videogames, Game Development Series, IGTA, Charles River Media Publishing \& Course Technology, Boston, 2007. (p.46)
} 
En ocasiones las historias provienen de otras historias que deben adaptarse a requerimientos técnicos y formales de nuevos proyectos. Los diseñadores de textos saben que las historias no se traducen fielmente de un medio a otro, en el trayecto sufren alteraciones y modificaciones; hay un préstamo de elementos e ideas que se ajustan a nuevas situaciones y resultan ser un factor creativo como en cualquier ejercicio artístico. Algunos escritores tratan de reproducir fielmente una historia en otro formato, como ciertas novelas llevadas al cine, aunque esto no siempre es posible, realizan una versión parecida a su fuente original. Las labores de adaptación se deben ajustar gracias a labores previas de diseño y planeación permiten conocer el medio para detectar su potencial.

\subsubsection{Recursos De Poética Digital}

Los medios digitales ofrecen a los creadores recursos de composición que debemos entender como herramientas en vías de experimentación cuya implementación es un verdadero reto para los escritores. Uno de los recursos digitales más importante es la interactividad, cuya creencia generalizada plantea dificultades al vincularla con la generación de historias, dado el carácter de "libre participación" de los usuarios, con frecuencia solo resultan historias poco coherentes. Si llevamos a cabo ciertas recomendaciones ligadas a la estructura de los videojuegos, las historias interactivas pueden conseguir algunas mejoras.

Partimos de que la interactividad es posible gracias a que la información puede articularse a través de vínculos o enlaces conectados entre sí conocidos como nodos. Éstos integran una red de datos que se articulan de diversas maneras, se articulan linealmente, en forma ramificada, jerárquica o dentro de gráficos acíclicos o cíclicos (loops). Al conectarlos, es posible la navegación dentro del sistema a través de distintos caminos estructurados. Los ordenadores permiten que estas "arquitecturas" de navegación sean muy complejas, jerárquicas, hipercubos, retículas o incluso presentan otras formas muy elaboradas. Entre más compleja sea la estructura interna de un sistema, los usuarios tienen más formas de moverse de un nodo a otro y potencialmente, encontrar más caminos para llegar a la información, aunque corren el riesgo de perderse en el ciberespacio textual y no conseguir historias coherentes. La forma más sencilla es la navegación lineal en la que cada nodo tiene al menos un vástago y un padre, como se muestra en esta imagen.

\footnotetext{
${ }^{736}$ RYAN, Marie-Laure., Narrative across media; the languages of storytelling, University of Nebraska Press, Lincoln, 2004 (p. 400)
} 

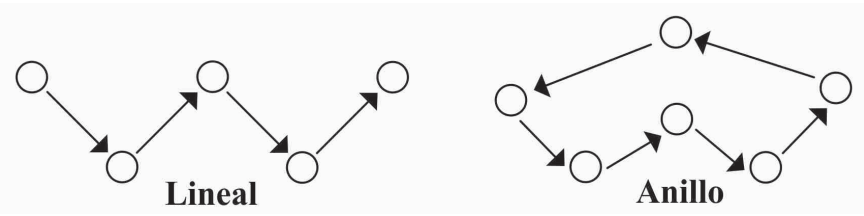

En una estructura jerárquica sólo hay un padre del que se desprenden varios vástagos en distintas generaciones, los cuales a su vez pueden regresar al padre.

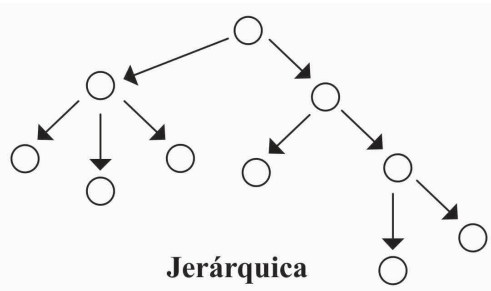

Hipercubo o hipertorus, son formas integradas por estructuras simétricas que permiten un considerable número de diferentes pasajes, véanse las imágenes.

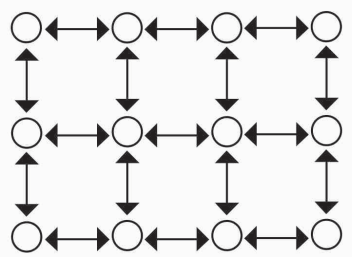

hipercubo

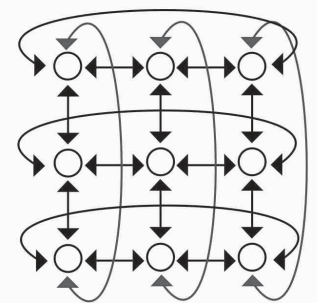

Hipertorus

Existen además los Grafos Acíclicos directos o dirigidos, los cuales tienen un punto de entrada, con un ancestro común y posee veredas que no son únicas y la ausencia de ciclos, es decir, no hay regreso.

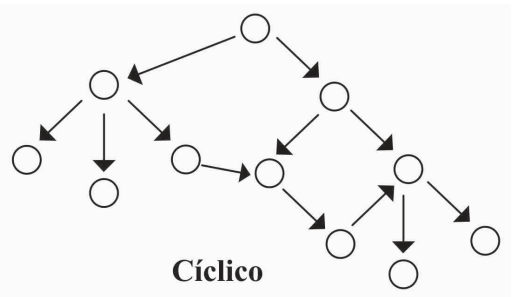

Traer a colación esto, que sin duda debe ampliarse, ${ }^{737}$ nos parece importante elemento fundamental para establecer nexos y conexiones entre los elementos que integran las historias. Podemos pensar en generar una historia a partir de sus estructuras, lo cual permite desarrollar complejas estructuras hipertextuales interactivas ${ }^{738}$. El reto de será crear una estructura que podamos asignarle nodos que "revistamos" de contenido, haciendo hincapié en que éste contenido tenga calidad y pueda convertirse en un material significativo. Las historias que nos gustan tienen un formato atractivo, pero sobre todo tienen elementos que proporcionan información que resulta interesante y atractiva.

\footnotetext{
${ }^{737}$ Este tema puede ampliarse con temas de teoría de gráficos, topología y teorías del hipertexto. Recomendamos revisar FRESS (File Retrieval and Editing System); HyperCard, StorySpace o Tinderbox. ${ }^{738}$ Véase: BERNSTEIN, Mark, "Can we talk about spatial hypertext", Eastgate Systems, Inc., Watertown, 2011 en: ACM Digital Library, 2011. [Texto on-line] en: http://portal.acm.org/guide.cfm Consultado: $25 / 06 / 2012$
} 


\section{Interactividad}

La interactividad puede llevarse a cabo desde el más simple estímulo-respuesta ante un clic del ratón y escuchar un sonido o encender un destello, moverse y navegar dentro de un menú de opciones, controlar objetos virtuales que realizan ciertas acciones, cambiar de página, abrir ventanas, accionar videos; establecer comunicación con otros elementos y otros usuarios, enviar, recibir o adquirir información y manipular diferentes objetos. De hecho este mismo clic puede hacer cosas realmente complejas como modificar las estructuras de las historias.

La interactividad ha cambiado nuestra experiencia, pasamos de ser miembros pasivos a adoptar un papel activo que dota de significados; ejerciendo un nuevo atributo, la agencia [agency]. Richard Boon ${ }^{739}$, propone cuatro formas básicas de interactividad en las narrativas las cuales están en función de los diferentes grados de participación del usuario y son: Narrativa Implícita, Narrativa Formal, Narrativa Interactiva e Historias Interactivas.

La Narrativa Implícita, llamada también narrativa emergente, introduce la interacción de elementos dentro del sistema del juego contribuyendo a que el usuario pueda determinar esos elementos como parte de una historia. Los juegos son sistemas de elementos interrelacionados que contribuyen a que le jugador genere un tipo de narrativa a partir de su experiencia.

Las Narrativas Formales incluyen métodos tradicionales para presentar sus historias y constituyen elementos planeados que se presentan en formas de diálogos, cartas o cualquier otra forma de texto. La labor de los diseñadores es encontrar el momento adecuando entre las acciones para desplantar estos textos que contribuyen a la creación de la historia. Pueden ser recursos que aparecen con ciertos formatos que se leen o escuchan; como cartas, notas, diarios, fotos, etc.

La Narrativa Interactiva combina elementos tanto formales de la narrativa con otros propios de los juegos, interactivos. Resulta difícil crear un material narrativo con tal grado de interactividad que cubra todas las situaciones posibles, así que al estar limitado a un número finito de opciones que el diseñador definirá previamente; el usuario no puede componer por completo la historia de manera autónoma, siempre existe un sistema previamente armado el cual no se puede alterar por completo

Las Historias Interactivas, difieren de la anterior al presentar un grado mayor de participación y cuyas acciones del usuario tiene consecuencias en la historia. No solo al elegir los caminos por donde avanzar, sino haciendo cambios estructurales profundos a las historias. Para ello debe existir un tipo de historia que pueda armarse de diferentes maneras. Esto demanda un verdadero trabajo de ingeniería de historias que deseamos experimentar.

\footnotetext{
${ }^{739}$ BOON, Richard, "Writing for games" en: BATEMAN, CHRIS (ed.), Game writing narrative skills for videogames, Game Development Series, IGTA, Charles River Media Publishing \& Course Technology, Boston, 2007. (p.44)
} 
La conexión entre ordenadores y lectores activos ofrece la posibilidad de recorrer los textos por diversos caminos. Ken Perlin ${ }^{740}$ señala que existe la interacción a múltiples niveles, la cual se aprecia como un fractal que se interrelaciona mediante diferentes detalles de una historia. Sin embargo debe establecerse un equilibrio entre la participación del lector y los planes del escritor. Al respecto, Michael Mateas ${ }^{741}$ enuncia que existen dos principales acercamientos a la interacción de historias o a la narración de historias interactivas, las narrativas estructuradas centradas en la trama y las simulaciones de procedimiento basadas en los personajes o agentes que interactúan con los usuarios quienes determinan estas narrativas emergentes. Lo óptimo sería que las historias se centraran tanto en su línea argumental, en sus personajes así como en las emociones que las acciones despiertan. De tal suerte que la orientación de la historia al elegir las elecciones, no resultarían del todo arbitrarias, sino que podrían ser coherentes y posibles.

Apreciamos piezas narrativas que invitan al lector a recomponer los textos, que avanzan en diversas direcciones, integran textos con diversos formatos, imágenes o cualquier otro recurso; sin embargo, estas prácticas no llegan a alterar de ninguna manera el argumento de la historia, ni el devenir de los personajes o de sus acciones. A pesar que ofrecen formas de "interactuar" con los textos, éstos no lo modifican en absoluto. Existe por lo tanto una gran diferencia entre interactuar con las historias y hacerlo únicamente con los medios. En nuestra búsqueda de conectar juegos y narrativas, no podemos dejar de mencionar el interés de estudiar las dificultades que generan uno y otro. Con relación a las historias de los videojuegos, los jugadores interactúan con los personajes de manera particular, tienen cierto control sobre ciertas acciones, lo que no implica que estas historias sean interactivas o que las decisiones sean enteramente libres y se consigan después de todo, historias coherentes. Otorgar completa libertad al usuario complica las historias no solo desde el plano del sentido que se relata, sino además de su estructura argumental. Richard Boon lo sugiere así, "some commentators consider it impossible to create a satisfying story while still providing such a degree of agency to the player due to the lack of authorial control ",742

El reto de los diseñadores de textos digitales es construir historias multigranulares que puedan conectarse entre sí a diferentes niveles de significación con el fin de que puedan conformar una línea narrativa que conserve afinidad y sobre todo, coherencia. Carolyn Handler Miller ${ }^{73}$, citando a Roach señala que los elementos interactivos se componen de una gran cantidad de pequeños pedazos, o trozos, los cuales pueden ser personajes, acciones o atmósferas. Si el texto es demasiado granular y el input del usuario es muy

\footnotetext{
740 PERLIN, Ken, “Toward Interactive narrative” (pp. 135-147), LNCS, Springer-Verlag Berlin, 2005. (p.142)

${ }^{741}$ MATEAS, Michael, “A preliminary poetics for interactive drama and games" (19-32) en: WARDRIPFRUIN, Noah \& MONTFORT, Nick, The new media reader, The MIT Press, Cambridge, 2003.

742 BOON, Richard, "Writing for games" en: BATEMAN, CHRIS (ed.), Game writing narrative skills for videogames, Game Development Series, IGTA, Charles River Media Publishing \& Course Technology, Boston, 2007. (p.47)

${ }^{743}$ HANDLER MILLER, Carolyn., Digital storytelling; a creator's guide to interactive entertainment, Focal Press, Burlington, MA, 2008. (p.64)
} 
frecuente, no habrá oportunidades para generar una historia. Por lo que se debe establecer un equilibrio entre la granularidad y solidez de un número apropiado de variables.

Player-driven storytelling [narrativa conducida por el jugador] es un término acuñado por Josiah Lebowitz y Chris Klug ${ }^{744}$ para designar aquellas historias en las que el jugador tiene mayor control sobre el progreso y desarrollo de la historia y puede modificarla y alterarla. Ambos enlistan ciertos tipos de historias que vale la pena considerar: historias con finales múltiples, historias ramificadas e historias abiertas. Las cuales admiten cierto grado o nivel de participación por parte de los usuarios-lectores o jugadores.

"Because interactivity can break up the cohesiveness of a narrative,
it becomes necessary to look for other ways to tie the various
elements together and to supply the momentum that, in traditional
storytelling would be supplied by the plot. Many professionals in
digital media believe that the best solution is to use a gaming model
as the core of an interactive work and build narrative elements
around it. Games provide an attractive solution because they involve
competition, contain obstacles and a goal, and achieving the goal is
usually a game's driving force"

Estamos convencidos que el juego puede convertirse en un vehículo muy útil para lograr la cohesión de los elementos granulares dentro de un sistema interactivo. Por ello sirve de modelo para diseñar narrativas. Existe por otro lado, una tradición de ficción interactiva no basada en modelos de juego. Recomendamos estos sitios en donde se puede apreciar y extender el tema ${ }^{746}$.

Agencia y Autoridad son conceptos relacionados con la interactividad y que se deben contemplar al tratar sobre las narrativas y los juegos de roles principalmente. "Agencia" describe las posibilidades de tomar acción dentro de las posibilidades que ofrece el sistema. "Autoridad" se refiere a la habilidad de cumplir y juzgar los resultados de esas acciones. De tal manera que la agencia propone y la autoridad lo lleva a cabo.

La agencia textual sería entonces el control que se tiene sobre el texto en cuestión. Dentro de los juegos de roles, la agencia está prediseñada formalmente pero su interpretación es flexible y dependiente de la participación de los jugadores que le dan forma a la historia mientras juegan. Los jugadores buscan que sus elecciones sean importantes y significantes para la historia. Sin importar cual sea el interés del juego contar una historia, ganar, o participar en una simulación - los jugadores no desean que sus acciones sean ignoradas, desean participar de diferentes maneras. "The more available types of agency, the more that authors will be able to create fabulae that go beyond their own character's $\operatorname{skin}^{747}$.",

\footnotetext{
744 LEBOWITZ, Josiah \& KLUG, Chris., Interactive storytelling for video games, Elsevier / Focal Press, Burlington, 2011. (p. 119)

${ }^{745}$ HANDLER MILLER, Carolyn., Digital storytelling; a creator's guide to interactive entertainment, Focal Press, Burlington, MA, 2008. (p. 63)

${ }^{746}$ Véase: http://collection.eliterature.org/ consultado: 19/06/2012.

747 KNOBEL, Michele \& LANKSHEAR, Colin, A new literacies sampler, Peter Lang Publishing, Inc., New York, 2007. (p.91)
} 
El reto para los narrajugadores es encontrar la manera de utilizar estos recursos con tal efectividad que permita a los usuarios tanto sentir que tienen el control así como obtener una experiencia narrativa significativa. Que en cierto modo, pueden ser creadores de narrativas.

\subsubsection{Recursos Hermenéuticos}

El trabajo de un diseñador de textos es dotar de sentido a un cúmulo de palabras, el manejo de los símbolos, conexiones y los enlaces que se pueden establecer con sus lectoresjugadores. El texto, según Helena Beristaín ${ }^{748}$, es un organismo cuyos elementos forman un todo coherente a diferentes niveles. Todo texto contiene explícitas o no, las marcas necesarias para su comprensión. Para otros teóricos como Dolezel, los textos literarios son "sistemas semióticos altamente organizados de producción significante, creativa e imaginativa. Para Lotman $^{749}$, la lectura de un texto polisémico parte de una doble experiencia, la comprensión de su contenido y el placer estético. Además, cada detalle del texto artístico adquiere más de un significado y más de una posible interpretación, debido a esta red de relaciones que se establece de manera intrínseca de acuerdo a su código y posibles lecturas que revelan diversos estratos semánticos, de manera similar a los palimpsestos ${ }^{750}$. El I Ching, es el mejor ejemplo de cómo una leyenda sugerida por el azar de las monedas, puede cobrar sentido ante los cuestionamientos y respuesta metafórica que el lector interpreta. Y por lo tanto el significado del texto está relacionado con el "horizonte de expectativas" del lector, el cual está condicionado por ciertos "códigos receptivos" que pueden variar de una persona a otra.

Por ello el diseñador de textos debe residir en generar historias estructuralmente creativas, implementando tratamientos innovadores con cierta complejidad simbólica y significativa. Es lo que hace que las historias sean interesantes y estimulantes a la audiencia; aunque precisamos que esto no depende del producto sino que está condicionado en gran medida por los gustos, modas, conocimientos y experiencias previas y por el estado de ánimo del usuario quien emite su opinión ante el texto.

El deseo de leer o jugar parte de un tipo de invitación que engancha al lector-jugador a querer participar activamente y armar la aventura o los acontecimientos en forma de una historia, ya sea explícita e implícita. Dotada con imágenes, objetos y ciertos elementos que dotan de sentido a las historias. Por ello cualquier detalle que se presenta, debe tener una función que enriquezca el contenido del proyecto. El manejo acertado de un contenido de mayor complejidad y significación, permite distinguir una buena obra de una estupenda.

\footnotetext{
${ }^{748}$ BERISTAÍN, Helena, Diccionario de retórica y poética, Editorial Porrúa, México, D.F., (p. 484)

${ }^{749}$ Citado por EAGLETON, Terry, Una introducción a la teoría literaria, Fondo de Cultura Económica, México, D.F., 1988. (p. 127)

750 Palimpsesto, que en griego significa "grabado nuevamente" y se refiere a un manuscrito que se ha escrito varias capas superpuestas de escritura.
} 
Sabemos que no todos los lectores-jugadores son iguales, algunos les gusta ir hasta el fondo de las historias y acuñar el mayor número de detalles, otros en cambio, sólo buscan llegar al final sin importar lo que dejan de conocer o entender. Por ello un reto será involucrar al usuario en historias que admitan múltiples lecturas que puedan completar con lo que saben y lo que les gusta. El objetivo es generar entornos inmersivos y atractivos que les permitan componer y adaptar historias, con múltiples significados que quieran vivir o jugar en más de una ocasión, por el interés de un nuevo descubrimiento cada vez.

\subsubsection{Recursos Formales}

Los elementos formales son aquellos que integran la estructura de un juego o de una historia, como las reglas, límites, resultados, castigos, intrigas, conflictos y otros. La estructura es el armazón o esqueleto constituido por la red de relaciones que establecen las partes entre sí. Es decir, se trata de un sistema articulatorio o relacional de hechos observados que constituyen un todo. Para Hjemslev la estructura es una entidad autónoma de relaciones internas constituidas en jerarquías susceptibles de descomponerse en partes vinculadas entre sí.

La estructura narrativa en el videojuego es "progresiva" según señala Chris Bateman ${ }^{751}$, la cual determina cuando y ante qué respuesta se permite el progreso en el juego. El jugador se enfrenta a una serie de entrenamientos, intentos (algunos fallidos) recibe castigos y recompensas. Conforme avanza o progresa en el juego, surgen más exigencias que demandan mayor destreza por parte de los jugadores. En un avance progresivo el jugador encuentra la manera de librar dificultades y cumplir retos y misiones. Si no hay avance, no hay juego, esto debiera estar relacionado también con las historias; si la historia no progresa, tampoco lo hace el juego.

Los jugadores adoptan los roles del juego, emprenden ciertas tareas y se vinculan al juego de diversas maneras; ya sea bajo el formato de "jugador contra jugador", "jugador contra el juego", "múltiples jugadores contra el juego" o el de la "competencia multilateral, juego cooperativo o competencia entre equipos". Ya sea los juegos individuales o colaborativos, las historias pueden recomponerse con la aportación de uno o de muchos jugadores.

Es importante apreciar cómo los elementos formales son la esencia de juegos e historias, con el fin de potenciar sus interrelaciones y construir mejores productos enlistamos algunos elementos:

Las Reglas definen el objetivo del juego y establecen las acciones permitidas de los jugadores, éstas debe ser claramente entendidas por los jugadores. Además de plantear los objetivos, restringen las acciones deben estar relacionadas con las historias.

\footnotetext{
${ }^{751}$ BATEMAN, CHRIS (ed.), Game writing narrative skills for videogames, Game Development Series, IGTA, Charles River Media Publishing \& Course Technology, Boston, 2007. (p.58)
} 
Los recursos (premios o castigos) son los elementos que otorgan valores, vidas y cualquier otro regalo o don que reciben los jugadores, que resultan muy apreciados y en ocasiones son el estímulo del jugador para continuar. En ocasiones el tiempo funciona como recurso que restringe o posibilita las acciones.

Conflicto, los jugadores se enfrentan a retos que deben superar. Los conflictos hacen que los objetivos del juego se vuelvan más difíciles de conseguir al plantear procedimientos, situaciones y límites que imposibilitan al jugador a actuar libremente imponiéndole obstáculos y generando dilemas por resolver.

Los límites, confirmado por Tracy Fullerton ${ }^{752}$ es lo que separa los juegos de lo que no lo son. Recordemos cómo Huizinga planteaba la idea del "círculo mágico" y como la aceptación del juego y sus límites también le da un carácter de temporal, al permitirle a jugador dejarlo en cualquier momento. Los límites son necesarios para establecer retos más interesantes. Un juego sin dificultades, tiempos restringidos y otros condicionantes, no despertarían el nivel emocional del jugador y su interés por jugar.

Enigmas y acertijos, son otro recurso formal de los videojuegos que contribuyen a la generación de un conflicto entre el juego y el jugador: como buscar explosivos contra reloj, salir de laberintos, abrir puertas y encontrar pócimas mágicas, entre otros. Por lo general se trata de retos que demandan cierta abstracción e ingenio y le permiten a los juegos, enriquecer sus historias a partir de estos retos por resolver. Tal vez incluso inviten a los diseñadores de texto a componer historias en las que el nivel de retos, recompensas y castigos sea parte de la dinámica de la historia. En donde el sistema tenga un sistema equilibrado entre las opciones que tienen los jugadores y el interés de apreciar mejores historias.

Tipos de estructuras en las historias de los juegos, tanto los juegos como las narrativas desarrollan diferentes maneras de estructurar sus historias. Los discursos narrativos pueden expandirse o contraerse, avanzar o retroceder. Los lectores y jugadores reconstruyen en su mente la información en el orden que suceden los acontecimientos y re-componen la historia. Estas se organizan bajo una estructura, entendida como la manera como se presentan los elementos que constituyen los juegos y las narrativas, los espacios, avatares y acciones se organizan y determinan el progreso del juego. Existen muy diversas maneras para representar las historias, en forma arbórea o en forma de bosque. Como una secuencia o grupo de acciones, escenas o actos. Los diseñadores de textos deben pensar en desarrollar diferentes esquemas narrativos en los que las acciones de las historias y las del juego se confundan, en donde el jugador explore el espacio narrativo. Chris Bateman ${ }^{753}$ refiere cuatro estructuras progresivas básicas de los juegos con orientación narrativa:

\footnotetext{
752 FULLERTON, Tracy., Game design workshop: a playcentric approach to creating innovative games, Morgan Kaufmann, Burlington, MA, 2008.

753 BATEMAN, CHRIS (ed.), Game writing narrative skills for videogames, Game Development Series, IGTA, Charles River Media Publishing \& Course Technology, Boston, 2007. (p.57)
} 
Lineal, aquella que el progreso del jugador se lleva a cabo a través de una serie lineal de niveles de juego en donde el reto es encontrar la manera de conducirse al siguiente nivel, por lo general la narrativa que se presenta tiene el formato de cut-scenes, mensajes de misiones, textos y otros materiales. Este tipo de estructura resulta ser la más sencilla y la que facilita en mayor grado la narrativa Continua, tiene semejanza con el formato anterior pero en ésta no hay rupturas o niveles por lo que el progreso se presenta como un avance progresivo en el cual incluso se puede regresar al principio. Las narrativas se presentan y ocurren en el momento que suceden los acontecimientos e incluso el jugador tiene el control de incluso, omitir el segmento narrativo, el cual no condiciona su avance.

De esfera o cubo, en la que se presenta un núcleo del cual se tiene acceso a otras áreas por lo general después de haber conseguido algunas tareas, es el caso de ciertos juegos en donde se llega a una espacio que conduce a otros lugares y siempre se puede volver al mismo origen y en el que cada elemento ofrece información o plantean nuevos retos o tareas que se deben buscar y completar. Y Contigua, una estructura que da la ilusión de crear un mundo explorable, en el cual no solo se tiene acceso a un solo espacio, sino que éste se conecta con otros espacios, y el jugador puede recorrerlos, la diferencia con la estructura continua, es que ésta no admite retrocesos y en cambio la contigua admite cualquier movilidad en todas direcciones. Esta libertad de movimiento dificulta un poco que se lleve a cabo una línea narrativa, excepto la que se puede desarrollar en cada nivel. El reto de los diseñadores es establecer estos mundos paralelos y la manera de interconectar historias que puedan eslabonarse de manera modular, teniendo en cuenta que el devenir de los acontecimientos deben respetar el orden de la historia y no pueden relatar algo que aún no sucede. De ahí la necesidad de diseñar de manera conjunta tanto la estructura del juego como la de la historia; puede servir el tener un diagrama de flujo que indique cómo es que el juego se irá desarrollando y qué tipo de estructura tiene para diseñar la historia que puede diseñarse detrás de los espacios, locaciones y acciones que se presentan en el juego.

Brenda Brathwaite e Ian Schreiber ${ }^{754}$ presentan su propia clasificación en la que consideran igualmente, las historias lineales, que progresan de un punto a otro, las ramificadas que permiten que la historia se presente con múltiples caminos y finales posibles. Una variante de estas historias es recurrir a veredas paralelas que pueden simultáneamente presentar sus puntos climáticos y regresar a la historia original. Otro tipo son las narrativas con finales abiertos o con múltiples hilos, que permiten a los jugadores comenzar en un lugar en particular o en diferentes lugares y avanzar en diversas direcciones, las cuales afectan el desarrollo y resultado del juego. Las historias emergentes surgen de la mecánica del juego y de la experiencia del jugador que crea su propia historia la cual no necesariamente fue planteada por el diseñador del juego y las algorítmicas, que son construidas por el ordenador con la ayuda de sistemas de

\footnotetext{
${ }^{754}$ BRATHWAITE, Brenda \& SCHREIBER, lan, Challenges for game designers, Course Technology, Boston, 2009. (pp. 174-175)
} 
Inteligencia artificial. Chris Bateman ${ }^{755}$ sugiere que un diseñador de juegos puede conducir al jugador y hacerlo avanzar mediante una estela de huellas o rastros a la que llama "los rastros de migajas de pan", y no es otra cosa que información y sugerencias otorgadas al jugador que le permitan mantenerse dentro de una línea narrativa.

\subsubsection{Cuarta Etapa: EDITAR}

\subsubsection{Recursos Analógicos}

Los libros se apoyan en palabras para crear imágenes y articular historias, el cine usa diálogos, imágenes, efectos sonoros y técnicas cinematográficas. Los videojuegos utilizan una infinidad de recursos que hemos venido apreciando. Resulta imposible no atender los aspectos formales de la narrativa impresa. Por ello este trabajo tuvo el interés de hacer un recuento de una diversidad de recursos que consideramos pueden detonar ejercicios creativos. Leer trabajos literarios ayuda a componer nuevas historias para proyectos digitales narrativos. Apoyarnos en anécdotas e historias conocidas es otra fuente creativa. Nuestra propuesta recomienda transformar una historia en un juego o un juego en una historia. Y exige que empleemos diversas técnicas, algunas muy sencillas como la aparición de hipervínculo en textos en pantalla hasta otros que afectan la estructura misma de los juegos a través de múltiples micro historias que integran una historia de mayor complejidad.

Existe una correlación entre la linealidad del juego y de la historia, entre menos lineal sea el primero, la historia debe componerse de manera más compleja y demanda más trabajo. Recordemos que nuestro interés es jugar las historias y conseguir la experiencia de poder armar y recomponer las historias a nuestro antojo. Aunque esto no es siempre posible, es un buen reto para emprender un nuevo formato de historias lúdicas. Por lo pronto, nos dice Chris Bateman, los diseñadores de textos "will continue to experiment with the narrative language of games and stretch the boundaries of interactive narrative by taking players on ever more inventive journeys ",756

\subsubsection{Recursos Digitales Multimedia}

Una historia digital requiere de ciertos recursos técnicos, el uso de software que permita la inserción de elementos visuales, sonoros y otorgue el control a los usuarios. Tracy Fullerton ${ }^{757}$ plantea cuatro líneas de investigación en el desarrollo de los recursos: la mecánica del juego, su estética, kinética y la tecnología empleada. La mecánica del juego es la serie de acciones que los jugadores repiten una y otra vez mientras se mueven a

\footnotetext{
755 BATEMAN, CHRIS (ed.), Game writing narrative skills for videogames, Game Development Series, IGTA, Charles River Media Publishing \& Course Technology, Boston, 2007. (p.91)

${ }^{756}$ BATEMAN, CHRIS (ed.), Game writing narrative skills for videogames, Game Development Series, IGTA, Charles River Media Publishing \& Course Technology, Boston, 2007. (p.84)

${ }^{757}$ FULLERTON, Tracy., Game design workshop: a playcentric approach to creating innovative games, Morgan Kaufmann, Burlington, MA, 2008. (p.213)
} 
través del sistema del juego, el cual no sólo se compone de un contenido sino también de acciones. Esperamos generar un sistema que dé las pautas y ofrezca posibilidades creativas-estructurales para armar historias, uno que utilice diversos recursos visuales y sonoros y presente ciertos "caminos" para armar las historias que los usuarios deben elegir y completar, sólo entonces podemos afirmar que el sistema es un generador interactivo de historias. Las composiciones actuales incluyen textos, sonido, imágenes fijas y en movimiento, recursos públicos y propios y una fuente inagotable de recursos, similar a una biblioteca infinita. Con la ventaja que el escritor, la publicación, distribución y la audiencia ahora está conectada dentro de una red global, inmediata, dotada de recursos ilimitados ${ }^{758}$. Basta apreciar el listado de "Algunas tareas de los escritores de medios digitales", en la sección de Anexos (pág. 275) de este mismo trabajo, para confirmar el universo literario de los nuevos entornos.

Encontramos una diversidad de opciones y debemos allegarnos de recursos que apoyen el diseño de los textos y relatos. La utilización de esquemas gráficos y diagramas de flujo puede ser de gran ayuda, sobre todo al diseñar historias ramificadas que los usuarios irán armando. Esto permitirá tener una visión gráfica que muestre el contenido del producto. Véase el siguiente cuadro.

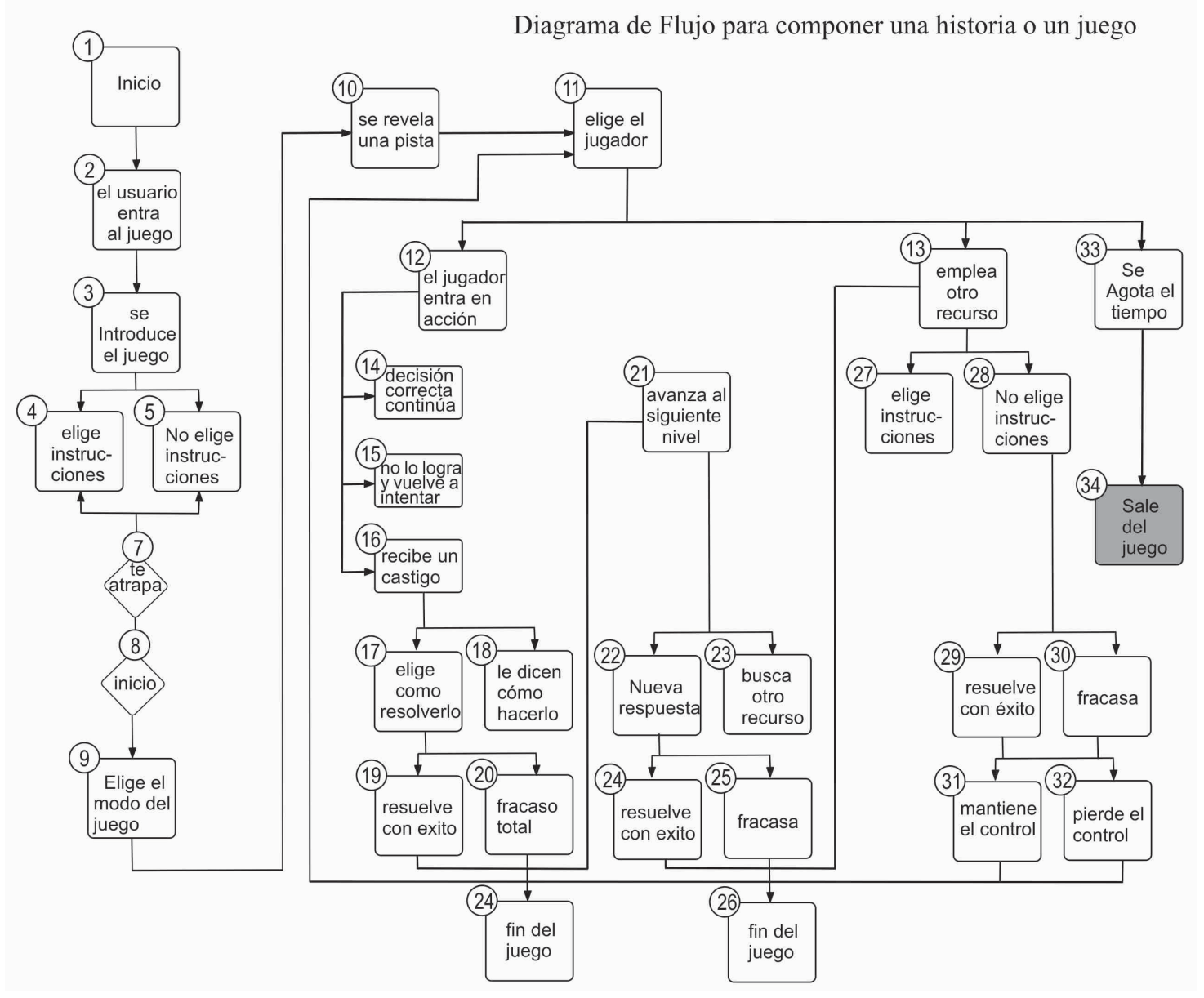

\footnotetext{
${ }^{758}$ Puede ampliarse esta información y conseguir recomendaciones de la International Game Developers
} Associaciton (IGDA). Véase: http://www.igda.org Consultado: 22/06/2012 
Notaciones visuales como mapas, esquemas, listas, e hipertextos ayudan a organizar espacialmente los contenidos. Con respecto a los hipertextos, las palabras y símbolos en pantalla cobran un significado por sí mismos además del sentido que le otorga su ubicación con relación a otros objetos, su forma, tamaño, incluso algún otro atributo como el color o su apariencia. Los sistemas utilizados para organizar ideas, como los que generan mapas mentales y conceptuales, y aquellos que permiten esquematizar elementos, como el de hacer notas, pueden ser una buena herramienta para estructurar narrativas digitales ${ }^{759}$. Esto por la facilidad de mostrar un grupo de elementos y visualizar las relaciones y los patrones de conexiones que poseen.

\subsubsection{Quinta Etapa: EVALUAR}

Todo proyecto debe someterse a un proceso de revisión crítico que permita evaluar sus elementos. Existe un parámetro que no debemos olvidar, el que despierte emociones y sea divertido, por eso la idea de tomar el juego como un resorte creativo que dote no solo de ingenio sino de experiencias que los usuarios puedan disfrutar e incorporar elementos dramáticos, confirma lo fascinante que pueden ser. Por lo tanto los juegos e historias deben estar equilibrados, ser divertidos y accesible, completos y claros.

Planea diseñar una historia que se pueda jugar, ¿Te resulta emocionante y divertido? ¿Sus elementos atraen a los usuarios? El reto será qué tanto las estrategias del juego como sus historias despierten emociones en los jugadores y les inviten a seguir jugando, el poder conseguir los objetivos, la competencia contra los adversarios, el poder tomar decisiones interesantes que pongan a prueba sus habilidades y límites, que revivan las fantasías de los juegos con el estímulo de la imaginación y ejerciten la exploración y el descubrimiento.

Armar una historia a partir de opciones que los jugadores pueden decidir pero que les resulten interesantes a diferentes niveles, desde aquellas decisiones que no impactan el resultado hasta aquellas que resultan críticas e impactan directamente e incluso pueden determinar el fin de la historia o de un suceso importante. Analizar qué tan convincente es el mundo creado por la historia, o qué tantos elementos ofrecen una riqueza conceptual que es aprovechada por la historia, o qué tan atractivo resultan las acciones y otros elementos que capturen la atención de la audiencia. Qué tan equilibrados resultan los momentos de suspenso y sorpresa, y qué tan claro y creíble resulta la historia son solo algunos de los elementos que se debe considerar y evaluar.

Todavía hay mucho por experimentar e implementar, esperamos contribuir con prácticas y sugerencias para diseñar narrativas interactivas. Admitimos que nuestras propuestas no resuelven el problema entre la interactividad y la narratividad pero lo señalan.

\footnotetext{
${ }^{759}$ Para ampliar el tema véase: Mark Bernstein, "Patterns of Hypertext" [texto on line] en: http://www.eastgate.com/patterns/Welcome.html y BERNSTEIN, Mark, "Can we talk about spatial hypertext", Eastgate Systems, Inc., Watertown, 2011 en: ACM Digital Library, 2011. [Texto on-line] en: http://portal.acm.org/guide.cfm Consultados: 25/06/2012
} 
"The craft of creating game narratives is more complicated than any other writing role in the modern world, and those who want to excel in this work must learn many skills and disciplines. Understanding how to construct the spine of a game, how to link that spine to the narrative, and how to effortlessly guide the player back to the path should they stray too far are all skills that any game writer should strive to master" Chris Bateman ${ }^{760}$

\subsection{EL MODELO DE NARRATIVAS LÚDICAS EN GRIM FANDANGO}

Deseamos concluir este apartado presentando un ejercicio que propone cómo enriquecer un juego a partir del modelo de narrativas lúdicas con el fin de complementar un juego conocido. Deseamos recomponer un texto exploratorio, que sea constructivo y creativo.

Entendemos que un buen juego no depende de una historia para que se disfrute, sin embargo, una historia puede hacer bastante y a lo largo de esta investigación no hemos encontrado razón alguna para no procurar hacer textos más jugables y juegos con mayores cualidades narrativas. Estamos convencidos que la posibilidad de interactuar con los sistemas digitales de nuestro tiempo demandan que ampliemos nuestro potencial narrativo al plantear secuencias de acciones que puedan despertar en los lectores un "gameplay" con mejores historias, más interesantes, claras, coherentes y estructuralmente más ricas y adecuadas. Si logramos que las historias contribuyan a estimular la curiosidad del jugador también estaremos estimulando su capacidad imaginativa y crítica que busque en los juegos, una manera de articular historias.

Hemos elegido el videojuego Grim Fandango ${ }^{761}$ (Lucas Arts, 1998) como modelo de análisis. Consideración sustentada por el componente narrativo que presenta una historia como componente esencial cuyos elementos, símbolos y referencias están asociados a un corpus semiótico de cierta complejidad estructural. El juego posee cualidades narrativas que se presentan principalmente a través de diálogos que van armando la trama en la que la exploración, los retos y acertijos que se van desplantando a lo largo del juego y

\footnotetext{
760 BATEMAN, CHRIS (ed.), Game writing narrative skills for videogames, Game Development Series, IGTA, Charles River Media Publishing \& Course Technology, Boston, 2007. (p.102)

${ }^{761}$ Un listado de juegos con buenos diálogos e historias que se desarrollan al interior, narraciones sólidas y bien estructuradas es la que ofrece GAMES RADAR, en su artículo "Best video game stories ever" en el que aparecen: Grim Fandango (1998), The longest journey (2000), Beyond good \& Evil (2003), Astro Boy: Omega factor (2004), Psychonauts (2005), Gabriel Knights: sins of the father (1993), BioShock (2007), Silent Hill (2001). Mass Efect 2, y los más recientes: Portal 2, The witcher 2, Bastion y Uncharted 3; éstos últimos del 2011. Véase: http://gamesradar.com Consultado:19/09/2012
} 
resultan cruciales para el juego y para la historia. El análisis propuesto sólo contempla las cuestiones de contenido temático y estructuración de las ideas, sin considerar ni las cuestiones artísticas de diseño visual y sonoro, ni las cuestiones técnicas propias del sistema informático o su programación.

Grim Fandango es un juego de rol (RPG), cuyo sentido se define como un juego basado en una línea argumental, semejante a una historia en el cual el jugador crea y toma el papel del personaje, y emprende acciones y toma decisiones que van permitiendo el desarrollo del juego. Este juego no permite modificar de manera significativa su línea narrativa, porque las decisiones están pre establecidas y no hay libertad para tomar otros rumbos. Posee un diseño gráfico muy atractivo y un manejo estupendo del sentido del humor. Pero cuya principal cualidad es ser una historia bien estructurada y coherente que se presenta principalmente a manera de diálogo entre los personajes.Se trata de una aventura gráfica cuya temática está inspirada en la tradición Pre hispánica Azteca en torno a la muerte. Tradición que plantea que al morir, el cuerpo abandona la vida terrenal para ir a vivir a la región de los muertos. Para ello debe emprender un viaje de cuatro años en los que deberá atravesar 8 regiones en las que se le impondrá alguna prueba o tarea para continuar y llegar a la novena región: el descanso eterno. Esta concepción mítica está revestida de sitios mágicos, personajes fantásticos y amuletos mágicos que sin duda ofrecen un potencial para desarrollar un juego de aventuras realmente interesante. Consideramos que el tema se presta para ser desarrollado a diversos niveles de complejidad, por las implicaciones filosóficas y antropológicas que denota y por lo tanto nos parece un magnífico ejemplo el cual nos gustaría concretar con estas propuestas.

A pesar de que $G F$ esté inspirado en la tradición mexicana antes mencionada; presenta no sólo pocas referencias a la fuente original, sino además, algunas inconsistencias con respecto a la mitología mexicana. Sin embargo, de ninguna manera esto desmerece el valor del juego, ya que logra fusionar algunas otras ideas que ampliaremos a continuación. Nos parece que es un ejemplo que clarifica una de las principales inquietudes de este trabajo de investigación: dotar de contenido a los proyectos artísticos. Entendemos que la calidad de un texto depende en gran medida de la información y contenidos que transmite, la claridad con la que lo lleva a cabo, el manejo adecuado de un léxico preciso y una estructura bien organizada que sea concisa y adecuada. Reconocemos que esto implica un ejercicio de composición textual que en ocasiones los artistas y diseñadores no contemplan, porque su interés está en desarrollar una forma, descuidando su contenido. $\mathrm{Y}$ porque no consideran que el dotar de información interesante a sus proyectos artísticos, amplía el interés de los lectores, usuarios o espectadores. Sería bueno que los artistas consideraran que sus piezas pueden enriquecerse gracias a una historia que aporte algo más que únicamente una experiencia estética, que sea significativa.

Retomando la idea anterior sobre el tema abordado de la tradición del día de muertos, sólo mencionamos que se trata de una filosofía de tal riqueza conceptual, que quienes la conocemos, nos hubiera gustado que pudieran haber aprovechado esto para dotar de un sentido de mayor profundidad filosófica y mitológica al juego. Sin embargo, resulta 
realmente ejemplar la manera como el juego logra incorporar diversos temas que resultan del todo ajenos, como la referencia a los movimientos revolucionarios latinoamericanos de la década de los 60's y 70's. Guerrillas, conspiraciones, sociedades paramilitares, se mezclan con una historia de muertos y logran darle un carácter divertido y en cierta manera justificable, dado que se requiere resolver un conflicto de corrupción y llevar a cabo una operación tipo militar. Qué mejor ejemplo que estos conflictos armados. Otro tema ajeno a la tradición, es el relacionado con la corrupción que existe incluso después de la muerte. Que satiriza el grado de descomposición social y vicio, ligado a casinos y cabarets que se vive al interior de la historia. Ambos temas, aunque ajenos, se conectan con coherencia en la trama de la historia.

Cuando pensamos en conducir líneas narrativas necesitamos pensar que los contenidos sean igualmente interesantes. No existe razón alguna por considerar que las cuestiones serias solo pueden ser tratadas bajo formatos similares a las lecciones escolarizadas y resultan ser no solo distantes sino opuestas a lo que se considera un formato de entretenimiento. Con $G F$ confirmamos que es posible integrar un buen juego a partir de la ludolización de una tradición mitológica ancestral.

La interface de $G F$ introduce al jugador al mundo de los muertos en el cual todos los personajes son calaveras amigables y tiene mucha similitud con el mundo de los vivos. El jugador se mueve a través del protagonista, Manny Calavera, el cual puede acceder a diferentes espacios a través de escaleras, puertas y ascensores. No es posible la manipulación de todos los objetos que se presentan gráficamente en los distintos espacios, lo cual nos hubiera gustado, dado la cantidad de objetos y símbolos que pudieran ampliar el contexto del juego. Solo es posible tomar aquellos que son necesarios para resolver un enigma. Estos objetos se van guardando en la solapa del traje blanco, al estilo Humphrey Bogart que usa el protagonista en la primera parte del juego y que en la segunda etapa cambia por una chaqueta militar.

La existencia de objetos ornamentales que no dan información, ni conducen a ningún otro lugar o no te conectan con nada es algo que se debe contemplar cuando diseñamos textos. Porque es preciso considerar sólo aquellos elementos que cumplen alguna función dentro de la historia. De manera similar, los diseñadores de juegos deben diseñar interfaces que permitan conducir el juego a varios niveles de información que pueda conectar otros ramales de la historia. Los objetos entonces tendrían una función como de "puentes" que permitan historias imbuidas o ramificadas al interior. $G F$ en cambio, presenta una linealidad narrativa sin brincos temporales o secuenciales. La acción se desarrolla a partir de una sucesión de aventuras conectadas cronológicamente. El juego se divide en 4 partes que corresponden a los 4 años que dura el viaje de las almas al descanso eterno y que en el juego son los cuatro años que le toman a nuestro héroe llegar a un desenlace. A lo largo de este tiempo se le presentan múltiples aventuras que le obligan a ir resolviendo algunos acertijos y el cumplimiento de algunas tareas.

La trama comienza cuando Manny Calavera recibe a un cliente para venderle un paquete de viaje con el que llegar al descanso eterno. Se da cuenta de que la calidad de los 
clientes ha decaído considerablemente y no puede vender el viaje conocido como "\#9" que es el más codiciado, por estar destinado únicamente a aquellas personas que han tenido una vida ejemplar y sólo les toma 4 minutos llegar al descanso eterno y no 4 años. Manny percibe que algo está pasando porque el empleado ejemplar de la compañía, Dominó, cada vez tiene más clientes de este tipo. Eso motiva a Manny a boicotear el sistema de comunicación de la compañía y contactar antes que Dominó a una posible clienta, que resultó ser Mercedes Colomar quien robará el corazón del vendedor. Mercedes desaparece y Manny confirma que algo no está bien, cuando es contactado por un grupo paramilitar que está averiguando este fraude de la venta ilegal de boletos \#9 y necesita la ayuda de Manny para resolverlo. Saben que alguien está robando los boletos y los está distribuyendo entre personas que no lo merecen. Por lo que decide unirse a este ejército rebelde y averiguar el paradero de su amada, recuperar los boletos y desentrañar el embrollo de la falta de clientes lo cual estará ligado a la venta ilegal de boletos. Para ello emprende un viaje en el cual se enfrentará a peligros y riesgos y deberá cumplir múltiples tareas antes de recuperar a su amada, encontrar a los culpables del fraude, devolver los boletos a sus dueños y conseguir el anhelado descanso eterno.

\subsubsection{Elementos Narratológicos}

Los juegos electrónicos han cambiando la noción de tiempo y espacio en cierta manera con relación a las narrativas tradicionales. Con los sistemas electrónicos es posible hacer recorridos y navegar por diferentes tiempos y escenarios. El poder de la interacción, ofrece además la posibilidad de que las decisiones que tome el jugador tengan una respuesta inmediata. Por lo que escribir guiones que admitan no sólo la navegación, sino brincos espacio-temporales es un reto tanto para quien lo escribe como para el usuario que debe aprender a "llenar los espacios" que lo integran. En Grim Fandango nos encontramos con una historia "unidireccional", entendida como una en la cual sólo es posible un avance progresivo, en cierto punto conducido por la trama argumental y no hay posibilidad de que se altere de manera alguna. Sin embargo posee cualidades narratológicas muy bien estructuradas, lo cual apreciamos a través de los diálogos entre los personajes.

Más allá de estos diálogos que se desplantan en la pantalla a manera de textos, no existe ningún otro elemento textual, del cual los usuarios pudieran obtener más información, como leer algún mensaje que resulte referencial y que pudiera aparecer en diversos formatos como libros, mapas o cartas. Tampoco son frecuentes anuncios, carteles y seguramente el desarrollo tecnológico no había desarrollado, en el tiempo que fue diseñado, los recursos cinemáticos conocidos como cut-scenes $^{762}$. Conocemos la trama de la historia gracias al diálogo. Esto sin duda en nuestro tiempo puede ampliarse y mostrar al interior del formato, nuevos y diversos modos de presentar información de manera creativa y efectiva.

\footnotetext{
${ }^{762}$ Son las pequeñas películas o información que se desplanta y detiene el juego para explicar o justificar lo que se necesita hacer.
} 


\section{Eventos y acciones}

Como todos los juegos de aventura, $G F$ implica avanzar, experimentar y encontrar la manera de resolver enigmas. Los diálogos y textos que se desplantan, permiten deducir lo que se necesita hacer, pero el jugador debe encontrar la manera de hacerlo lo cual en ocasiones no resulta tan claro o fácil. Las acciones van de lo razonable hasta lo verdaderamente imposible y absurdo. Desde utilizar una llave para abrir una cerradura hasta conseguir libros para intercambiar con abejas por herramientas o caminar por el fondo del mar con la guía de un robot-lámpara hasta escapar de un pulpo gigante que conduce un submarino. Esto nos obliga a cuestionarnos. ¿Hasta qué punto las historias coherentes que tienen cierta información y contenidos interesantes se ligan a otras, que no lo son, desmereciendo su potencial. Lo que pudiera ser un material de cierta calidad se confunde con una alegoría, de hechos, sin sentido en relación a una tradición que es resultaría interesante conocer y abordar con mayor detalle y concordancia.

\section{El tiempo}

Una de las principales diferencias entre la narrativa textual y los sistemas interactivos digitales, como el videojuego, reside en el manejo del tiempo. En los juegos las acciones suceden en tiempo real, justo en el momento que el usuario elige una opción, las historias se van desdoblando en algo que Chris Bateman ${ }^{763}$ designa como flujo textual: están sucediente en un tiempo actual. Sin embargo en las narrativas textuales tradicionales, los acontecimientos parecieran que suceden en un tiempo pasado. Por lo tanto resulta difícil armar una historia que va sucediendo a partir de las elecciones del usuario. La narración presupone brincos temporales y un manejo del tiempo comprimido, que relate lo sucedido en un tiempo menor. El tiempo de $G F$, tal como lo vimos en el apartado $E l$ manejo del tiempo, ¿Cuál tiempo $?^{764}$ en este mismo trabajo, plantea un tiempo del relato, el cual nos tomaría relatar los acontecimientos sucedidos, una vez que conozcamos la trama. El tiempo del jugador es lo que le tomaría jugar toda la aventura y finalmente el tiempo de la historia, es decir el tiempo que el juego toma para presentar los acontecimientos. En $G F$, el tiempo es ficticio si lo comparamos a nuestro tiempo, el videojuego sucede en 4 años, lo cual no corresponde a las aproximadas 4 horas que nos tomaría jugar toda la aventura. Este manejo de un tiempo comprimido, es dinámico en el sentido que nos permite llevar a cabo brincos no sólo temporales sino, además cambios de espacios o escenarios en donde se desarrolla la historia. Por su parte, el tiempo de la narración, corresponde con el tiempo de la historia, sucede de manera lineal, con algunas interrupciones cuando se tiene que detener el flujo de la historia para emprender una tarea. Pero el tiempo transcurre de manera cronológica, sin retrocesos o paralelismos de diversas historias.

\footnotetext{
${ }^{763}$ Citado en este mismo trabajo (pag.141) Véase: BATEMAN, CHRIS (ed.), Game writing narrative skills for videogames, Game Development Series, IGTA, Charles River Media Publishing \& Course Technology, Boston, 2007. (pp.27-41)

${ }^{764}$ Véase pág. 162 de este mismo trabajo.
} 
Debemos considerar crear historias con múltiples tiempos y acontecimientos que se sucedan de manera paralela. Esto debe ser un reto para los diseñadores de textos quienes a partir de la experimentación narrativa pueden jugar con estos recursos temporales. Ya no es necesario contar una historia en el sentido estricto que suceden los acontecimientos en tanto podamos inferir cómo eslabonarlos unos a otros de manera coherente. Sabemos que las historias pueden no comenzar a ser relatadas en un principio y que pueden a su vez, interconectar muchas otras posibles historias relatadas desde diversos ángulos. Es lo mismo que jugar en diversos niveles bajo el poder de distintos personajes, lo cual es posible en los videojuegos actuales.

Los espacios en los que se desarrolla la acción se van desplantando de manera secuencial y tienen relación con el viaje del héroe. Cada uno es un escenario para relatar parte de la historia y contribuyen a que ésta se vuelva más inmersiva al favorecer el tránsito del usuario a través de diferentes momentos de la historia. Es importante considerar que la descripción de los lugares debe ser significativa para la historia. Es preciso diseñar un espacio narrativo, como si fuera una estructura o andamiaje que presente de manera particular los elementos del proyecto. Esto nos remite al estudio de Steffen Walz ${ }^{765}$, quien denomina arquitectura lúdica a ciertos modelos físicos que sirven para organizar cualquier elemento. Es una especie de modelo asociado a un espacio físico conocido que distribuye en cierto modo los elementos de una historia y plantea una manera de articulación. Entre las estructuras están los mosaicos tipo panal de abeja, los laberintos, mapas y otras construcciones como castillos, casas de muñeca, estadios, teatros o el panóptico; todos pueden servir como metáfora para organizar de manera estructural una historia o un juego que pudiera apreciarse desde distintas ópticas. Esto nos permite proponer patrones para armar las historias, lo cual resultaría útil para emprender cualquier proyecto de diseño ya sea textual o visual. Dentro de los formatos interactivos la secuencia resulta ser diferente a las historias tradicionales. Porque estas estructuras deben tener múltiples veredas para transitar. En cierta medida, novelas como Rayuela de Julio Cortázar ${ }^{766}$ o Compsition No. 1 de Marc Saporta ${ }^{767}$, han permitido formar un tipo de lector "armador" de historias; uno que puede conectar, gracias a su experiencia algo semejante a una historia. En un videojuego la secuencia no está determinada por un discurso narrativo, sino por el material y las posibilidades de navegación que permite su programación. Por ello resulta necesario ligar la narrativa a una forma arquitectónica por donde navegar, si buscamos diseñar textos interactivos. Celia Pearce ${ }^{768}$ plantea las semejanzas entre un espacio arquitectónico y un ambiente rico el cual define como: un medio que provoca experiencias. Un inmueble con habitaciones, corredores, ventanas, iluminación despierta sensaciones. Esta idea debe contemplarse al diseñar textos para entornos interactivos: ofrecer sensaciones $y$ experiencias por donde se pueda explorar y circular.

\footnotetext{
${ }^{765}$ STEFFEN P. WALZ, Toward ludic architecture, the space of play \& games, ETC Press, 2010, [Texto online] en http://repository.cmu.edu/etcpress/5/ Consultado:07/10/2012

${ }^{766}$ Véase Página 77 de este estudio.

767 SPORTA, Mark, Composition No. 1, Visual Editions, London $(1962,2011)$

768 PEARCE, Celia, The interactive book, a guide to the interactive revolution,McMillan Technichal Revolution, 1997. (p.25-28)
} 
La narrativa entonces puede verse como un andamiaje que facilite la organización de los contenidos, de la misma manera como la arquitectura puede convertirse en una manifestación narrativa, un espacio que tiene algo que relatar a sus visitantes. Los videojuegos y las historias deben partir de un guión que permita la navegación a través de los diferentes espacios. El recorrido completo debe estar bien estructurado a partir de fragmentos jugables que puedan irse uniendo a otros similares.

En $G F$ los espacios del juego incluyen los interiores de la Compañía de Viajes DOD [Department of Dead] que muestra varios espacios como la oficina de Manny, la del jefe Don Copal, el escritorio de la secretaria, los elevadores que permiten la circulación al garaje y al servidor de mensajes. En los alrededores hay un mercado callejero y de manera oculta se llega al cuartel secreto de la LSA Lost Source Alliance que dirigen Salvador Limones, Olivia Ofrenda y la misma Secretaria Eva de DOD quien es una espía. Al emprender el viaje, acompañado de un personaje que funge de chofer (y que pudiera tener cierta similitud con el perrito pelón que acompaña a las almas al descanso eterno, según la mitología azteca) tienen que atravesar El Bosque de los Castores para llegar a Ciudad Ruvacava, última frontera antes de embarcarse al Limbo o región del descanso eterno. En esta ciudad se encuentran varios espacios lujosos, restaurantes, casinos y cafés, como el Blue Casket o el Café Calavera. Otro sitio es el muelle de Ciudad Ruvacava y el interior de un barco que hace travesías a la última estación de tren que conduce al descanso eterno.

Es importante considerar que debe existir afinidad entre los espacios del juego y la narrativa, porque la trama debe organizarse a partir de la acciones de la audiencia dentro de estos espacios. Es la manera como diversas secuencias narrativas se van ligando entre sí, a partir de los diferentes espacios que van apareciendo conforme transcurre el viaje de Manny. Basta considerar la necesidad de generar espacios que sean acordes a las emociones que genera la historia, tal como lo señala Max Giovanoli de esta manera:

New narratives based on intermediate affinity spaces overcome the limits of traditional stories, transforming them into real multi-sensory experiences.

They tend to constantly research avant-garde technological universes and narrative experimentation to create them, together with the audience. Considereing the creation of imaginative universes, the most effective "affinity spaces" for transmedia tales are moving experiences, choice excitement and the use of expanded environments."

Será interesante que los juegos puedan tomar diferentes caminos en los que la historia tenga diversas formas de avanzar. Al pensar en $G F$, sugerimos se pudieran incluir las nueve regiones que las almas de los muertos tienen que atravesar para llegar al descanso eterno según dicta la tradición. Esto atendiendo a la connotación semi-fantástica que cada región representa, lo cual además de ser un recurso de gran plasticidad, puede prestarse a desarrollar nuevas líneas narrativas. Así mismo, también se podrían incluir algunos otros cielos y firmamentos habitados por dioses como Tlaloc o Tezcaltlipoca, también de la

\footnotetext{
${ }^{769}$ GIOVAGNOLI, Max, Transmedia Storytelling, Imagery, shapes and techniques, ETC Press, 2011. (pp.7172) Texto on-line en: http://www.etc.cmu.edu/etcpress/files/TransmediaStorytelling-MaxGiovagnoli.pdf Consultado: $28 / 09 / 2012$
} 
mitología Azteca, quienes podrían aportar otra línea argumental que enriquezca nuestra historia. Porque siempre es interesante plantear mundos alternos, en ocasiones reales, imaginarios o posibles, eso es un reto para cualquier diseñador. $Y$ en el caso de esta tradición, retomar el tema del tránsito entre el mundo de los vivos y los muertos, sin afán de convertirlo en otra película de zombies, ofrece un potencial creativo por desarrollar que consideramos muy apropiado para un juego de aventuras.

Personajes Grim Fandango presenta un nutrido grupo de personajes muy bien caracterizados, creíbles y coherentes con el papel que desempeñan, se destaca su personalidad, acorde a su aspecto, vestimenta e incluso voz y los diálogos en los que participan. El protagonista, Manny Calavera se muestra como un funcionario profesional que tiene un gran compromiso moral de descubrir una red de conspiración y rescatar a su amada. Un caballero que jamás pierde la compostura ni el ánimo para continuar con su búsqueda y emprender un viaje.

En DOD trabaja Dominó, uno de los empleados ejemplares quien estará coludido con el jefe, Don Copal y a su vez está controlado por Le Manns, quien tiene el control de los boletos. Glottis, el chofer que conducirá a Manny en su viaje es un perro-monstruo, dos veces más grande que el auto que conduce resulta un poco absurdo, dado que si nos referimos a la mitología mexicana, existe un amigo inseparable de las almas, un perrito bermejo que se vuelve inseparable. Eva la secretaría-espía que trabaja en DOD como espía al servicio de Salvador Limones, el jefe de la Revolución, quien junto a Olivia Ofrenda persiguen a los detractores de la conspiración. Otro personaje es la bella Mercedes Colomar, por quien el protagonista decide emprender su aventura. Algunos otros personajes secundarios que ayudan al curso de la historia son: Celso Flores viajero que anda en busca de su esposa y algunos otros informadores como Lupe, la encargada del guardarropa del restaurante o Carla una funcionaria de seguridad de Ciudad Ruvacaba y otros trabajadores del muelle o del barco que los conducirá al descanso eterno.

Cada personaje debe desarrollar su propia historia que pueda ligarse a una historia mayor y pueda establecer conexiones con otros personajes en distintos momentos. Eso haría historias más complejas y más fáciles de establecer interacción con el usuario, el que podría elegir por dónde circular y en qué manera regresar a una historia principal o recorrer un camino diferente. Los personajes que pudiéramos crear de manera paralela, que respondieran de manera más coherente con la tradición del día de muertos y que pudieran aportar un sentido más significativo a la historia serían los siguientes:

- Un perrito pelón de la raza $i z c u i n t l i^{770}$, el cual es un fiel compañero de las almas que emprenden el viaje a la región de los muertos.

- Los señores de la muerte, entendidos como una pareja de dioses que residen y gobiernan el mundo de los muertos y también son los señores de la vida eterna, una dualidad que está presente en el mundo prehispánico.

\footnotetext{
${ }^{770}$ También conocida como Xoloizcuintli, una raza de perros pelones originaria de México.
} 
- Un colibrí, ave de hermoso plumaje, símbolo azteca de la resurrección, que representaba a las almas que después de 4 años podían convertirse en éstos y tenían la posibilidad de regresar a la tierra.

- Un guerrero muerto en batalla, una doncella sacrificada, una mujer muerta de parto y un bebe muerto podrían ser personajes de esta versión que proponemos. Cada uno al dar la vida por sus dioses, tenían asegurado un espacio en otros cielos gobernados por otros dioses y ahí debían cumplir una tarea que resultaba fundamental para el devenir de la vida en la tierra.

- Otros personajes, que podríamos incluir que ampliarían las posibilidades de insertar historias dentro de las historias serían otras deidades como Tláloc, dios de la lluvia, Quetzalcóatl o la Estrella de la mañana, y el perverso Tezcaltlipoca; tampoco se trata de abusar con la cosmogonía y enlistar completamente el panteón mexica, pero existen leyendas detrás de cada uno de estos personajes que pudieran ampliar las historias y sobre todo, al tener una fuerte concepción filosófica, podría ligarse a formas de pensamiento y a otros sucesos que sería interesante explorar.

Es preciso que cada personaje delimite con mayor detalle su aspecto, carácter y función dentro de la historia. Ya que son los elementos más importantes para la credibilidad y el desarrollo de una historia, al ser los principales intermediarios entre la historia y la audiencia, éstos deben no sólo revelar su personalidad sino sobre todo, develar la trama.

\subsubsection{Elementos Hermeneúticos}

El manejo de símbolos es una de las virtudes del juego. El cual se presenta como un texto coherente a diferentes estratos semánticos. Destacan los elementos gráficos de objetos que aportan un contenido semántico que se orienta hacia la mitología mexicana, algunos elementos como la noción del viaje de las almas después de la muerte; a un sitio muy parecido al de los vivos, en donde pueden incluso volver a morir, lo que curiosamente representan llenando de flores. Existen además objetos que hacen referencia a la tradición prehispánica de la celebración, pero en ocasiones haciendo una fusión con la tradición del Halloween norteamericano, como es el caso de los corazones que aparecen latiendo, haciendo alusión al sacrificio humano mexica, pero sobre unas telarañas, símbolo propio de dicha celebración. Otro símbolo es el del conductor, que para la tradición es un perrito color bermejo, un amigo será inseparable durante este trayecto. Proliferan otros símbolos que hacen referencia a la cultura mexicana como, piñatas, pan de muerto, música de mariachi, además de que la entonación y algunas palabras en los diálogos no están traducidas al inglés. Los nombres de personajes como Olivia Ofrenda y Don Copal también confirman la referencia a la celebración del día de los muertos: ofrenda como la serie de obsequios que se hacen a los difuntos que visitan a sus familiares vivos durante esta fiesta, y copal, en relación a una resina que se utiliza con fines ceremoniales en estos días. Otro símbolo que aporta importantes significados a 
la historia es el desarrollo del viaje del héroe, tema que por cierto fue analizado en este mismo estudio bajo la óptica de los primeros estructuralistas como Vladimir Propp y epecialmente Joseph Cambell ${ }^{771}$, ambos inspirados en mitos e historias tradicionales, asunto muy recurrente en la filmografía y novelística de todos los tiempos.

Resulta interesante revisar en este mismo estudio el apartado de las cualidades de los personajes para poder plantear modelos que puedan desarrollarse de manera más simbólica. Manny, caracterizado al estilo de Rick Blaine con su traje blanco inmortalizado en Casablanca $^{772}$, confirma la personalidad del héroe y su integridad moral al emprender esta aventura. Los espacios del juego presentan gran detalle de simbolos; tanto la oficina de la Compañía de viajes, como el centro de operaciones de LAS Lost Souls Alliance, presentan elementos que aportan información importante: como la red de operaciones clandestinas y el envío de mensajes usando palomas, que por cierto también aparecen en forma de esqueletos. Existe además referencia a casinos, sitios de corrupción a través de establecimientos de lujo, conducidos por personajes de la mafia. En cierto modo el colorido gráfico es coherente y complemento de la historia, los diálogos y voces de los personajes, los símbolos que enriquecen la información y confirman que es un juego muy consistente lo que pudiera contemplarse como un excelente modelo por su coherencia interna.

Entre los objetos que el protagonista va encontrando hay llaves, extinguidores, fotografías, naipes, pan de muerto, una botella de licor y algunos otros, pero curiosamente el objeto con mayor utilidad para Manny es una guadaña tipo retráctil que lo mismo utiliza para quitar telarañas, como para abrir bultos o jalar objetos. En la mitología no existe este elemento, eso es posterior y corresponde a la visión católica de la concepción de la muerte. Podemos apreciar el valor que las referencias generan a partir de los símbolos culturales heredados, los cuales ayudan a crear el imaginario colectivo propio del juego, cualidad que se debe apreciar al diseñar cualquier texto.

\section{Los símbolos y la interpretación de la historia}

En cierta manera los símbolos contribuyen a aumentar la conexión de los lectoresjugadores con las historias, ya que confirman las emociones que trasmiten los juegos. De ahí que las emociones que se desprenden de las tareas, los castigos, o los premios sean determinantes para que se conserve el interés del jugador por continuar. Ray Muzyka ${ }^{773}$, CEO de BioWare, sugiere que una narrativa se vuelve una buena historia en cuanto evoca una respuesta emocional. GF presenta una variedad de manifestaciones emocionales distintas producto de los momentos de suspenso, aventura, romance y decepción que se dan a lo largo de la trama. Eso permite que las historias tengan esos clímax y puntos de mayor tensión junto a otros que son puramente informativos. Al respecto, cualquier elemento narrativo ayuda a reconstruir los temas y los mensajes en la historia.

\footnotetext{
${ }^{771}$ Véase apartado 3.3 Teorías para componer textos, (páginas 84-91) en este mismo estudio.

772 Película Casablanca, de Michael Curtiz y Carl Jules Weyl, Warner Bros. 1942

${ }^{773}$ Citado por Ammon Horn, Narrative in Video Games, en: http://gamesareevil.com/2009/04/narrativein-video-games/ Entrevista BioWare on Narrative \& More, Game Daily.com Consultado:25/09/2012
} 
Por lo general, las historias se originan a partir de un conflicto, uno que se puede plantear a diferentes niveles y que generalmente afecta al héroe, al despertarle ciertas emociones. Es justamente la posibilidad de solidarizarnos y ayudar al héroe lo que genera el interés de leer o jugar la historia. Por ello las emociones son un elemento fundamental en la composición de historias. Porque evidencian momentos de tensión, alegría o suspenso que deben contener las buenas historias: transmiten dosis apropiadas de distintas emociones. Es lo que permite a un usuario conectarse con la historia a través de sus protagonistas. De ahí la importancia de generar historias que contagien sensaciones y emociones. Por ello enfatizamos la necesidad de presentar eventos y situaciones que resulten significativos, memorables, efectivos y generen emoción al usuario.

El manejo y desarrollo de las emociones al interior de las historias es muy importante para conseguir esta complejidad narrativa y por ello es otro de los retos por considerar al construir historias interactivas. Buscamos generar historias en donde los usuarios puedan elegir opciones que el sistema les presente y por las cuales puedan avanzar en la historia considerando las emociones que dichas opciones generan. Así una historia puede tener diferentes modos de avance a partir de los sentimientos que transmitan los personajes, pudiendo siempre tomar varias opciones, sin perder el sentido y coherencia de las historias. Se sugiere conocer y apreciar cómo se da el sistema automático de generación de argumentos, MEXICA de Rafael Pérez ${ }^{774}$. Si esta propuesta funciona para generar historias con mejores contenidos y coherencia, sin duda debe utilizarse como modelo para la generación de textos interactivos elaborados por personas y no por sistemas automáticos. Se recomienda revisar dicho estudio ${ }^{775}$ para tener una idea de cómo es manejo de emociones al servicio de la creación en sistemas artificiales. MEXICA genera diversas historias a partir de elementos independientes que poseen vínculos emocionales, que además de generar cierta tensión entre los personajes, principalmente permite el avance de la historia. Un ejemplo que opone los siguientes vínculos emotivos:

El enemigo hiere al caballero. La princesa cura al caballero herido. El caballero mata al enemigo. El Caballero recompensa a la princesa.

Las posibles emociones que se pueden desprender de cada una de estas situaciones por separado, determinará qué rumbos pueda tomar la historia al final; desde "El enemigo hiere al caballero" los efectos y posibilidades que pueden desprenderse son muchos, desde la idea de que el caballero pueda aliarse al enemigo o acobardarse y evitar confrontarlo o la apatía de la princesa por hacer algo, o si ésta fuera raptada admitiría, en cada opción, muy diversas historias posibles que generaría diferentes momento de tensión que contribuyen a cobrar mayor interés en los usuarios. Porque buscamos generar

\footnotetext{
${ }^{774}$ Véase este mismo estudio, pag. 101.

775 PEREZ, Rafael, "Employing emotions to drive plot generation in a computer-based storyteller", Science Direct, (2007) [artículo on-line] en: http://digis.ewha.ac.kr/data/test/employing.pdf Consultado: $29 / 09 / 2012$
} 
mundos de fícción complejos en donde tanto los espacios, los caracteres de los personajes y sus acciones sean coherentes y logren delinear mundos imaginativos que ofrezcan la información y referencias necesarias para enriquecer la experiencia narrativa.

Resulta fundamental encontrar la manera de articular historias con formatos que admitan la elección de diversos rumbos. Que partan de situaciones que tengan una carga emotiva que oriente la toma de decisiones y determinen el avance y rumbo de las historias. En el caso de $G F$ no es posible tomar diferentes caminos, su historia lineal sólo admite un único modo de avance, por ello es importante el diseño de múltiples posibilidades de interconexión de caminos alternos, con historias autónomas que puedan conectarse en la mente e imaginación del jugador. Por lo que es necesario su interpretación o reconstrucción de la historia. Al respecto Max Giovagnoli ${ }^{776}$ menciona que la imaginación favorece la organización de patrones o scrips que facilitan la reconstrucción e interpretación de los cuentos y lo dice así:

The human imagination develops through the accumulation and
specialization of the senses - visual and auditory stimuli will be
ordered in logical patterns inside of us: they are called scripts.
This will create a close net of deductive associations and predictions
that will lead the spectator to the reconstruction and interpretation of the tale.

Es preciso conocer cómo funciona la imaginación de la audiencia para presentar de manera efectiva mitos, símbolos y cualquier otro elemento significativo para que el usuario pueda crear sus caminos de significación, que se conviertan en partes de la historia al participar activamente y emocionalmente. Entre más respuestas emotivas ante diversas situaciones se obtengan, más complejas se construirán las historias. Gracias a estos elementos semánticos que amplían el significado, ampliando el repertorio imaginativo de los usuarios. El jugador entiende la historia y mejor aún, sabe que puede modificar el destino de la misma gracias a que puede ir resolviendo los problemas que se le presentan, aprecia cómo su interpretación en la historia es fundamental para que pueda avanzar a lo largo de este sistema participativo.

La interpretación se genera a partir de la información ofrecida por el juego, por las acciones que se sugieren y también por aquellas referencias que el jugador es capaz de deducir. Porque en un juego el objetivo se centra en las decisiones que puede tomar el jugador. De la misma manera como nos enfrentamos a situaciones cotidianas como resolver conflictos, adquirir objetos, relacionarnos con personajes, expresar nuestros sentires y emociones o sobrellevar retos. Un jugador debe tomar decisiones y encontrar significados para armar algo parecido a una historia.

\footnotetext{
${ }^{776}$ GIOVAGNOLI, Max, Transmedia Storytelling, ETC Press, 2011, Texto on-line en: http://www.etc.cmu.edu/etcpress/files/TransmediaStorytelling-MaxGiovagnoli.pdf Consultado: 26/09/2012
} 


\subsubsection{Elementos Formales}

Los géneros narrativos o lúdicos. Sin importar el género de juego para el cual se escriba, ya sea del tipo de estrategia, de aventura, rol o de plataforma. O se trate de un juego de ciencia ficción, misterio, romance o fantasía; requieren el diseño de un guion narrativo que permita en cada caso encontrar la mejor manera de contar su historia entre las acciones y acontecimientos que se llevan a cabo. Entre los elementos que apreciamos se pueden utilizar están los cut-scenes que tienen características cinemáticas y otros recursos menos elaborados son los llamados "shout-outs", mensajes de texto que sugieren un diálogo o dan alguna instrucción. En ocasiones se usan imágenes que representan libros, mensajes, notas periodísticas que van ampliando la información y permiten introducir nuevos elementos a la historia. Los acertijos también permiten ir armando una historia. Muchos otros elementos que aparecen aislados, ofrecen un contenido semiótico que también contribuye a enriquecer las historias. GF, no utiliza cut-scenes; únicamente "shout-outs".

Debemos considerar que un buen juego no depende únicamente de los temas que aborda, sino en la manera cómo manejan la información que permita despertar en los jugadores el suspenso y el deseo de jugar y de completar las historias que juega. Porque los juegos son mundo incompletos que necesitan un jugador para completar y armar lo mejor posible estos mundos de ficción. Un jugador que tenga deseos de explorar, avanzar y sin duda armar las mejores historias. Si le damos esta posibilidad de interacción al usuario, porque no pedirle le participe con su experiencia, imaginación y también con sus conocimientos; esto puede sobre todo ser un estímulo para acercarse a los libros y conocer temas que pudieran interesarle y promover la educación. No vemos porque un videojuego no pueda instruir, al mismo tiempo que está demandando el tiempo y atención de niños y jóvenes, mucho podría hacer al respecto. Porque al ver las cualidades estupendas de Grim Fandango, pienso en lo mucho que podrían haber hecho si los diseñadores hubieran tenido mayor información sobre el tema y hubieran utilizado otros recursos para mostrar la información que no sea exclusicamente a través de los diálogos de los personajes.

Dentro de una misma historia existen varios niveles de entendimiento. En el primer caso, un jugador podría jugar sin tener noción alguna sobre la concepción prehispánica del culto a la muerte y su experiencia lúdica no se vería afectada de ninguna manera. En un segundo nivel, otro tipo de jugador, al tener conocimiento de estas referencias, le añadiría más interés humano y su experiencia de juego se vería enriquecida por estas connotaciones que le remitan a entender el porqué de las acciones y apreciar símbolos que pueden ser ligas a otros niveles de significación. Porque de manera paralela, en un tercer nivel de complejidad narrativa, buscamos que las historias argumentales primarias puedan acompañarse de otras historias que puedan interrelacionarse en distintos puntos y que le permitan hacer múltiples conexiones internas con otros hechos, historias y acontecimientos de su experiencia cultural adquirida.

Porque más allá que podamos inspirar la historia en la estructura aristotélica de inicio/ conflicto / resolución, los proyectos multimedia deben acoplarse a una estructura mejor 
diseñada que invita a la audiencia convertirse en parte del mundo de ficción, que interactúe con la historia y siente que puede agenciarse del mundo narrativo a través de la solución de enigmas o acertijos. Y puedan presentar hilos narrativos de cierta complejidad, porque es un elemento fundamental que debemos considerar al diseñar narrativas interactivas; ofrecer historias que tengan contenidos de calidad, bien estructuradas, personajes sólidos, diálogos cortos pero adecuados, entretenidos y con un formato innovador e interesante.

La revolución que se ha iniciado en torno a la producción de historias, debe atender tanto a su contenido como a su forma; debemos experimentar el potencial que ofrece la tecnología digital y enriquecerla con recursos que nos recuerden que los libros ahora pueden ser algo más que libros, que pueden emigrar a medios muy diversos y parecerse más a los juegos, a ejercicios interactivos o instalaciones artísticas creativas.

Hay mucho por seguir analizando para estar al pendiente de nuevas formas emergentes de las narrativas y los juegos. La planeación debe ser la clave para construir buenas historias que puedan traducirse en experiencias narrativas lúdicas que acompañen cualquier proyecto cultural o artístico. Con paciencia y práctica se pueden generar historias jugables que sean fantásticas. Esperamos que Grim Fandango sea un buen modelo que permita seguir explorando y perfeccionando estas cualidades narrativas que los juegos pueden contener. 


\section{150 RETOS PARA NARRAJUGADORES}

"By keeping our mind fresh and your creative muse on edge, you'll never run out of things to write ${ }^{\prime 777}$

Erin Whitmer

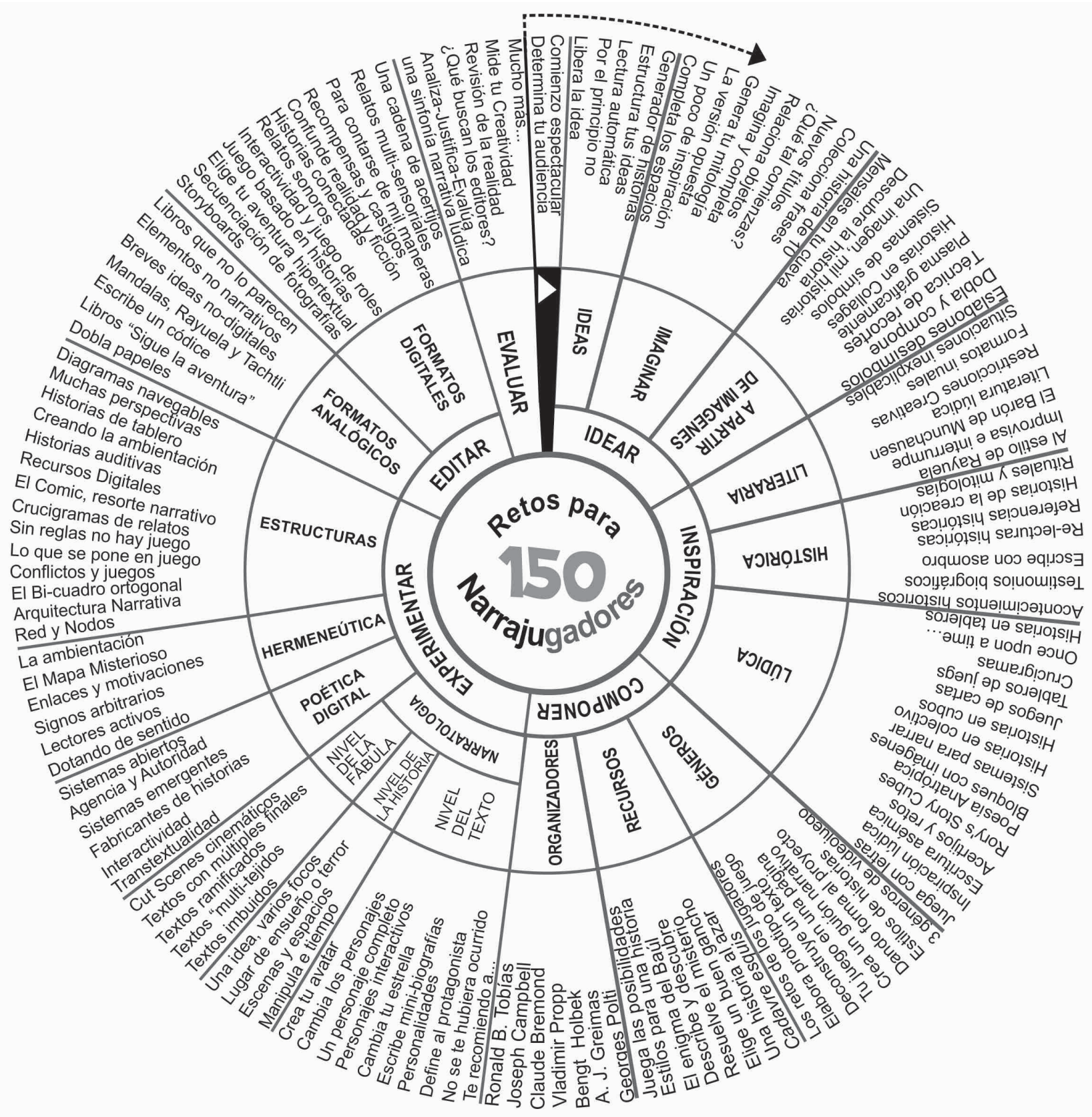

${ }^{777}$ WHITMER, Erin, "Writing exercises to build creativity” [Artículo online] en: http://voices.yahoo.com/writing-exercises-build-creativity-173107.html?cat=35 Consultado: 28/06/2012. 
A partir del esquema anterior, ofrecemos un abanico de estrategias narrativas similar a un taller de escritura creativa, orientado a llevar a cabo prácticas en entornos digitales que tengan como principal motor el juego y el videojuego. Proponemos un modelo que guíe las actividades y permita experimentar de manera sistemática, la composición de textos. La intención es ejercitar las destrezas narrativas para el diseño de textos que acompañen cualquier proyecto artístico, ya sea que cumplan un propósito de entretenimiento o puedan tener cualquier otro fin práctico, como la divulgación de información educativa, de promoción o entrenamiento. Lo que buscamos es componer textos de cierto nivel de complejidad e innovación; que puedan enriquecer cualquier trabajo.

Planteamos este apartado como una serie de "misiones lúdicas" semejante al estilo de un juego de aventuras en la que los interesados puedan llevar a cabo ciertas tareas. Estos aventureros narrativos o narrajugadores, irán avanzando a lo largo de una serie de ejercicios que demandan cada vez, un mayor nivel de complejidad. El reto es combinar la narrativa y los juegos, a través de tareas que facilitan las labores de los narradores y guionistas. Para ello consideramos conformar un modelo que integre un plan conducido y sistemático de ejercicios inspirados en juegos que ofrecen un andamiaje por donde conducir, diseñar reglas y aplicar los demás recursos.

Tres implicaciones fueron consideradas; primero, apreciamos la habilidad del lector como constructor de las historias que lee o juega, de tal suerte que formar escritores atiende a la posibilidad dual de formar lectores-jugadores; segundo, la mecánica de la composición debe partir de consideraciones propias del género que se está tratando de crear, por lo que apreciaremos tanto géneros narrativos como de videojuegos, y tercero, por más experimental que se pretenda llevar a cabo la estructura narrativa, se deben atender las reglas básicas propias del discurso narrativo para admitir aquello que lingüísticamente aceptable.

Clasificamos los ejercicios bajo los mismos parámetros que hemos venido proponiendo en el apartado anterior (las cinco acciones: Idear, Componer, Experimentar, Editar $Y$ Evaluar) a las que proponemos ciertas tareas.

Adquirir una idea es lo que necesitamos para comenzar a componer una historia. Podemos obtener ideas a partir de ciertas estrategias y actividades que estimulan la imaginación y otras técnicas tipo lluvia de ideas, mapas mentales y otros recursos como las fuentes literarias, históricas o juegos que son estupendos generadores de ideas. Con este apartado esperamos contribuir a que sus ideas se conviertan en historias. 


\subsection{LABORES PREVIAS}

Determina tu audiencia, ¿Para quién vas a elaborar tu proyecto? Elige uno de tus videojuegos favoritos e imagina cómo sería si cambiaras radicalmente la audiencia. Escribe aquellos detalles que debes modificar de acuerdo a ésta.

Piensa en un comienzo espectacular para tu historia, uno que logre atrapar la atención de la audiencia y lo sumerja en esta. Entre más y mejor control le des al jugador, mayor grado de inmersión tendrá. Describe qué cosas puede hacer el jugador a lo largo de la historia, enlista las opciones que dispone.

Echa mano de tus recuerdos, ¿Tienes algunas ideas producto de tu experiencia o recuerdos que puedan desarrollarse en un juego?

\section{Consideraciones importantes antes de comenzar:}

Diseña juegos con sus propios mecanismos de juego, piensa más allá de la existencia de los géneros de juego.

a. Enfoca la atención a nuevos jugadores con nuevos gustos y aficiones.

b. Busca integrar la historia y el gameplay.

c. Profundiza en la empatía de los personajes de los juegos e historias.

d. Produzcan un gameplay más emotivo.

e. Descubre la relación entre jugar y aprender. 


\subsection{PRACTICAS PARA IDEAR RELATOS}

Libera la idea, apaga la pantalla del ordenador o cúbrelo. Comienza a escribir tu relato sin considerar los errores, esto te permitirá enfocarte en su contenido, sin importar la gramática o la ortografía.

Por el principio no, comienza a escribir en la mitad, es decir ni al principio, ni al final de la historia, sino en un punto intermedio. No existe regla alguna que indique que debes comenzar a escribir tu historia desde un comienzo; si tienes una escena clara, comienza por ella: puedes escribir las escenas en desorden, luego ir llenando los espacios faltantes. Ayúdate de un esquema que te permita organizar las secuencias y no perderte.

Lectura automática, escribe lo primero se te venga a la mente por 10 a 15 minutos, de todo esto saldrá algo rescatable que puede dar pié a una buena historia.

Estructura tus ideas, Crear un esquema a partir de una idea principal; enlista las ideas que se desprenden de esa idea; diagrama tus ideas, en esquemas, listas, estructuras arbóreas, mapas mentales.

Generador analógico/digital de historias, anuncia de alguna manera la solicitud de encontrar colaboradores para generar ideas, personajes, situaciones que puedan convertirse en historias. Proponer la forma de integrar a una comunidad ya sea mediante la colocación de buzones o urnas para que puedan dejar sus papeletas con sus propuestas en un lugar público. Las Papeletas pueden contener algún planteamiento que les facilite su participación. Y luego facilite las labores del "armador" del texto. Quizá te resulte enviar propuestas por mail o por otro medio digital. 


\subsection{PRÁCTICAS PARA IMAGINAR HISTORIAS}

Completa los espacios, termina la siguiente oración insertando tres palabras de tu imaginación y apreciarás el comienzo de una historia. Si lo haces en grupo observa qué tantas posibilidades distintas tienes para comenzar a imaginar una historia.

$M i$ es como un (a) porque

Un poco de inspiración, escribe una historia inspirada en la tradición mitológica. Puedes escribir el guión sobre las tinieblas y el caos; o adaptar el mito de la creación para un sketch de animación o para un juego de un mundo imaginario.

La versión opuesta, considera un mito que te guste y genera la versión opuesta o diferente a ese mundo con las ausencias y dificultades que no se muestran en la versión original.

Genera tu mitología, Ayúdate de la siguiente hoja y rellena los espacios con las ideas que se te ocurran para crear un lugar mítico; similar al juego de "Ser Dios", en el que puedes crear el entorno de tu mundo narrativo, del cual podrás obtener un sin número de historias.

\section{Imagina y completa}

Erase una vez un mundo creado su mundo a partir de habitado por un y un poco de Dios Que habia - con la ayuda de

Al crearlo, dividió el del (la) , y al primero le dio el poder de mientras que al segundo le favoreció con

Tomó algunos minerales y los mezcló con y creó al primer ser que nombró y le creó una compañera a la que llamó , juntos poblarían el mundo y tendrían la misión de $y$ de

Pronto el mundo comenzó a poblarse y comenzaron a convivir con otras criaturas vivientes llamadas las que tenían la peculiaridad de y a los cuales tuvieron que proteger de otra especie animal que era sumamente

Un día sufrieron una de las catástrofes más devastadoras, la gran que tuvieron que sortear hasta que el mundo se extinguió y sólo quedaron estos fragmentos míticos que recordamos. 
Relaciona objetos, pide a un amigo o familiar que elija siete objetos que encuentre por ahí y los guarde en una caja o bolsa; sin ver, al azar ve tomando uno por uno y escribe lo primero que se te venga a la mente por un minuto. Luego trata de armar los objetos en una historia coherente. Pueden buscar objetos realmente extraños y poco comunes. Como este $^{778}$.

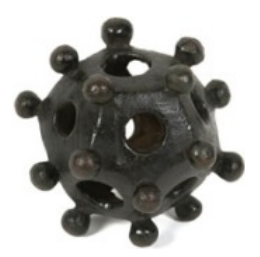

¿Qué tal estos comienzos? Comienza a generar tu historia.

En la profundidad del valle silencioso...

Con el cantar de los gallos...

Con un aspecto horroroso...

Nuevos títulos, visita una librería, elige al azar diez libros y escribe sus títulos; a partir del título, la portada a alguna imagen o palabra, escribe una idea que se desprenda de cada uno. Luego trata de conectar tus ideas en una historia. Resuelve escribir sobre alguno o algunos títulos o trata de conectar los que desees.

Colecciona frases, dichos, diálogos, títulos de libros o películas que te resulten interesantes. Elige algunas que te inspiren a comenzar tu propia historia.

Una historia de 10, recomendamos estos 10 títulos, puedes elegir otros, trata de generar una historia, una escena o una novela completa a partir de la relación y organización de éstos. Trata de hacer tu argumento, utilizándolos todos, sin importar el orden de aparición.

a. El país de las sombras Largas.

b. Grandes esperanzas.

c. De Paris a la Patagonia

d. La tercera mujer.

e. El ácrata de la magallanía.

f. Rondas de la niña mala.

g. La piel del cielo

h. El museo de la inocencia

i. Timbuktu

j. Héroe de cristal.

778 Objeto del Museo Birmingham, [imagen online] en:

http://www.schoolsliaison.org.uk/kids/access/victorian/index_victorian.htm Consultado: 24/05/2012. 


\subsection{GENERAR HISTORIAS A PARTIR DE IMÁGENES}

Deja mensajes en tu cueva, Inspírense en los muros pintados y grabados de las Prehistoria. Imaginar los posibles mensajes ocultos en estas rocas. Reconocer el valor del lenguaje escrito y sustituirlo por el manejo de imágenes para expresar una idea o presentar un mensaje.

\section{Plasma gráficamente los siguientes mensajes:}

a. Receta para hacer un caldo de mamut (no olvides la lista de abasto y cómo conseguir los ingredientes)

b. Lección didáctica para cazar un antílope.

c. Construye una casa y los planos constructivos paso a paso.

d. Carta a tu padre o madre.

e. Registra tu viaje a...

f. Una carta de amor.

g. Preserva la historia de tu familia.

h. Un cuento para antes de dormir.

i. Los 10 peligros de la vida.

j. Tratamiento de enfermedades con métodos mágicos

k. Elabora un tratado sobre "La crianza y juegos de los niños.

\section{Considera lo siguiente:}

Tienes varias opciones, elaborar estos textos gráficos como si fueras habitante de la prehistoria, y además te proponemos que elabores estos mismos contextualizados en nuestro momento actual; el tratamiento de los contenidos seguramente será muy diferente, dependiendo de la época y el contexto socio cultural.

Al relatar historias encontramos muy diversas maneras de comunicar, invocar al auxilio divino, expresar sentimientos, interactuar con los semejantes, enseñar a los pequeños, divertir o entretener. Apreciamos cómo pueden cumplir con ciertos objetivos, puedan ubicarse en diferentes culturas, haciendo referencias que lo reflejen; así como contemplar el punto de vista, las diversas creencias que pueden desencadenar o su ubicación geográfica y cronológica.

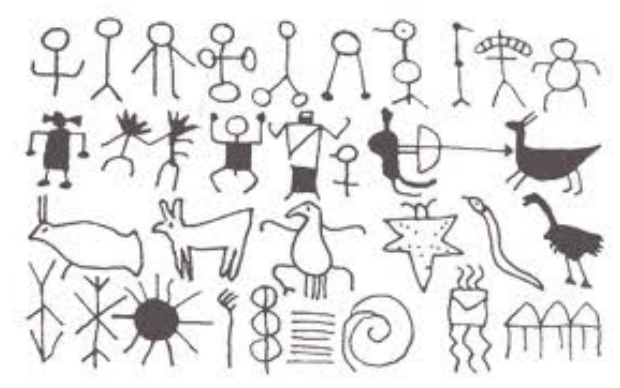




\section{¿Qué historia (s) descubres?}

Imagina y escribe la historia oculta que encuentres en la vasija de Dyplon. Te sugerimos enlistar sus elementos y observar la distribución y estructura de éstos. Los "espacios" de la pieza pueden ser una clave para determinar distintas escenas de tu historia. Luego encuentra la manera de conectar imágenes y escenas en un todo, es decir en una trama completa de una historia. Ponemos a prueba tu imaginación, veamos que puedes hacer si partes de ciertas imágenes. Plantea una manera de conectar sus elementos y niveles, ¿Podrías ligarlo con un videojuego en el que avanzas a regiones y niveles, inténtalo?

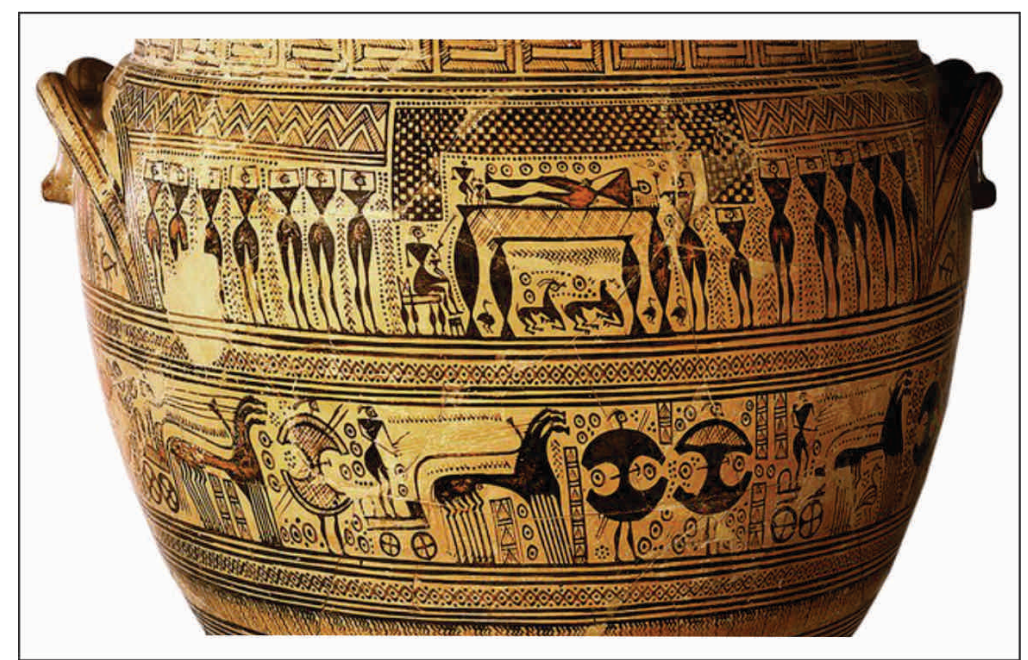

Una imagen, mil historias. Muros pintados, vasijas, tapices, carteles y cualquier otra manifestación gráfica puede ser un detonante para generar historias. Trata de generar las historias a estas piezas.

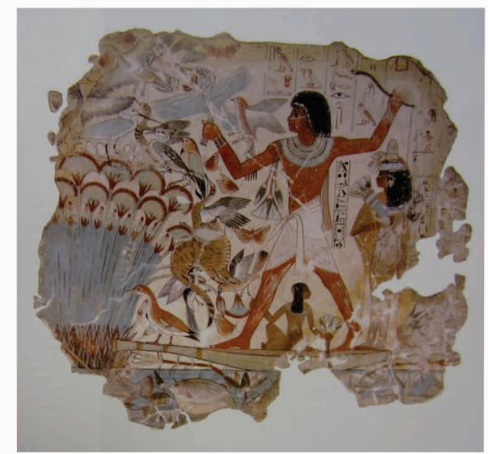

Egipto, Cazando aves en el pantano British Museum, London, 1390 A.C.

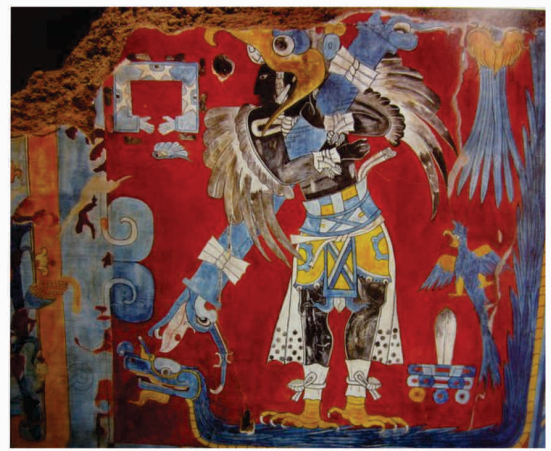

Mexico, Mural del Hombre-Águila, Cacaxtla Tlaxcala, 800 d.C.

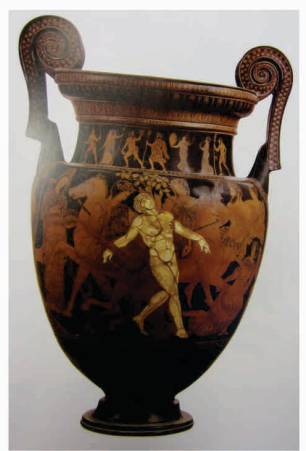

Grecia, Talos Krater, Jatta, 400 a.C. 
Usa otros sistemas de símbolos como, la pictografía utilizada en los códices Aztecas o en los glifos mayas que decoraban cerámicas, muros, estelas, pirámides y se tallaban en madera o piedra.

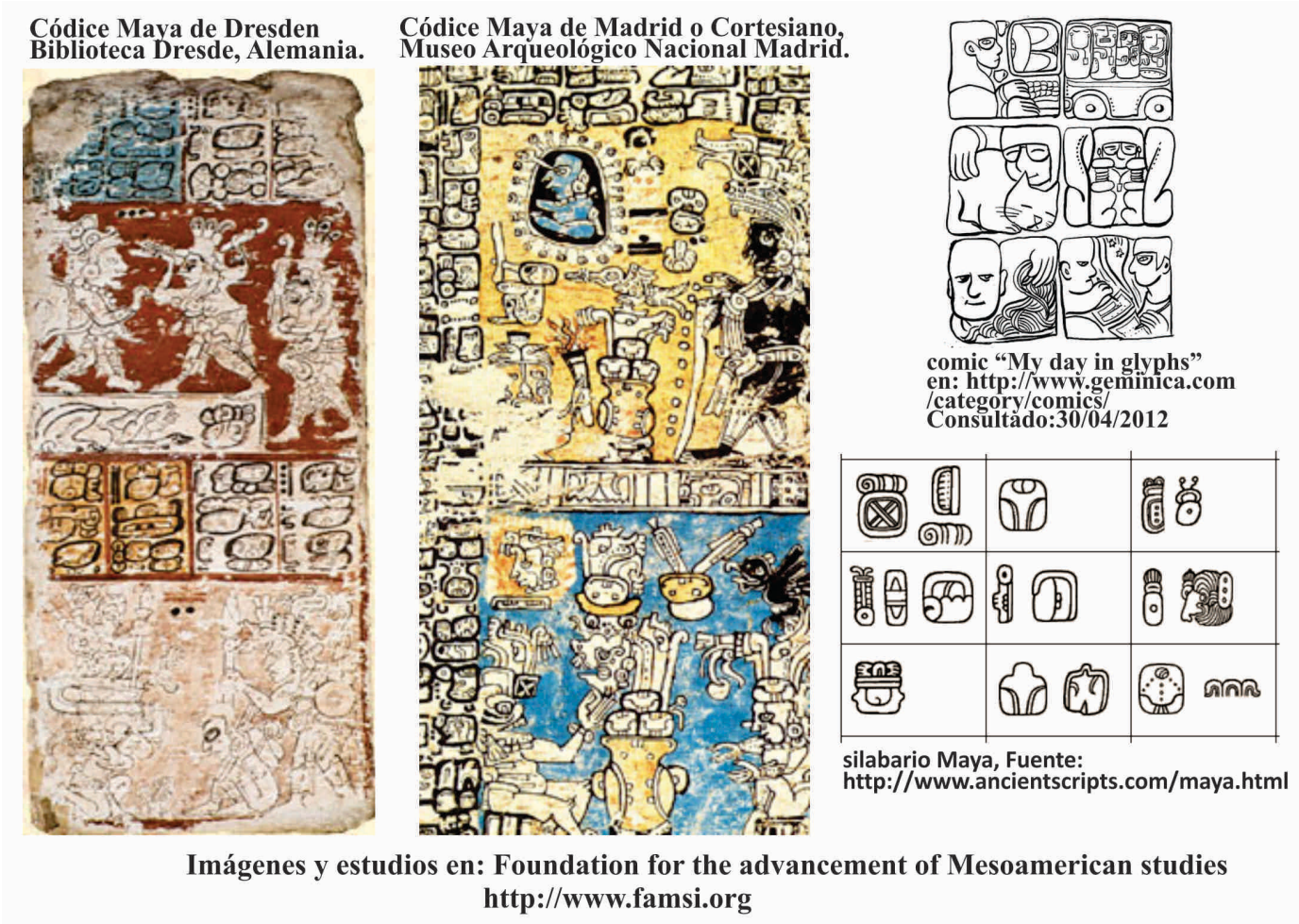

Historias en Collages, yuxtaponer escenas, imágenes, sonidos de distintas fuentes en una pieza, al estilo de André Bretón y sus amigos quienes hacían un recorrido por los diferentes cines sin terminar de ver una película. Los documentales históricos hacen secuencias de elementos visuales, sonoros y algunos textos. Pensar en hacer un collage artístico mediante la fusión de imágenes dispares y arbitrarias. Elaborar un segundo ejercicio en forma de documental en el que se deben insertar el mayor número de elementos que tiene cierta relación entre sí.

Técnica de recortes, Max Ernst recortaba imágenes de revistas y periódicos y las recomponía y pegaba; te proponemos hacer lo mismo con materiales digitalizados que se obtengan al azar y se reordenen para crear un nuevo producto. Esta técnica puede hacerse con cualquier objeto, incluso palabras y textos; puedes recortar una hoja de texto en cuatro secciones rectangulares, reacomodarlas y después tratar de reescribir el texto tratando de compensar los rompimientos de sentido y obligándose a improvisar e innovar en el proceso.

Algunos escritores como Willian S. Burroughs en el Beat Hotel, Julio Cortázar en Rayuela utilizaron esta técnica de cortar, reordenar y reeditar, la cual puede aplicarse a imágenes visuales o sonoras.

Dobla y compón, toma dos hojas de dos diferentes textos lineales, que tengan el mismo espacio interlineado, córtalas por la mitad y combínalas; aunque resulte algo 
difícil de leer, puedes tratar de recomponer un nuevo sentido que las aglutine. Tristan Tzara ofreció crear un poema, sacando de manera aleatoria palabras recortadas de un sombrero.

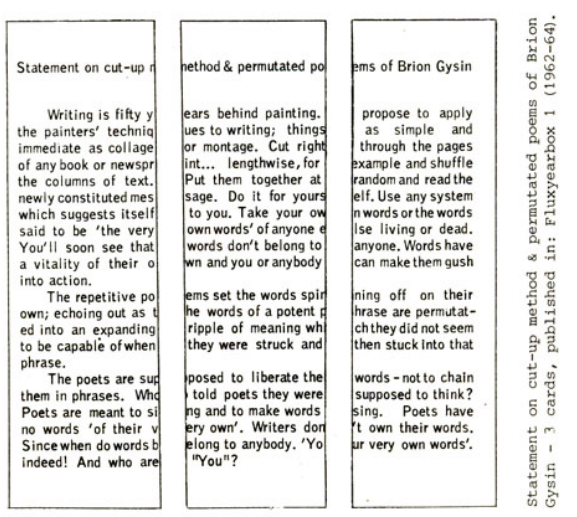

Eslabones de símbolos que cuentan una historia, Recorta los símbolos Adinkra, conoce su significado. Al azar elige algunos y organízalos como si fueran los eslabones de una historia. Trata de componer una, a partir de los conceptos que representan y llena los espacios con tus propias ideas con el fin de que te resulte una historia coherente y completa. Estos símbolos representan un sistema de valores universales. Se utilizan en la costa occidental de África para decorar cerámica, textiles o piezas ornamentales. 


\subsection{FUENTES DE INSPIRACIÓN LITERARIA, HISTÓRICA O LÚDICA}

\subsubsection{Fuentes Literarias}

Situaciones insólitas o preguntas inexplicables: Prueba inventar una nueva vitamina e imagina su utilidad. Un experimento ha permitido que te salga una tercera mano; en qué forma te simplificaría o complicaría la vida, Describe tu vida si tuvieras diez centímetros de altura; ¿Qué se podrían platicar dos vestidos dentro de un armario?

Formatos usuales e inusuales: Formatos Inusuales: emplear formatos de cartas, decálogos, entrevista, anécdota, exposición epílogo, flashback [Secuencia retrospectiva], vaticinar o presagiar, monólogo interior, entrevista, decálogo, epitafio, canciones, acrósticos, nota periodística, figuras retóricas como acrósticos, lipogramas, anagramas, historias ocultas o encriptadas.

Restricciones creativas, tomadas del colectivo OuLipo ${ }^{779}$

a. Texto quimera - identifica los sustantivos, adjetivos y verbos de un texto. Sustituye estos por otros al azar y recompón el texto para evitar incompatibilidades.

b. Un Cuento con muchos caminos - toma como ejemplo una estructura ramificada, cada rama ofrece una parte de una historia que a su vez se ramifica en más elementos. Construye una versión del relato seleccionando un camino de soluciones siguiendo un paso en particular.

c. Locuciones improbables - selecciona dos dichos o refranes conocidos y pártelos por la mitad, luego intercámbialos entre sí, para generar una nueva frase que puedes continuar como motivo para una historia: "tomar el diablo por la cola" y "castillos de construcción de España" obtenemos: "Tomando el diablo en España" y "Construyendo castillos por la cola".

d. Esfinge - narraciones en las que ningún elemento indique el sexo de un personaje o narrador.

e. Textos de arranque - frases que permiten el inicio de un texto como: Se me olvidó... No soy el tipo de... Lo siento por... Me pregunto si...

f. Conectando la línea - Dada una frase inicial y una de llegada o final, establecer la frase o frases intermedias. Se trata de ligar dos ideas que pueden parecer distantes y encontrar una idea que las una a las dos.

g. $\mathbf{S}+7-$ método que sugiere reemplazar cada sustantivo del texto por otro encontrado siete palabras después en un diccionario.

\footnotetext{
${ }^{779}$ Véase sitio de Internet para ampliar las constricciones oulipianas en: http://www.oulipo.net/oulipiens/document13302.html Consultado: 26/06/2012.
} 
Literatura lúdica como modelo: Inspiración literaria, evitar la escritura estereotipada; partir de estímulos literarios: hacer variaciones, personalizaciones o actualizaciones, pueden ser elementos referenciales para escribir textos completamente autónomos.

El Barón de Munchausen de Rudolf Erich Raspe, una fuente creativa de aventuras, argumentos fantásticos y hechos sorprendentes, lugares inexistentes, animales imaginarios, habitantes de la luna, costumbres extraordinarias y acontecimientos sobrenaturales. Por su ingenio y plasticidad, son un estupendo resorte para el diseño de cómics, animaciones y otros formatos. Proponemos escribir una nueva aventura donde aparezcan nuevos seres fantásticos con costumbres ajenas a las nuestras, lugares remotos y medios de transporte poco usuales. Deben darle un aire de veracidad a la historia, apoyados en elementos reales, personajes conocidos.

"Aturdido por el golpe, tardé un momento en volver en mí, cuando en estas que me doy cuenta, asombradísimo de que me he caído dentro de la biblioteca de Alejandría y estoy sumergido en un mar de libros"

Imagina los libros que tuvo en sus manos y que aventuras comenzaron a partir de esas lecturas.

"la obra literaria no tiene que contener nada real, ninguna observación acerca del mundo, nada salvo combinaciones de objetos totalmente imaginarios ${ }^{\prime 781}$.

Improvisa la historia y sortea las interrupciones, cuenta una historia en primera persona, al estilo del Barón Munchausen, hazlo en un grupo en el que cada integrante participe conformando una estructura narrativa más compleja. Interrumpe la historia y cambia las líneas narrativas con mayores peligros y dificultades. Improvisa y busca la manera más convincente para continuar la historia.

Escribe al estilo de Rayuela de Julio Cortázar, la novela suma varios matices lúdicos a distintos planos en relación con el lector, el lenguaje y el juego. El juego que propone Cortázar se reformula constantemente, una rayuela que puede borrarse y volverse a trazar con una tiza y tomar una nueva forma. El lector comienza a jugar cuando logra ingresar al caos lúdico, crea y reconstruye significados a partir de identificar saberes comunes. Te proponemos hacer tu rayuela, una historia que brinca, juega y en ocasiones se tropieza, revisa estos ejercicios:

\footnotetext{
${ }^{780}$ RASPE, Rudolf Erich, El barón de Munchausen, Grupo Anaya, Madrid, 2000.

${ }^{781}$ ROUSSEL, Raymond, How I wrote certain of my books, Exact Change, Cambridge, 1995.
} 
a. Capítulo 68, del lenguaje "Gíglico" o lenguaje musical - inventado por la Maga y compartido con Oliveira. Lee el texto y trata de copiar el estilo, combinando varias palabras para formar una nueva: "Des-escribir" para recomponer.

Apenas él le amalaba el noema, a ella se le agolpaba el clémiso y caían en hidromurias, en salvajes ambonios, en sustanlos exasperantes. Cada vez que él procuraba relamar las incopelusas, se enredaba en un grimado quejubroso y tenía que envulsionarse de cara al nóvalo, sintiendo cómo poco a poca las armillas se espejunaban, se iban apeltronando, reduplimiendo, hasta quedar tendido como el trimalciato de ergomanina al que se le han dejado caer una filulas de carioconcia. $Y$ sin embargo era apenas el principio, porque en un momento dado ella se tordulaba los hurgalios, consintiendo en que él aproximara suavemente sus orfelunios. Apenas se entreplumaban, algo como un ulucordio los encrestoriaba, los extrayuxtaba y paramovía, de pronto era el clinón, la esterfurosa convulcante de las mátricas, la jadehollante embocapluvia del orgumio. Los esproemiso del merpasmo en una sobrehumítica agopuasa.

¡Evohé! ¡Evohé! ${ }^{782}$. Volposados en la cresta del mureflo, se sentían balparamar, perlinos y márulos. Temblaba el troc, se vencían las marioplumas, y todo se resolviraba en un profundo pínice, en niolamas de argutendidas gasas, en carinias casi crueles que los ordopenaban hasta el límite de las gunfias.

b. El Juego del Cementerio - Una burla al diccionario en el juego entre

Talita y Oliveira en el capítulo 41. Juega con palabras cacofónicas.

"Hartos del cliente y de sus cleonasmos, le sacaron el clíbano y el clípeo y le hicieron tragar una clica. Luego le aplicaron un clistel clínico en la cloaca, aunque clocaba por tan clivoso ascenso de agua mezclada con clinopodio, revolviendo los clísos como cierizón clorótico." - Joder - dijo admirativamente Oliveira. Pensó que también joder podía servir como punto de arranque, pero lo decepcionó descubrir que no figuraba en el cementerio [diccionario]; en cambio en el jonuco estaban jonjobando dos jobs, ansiosos por goparse; lo malo esra que el jorbín los había jomado, jitándolos como jocós apestados."

c. Incluye lo que se te antoje - Inserta otros recursos a tu historia - como lo hace Rayuela que integra letras de tangos o canciones de Jazz (capítulos 87 y 106) Poesía (capítulos 121, 149), utilización de diversas lenguas a lo largo del texto, artículos científicos (capítulo 62); noticias periodísticas, reflexiones de introspección (capítulo 75); cartas, etc. Edifica tu obra sobre la base de partes sueltas, al fin que podrás decir: " $m i$ libro se puede leer como a uno le dé la gana”.

\footnotetext{
${ }^{782}$ Cita del mismo autor: ¡Evohé!: grito de las bacantes para aclamar o invocar a Baco.

${ }^{783}$ Tomado de: CORTÁZAR, Julio, Rayuela, Editorial Cátedra, Madrid, 2011. Capítulo 41 (pp. 393-394)
} 
Entendemos que el arte de contar historias es un asunto complejo y que requiere de dedicación. El tener una fuente en una pieza literaria más allá de hacer una copia debe verse como un aliado para la construcción de estructuras narrativas, las cuales, según confirma, no existen límites para el tipo de historias que los videojuegos pueden contar. Sin duda muchos videojuegos poseen historias recurrentes o clichés estereotipados que sin duda requieren del ingenio de los narrajugadores para generar giros a esas historias por demás trilladas. Piensa en la manera como alteramos esas historias de manera creativa.

\subsubsection{Fuentes Históricas}

Rituales y mitologías para escribir un mito colectivo, piensa en una historia al propio estilo de las mitologías clásicas. Identifica una idea a partir de un acontecimiento cotidiano, la vida, la naturaleza, la creación del hombre y de su entorno (piensa cómo crearías un hombre actualmente con todos los adelantos y recursos).

Historias de la creación. Trata hacer un poema sobre la oscuridad del caos o una visión de ciencia ficción sobre el origen del universo o un sketch cómico de un diálogo con un Dios.

Referencias históricas reales, Elige un periodo histórico y enlista una serie de objetos, acontecimientos y personajes que coincidieron en este periodo. Busca hacer una historia con el mayor número de detalles de la época. Te proponemos esta noticia para articular tu historia.

Burnt, claves de una civilización perdida ${ }^{784}$

Burnt, en Irán es un tesoro arqueológico producto de una de los mayores asentamientos urbanos de la humanidad. La ciudad abarca un área de 151 hectáreas, construido alrededor del años 3200 a.C. y abandonado un milenio después, alrededor del 2100 a.C. La ciudad presenta cuatro etapas de civilización y fue demolida por el fuego en tres ocasiones. Tomó su nombre de su último incendio porque nunca fue reconstruida nuevamente.

El juego de backgammon, dados, semillas de alcaravea y numerosos hallazgos

\footnotetext{
784 Tomado de Press Tv [Nota informativa] Abril 11, 2007. "Burnt City, key to lost civilization" [Texto online] en: http://edition.presstv.ir/detail/5668.html Consultado:27/06/2012.
} 
metalúrgicos como pedazos de escoria y crisol, están entre los artefactos encontrados en las excavaciones. El backgammon desenterrado esta hecho de 60 piezas de turqueza y ágata y tiene un tablero rectangular de ébano.

Otros objetos encontrados en el sitio incluyen un cráneo humano con señales que sugieren se le practicó una cirugía de cabeza. Más de 600 esqueletos han sido desenterrados, fueron encontrados en diferentes posiciones lo que puede sugerir que en esta ciudad coexistían diferentes culturas. Los arqueólogos también descubrieron el primer ojo artificial del que se tiene noticia. Es una media esfera de un material muy ligero cubierto de una fina capa dorada y grabada en el centro con un círculo que representa el iris y unas líneas semejando los rayos solares. Una perforación en el ojo sugiere que era para mantenerlo en posición. El ojo perteneció a una mujer quizá una especie de adivina; debió ser una figura impactante, ya que medía $1.82 \mathrm{~m}$ de alto, mucho mayor que el promedio de estatura de las mujeres de ese tiempo. Tendría entre 25 y 30 años cuando murió. Su estructura craneal sugiere orígenes africanos y piel oscura. Se desconoce la causa de su muerte. Entre 2900 y 2800 a.C. la ciudad era un lugar de comercio y riqueza. Las excavaciones sugieren que los habitantes eran una civilización de agricultores y artesanos, No se encontraron armas en el sitio, lo que sugiere la pasividad de los residentes.

Relecturas históricas: qué tal si... elige un texto que aprecies. Toma el inicio y escribe la misma versión pero de modo opuesto o completamente diferente, luego desarrolla este nuevo comienzo en una historia completa.

Escribe con asombro, escribe una historia de cualquier cosa, incluso de algo ordinario y común y muestra un sentido de asombro ante eso que parece muy trivial.

Testimonios biográficos: leer relatos de diferentes épocas, culturas o creencias resulta un estupendo resorte creativo. Te proponemos leer la biografía de un personaje, lo ubiques en una época distinta y en una cultura diferente. Enlista en cada apartado las cualidades que deseas considerar en tu historia.

Tomar un acontecimiento o periodo histórico; pensar en sustituirlo, combinarlo, adaptarlo, modificar, magnificar, darle otro enfoque, recomponer; pueden considerar un Anecdotario, referencias culturales, geográficas, históricas, biográficas y otras. Las historias formaron parte de rituales religiosos y culturales desde la antigüedad, algunos basados en acontecimientos y sucesos míticos. Dos formas de interacción social antigua como son los rituales y los juegos fueron formas culturales que facilitaron la generación de la narrativa y que hoy apreciamos a través de medios digitales. Ambos son interactivos, participativos, facilitan el seguir roles, son dramáticos y son profundamente inmersivos. Además el tipo de mito conocido como el viaje de héroe facilita la generación de narrativas tanto analógicas como digitales. 


\subsubsection{Fuentes Lúdicas}

Juegos de tablero para contar historias, Tomar prestado elementos de juegos tradicionales de tablero, juegos tan antiguos como los encontrados en las tumbas reales de faraones y reyes, difundidos en culturas antiguas hace miles de años; para entrenar a los jugadores en labores de diplomacia y de estrategias marciales. Algunos también cuentan con elementos de suerte y azar. Te proponemos elaborar un relato inspirado en estos tableros.

Once upon a time... A partir de este comienzo bien conocido de los cuentos de hadas se crean historias a partir de un bonche de tarjetas o de cartas de juegos como la lotería, el tarot o de algún otro juego. El ejercicio consiste en seleccionar las tarjetas al azar, generan una serie de historias interconectadas a partir de las ideas que evocan las tarjetas. Es un resorte narrativo muy útil que puede tener múltiples variantes.

Al estilo de crucigramas con cartas semejante a lo que hizo Italo Calvino con el Castillo de los destinos cruzados $^{785}$ y la baraja del tarot. Este ejercicio puede hacer que el ejerció narrativo sea aún más complejo si se incluyen las reglas del juego para organizar las cartas de tal manera que tengan además una interconexión de las tarjetas.

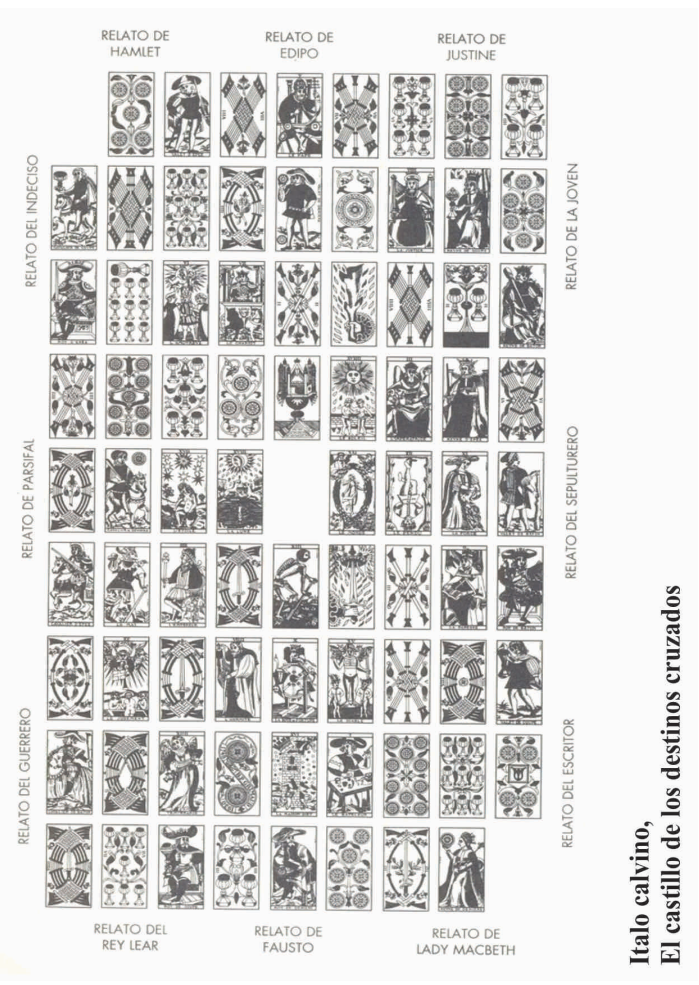

Utilizar tableros de juegos de mesa, tarjetas y otros juegos se puede además ceñir a cierta composición narrativa sujeta a las reglas del juego.

\footnotetext{
${ }^{785}$ Citado aquí mismo (pag. X) véase: CALVINO, Italo, El castillo de los destinos cruzados, Ediciones Siruela, Madrid, 2010. (p.15).
} 
Juegos rudimentarios para contar historias, Series de tarjetas o cartas ilustradas con personajes, lugares, objetos, acciones, eventos y cualquier otro elemento que permita generar historias. Genera tus propias series de tarjetas, recortando imágenes, es un buen ejercicio para iniciar a generar historias. Tarjetas que al elegirlas presentan un cierto orden de personajes, lugares, objetos y eventos que pueden ayudar igualmente, pueden crearse historias colectivas, ramificadas, historias encadenadas con las historias de otros participantes; Pueden usarse cartas prefabricadas y utilizadas para otros juegos como las barajas de la lotería, o algunas hechas con el fin de ser motores narrativos como The goose Bumps storytelling card game; The helpless Doorknob, de Edward Gorey, tarjetas ilustradas que pueden organizarse en cualquier orden y generar una historia a partir de personajes que llevan a cabo acciones que resultan inexplicables: Alfredo regresó de Novaya Zemlya; Adela estuvo desorientada en el fueneral de Alaric; Alethea se esfumó de un día de campo; Temas extraños que sugieren argumentos por componer que de a cuerdo al género, puedan organizarse de manera creativa.

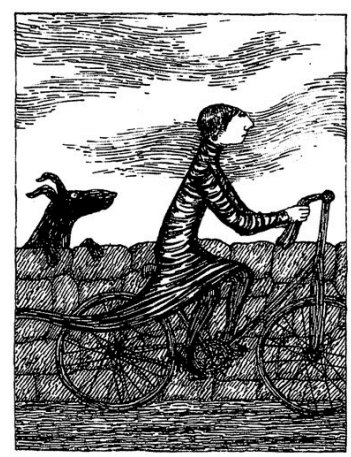

Agatha pedalled to the neighbouring village for help.

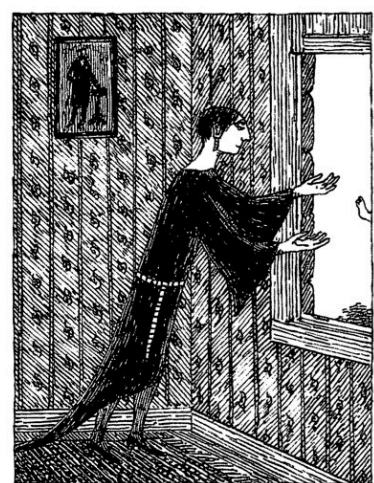

Adela flung Angela's baby from an upstairs window.

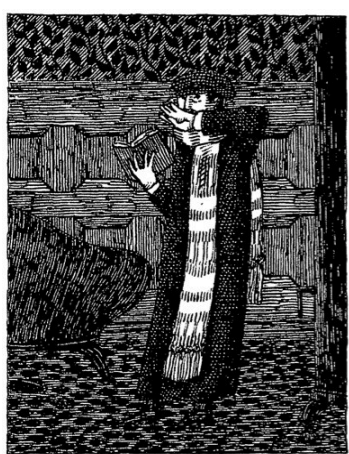

Andrew came across a horrid secret in Adela's diary.

\section{Tarjetas de Keith Baker, Gloom, 2004}

Historias barajadas, elaboradas a partir de la elección de elementos, requiere de ciertos elementos básicos: el género, la estructura, las reglas y el balance entre juego e historia. Las tarjetas o dados, solo ofrece una parte estructural de las historias y una manera de articularlas o ensamblarlas. La interacción de narra-jugador logra que esto se convierta en un marco narrativo; mientras que la imaginación e improvisación del creador es básico a partir de la inspiración de la mecánica del juego.

Cubos gráficos que al lanzarlos, muestra los elementos que se deben articular para comenzar a contar una historia.

Armar historias en colectivo, seguir una misma línea, hacer varias historias ramificadas a partir de ligar unas tarjetas a otras; no resultan historias satisfactorias a menos que agreguemos ciertas reglas, una estructura y podamos identificar los elementos de un género propio. 
Combina elementos narrativos con sistemas para narrar historias como la competencia y la utilización de reglas, que inviten a la interacción y a la participación activa, el reto simultáneo de contar una historia y jugar un juego, pensando en tácticas, estrategias y evitar que otro jugador te venza.

Bloques con imágenes o pequeños textos que elegidos al azar, presentan una manera de secuencia que facilita el inicio de la narración: Esta es la historia de un sapo que vivía en un charco apestoso detrás de un columpio del parque; que decide un día conocer el colegio de los niños que jugaban por las tardes.... Así comienza la aventura. Acciones, personajes y situaciones que se van encadenando de manera sencilla y que permite establecer historias realmente complejas; estas requieren de más trabajo que el simple encadenamiento de elementos, requieren del diseño de estructuras intrínsecas para crear mejores historias, porque con esto se pueden generar simples narrativas, no historias, y la clave es contar con una estructura que permita generar buenas historias.

Cubo de Poesía Anatrópica ${ }^{\mathbf{7 8 6}}$, inspirado en el cubo diseñado por Samuel Sarmiento (2003), basado en El Cubo de Rubik, al que agregó una idea a cada una de las 9 ventanas de los 6 lados del cubo y propone construir el texto poético a partir del movimiento y acomodo de sus lados. Cada que el cubo se mueve, se alteran sus caras y por ende las ideas que relaciona lo que abre una nueva posibilidad combinatoria cada que se mueve. Esto sirve de resorte narrativo. Aunque el cubo originalmente se elaboró para poesía, ésta misma idea puede tomarse para hacer relatos y otro tipo de texto más extensos.

Las 9 ventanas de uno de los lados contienen los siguientes textos:
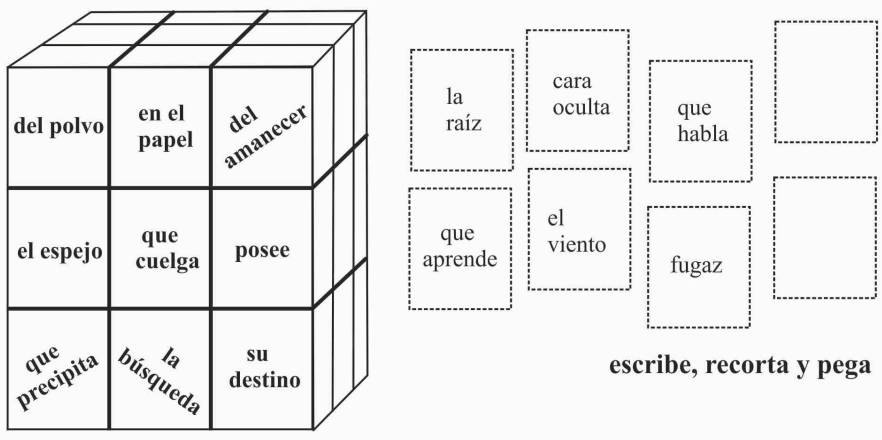

\footnotetext{
${ }^{786}$ Anatropismo, proviene del griego "trop", acción de mover y el prefijo "ana", que indica la dirección. El anatropismo es la construcción del discurso poético a través del movimiento. Véase:

http://cuboanatropico.blogspot.mx consultado: 26/06/2012
} 
Rory's Story Cubes ${ }^{787}$, es un juego de 9 dados que tienen el diseño de diferentes objetos en cada uno de sus 6 lados. Uno de sus aplicaciones es el de la inspiración creativa para inventar historias. Los dados giran y según las imágenes que aparecen pueden irlas conectando en forma de historia.

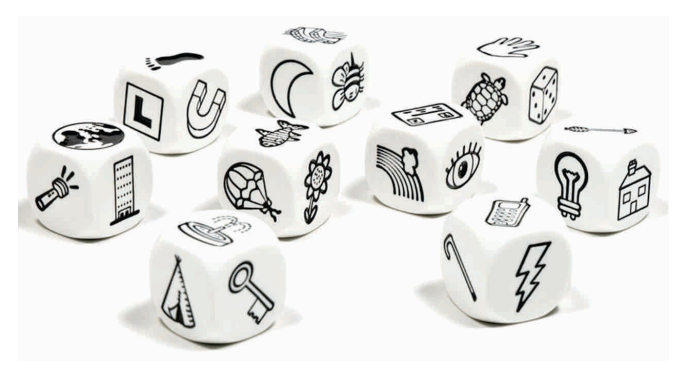

Historias con acertijos, retos $\mathbf{y}$ competencias, historias en forma de rompecabezas (tests, quiz, puzles, mazes) Retos, Fantasías y misterios por resolver. Competencia: incluir objetivos competitivos, llevar registro de puntos, hacer apuestas, que demanden un nivel de habilidades de cierta complejidad, que tomen riesgos, que requieran diseñar una estrategia, sortear obstáculos y oponentes.

Escritura asémica (inventada) contar algo de lo que no saben nada o de algo que jamás hayan escuchado. Navega a través del absurdo; algunas historias están basadas en ideas poco creíbles e ilógicas, otras están inspiradas en razonamientos de pensamiento lateral que busca encontrar soluciones muy extrañas a ciertos acertijos dados. Reta contar historias al estilo de Las aventuras extraordinarias del Barón Munchausen de Rudolf Erich Raspe. ${ }^{788}$ Relatar algo de lo que no saben nada o jamás han escuchado; o contestar una pregunta de origen fantástico: ¿Cómo probar a la comunidad real que el mundo no es redondo? ¿Que la luna sí es de queso? ¿Qué los bebes vienen de Paris? La respuesta debe ser sorprendente, fantástica y dramática, completamente loca.

Inspiración lúdica, en un par de enunciados, plantea el argumento de una historia, capturando la esencia de los acontecimientos. Por ejemplo; "Un alma se desprende del cuerpo de una persona mientras sueña, un día despierta sin que su alma haya regresado, al alma y el cuerpo encuentran la manera para reunirse", así se inicia una aventura que debes continuar.

Juega con letras, te planteamos un ejercicio tipográfico en el que las letras, sus formas, tamaños y colores sean parte del proyecto o como los caligramas, utilicen una sintaxis elíptica para formar imágenes con los textos. Te proponemos escribir un texto que luego se adapte a un formato visual creado con tipografías.

\footnotetext{
${ }^{787}$ Véase: http://www.storycubes.com Consultado 20/06/2012.

${ }^{788}$ Véase: http://www.munchausen.org/en/index_en.htm Consultado 20/06/2012.
} 


\subsection{COMPONER HISTORIAS}

\subsubsection{Determinar Un Género ¿De Juego O Literario?}

El concepto de género lo entendemos como un conjunto de constantes retóricas y semióticas que identifican las obras y permiten su clasificación de acuerdo a su contenido. Te proponemos conocer y apreciar las cualidades de cada uno. Son una herramienta fundamental para comenzar a escribir historias. A continuación enlistamos los géneros de los videojuegos propuesto por Wendy Despain ${ }^{789}$ : Massively Multiplayer Online Games, Role playing games, Adventure Games, Action-Adventure Games, Platform Games, First Person Shooters, Real-Time strategy, games, Sport games, Simulator games, Driving games, Horror Games, Science-Fiction and Fantasy, Sandbox Games, Alternate Reality Games, Serious Games, Casual Games, Interactive Fiction.

Por otra parte agregamos también una sencilla clasificación sobre los géneros literarios, los cuales podemos clasificar en: Narrativa (épica); epopeya, romance, fábula, epístola, cuento, leyenda, novela; Poesía (lírica): oda, himno, elegía, égloga, canción, sátira, epigrama y Teatro (dramática); tragedia, comedia, drama, ópera, paso, entremés y sainete, auto sacramental, melodrama.

Elige tres géneros propios de los videojuegos y propón tres métodos diferentes de presentar el objetivo del juego al jugador. Por ejemplo, en un juego- de-estrategia-entiempo-real el jugador necesita sortear ciertos obstáculos. En un juego de simulación, debe encontrar la manera de comunicarse con su alma y en un juego serio, busca la manera racional de explicar el fenómeno de la separación del cuerpo y del alma.

Estilos de las historias, recuerda lo que hiciste ayer, a dónde fuiste, a quién viste, qué comiste, vestiste o pensaste. Enlista las tareas específicas que tuviste que llevar a cabo durante el día. Ahora escribe eso en forma de un diálogo, como si te lo platicaras a ti mismo o se lo platicara a alguien, pero dando información durante el proceso y escríbelo en tiempo presente.

Dando forma a la idea, de acuerdo al modelo del arte dramático, existen cinco elementos: estilo, argumento, personaje, ambiente y tema que durante los pasados veinte siglos se han utilizado en el teatro, novelas, cine, televisión. Los videojuegos no son la excepción para contenerlos.

\footnotetext{
${ }^{789}$ DESPAIN, Wendy (editor), Writing for video game genres, from fps to rpg, A.K. Peters, Ltd, Wellesley,
} MA, 2009. 
a. Estilo - es lo que permite que el juego se ejecute y nos permite entender que cada juego es diferente, el estilo se apoya en los diferentes géneros y le añade un elemento de simulación (que permite la existencia en el mundo del juego) y un formato de acción y aventura que demanda la solución de problemas y enigmas a través de elecciones estratégicas.

b. Argumento - los juegos poseen una estructura argumental en dos diferentes niveles, la historia propuesta por el diseñador y la que el jugador crea a partir de su experiencia de juego. Los juegos son herramientas que permiten a los jugadores crear historias. Los juegos no deben perderse en descripciones interminables, diálogos eternos o cut scenes excesivas, las acciones del juego deben ser parte del argumento que el mismo jugador debe descubrir mientras se divierte.

c. Personaje - Es el hilo conductor de la historia, el que lleva a cabo las aventuras y quien no sólo enriquece la historia sino la reformula.

d. Escenario - la ambientación es fundamental para los videojuegos; catacumbas, mazmorras, castillos encantados, barrios peligrosos. Experimentar con espacios diferentes como el interior de una juguetería, del cuerpo humano o en el motor de un automóvil. Los espacios pueden ampliarse.

e. Tema - es la idea que el autor trata de expresar con el juego. Es la manera como presenta y desarrolla sus ideas.

Elige un género de videojuego y crea un guión narrativo en el que la historia progrese a través de tres misiones o niveles que lleve a cabo el personaje-jugador. Puedes comunicar la historia a través de la acciones del personaje sin diálogos o cutscenes. Siguiendo el mismo tema, un ejemplo sería plantear tres diferentes tareas que debe emprender el personaje sin alma para conseguir llegar al lugar en donde los sueños conducen a las almas.

Relata en una página, la historia completa de la aventura "En busca de mi alma dormida" en la que narre el hilo argumental de la historia completa, a través de una posible trama, es decir, un orden particular para organizar los acontecimientos, de entre varios posibles. Recuerda que se deben incluir retos, misiones y recompensas en cada acción.

Un ejercicio de de-construcción puede llevarse a cabo, si eligen un juego y lo analizan de manera formal, revisando como están organizados sus elementos formales, dramáticos, como se estructuran las acciones, las características de los personajes y el entorno, y los esquemas de acción de la historia. Descomponer un juego conocido, para obtener un modelo puede ser muy útil. Determinar algunas cuestiones como el conflicto propio del juego, las reglas y formas de proceder, sobre las acciones que llevan a cabo los usuarios y cuando intervienen, o el número de jugadores posibles, o a quien se dirige la 
audiencia o las restricciones del sistema o del entorno. Será importante determinar los objetivos de cada jugador, sus principales acciones en la historia y cómo la transforman, y como se articulan las reglas y las recompensas.

Elabora un prototipo de juego en un tablero que permita simular las relaciones y características de la idea por desarrollar. Settlers of Catan de Klaus Teuber y Carcassonne de Klaus-Jurgen Wrede son solo algunos juegos de tablero entre muchos otros inspiradores de ideas. ${ }^{790}$

Enlista el tipo de retos que los jugadores deben enfrentar y las maneras de afrontarlos y de expresarse a través de la fantasía y el juego. Describe cómo interactúan estos elementos y como pueden implementarse. Tracy Fullerton ${ }^{791}$ plantea algunos tipos de decisiones que se pueden considerar al diseñar textos y juegos, estos son: Inconsecuentes, no impactan el resultado; Menores, tienen un pequeño impacto ya sea directo o indirecto; Necesarios, con un impacto indirecto pero retardado; Importantes, que impacta directa e inmediatamente; y Críticos, que está en juego la vida o muerte del jugador. De la misma manera las estrategias para articular historias pueden tener estos diferentes grados de retos.

\subsubsection{Recursos de Composición}

Descubrir qué decir (tema: de qué hablar, qué decir y cómo decirlo) (referir oral, visual o lingüísticamente una sucesión de hechos interconectados, causales y lógicos. Tomar un tema: aliens, robots y el espacio; animales e insectos; transportes; dinosaurios; magia y hechicería; héroes y villanos; princesas y castillos; detectives y espías.

Cadavre esquis: historias tipo "Round Robin", colaborativas (historia creada por colectivos) Tomar como ejemplo el juego Pantheon, creado por Robin D. Laws ${ }^{792}$; el cual se integra de 5 tipos de juegos en los cuales es preciso crear personajes y contar una historia "Round-robin", en la que en cada turno, los jugadores agregan una nueva idea a la historia.

\footnotetext{
${ }^{790}$ La lista puede ampliarse en: www.funagain.com o www.boardgames.com Consultados: 09/06/2012.

791 FULLERTON, Tracy., Game design workshop: a playcentric approach to creating innovative games, Morgan Kaufmann, Burlington, MA, 2008. (p.318)

${ }^{792}$ Véase: http://robin-d-laws.livejournal.com/ Consultado: 10/04/2012
} 
Una historia al azar; Toma al azar un libro y elige dos capítulos de manera aleatoria; escribe la primera línea de uno y la última del segundo; luego escribe una breve historia con ambas ideas, usándolas como parte final de la misma.

Elige un buen gancho; comienza una historia con una idea que atrape el interés del usuario, una buena anécdota. Te proponemos revisar la Pirámide de las Jerarquías de Necesidades humanas de Abraham Maslow ${ }^{793}$, como una propuesta para retomar ideas de menor a mayor complejidad: Partir de historias que aborden necesidades básicas, de seguridad y protección, de afiliación y afecto, de estima hasta las de autorrealización y resolución de problemas, en las que la creatividad y espontaneidad son parte fundamental del desarrollo del relato.

Resuelve el misterio, Inspirado en el juego Youdunnit, Locked Room Murder, Backwards in time ${ }^{794}$. El cual aborda un tratamiento muy original, trata sobre un supuesto crimen que has cometido y se abre el caso para resolverlo. Un detective investiga a los personajes involucrados y mientras el jugador debe armar una red de conexiones entre los personajes y crear la historia de cada uno. Deberá organizar la historia por niveles que equivalen a tiempo, es decir horas en el pasado: hace 2 horas, 3 horas, 5 horas, 10 horas, etc. El formato puede ser utilizado para generar este género de historias de misterio que puedan revestirse con otros temas y personajes.

Describe el lugar y descubre la historia; este ejercicio tiene como describir espacios con aquellos detalles que resulten representativos para el desarrollo de una historia. Simulen un recorrido en una casa, plasmen su interior y exterior. ¿Qué ven, escuchan, huelen y sienten? En ocasiones comenzar con las descripciones del espacio pueden detonar una historia en cierto punto.

El enigmático sonido del Baúl; todos escuchamos sonidos que provienen de otros lugares como: armarios, cajuelas del coche (durante un viaje) pero qué tal sonidos provenientes de hornos de microondas, zapatos, mochilas escolares. Puede ser aterrador o divertido, qué historia se desencadena al descubrir tal sonido. El baúl puede sustituirse por cualquier otro objeto; incluso de uno que no se describa, que sea imaginario.

\footnotetext{
${ }^{793}$ MASLOW, Abraham, A theory of human motivation, [Texto on-line] en: http://www.emotionalliteracyeducation.com/abraham-maslow-theory-human-motivation.shtml Consultado: 01/07/2012.

${ }^{794}$ Véase: http://playthisthing.com/youdunnit Consultado: 08/04/2012
} 
Estilos para una historia, busquemos inspiración en Ejercicios de Estilo de Raymond Queneau ${ }^{795}$ quien escribió 99 variaciones de una historia breve y trivial. Richard Nordquist ${ }^{796}$ admite que Queneau no inventó este ejercicio creativo, ya que se tiene noticias de que en época de William Shakespeare se utilizaba como referente una guía retórica escrita por Desiderius Erasmus, De Copia $^{797}$, la cual presentaba instrucciones sistemáticas de cómo embellecer, ampliar y dar variedad al discurso oral y escrito a través de la exhibición de 150 variaciones de la expresión "Su letra me agradó enormemente".

Al ejercitar la posibilidad de expresar una idea de diferentes maneras nos confirma cómo al escribir nos enfrentamos a múltiples lectores con diferentes intereses y por lo tanto debemos aprender a decir lo mismo de diferentes maneras, promoviendo la experimentación estilística y la flexibilidad creativa. Ejercicios de estilo plantea una historia por demás trivial, con personajes planos carente de suspenso o clímax; el ingenio lo obtiene justo del inventario de propuestas retóricas que revelan la habilidad del autor. La anécdota que relata es la de un joven que viaja en un autobús muy concurrido y se molesta con un pasajero quien le empuja cada que alguien pasa y luego ocupa un lugar vacío. Dos horas después, el mismo sujeto se encuentra platicando con un amigo quien le dice que debe ponerse un botón en el abrigo.

Transcribimos algunos estilos que se generan de esta idea original:

\section{a. Lítotes $^{798}$}

Éramos unos cuantos que nos desplazábamos juntos. Un joven que no tenía aire de muy inteligente, habló unos instantes con un señor que se encontraba a su lado; después fue a sentarse. Dos horas más tarde, me lo encontré de nuevo; estaba en compañía de un amigo y hablaba de trapos.

\section{b. Metafóricamente}

En el centro del día, tirado en el montón de sardinas viajeras de un colóptero de abdomen blancuzco, un pollo de largo cuello desplumando arengó de pronto a una, tranquila, de entre ellas, ay su lenguaje se

\footnotetext{
795 QUENEAU, Raymond, Ejercicios de Estilo, Cátedra, Madrid, 1999.

${ }^{796}$ NORDQUIST, Richard, “Copia: Raymond Queneau's exercises in style” [Artículo online] en: http://grammar.about.com/od/rhetoricstyle/a/copiaquen.htm Consultado: 27/06/2012.

${ }^{797}$ Véase: Copia: foundation s of the abundant style [artículo online] en: http://en.wikipedia.org/wiki/Copia:_Foundations_of_the_Abundant_Style Consultado: 01/07/2012.

${ }^{798}$ Figura retórica relacionada con la ironía, mediante la cual se afirma algo, negando lo contrario.
} 
desplegó por los aires, húmedo de protestas. Después atraído por un vació el pajarito se precipitó sobre él. En un triste desierto urbano, volví a verlo el mismo día, mientras se dejaba poner las peras a cuarto a causa de un botón cualquiera.

\section{c. Comedia}

\section{ACTO PRIMERO}

\section{Escena I}

(En la plataforma trasera de un autobús $S$, un día, hacia las doce de la mañana.)

EI COBRADOR.- iLos billetes, por favor!

(unos viajeros le pagan.)

Escena II

(El autobús se detiene.)

EL COBRADOR.- iDejen paso! iDelante hay sitio! iDejen paso! iCompleto! iTilín! iTilín! iTilín!

\section{ACTO SEGUNDO}

\section{Escena I}

(El mismo decorado.)

PRIMER VIAJERO (joven, cuello largo, cordón alrededor del sombrero) Se diría, señor que usted me pisotea adrede cada vez que pasa la gente.

SEGUNDO VIAJER (se encoje de hombros)

(Baja un tercer viajero.)

PRIMER VIAJERO (dirigiéndose al público): iEstupendo! iUn sitio libre! iAllá voy! (Se precipita sobre él y lo ocupa)

ACTO TERCERO

Escena I

(La plaza de Roma.)

UN JOVEN ELEGANTE (al primer viajero, ahora peatón) - El escote de tu abrigo es demasiado ancho. Deberías estrecharlo un poco haciéndote subir el botón hacia arriba.

Escena II

(En un autobús $S$ que pasa por delante de la plaza de Roma)

CUARTO VIAJERO.- Mira, el tipo que se encontraba hace poco conmigo en el autobús y que se enzarzaba con otro tío. Qué casualidad. Escribiré sobre eso en una comedia en tres actos y en prosa.

¿Crees poder hacer un ejercicio similar, a partir de una anécdota sencilla? ¡Inténtalo! 
Juega con las posibilidades, al escribir nos enfrentamos a la libre elección de los elementos que pueden integrar nuestro relato. Cada uno de los elementos puede integrar una matriz, la cual puede llevar a cabo ciertas posibilidades combinatorias. En ocasiones sustituir un elemento por otro, puede darle mayor o menor realce o impacto a la historia. Te Recomendamos completar esta matriz, plantear los cambios y desarrollar tres diferentes ramas que te permitan el diseño de una pieza narrativa que luego pueda convertirse en un proyecto multimedia e incluso el guion para un videojuego. Lo importante es apreciar cómo la misma idea puede tomar diferentes rumbos, dependiendo de la interrelación de sus componentes.

Matriz para el diseño de un Videojuego
\begin{tabular}{|l|l|l|l|}
\hline & opción 1 & opción 2 & opción 3 \\
\hline Título & & & \\
\hline Género & & & \\
\hline $\begin{array}{l}\text { Idea por } \\
\text { desarrollar }\end{array}$ & & & \\
\hline Audiencia & & & \\
\hline $\begin{array}{l}\text { Mecánica } \\
\text { del juego }\end{array}$ & & & \\
\hline
\end{tabular}

\subsubsection{Organizadores de Relatos}

Todo resulta más fácil si contamos con una "receta" que nos ayude un poco. Evitando que esto sea una limitante que reduzca la inventiva, debemos ver los organizadores de relatos como aquellos elementos que los teóricos han propuesto para facilitar el trabajo de los creadores. Con esto el trabajo apenas está esbozado, lo verdaderamente importante será el ingenio que los escritores impriman a cada uno de los siguientes modelos. Te proponemos conocer las siguientes teorías para que puedas aplicarlas para construir historias:

Georges Polti ${ }^{799}$, Realizó un inventario sobre la totalidad de situaciones dramáticas que pueden existir en el teatro y en la literatura; argumentando que sólo pueden existir 36 tramas posibles: I - Súplica II - Rescate III - Crimen perseguido por venganza IV Venganza de parientes sobre parientes V-Persecución VI-Desastre VII - Víctimas

${ }^{799}$ POLTI, Georges, Les trente-six situations dramatiques, Mercure de France, Paris, 1895. 
de la crueldad o la desgracia VIII - Rebelión XIX - Empresas atrevidas X-Secuestro XI - Enigma XII - Logro o consecución XIII - Enemistad de parientes XIV - Rivalidad entre parientes XV - Adulterio homicida XVI - Locura XVII - Imprudencia fatal XVIII - Crímenes involuntarios de amor XIX - Asesinato de un pariente no reconocido XX Auto sacrificio por un ideal XXI - Auto-sacrificio por los parientes XXII - Todos sacrificados por una pasión XXIII - Necesidad de sacrificar personas amadas XXIV Rivalidad entre superior e inferior XXV-Adulterio XXVI - Crímenes de amor XXVII - Descubrimiento de la amada XXVIII - Obstáculos de amor XXIX - Un enemigo amado XXX - Ambición XXXI - Conflicto con Dios XXXII - Celos equivocados o erróneos XXXIII - Juicios erróneos XXIV - Remordimiento XXXV - Recuperación de una persona perdida XXVI -Perdida de personas amadas.

Algirdas J. Greimas ${ }^{\mathbf{8 0 0}}$, Propone la siguiente secuencialidad narrativa de cinco pasos: 1 - Partida del héroes versus regreso; 2 - Creación de la falta vs. Liquidación de la falta; 3 - Establecimiento de la prohibición vs. Transgresión de la prohibición; 4 Carencia (disyunción entre el personaje y el objeto de valor) vs. Liquidación de la carencia (conjunción personaje y objeto de valor); 5 - Ruptura del contrato vs. Restablecimiento del contrato.

Bengt Holbek $^{\mathbf{8 0 1}}$, en Interpretation of fairy tales (1987) plantea los 5 movimientos siguientes: Movimiento 1: la princesa actúa de manera no inteligente y es aprisionada por una fuerza maligna. Movimiento 2: el joven se va de casa, y se gana una herramienta mágica al actúan sabiamente. Movimiento 3: el joven libera a la princesa, se enamoran. Movimiento 4: la princesa ayuda al chico y escapan. Movimiento 5: se reconocen como una pareja casadera.

Vladimir Propp ${ }^{\mathbf{8 2}}$, Publica en 1928 la Morfología del cuento y enlista las siguientes 31 funciones: 1 - Alejamiento. Uno de los miembros de la familia se aleja. 2 Prohibición. Recae una prohibición sobre el héroe. 3 - Transgresión. La prohibición es transgredida. 4 - Conocimiento. El antagonista entra en contacto con el héroe. 5 Información. El antagonista recibe información sobre la víctima. 6 - Engaño. El antagonista engaña al héroe para apoderarse de él o de sus bienes. 7 - Complicidad. La víctima es engañada y ayuda así a su agresor a su pesar. 8 - Fechoría. El antagonista causa algún perjuicio a uno de los miembros de la familia. 9 - Mediación. La fechoría es hecha pública, se le formula al héroe una petición u orden, se le permite o se le obliga a

\footnotetext{
${ }^{800}$ GREIMÁS, A.J. Structural Semantics: an attempt at a method. University of Nebraska Press, Lincoln, 1983.

${ }^{801}$ HOLBECK, Bengt, Interpretatio of fairy tales, Akateeminen Kirjakauppa, Helsinki, 1987.

802 PROPP, Vladimir, Morphology of the folk tale, Texas University Press, Austin, 1968.
} 
marchar. 10 - Aceptación. El héroe decide partir. 11 - Partida. El héroe se marcha. 12 Prueba. El donante somete al héroe a una prueba que le prepara para la recepción de una ayuda mágica. 13 - Reacción del héroe. El héroe supera o falla la prueba. 14 - Regalo. El héroe recibe un objeto mágico. 15 - Viaje. El héroe es conducido a otro reino, donde se halla el objeto de su búsqueda. 16 - Lucha. El héroe y su antagonista se enfrentan en combate directo. 17 - Marca. El héroe queda marcado. 18 - Victoria. El héroe derrota al antagonista. 19 - Enmienda. La fechoría inicial es reparada. 20 - Regreso. El héroe vuelve a casa. 21 - Persecución. El héroe es perseguido. 22 - Socorro. El héroe es auxiliado. 23 - Regreso de incógnito. El héroe regresa, a su casa o a otro reino, sin ser reconocido. 24 - Fingimiento. Un falso héroe reivindica los logros que no le corresponden. 25 - Tarea difícil. Se propone al héroe una difícil misión. 26 Cumplimiento. El héroe lleva a cabo la difícil misión. 27- Reconocimiento. El héroe es reconocido. 28 - Desenmascaramiento. El falso queda en evidencia. 29 Transfiguración. El héroe recibe una nueva apariencia. 30 - Castigo. El antagonista es castigado. 31 - Boda. El héroe se casa y asciende al trono.

Claude Bremond $^{803}$, Una función que abre la posibilidad del proceso, ya sea una conducta a observar o un acontecimiento a prever; 2- Una función que realiza esta conducta o acontecimiento en acto y 3- Una función que cierra el proceso en forma de resultado alcanzado. La esferas de acción propuestas son: cumplimiento de la tarea Intervención del aliado - Eliminación del adversario - La negociación - La agresión Retribuciones - Recompensa y venganza - Proceso de degradación - La falta - La obligación - El sacrificio - El castigo. Con estas acciones es factible dar forma a cada acción; ligarlas de manera secuencial y coordinar los roles de los personajes jugando con las posibilidades disponibles; permitiendo un modelo narrativo organizado.

Joseph Campbell ${ }^{804}$, Plantea la existencia de un único mito, basado en la figura del héroe y las tres etapas: la partida, la iniciación y el regreso; que a su vez se componen de varias partes y pueden permite el comienzo y estructuración de una historia: una separación del mundo; una penetración de un tipo de fuente de poder; y el regreso de una vida engrandecida. Las tres partes se componen a su vez de:

I - La Partida: La llamada a la aventura. $\quad 1.2$ Rechazo a la llamada. 1.3 Ayuda sobrenatural. 1.4 El cruce del umbral. 1.5 El renacimiento. II - La Iniciación: 2.1 El camino de las pruebas. 2.2 El encuentro con la divinidad. 2.3 La mujer como tentación. 2.4 Expiación (desagravio) con el padre. 2.5 Apoteosis. 2.6 Bendición

\footnotetext{
${ }^{803}$ Tomado de: "La lógica de los posibles narrativos" (pp. 99-121), en: BARTHES, Roland et al, Análisis estructural del Relato, Premia Editores, México, D.F., 1986.

${ }^{804}$ CAMPBELL, Joseph., The hero with a thousand faces, Joseph Campbell Foundationd \& New World Library Press, Novato, 2008.
} 
Final. III - El Regreso: 3.1 El rechazo del regreso. 3.2 El vuelo mágico. 3.3 El rescate desde el mundo normal. 3.4 El cruce del umbral. 3.5 Maestro de dos mundos. 3.6 Libertad para vivir.

Campbell también sugiere que el diagrama contiene los siguientes pasos y elementos: Llamado a la aventura- ayudante - Cruce del umbral - hermano - batalla - dragónbatalla - Desmembramiento - Crucificción - Rapto - viaje nocturno - viaje maravilloso - encuentro con la divinidad - Ayudantes de la tarea - (1. matrimonio, 2. Desagravio con el padre, 3. Apoteósis, 4. Robo del elixir) - vuelo - (Regreso - Resurrección - Rescate lucha en el umbral) - Elixir.

Ronald B. Tobías ${ }^{\mathbf{8 0 5}}$, Propone 20 argumentos maestros para construir las historias. En 20 master plots and how to build them, (1934) los enlista así: 1 - Intriga 2 - Aventura 3 - Persecución 4 -Rescate 5 - Escape 6-Venganza 7 -Acertijo o prueba 8 Rivalidad 9 - Miseria o desamparo 10 - Tentación 11 - Metamorfosis 12 Transformación 13 - Maduración 14 -Amor 15 -Amor prohibido 16 - Sacrificio 17 - Descubrimiento 18 -Desdicha 19 -Ascensión 20 -Descenso.

${ }^{805}$ TOBIAS, Ronald B., 20 Master plots and how to build them, Writer's Digest Books, Cincinnati, 1993. 


\subsection{EXPERIMENTAR}

\subsubsection{Recursos Narratológicos}

Para poder trazar el desarrollo de una historia es preciso tener en claro que éstas se articulan a diferentes niveles, bajo ciertas estructuras narrativas que distinguen ciertas categorías. Los teóricos los han designado con diferentes términos pero en esencia se trata de personajes o agentes; acciones, argumento o trama; espacio, escenario o entorno; narradores y manejo del tiempo.

\subsubsection{Nivel Del Texto}

a. Agente narrativo, Te recomiendo a... Qué te parece escribir a otra persona lo maravilloso que eres pero haciéndolo como si alguien más lo estuviera diciendo, escríbelo en tercera persona: Mi querido amigo.... Es una persona extraordinaria porque desde que nació le ha tocado sortear una infinidad de adversidades... Te proponemos convencer a tu interlocutor de que la persona de quien estás hablando (tu mismo) es genial.

b. No se te hubiera ocurrido, toda historia está relatada desde la visión de uno o varios narradores. Todos pueden narrar las historias. Pueden ser incluso seres inanimados que se personifican y plantean su propia experiencia. Te sugerimos recomponer algún cuento tradicional bien conocido desde el punto de vista de un personaje oculto; qué tal contar la versión del antagonista o de cualquier otro personaje e incluso plantear la visión del caballo, la espada, la escoba de la bruja o los zapatos del hechicero malvado. La literatura y el cine se han nutrido de contar la misma historia desde diferentes perspectivas. Busca un ángulo divertido e ingenioso para narrar tu historia.

c. Define al protagonista, escribe tres adjetivos que contengan tres sílabas (ejemplo: Va-lien-te, tram-po-so, ló-gi-co) Combina la primera sílaba del primer adjetivo con la primera del segundo y la segunda con la tercera sílaba del tercero. Nuestro ejemplo arrojaría: "Vapoco" con esas cualidades inicia a darle forma a tu personaje, usa el término como un apodo. El príncipe Vapoco tenía tres virtudes y tres debilidades... (continúa tú la historia).

d. Personalidades múltiples, los personajes que admiramos y recordamos de las novelas o el cine tienen personalidades bien definidas y estructuradas. Diseñar 
personajes con personalidades íntegras requiere de revisar algunos estudios sobre psicología. Lo que te proponemos es algo más sencillo, que te ayudará a determinar la personalidad de tus personajes, revisa el Eneagrama de la Personalidad propuesto por Gurdjieff ${ }^{806}$. Genera con el esquema anterior el perfil detallado de tu personaje. Una vez que lo determines, no olvides incluir sus aficiones, temores características físicas, ocupación, etc., Puedes basarte en alguien que te resulte conocido. Lo importante es generar un personaje bien definido.

e. Escribe mini-biografías, elige un personaje y elabora su biografía; parte de lo básico: edad, nombre, estado civil, lazos familiares, ocupación, apariencia, descripción física, carácter, pensamientos y sentimientos que despierta. Las vidas de las personas son elementos muy valiosos para desencadenar historias. El ejercicio reside en hacer algo realmente breve y sustancioso.

f. Una historia con una "estrella" diferente; todos estamos acostumbrados a encontrar a los personaje estereotipados de en un cuento o historia tradicional. Te sugerimos importar personajes de otros cuentos y determinar sus actitudes, creencias y comportamientos dentro de una nueva situación, que replanteen su personalidad a partir de esta nueva historia. ¿Qué tanto cambiarían el sentido de la historia? Procuren generar una historia interesante y atractiva.

g. Personajes de entornos interactivos, son personajes controlados por el usuario y por el sistema, se comunican con los personajes y pueden incluso crearlos y controlarlos en forma de Avatares. Algunos softwares ayudan a crearlos gráficamente como, SP Studio ${ }^{807}$, Portrait Illustrator Maker ${ }^{808}$, o el Flash Face app ${ }^{809} \mathrm{Te}$ proponemos establecer contacto con tu avatar y relatar una historia en donde los dos vivan una aventura en dos realidades distintas, la virtual y la real. En ocasiones esta frontera puede borrarse y en otras es una muralla infranqueable.

h. Un personaje completo, describe a un personaje con el mayor detalle posible, elige su nacimiento dentro de un momento histórico definido. Plantea su pasado y planes para el futuro. Nómbralo, determina su género, raza, edad (en el momento del relato). Determina sus aficiones, cualidades, ocupación, creencias.

\footnotetext{
${ }^{806}$ Véase el punto Creación de Personajes, dentro del apartado 5.1.2 Componer en este mismo trabajo.

${ }^{807}$ SP Studio, http://www.sp-studio.de/index.htm Consultado: 01/07/2012

${ }^{808}$ Véase: http://illustmaker.abi-station.com/index_en.shtml/ Consultado: 01/07/2012

${ }^{809}$ Véase: http://flashface.ctapt.de/index.php Consultado: 01/07/2012
} 
i. Cambia los personajes, en una historia conocida, imagina cómo se alteraría la historia si otro protagonista apareciera y cambiara el punto de vista de la historia. Te proponemos invitar a un personaje ajeno a esta historia y cambiar el rumbo de la misma.

j. Crea tu Avatar, Janet Murray ${ }^{810}$ señala que los entornos digitales nos permiten ponernos una máscara y actuar a través de un avatar, una especie de personaje con un traje inteligente que permite a los jugadores sentirse en su lugar y recorrer a su antojo el mundo virtual y no sólo presenciarlo, sino ejecutarlo todo. Una de las ventajas es que actuar a través de un avatar estimula la imaginación y la improvisación. Seguramente hay cosas que no te atreverías a hacer, sin embargo piensa todo lo que tu avatar podría hacer en tu lugar; enlístalo y luego puedes darle forma de un relato.

\subsubsection{Nivel de la Historia}

a. Jugando con el tiempo, Manipular el tiempo y el espacio a su antojo, expandiendo o contrayéndolo. Te proponemos tomar como modelo una novela histórica y replantear el hecho histórico diferente de cómo sucedió realmente. A este género se le conoce como ucronía o novela histórica alternativa. Un ejemplo sería cambiar los resultados de las guerras. También podemos considerar el punto jonbar, entendido como un acontecimiento relevante que determina la historia futura, como el hallazgo de una vacuna contra una enfermedad, antes incurable, la invención de una máquina del tiempo, o la existencia de los dinosaurios, sólo por mencionar algunos, Quizá puedas sugerir algunos otras ucronías y puntos jonbar. Este será un buen ejercicio para los lectores y escritores de sucesos históricos, al permitirse en una ficción plantear de manera hipotética los acontecimientos si hubieran tomado otro giro.

b. Instalando el espacio para el juego, te proponemos describir las escenas en donde se desarrollará la historia del juego. A diferencia de otros medios los juegos son episódicos y se estructuran por niveles, por lo que se requieren múltiples oponentes, locaciones y entornos. Estos niveles tienen subniveles y misiones (objetivos que llevar a cabo). Lo óptimo para el desarrollo de los

${ }^{810}$ MURRAY, Janet H., Hamlet en la Holocubierta, el futuro de la narrativa en el ciberespacio, Paidós, Barcelona, 1999. (p.126) 
juegos es tener una historia con una avenida principal de la cual bifurcan otros accesos. Los espacios deben estar en cierto modo comunicados y deben dar la ilusión de libre movilidad. Diseña 6 diferentes espacios de un juego con diferentes locaciones, niveles y misiones. En cada uno habrá un personaje particular, un tipo de reto a vencer así como un tipo de recurso.

c. Lugar de ensueño o terror, piensa en escribir una historia inspirada en el lugar más hermoso que hayas visto. Puedes también hacerla partiendo del lugar más horroroso. Reflexiona sobre cómo el diseño del espacio determina las cualidades de las historias. Describe el mismo lugar con esta doble posibilidad: un lugar de ensueño o de terror, piensa en hacerlo a partir de un hospital psiquiátrico o un jardín botánico, cualquier lugar te permitirá hacer este doble ejercicio.

d. Una idea con varios puntos focales, las historias se narran desde la perspectiva y punto de vista particular de algún observador. La literatura ha experimentado una gran variedad de posibilidades; narradores omniscientes que lo saben todo, incluso lo que los personajes piensan y sienten; narradorespersonajes que van aportando su propia visión de los hechos y que incluso van contando la historia desde sus perspectivas. También existe la posibilidad de que las historias sean narradas por objetos inanimados que están presentes en las escenas y relatan, lo que "ven" o cualquier otro elemento de la historia como unos anteojos, o la mascota o desde la focalización de los zapatos del protagonista.

\subsubsection{Nivel de la Fábula}

a. Textos imbuidos ${ }^{811}$, historias dentro de otra historia al mismo estilo de las muñecas rusas, o de Las mil y una noches o del Ingenioso Hidalgo Don Quijote de la Mancha, El Manuscrito encontrado en Zaragoza de Jan Potocki, El misterio del solitario De Jostein Gaarden quien cuenta la historia de una marinero que cuenta la historia de otro marinero y de otro marinero. Piensa en armar historia que contengan a su vez otras historias.

b. Textos "multi-tejidos", imagina componer un texto en el que una gran cantidad de sus elementos se entretejen simultáneamente en un gran tapete de significación. Plantea usar sistemas gráficos para identificar no sólo los

\footnotetext{
${ }^{811}$ Para ampliar el listado de literatura y cine en habla inglesa, véase: "Story inside a story" [artículo online] en: http://en.wikipedia.org/wiki/Story_within_a_story Consultado: 27/06/2012.
} 
elementos sino sus puntos de encuentre y las posibles conexiones que se establecen entre sí. Las historias son mundo de elementos conectados, nada es gratuito y tiene cierta repercusión en los demás y en el todo.

c. Textos ramificados, presentan al jugador muchas maneras de recorrer o atravesar las historias con varios posibles finales. Los caminos cambian según las decisiones de los jugadores. Estos textos se componen de veredas paralelas, historias que en ciertos puntos convergen y otros regresan a situaciones iniciales. Los jugadores pueden deambular por diferentes lugares pero el sistema los obliga a llegar siempre al mismo lugar. Todavía no se han logrado escribir historias y juegos del todo interactivos, porque las acciones están sujetas al sistema pre establecido y al contexto. Te proponemos comenzar tres historias de manera paralela y buscar ciertos puntos a lo largo de cada una en los que puedan conectarse.

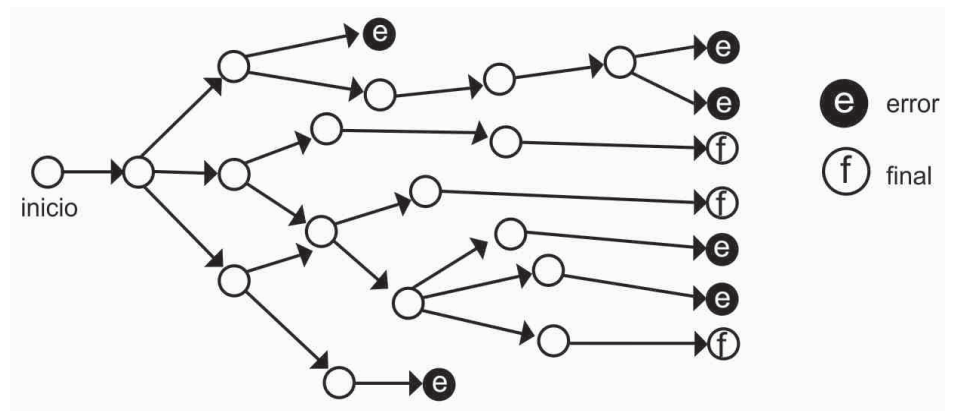

d. Textos con múltiples finales, Trata de comenzar una historia en diferentes puntos y avanzar cada uno por diferentes direcciones, cada una de estas direcciones plantea una posibilidad distinta de juego. Sin duda no es un ejercicio fácil, son historias difíciles de escribir ya que sus hilos narrativos deben encajar en algún momento de manera coherente y cobrar sentido, sin embargo consideramos que tienen mejores posibilidades creativas que las historias ramificadas.

e. Cut Scenes y textos cinemáticos, el juego se detiene para mostrar estos fragmentos que señalan o presentan información a manera de texto o cinemática que permite entender el mecanismo del juego, ya sea mediante una retrospección o planteando ciertos sucesos que desconocemos y que son útiles para el desarrollo del juego. Son una especie de avances narrativos que los diseñadores presentan a manera de filme. En ocasiones tienen el formato de un diálogo entre varios personajes o en forma de nota, letrero, cartel, incluso algún libro. 


\subsubsection{Recursos De Poética Digital}

Transtextualidad, aprender a leer, escribir e interactuar a través de plataformas, medios y herramientas orales, escritas, analógicas, digitales de medios impresos, cine, radio, redes sociales, hipervínculos y otros elementos que pueden interrelacionarse en un texto. Es la habilidad adquirida de darle sentido al mundo de la ficción, al recopilar información a lo largo de la historia y convertirla en una experiencia de entretenimiento. Novelas que son adaptadas al cine o a un videojuego como la serie de Harry Potter, te proponemos diseñes un proyecto radiofónico, uno educativo o uno artístico inspirado en el mundo del famoso mago Potter.

Interactividad, aplicar la tecnología digital para relatar historias interactivasparticipativas e inmersivas. La idea de poder convertirse en participantes activos y tomar decisiones sobre el rumbo de las historias es algo que a los narrajugadores entusiasma. La creación de dispositivos y tecnología que nos permita introducirnos en las historias y transformarlas a nuestro antojo, es algo que esperamos conseguir. Uno de los asuntos por considerar al escribir historias para entornos digitales es lograrlo de manera conjunta conservar una coherencia interna de la narrativa, porque las historias no sólo son secuencias de eventos, sino que cada elemento que aparece debe ser significativo. En cierto sentido la poética del usuario debe despertar las siguientes cualidades: curiosidad, suspenso, placer estético, autosatisfacción e inmersión. Son elementos que los escritores deben contemplar.

Juegos Fabricantes de historias, los narrajugadores deben construir historias basados en las estructuras de un juego y consideren elementos de interactividad y competencia. Te retamos a contar una historia que se pueda jugar de manera simultánea, pensando en que sea necesario formular estrategias tácticas para ganar la partida y llegar al desenlace de la historia. Traten de equilibrar tanto la experiencia lúdica como la narrativa.

Sistemas emergentes, estas historias surgen a partir de la mecánica propia del juego y se crean por la experiencia del jugador, quien se convierte en un creador. Estos sistemas son ajenos al mundo creado por el diseñador. Un caso que lo ejemplifica es la serie de los Sims. Mundos que se crean al mismo tiempo que se juegan en donde las historias las crean los jugadores a partir de las elecciones que toman, los personajes que eligen, los ambientes que generan y las situaciones que inventan. Resulta básico improvisar historias mientras se construye el entorno y se genera un contexto. Al jugar respóndete ¿Qué historia está detrás de esto? 
Agencia y Autoridad, al diseñar reglas y estructuras para las narrativas colaborativas ya sea en línea o analógicas, es importante considerar los tipos de agencia y autoridad disponible para los participantes. Plantea qué posibilidades tiene el jugadores para cambiar las reglas de juego, ¿Qué tal si decide cambiar ciertas partes de los juegos? ¿Qué opciones tendría, qué alternativas, con qué tendría que lidiar, qué debe sacrificar? Pensar en diseñar historias que puedan ser manipuladas y reconstruidas por los usuarios, debemos permitirles hacer cambios, alterarlas y descomponerlas. Al ofrecerles agencia y autoridad, les demos la posibilidad de ser creadores de narrativas que les abren la posibilidad a un tipo de participación no sólo lúdica, sino narrativa. Escribe el guión de una historia que tenga un gran diversidad de posibilidades de avance diferente y deja partes en blanco para que los usuario puedan completar con su ingenio e inventiva esos faltantes.

Sistemas abiertos, Marc Saporta presenta su novela Composition no. $1^{812}$ en una caja con ciento cincuenta páginas sueltas que pueden barajarse y leerse en el orden que el lector desee, demandando una activa participación. Es una obra con 150 posibles comienzos y el mismo número de finales, historias para leer, desechar, barajar y reinventar. El sueño de todo lector: recomenzar la lectura de manera más atractiva tal como lo dice Tom Uglow en la caja, "If the story doesn't capture you, maybe you should start again." Te proponemos hacer un texto a partir de fragmentos de otros textos, pings, correos electrónicos, SMS, o cualquier otro modo de comunicación digital. Pensar además en utilizar otros formatos: novelas inspiradas en Facebook o Twitter, no es algo nuevo, en la red ya circulan.

${ }^{812}$ SAPORTA, Mark, Composition No. 1, Visual editions publisher, London, 1962. 


\subsubsection{Recursos Hermenéuticos}

Dusk in Cairo ${ }^{813}$

You are walking down a dusty street, on your way to a museum. You wish to discover the origin of a symbol found in a book belonging to your father the archeologist. Your father had told you, before he died, that this book contained his life's work. Suddenly, you hear footsteps. A man grabs the shoulder of your leather jacket. He says he is Horace, a friend of your father's, and if you come with him, he can help you. You stop in Cafe Tut -- he is charming and surprisingly knowledgeable about your father. You absorb his every word, until you suddenly get an eerie feeling... Horace is asking strange questions about the book. Your father's book. You then notice a suspicious gun-like bulge in his suit jacket. You slowly get up, mentioning the restroom, and then bolt out of the cafe, barely evading Horace's hands as you jump into the nearest taxi. "Quick, get me to the museum," you scream over the sound of the screeching tires. You relax as you see Horace getting smaller though the rear window of the cab. "Yes, Sir," the gold-toothed cabbie replies with a smile, heading quickly in the wrong direction.

Dotar de sentido, escribir una historia que resulte significativa no sólo por la anécdota que se relata sino por el contexto en el que está inmerso. Los sucesos cobran mayor realce cuando los relacionamos con algo conocido o concreto. El valor de preservar la memoria de las personas fue uno de los orígenes de los primeros narradores orales. Te proponemos remontarte al pasado y plantear un relato que tenga conexión con asuntos "importantes y significativos", esto servirá para que tu historia sea preservada para la eternidad porque además de ser un relato ilustrativo y divertido, aporta información importante sobre el contexto y su momento. El sentido de un texto favorece que éste trascienda y sea recordado.

Participación activa del lector, para Julio Cortázar no hay novela sin lectorcreador. La literatura es vida compartida... "Por lo que a mí respecta, me pregunto si alguna vez conseguiré hacer sentir que el verdadero y único personaje que me interesa es el lector, en que algo de lo que escribo debería contribuir a mutarlo, a desplazarlo, a extrañarlo, a enajenarlo"(...) Hacer del lector un cómplice, un camarada de camino ${ }^{814}$. Pide a tu lector te ayude a completar tu historia, establece un diálogo y busca la manera

\footnotetext{
${ }^{813}$ Fragmento de Oz Project, de WEYHRAUCH, Kelso M., y BATES, J, "Dramatic Presence" en The journal of Teleoperators and virtual environments, Vol. 2, Núm. 1, MIT Press [Texto on line] en: http://www.cs.cmu.edu/afs/cs/project/oz/web/overview2.html Consultado: 01/06/2012 ${ }^{814}$ Citado por: Miriam Cabello Murillo “La maga, Rayuela de Julio Cortázar" [artículo online] en: http://www.ctv.es/USERS/borobar/la_maga.htm Consultado: 26/06/2012.
} 
de que juntos le den forma a una historia. ¿Cómo planteas tu historia si tienes que involucrar al lector? ¿Qué propuesta sugieres?

Signos arbitrarios, te proponemos crear un lenguaje artificial artístico o Langart, que sirva para dar voz a personajes no humanos, para dar mayor credibilidad a una civilización perdida, puedes diseñar el nuevo alfabeto, enlistar un vocabulario básico y escribir textos o diálogos, no olvides poner los subtítulos.

Enlaces y motivaciones, en puntos anteriores comentamos cómo los jugadores crean una narrativa interna mientras el juego progresa; los juegos pueden enriquecerse aún si cuentan con mejores historias. En cierto modo entendemos la función del lector como un constructor de imágenes y conexiones que le da sentido al todo lo que se le presenta y es capaz de "llenar" los espacios con sus propias aportaciones imaginativas para que las historias cobre sentido y lógica. En ocasiones escuchamos las historias que los jugadores se inventan y resultan ser muy ingeniosas. Puedes elegir un juego y te proponemos escribir la parte de la historia que no te relata y que debes articular de manera autónoma. Te proponemos ampliar y enriquecer esa historia lo más que puedas.

El "Mapa Misterioso", comienza tu historia a partir de la supuesta existencia de un mapa. Imagina lo que el mapa señala, sus direcciones, indicaciones, plantea la información que ofrece, los obstáculos y los lugares a donde conduce: a un tesoro o a un gran problema. Establece enlaces entre los lugares y haz conexiones con otras acciones que sean significativas a la historia.

La ambientación, debe ofrecer información significativa a la historia, ya sea de manera concreta o sugestiva. En cierta manera los jugadores juegan por la oportunidad de explorar mundos a los que no tendrían manera de explorar de ninguna otra manera. Imagina qué mundo te gustaría explorar. Y enlista los elementos cómo influyen en el desarrollo de la historia, quizá ofrecen información relacionada con otras historias, culturas o acontecimientos sucedidos; piensa en establecer conexiones a diferentes niveles que aporten información a tu historia. 


\subsubsection{Recursos Formales o Estructurales}

Nodos que te conectan a una red infinita; traza una ruta en un mapa, marca un trayecto y esquematiza una serie de acontecimientos conectados. Encuentra la manera de hacer una historia basada en una trayectoria pre establecida. Puedes utilizar el esquema de las estaciones del metro y determinar para cada línea una posible trama argumental, ubica dónde hay conexiones. Puedes hacerlos con planos de metro más complejas. Incluso hasta los nombres de las terminales te den algo de inspiración.

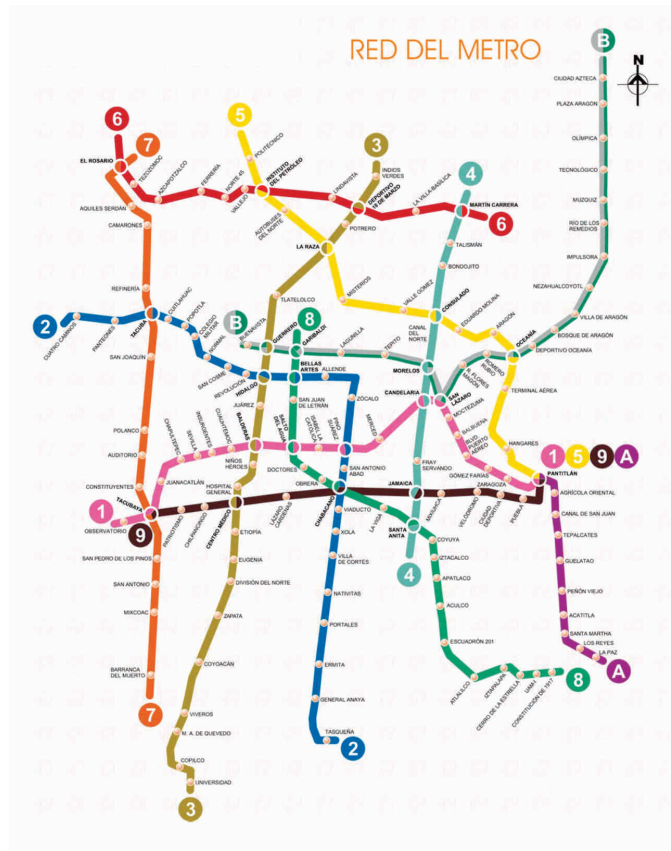

Arquitectura Narrativa, textos imbuidos, encadenados, conectados, con brincos temporales y espaciales, fragmentados, con varias perspectivas. Escribir resultará más sencillo si contamos con un andamiaje por donde transitar para armar nuestras historias. Te proponemos experimentar una estructura gráfica con sus respectivas interconexiones, seguramente querrás comenzar con planos más sencillos que después puedan ampliarse con mayores conexiones.

El Bi-cuadro ortogonal, la vie mode d'emploi de Georges Perec es una novela construida bajo la estructura matemática de un bi-cuadro ortogonal de 10 órdenes. El Atlas de literatura Potencial ${ }^{815}$ sugiere hacer el siguiente ejercicio con cuadro similar de 3 órdenes. La propuesta resulta válida por lo que facilita hacer las modificaciones pertinentes para generar nuevas propuestas narrativas a partir de la interrelación de los elementos. Supongamos una historia de tres capítulos en la cual se incluyen tres personajes; P1, P2 y P3. A cada uno le daremos dos series de atributos, por ejemplo, un

\footnotetext{
${ }^{815}$ Citado por: "Exercises Bi-carré latin orthogonal” [blog] http://mosse.blogspot.com/2005/05/exercisesbi-carr-latin-orthogonal.html Consultado: 27/06/2012.
} 
tipo de sombrero: kepís (K), Sombrero de copa (C) y una boina (B) y una cosa que puede tener a la mano: un Perro $(\mathrm{P})$, una maleta $(\mathrm{M})$ y un ramo de flores $(\mathrm{R})$. El ejercicio consiste en elaborar una historia en la que estos personajes tengan los seis elementos, pero jamás tendrán el mismo par de objetos de manera simultánea. Esto sólo es un parámetro que deberán sustituir por otros elementos para componer sus propias historias. Realmente puede ser un buen resorte narrativo por experimentar.

\begin{tabular}{|c|c|c|c|c|}
\hline & $\begin{array}{c}\text { Personaje } \\
1 \\
\end{array}$ & $\begin{array}{c}\text { Personaje } \\
2 \\
\end{array}$ & $\begin{array}{c}\text { Personaje } \\
\mathbf{3} \\
\end{array}$ & 2 grupos de objetos: \\
\hline $\begin{array}{l}\text { Primer } \\
\text { Capítulo }\end{array}$ & $\mathrm{KM}$ & BR & $\mathrm{CP}$ & $\begin{array}{l}\text { Kepís (K) } \\
\text { Boina (B) }\end{array}$ \\
\hline $\begin{array}{l}\text { Segundo } \\
\text { Capítulo }\end{array}$ & BP & $\mathrm{CM}$ & $\mathrm{KR}$ & Sombrero de Copa (C) \\
\hline $\begin{array}{l}\text { Tercer } \\
\text { Capítulo }\end{array}$ & CR & $\mathrm{KP}$ & $\mathrm{BM}$ & $\begin{array}{l}\text { Maleta (M) } \\
\text { Ramo de Flores (R) }\end{array}$ \\
\hline
\end{tabular}

En el primer capítulo el P1 tendrá un kepís y una maleta, P2 una boina y un ramo y P3 un sombrero de copa y un perro; en el segundo P1 tendrá una boina y un perro, P2 un sombrero de copa y una maleta y P3 tendrá un kepí y un ramo; y en el tercer capítulo P1 tendrá un sombrero de copa y un ramo, P2 un kepís y un perro y P3 una boina y una maleta.

Después de este diagrama, busca la manera de inventar las historias justificando las sucesivas transformaciones y la relación entre sí.

Conflictos también en los juegos, son básicos para generar cierta tensión dentro de las historias y los juegos. Los conflictos se pueden dar a diferentes niveles y tener diferentes expresiones. Podemos considerar conflictos del hombre frente a sí mismo, o frente a la humanidad, o a otro hombre, a la naturaleza, al destino, a la tecnología y las máquinas, a los sistemas. Plantea los conflictos que pueden generarse en cada uno de estos niveles, seguro serán un detonante para desarrollar en una historia.

Lo que se pone en juego, en un juego o en una historia se ponen en juego la dualidad de fuerzas antagónicas como la vida y la muerte, la riqueza y la pobreza, el amor o el desamor, la felicidad y la tristeza, el triunfo y la derrota, la seguridad y la inestabilidad. Plantea un ejerció de reacción en cadena en el cual un acontecimiento conlleva a otro (elige acontecimientos que sean "desdichados" o "favorables") Flint Dille y John Zuur Platten, sugieren el siguiente ejercicio: "Escribe una secuencia de eventos en los cuales se escale el nivel de emoción: vas conduciendo y estás tratando de beber un café muy caliente, el auto y al pisar un tope derramas el café en tu camisa limpia y te 
quemas, la distracción hace que golpees al coche de adelante que se ha detenido. Volteas $y$ descubres que el conductor viene hacia ti con un bate en la mano... "816 Lo que sigue te corresponde a ti resolver en el sentido que decidas.

Sin reglas no hay juego, piensa en un juego que no tenga reglas y describe como sería la mecánica del juego. ¿Más fácil o difícil? Verás que será imposible jugarlo. Una de la función más importante de la narrativa es ayudar al jugador a entender las reglas del juego y a establecer las expectativas que debe llevar a cabo al jugar. ¿Cómo conseguirá ganar? ¿Qué acciones puede llevar a cabo? ¿Qué efectos pueden tener esas acciones? ¿Qué los puede llegar al éxito? Te sugerimos planear la mecánica del juego y determinar las reglas. Confirma que están completas y son acordes a resolver las situaciones que enfrentarán los jugadores.

Crucigramas de relatos, qué tal formular una historias a partir de una estructura gráfica tipo crucigrama. Este ejercicio está inspirado en El castillo de los destinos cruzados de Italo Calvino $^{817}$, quien elabora la novela a partir de la interconexión de las cartas de la baraja del Tarot. Te proponemos hacer lo mismo usando una serie de tarjetas de "La Lotería" o puedes elaborarlas con textos y recortes de imágenes. Organiza un entramado de tarjetas que puedes ir conectando entre sí e improvisando un fragmente de historia con cada una.

Un comic como resorte narrativo para elaborar una historia. Esta idea la aporta Italo Calvino en la nota preliminar de El Castillo de los destinos cruzados, te proponemos hacer algo similar.

"Algunas personas salvadas de una misteriosa catástrofe se refugian en un motel semidestruido, donde sólo ha quedado una hoja de periódico chamuscado: la página de los tebeos. Los sobrevivientes, que han perdido el habla por el miedo, cuentan sus historias con ayuda de las viñetas, pero no siguiendo el orden de cada tira, sino pasando de una a otra en columnas verticales o en diagonal" ${ }^{818}$

Recursos Digitales, te proponemos hacer una historia gráfica a partir de imágenes o fotografías raras que puedas acompañar de una historia con varios pasajes. Quizá quieras remontarte a los orígenes del cine para apreciar el manejo y desarrollo de las percepciones visuales y algunos recursos que empleaban entonces y contrástalos con los que podemos utilizar hoy en día (Interactivos, historias gráficas, elige tu aventura, y otros). Puedes plantear una visión contemporánea del cine mudo.

\footnotetext{
${ }^{816}$ DILLE, Flint, \& ZUUR PLATTEN, John, The ultimate guide to video game writing and design, Skip Press, New York, 2007. (p. 29)

${ }^{817}$ CALVINO, Italo, El castillo de los destinos cruzados, Ediciones Siruela, Madrid, 2010.

${ }^{818}$ CALVINO, Italo, Op. Cit (p.15)
} 
Historias auditivas, Al crear una historia para un videojuego, tenemos dos medios para relatarla: por un lado está el video que compuesto por los gráficos, el texto y la interface gráfica y por el otro, el audio que se compone de las voces, los efectos de sonido y la música. En este ejercicio te sugerimos enfocar la atención en el audio y en los elementos auditivos que tu historia requiere, por lo que te sugerimos delimitar: La voz en escena: los diálogos que dirán tus personajes. Las voces fuera de escena: las palabras, frases y diálogos que escucharás aunque no se vean los personajes. Y las voces superpuestas, es decir la voz del personaje que se le escucha fuera de cámaras, como si estuviera comentando algo más y le diera mayor información y credibilidad al relato con una explicación extra. Te proponemos elaborar el guion auditivo también con los efectos especiales, enlistando aquellos sonidos (chirriar de puertas, engranajes, gotas de agua o cualquier otro que requiera tu historia) y delimites los momentos de tensión para que selecciones fragmentos musicales acordes al desarrollo de la historia.

Creando la ambientación. Descripción de Oblivion $^{819}$, ubicado en la provincia de Cyrodiil, situado al suroeste de Morrowind. La región posee un clima muy variado, desde vastos bosques de coniferas repletos de flora y fauna, hasta zonas nevadas y frías, pasando por cordilleras, desiertos y zonas pantanosas. En estas zonas hay multitud de cuevas, ruinas, asentamientos y tierras cultivadas que dan vida a todo el territorio. En una dimensión paralela a la región real, con una geografía completamente distinta: se observa un macizo rocoso sobre una base volcánica habitada por enemigos y flora característica. La ciudad Imperial es la capital de la región de Cyrodiil, situada en una isla bastante grande situada en el lago Rumare, ésta ciudad posee enormes murallas y se encuentra dividida en nueve distritos. La ciudad de Anvil es un puerto muy importante a donde llegan los navegantes de tierras lejanas... continúa la descripción a partir de este lugar, echa a andar tu imaginación.

Historias convertidas en tablero de juego, Rawdon Wilson refiere el tablero de juego que elaboró a partir de la novela El puente de Juan Luis Rey, de Thornton Wilder. Pasar una historia de un medio a otro es un buen ejercicio. Este tablero puede hacerse como una escenografía con diferentes caminos por donde transitar. Se puede hacer un doble ejercicio: determinar una historia y componer su tablero e instructivo de juego o partir de un juego de tablero y crear una historia.

Muchas perspectivas: Historias ramificadas a partir de historias conectadas. El puente de Juan Luis rey trata la vida de varios personajes que coinciden cruzando un

\footnotetext{
${ }^{819}$ Referencia al juego The Elder scrolls IV: Oblivion, Bethesda Games studis, Diseñador: Ken Roston, 2007. [Sitio de Internet] en: http://www.elderscrolls.com/oblivion/ Consultado: 27/06/2012.
} 
puente colgante en el momento que se cae. Podemos retomar la idea y hacer una historia con otros accidentes similares y plantear una historia en la que se enlacen esos accidentes, tal como en la novela las vidas de los personajes estaban conectados de alguna manera. Un buen ejercicio es plantear las múltiples perspectivas para manejar y conectar los temas, cualquier tema o acontecimiento puede servir de similar con diferentes perspectivas y muchas conexiones, al propio estilo de hipervínculos textuales.

Diagramas interactivos Navegables: los usuarios pueden hacer sus propios caminos a través de la historia y los entornos virtuales. Te proponemos seguir el siguiente diagrama el cual te ayudará a escribir un hipertexto, usa tu ingenio para modificar este esquema y proponer la temática y su contenido a tu antojo:

1. ¿Quieres conocer la leyenda del baúl mágico?
a. Si, ve a 4 .
b. No, ve $2 a$

2. ¿Quieres escuchar la historia de la niña que cantaba dormida?
a. $\mathrm{Si}$, ve a 16
b. No, ve a 3

3. ¿Prefieres escuchar la aventura del mejor cuenta cuentos del mundo?
a. Sí, ve a 17.

b. No, ve a 21

4. Erase una vez un carpintero que encontró un árbol que resplandecía en el bosque. Todos los días al terminar su trabajo caminaba a casa y con cierta frecuencia, sobre todo cuando el cielo estaba más oscuro, era posible apreciar los destellos de aquel majestuoso árbol. Un día....

a. Si deseas escuchar una idea diferente ve a 9.

b. Si ésta idea te gusta ve a 5 .

5. El carpintero se lo platicó a su mujer. Y ella recordó una antigua leyenda de un bosque encantado que...

a. Si prefieres que se lo platique a su vecino ve a 6 .

b. Si prefieres que lo sepa su mujer ve a 7.

6. Su vecino que era un hombre ambicioso, corrió esa misma noche al bosque a buscar el árbol destellante.

7. La mujer y el carpintero regresaron al bosque esa misma noche con la intención de

a. Si quiere escuchar otra propuesta ve a 8.

b. Si quieres escuchar esta misma ve a 10.

8. El árbol brillaba con mayor intensidad esa noche en particular y...

a. Si prefieres terminar en otra idea ve a 7.

b. Si esta idea te gusta ve a 10.

9. Hace muchos años había un bosque encantado, nadie lo había visitado, perro los ancestros platicaban de él.

a. Si deseas saber lo que sigue, ve a 11.

b. Si deseas quedarte con esta idea ve a 10.

10. El lugar estaba habitado por seres que hablaban en colores, soñaban olores y y veían sonidos.

a. Si quieres saber lo que soñaban, veían y escuchaban, por favor imagínalo y cuéntalo. Luego ve a 11. 
b. Si no tiene interés en saberlo ve a 12.

11. Uno de los seres más creativo del bosque era... Tenía la cualidad de... y de ser... por lo que era muy querido y respetado por todos.

a. Si quieres saber que aventura vivió ve a 13.

12. Uno de los grandes peligros para llegar a este lugar era un caudaloso río que...

a. Si tienes deseos de saber más sobre el rio ve a 15.

b. Si prefieres ir directo a la montaña de sal, ve a 13.

13. La montaña de sal era un lugar sagrado, personas de los lugares más recónditos de la tierra, llegaban a este lugar para...

a. Si quieres averiguar quien vivía en esta montaña ve a 14.

b. Si quieres saber qué poderes mágicos tenía este extraño personaje, ve a 14.

14. La montaña tenía la forma de un gran laberinto. Muchos lograban encontrar el acceso a... y muchos otros no lograban salir a causa de...

a. Si quieres sabe más del laberinto ve a 15.

b. Si necesitas ayudar a alguien a salir de él, también ve a 15 .

15. El laberinto tenía una regla especial para circular, un especie de código que permitía avanzar: 3D-2I-1F (tres vértices derechos, 2 izquierdos, uno frente) hasta llegar al final y de regreso.

a. Si deseas averiguar algo más ve a 16.

b. Si no quieres saber más ve a 21.

16. El laberinto...

a. Si la idea te gusta ve a 18.

b. Si no te gusta, ve a 21 .

17. Un hombre que vivió acomodando los libros de una vetusta biblioteca y un día decidió emprender un viaje por el mundo con el fin de...

a. Si te gusta este inicio de la historia ve a 19.

b. Si no te gusta ve a 21 .

18. El mismo día que emprendió su viaje se encontró con... quien le regaló un... el cual le confió el siguiente secreto

a. Si deseas escuchar lo que sigue ve a 20.

b. Si no quieres saber el secreto ve a 21 .

19. El secreto le permitiría hacer su viaje de manera más placentera y segura.

a. Si quieres saber el desenlace, ve a 22

b. Si no quieres saber que pasó, ve a 21 .

20. Esta historia necesita que le escribas el final y la termines. Esta historia no tiene final porque ...

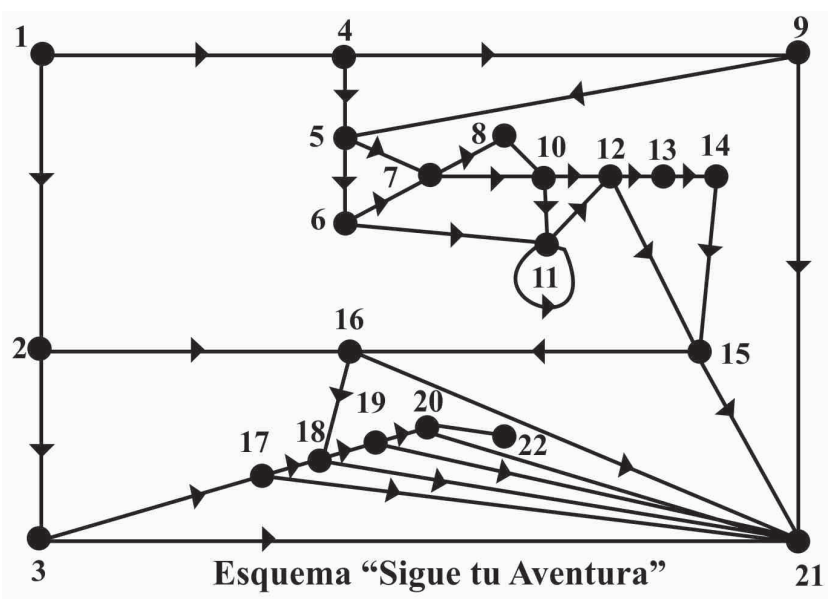




\subsection{EDITAR}

\subsubsection{Historias En Formatos Analogicos}

Dobla papeles, escribe una historia aprovechando los dobleces de una figura de origami. Al desdoblarla irá apareciendo un fragmento de una historia.

Usando un formato de acertijo (Puzzle), crear un juego basado en mosaicos, pueden usar tarjetas que describan los procesos de exploración que deben llevar a cabo los jugadores. Organizar las tarjetas de tal manera que sólo organizadas de una forma en particular pueda completarse satisfactoriamente el juego. Te proponemos organizar todos los elementos del juego en dos tipos diferentes de acertijos en una hoja (sudokus, crucigramas, gato). "Good puzles contribute to plot, carácter and story development. Good puzles draw the player into the fictional world. Good puzles can make a game great ${ }^{820}$

Escribe un códice. "Hay en el mundo libros raros y llenos de misterios, escritos en tiempos remotos que ya nadie sabe leer; o apenas pueden ser descifrados por los especialistas... Este es el caso de los códices del México Prehispánico como La tira de la peregrinación, o Códice Boturini, un mensaje cifrado en caracteres muy distintos a los que usamos hoy día"821. Recomendamos ver el documental Tlacuilo ${ }^{822}$. Los Tlacuilos eran quienes escribían los códices conocidos como "pintores de palabras", para apreciar cómo se lee un códice y como puede inspirar a la creación de proyectos digitales.

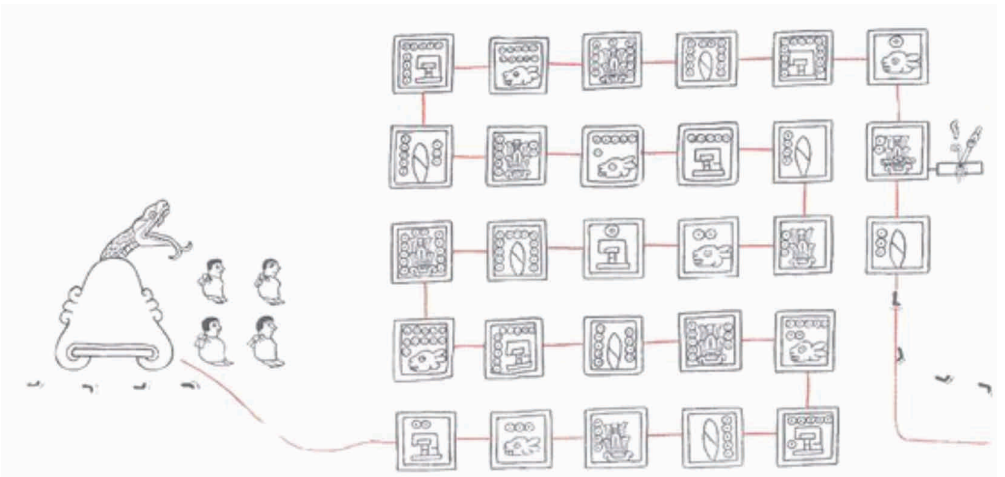

Tira de la Peregrinación, la línea señala el orden de la lectura.

\footnotetext{
${ }^{820}$ BATES, Bob, Designing the puzle, GDC, 1997, [Artículo online] en: http://www.scottkim.com/thinkinggames/GDC00/bates.html consultado: 03/07/2012

${ }^{821}$ GALARZA, Joaquín y LIBURA, Krystiyna M., Para leer La tira de la peregrinación, Tecolote, México,D.F., 2002.

${ }^{822}$ Tlacuilo, [Documental online] http://www.youtube.com/watch?v=GuN9flsR-Og Consultado: 29/06/2012. Puede consultarse estudio de Pamela Díaz Loubet en: http://es.scribd.com/doc/41380410/Resumen-Tlacuilo Consultado: 29/06/2012.
} 
Mandalas, Rayuela y Tachtli, con estas tres propuestas gráficas, te proponemos generar una historia en tres partes, usando cada uno como fuente creativa para inventarla; investiga los juegos y sus reglas puedes incluso ceñirte a estas para generar la historia.

Breves ideas no-digitales, Te proponemos experimentar estas ideas que sugieren Brenda Brathwaite e Ian Schreiber ${ }^{823}$ :

a. Crea un juego basado en tarjetas sobre la exploración de un famoso explorador.

b. Toma una novela o cuento de dominio púbico y crea un juego de tablero que se acerque lo más posible a la estructura narrativa de la historia.

c. Inventa un juego de carta que enseñe el arte de contar historias (y no sólo el rehacerlas, como en el caso de Once Upon a time de Knizia)

d. Crea un juego en cualquier medio acerca de un narrador desanimado que se convierte en un gran escritor.

e. Piensa en alguien que conoces personalmente y te inspira. Crea un juego que refleje esa inspiración.

f. Diseña un juego de tablero en donde cada jugador sea un superhéroe y el objetivo sea desarrollar el "viaje" del héroe. Considera qué poderes tiene cada uno y debilidades, ¿Se ayudan o se molestan durante su viaje? ¿A dónde deben llegar? ...

g. A un juego de estrategia añade una historia. Sin modificar las reglas, juega y observa cómo se transforma el juego cuando hay una sucesión de acontecimientos relatados.

Elementos no narrativos, te proponemos hacer una historia y convertirla al formato de una carta oficial, un instructivo de viaje o vida, un interrogatorio, o un reporte.

Libros que no lo parecen, libros en caja, libros objeto, libros como piezas creativas, te proponemos hacer una historia al estilo de las Flux Boxes ${ }^{824}$.

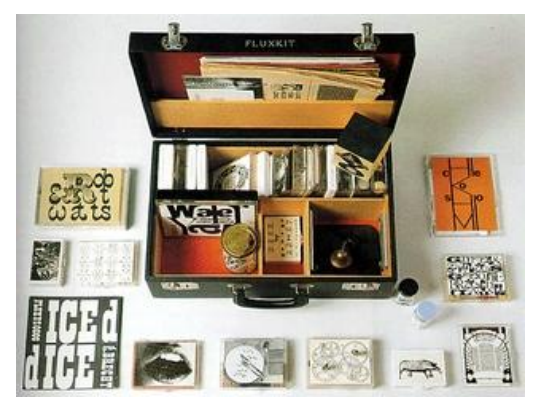

George Maciunas, Fluxkit

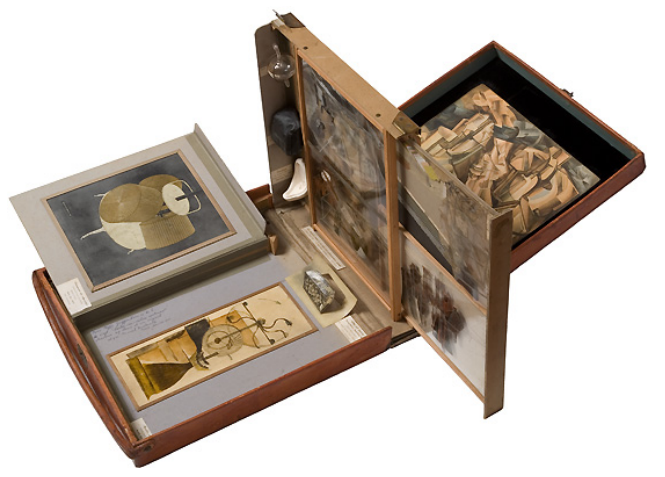

Marcel Duchamp, Boîte-en-Valise

\footnotetext{
${ }^{823}$ BRATHWAITE, Brenda \& SCHREIBER, lan, Challenges for game designers, Course Technology, Boston, 2009. (p.188)

824 Para conocer algunos otros proyectos de libros experimentales artísticos véase: [sitio de internet] http://www.visual-editions.com/ Consultado: 28/06/2012.
} 


\subsubsection{Proyectos Digitales}

Una de las fortalezas de los videojuegos es ofrecer el poder de la inmersión en otras realidades, otros mundos en situaciones convincentes que atrapan la atención y se vuelven incluso, adictivas.

Storyboard, crea un conjunto de ilustraciones que organiza secuencialmente la narración de los hechos de tu juego-historia. Esto te permite pre visualizar las escenas y secuencias y hacer las anotaciones pertinentes para cada una en escenas bien descritas que después puedas completar los detalles. Enlista los obstáculos principales que el jugador en el papel del héroe debe sobrellevar para ganar el juego.

Secuenciación de fotografías, contar historias a partir de secuencias de fotografías al estilo de Duane Michals, una sucesión de fotografías que conforma una historia. También agregó dibujos y textos a sus imágenes para ampliar su contenido y sentido.

Elige tu aventura hipertextual, genera historias al mismo estilo de los libros infantiles "Choose your own adventure ${ }^{825 " ~(C Y O A) ~ q u e ~ g r a c i a s ~ a ~ l a ~ i n t e r a c c i o ́ n ~ d e l ~}$ lector la historia puede tomar diversos rumbos y finales. En Iberoamérica se conocen como "Tú decides la aventura". Las posibilidades son múltiples, algunas son sensatas otras temerarias y otras realmente fascinantes, cada lectura es una posibilidad diferente, no hay opciones erróneas sino diferentes. Puedes ayudarte de un esquema gráfico para diseñar tu aventura ${ }^{826}$.

Juego basados en historias, te retamos a hacer un diseño sencillo de un juego que tenga una historia coherente y atractiva y que luego utiliza un software editor de juegos. Sigue estos pasos:

a. Esboza la trama de una historia, decide lo que el jugador hará, qué lugares visitará y cómo terminará el juego.

b. Diseña un mapa o un esquema con la serie de espacios que recorrerá con el fin de visualizar el espacio y asegurar que los componentes interactúen de manera correcta.

c. Enlista en cada espacio, los objetos que contiene, primero señala los elementos principales como objetos mágicos, llaves, armas o cualquier otro que ayude a resolver los acertijos del juego. Luego agrega los otros elementos visuales que dan información pero que no aportan utilidad a la trama.

\footnotetext{
${ }^{825}$ Véase: http://www.cyoa.com/ Consultado: 28/06/2012

${ }^{826}$ Véase: http://samizdat.cc/cyoa Consultado: 28/06/2012
} 
d. Puedes descargar un software que genere juegos basados en textos o historias como Inform $^{827}$. Sigue las indicaciones con tu propuesta.

Interactividad y juego de roles, las historias no sólo deben ser una secuencia de acciones, deben contener cierta complejidad que permita conectar a sus usuarios a través de la evocación de sentimientos y reacciones emotivas, las dificultades a las que se enfrentan los personajes deben compartirse por los jugadores.

Relatos sonoros, Crea una exhibición para un museo para niños en donde exploren la sonoridad de las palabras. Juegos cacofónicos, ritmos diversos, canciones, trabalenguas, poesías fonovisivas, fusiones onomatopéyicas y otras que se pueden revisar el apartado "Las vanguardias, el juego desbordado" 828.

Historias conectadas, diseña el número total de historias que se pueden conectar entre sí, escribir cada suceso de manera independiente en una tarjeta. Escribir todos los sucesos posibles, barajarlos y acomodarlos de cierto modo que pueda generar una historia, si es posible, entonces será necesario descomponerla en más componentes modulares. Las historias deben contener cierta flexibilidad de articulación, pedazos de historia que se interconecte con otros en diferentes direcciones.

Confunde realidad y ficción, Elabora un texto de cosas increíbles pero dale un fuerte grado de verosimilitud. Que parezca que todo tiene una explicación lógica ante algo que no lo es.

Incluye recompensas y premios. Historias que involucran al lector y le ofrecen castigos y premios si no logra descifrar y resolver los enigmas que se plantean, diseña un texto que pueda ir brincando de un apartado a otro, según va avanzando o retrocediendo y al final, pueda determinar si tuvo más aciertos que errores, por el lugar a donde llega finalmente.

Para contarse de mil maneras, considera una enorme cantidad de medios diferentes para contar una historia. Si partimos del listado de elementos que requieren ser escritos, podemos obtener una infinidad de propuestas que pueden utilizarse como formatos para relatar historias, unos son más accesibles que otros, pero al final, todos pueden contar a su modo, una historia. Primero enlista "Todo lo que debe escribirse" como: diarios, recetas, telegramas, canciones, tarjetas de felicitación, cartas comerciales y formales, listado de compras, libros de instructivos, y mucho más. Luego trata de contar una historia siguiendo ese modo.

Relatos multi-sensoriales, historias para débiles visuales, con alto grado de sonoridad y manejo de referencias olfativas, gustativas y de tacto. ¿Cómo contar una

\footnotetext{
${ }^{827}$ Véase: Inform: http://inform7.com/ consultado: 29/06/2012.

${ }^{828}$ Véase aquí mismo pág. 54 de este mismo trabajo
} 
historia detallando sus cualidades físicas y visuales a alguien que no puede ver? Ejercita tu ingenio. El ejercicio del programa de radio te puede ayudar.

Una cadena de acertijos, para Andrew Rollins y Dave Morris ${ }^{829}$, los juegos pueden definirse como una serie de acertijos conectados. Planea los tipos de acertijos que puedes ligar, considera que se trata de problemas específicos que el jugador debe resolver. Una vez que determines los problemas, revístelos con los elementos propios de los géneros, la temática y los espacios y personajes diseñados. Piensa en recoger algo a cambio de puntos ganar territorios haciendo algún tipo de conquista, participar en alguna competencia, eliminar obstáculos o derrotar enemigos, explorar y descubrir cómo resolver problemas. Son solo algunas ideas para generar los acertijos y pensar en sus estrategias de solución. Bob Bates da la siguiente recomendación al diseñar acertijos o puzzles: "make sure your puzzles enhance the game, rather than detract from it. Use puzzles to draw the player into your story and learn more about your characters. Develop player empathy and strive for that perfect level of frustration that drives a player forward instead of turning him away. And above all - Play Fair!" 830

${ }^{829}$ ROLLINS, Andrew y MORRIS, Dave, Game architecture and design, New Riders, Berkeley, 2004. ${ }_{830}^{(p .37)}$

${ }_{830}^{8}$ BATES, Bob, "Designing the puzle", GDC, 1997, [Artículo online] en:

http://www.scottkim.com/thinkinggames/GDC00/bates.html consultado: 03/07/2012 


\subsection{PRODUCTO FINAL: EVALUAR}

Al considerar el videojuego como una sinfonía de elementos lúdicos y narrativos, la complejidad que demanda tanto en el plano estético, técnico, lúdico y narrativo lo hacen que sea un medio realmente atractivo y con grandes posibilidades de creación para cualquier artista plástico y literario. Proponemos como práctica analizar los siguientes juegos:

1. The Elder Scrolls IV: Oblivion

2. Shadow of the Colossus

3. Bioshock

Analiza, justifica y evalúa, con una visión crítica y objetiva, los elementos que integran cada uno a partir de las consideraciones conceptuales siguientes: curiosidad, suspenso, placer estético, autosatisfacción e inmersión a partir de los sistemas interactivos.

\section{ANALIZAR}

- ¿Cuál es género empleado por el juego?

- ¿Conoces otro juego parecido?

- ¿Qué te inspira de este juego?

- ¿Te parece una propuesta original y porqué?

- ¿Cuál es el objetivo (s) del juego?

- ¿Qué incita al juego y a la búsqueda?

\section{JUSTIFICAR}

- ¿Cuál es la aportación del juego?

- ¿Resulta un tema y tratamiento original?

- ¿Qué elementos atractivos posee?

- ¿Contiene retos y enigmas interesantes?

- ¿Posee una historia que quieran descubrir y jugar?

- ¿Cómo podrías mejorar la historia?

EVALUAR

- ¿Es divertido?

- ¿Conduce un buen gameplay?

- Contiene elementos significativos.

- Encuentras una historia coherente.

- ¿Te parece creativa la manera cómo surge la historia?

- ¿Qué le hace falta al juego? 
Hacer análisis conducidos a juegos, es la mejor manera de saber cómo componer historias atractivas para ser utilizadas en proyectos multimedia.

¿Qué buscan los editores? un principio de historia impactante, que despierte algún interés y un final que aluda a una historia profunda que resuene en nuestro recuerdo. Identificar una imagen visual dominante. Que encontremos un narrador adecuado. Que las historias se dirijan a los sentidos del lector, tengan sabor y contexto. Qué el marco en el que se desarrolla la historia sea interesante. Que puedas añadir "texturas" a tus textos con ecos (frases que se repiten en distintos puntos de la historia), alusiones, retrospecciones, símbolos, mitos, metáforas y otros recursos textuales como letras de canciones, cartas, anuncios, etc., La historia contiene cierta estructura: plantea una situación, la complica y se resuelve.

Revisión de la realidad, toma una secuencia de tu juego favorito y enlista todos los elementos que descubren se utilizaron para crearlo. Considera los personajes y todas las criaturas que aparecen, los entornos y espacios, niveles y mundos que plantean, las animaciones, texturas e incluso las condiciones climáticas, los sonidos y música, y cualquier otro detalle o efecto especial. Por un lado apreciarás todo el trabajo involucrado y quizá propongas una nueva manera de crear las secuencias de otro modo.

Creatividad ¿Cómo medirla? Consideramos un texto creativo porque está basado en una diversidad y complejidad de conceptos organizados que constituyen un todo que plantea una secuencia de eventos que resultan significativos. En este apartado reconocimos las labores del diseñador de textos como parte de un proceso que debe plantearse a diferentes niveles y bajo distintas perspectivas de desarrollo. Componer historias es integrar una amalgama de elementos muy diversos, gracias a un esquema, aprenderemos a generar historias que resulten satisfactorias para la audiencia, las historias deben tener cierta credibilidad, dar la ilusión de realidad, al respecto Mark Riedl y Michael Young ${ }^{831}$ sostienen que es importante considerar los siguientes elementos: el espacio es relevante, el lenguaje define claramente las reglas y se convierte en un generador de acontecimientos causales y coherentes, las motivaciones de los personajes, temas y el conocimiento del mundo no sólo son creíbles y complejos, sino interesantes. Margaret Boden ${ }^{832}$ ofrece una clasificación de los sistemas creativos en dos: Creatividad exploratoria y Creatividad transformacional. La primera es el proceso de búsqueda dentro de un área o espacio conceptual gobernado por ciertas reglas. En cambio la creatividad Transformacional es el proceso mediante el cual no sólo se llevan a cabo las reglas sino además se transforman e identifican en un nuevo sub-espacio creativo. Este es el tipo de creación que perseguimos para crear nuestras historias; uno que no persigue la invención de un nuevo género de historias, sino uno que procure la invención de un tipo particular de narrativas que resulten ingeniosas y novedosas para ser contada. Ello desea ser el sustento de este trabajo, encontrar en todo tipo de recursos narrativos y formas

\footnotetext{
${ }^{831}$ RIEDL, Mark O. y YOUNG, Michael R., "Story Planning as exploratory creativity: techniques for expanding the narrative search space", http://liquidnarrative.csc.ncsu.edu/pubs/ngc.pdf Consultado: 12/10/10

${ }^{832}$ BODEN, Margaret A., The creative Mind: myths and mechanisms, Basic books, New York, 1990.
} 
tradicionales, una posibilidad de invención creativa innovadora. Con cierto humor James Warner ${ }^{833}$ plantea el futuro de la literatura, lo transcribimos en anexos, porque no deja de ser ingenioso poder hacer predicciones.

"The real problem is developing ideas, recreating them into whole sprays of new and exciting ideas. Let's plunge into the wild side of the brain where connections and logical thinking aren't as important as the slides and slips of intuitive leaps" ${ }^{\prime 834}$.

"Destruir la literatura, quebrar los hábitos del lector, desadornar las palabras, escribir mal, etcétera, es lo que insistía tanto el Morelli de Rayuela, son metáforas de algo muy simple: la literatura se asfixia por exceso de convencionalismos y de seriedad. Hay que purgarla de retórica y lugares comunes, devolverle novedad, gracia, insolencia, libertad" ${ }^{\prime 835}$.

\footnotetext{
${ }^{833}$ Véase Anexo 4, pág. 276 de este trabajo.

${ }^{834}$ DODD, Nancy Ellen, "Creating ideas for the middle act" [artículo online] en: http://www.thewriterscompass.com Consultado: 28/06/2012.

${ }^{835}$ Prólogo de Mario Vargas Llosa a las obras completas de Julio Cortázar en:

http://redescolar.ilce.edu.mx/redescolar/memorias/entrale_autor/lo_que_se_ha_dicho/cortprologo4.htm Consultado: 01/07/2012.
} 


\section{CONCLUSIONES}

En los últimos 20 años ${ }^{836}$ el videojuego se ha analizado desde múltiples perspectivas y bajo muy diversas temáticas, en este estudio se planteó la revisión del videojuego ligado a la composición literaria. Nuestra línea conductora fue establecer el mayor número de analogías y coincidencias entre las narrativas y los juegos. Componer historias a partir de experiencias que asociamos a juegos, promover la creación literaria a partir de juegos que puedan experimentar los escritores y lectores para armar un nuevo tipo de historias digitales lúdicas.

Nuestra principal tarea fue vincular el lenguaje al juego y a la creación artística con el fin de proponer una metodología de composición narrativa que pueda adaptarse y favorecerse de las propiedades que los entornos digitales ofrecen. Al comienzo de la investigación, intuíamos cierta influencia de las prácticas lúdicas sobre la posibilidad de generar narrativas digitales; ahora entendemos con mayor claridad el papel del juego como motor creativo en la composición de relatos, guiones y todo tipo de narrativas. Sobre todo en aquellos textos que buscan un mayor grado de innovación y originalidad. Este estudio nos permitió entender cómo construir nuevos productos narrativos y detectar cómo utilizar nuevos lenguajes, articular formatos más complejos, que pueden generar productos acordes a las posibilidades técnicas de nuestro tiempo.

En un inicio teníamos una visión borrosa de cómo el lenguaje y el juego incentivaban las labores creativas de artistas, escritores y diseñadores de juegos. Gracias a las conexiones que pudimos establecer a partir estudios críticos de diversos especialistas consultados y analizar piezas literarias, juegos y videojuegos que presentan cualidades dignas de elogio; determinamos que efectivamente el lenguaje y el juego son herramientas fundamentales que los creadores de nuevos medios deben conocer y experimentar si desean incursionar en la composición de textos. Porque el impacto que las nuevas prácticas tecno-artísticas han generado en artistas y jugadores, nos motiva a prestar atención a los recursos disponibles para fortalecer las labores de creación. Para ello buscamos en todo momento, ofrecer un panorama crítico y propositivo que mostrara las cualidades y propiedades tanto de los juegos como de las historias y sugiriera prácticas narrativas jugables, experimentales, innovadoras que favorecen la composición de piezas visuales, discursivas, textuales ya sea para entornos analógicos o digitales.

La intuición previa de conectar el lenguaje con las narrativas y el juego nos permitió entender cómo se interrelacionan a varios niveles y cómo han influenciado la producción artística actual, a través de la literaria, la cinematografía, la música y por supuesto su influencia en el videojuego. Confirmamos que se trata de nuevas prácticas estéticas que privilegian nuestra experiencia contemporánea. Reconocemos al juego como motor de creación y apreciamos las afinidades entre el juego y el arte. Iniciamos una trayectoria de búsqueda de historias en las que el juego fue determinante para modelar el lenguaje. Queríamos demostrar que efectivamente el lenguaje se ha visto favorecido por ejercicios y prácticas lúdicas en un afán de componer narrativas.

\footnotetext{
${ }^{836}$ Para conocer sobre el inicio de los estudios académicos sobre el video juego se recomienda revisar la Introducción de WOLF, Mark J.P. y PERRON Bernard, The Video game Theory Reader, Routledge, 2003. Puede verse su traducción en: http://www.upf.edu/materials/depeca/formats/pdf arti esp/wolf esp .pdf Consultado: 08/12/2012
} 
Este estudio replanteó la importancia de relatar historias y estimular su práctica; una vez que pudimos apreciar la importancia de que las piezas de arte puedan contar con un guion narrativo, o una historia que exista detrás y dé sustento o fortaleza a la creación, al ser una pieza que contenga alguna idea, concepto o estructura narrativa que la enriquezca. Lo cual esperamos sea del interés de los creadores que buscan generar ideas o mejorarlas. Porque estamos convencidos que las historias incentivan la creación original y pueden contribuir para replantear la producción artística, tal como pudimos apreciar al conocer textos basados en fórmulas matemáticas o algoritmos, historias que se observan en edificios o piezas de cerámica. Planteamos la necesidad de que los creadores establezcan el mayor número de conexiones multidisciplinares en el campo artístico y en este caso, literario. Porque requerimos resortes creativos que nos permitan jugar con múltiples posibilidades de interconexión creativa; emplear todo tipo de elementos, recursos, archivos, formatos, etc. Porque estamos convencidos de la importancia de replantear o reciclar modelos previos para construir nuevas formas artísticas. Nuestra propuesta es retomar la literatura, por ser la base de nuestra formación profesional y porque este estudio nos permitió detectar las cualidades creativas que están en espera que los creadores descubran e implementen.

Integramos nuestro trabajo a partir de contrastar cuatro visiones principales: la antropológica, la narratológica, la ludológica y la artística. Desde estas perspectivas conformamos el andamiaje teórico que permitió soportar nuestra propuesta metodológica: generar un proceso sistemático que facilite la construcción de historias. Analizamos los elementos que intervienen y propusimos un camino para emprender labores de composición narrativa que determinamos como "narrativas lúdicas" por estar inspiradas en prácticas asociadas a juegos. Con estas cuatro visiones esperamos conseguir un panorama más completo del fenómeno narrativo ligado a prácticas lúdicas que pueda promover las labores de los diseñadores de relatos que encuentren en la literatura y en el juego tradicional o el videojuego herramientas de creación.

A partir de la perspectiva antropológica pudimos reflexionar sobre el lenguaje, materia esencial de las historias y sobre su relación con el desarrollo de la humanidad, pudimos apreciar su trascendencia e importancia al adecuar nuevos recursos que revaloren el lenguaje como medio de expresión y creación. Relatar sucesos y convertir en historia todo lo que le rodea, es una de las habilidades esenciales del ser humano; lo que deseamos destacar es la búsqueda permanente por hacerlo de manera más original, mostrando su ingenio y proyectando su ingenio. Porque en el origen de los tiempos las historias tenían la convicción de comunicar, informar o educar y posteriormente, el hombre animado por trascender o mostrarse original desarrolló un espíritu creativo y comenzó a componer mejores historias. A lo largo del trabajo pudimos entender sobre el pasado de las historias y nuestro origen vinculado a éstas. Pudimos apreciar cómo están ligadas al desarrollo del pensamiento y de la tecnología. En esencia reconocimos como la capacidad de comunicación determinó el grado de avance socio cultural, pero el hombre desarrolló funciones más complejas, como el poder recordar, preservar la memoria, transmitir sentimientos o saberes y encontró maneras originales para llevarlo a cabo, lo que permitió que el lenguaje, el pensamiento y la capacidad artística y creativa se vincularan en una búsqueda continua de innovación. Innovación que estuvo determinada por ciertas prácticas experimentales que asociamos con el juego, por lo que resultaron fundamentales.

Nos resultó muy interesante apreciar que cuando los primeros hombres tuvieron la conciencia de sepultar a sus muertos surgió el deseo de preservar su memoria y relatar sus historias utilizando medios que le ayudaran a expresarse con un fin estético. El lenguaje debe ser revalorado no sólo por la importancia y trascendencia que representa sino por el potencial 
creativo que permite. Reconocemos que debe ser un recurso que los artistas contemporáneos deben experimentar a la par del manejo de colores, líneas, o los medios electrónicos.

En un segundo momento de la investigación emprendimos la tarea de identificar piezas literarias que habían sido creadas con matices lúdicos, es decir utilizando fórmulas semejantes a juegos de palabras, ingeniosos modelos armables, o piezas estructuradas con la ayuda de tableros o juegos de cartas. Identificarlas más allá de enlistarlas buscaba determinar aquellas cualidades que pueden emigrar a un tipo de narratología lúdica que incluso puede generarse en entornos digitales. Finalmente, la cuarta visión de este estudio buscaba analizar y reflexionar sobre asuntos estéticos y artísticos como base teórica y conceptual que facilitara la capacidad inventiva y artística de nuestros jóvenes estudiantes interesados en componer textos, mediante prácticas que podemos asociar a juegos literarios. En ésta búsqueda de fenómenos innovadores, retomamos ciertas prácticas vanguardistas del siglo $\mathrm{XX}$, incluso nos remontamos a formas iconográficas clásicas que dieron origen a una literatura visual y auditiva mucho antes del surgimiento de los sistemas digitales, las instalaciones multimedia o el arte del software multimedia. Textos visuales o sonoros impresos en papel, experimentaciones que muestran líneas de desarrollo en espera de ser retomadas por nuevas generaciones de artistas.

Porque con este estudio esperamos armar mejores historias a costa no sólo de utilizar recursos tecnológicos más sofisticados; sino aprovechar ciertos recursos como la participación colectiva de las redes sociales, incluir prácticas interactivas o reformular versiones multimedia, que tengan presente la construcción de discursos visuales: textos que sean apreciados como imágenes e imágenes valoradas como textos. Utilizar recursos que enriquezcan la estructura y la significación de las piezas, incentivando la elaboración de textos sensorial e intelectualmente más elaborados, cuyas cualidades interactivas, enciclopédicas o hipertextuales sean utilizadas de manera óptima.

Deseamos favorecer la ejercitación y práctica conducida de los interesados en componer narrativas, pero enfatizando las siguientes ideas: el valor del lenguaje y el poder de la significación que una pieza puede adoptar para complementarla y enriquecerla, mediante estructuras de cierta complejidad semántica, es decir que poseen más de un sentido. Trabajar los formatos, estructuras o arquitecturas narrativas para experimentar diversas formas, ya sean no lineales o adaptaciones estructurales basadas en juegos y videojuegos, de forma que estos formatos amplíen y complementen el contenido y no solo su complejidad estructural.

Con este trabajo pudimos apreciar no sólo la predisposición que las personas poseen para relatar historias, sino la diversidad temática y complejidad estructural que desde siempre han buscado los escritores con el afán de innovación. En un intento de reconocer las propiedades de la narrativa en nuevos medios, fue preciso echar un vistazo al pasado, retomar la tradición literaria y desde ahí, replantear nuevas posibilidades de creación. El resultado analizado fue amplio y variado: piezas y productos narrativos con nuevos lenguajes, tratamientos originales, estructuras complejas y diversidad de formatos. Esto lo apreciamos al conocer textos de la tradición clásica o de distintos momentos culturales como durante las vanguardias del siglo XX y el trabajo de colectivos tecno-artísticos como el colectivo Oulipo y pudimos apreciarlo con mayor detalle a través de ciertas obras literarias ligadas a experiencias lúdica: novelas inspiradas en juegos de cartas, acertijos y formatos de tableros o juegos como son el caso de Rayuela de Julio Cortazar, Juego de Cartas de Max Aub, La vida, Instrucciones de Uso de Georges Perec o El castillo de los destinos cruzados de Italo Calvino. En estas obras apreciamos cualidades narrativas como la ruptura de sus formas o del orden secuencial, la necesidad de la evolución permanente y de la búsqueda de nuevas maneras de narrar y crear. Y si contemplamos los nuevos instrumentos de 
creación, divulgación y reproducción técnica que tenemos disponibles actualmente, nos resulta imperativo comenzar a orientar nuestra atención a la creación de estos nuevos canales de producción.

Este estudio buscar ser un estímulo para incrementar las habilidades narrativas de las nuevas generaciones, que encuentren en el lenguaje y su manipulación lúdica, una herramienta de creación que pueda verse materializada en diversos proyectos. Que construyan historias con mejores estructuras narrativas, con mayor ingenio creativo y lúdico que sean acordes a una nueva era de creación. Esperamos que este trabajo pueda ser una guía que oriente la producción artística en nuevos medios, que estimule conocer el pasado para experimentar el futuro. Por ello nos resultó tan útil y estimulante conocer algunos modelos literarios, juegos de palabras, lenguajes inventados, formatos gráficos y visuales o fórmulas matemáticas o recetas lúdicas para componer historias.

Esperamos despertar el interés de adaptar la tradición de antaño a nuevos formatos, pantallas y sistemas digitales, pero sin perder una cualidad importante, que denoten cierto grado de complejidad narrativa o estructural. Para ello vinculamos cualidades, formas y estructuras propias de los videojuegos para aprovechar esas cualidades, que han formado un nuevo tipo de "lectores-jugadores" de historias. Estamos convencidos que las historias puedan adoptar esas cualidades que vuelven a los juegos tan atractivos, lo que implica mejorar las estructuras narrativas, y generar juegos con mejores guiones e historias. Porque con la era digital, la conjunción de las como medio para narrar historias, abre la posibilidad de generar estructuras multidimensionales, granulares o modulares que además de ser permutables, ofrecen un potencial de creación por explorar: la búsqueda y experimentación de nuevos formatos que persigan la innovación permanente para componer nuevas historias de mayor complejidad y contenidos más interesantes.

Este trabajo nos confirma que tenemos la predisposición a armar todo en forma de una historia y que cualquier objeto puede ser un detonante para armarlas, tal sería el caso de generar un relato a partir de una imagen plasmada en una vasija, un tapiz o un cuadro. En este intento de ofrecer recursos para escritores, debemos considerar el mayor número de elementos disponibles: ligar la sonoridad de las palabras, la riqueza de las imágenes como elementos que colaboren a crear mejores historias, utilizar el diseño de estructuras visuales, partir de celdas interconectadas a través de reglas predefinidas, como fue el intento de Lewis Carroll en A través del Espejo ${ }^{837}$ quien relata su historia siguiendo los movimientos propios de un juego de ajedrez. Este estudio nos invita a construir historias que surjan de trayectorias y estrategias de algunos juegos.

De manera particular uno de los proyectos que nos gustará retomar es el trabajo inconcluso de Italo Calvino, El Motel de los destinos cruzados, el cual sigue una dinámica similar a la de El Castillo de los Destinos cruzados ${ }^{838}$ revisado en el apartado Narrans et Ludens. Esta obra es una especie de crucigrama textual a partir de las relaciones que generan al acomodar de manera aleatoria cartas del Tarot. Dicho texto plantea una manera de crear una estructura que permita interconectar los elementos dentro de una historia y con ello generar un marco narrativo. Consideramos que es un formato que particularmente nos interesa para generar narrativas complejas en entornos digitales. Podemos apreciar en el prólogo de dicha novela, el argumento que pensaba desarrollar y jamás llevó a cabo, pero que habría iniciado así:

\footnotetext{
${ }^{837}$ Carroll, Lewis. A través del Espejo, Alianza, Madrid, 2001.

${ }^{838}$ Op. Cit.
} 
Algunas personas salvadas de una misteriosa catástrofe se refugian en un motel Semidestruido, donde sólo ha quedado una hoja de periódico chamuscada: la página de los tebeos. Los sobrevivientes que han perdido el habla por el miedo, cuentan sus historias con ayuda de las viñetas, pero no siguiendo el orden de cada tira, sino pasando de una a otra en columnas verticales o en diagonal ${ }^{839}$.

Esta propuesta fue lanzada por Calvino en 1973, quien no pudo realizarla en parte porque los ordenadores aún no estaban disponibles. Si hubiera tenido un equipo informático, hubiera sido posible componer este texto de tal complejidad estructural y con múltiples niveles de conexión simultánea, conformado por una estructura con innumerables rutas posibles de recorrido, algunas con ciertas multisecuencialidades temporales; otros relatos a diferentes niveles de verticalidad, que planteaban un mismo acontecimiento a partir de distintas opiniones, o desde diferentes ángulos o ante situaciones diferentes. Lo interesante de esta complejidad narrativa es que hoy contamos con los recursos tecnológicos que nos facilitarían llevarla a cabo. Para ello habría que considerar su composición en tres dimensiones; como si incluyéramos varios ejes que demandan un nivel de complejidad semiótica o simbólica que permite conformar una historia a partir de sus significados más profundos y sus connotaciones contextuales. Otro atractivo que ofrece este modelo es poder involucrar a un usuario-lector-jugador que pueda ir armando su historia mientras va jugando, en un ejercicio lúdico similar a un videojuego que pueda diseñarse a partir de un tipo de narrativa hipertextual, multigranular, es decir, que esté compuesto por módulos que se interrelacionan de manera tridimensional, con diferentes niveles de conexión.

Otra cualidad narrativa apreciada en este estudio y que deseamos destacar, es el concepto de palimpsesto, noción que asociamos a la idea de conformar un texto que se integra a partir de interponer varias capas de información que los usuarios o jugadores van descubriendo y pueden inferir gracias a su propia experiencia, su participación activa, los conocimientos que poseen o el grado madurez que han adquirido de lecturas y juegos previos. Este palimpsesto textual que proponemos para componer narrativas, puede integrarse de diversas maneras, ya sea por múltiples escenarios en donde distintos personajes llevan a cabo un sinnúmero de acciones, integrando una red textual con distintos ejes que permita al usuario interactuar y dar forma a una historia en la cual se establecen múltiples posibilidades por donde avanzar. De manera similar a como los juegos de ordenador ofrecen diversos recorridos y demandan la participación y solución de enigmas o cumplimiento de tareas. Se trata de crear textos que despierten el interés de los lectores y jugadores por participar y ampliar las posibilidades narrativas a partir de cada acción que emprenden: acciones paralelas, tramas ramificadas, puntos de vista múltiples, solución de enigmas y otros recursos que esperamos los artistas tengan deseos de integrar a sus piezas digitales; en donde puedan coincidir varios conceptos y por ende, significados. Este recurso puede aplicarse a proyectos de distintos tipos, ya sean informativos, divulgativos, educativos, persuasivos o artísticos. Porque en el fondo buscamos ofrecer propuestas que puedan revestirse con formatos y tratamientos muy diversos.

Estamos convencidos que el videojuego presenta un potencial técnico y artístico que aporta importantes elementos y recursos a los creadores. Visto desde la óptica de los elementos narratológicos, pudimos identificar las cualidades que comparten y distinguen a las narrativas y los videojuegos y pudimos conformar una poética de elementos digitales en la que reflexionamos en torno a la transtextualidad o posibilidad de utilizar múltiples canales de creación y difusión de las piezas. Así como apreciamos la relación entre el autor, la pieza, el usuario y los mecanismos

${ }^{839}$ CALVINO, Italo, El castillo de los destinos cruzados, Siruela, Madrid, 2010. 
de interacción que se establecen; así como los niveles de inmersión, emergencia o significación que se pueden explorar y desarrollar en la composición.

Por ello este estudio propone llevar a cabo un proceso sistemático de creación, pensando en facilitar estas acciones de manera ordenada para estimular las habilidades narrativas lúdicas; entendidas como ciertas prácticas que faciliten la experimentación de recursos narratológicos generales como el manejo del tiempo, los personajes o la incrustación de diferentes historias, pero reflexionando en cómo pudiera hacerse en entornos digitales. Algunos recursos como la utilización de reglas (básico en todo juego) nos recuerdan que por más libertad experimental que deseemos llevar a cabo, existen convenciones tanto formales, semánticas o estructurales que no podemos omitir. Sería muy pretencioso mencionar que este modelo que presentamos formará escritores o guionistas, eso requiere de dedicación y trabajo por parte de los escritores. Esta propuesta es una guía que pueden desarrollar y servirá para apreciar los recursos que puede echar mano, pero el verdadero trabajo resultará al emprender un proyecto y considerar estos elementos que nos resultan necesarios atender. Esta guía no servirá si no se emprenden acciones creativas y originales, por ello quisimos mostrar un numero considerable de piezas que pueden ser detonantes de nuevos proyectos.

En esencia, la propuesta para emprender esta experimentación narrativa está asociada con ciertas prácticas lúdicas porque estamos convencidos que el juego es un vehículo de creación que favorece la composición y ofrece un potencial de invención que deseamos promover y estimular. Partimos de la idea de que existen semejanzas entre el proceso creador del artista y el proceso lúdico-creativo del jugador, ya que ambos llevan a cabo prácticas exploratorias y reconstructivas. El juego revitaliza la imaginación del artista, basta ponerse en el papel de otra persona en un juego de roles, tener que resolver un problema o emprender actividades simuladas; para apreciar cómo la imaginación del artista o del jugador se estimulan.

La tradición literaria contemporánea se ha nutrido del juego, esto lo apreciamos en piezas artísticas y literarias que demandan la participación del lector-espectador como si fuera un jugador, tal cómo hemos venido diciendo, el juego propicia la invención de fantasías a partir del desarrollo imaginativo, las simulaciones, el juego de roles o de pretender ser. Podemos basar la composición artística en el juego por ser espontáneo y creativo. Mediante el juego confirmamos que es posible romper con la seriedad y el orden, lo que experimenta ciertas potencialidades y produce nuevos significantes, jugamos con palabras, inventamos paradojas, utilizamos formatos de rompecabezas, laberintos o estructuras armables para presentar nuevas dimensiones de creación. Por ello la literatura es considerada un juego del intelecto. Para aprender a componer textos narrativos fue preciso reconocer la importancia tanto de relatar historias como el de poder jugarlas y señalar las cualidades narrativas y las lúdicas. Porque ante todo, buscamos dotar de recursos que faciliten las labores de los artistas y el juego es un elemento indispensable porque su práctica demanda la solución de problemas y en cierta forma estimula el instinto creativo de los artistas. El juego como detonante de historias, como modelo para organizar estructuras narrativas, como modo experimental la escritura, confirma cómo el hombre ha desarrollado su proceso creativo hasta tal punto que resulta borroso ver el límite entre creación artística y juego.

No resulta una novedad el uso de ciertas prácticas asociadas a juegos como proceso o estrategia creativa para la generación de obras, en cierta manera nos hemos familiarizado con pinturas hechas a partir de reproducciones que rompen con la seriedad y el orden de los cánones establecidos por la tradición y buscan la experimentación, juegan con múltiples versiones, visiones y significantes. Dando completa libertad a la creación a través de reconfiguraciones, 
collages, piezas que escapan de la norma, indeterminadas, interactivas, piezas que se componen de objetos comunes no reconocidos como estéticos como el Ready-Made, o el arte pop que sin duda serían motivo de otro estudio pero que confirman la influencia lúdica en el arte.

Retomando nuestro interés en textos creados a partir de colaboraciones lúdicas, hemos subrayado el caso de Dadaístas como Robert Desnos, Paul Eluard, André Bretón o Tristan Tzara al escribir sus Cadáveres Exquisitos, tomando turnos al azar y componiendo sus relatos encadenados de manera casi automática. Ese mismo ejercicio narrativo fue llevado a la pintura, al collage y por supuesto al cine y a otras manifestaciones artísticas contemporáneas. De la misma manera, esto debe ampliar nuestra imaginación y permitirnos hacer estas migraciones. Pensar por ejemplo en Marcel Duchamp y su fascinación por el ajedrez así como Guy Debord ${ }^{840}$ y su juego de Guerra Kriegspiel o el manifiesto de George Maciunas ${ }^{841}$ sobre FLUXUS o el arte divertido (1965) "simple, sin pretensiones, sin requerimiento de habilidad alguna, ensayos, ni utilidad, un chiste, un juego de niños, una pieza de Duchamp".

Esperamos que estos postulados e ideas sirvan para emprender proyectos narrativos o artísticos en los cuales podamos confirmar la influencia de prácticas lúdicas.

Con el advenimiento del videojuego ampliamos nuestro entendimiento al ver cómo han influenciando algunas prácticas en la plástica: pinturas que emplean formatos propios de pantallas como son los diseños gráficos poligonales en 3D, de John Carmack; o las imágenes "pixeleadas" de John Haddock. Diseños basados en hardware o en escenas de personajes de videojuegos como Brody Condon, Hillary Mushkin ${ }^{842}$. Trazos creados a partir de trayectorias de jugadores o el video mapping $^{843}$ o la música 8Bits de un GameBoy. Estos ejemplos pueden ampliarse mucho más, lo que interesa es destacar la creciente tendencia de la composición literaria a través de ejercicios de literatura visual, de lecturas a partir de letras en movimiento o los poemas ilustrados propios del género de la literatura electrónica y sus nuevas formas de composición.

Sin duda confirmamos que el videojuego ofrece nuevas formas de creación, basta retomar su sentido de vértigo y movimiento; contemplar su formato de niveles o plataformas en donde hay avance y progresión, en el que el ambiente inmersivo permite a los espectadores y actores vivir en carne propia la exploración interactiva. Una exploración que conlleva una carga emotiva sustentada por la necesidad de resolver acertijos o enigmas, completar tareas o decodificar mensajes. Otro aspecto que el videojuego ha permitido contemplar es la posibilidad de participación activa no sólo como jugador sino como autor y poder recomponer versiones mejoradas o personales de proyectos colectivos, juegos y otros proyectos digitales. En todos estos casos, apreciamos como es el juego el motor creativo y en esta búsqueda de migrarlo a los formatos literarios queremos promover nuevas prácticas de composición inspiradas en la experimentación de formas, introducir retos por resolver e incluso premios o castigos que puedan armarse a diferentes niveles de complejidad.

En el Apartado Homo Ludens presentamos cuál ha sido la relación del hombre y el juego en relación al instinto que impulsa el proceso de creación y estimula una actitud en la que afloran las emociones y la imaginación. De tal manera que éste no sólo ha sido un elemento fundamental en el desarrollo humano desde el punto de vista cultural, como un entretenimiento, sino además

\footnotetext{
${ }^{840}$ Véase: http://www.notbored.org/nathan-heller.html Consultado: 8/12/2012

${ }^{841}$ Véase: http://www.artnotart.com/fluxus/gmaciunas-artartamusement.html Consultado: 5/12/2012

${ }^{842}$ Véase: http://www.hillarymushkin.com/ Consultado: 5/12/2012

${ }^{843}$ Véase: http://www.urbanscreen.com/usc/category/projects 8/12/2012
} 
como un impulso a la imaginación. Esto justifica la necesidad de encontrar los medios para estimular el desempeño de niños y jóvenes y que ejemplificamos con una experiencia personal que estimuló este trabajo de investigación. Por años he conducido talleres de arte y creatividad con niños y jóvenes. Con mucha frecuencia, los productos de estos artistas se veían influenciados por formas conocidas que copiaban de sus series de televisión, revistas o sus videojuegos. De entrada, les resulta difícil crear algo original o diferente a lo que conocen, además existe un cierto temor o falta de ingenio para hacerlo. Buscamos que los creadores generen un guion o un texto que dé significado a su creación. Apreciamos su dificultad para ligarlo a una historia o utilizar el lenguaje para expresarlo. Uno de los recursos que hemos comprobado positivamente es proporcionar a los estudiantes textos o relatos literarios como fuente creativa, y también una metodología para darle forma a esas historias conocidas: el juego se convirtió en una práctica para reformular y estructurar nuevas posibilidades de creación. Convencidos de la importancia de este tipo de estímulos o resortes creativos, revaloramos el lenguaje y entendimos el origen, importancia y trascendencia de la composición de historias. Si deseamos promover nuevas maneras de componer relatos, debemos acercarnos a la tradición para desde ahí proponer nuevos formatos, estructuras y contenidos que sigan rindiendo culto al lenguaje. Porque es una herramienta que debemos revalorar y exportar a nuevas plataformas y sistemas tecnológicos porque no sólo ha sido una herramienta para el intelecto sino, para la creación artística. Relatar historias ha sido una necesidad vital, por ello el Homo narrans ha acoplado su potencial creativo a las herramientas tecnológicas de su momento: tabletas de barro, papiros, papel o pantallas. En cada momento y ante cada recurso; deseamos entender qué elementos debe migrar para llevar a cabo la producción narrativa en medios digitales.

Uno de los fundamentos que ha guiado esta parte del estudio es la fusión de la visión narratológica y la lúdica, buscando un punto de partida que sirva como modelo para ejemplificar la optimización del manejo lúdico del lenguaje, para analizarlo se han enlistado diferentes momentos y estrategias en los que el lenguaje se convierte en un instrumento y al mismo tiempo un objeto de creación, mediante códigos secretos, lenguajes artísticos y juegos poéticos. Textos compuestos de imágenes, formas criptográficas, laberínticas, juegos del ingenio literario que expanden el potencial del juego como motor creativo. El surgimiento de estructuras combinatorias, semejantes a piezas armables que reflejan ciertas prácticas lúdicas. El juego ha permitido la exploración de nuevas maneras de organizar el lenguaje, y por ello, su contribución a la literatura es innegable. Juegos sonoros y visuales en textos como los technopaegnia y los caligramas, nos invitan a recomponer historias utilizando estructuras y modelos lúdicos. El ordenador no fue el primero en conseguir textos multimedia; ya que estaríamos olvidando la tradición ancestral que promovió la generación de textos fragmentarios, con características visuales y sonoras que resultan imprescindibles para entender las posibilidades de creación de los entornos digitales contemporáneos.

En nuestro análisis sólo contemplamos una pequeña muestra de obras literarias, pero que estamos seguros servirán de pauta, porque más allá de agotar el tema, esperamos despertar el interés que permita aumentar este listado con otras obras semejantes. Esperamos que los guionistas y diseñadores de textos puedan ampliar sus referencias y puedan facilitar su acercamiento a un cierto tipo de literatura lúdica. Si logramos que los diseñadores de textos incluyan cualidades "jugables" al armar sus historias, es decir que logren introducir códigos ingeniosos, estructuras que presenten elementos que requieran de la participación del lector en solucionar problemas y acertijos que sobre todo estimulen su imaginación, entonces valdrá la pena considerar las 
cualidades de los videojuegos como recursos valiosos para la creación de historias. Porque se trata de incorporar elementos que poseen un grado insuperable de inmersión que además sean atractivos a los usuarios. El videojuego ofrece nuevos campos de exploración narrativa que es preciso atender y experimentar porque quisiéramos que la lectura se volviera una tarea tan inspiradora y cautivadora como los videojuegos. Que los lectores pudieran crear su propio "círculo mágico" a partir de nuevos formatos de lecturas interactivas. Pero que además pudiéramos influir en el diseño de proyectos que puedan desarrollar un potencial narrativo inspirado en el valor del lenguaje y su potencial lúdico

Así mismo, fue de utilidad conocer las teorías estructuralistas para componer historias. Deseamos destacar que la narrativa contemporánea es producto de la evolución de una rica herencia cultural y de un amplio panorama de experimentación literario que la humanidad ha venido desarrollando desde siempre y que nos resultó interesante abordar en este estudio. Gracias a ello, pudimos apreciar cómo las historias de nuestro tiempo han migrado a nuevos formatos electrónicos, sin embargo resulta innegable apreciar la influencia de novelas y textos literarios contemporáneos analógicos en la producción de la narrativa digital.

Con esta investigación confirmamos cómo el lenguaje ha permitido al hombre dejar huella de sus progresos, ser testigo de su memoria, de sus saberes y ser materia creativa para el gozo y la invención. Porque entendemos que el lenguaje es la materia prima para generar historias con nuevos dispositivos electrónicos y resulta necesario revalorarlo y adaptarlo a las condiciones tecnológicas y culturales actuales. Gracias al lenguaje podemos construir imágenes mentales (tanto visuales como auditivas) según nos dice Gerd Waloszeck ${ }^{844}$ que afloran la genialidad poética de las personas, o como apunta Herbert Read ${ }^{845}$, dio origen al desarrollo de la imaginación. El lenguaje se nutrió del juego y surgió el lenguaje metafórico, ampliando su riqueza de significación, promoviendo la idea de componer estructuras narrativas más complejas y más creativas. Historias de múltiples lecturas. La invención de símbolos y por ende de las metáforas y los mitos, como fuentes de creación.

A lo largo de este estudio apreciamos la relación entre la composición de relatos o narrativas y la capacidad lúdica que poseemos. Porque el ingenio creativo está relacionado con prácticas espontáneas, experimentales y permanentes que han permitido la innovación no sólo tecnológica, sino también artística. En esta búsqueda artística, los creadores demandan su autonomía y no quieren ser valorados por méritos de otras disciplinas. Analizar videojuegos a partir de las historias que relatan ha despertado ideas encontradas. Al iniciar este trabajo sabíamos que había un conflicto que debíamos atender y más allá de tomar postura, debíamos conocer y tratar de conciliar.

Ludologos y narratólogos enfrentan sus posturas: los juegos son juegos y no relatan historias frente a la noción que sostiene que detrás de todo existe una historia. Nuestro estudio retomó las opiniones de ambas tendencias, analizándolas, reconocimos la necesidad de autonomía que buscan los ludólogos, frente a la postura de los narratólogos de apreciar el valor que las historias le otorgan a los juegos. Más allá de tomar partido, establecimos un panorama que mostrara las coincidencias y diferencias entre los juegos y las narrativas; porque a pesar del menosprecio de algunos ludólogos, relatar historias de ninguna manera limita o reduce las cualidades lúdicas de ningún juego. Planteamos desdibujar sus diferencias con el afán de entender

\footnotetext{
${ }^{844}$ WALOSZEK, Gerd, Narrative User Interfaces [Texto on-line] en: ¿Qué son las historias? En: http://www.sapdesignguild.org/community/design/narrative interfaces.asp Consultado: 10/07/2010

${ }^{845}$ READ, Herbert, Imagen e Ideas, Fondo de Cultura Econòmica, Mexico, 1957. (p.38)
} 
lo que uno puede hacer por el otro en un intento de conciliar y mejor aún, potenciar su vinculación al servicio de la composición de mejores juegos e historias, subrayando un nuevo nivel de hibridación que repercuta en la narración apropiándose de dinámicas de juego.

Resulta innegable cómo los jugadores aprecian una buena historia. No sólo porque éstas se convierten en elementos que ayudan a enriquecer el sentido del juego al ir involucrando al jugador a través de mecanismos más participativos y significativos. Esto es un reto para el diseño de guiones narrativos que contemplen el mayor número de detalles para que los juegos y las historias se vuelvan elementos indivisibles y complementarios; de ninguna manera deseamos que sean opuestos.

Este trabajo espera ser una invitación a contemplar piezas literarias así como conocer las propuestas que los estructuralistas formulan a través de sus modelos de situaciones dramáticas que son de incontable ayuda para aquellos interesados en generar relatos. Desde Platón, la búsqueda por encontrar modelos universales para componer historias ha estado vigente: analizar las funciones de Vladimir Propp, las Treinta y seis situaciones dramáticas de Georges Polti, la nocion del Héroe de mil rostros de Joseph Campbell y algunos otros que se pueden revisar en este trabajo; confirmó la importancia de identificar regularidades narratológicas a partir de estructuras prediseñadas y el poder segmentar o articular las historias a partir de éstas y de manera semejante a considerar relatos compuestos de elementos modulares que pueden interconectarse de manera semejante a como se lleva a cabo la escritura de los algoritmos informáticos. Estamos seguros que a partir de un listado de acciones, es posible revestir las composiciones textuales con propuestas temáticas y conceptuales realmente ingeniosas y artísticas. Basta apreciar la Colección de Electronic Literature ${ }^{846}$ de Katherine Hayles, Nick Montfort, Scott Rettberg y Stephanie Strickland, para apreciar cómo las fronteras entre literatura, juego y arte digital están cada vez más difusas y presentan mayor potencial creativo. Potencial que en este trabajo retoma el sentido que el juego ofrece como sustento de creación literaria o como medio de experimentación gráfica, visual o formal. Poemas visuales como Arteroids (2003) de Jim Andrews ${ }^{847}$, o juegos inspirados en ficciones literarias como el caso de The Intruder (1999) de Natalie Bookchin ${ }^{848}$, quien tomó La Intrusa ${ }^{849}$ de Jorge Luis Borges y los convirtió e una serie de 10 juegos de ordenador en el que se desplantan fragmentos del texto. O Viewing Axolotls (2004) de Regina Celia Pinto ${ }^{850}$, basada en el cuento Axolotl de julio Cortazar ${ }^{851}$, confirma cómo la literatura está en espera de ser releída bajo nuevos formatos, recompuesta de maneras innovadoras, empleando los recursos tecnológicos de forma óptima e ingeniosa.

Poder acercarnos a los sistemas informáticos que generan textos e historias como Tale-Spin, Minstrel, Mímesis, Brutus o Mexica; sistemas basados en plantillas pre-programadas que están inspirados en juegos, teoría teatral, inteligencia artificial que son referentes para los interesados en componer historias en nuevos medios. Estos modelos están muy cerca de los primeros videojuegos, las Aventuras Conversacionales a las que hemos dedicado el apartado sobre las Generalidades sobre los juegos digitales en el que apreciamos el surgimiento y evolución de un

\footnotetext{
${ }^{846}$ Véase: http://collection.eliterature.org/1/ consultado 22/11/2012.

${ }^{847}$ Véase: http://www.poemsthatgo.com/gallery/fall2003/arteroids/ Consultado: 04/02/2012

${ }^{848}$ Véase: http://bookchin.net/projects/intruder.html Consultado: 04/02/2012

${ }^{849}$ Léase el cuento La Intrusa de Jorge Luis Borges en:

http://www.ciudadseva.com/textos/cuentos/esp/borges/intrusa.htm Consultado: 04/02/2012

${ }^{850}$ Véase: http://arteonline.arq.br/axolotes/game.html Consultado: 04/02/2012

${ }^{851}$ Léase el cuento Axolotl de Julio Cortazar en:

http://www.ciudadseva.com/textos/cuentos/esp/cortazar/axolotl.htm Consultado: 04/02/2012
} 
medio ligado al lenguaje, mediante el manejo de diálogos y que replantea nuevos formatos de composición.

Con el fin de mostrar cómo integrar elementos narratológicos, analizamos el videojuego Grim Fandango, con el fin de mostrar aquellas cualidades que requerimos considerar para enriquecer cualquier proyecto. En el caso concreto del videojuego analizado, el tema abordado sobre la tradición Pre-Hispánica sobre el día de Muertos, resulta de tal riqueza conceptual que nos hace pensar cómo ciertos proyectos pueden enriquecerse con una mayor profundidad temática al contemplar cuestiones filosóficas o mitológicas entre su entramado narrativo y no sólo presentar diálogos bien articulados, personajes bien caracterizados, elementos simbólicos cuyas connotaciones amplían los niveles semánticos de la historia. Otra cuestión por destacar es que el entorno visual, es decir los elementos del entorno que resultan no sólo coherentes sino complementarios al desarrollo del relato y de las acciones del juego.

Esperamos que esta tesis sea un hilo conductor para comenzar a construir historias y relatos, aprovechando la capacidad innata que poseemos de poder jugar con todas las historias que se nos ocurran, entrelazando formas tradicionales y nuevas maneras de componerlas. Por ello ofrecemos una serie de actividades pensadas para conducir talleres de composición narrativa con estudiantes y jóvenes creadores porque estamos convencidos que la capacidad creadora puede ser desarrollada y resulta más fácil si existe una guía que pueda conducir y detonar su ingenio a través de prácticas que faciliten su labor.

150 Retos para Narrajugadores, es el apartado final que retoma de manera sistemática una propuesta para integrar los elementos que intervienen en la composición de relatos y que además, retomará el juego como motor para llevar a cabo prácticas que esperamos sean un verdadero resorte creativo, esperando disfruten componer las mejores historias que jamás han jugado. Convencidos de que sólo hace falta un pequeño resorte para impulsar y revitalizar la imaginación, planteamos estos retos buscando promover ese impulso creativo natural que está latente y en espera de convertirse en un producto exploratorio y constructivo. Propusimos tareas y reglas con el único afán, tal como afirmaban los miembros de OuLiPo, para ser libres, para incentivar la creación.

Partimos de las cualidades comunes de los juegos, las narrativas y los entornos digitales, y clasificamos sus cualidades bajo cuatro aspectos fundamentales: los Elementos Narratológicos que contemplan aquellos recursos textuales que ayudan a estructurar el texto, es decir lo que se dice y la forma cómo se dice. Los Elementos de Poética Digital que consideran tanto las cualidades que permiten la edición, expresión y transmisión de los textos como los elementos propios de la interactividad e inmersión, así como los sistemas digitales abiertos que están en espera de la participación activa de los usuarios. Las Cualidades Hermenéuticas que favorecen la composición de textos complejos que admiten diversos sentidos y significados a diferentes niveles. Y los Elementos Formales o Estructurales que buscan organizar los contenidos a partir de andamiajes narrativos que tengan cierto ingenio e innovación y que se relacionen con el sentido y el tema para conformar textos integrados. De este modo, las tareas planteadas en estos cuatro aspectos, pueden facilitar su labor respecto a: el papel del usuario-lector que participa en la toma de decisiones para articular las historias. Ya sea mediante el seguimiento de patrones, fórmulas o teorías, aunque subrayamos que de ninguna manera planteamos el seguimiento de recetas para componer buenas historias, se trata de retos, en el sentido estricto que demandan el ingenio creativo lúdico de los escritores y diseñadores de textos quienes deben contemplar una infinidad de elementos para componer sus historias. Por ello en El Proceso de Creación para 
Estimular Habilidades Narrativas Lúdicas, mostramos elementos que los escritores deberían considerar al componer sus narrativas, y que nosotros designamos como resortes creativos porque estamos convencidos que favorecen la composición de historias. Porque el análisis realizado de cómo han adaptado los sistemas digitales la manera de generar historias, desde los sistemas automáticos hasta los complejos sistemas que conforman los videojuegos, nos ha mostrado la necesidad de diseñar ciertas estructuras que permitan adaptar los contenidos en forma de historias, las cuales en ocasiones sólo necesitan un pequeño resorte que permita que las ideas fluyan y tomen forma. Desde favorecer la elección de temas, procedimientos, formatos y recursos para jugar a armar historias.

Lo verdaderamente creativo debe detonarse a partir de esta guía, gracias al revestimiento que los artistas den a sus creaciones, inspirados por el juego y el lenguaje. Porque estamos seguros que la labor de los artistas puede enriquecerse si se amplía su visión en torno al videojuego, ofreciéndoles un potencial que pueden aprovechar, con ello esperamos contribuir en la formación de una nueva generación de escritores-jugadores que entiendan el valor de ampliar su capacidad creativa y sus expectativas. 


\section{RESÚMENES}

\section{Resumen en castellano}

Con esta tesis buscamos establecer el mayor número de coincidencias entre lenguaje, narratología y videojuego con el fin de detectar, nuevas estructuras narrativas que puedan aplicarse a la creación artística multimedia. El objetivo principal de esta investigación es proporcionar un modelo de Narrativa lúdica que estimule a los creadores artísticos en nuevos medios, a que revaloren el lenguaje, la narración y las estrategias del juego como recursos de creación.

Nuestro punto de partida fue la relación que existe entre las personas las historias y los juegos; pudimos apreciar que no sólo son herramientas de comunicación y expresión, sino que se enriquecen y complementan mutuamente. A lo largo del tiempo la herencia narrativa se ha adecuado a las condiciones culturales y tecnológicas existentes.

En un segundo momento pudimos conocer algunas piezas literarias que fueron concebidas a partir de juegos y por ello designamos como narrativas lúdicas, cuyas características pueden considerarse como modelos que estimulen el trabajo profesional de escritores, guionistas o diseñadores de textos interesados en integrar relatos a sus piezas como una aportación a la narratología y a la poética digital contemporáneas.

En la tercera parte exploramos las características que los videojuegos y los atributos que podemos asociar con la composición de relatos, como el sentido de vértigo y de movimiento, su formato de niveles o plataformas que muestran un modo de avance y progresión en el que además propicia el ambiente inmersivo que permite a los espectadores vivir en carne propia la experiencia.

A través de este estudio mostramos un balance entre las posturas críticas que han distanciado los juegos de las narrativas; confirmando que no existe razón para tal distinción, sino al contrario, existen elementos que aseguran su mutua dependencia. Lo cual confirma nuestra tesis de utilizar ciertas cualidades de los juegos para experimentar formatos narrativos más complejos similares a la idea del palimpsesto, entendido como un texto que se desarrolla a lo largo de diversos ejes, compuesto por un sinnúmero de acciones, formando una red con múltiples posibilidades de lectura e interpretación.

En el último apartado proponemos prácticas que puedan orientar tanto a profesores, estudiantes e interesados en incursionar en el mundo del diseño de textos y guiones. Que sean un laboratorio de experimentación lúdico-narrativo, el cual contribuya a formar Narrajugadores, que afloren la genialidad poética nutrida a partir del juego con propuestas que puedan revestirse con temáticas y tratamientos muy diversos.

Concluimos nuestro estudio confirmando cómo el juego y el lenguaje son herramientas indispensables que los creadores artísticos pueden considerar para proponer un tipo de narrativas jugables, experimentales e innovadoras. La necesidad de replantear la importancia de relatar historias y estimular su práctica, para cualquier artista interesado en complementar sus piezas. 


\section{Abstract English}

This thesis seeks to establish the largest number of coincidences among language, storytelling and videogames, in order to determine new narrative structures that can be applied to the creation of analogical or digital artworks. The main objective of this research is to provide a model of game-based narrative that encourages young students to revalue language, storytelling, and game structures in order to contribute to contemporary poetics.

Our starting point was the relationship that exists between people, stories and games. We observed that they are, not only tools for communication and expression, but they also enrich and complement one another. Over time, the narrative heritage has adapted itself to the existing cultural and technological conditions. Who demands to find new ways for storytelling.

In the second phase we studied literary pieces that were conceived from games and therefore classified as game-based narratives. The characteristics of these pieces can be considered models that stimulate writers or text designers in their professional work, and who are interested in integrating composition of texts into their pieces. This effort is intended to contribute to narratology and poetic studies.

In the third part, we explored video games, their features and attributes which we associate with the composition of stories, such as a sense of vertigo and movement. Their format or platform structure with a particular progressive form also promotes vivid immersive and interactive experiences to the gamers.

With this study, we show a balance between critical positions that have distanced the games from narratives; confirming that there is no reason for such a distinction, but that rather, there are elements that ensure their mutual dependence. This confirms our thesis about the use of game-based stories to experiment with more complex narrative formats similar to the idea of the palimpsest, understood as a text that develops along different axes, composed of a myriad of actions, and forming a network with multiple possibilities of reading and interpretation.

In the last part we propose conducted practices that can guide teachers, students and others who are interested in venturing into the world of text and script design. So these proposed practices can be used as experimental game narrative laboratories that contribute to form game tellers who may experience a poetic creativity nourished by the game through proposals coated with very diverse thematic and treatments.

We conclude our study confirming how basic game and language are as tools that creators have to consider to propose a kind of experimental and innovative game-based narrative. May this study invite the reader to rethink the importance of telling stories and stimulate its practice in new ways. 


\section{Resum en Valencià}

Amb aquesta tesi busquem establir el major nombre de coincidències entre llenguatge, narratologia i videojoc amb per tal de detectar, noves estructures narratives que puguin aplicar-se a la creació artística multimèdia. L'objectiu principal d'aquesta investigació és proporcionar un model de Narrativa lúdica que estimuli als creadors artístics en nous mitjans, que revaloren el llenguatge, la narració i les estratègies del joc com a recursos de creació.

El nostre punt de partida va ser la relació que existeix entre les persones les històries i els jocs, vam poder apreciar que no tan sols són eines de comunicació i expressió, sinó que s'enriqueixen i complementen mútuament. Al llarg del temps l'herència narrativa s'ha adequat a les condicions culturals i tecnològiques existents.

En un segon moment vam poder conèixer algunes peces literàries que van ser concebudes a partir de jocs i per això designem com narratives lúdiques, amb unes característiques que poden considerar com a models que estimulin el treball professional d'escriptors, guionistes o dissenyadors de texts interessats a integrar relats a les seves peces com una aportació a la narratologia i la poètica digital contemporànies.

A la tercera part explorem les característiques que els videojocs i els atributs que podem associar amb la composició de relats, com el sentit de vertigen i de moviment, el seu format de nivells o plataformes que mostren una manera d'avanç i progressió en què a més afavoreix l'ambient immersiu que permet als espectadors viure en carn pròpia l'experiència.

A través d'aquest estudi mostrem un balanç entre les postures crítiques que s'han distanciat els jocs de les narratives, confirmant que no hi ha raó per a tal distinció, sinó al contrari, hi ha elements que asseguren la seva mútua dependència. La qual cosa confirma la nostra tesi d'utilitzar certes qualitats dels jocs per experimentar formats narratius més complexos similars a la idea del palimpsest, entès com un text que es desenvolupa al llarg de diversos eixos, compost per un sens fi d'accions, formant una xarxa amb múltiples possibilitats de lectura i interpretació.

En l'últim apartat proposem pràctiques que puguin orientar tant a professors, estudiants $\mathrm{i}$ interessats en incursionar en el món del disseny de texts i guions. Que siguin un laboratori d'experimentació lúdic-narratiu, que contribueixi a formar Narrajugadors, que aflorin la genialitat poètica nodrida a partir del joc amb propostes que puguin revestir amb temàtiques i tractaments molt diversos.

Concloem el nostre estudi confirmant com el joc i el llenguatge són eines indispensables que els creadors artístics poden considerar per proposar un tipus de narratives jugables, experimentals i innovadores. La necessitat de replantejar la importància de relatar històries i estimular la seva pràctica, per a qualsevol artista interessat en complementar els seus obres. 


\section{BIBLIOGRAFIA}

LIBROS

\section{HOMO NARRANS}

ABBOT, H. Porter, The Cambridge introduction to narrative, Cambridge University Press, Cambridge, 2008.

AVIS, Paul, God and the creative imagination: metaphor, symbol and Myth, Routledge, New York, 1999.

BLAVATSKY, Helena Petrovna, Isis sin velo, Colofón, México, D.F., 2006.

BARTHES, Roland, "Introducción al análisis estructural de los relatos", Premiá editora de libros, Tlahuapan, 1982.

BENJAMIN, Walter, The work of art in the age of its technological reproducibility and other writings on media, Harvard University Press, Cambridge, Ma, 2008.

BRUNER, Jerome, Acts of Meaning, Harvard University Press, Cambridge MA, 1990.

CAMPBELL, Jeremy., El hombre gramatical, Fondo de cultura económica, México, 1989.

CAMPBELL, Joseph, The hero with a thousand faces, Joseph Campbell Foundationd \& New World Library Press, Novato, 2008.

CARR, Nicholas, The Shallows; What the Internet is doing to our brains, W.W. Norton \& Company, New York, 2010.

CHATMAN, Seymour, Story and discourse; narrative structure in fiction and film, Cornell University Press, Ithaca, 1978.

DUMEZIL, George, Del mito a la novela, Fondo de Cultura Económica, México, D.F., 1993.

ELIADE, Mircea, Mito y realidad, Kairos, Madrid, 2002.

EISENSTEIN, Elizabeth L., The printing revolution in early modern Europe, Cambridge University Press, 1983, 2005.

FRASER, James, The golden bough, Mcmillan, NewYork, 1922.

FLUDERNIK, Monika, An introduction to narratology, Routledge, Great Britain, 2009.

GARDNER, Howard, Multiple intelligences, Basic Books, New York, 2006.

GOODY, J. \& WATT, I., The Consequences of literacy de Jack Goody (Eds.), Cambridge University Press, Cambridge, 1968.

GRIJELMO, Álex, Defensa apasionada del idioma español, Taurus, México D.F., 2002.

HAVELOCK, Erik A. The muse learns to write, Yale University Press, New Haven, 1986.

LEVI-STRAUSS, Claude, El pensamiento salvaje, Fondo de Cultura Económica, México, D.F. (1964)

LEVI-STRAUSS, Claude, Mito y significado, Alianza Editorial, Madrid, 2002.

MCLUHAN, Marshall, The Gutenberg galaxy: the making of typographic man, University of Toronto Press, Toronto, 1962.

NILES, John D., Homo Narrans, the poetics and anthropology of oral literature, University of Pennsylvania, Phyladelphia, 1999.

MÜLLER, Friedrich Max, Three lectures on the science of language and its place in general education, Bibliolife, 2008.

ONG, Walter J., Orality and literacy: the technologizing of the Word, Routledge, New York, 1982

PAZ, Octavio, El arco y la lira, Fondo de Cultura Económica, México, 1956.

PRINCE, Gerald, A Dictionary of narratology, University of Nebraska Press, Lincoln, 2003. 
READ, Herbert, Imagen e idea, Fondo de Cultura Económica, México, 1957.

SAPIR, Edward, El Lenguaje, Fondo de Cultura Económica, México, 1954.

SHANK, Roger C., Tell me a story; narrative and intelligence, Northwestern University Press, Evanston, 1990.

SPIRKIN, A.G., "Origen del lenguaje y su papel en la formación del pensamiento", En:

GORSKI, D.P., KIPNIN, P.V. et Al (eds.), Pensamiento y Lenguaje, Editorial Grijalbo, México, D.F., 1961.

SWADESH, Mauricio, El lenguaje y la vida humana, Fondo de Cultura Económica, México, 1966.

WITTGESTEIN, Ludwig, Philosophical Investigations, Blackwell publishing, Malden, Ma,1953.

\section{HOMO LUDENS}

BONET, J.M., El aporte de la poesía al arte moderno, El poeta como artista. Las Palmas de Gran Canaria, Centro Atlántica de Arte Moderno, 1995.

BRIAN, Edwards, Theory of play and postmodern fiction, Garland Publishing, New York, 1998.

CARAMEL, L., LOERS, V., Y CRISPOLTI, E., (eds.) Vanguardia italiana de entreguerras;

Futurismo y Racionalismo. IVAM, Valencia, 1990, (p.24)

CARRÁ, Carlo, Guerrapittura, S.P.E.S - Salimbeni, Florencia, 1978.

CALLOIS, Roger, Los juegos y los hombres; la máscara y el vértigo, Fondo de Cultura Económica, México, 1994.

COLIN, Georges, Compendio de psicología infantil, Kapelusz, Buenos aires, 1974.

CONLEY, Tim \& CAIN, Stephen, Encyclopedia of fictional and fantastic languages, Greenwood Press, Westport, 2006.

DEPERO; F., Depero Futurista - Libromacchina imbullonato, SPES, Florencia, 1987.

DONALD, Merlin W., Origins of the Modern Mind: Three stages in the evolution of culture and cognition, Harvard University Press, Cambridge, 1991.

DONALD, Merlin, A mind so rare: the evolution of human consciousness, W.W. Norton,

New York, 2001.

DUCHATEAU, Jacques, Zinga huit, Gallimard, 1967.

DYSON, John-Paul (Ed.) "The cultural origins and play philosophy of play workers: an Interview with Penny Wilson" (pp. 269-282) en: American Journal of Play, University of Illinois Press, Vol. 1 Number 3, Champaign, Ill, 2009.

FLANAGAN, Mary., Critical play: radical game design, The MIT Press, Cambridge, 2009.

FINK, Eugene., Oasis de la felicidad, Centro de Estudios Filosóficos, UNAM, México, D.F., 1966.

FOUCAULT, Michael, Les mots et les choses, Siglo XXI Editores, México, 1968.

FREUDENTHAL, Hans, Lincos: Design of a language for cosmic intercourse, North Holland Publishing Company, Amsterdam, 1960.

GIRAUD, Pierre, La Semiología, Siglo XXI Editores, Mexico, 1972.

GUINESS G. \& HURLEY, A. (Eds.) Auctor Ludens, essays on play in literature, John Benjamins Publishing Co., 1986.

HIGGINS, Dick et al, The Great Pamplhlet Series, Something Else Press, New York, 1965-1967.

HENRICKS, Thomas, "The nature of play: an overview" (pp.80-125) en: DYSON, Jon-Paul (Ed.), American Journal of Play, Vol.1, Num.2, Champaign, ILL, 2008.

HOGBEN, Lancelot, Interglossa: a draft of an auxiliary for democratic world order, being an attempt to aply semantic principles to language design, Penguin Books, New York, 1943.

HUIZINGA, Johan, Homo Ludens, a study of the play element in culture, The Beacon Press, Boston, 1950.

KASPER, M., Saint Ghetto of the loans, Uggly Duckling Presse, New York, 2006.

KLIMA, Stefan, Artist Book: a critical survey of the literature, Granary Books, New York 1998.

LE LIONNAIS, "LIPO: First Manifesto", en: MOTTE, Warren F., OULIPO: a Primer of potential literature, Nebraska University Press, Lincoln, 1986. 
LESCURE, Jean, "Brief history of the Oulipo" (pp.32-39) en: MOTTE, Warren F., OULIPO: a Primer of potential literature, Nebraska University Press, Lincoln, 1986.

MATHEWS, Harry \& BROTCHIE, Alastair (eds.), Oulipo Compendium, Atlas Press, London and Make Now Press, Hollywood, 2005.

McDEVITT, Jack, The Hercules text, Ace Books, New York, 1986.

MOTTE, Warren F., OULIPO: a Primer of potential literature, Nebraska University Press, Lincoln, 1986.

MOTTE, Warren F., Playtexts: lúdics in contemporary literature, University of Nebrasca Press, Lincoln, 1995.

McLUHAN, Marshall, Understanding Media, Gingko Press, Corte Madera, Ca., 2003.

MUNARI, Bruno \& D'ALBISOLA, Tullio, l'anguria lirica, Edizione futuriste di Poesía. Litolatta, Savona, Roma, 1934.

QUENEAU, Raymond, Ejercicios de estilo, Cátedra, Madrid, 1999.

READ, Herbert, Imagen e idea, Fondo de Cultura Económica, México, 1957.

SERRA, Marius, Verbalia; juegos de palabras y esfuerzos del ingenio literario, Península, Madrid 2000.

ROSENFELDER, Mark, The language construction kit, Yonagu Books, Chicago, 2010.

ROUSSEL, Raymond, Locus Solus, Gallimard, Paris, 1963.

ROUSSEL, Raymond, Impressions of Africa, Dalkey Archive Press, Champaign, Ill., 2011.

SALEN, \& ZIMMERMAN SALEN, K. \& ZIMMERMAN, E., Rules of play; game design fundamentals, The MIT Press, Cambridge, 2004.

SCHOLES, Robert, et al, The nature of narrative, Oxford University Press, New York, 1966.

SUTTON-SMITH, Brian, Toys as culture, Gardner Press Inc., Mattituck, NY, 1986.

SUTTON-SMITH, Brian, "Play theory: a personal journey and new thoughts", (pp.80.123)

en: DYSON, Jon-Paul (Ed.), American Journal of Play, Vol.1, Num.1, Champaign, ILL, 2008.

SWADESH, Mauricio., El lenguaje y la vida humana, Fondo de Cultura Económica, México, 1966.

TOMMASINI, Vittorio Osvaldo, Farfa Il miliardario delle fantasia, Marco sabatelli Editore, Savona, 1986.

VALDIVIA, BENJAMÍN, La literatura como arte, en Los Objetos Meta-Artísticos, Azafrán y Cinabrio ediciones, Guanajuato, 2007.

WARDRIP-FRUIN, Noah \& MONTFORT, Nick, The new media reader, The MIT Press, Cambridge, 2003.

WRIGHT, Will, (Forward) En: FREEMAN, David (Ed.), Creating Emotion in Games: the craft and art of emotioneering, New Riders Games, Indianapolis, 2003, (pp. xxxii).

\section{NARRANS ET LUDENS}

AMORÓS, Andrés, Introducción crítica, en CORTÁZAR, Julio, Rayuela, Cátedra, Madrid, 2011.

AUB, MAX, Juego de cartas, Cuadernos del Vigía, Granada, 2010.

BARTHES, Roland et al, Análisis estructural del Relato, Premia Editores, México, D.F., 1986.

BARTHES, Roland, Image, Music \& Text, Hill and Wang, New York, 1978.

BREMOND, Claude, "La lógica de los posibles narrativos" (pp. 99-121), en: BARTHES, Roland et al, Análisis estructural del Relato, Premia Editores, México, D.F., 1986.

BRETON, André, Nadja, Grove Press, New York, 1960.

CABRERA INFANTE, Guillermo, Tres tristes tigres, Seix Barral, Barcelona, 1967.

CALVINO, Italo, El castillo de los destinos cruzados, Ediciones Siruela, Madrid, 2010.

CAMPBELL, Joseph, The hero with a thousand faces, Joseph Campbell Foundationd \& New World Library Press, Novato, 2008.

CONSTANTINI, Humberto, Háblenme de Funes, Editorial Nueva Imagen, Buenos Aires, 1980. 
CORTAZAR, JULIO, Rayuela, Cátedra, Madrid, 2011. (En Introducción de Andrés Amorós)

CORTAZAR, Julio, 62 Modelo para armar, Alfaguara, Buenos Aires, 1995.

CORTAZAR, Julio, Último round, Siglo XXI Editores, México, D.F., 1985.

DAVIS, Todd F. \& WOMACK, Kenneth, Formalist criticism and reader-response theory, Palgrave, New York, 2002.

ECO, Umberto, The search for the perfect language, Blackwell Publishing, Malden, Ma.,1995.

FIELD, Syd, Screen play; the foundations of screenwriting, Bantam Dell - Random House, Inc., New York, 2005.

GARCÍA MARQUEZ, Gabriel, Cien años de soledad, Editorial Sudamericana, Buenos Aires, 1967.

GUZMÁN, Jorge, Job Boj, Seix Barral, Barcelona, 1967.

GREIMAS, Algiras, j. "Elementos para una teoría de la interpretación del relato mítico" (pp. 3976) en: LAFOURCADE, Enrique, Editorial Zig Zag, Santiago de Chile, 1965.

HOWARD, David \& MABLEY, Edward., The tools of screenwriting; a writer's guide to the craft and elements of a screenplay, St. Martin's Press, New York, 1993.

LEÑERO, Vicente, Garabato, Editorial Planeta, México, D.F., 2008.

MASSIANI, Francisco, Piedra de Mar, Monte Ávila Editores, Caracas, 1981.

MCKEE, Robert., Story; substance, structure, style and the principles of screenwriting, HarperCollins Publishers, Inc., New York, 1997.

MEJIA VALLEJO, Manuel, Aire de Tango, Plaza \& Janés Editores, Bogota, 1979.

MURRAY, Janet H., Hamlet en la Holocubierta, el futuro de la narrativa en el ciberespacio, Paidós, Barcelona, 1999.

MURRAY, Janet., "From Game-story to cyberdrama" (pp.2-11) En: HARRIGAN, Pat \& WARDRIP-FRUIN, Noah., First Person, New Media as story, Performance and game, The MIT Press, Cambridge, 2004.

NOVOKOV, Vladimir, Pale Fire, Vintage International, New York, 1989.

PAVIC, Milorad, Diccionario Jázaro, Anagrama, México, D.F. 1998.

PEREC, Georges, La vida: instrucciones de uso, Editorial Anagrama, Barcelona, 1988.

PROPP, Vladimir, Morphology of the folk tale, Texas University Press, Austin, 1968.

RYAN, Marie-Laure., Narrative as virtual reality: Immersion and interactivity in literature and electronic media, The Johns Hopkins University Press, Baltimore, 2001 (p. 186)

ROUSE, Richard III, Game Desisng theory \& Practice, Wordware Publishing, Plano, Tx., 2004. (p.47)

SANCHEZ, Nestor, Siberia blues, Paradiso Ediciones, Buenos Aires, 2006.

SAÍNZ, Gustavo, Obsesivos días circulares, Joaquín Mortíz, México, D.F., 1969.

SARDUY, Severo, De dónde son los cantantes, Seix Barral, Barcelona, 1980.

SMITH, Mark \& THOMSON, Jamie, Falcon: the dying sun v.5, Sphere, 1986.

SAPORTA, Marc, Composition no. 1, Simon \& Shuster, New York, 1963.

TOBIAS, Ronald B., 20 Master plots and how to build them, Writer's Digest Books, Cincinnati, 1993.

TODOROV, Tzvetan, "Las categorías del relato literario" (pp. 159-195) en: BARTHES, Roland et al, Análisis estructural del Relato, Premia Editores, México, D.F., 1986.

TURKLE, Sherry., The second self: computers and the human spirit, The MIT Press, Cambridge, 1984, 2005.

TURKLE, Sherry., Life on the screen: identity in the age of the internet, Simon \& Schuster Paperbacks, New York, 1995.

VARGAS LLOSA, Mario, La casa verde, Alfaguara, México, D.F. 2005.

VOGLER, Christopher, The writer's journey; mythic structure for writers, Sheridan Books, Inc., Chelsea, 2007.

WATERFIELD, R. \& DAVIES, W., Money spider, Penguin Books, New York, 1988.

WILSON, R. RAWDON, Palamede's shadow; explorations in play, game \& narrative theory, Northeastern University Press, Boston, 1990. (p. 10) 


\section{JUEGOS NARRATIVOS DIGITALES}

ALDRICH, Clark., The complete guide to Simulations and serious games, Pfeiffer Publishing, 2009.

AARSETH, Espen J., Cybertext: Perspectivess on ergodic literature, The Johns Hopkins University Press, Baltimore, 1997.

AARSETH, Espen, "Genre trouble: narrativism and the art of simulation" (pp. 45-55) en: WARDRIP-FRUIN, Noah \& MONTFORT, Nick, (Eds.) First Person: New Media as story, performance and game, The MIT Press, Cambridge, 2004.

BAL, Mieke, Narratology; Introduction to the theory of narrative, University of Toronto Press, Toronto, 2009.

BARTLE, Richard A., “Alice \& Dorothy play together," (pp.105-117) en: HARRIGAN, Pat \& WARDRIP-FRUIN, Noah., Third Person, Authoring and exploring vast narratives, The MIT Press, Cambridge, 2009.

BATEMAN, CHRIS (ed.), Game writing narrative skills for videogames, Game Development Series, IGTA, Charles River Media Publishing \& Course Technology, Boston, 2007.

BENJAMIN, Walter, The work of art in the age of its technological reproducibility and other writings on media, Harvard University Press, Cambridge, Ma, 2008.

BOLTER, Jay David, Writing space: computers, hypertext, and the remediation of print, Georgia Institute of Technology, Routledge, New York, 2001.

BRYCE, JO (eds.), Understanding digital games, Sage Publications, Thousand Oaks, 2006.

CAMPBELL, Joseph., The hero with a thousand faces, Joseph Campbell Foundationd \& New World Library Press, Novato, 2008.

CRAWFORD, Chris., Cris Crawford on interactive storytelling., New Riders Press, Berkeley, 2005.

CSIKSZENTIMIHALYI, Mihaly, "Does being human matter-on some interpretative problems of comparative ludology" en Behavioral \& Brain Sciences 5, Núm.1, 1982.

COSTIKIAN, Greg, "Games, storytelling and breaking the string" (pp. 5-14) en: HARRIGAN, Pat $\&$ WARDRIP-FRUIN, Noah., Second Person, Role-Playing and story in games and playable media, The MIT Press, Cambridge, 2007.

EGENFELDT N. Simon, HEIDE S. Jonas \& PAJARES T. Susana., Understanding Videogames: The essential introduction, Routledge, New York, 2008.

FULLERTON, Tracy, Game design workshop: a playcentric approach to creating innovative games, Morgan Kaufmann, Burlington, MA, 2008.

GEE, James Paul., What video games have to teach us about learning and literacy, Palgrave Macmillan, New York, 2003.

HAUSKEN, Liv, "Textual theory and blind spots in media studies", (pp.391-403) en: RYAN, MarieLaure., Narrative across media; the languages of storytelling, University of Nebraska Press, Lincoln, 2004.

HINDMARCH, Will, "Storytelling games as a creative medium" (pp.47-56) en: HARRIGAN, Pat \& WARDRIP-FRUIN, Noah., Second Person, Role-Playing and story in games and playable media, The MIT Press, Cambridge, 2007.

JUUL, Jesper, Half-Real: Video games between real rules and fictional worlds, The MIT Press, Cambridge, 2005.

JUUL, Jesper, “Games telling stories?”, (pp. 219-226) en RAESSENS, Joost \& GOLDSTEIN, Jeffrey

(eds.), HandBook of Computer Game Studies, The MIT Press, Cambridge, 2005.

KONZAK, Lars, "Philosophical game design" (pp. 33-44) en: WOLF, Mark J.P. \& PERRON, Bernard, The Videogame theory reader 2, Routledge, New York, 2006.

KUCKLICH, Julian, "Literary theory and digital games" (pp.95-111) en: RUTTER, Jason \&

LAUREL, Brenda., Computers as theatre, Adidson-Wesley Publishing Company, 1993.

MONTFORT, Nick, The new media reader, The MIT Press, Cambridge, 2003.

MURRAY, Janet H., Hamlet en la Holocubierta, el futuro de la narrativa en el ciberespacio, Paidós, Barcelona, 1999.

RICOUER, Paul, The narrative function, Hermeneutics and the human sciences, Cambridge University Press, Cambridge, 1981 
RYAN, Marie-Laure., Narrative as virtual reality: Immersion and interactivity in literature and electronic media, The Johns Hopkins University Press, Baltimore, 2001.

RYAN, Marie-Laure., Narrative across media; the languages of storytelling, University of Nebraska Press, Lincoln, 2004.

RYAN, Marie-Laure., Avatars of story, University of Minnesota Press, Minneapolis, 2006.

SALEN, K. \& ZIMMERMAN, E., Rules of play; game design fundamentals, The MIT Press, Cambridge, 2004.

SALEN, Katie \& ZIMMERMAN, Eric, The game design reader: a rules of play anthology, The MIT Press, Cambridge, 2006.

SCHOLES, Robert \& KELLOG Robert, The nature of narrative, Oxford University Press, New York, 1966.

TORTOLERO, Xochitl, El videojuego en la formación de sensibilidades creativas (2008) [proyecto de DEA] del cual surgió el interés de llevar a cabo una investigación que abordara el videojuego desde la óptica narratológica.

VOGLER, Christopher, The writer's journey; mythic structure for writers, Michael Wiese Productions, Studio City, 2007.

WALLIS James "Making games that make stories" (pp. 69-80) en: HARRIGAN, Pat \& WARDRIPFRUIN, Noah., Second Person, Role-Playing and story in games and playable media, The MIT Press, Cambridge, 2007.

WILSON, R. RAWDON, Palamede's shadow; explorations in play, game \& narrative theory, Northeastern University Press, Boston, 1990.

WOLF, Mark J.P. \& PERRON, Bernard, The Videogame theory reader, Routledge, New York, 2003.

\section{LIBROS DIGITALES}

\section{HOMO NARRANS}

CAMPBELL,Joseph, Los Mitos, su importancia en el mundo actual, Editorial Kairòs, S.A, Barcelona, 1993 [Texto On-line] en:

http://books.google.com.mx/books?id=8phkYfFF6OEC\&pg=PA318\&dq=LOS+MITOS+EN+EL +TIEMPO+de+Joseph+Campbell\&hl=es\&ei=kpljTtCFD9DKsQLu2uHBCg\&sa=X\&oi=book re sult\&ct $=$ result\&resnum $=2 \& v e d=0$ CDEQ6AEwAQ $\# v=$ onepage $\& q=L O S \% 20 \mathrm{MITOS} \% 20 \mathrm{EN} \% 20$ EL\%20TIEMPO\%20de\%20Joseph\%20Campbell\&f=false

WHITE, HAYDEN, The content of the form: narrative discourse and historical representation, John Hopkins University Press, Baltimore,1987:

En:http://books.google.com/books?id=3GWqOS2IsC\&pg=PA215\&hl=es\&source=gbs toc $\mathrm{r} \& \mathrm{ca}$ $\underline{\mathrm{d}=4 \# \mathrm{v}=\text { onepage } \& \mathrm{q} \& \mathrm{f}=\text { false }}$

\section{HOMO LUDENS}

KNOWLES, Alison, By Alison Knowles, Great Bear Pamphlet, 1965, en:

http://www.mdfschool.ru/files/knowles by.pdf

LORENZ, Konrad, The foundations of ethology, Springer-Verlag, New York, 1981.

$\mathrm{http} / /$ books.google.com/books?id=2Y4ptmJiGIkC\&printsec $=$ frontcover\#v=onepage \&q\&f=false (p. 336) Consultado:14/09/2011

RABELAIS, Francis, Gargantua \& Pantagruel, Capítulo 2, XXXII, [Texto on-line] en: http://www.gutenberg.org/files/1200/1200-h/p2.htm\#2HCH0030 Consultado: 25/09/2011

SABAU, García Maria Luisa, Mexico en elmundo de las colecciones de arte; Mesoamerica 1, Editorial UNAM/CONACULTA, México, D.F., 1994. [Versión on-line] en: 
http://books.google.com/books?id=3gaalyLkJykC\&pg=PA80\&dq=la + dualidad + en + el + mundo + pr ehisp\%C3\%A0nico\&hl=en\&ei=6sx4TsO5DYzKsQKfi_WzCQ\&sa=X\&oi=book_result\&ct=resul t\&resnum $=3 \&$ ved $=0$ CDQQ6AEwAg\# $\mathrm{v}=$ onepage \& $\mathrm{q} \& \mathrm{f}=$ false

(p. 80) Dualidad

SIMONS, Jefferey, Silverpowdered olivetrees: Reading Joyce in Spain, en Google Books

\section{NARRANS ET LUDENS}

CAMARERO, JESUS, Metaliteratura, estructuras formales literarias, Editorial Anthropos, Barcelona, 2004.

Texto-on line] en Google Books.

http://books.google.com. $m x /$ books? id $=f X G s K B 7 j L v g C \& p g=P A 240 \& l p g=P A 240 \& d q=C A M A R E$ RO, + JESUS, + Metaliteratura, + estructuras + formales + literarias, \& source $=b l \& o t s=I Y a 7 i R p Q H d$ \&sig=MY3w2dQ5r2IcqzP5I7Z1UHisYCE\&hl=es-

$419 \& s a=X \&$ ei $=j y x l T$ 6YHaaw2QXM05GvCA\&sq $i=2 \& v e d=0 C E U Q 6 A E w B Q \# v=$ onepage $\& q=C$ AMARERO $\% 2 C \% 20 J E S U S \% 2 C \% 20$ Metaliteratura $\% 2 C \% 20$ estructuras $\% 20$ formales $\% 20$ literari as $\% 2 C \& f=$ false

TESIS

\section{HOMO LUDENS}

MONTALVO, Blanca, La narración espacial: propuesta para el estudio de los lenguajes narrativos en el arte multimedia, Tesis doctoral, Universidad Politécnica de Valencia, Departamento de Escultura, Valencia, 2003.

\section{NARRANS ET LUDENS}

BROOKS, Kevin M., Metalinear cinematic narrative: theory, process and tool, [Tesis doctoral] MIT, Media Arts and Sciences, 1999 [Texto on-line] en:

http://alumni.media.mit.edu/ brooks/dissertation.html Consultado: 30/11/201

GUERRA, Fabio W., Engenharia de Estorias, 2008 [Tesis de Maestría] [Texto on-line] en: http://biblioteca.universia.net/html bura/ficha/params/title/engenharia-estorias-um-estudogera $\% \mathrm{C} 3 \% \mathrm{~A} 7 \% \mathrm{C} 3 \% \mathrm{~A} 30-$ narra $\% \mathrm{C} 3 \% \mathrm{~A} 7 \% \mathrm{C} 3 \% \mathrm{~A} 3 \mathrm{o}$-automatica-estorias/id $/ 35229700 . \mathrm{htm} 1$

\section{JUEGOS NARRATIVOS DIGITALES}

GUNDER, Anna, Hyperworks on digital literature and computer games [Tesis doctoral] Uppsala University, Department of Literature, Suecia, 2004.

JOO ONG, Teong, Interactive storytelling engines, [Tesis doctoral] Texas A \& M, 2006. [Texto on-line] en: http://repository.tamu.edu/bitstream/handle/1969.1/4401/etd-tamu-2006B-CPSCong.pdf;jsessionid=3F184BE20F4517109CFE9BB76C061586? sequence $=1$ Consultado: 03/02/2012 
SANCHEZ COTERÓN, Lara, Arte y videojuegos: mecánicas, estéticas y diseño de juegos en prácticas de creación contemporánea, [Tesis doctoral], Universidad Complutense de Madrid, Facultad de Bellas Artes, 2012 [Texto on-line] en:

http://www.academia.edu/2109074/Arte_y_Videojuegos_mecanicas esteticas_y_diseno_de jueg os_en_practicas_de_creacion_contemporanea Consultado: 11/11/2012.

\section{ARTÍCULOS ON-LINE}

\section{HOMO NARRANS}

CAMPBELL, Joseph., "Los mitos, su importancia en el mundo actual”, Editorial Kairós, Barcelona, 1993: http://en.wikipedia.org/wiki/The Power_of Myth LEVI, Eliphas, Fábulas y símbolos: http://upasika.com/docs/levi/Levi\%20Eliphas\%20-\%20Fabulas\%20y\%20simbolos.pdf DENA, Christy \& GLEESON, Catherine, “The New Writing Universe”, en: The Writer's guide to making digital living: http://www.australiacouncil.gov.au/writersguide/newwritinguniverse/ DURCAN, Liam: http://braindetectives.blogspot.com/

FIFE, Austin E., "Myth formation in the creative process": http://www.j.stor.org/pss/1520664 LOPEZ PORTILLO, Esther, "El Castillo de los destinos cruzados de Italo Calvino": http://sepiensa.org.mx/contenidos/2005/1 castillo/castillo_1.htm MATEAS, Michael \& SENGERS Phoebe, "Narrative Intelligence": http://users.soe.ucsc.edu/ michaelm/publications.html MOYERS, Bill, [Entrevista a Joseph Campbell], "The power of Myths": http://en.wikipedia.org/wiki/The Power of Myth NORDQUIST, Richard, "What is language?"; http://grammar.about.com/od/grammarfaq/f/whatislang.htm PRINCE, Gerald, “Observaciones sobre la narratividad", Criterios num. 29, 1991: http://es.scribd.com/doc/32944921/Gerald-Prince WALOSZEK, Gerd, Narrative User Interfaces [texto on-line] en: Qué son las historias en: http://www.sapdesignguild.org/community/design/narrative interfaces.asp WARNER, James "The future of books" http://www.mcsweeneys.net/articles/the-future-of-books

\section{HOMO LUDENS}

BENABOU, Marcel, "Une liste de contraintes oulipiennes" en: http://www.oulipo.net/oulipiens/document13302.html.

CAMPLIN, Troy E., "literature as a game: game-play in reading, creating and understanding literature", Consciousness, Literature and the Arts, Vol. 7, Num. 2, 2006, (P. 33) en: http://blackboard.lincoln.ac.uk/bbcswebdav/users/dmeyerdinkgrafe/archive/camplin.html CARUSO, Di Luciano, "Ebrezza trionfale nel Futurismo, anche", en Ameritalia 1, Núm.1 (2002) en: http://www.ameritalia.id.usb.ve/Amerialia.001.caruso.htm FERRUA, Pietro, "Suerte y desdicha del letrismo cinematográfico", en revista Miradas, Escuela Internacional de cine y televisión, en:

http://www.eictv.co.cu/miradas/index.php?option=com content\&task=view\&id=383\&Itemid=53 FINKEL, Irving (Entrevista) por: GREEN, William, "Big Game Hunter", Time Specials, June 19, 2008. en:

http://www.time.com/time/specials/2007/article/0,28804,1815747 $1815707 \quad 1815665,00 . h t m l$ FLOWERS, Jim, "Of all Dem Saints": http://allsaintsmobile.net/blog/2010/02/of-all-dem-saints/ KRENTZ, Arthur, "Play and Education in Plato's Republic"en: http://www.bu.edu/wcp/Papers/Educ/EducKren.htm 
KRAMER, Wolfgang, "What is a game?" (2000) en:

http://www.thegamesjournal.com/articles/WhatIsaGame.shtml

LORENZ, Konrad, The foundations of ethology, Springer-Verlag, New York, 1981:

http://books.google.com/books?id $=2$ Y4ptmJiGIkC\&printsec $=$ frontcover\#v $=$ onepage\&q $\& \mathrm{f}=$ false

DE COZAR, Rafael, Poesía e Imagen; formas difíciles de ingenio literario:

http://www. josecrespo.es/pdf/poesia_e imagen_rafael_de_cozar.pdf

FENOLLOSA, Ernest, "The chinese written character as a medium for poetry" (1920) en:

http://www.pileface.com/sollers/IMG/pdf/The Chinese Written Character As A Medium For Poetry Ernest Fenollosa-Ezra Pound_pdf

GACHE, Belen, "Poesía visual como género híbrido en las fronteras entre el leer y el ver",

Revista De Guarda, No. 2 (pp. 137-150), 2006 en:

http://www.paginasdeguarda.com.ar/ pdf/articulos/2 gache.pdf. en:

GACHE, Belem, "De Ekfrasis, Caligramas y Rebus" en:

http://findelmundo.com.ar/belengache/rebus.htm

GACHE, Belén, "La poesía visual como máquina de guerra del lenguaje", en: Poesía visual

Argentina, Ediciones Vórtice, Buenos Aires, 2006. en:

http://www.findelmundo.com.ar/belengache/libropvisual.htm Consultado: 16/11/2011

GOMRINGER, Eugen, The book of hours and Constellations, en:

http://www.ubu.com/historical/gomringer/Gomringer-Eugen_Book-of-Hours-and-

Constellations.pdf

GUIHARD; Karine, Le Surréalisme Révolutionnaire, suivi de projet de these sur l'oeuvre de

Christian Dotremont; en: http://karine.guihard.pagesperso-orange.fr/docs/dea.pdf

HAUNG, Bei, "Le mouvement et la fixation: la pratique claudélienne de la calligraphie dans Cent phrases pour éventails"Boletín de la Sociedad Paul Cludel, Núm. 196, en: http://www.paulclaudel.net/print/book/export/html/176 18/12/2011

LESCURE, Jean, "Brief history of the Oulipo" (pp. 172-176) en: [Mettre la langue sous corset pour faire jaillir l'imaginaire?] citado por : PROUST, Jean-Marc, “Avec l'Oulipo, les mots son un jeu depuis 50 ans", Slate, 24/10/2010, en: http://www.slate.fr/story/30693/oulipo

MANCEBO, Juan, "Palabras en libertad a la poética de acero", en:

http://www.uclm.es/profesorado/juanmancebo/descarga/textos/palabraslibertad.pdf

MANCEBO, ROCA, Juan Agustín, "El mago futurista en tres momentos, pintura, teatro diseño, publicidad y arquitectura en Fortunato Depero", en:

http://www.uclm.es/profesorado/juanmancebo/descarga/textos/Mago\%20Futuistas.pdf

DONALD, Merlin, Precis of Origins of the Modern Mind: Three Stages in the Evolution of

Culture and cognition en: http://www.genling.nw.ru/Staff/Psycholinguistics/Precis.pdf

MOLNAR, Albert, Lusus poetici, 1614, en el Web site The library of symbolism en:

http://www.camrax.com/symbol/figurepoemsintro.php4 Consultado: 2/12/2011.

MONTI, Enrico, The reception of ideograms in Early 20th Century European Poetry, Review of literatures of the European Union, 8, (2008) en:

http://www.rilune.org/ENGLISH/mono8/ideograms.htm

MURIEL, Felipe, "Pintar con la palabra", Revista Séneca Digital, Núm 3, 2010, en:

http://www.juntadeandalucia.es/averroes/iesseneca/revista/spip.php?article24

ORTÍZ PAREDES, Jesús, El deporte como juego; un análisis cultural, Tesis Doctoral,

Universidad Alicante, 2002. (pp.13-18) [Texto On-line] en:

http://www.cervantesvirtual.com/autor/paredes-ortiz-jesus--0/

PAPPAS, Alexandra, "Language Arts: The Hellenistic Tecnhopaegnia as art historial theory and practice", en: TANNER, Invention of art history in ancient Greece, 2006, en:

http://apaclassics.org/images/uploads/documents/abstracts/Pappas_1.pdf

RUIZ LOZANO, PERE, "Palíndromos literarios y literatura palindrómica", en:

http://www.albaiges.com/cpi/icpi/palindromosliterariosliteraturapalindromica.htm

SABATINI, Federico, "It can be all in one language: Poetry and "Verbivocovisual" language in

Joyce and Pound, riLUnE, núm. 8, 2008, pp. 97-114. En:

http://www.rilune.org/ENGLISH/mono8/IdeogramsArticles.htm

SCUDIERO, Maurizio, "Italian Futurist Book",en:

http://colophon.com/gallery/futurism/ 
SKOMOROCHO, Dimitri et al., Monastic sign language, Benedictine communication in the IIth Century England, en: http://www.thebluefool.com/society/artsci/MSL_Report.pdf

VAZQUEZ ROCCA, Adolfo, "El Hipertexto y las nuevas retóricas de la postmodernidad, textualidad, redes y discurso excéntrico" en PHILOSOPHICA, Revista del Instituto de filosofía de la Pontificia Universidad Católica del Valparaíso, Chile, Vol.27, 2004.

\section{NARRANS ET LUDENS}

AARNE, Anti, The types of folktale: a classification and bibliography. Translated and enlarged by Stith Thompson, Communications, FF Communications, Helsinki, 1961), en:

http://scandinavian.wisc.edu/mellor/taleballad/pdf files/motif types.pdf

AARRE, Mari, "The Aesthetics of language", en:

http://www.randistrand.no/tekst/textenglish.html

ABREGO, Perla, "Tango y mito en el Aire de Tango de Manuel Mejía Vallejo", en:

http://www.ucm.es/info/especulo/numero28/tangomit.html

BEC, Emmanuel, "La vie mode d'emploi de Georges Perec en:

http://mathenjeans.free.fr/amej/edition/actes/actespdf/95121128.pdf

CABRERA M., ANTONIA J.,"Nicanor Parra y poesía visual", en:

http://www.letras.ufmg.br/espanhol/Anais/anais paginas \%200-502/Nicanor\%20Parra.pdf

ELISABET, "Hermeneia, la literatura en la era digital, Entrevista a Laura Borras", Revista

Literaria Prosofagia núm. 9, Agosto 2010. [Texto on-line] en:

http://issuu.com/prosofagia/docs/prosofagiagosto2010online

FAIDUTTI, Bruno, “Themes \& Mechanics 1.0", 2005. en:

http://www.thegamesjournal.com/articles/ThemesMechanics1.shtml

FOUCES, Covadonga G., Entrevista a Paolo Fabbri [16 de noviembre de 2000] en:

http://www.antroposmoderno.com/antro-articulo.php?id articulo $=510$

GARCÍA LANDA, José A., Acción, relato, Discurso: Estructura de la ficción narrativa [Texto on-line] en:

http://www.unizar.es/departamentos/filologia inglesa/garciala/publicaciones/ard/1.2.Accion.html GORDON, José Gordon, "Cadáver exquisito: Azar y poesía colectiva", en:

http://redescolar.ilce.edu.mx/redescolar2008/proyectos/imaginantes_secundaria/pdf/cadaverexqui sito.pdf

JENKINS, Henry, “Transmedia storytelling” (2003), en:

http://www.technologyreview.com/biomedicine/13052/? $\mathrm{a}=\mathrm{f}$

KLEMENS, Franz \& NISCHELWITZER, Alexander, “Adaptive digital storytelling: a concept for narrative structures in digital storytelling build on Basic storytelling principles, adaptive story schemas and structure mapping techniques" [Artículo on-line] en:

http://www.mediaeducation.gr/adst paper.pdf

KULIN, Katlin, "Discurso 62. Modelo para armar de Julio Cortázar", en:

http://revistas.ucm.es/index.php/ALHI/article/view/ALHI8383110099A/24314

MONTFORT, Nick, "Literary Games", en Poems That Go, núm.14, 2003, en:

http://www.poemsthatgo.com/gallery/fall2003/print article games.htm

MOYANO, Marisa, "Tres tristes tigres" [Artículo on line] en:

http://www.ucm.es/info/especulo/numero28/trestigr.html

PLATON, Dialogo El Fedro (370 a.C.) sobre el valor de la retórica de la escritura y su relación

con la memoria [Texto on-line] en: http://www.filosofia.org/cla/pla/azc02261.htm

SIMONS, Jan, "Narrative, games \& theory" en Game Studies, Vol. 7, Issue 1, 2007. en:

http://gamestudies.org/0701/articles/simons

VALLES C., José R., "Max Aub: juegos narrativos en juegos de cartas”, en:

http://www.jornada.unam.mx/2007/11/04/sem-jose.html

SHUT, Kevin, "Technology tells a tale: digital games and narrative", [Texto on-line] en:

http://www.digra.org/dl/db/05150.17157

STOCKMANN, Britta \& JAHNKE, Jens, "Playing by the book, literature and board games at the beginning of $21^{\text {st }}$ century", en: http://www.hc.amu.edu.pl/numery/5/stockjahnke.pdf 
VAZ DA SILVA, Francisco, "Bengt Holbek and the study of meanings in fairy tales" [Artículo on-line] en: http://socrates.berkeley.edu/ caforum/volume1/pdf/silva.pdf 12/03/2012

\section{JUEGOS NARRATIVOS DIGITALES}

BECKER, Katrin, "The invention of good games: Understanding learning design in commercial video games" (Tesis doctoral) University of Calgary, 2008. (p. 61) [Texto on-line] en:

http://www.minkhollow.ca/becker/papers/becker_thesis.pdf

CARLQUIST, JONAS, "Playing the story; computer games as a narrative" genre, HUMAN IT 6.3 (2002): (pp. 7-53) en: http://etjanst.hb.se/bhs/ith/3-02/jc.pdf

COSTIKIAN, Greg, "Where Stories End and Games Begin" [Artículo on-line] en:

http://www.costik.com/gamnstry.html

CHURCH, Doug, "Formal abstract design tools"; Gamasutra, Julio 16, 1999. [Texto on-line] en: http://www.gamasutra.com/view/feature/3357/formal abstract design tools.php Consultado:

DAVIDSON, Drew, Stories in between, narratives and mediums@ play, CMBook, [texto online] en:

https://portal.acm.org/purchase.cfm?id=1503495\&CFID=25468422\&CFTOKEN=44521682

ESKELINEN, Markku, "Cybertext theory and literary studies", a user's manual" The electronic Book Review, 12 (2001) [Artículo on-line] en: http://www.altx.com/ebr/ebr12/eskel.htm

ESKELINE, Markku, "Towards computer game studies, Introduction: Ludology and narratology, [Artículo on line] en Electronic Book Review, 2004:

http://www.electronicbookreview.com/thread/firstperson/anticolonial?mode=print

ESKELINEN, Markku, "Cybertext theory and literary studies", a user's manual" The electronic

Book Review, 12 (2001) [Artículo on-line] en: http://www.altx.com/ebr/ebr12/eskel.htm

ESKELINEN, Markku \& KOSKIMAA, Raine, "Towards a functional theory of media",

Cybertext Year book, [Texto on-line] en: http://cybertext.hum.jyu.fi/index.php?browsebook=5

FRASCA, Gonzalo, "Ludology meets narratology: similitude and differences between (video)

games and narrative" (1999) [Texto on line] en: http://www.ludology.org/articles/ludology.htm FRASCA, Gonzalo, "Ludologists love stories, too: notes from a debate that never took place"

[Artículo on-line] en: http://www.ludology.org/articles/Frasca_LevelUp2003.pdf

JENKINS, Henry, "Game design as narrative architecture" [Artículo on-line] en:

http://web.mit.edu/cms/People/henry3/games\&narrative.html

JUUL, Jesper, "A clash between game and narrative" (1998) [Artículo on-line] en:

http://www.jesperjuul.net/text/clash between game and narrative.html

JUUL, Jesper, "Games telling stories?" (pp. 219-226) en: RAESSENS, Joost \& GOLDSTEIN,

Jeffrey (eds), HandBook of Computer Game Studies, The MIT Press, Cambridge, 2005.

JOYCE, Michael, Afternoon, (1996) [Sitio web] en:

http://www.eastgate.com/catalog/Afternoon.html

KREIMEIER, Bernd, "The case for game design patterns" Gamasutra, March 12, 2002. [Texto on-line] en:

http://www.gamasutra.com/view/feature/4261/the case for game design patterns.php KÜCKLICH, Julian, "Perspectives of Computer Game Philology", GAME studies, the international journal of computer game research $(3,1) 2003$. [Artículo on-line] en: http://www.gamestudies.org/0301/kucklich/ Consultado: 19/11/2011

MATEAS, Michael \& STERN Andrew, Build it to Understand it: "Ludology meets narratology in game design space", [Artículo on-line] en:

http://users.soe.ucsc.edu/ michaelm/publications/mateas-digra2005.pdf

PAJARES TOSCA, Susana, ¿Jugamos una de vampiros? De cómo cuentan historias los videojuegos., Comunicación no. 7, 1, 2009 (pp.80-91) [Artículo on-line] en:

http://www.revistacomunicacion.org/pdf/n7/articulos/a6 Jugamos_una de vampiros_De como cuentan historias los videojuegos.pdf

POSADAS, José Guadalupe [Grabador mexicano del siglo XIX]:

http://www.artcyclopedia.com/artists/posada_jose_guadalupe.html 
PEREZ, Rafael \& SHARPLES, Mike, "Three computer-based models of storytelling: BRUTUS,MINSTREL and MEXICA", [texto on-line] en:

http://www.lsri.nottingham.ac.uk/msh/Papers/MEXICA\%20KBS.pdf Consultado: 06/07/2010 PEREZ, Rafael, BRUTUS,MINSTREL and MEXICA" [texto on-line] en:

http://www.lsri.nottingham.ac.uk/msh/Papers/MEXICA\%20KBS.pdf

PIMENTEL, Luz Aurora, El relato en Perspectiva, Siglo XXI editores, México, D.F., 1998 (Introducción) [fragmentos del texto on-line] en:

http://www.lpimentel.filos.unam.mx/sites/default/files/textos/introduccion-relato-prespectiva.pdf PRINCE, Gerald, "Observaciones sobre la narratividad”, Criterios, 29 (pp. 25-34) La Habana, 1991. [Artículo on-line] en: http://www.criterios.es/pdf/princeobservaciones.pdf Consultado: 20/12/2012.

SHUT, Kevin, "Technology tells a tale: digital games and narrative", [Texto on-line] en: http://www.digra.org/d1/db/05150.17157 


\section{WEBLOGRAFIA}

\section{HOMO NARRANS}

ARTE RUPESTRE LEVANTINO: http://www.liceus.com

AZTEC AND MAYA CALENDAR: http://www.azteccalendar.com/

CAMPBEL, Joseph: http://www.jcf.org

CUEVA DE LAXCAX: http://www.lascaux.culture.fr

DICCIONARIO DE LA REAL ACADEMIA ESPAÑOLA: http://www.rae.es

EPCC Pôle International de la Prehistorie: http://www.pole-prehistoire.com,

PINTURA RUPESTRE LEVANTINA en: $h$ ttp://www.arteespana.com,

ROCK ART RESEARCH INSTITUTE en: http://www.bradshawfoundation.com

\section{HOMO LUDENS}

ADAMAR en: http://www.adamar.org/ivepoca/node/232

ASOCIACIÓN UNIVERSAL DE ESPERANTO en: http://www.uea.org/info/hispana.html

ARTE CALIGRÁFICO: http://www.worldofcalligraphy.com/calligraphyartists.html

ANGORJ: http://www.imdb.com/title/tt0229990/

ARTLANGS: http://en.wikipedia.org/wiki/Artistic language

BRECHT George, Two exercises, 1961: http://www.artnotart.com/fluxus/gbrecht-twoexercises.html

BRULL, Mariano; http://www.poesi.as/Mariano_Brull.htm

CLAUDEL, Paul; http://www.paul-claudel.net/

CENTER FOR BOOK ARTS IN NEW YORK: http://centerforbookarts.org/

CENTRO DE DOCUMENTACIÓN E INVESTIGACIÓN SOBRE LA VANGUARDIA HISTÓRICA

PRIMO CONTI: http://www.fondazioneprimoconti.org/archivio/fondi/cangiullo_francesco.html

COLEGIO DE PATAFÍSICA: http://www.college-de-pataphysique.org/college/accueil.html

CONLANGS: http://www.frathwiki.com

DUCHAMP, Duchamp's Boite-en-valise, or Box in a Suitcase en sitio Internte de MOMA:

http://www.moma.org/interactives/exhibitions/1999/muse/a rtist_pages/duchamp_boite.html

EL ARTE DE LOS RUIDOS (Manifiesto Futurista) en:

http://www.uclm.es/artesonoro/elarteruido.html

ENGLANGS: http://en.wikipedia.org/wiki/List_of_constructed_languages\#Literature

ENIGMA Machine:

http://www.dmoz.org/Science/Math/Applications/Communication_Theory/Cryptography/Historical/y

Simulador de Enigma en: http://russells.freeshell.org/enigma/

EXHIBICIÓN: Words in Freedom: Futurismo at 100 [en Museo de Arte Moderno de Nueva York] en:

http://www.moma.org/interactives/exhibitions/2009/futurism/ Consultado: 28/11/2011

FUTURISMO, MANIFIESTO DE MARINETTI, en: http://arteest.org/futurism.htm

EL UNIVERSO FUTURISTA: http://www.proa.org/esp/exhibition-el-universo-futurista.php

FROMMER, Paul: http://naviteri.org/

GOMRINGER, Eugene: http://culpinak.blogspot.com/2006/06/galaxia-eugen-gomringer.html

CONCRETISMO: http://concretismo.zip.net

HUIDOBRO, Vicente: http://www.memoriachilena.cl/temas/dest.asp?id=huidobrocaligramas

http://bib.cervantesvirtual.com/portal/bnc/huidobro/huidobro.shtml

http://www.hahakid.net/forallseasons/storyboard.html

INCUBUS: HTTP://EN.WIKIPEDIA.ORG/WIKI/INCUBUS_(1966_FILM)

JUEGO DE LA OCA (historia) http://www.juegodelaoca.com/Origenes/origenes.htm

KNOWLES, Alison: http://www.aknowles.com/eventscore.html

LEMAITRE, Maurice: http://mauricelemaitre.wordpress.com

http://ubu.com/film/lemaitre_film.html

MANIFIESTO LETRISTA en: http://www.391.org/manifestos/1942isidoreisou letterist.htm Sitio Oficial:

http://www.thing.net/ grist/lnd/lettrist/isou.htm.

MUSEO DEL JUEGO: http://www.museumofplay.org consultado el 27/05/2008

MURGUİA, Alejandro: Hurgapalabras, http://hurgapalabras.blogspot.com/2007/10/jitanjforas.html

NA'VI en: http://www.learnnavi.org/ 
OKRENT, Arika, In the land of invented languages:

http://inthelandofinventedlanguages.com/index.php?page=languages

OULIPO

Sitio oficial: http://www.oulipo.net y http://www.nous.org.uk/oulipo

Oulipianos: http://www.oulipo.net/oulipiens

Potencialidades [Ou-X-Po]: http://ouxpo.voila.net/page1/index.html

OubaPo: http://gciment.free.fr/bdoubapo.htm

PEREC, Georges: http://associationgeorgesperec.fr/

QUENEAU Raymond: http://www.queneau.net

REVUE DES LITTERATURES DE L'UNION EUROPEENE: http://www.rilune.org

ROUSSEL, Raymond [Entrevista a] en:

http://www.elpais.com/articulo/cultura/explosion/Raymond/Roussel/elpepicul/20111024elpepicul_1/Tes TOLKIEN LANGS:

http://www.uib.no/People/hnohf/nevbosh.htm o en: http://www.freewebs.com/lordfingulfin/index.htm

http://www.tolkien-online.com/tolkien-language.html

VISION LEAP: http://www.divisionleap.com

ZAZIE DANS LE METRO: http://www.complete-review.com/reviews/queneaur/zazie.htm

\section{NARRANS ET LUDENS}

ARTEROIDS; [Generador de textos on-line]: http://www.vispo.com/arteroids/

AUB, MAX: http://www.maxaub.org

BAD MACHINE [Generador de textos on-line]

http://www.poemsthatgo.com/gallery/fall2003/bmch/index.htm

BOOKCHIN, Natalie [generador de textos on- line]: http://bookchin.net/intruder/index.html

BORGES, Jorge Luis, La intrusa, Ciudad SEVA [Texto on-line] en:

http://www.ciudadseva.com/textos/cuentos/esp/borges/intrusa.htm

CHOOSE YOUR OWN ADVENTURE: http://www.cyoa.com/

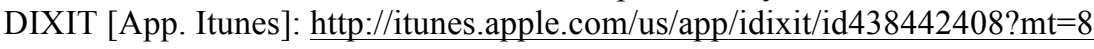

DOMINOA [Literary game] http://www.servus.at/dominoa/englexpl.html

ELECTRONIC LITERATURE ORGANIZATION

http://eliterature.org

FAIRY TALE GENERATOR: http://www.brown.edu/Courses/FR0133/Fairytale Generator/gen.html

FANTASY FLIGHT GAMES [Reiner Knizia], en:

http://new.fantasyflightgames.com/edge minisite.asp?eidm $=62$

FOLKTALES (International Types): http://oaks.nvg.org/uther.html

GABLE, Rebecca, The Settlers of Catan, Amazon Crossing, Las Vegas, 2003.

http://www.catan.com

GOZZI, Carlo, http://carlogozzi.com/

KOSMOS, http://www.kosmos.de/

LE CADAVRE EXQUIS, [Juego literario colaborativo]:

http://www.lecadavreexquis.net/terms/

MAD LIBS: http://www.wordlibs.com http://www.madlibs.org http://www.rinkworks.com/crazytales.

Mad Lib de Mario Heidenbrink en http://www.angelfire.com/magic/masterdam

ONCE UPON A TIME, http://www.atlas-games.com/onceuponatime/

PREUßLER OTFRIED, [Diseñador de libros para niños]

http://www.preussler.de/index 1.htm

RORY'S STORY CUBES, http://www.storycubes.com

STORYMATIC: http://www.thestorymatic.com/;

TEUBER, Klaus [Juego de tablero]: http://anno.de.ubi.com/

http://collection.eliterature.org/2/works/hennessy frogger_jabber.html

TEUBER, Klaus, Catan das Kartenspiel, [sitio web] en:

http://www.catan.com/electronic-games.html 


\section{JUEGOS NARRATIVOS DIGITALES}

222 CONTRA EL CANGREJO: http://www.caad.es/?q=node/1495

ADVNT [árbol genealógico de Russel Dalengerg] en: http://www.mipmip.org/adv/advfamily.shtml AGE OF EMPIRES: http://ageofempiresonline.com

ADVENTURE GAMERS: http://www.adventuregamers.com

ASSASSIN'S CREED: http://assassinscreed.es.ubi.com/brotherhood/

CAAD [Club de Aventuras AD]: http://www.caad.es

CAESAR IV: http://caesar4.heavengames.com/

CAESAR III: http://caesar3.heavengames.com/info/lester-q.shtml

CIVILIZATION: http://www.civilization.com/

COMMAND \& CONQUER: http://www.commandandconquer.com/

INFOCOM: http://adventure.if-legends.org/Infocom.html

HALF LIFE: http://orange.half-life2.com/

KONAMI: http://www.konami.com/

LUCAS ARTS ( http://www.lucasarts.com

LOS TRABAJOS DE HÉRCULES: http://www.the12labors.com

MERISTATION (http://www.meristation.com

MIGHT AND MAGIC: http://mightandmagic.es.ubi.com/HeroesV toe.php

MOBY GAMES http://www.mobygames.com

NOMIC [Juego de Peter Suber]: http://www.earlham.edu/ peters/nomic.htm

PACMAN: http://pacman.com/en/

RISE OF NATIONS: http://www.riseofnations.com

SIERRA ON-LINE (http://www.sierragamers.com

SCUMMVM: http:///www.scummvm.org

SUDDEN STRIKE: $\underline{\text { http://www.suddenstrike.com }}$

TENNIS FOR TWO: http://www.abadiadigital.com/articulo/tennis-for-two-el-primer-videojuego-de-lahistoria/

TEXT ADVENTURES: http://www.whitestick.co.uk/text.html

THE SIMS: http://www.thesims.com

THE WRITER'S GUIDE to making a digital living: choose your own adventure" (2008) en:

http://www.australiacouncil.gov.au/writersguide

TOOLS FOR TALES: http://ic.media.mit.edu

TRANSILVANIA CORRUPTION: http://www.aliensuavito.com/juegos.php

VENENARIUS VERBORUM:

http://iplayif.com/?story=http://caad.es/jarel/games2/venenariusverborum.z5

ZORK: http://www.thezorklibrary.com/history/00-resources.html 


\section{SITIOS WEBS \\ RECOMENDADOS}

\section{LITERATURA DIGITAL}

Organizaciones y grupos de estudios Universitarios sobre Narrativas Digitales

Arbeitsgruppe Narrativik An Der Philipps Universität Marburg

http://staff.uni-marburg.de

Association for applied Interactive

Multimedia

http://www.aaim.com

Australian Center for the moving Image

http://www.acmi.net.au

CNR, Center for Narrative Research,

University of East London

www.vel.ac.uk/cnr/index.htm

Narratologies Contemporaines CNRS-

EHESS, Paris

http://narratologies.ehess.fr

ICN, Interdisciplinary Centre for

Narratology University of Hamburg,

Germany

http://www.icn.uni-hamburg.de/

Carnegie Mellon University: ETC

Entertainment Technology Center

http://www.etc.cmu.edu/

Center for Digital Story Digital World

It University Of Copenhagen

http://www.itu.dk/en/Forskning/competencer

Center for Digital Story

http://www.storycenter.org/

Center for Narratological Studies

University Southern Denmark

http://www.sdu.dk/en/Om_SDU/Institutter_cent re/Idk/Forskning/Forskningsprojekter/C_Narrat

ologi

DAC, Digital Art and Culture

Brown \& Bergen, Norway

http://www.stg.brown.edu/conferences/DAC/

Digital Word IT University of Copenhagen

http://it-c-dk

ICN Interdisciplinary Centrum für

Narratology University of Hamburg

http://www.icn.uni-hamburg.de/

Institute for the future of the Book

http://www.futureofthebook.org/

Image \& Narrative, Facultad de Artes K.U.

Leuven, Belgica

http://www.imageandnarrative.be/

The International Society for the Study of

Narrative

http://narrative.georgetown.edu
IRIS, Integrating Research in Interactive

Storytelling

http://iris.scm.tees.ac.uk

Hermeneia Grupo de Investigación

http://www.hermeneia.net

Hipertulia: catálogo de recursos de crítica

literaria hipertextual y obras hipertextuales.

Dirigido por Susana Pajares Tosca.

http://www.ucm.es/info/especulo/hipertul/

Liquid Narrative Group

http://liquidnarrative.csc.ncsu.edu

La literatura en la red: Recursos pedagógicos de Juan Antonio Cardete

http://www.lasombradelmembrillo.com/litredjac 2006.htm

Project Narrative de Ohio State University

http://projectnarrative.osu.edu

Waag Society for art, science and technology

http://waag.org/nl

The writer's guide

http://www.australiacouncil.gov.au/writersguide

Reuniones y congresos sobre Literatura Digital

ICIDS, International Conference on

Interactive Digital Storytelling

www.icids.2009.ccg.pt

ICVS, International Conference on Virtual Storytelling

http://www.virtualstorytelling.com/indexVS.ht $\mathrm{m}$

TIDSE, Technologies for Interactive Digital Storytelling \& Entertainment

http://icids.org/2004/

E-Poetry: An International Digital Poetry

Festival http://epc.buffalo.edu/e-poetry/2011/

Recursos y proyectos de Literatura electrónica

\section{Escribit}

http://escribit.net/

Electronic literature organization

http://eliterature.org/

Electronic Literature Collection

http://collection.eliterature.org/

The ELO conference

http://el.eliterature.org/

The Interactive Fiction Archive

http://www.ifarchive.org

OBX, Laboratory for Experimental Media

http://www.obslabs.net

Resources for the study and teaching of

electronic literature

http://dtc-wsuv.org/mla2012/resources.html 
CEL, Consortium for Electronic Literature http://directory.eliterature.org/consortium ELMCIP, Electronic Literature as a Model of Creativity and Innovation in Practice http://elmcip.net

Zarf's Interactive Fiction

http://eblong.com/zarf/if.html

Interactive Fiction Competition 2010

http://www.ifcomp.org

Rule-based

http://eblong.com/zarf/essays/rule-based-if/

Curveship

http://curveship.com

Project "N" Narrative

http://projectnarrative.osu.edu/

\section{Revistas y Publicaciones}

AJCN Amsterdam International Electronic Journal for Cultural Narratology

http://cf.hum.uva.nl/narratology

IDMAA

International Digital Media and Arts

Association Journal

URL: http://wwwidmaa.org/journal

Turbulence

http://www.turbulence.org

The Drunken Boat: An Online Journal of Art and Literature

http://www.thedrunkenboat.com

EBR, Electronic Book Review

http://www.electronicbookreview.com

Hyperrhiz: New Media Cultures Journal

http://www.hyperrhiz.net

LEA, Leonardo Electronic Almanac ( LEA

http://www.leoalmanac.org

Hislibris

http://www.hislibris.com/

Sitio del Idioma Español

http://www.elcastellano.org/consultas.php?Tag= etimolog\%EDa\&Pag=1

Society for Cinema and Media Studies

http://www.cmstudies.org/

Cybertext year book

http://cybertext.hum.jyu.fi/index.php?browsebo

ok=4

The New River: A Journal of Digital Writing \& Art

http://www.cddc.vt.edu/journals/newriver/11Fal 1/index.html

TIR-W, The Iowa Review Web (TIR-W)

http://iowareview.uiowa.edu/TIRW/vol9n2/

Poems That Go

http://www.poemsthatgo.com

frAme: Journal of Culture \& Technology

http://www.framejournal.net

Recursos Para Escritores De Medios

Digitales
ANNIE exploratory learning and narrative for games

http://liquidnarrative.csc.ncsu.edu/index.php/our -systems/123-annie

Authoring software

www.narrabase.net

Calaméo

http://en.calameo.com/

Celtx

www.celtx.com

Cyberart database, CCRI, University of

Singapore

http://www.cyberartsweb.org/

Creative Writing \& New Media Archive

http://www.hum.dmu.ac.uk/transliteracy/

The Electronic Labyrinth

http://www2.iath.virginia.edu/elab/

Folding Story

http://foldingstory.com/

Frotz Interpreter

http://frotz.sourceforge.net

Glogster

http://www.glogster.com/

HUGO de Kent Tessman

http://www.generalcofee.com

Inform Compiler de Grahan Nelson

http://www.inform-fiction.org

Issuu

http://issuu.com

Q10

http://www.baara.com/q10

TADS de Michael Roberts

http://www.tads.org

Tar Heel Reader

http://tarheelreader.org/write-a-book/

Text block writer

http://text-block-writer.en.softonic.com/

Ywriter

http://www.spacejock.com/yWriter5.html

Storybird

http://storybird.com/

Storybook

http://www.novelist.ch/joomla/

Issuu

http://issuu.com/

Inform

http://inform7.com/

The Mediatized stories Project

http://www.intermedia.uio/mediatized

Tools for Tales

http://ic.media.mit.edu/

Story Box

http://www.storyboxproject.com

Scriptopus, a collaborative writing game

http://www.scriptopus.com/stories/83

The virtual storyteller

http://wwwhome.ewi.utwente.nl/ theune/vs/

Witness Narrator Agents

http://www.cs.nott.ac.uk/ nem/ 


\section{JUEGOS DIGITALES}

Game Theory

http://www.iep.utm.edu/game-th/

Hopstory I y II

http://www.valentinanisi.com/hopstory.html

Guía para conocer aventuras de texto

http://www.microheaven.com/ifguide

The Interactive Fiction Archive

http://www.ifarchive.org

\section{Congresos y Reuniones sobre juegos}

Game Research Lab, Tampere University

http://gamelab.uta.fi/?page_id $=30$

IEEE Symposium on Computational

Intelligence and Games

http://ieeexplore.ieee.org/stamp/stamp.jsp?arnu mber $=04442264$

AIIDE, Artificial Intelligence and Interactive Digital Entertainment Conference

http://www.aiide.org/

AAAI, Artificial Intelligence and Interactive Entertainment

http://www.aaai.org/Conferences/AIIDE/aiide.p hp

GDC Game Development Conference

http://www.gdconf.com/

DIGRA, Digital Games Research Conference

http://www.digra.org/

Level Up Conference Utrecht

http://www.informatik.uni-trier.de

The Philosophy of Computer Games conference http://www.gamephilosophy.org

Revistas y Publicaciones periódicas sobre videojuegos y narrativas

Storyworlds: A Journal of Narrative theory. http://muse.jhu.edu/journals/storyworlds/

The International Journal of Computer

Game Research

http://gamestudies.org/1102

Gate \& Game Journal Research for Training and Entertainment

http://gate.gameresearch.nl

Eludamos; Journal for computer game culture

http://www.eludamos.org/index.php/eludamos

$\mathrm{G} \& \mathrm{C}$, Games and Culture

http:/gac.sagepub.com/

Games Radar

Artículos y estudios sobre videojuegos

http://gamesradar.com
Motores gráficos sobre entornos virtuales

OGRE,

Object-Oriented Graphics Rendering Engine

http://www.ogre3d.or

JMONKEY, Java Monkey Engine

http://jmonkeyegnine.com

Game Blender

http://www.gameblender.org/

Irrlicht

http://irrlicht.sourceforge.net/

CrystalSpace

http://www.crystalspace3d.org

Torque

http://www.garagegames.com

Game Maker

http://www.yoyogames.com/gamemaker/studio

Alice

http://www.alice.org

Aurora Engine

http://nwn.bioware.com

Unity

http://unity3d.com

UDK: Unreal Development Kit

http://www.udk.com

CryEngine 2:

http://www.crytek.com/cryengine/cryengine2/o verview

SandBox 2

http://www.crymod.com/portal.php

Referencias de literatura y videojuegos

CAAD Club de aventuras AD

conversacionales http://www.caad.es/

Aventuras conversacionales (online)

http://www.taringa.net/posts/juegos-

online/13483873/Aventuras-conversacionales-

online .html

Catálogo de Aventuras de texto

http://www.wurb.com/if/intro

SPAG, Society for the promotion of

adventure games

http://www.ifarchive.org/if-archive/

iFiction

http://www.ifiction.org

Revista de Ficción Interactiva

http://www.xyzzynews.com/

The influence of literature in videogames

http://xbox.ign.com/articles/709/709150p1.html

The influence of literature and Myth in

videogame

http://xbox.ign.com/articles/709/704806p4.html

Proyecto RIDERS Research in Interactive

Drama environments, Role-play and Story-

telling

http://www.riders-project.net/ 
Centros de investigación sobre

Video juegos

ResearchGroupsLearning Games Initiative http://lgi.mesmernet.org/

UCSC Center for Games and Playable Media http://eis-blog.ucsc.edu/2010/10/int-sym/

Critical Videogame theory

http://buzzcut.com/

Terra Nova: Simulación + Sociedad + Juego

http://terranova.blogs.com/

Webblog de Greg Costykian

http://www.costik.com/weblog/

Ludology; sitio de Gonzalo Frasca

http://www.ludology.org/

Gameology

http://www.gameology.org/

Gamestudies Organization

http://gamestudies.org/1201

The Ludologist, Blog on computer game

studies de Jesper Juul

http://www.jesperjuul.net/ludologist/

International Arcade Museum

http://www.arcade-museum.com

The Entertainment Software Association

http://theesa.com/

The International Journal of Computer

Game Research

http://gamestudies.org

The British Academy Video Games Awards

http://www.bafta.org/games/awards/

Ludonauts

http://www.lodonauts.com

MobyGames

www.mobygames.com

Game Research

http://game-research.com

IGN, Imagine Games Network

http://www.ign.com/

\section{Recursos}

Game Sound, resources for educators all dealing with game audio.

http://www.gamessound.com

Juegos por conocer

39 clues, Juego de pistas para salvar al mundo: http://www.the39clues.com/

Metro 2033: Book + game

http://transmediadesign.org/metro-2033-bookgame/

Yupis (sección juegos con palabras)

http://es.yupis.org/juegos-letras/

Juegos en Arameo

http://aramaicdesigns.rogueleaf.com/games/

www.gamespy.com/games

GAMBIT Game Lab, Singapore-MIT

http://gambit.mit.edu/loadgame/improviso.php 
ANEXOS

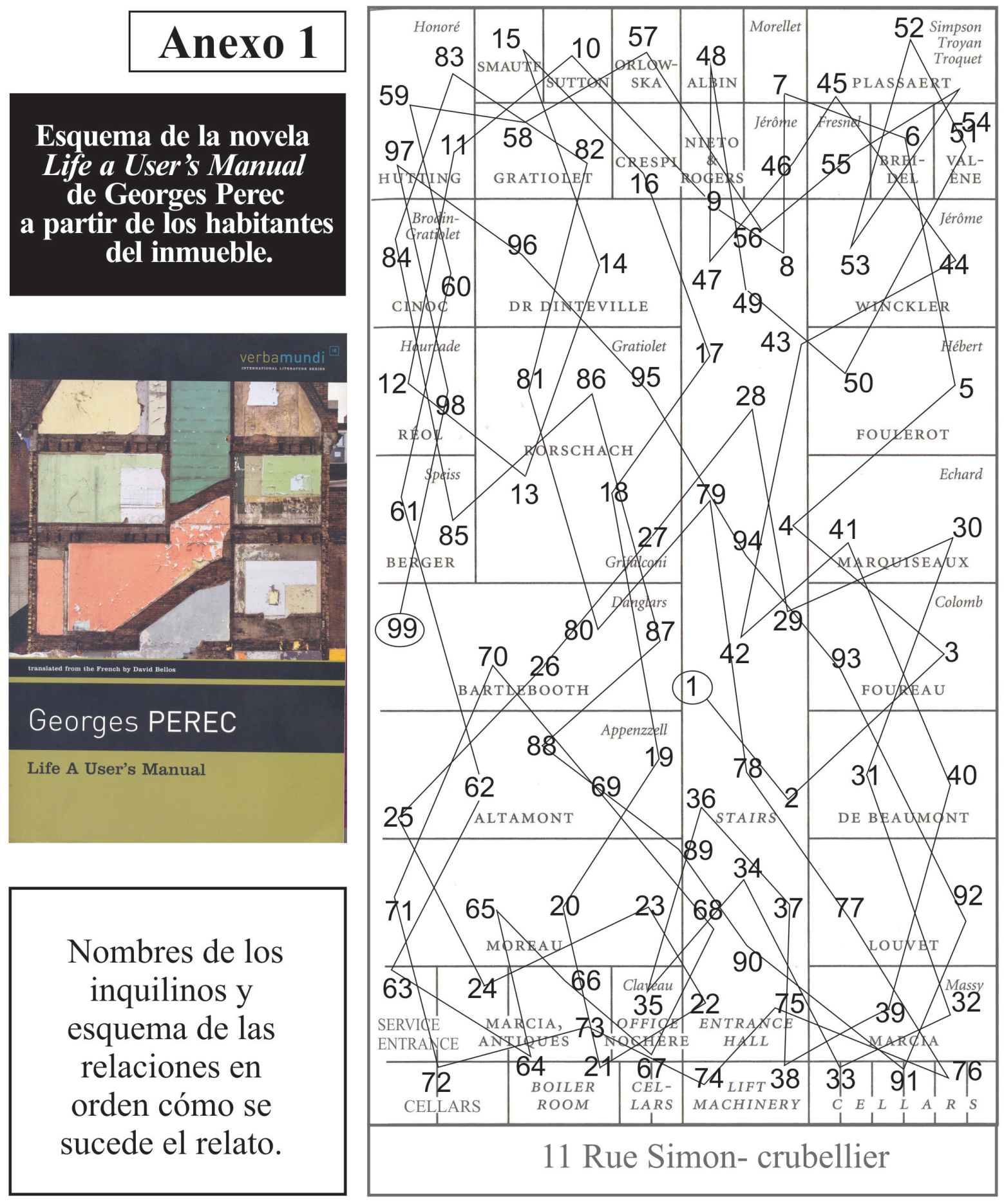




\section{Anexo 2}

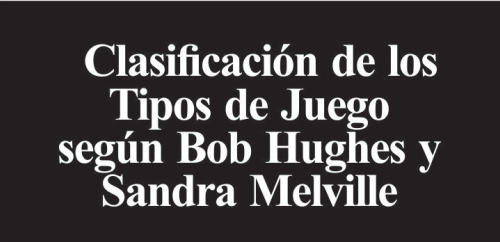

Publicado en:

A playworker's taxonomy of play types, PLAYLINK, London, 2002

1 Juego Simbólico - que permite el control, la exploración progresiva y el aumento del riesgo.

2 Juego Rudo - que admite el encuentro cercano con la lucha, en donde se mide la fuerza.

3 Juego Socio dramático - en el que se comparten experiencias reales y potenciales de naturaleza personal, social o interpersonal.

4 Juego de Representación social - mediante el cual se revelan y exploran normas y criterios de interacción social.

5 Juego Creativo - juego que demanda ingenio de nuevas respuestas, nuevas conexiones e incorpora elementos sorpresa.

6 Juego Comunicativo - en el que se usan palabras, gestos, señas, mímica, actuación, cantos o juegos del lenguaje.

7 Juego Dramático - que relatan eventos en los que se participa directamente.

8 Juego Profundo - que permite enfrentarse a riesgos y amenazas para desarrollar habilidades de supervivencia y vencer el miedo.

9 Juego Exploratorio - mediante la manipulación de objetos.

10 Juego de Fantasía - que reorganiza las experiencias de manera imaginativa, siendo poco probable que se produzcan.

11 Juego imaginativo - que no aplica las reglas convencionales que gobiernan el mundo físico.

12 Juego Locomotor-que requiere de movimientos para llevarlo a cabo.

13 Juego de Dominio - que permite adquirir el control físico y afectivo de los entornos.

14 Juego de Objeto - es el que utiliza secuencias infinitas de manipulación ojo-mano.

15 Juego de Rol- que permite la exploración de maneras de ser, generalmente de un personaje intenso.

16 Juego Recapitulativo - juego que demanda la exploración del origen, las historias y los rituales para apreciar etapas evolutivas. 


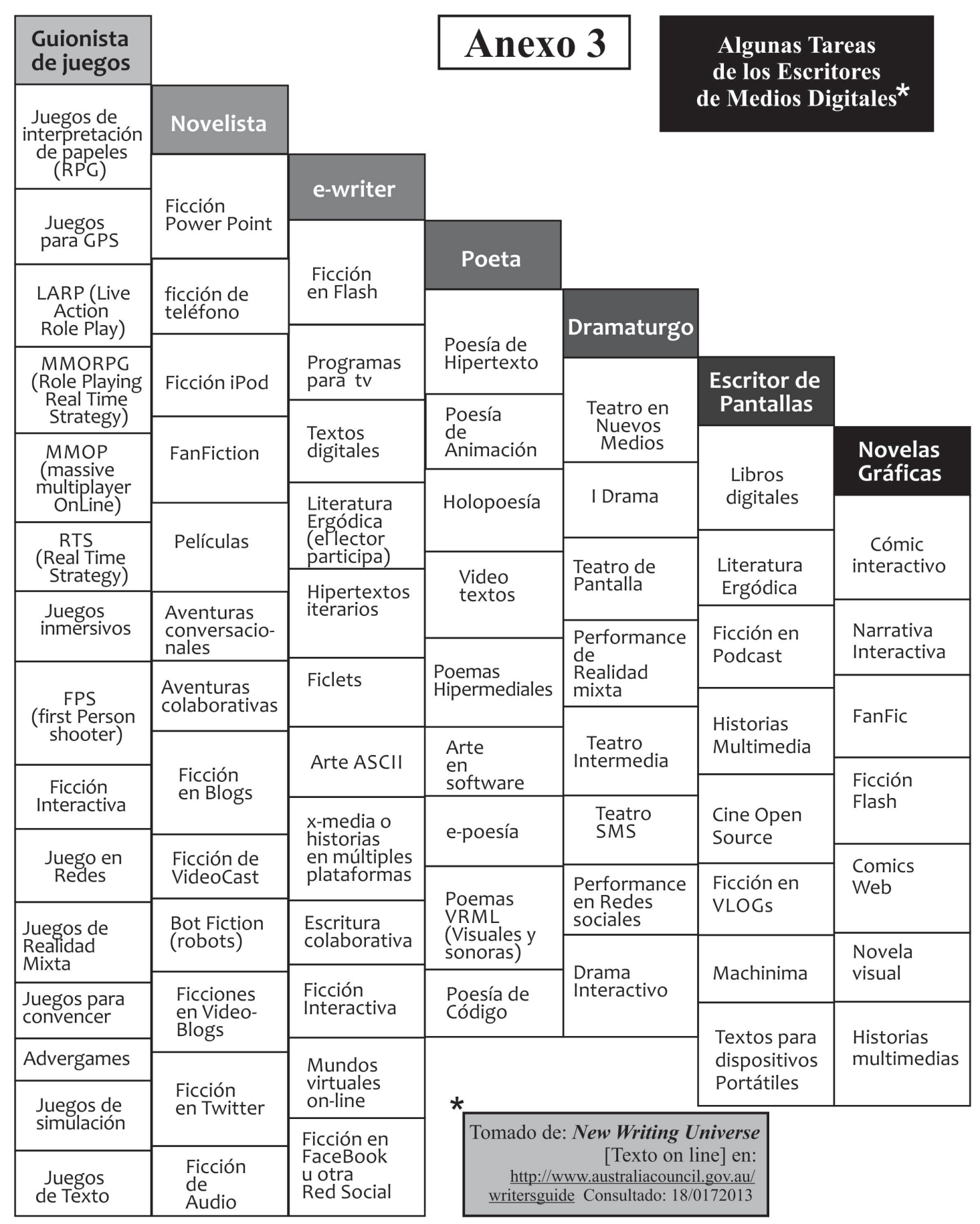



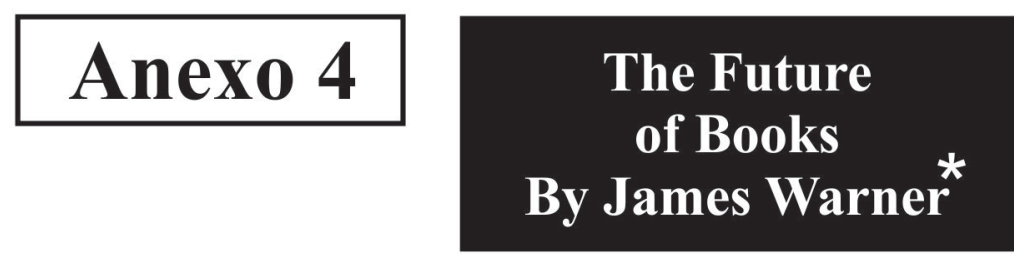

\section{0: All Books Will Be Cross-Platform and Interactive.}

Future "books" will be bundled with soundtracks, musical leitmotifs, 3-D graphics, and streaming video. They'll be enhanced with social bookmarking, online dating, and alerts from geo-networking apps whenever someone in your locality purchases the same book as you - anything so you don't have to actually read the thing. Authors will do their own marketing, the reader will be responsible for distribution, the wisdom of crowds will take care of the editing, and the invisible hand of the market will perform the actual writing (if any). Writers will respond either by going viral or by going feral.

\section{0: All Books Will Be Crowdsourced and Cloud-Based.}

Novelists will start out designing their characters in the form of sets of vinyl figurines. If these generate enough buzz, fans will produce the actual novel collaboratively as a wiki. As you read it, thermal cameras will measure your physiological signals, including flickers in eye movement, facial muscle contractions, and heart rate, to determine where you want the story to go next - it will be expected to read itself to you, explain itself, and unobtrusively weave your incoming text messages into the dialogue. You will also be able to fine-tune details of how the characters are digitally rendered, fire at them, and (when imperative) indulge in cybersex with them. If a novelist is posthumously discovered, his or her vinyl figurines may wind up as collector's items.

\section{0: Authors Will Become Like Tamagotchi.}

Having determined that what readers want is a "sense of connection," publishers will organize adopt-an-author promotions, repackaging writers along the lines of Webkinz and other imaginary pets. "Feeding" your favorite authors by buying their books will make their online avatars grow less pale and grouchy. If they starve to death on your watch you will lose social networking points. Book clubs will cultivate with their favorite writers the warm, fuzzy, organic bond a trainer develops with his or her Pokémon, a process that will culminate in staged fights-to-the-death between your author and the author sponsored by another book club. These fights will occur offline, since there will be one or two bookstores left and something has to happen there.

\section{0: Analog Reading Will Be Digitally Simulated.}

As people spend more and more of time immersed in massively multi-player role-playing games, they will begin to crave some downtime. Virtual simulation worlds will start to include hideaway "libraries" you can lock yourself into. There you'll be able to climb into a virtual bath and lovingly turn the pages of a pixilated representation of one of those dogeared tomes - reliant on old-school linear narrative - that by this time will have been made illegal in the real world. Perfectly reproduced will be the sensation of turning the pages, the crack of the spine, and even the occasional paper cut. By 2052, 95\% of the activity of $73 \%$ of role-players will take place in these hideaways, since they'll be the only place to escape the incessant building of community and connectivity that will by then be such an infuriating aspect of offline reality. 


\section{0: Physical Books Will Make a \\ Comeback in Annoying Contexts.}

As printed matter gets harder to obtain, Antiquarian Archipelago will become a popular infotainment show, starring heavily-armed archivists who teleport from island to island in search of rare gems. Meanwhile new printed works will continue to be released-in the form of dust jackets made from edible fungi - as faux-antique treasures at Renaissance Fairs and related nostalgic historical reenactments. The last bibliophile will traverse the city in a daze, wondering where the bookstores went. Meanwhile all of human knowledge will be encrusted onto a chip and sent into outer space by sixth graders, as a ploy to get out of doing their homework.

\section{0: We Will All Become Cyborgs.}

New brain-computer interfaces will redefine narrative, as electrodes implanted in the neocortex induce stories to form, without the intervention of a third party, as sustained hallucinations. Hence the "readers" of the future will spend most of their time in an epileptic fugue state. Artificial intelligences will use deep-structure pattern-recognition, predictive modeling, and information theory to ensure each new trance state is popular enough to get upvoted on the hottest content-ranking platforms. Nanobots in our bloodstream will inform us how to behave, coordinating our actions with real-time marketing data on behavioral and attitudinal trends, until the very concept of individuality is reconfigured, resulting in the death of independent thought and the elimination of many of our descendants by transpersonal mindviruses.

\section{0: A Golden Age of Informational Fluidity.}

For the benefit of those people at future-of-publishing panels - there's always one, for some reason - who insist it's really not about the text but the smell of the book, books will by this time be available exclusively as lines of fragrances. Subsequently, humans will modify themselves into a species with a powerful olfactory sense, able to read underwater by decoding strings of pherormones. Aroma-bibliography will triumph, as vast epics are composed for newly developed scent receptors, transforming the rising seas into a giant bath of community-assisted transmedia content. Also around this time, the oral literature of dolphins will be deciphered and will turn out, inexplicably, to be all about vampires.

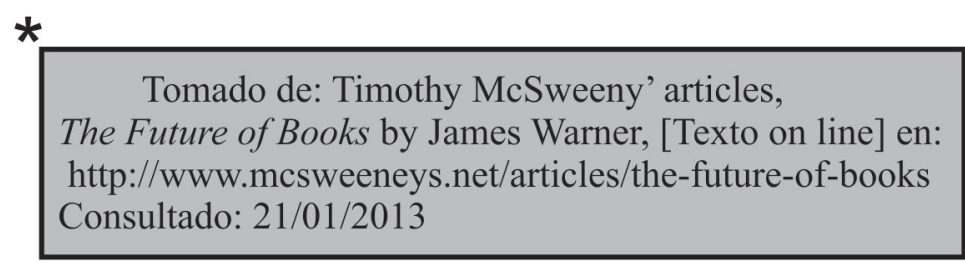


